Sheila Fernandes Pimenta e Oliveira

Daniel Facciolo Pires

Marinês Santana Justo Smith

Silvia Regina Viel

Welton Roberto Silvia (Orgs.)

\title{
COMPROMISSO COM A FORMAÇÃO DE QUALIDADE E A PESQUISA NA PSICOLOGIA
}

\section{Coleção: Ciência e Desenvolvimento, v. 13.}
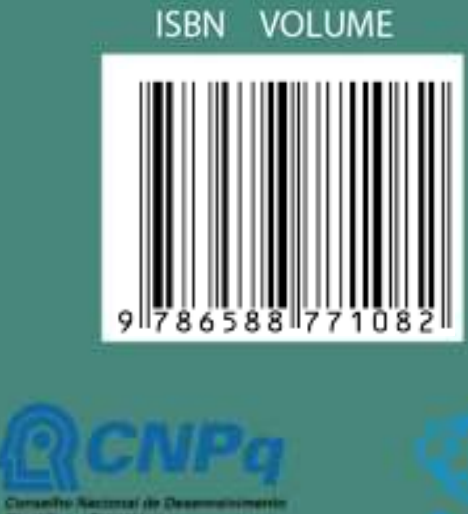

ISBN COLECCĀO

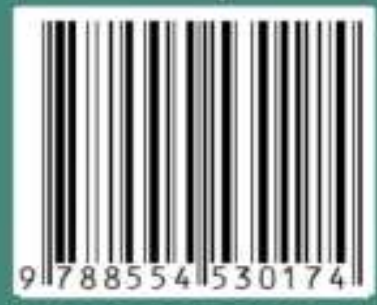

IC Uni-FACEF
$10.29327 / 531527$

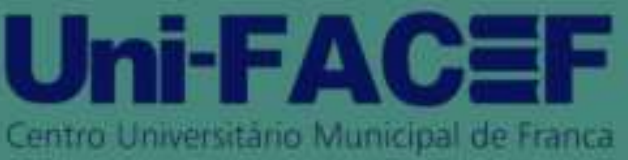


Sheila Fernandes Pimenta e Oliveira

Daniel Facciolo Pires

Marinês Santana Justo Smith

Sílvia Regina Viel

Welton Roberto Silva (Orgs.)

FRANCA

Uni-FACEF

2020 


\title{
Corpo Diretivo
}

\author{
REITOR \\ Prof. Dr. José Alfredo de Pádua Guerra \\ VICE-REITOR \\ Prof. Dr. Alfredo José Machado Neto \\ PRÓ-REITORA DE ADMINISTRAÇÃO \\ Prof ${ }^{a}$. Dra . Melissa Franchini Cavalcanti Bandos \\ PRÓ-REITORA ACADÊMICA \\ $\operatorname{Prof}^{\mathrm{a}}{ }^{\mathrm{Dr}}{ }^{\mathrm{a}}$ Sheila Fernandes Pimenta e Oliveira
}

PRÓ-REITORA DE EXTENSÃO, CULTURA E DESENVOLVIMENTO COMUNITÁRIO Prof ${ }^{a}$. Ma. Flávia Haddad França

PRÓ-REITOR DE PESQUISA E PÓS-GRADUAÇÃO e COORDENADOR DE PÓS-GRADUAÇÃO LATO SENSU Prof. Dr. Sílvio Carvalho Neto

COORDENADOR DE PÓS-GRADUAÇÃO STRICTO SENSU

Prof. Dr. Paulo de Tarso Oliveira

COORDENADORA PEDAGÓGICA

Prof ${ }^{\mathrm{a}}$ Dr ${ }^{\mathrm{a}}$ Edna Maria Campanhol

COORDENADORA DE MARKETING

Prof $^{a}$ Ma. Alba V. Penteado Orsolini

ASSESSOR JURÍDICO

Prof. Me. Paulo Sérgio Moreira Guedine

CHEFE DE DEPARTAMENTO DO CURSO DE ADMINISTRAÇÃO

Prof. Me. Cyro de Almeida Durigan

CHEFE DE DEPARTAMENTO DO CURSO DE CIÊNCIAS CONTÁBEIS

Prof. Me. Orivaldo Donzelli

CHEFE DE DEPARTAMENTO DO CURSO DE CIÊNCIAS ECONÔMICAS

Prof ${ }^{a}$. Ma. Ana Tereza Jacinto Teixeira

CHEFE DE DEPARTAMENTO DO CURSO DE COMUNICAÇÃO SOCIAL - Publicidade e Propaganda Prof. Ma. Fúlvia Nassif Jorge Facuri

CHEFE DE DEPARTAMENTO DO CURSO DE ENFERMAGEM Prof $\stackrel{\text { a }}{\text {. Dra }}$. Lívia Maria Lopes Gazaffi

CHEFE DE DEPARTAMENTO DO CURSO DE ENGENHARIA CIVIL Prof. Me. Anderson Fabrício Mendes

CHEFE DE DEPARTAMENTO DO CURSO DE ENGENHARIA DE PRODUÇÃO

Prof. Dr. Flávio Henrique de Oliveira Costa

CHEFE DE DEPARTAMENTO DO CURSO DE LETRAS

Prof $^{\mathrm{a}} \mathrm{Dr}^{\mathrm{a}}$ Ana Lúcia Furquim de Campos-Toscano

CHEFE DE DEPARTAMENTO DO CURSO DE MATEMÁTICA

Prof. Dr ${ }^{a}$ Sílvia Regina Viel

CHEFE DE DEPARTAMENTO DO CURSO DE MEDICINA

Prof ${ }^{a}$ Dr. Frederico Alonso Sabino de Freitas

CHEFE DE DEPARTAMENTO DO CURSO DE PSICOLOGIA

Prof ${ }^{\mathrm{a}} \mathrm{Dr}^{\mathrm{a}}$ Maria de Fátima Aveiro Colares

CHEFE DE DEPARTAMENTOS DOS CURSOS DE SISTEMAS DE INFORMAÇÃO, ENGENHARIA DE SOFTWARE e CIÊNCIA DA COMPUTAÇÃO

Prof. Dr. Daniel F. Pires 


\section{Comissão Científica}

Sheila Fernandes Pimenta e Oliveira (Uni-FACEF)

Daniela de Figueiredo Ribeiro (Uni-FACEF)

Melissa F. Cavalcanti Bandos (Uni-FACEF)

Bárbara Fadel (Uni-FACEF)

Sílvia Regina Viel (Uni-FACEF)

Marinês Santana Justo Smith (Uni-FACEF)

Ana Lúcia Furquim Campos-Toscano (Uni-FACEF)

Daniel F. Pires (Uni-FACEF)

Sílvio Carvalho Neto (Uni-FACEF)

Emerson Rasera (UFU)

Renato Garcia de Castro (UNICAMP)

Pedro Geraldo Tosi (UNESP)

Vânia de Fátima Martino (UNESP)

\section{Comissão Organizadora}

José Alfredo de Pádua Guerra

Alfredo José Machado Neto

Sheila Fernandes Pimenta e Oliveira

Melissa Franchini Cavalcanti Bandos

Sílvio Carvalho Neto

Marinês Santana Justo Smith

Sílvia Regina Viel

Welton Roberto Silva

Noemia Lopes Toledo

Lucas Antônio Santos

Alexandre Manoel Pereira

Édney Wésley Antunes 
(C) 2020 dos autores

Direitos de publicação Uni-FACEF

www.unifacef.com.br

Coleção: Ciência e Desenvolvimento, v. 13.

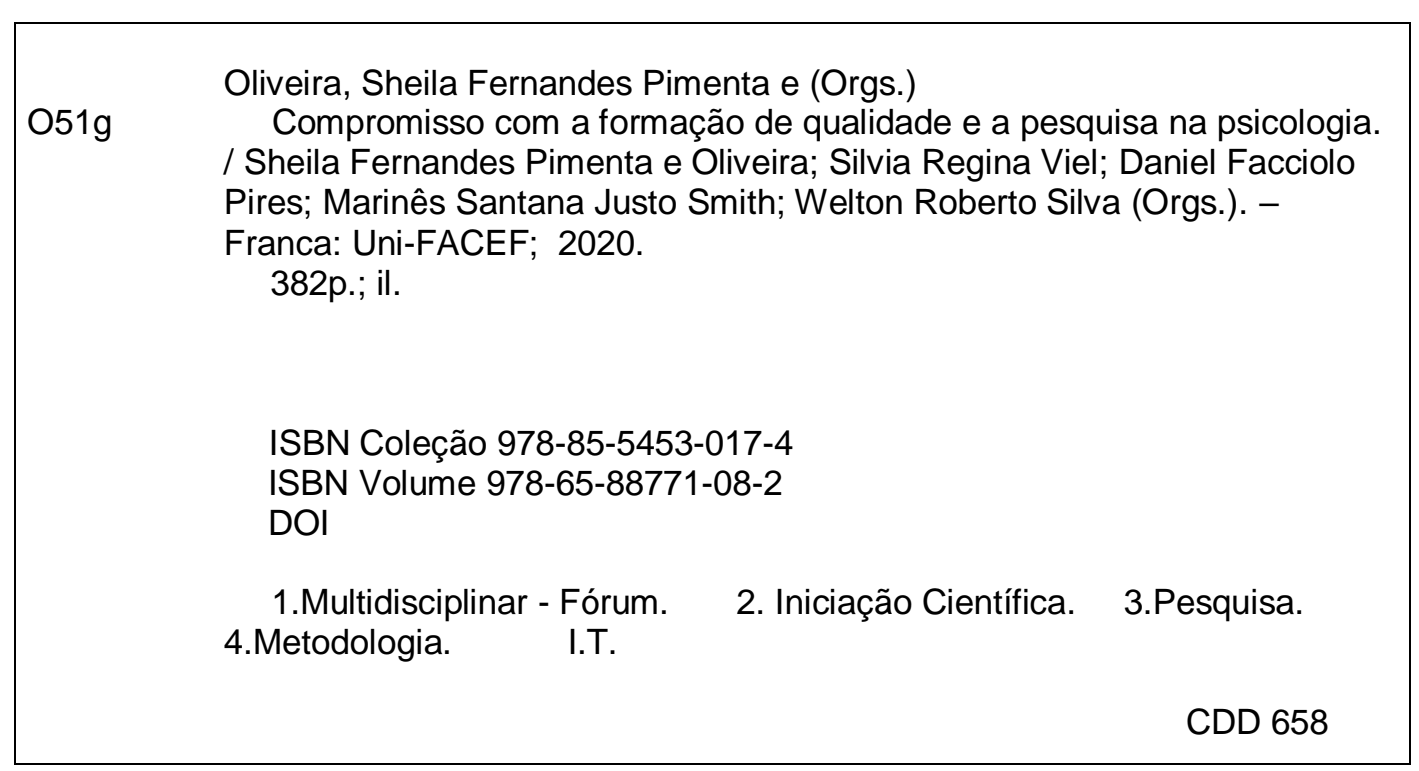

TODOS OS DIREITOS RESERVADOS.

É proibida a reprodução total ou parcial, de qualquer forma ou por qualquer meio. A violação dos direitos de autor (lei no. 9.610/98) é crime estabelecido pelo artigo 184 do código Penal. Todo o conteúdo apresentado neste livro é de responsabilidade exclusiva de seus autores.

Editora Uni-FACEF Centro Universitário Municipal de Franca

Associada à ABEC - Associação Brasileira de Editores Científicos 


\section{PREFÁCIO}

A pesquisa, na área da Psicologia, vem sendo valorizada no UniFACEF desde a criação do curso de Psicologia na IES (2005), com incentivo dos docentes do curso e da IES em dar apoio, orientando, buscando bolsas de fomento aos estudantes interessados em investir seu tempo de formação nessa atividade e até promovendo eventos científicos anualmente, para estimular a apresentação e a publicação dos trabalhos produzidos pela comunidade acadêmica.

Um dos marcos da valorização da pesquisa no Uni-FACEF, e mais especificamente no curso de Psicologia, é a motivação da criação do Comitê de Ética em Pesquisa na IES. Em 2006, em virtude de uma solicitação da FAPESP, como último pré-requisito para aprovação de bolsas de fomento de Iniciação Científica para projetos elaborados por estudantes do curso de Psicologia, a IES se mobilizou para criação de um Comitê de Ética em Pesquisa próprio. Já vislumbravam que muitas pesquisas seriam produzidas na Instituição, desde Iniciação Científica, passando pelos Trabalhos de Conclusão de Curso, até as pesquisas de Mestrado, portanto era preciso criar condições para garantir a eticidade das mesmas. Desde então, com a aprovação do Comitê de Ética em Pesquisa do Uni-FACEF, pela Comissão Nacional de Ética em Pesquisa (CONEP) dezembro de 2006 até hoje, o maior número de protocolos de pesquisas submetidos para apreciação é do curso de Psicologia.

O incentivo institucional e dos docentes pela pesquisa no curso de Psicologia teve frutos entre o corpo discente, que tem procurado as bolsas de fomento à pesquisa como estratégia para aprofundar seus estudos e melhorar suas condições de construir e desenvolver projetos capazes de responder às suas questões acerca do fenômeno psicológico. Nesse sentido, cabe ressaltar - elevado número de projetos de pesquisa anualmente submetidos e aprovados nos processos seletivos para concessão de bolsas do $\mathrm{CNPq}$ e bolsas do Uni-FACEF na área da Psicologia.

Em 2020, quinze anos depois de sua criação, podemos considerar que o curso de Psicologia do Uni-FACEF conseguiu se consolidar como um curso engajado com a produção de conhecimento e a formação de profissionais de qualidade. $O$ papel da pesquisa nessa formação de qualidade 
é muito discutido na literatura, uma vez que a construção ativa conhecimento motiva o aprendizado ao questionamento, ao pensamento crítico e à apropriação do conhecimento, bem como à consequente formulação de novas questões a serem respondidas. O mundo e o ser humano, como uma parte desse grande e complexo sistema, estão em constante mudança, portanto não basta um curso que "ensine" a replicar o conhecimento consolidado, mas que também incite o profissional em formação a desenvolver conhecimento.

Esse e-book reúne artigos escritos por estudantes e bolsistas de Iniciação Científica do curso de Psicologia, sob a orientação de docentes, que versam sobre diversas temáticas e que contribuem para o conhecimento em diferentes áreas da Psicologia. Os artigos apresentados, a seguir, foram desenvolvidos, a partir que questões que intrigam nossos estudantes, que foram motivadoras para o desenvolvimento de pesquisas bibliográficas e de campo. Também temos artigos que são decorrentes de enfrentamentos realizados nas práticas de estágio curriculares, em que os estudantes se debruçaram em problemáticas complexas da psicologia e desenvolveram contribuições relevantes e que merecem ser compartilhadas com outros profissionais.

Finalizo parabenizando os autores pela produção e convidando os leitores a conhecerem contribuições tão significativas, em um momento crítico, para a produção científica na área das ciências humanas e sociais em nosso país. Felizmente o Uni-FACEF continua apoiando efetivamente as pesquisas na área!

Prof $=$ Dr ${ }^{a}$ Maria Cherubina de Lima Alves Docente Uni-FACEF Centro Universitário Municipal de Franca 


\section{SUMÁRIO}

A CARTOGRAFIA DE UMA RELAÇÃO FAMÍLIA-ESCOLA EM UM CONTEXTO ESCOLAR DE VIOLÊNCIA

A CONSOLIDAÇÃO DA AUTOESTIMA EM CRIANÇAS COM CICATRIZES CIRÚRGICAS, A PARTIR DA TERCEIRA INFÂNCIA

A DOCILIZAÇÃO DOS CORPOS: repressão sexual e a potencialidade da masturbação e do orgasmo na emancipação feminina

A INFLUÊNCIA E AS CONSEQUÊNCIAS DE UM DIAGNÓSTICO DE PSICOPATIA NA VIDA DE UM INDIVÍDUO NA SOCIEDADE ATUAL

A PERSPECTIVA DA EQUIPE TÉCNICO-ADMINISTRATIVA DE UMA ESCOLA ESTADUAL ACERCA DA VIOLÊNCIA ESCOLAR: uma pesquisa etnográfica.

ADOLESCÊNCIA: um ser biopsicossocial

ALZHEIMER: um estudo teórico acerca da doença e os malefícios que ela causa a memória.

APLICAÇÕES TEATRAIS NO DESENVOLVIMENTO PESSOAL DE PACIENTES COM TRANSTORNOS PSÍQUICOS

AQUISIÇÃO DE ESTEREÓTIPOS DE GÊNERO NA INFÂNCIA: uma análise do relato materno

AS PRÁTICAS EDUCATIVAS PARENTAIS COM CRIANÇAS EM FASE PRÉ-ESCOLAR: análise no contexto da cibercultura

COMO A MÍDIA IMPACTA NA NEGAÇÃO DO ENVELHECIMENTO HUMANO NOS DIAS ATUAIS

COMPREENDENDO O TRANSTORNO DA CONDUTA: uma análise sobre o caso de Mary Bell.

HÁBITOS E PADRÕES DE COMPORTAMENTO: zona de conforto.

MULHERES DA ATUALIDADE E ARQUÉTIPOS DAS DEUSAS

MÚSICAS BRASILEIRAS ATUAIS: um retrato do machismo na cultura 209 
O CORPO NA PSICANÁLISE: genealogia do conceito e crítica a partir de uma perspectiva de gênero

O NARCISISMO E O RELACIONAMENTO ABUSIVO: UMA ASSOCIAÇÃO 238

O PAPEL DOS AVÓS: importância desta relação para o desenvolvimento dos avós e dos netos.

O SILÊNCIO E A NEGAÇÃO DO ABUSO SEXUAL INFANTIL INTRAFAMILIAR

PERCEPÇÕES DE ADOLESCENTES SOBRE A INFLUÊNCIA PARENTAL NA ESCOLHA PROFISSIONAL

PESQUISA ETNOGRÁFICA COM ALUNOS DOS ANOS FINAIS DO ENSINO FUNDAMENTAL: perspectivas acerca das violências no contexto escolar.

PESQUISA-INTERVENÇÃO SOCIODRAMÁTICA COM PROFESSORES: as violências na escola

RELAÇAO MATERNA EM GAROTAS ANORÉXICAS: análise fílmica

REVISÃO DOS IMPACTOS DO ABANDONO AFETIVO ENTRE PAIS E FILHOS PELO USO DA TECNOLOGIA.

TRANSTORNO DISSOCIATIVO DE IDENTIDADE ASSOCIADO A EVENTOS TRAUMÁTICOS: um recorte sobre o longa metragem O Segredo de Marrowbone

"TRATAMENTO" DE CONVERSÃO DA HOMOSSEXUALIDADE E A PERPETUAÇÃO DA CULTURA HOMOFÓBICA 355

VIOLÊNCIA E ABUSO SEXUAL: sua repercussão na vida da mulher 366 ÍNDICE 


\section{A CARTOGRAFIA DE UMA RELAÇÃO FAMÍLIA-ESCOLA EM UM CONTEXTO ESCOLAR DE VIOLÊNCIA}

Gabriela Maia de Almeida

Daniela de Figueiredo Ribeiro

\section{INTRODUÇÃO}

A literatura aponta que a relação família e escola é um tema ainda necessita de estudos. A relação entre ambas as instituições é fundamental para a formação psicossocial da criança e do adolescente. Apesar de diversos autores (RIBEIRO 2004; DESSEN E POLONIA 2007; ABRAMOWICZ 2013; CORTELLA 2014; VIDOTTI, 2017) apontarem que a participação da família na educação é de suma importância, percebe-se ainda, que a presença da violência, estigmas, preconceitos, ausência de vínculo e de relação tornam essa aproximação distante.

Neste sentido Dove, Zorotovich e Gregg (2018) concebem a relação família e escola mensurando o sentimento de conectividade e adesão das famílias a escola e o nível de envolvimento e participação na comunidade escolar. Para os autores pensar em comunidade escolar é incluir os familiares, professores, administradores e políticas escolares, que corresponde a um sistema que influencia a aprendizagem e o desenvolvimento das crianças na escola.

A relação família-escola também foi abordada por Dessen e Polonia (2007), apontando que o vínculo entre ambas implica no desenvolvimento social e cognitivo, bem como contribuem para o sucesso escolar do aluno. A pesquisa caracterizou o contexto familiar e escolar como espaços afetivos para a aprendizagem e o desenvolvimento humano e que há uma diferença entre as duas instituições, sendo a escola responsável pelo processo de ensino e aprendizagem e a família pelo processo de socialização, as condições básicas de sobrevivência e o desenvolvimento social, cognitivo e afetivo. Assim como Dove, Zorotovich e Gregg (2018), os autores reconheceram a relação família e escola como uma possibilidade de apoio e transformação.

Para Cortella (2014) o contexto escolar e familiar está misturado atualmente, não há um limiar que posicione a função de cada instituição. A ideia de cooperação como valor na relação família e escola é uma perspectiva de construção de pessoas, ou seja, está além da formação aluno, ela passa por uma formação cidadã apoiada pelas duas instituições fundamentais na vida das crianças e adolescentes. Além disso, ressalta-se que os valores transmitidos nas escolas e nas famílias são diversos e responsáveis pela formação de cidadãos, por isso, ambas devem coexistir sem gerar um ciclo de 
culpas, mas sim construção de valores sociais e respeito entre as múltiplas perspectivas.

No mesmo sentido, Ribeiro (2004) realizou apontamentos similares há quase 12 anos atrás. Notou-se que a relação família e escola passa pela hierarquização e assunção de papéis sociais estereotipados. Observou-se ainda, que a dinâmica perpetuada no contexto escolar provoca a exclusão de classes sociais populares, em que parte delas está localizada na escola pública.

Na mesma perspectiva de Ribeiro (2004), Vidotti (2017) também compreendeu que a escola possui um modelo de família ideal no qual os papéis sociais são estereotipados. Há uma falsa crença de comprometimento que foi revelada no estudo, porque através das entrevistas com os pais observou-se que eles possuíam interesse pela vida escolar de seus filhos e interesse em poder fazer parte da dinâmica escolar. Ações como atrair a participação das famílias, por meio de eventos, por exemplo, dia das mães, festa junina ou apresentações colaboraram para a aproximação e formação de vínculo com a escola, no sentido de estabelecer uma comunicação democrática. Entretanto, há diversos desencontros entre a família e a escola por não comporem uma equipe de gestores e educadores preparados para 0 acolhimento e ainda o vício da escola em procurar a família como apoio para questões de falhas na aprendizagem e problemas de disciplina. (VIDOTTI, 2017).

Além dos desencontros, ciclos de culpa e insatisfação de ambas as instituições se observou na pesquisa de Ribeiro (2019) a violência dentro do contexto escolar. Este agravante provocou o êxodo escolar de 38.126 crianças nos anos finais do fundamental. Neste sentido mapear a violência proporciona 0 reconhecimento do tipo de relação entre a família e a escola, por exemplo, e como ambas as instituições lidam com a diversidade. As questões relacionadas às práticas violentas, o clima escolar, as relações escolares, permitem uma análise do fenômeno de discriminação e estigmatização presente no contexto escolar entre os agentes escolares.

Ainda, pensando no enfrentamento da violência do contexto escola, as pesquisas de Abramowicz (2013) e Silvério (2013) discutem pontos fundamentais da exclusão social brasileira e a sua relação violenta com a diversidade, que reverbera na relação família e escola. Além disso, refletem sobre como as transformações do final do período do autoritarismo brasileiro transformaram o campo social em segmentos considerados discriminativos e estigmatizados em relação à diversidade cultural.

Abramovay e Rua (2003), também apontaram que a violência nas escolas, possui inúmeras complexidades e multifaces. No passado, a percepção de violência no contexto escolar se continha na relação professor e aluno, em punições e castigos, atualmente há uma expansão da violência escolar. Esta se faz presente nas relações professor e aluno, aluno e aluno, 
família e escola e no âmbito institucional. Além disso, aponta-se a violência como uma temática para além da violência física, incluindo assim a ética, política e a violência simbólica. A conjuntura desse paradigma novo de violência dá visibilidade para compreender o contexto escolar atual brasileiro.

$\mathrm{Na}$ perspectiva do reconhecimento da singularidade, respeito a diversidade e o cuidado com o vínculo, pode-se constituir o espaço escolar como um ambiente de despertar para a humanização. Para isso, a escola precisa ser reconhecida como um espaço de pertencimento para todos, de dimensões múltiplas, compartilhadas pela família, alunos, gestores e professores. Compreende-se que a escola, sem dúvidas pode se constituir como um espaço de produção subjetiva da violência, no entanto quando a comunidade rejeita a produção é possível produzir afetos nas relações e construir uma subjetividade social sem reproduzir a violência do panorama mundial. Sendo assim, o objetivo deste estudo foi compreender aspectos da relação família-escola em um contexto escolar público com queixas de violências em seu cotidiano. Além disso, observar o cotidiano escolar e as situações de interação família-escola, para obter indicação de famílias para a fase de intervenção e entrevista. Buscou-se também, proporcionar um espaço para a escuta das famílias envolvidas em situações de violência e compreender a relação entre uma família indicada pela escola com envolvimento em situações de violências e a diretora da escola.

\section{METODOLOGIA}

Este estudo caracteriza-se como uma pesquisa-intervenção de natureza qualitativa. Esta visa entender e compreender os significados nas ações comportamento dos sujeitos que participam do estudo respondendo a questões muito particulares (MINAYO, 1994, p. 22). Além desta característica este trabalho também se propôs a desenvolver uma pesquisa-intervenção que é concebida como um conhecimento de ação sobre a realidade, construída no curso da pesquisa com a presença ativa da comunidade participante do processo e o pesquisador. "A noção de qualitativo aqui está ligada aos sentidos produzidos nas relações, nas turbulências da alteridade, que podem promover diálogo, análise e compreensão do que se vive". (RIBEIRO, 2018, p.10).

Como método de condução da pesquisa-intervenção, optou-se pelo Psicodrama, teoria criada pelo psiquiatra romeno Jacob Levy Moreno. Para Contro (2006) o Psicodrama busca a transformação social, aproximandose tanto da pesquisa-intervenção como da pesquisa-ação crítica. $O$ pesquisador acompanha a singularidade dos modos de subjetivação, e não visa à obtenção de um resultado a ser interpretado.

Utilizou-se, ainda, nessa pesquisa, a etnografia. Vidotti (2017) compreende que o modelo etnográfico na pesquisa qualitativa tem enfoque no 
comportamento social no cenário e contexto onde ocorrem as observações, interpretações e vivências. Para Ribeiro (2004) a abordagem etnográfica permite uma investigação sistemática das situações do cotidiano observado e vivenciado pelo pesquisador. Ressalta também que por meio da abordagem se obtém uma compreensão profunda sobre a visão dos sujeitos sobre o meio social que os circundam.

Outra característica deste estudo foi aproximação com o método da cartografia. Para Passos, Kastrup e Tedesco (2015) a pesquisa de campo requer a habitação de um território que, em princípio, não é habitado pelo pesquisador. Nesta medida, a cartografia se aproxima da pesquisa etnográfica e lança mão da observação participante. O pesquisador mantém-se no campo em contato direto com as pessoas e seu território existencial. O tipo de atividade e o grau de envolvimento do pesquisador variam, dependendo do grupo, podendo ir da observação participante à participação observante. Além de observar, o etnógrafo participa, ao mesmo tempo modifica e vai sendo modificado pela experiência etnográfica. $O$ cartógrafo mergulha nas intensidades do presente para dar voz aos afetos que pedem passagem, indo além da tarefa do etnógrafo.

A pesquisa foi realizada em uma escola Estadual localizada num bairro periférico de uma cidade do interior de São Paulo, que apresentava queixas de violências no cotidiano escolar como depredação, vandalismo, brigas, desinteresse, e dificuldades na relação entre a família e escola. Em 2019 iniciou-se uma intervenção com o objetivo de favorecer a participação da família no contexto escolar, investigar as violências vivenciadas no cotidiano e aproximar a relação família-escola com o projeto de intervenção "Cinema na escola". O estudo caminhou junto ao estágio de Psicologia Escolar de uma Universidade do interior de São Paulo.

A pesquisadora responsável e supervisora do estágio conduzia uma pesquisa maior, "Enfrentamento das violências e melhoria da convivência escolar nos anos finais do ensino fundamental: Uma pesquisa-intervenção sociodramática". Foi desta pesquisa, em conjunto com o estágio, que foram desenvolvidas outras frentes de pesquisa que propunham enfrentamentos das violências. Entre essas frentes, observou-se a necessidade de investigar a relação com as famílias. Além disso, pesquisa maior contou com a presença de uma equipe de 18 estagiárias, uma pesquisadora de mestrado, quatro pesquisadoras da graduação, uma pedagoga psicodramatista e a pesquisadora responsável, que orientava a intervenção preparando o grupo para o papel de estagiário e pesquisador. $O$ grupo se reunia semanalmente por 4 horas para discussões, supervisões e orientações.

Durante a pesquisa com as famílias foram visitadas 28 casas. 0 primeiro grupo visitado, o de alunos indicados por queixa violência na escola, tiveram 18 indicações de alunos do ensino fundamental e 5 indicações de 
alunos do ensino médio, todas as indicações da escola partiram das queixas de violência com as quais os alunos se envolviam. No entanto apenas uma família se mostrou disposta a falar sobre o tema e por isso foi escolhida para a pesquisa. Essa é a família de Maria (nome fictício) teve três de seus filhos indicados pela escola por queixa de violência, Beto, Bruna e Bianca (nomes fictícios). A família foi acompanhada por cerca de cinco meses. Foram realizadas duas entrevistas com Maria e sua família e uma entrevista com a diretora da escola que acompanhou todo o processo da pesquisa.

As visitas à escola e às casas das famílias de alunos indicados foram registradas em um diário de campo. Nele foram descritas informações sobre os aspectos socioeconômicos, culturais e as percepções da pesquisadora e a estagiária em cada encontro. Além disso, contém os avanços e frustrações vivenciados no projeto e na pesquisa, bem como as mudanças adotadas ao longo do processo.

Nas entrevistas realizadas com a família escolhida para a pesquisa e a diretora, utilizou-se a entrevista cartográfica. Segundo Tedesco, Sade e Caliman (2015) a cartografia "requer que a escuta e o olhar se ampliem, sigam para além do puro conteúdo da experiência vivida, do vivido da experiência relatado na entrevista". O pesquisador fica atento para perceber as pistas, as expressões faciais, a hesitação e o discurso que não é linear.

É importante ressaltar também, que foram apresentados cartões com os temas nas três entrevistas de profundidade. O emprego desta estratégia de entrevista tem sido utilizado nas pesquisas do Grupo de Estudos e Pesquisas "Subjetividade e Educação" - GEPSEd, coordenado pelo Prof. Dr. Antônio dos Santos Andrade, desde 2002 (vide Carraro, 2003; Silva, 2003; G; Luciano, 2006; Peres, 2006 e Carraro, 2008) e já foram realizadas diversas pesquisas com este método. Além disso, antes de iniciar as entrevistas foi apresentado o Termo de Consentimento Livre e Esclarecido e, só após a assinatura do termo a entrevista se iniciou, sendo também aprovados no Comitê de Ética em Pesquisa sob o CAAE 08975119.6.0000.5384.

Para Passos, Kastrup e Tedesco (2015), a experiência cartográfica está em se implicar, cultivar uma posição de estar com a experiência e não sobre esta. A cartografia introduz o pesquisador numa rotina singular em que não se separa teoria e prática, espaços de reflexão e ação. $O$ conhecer e o agir passam a habitar uma experiência comum e não mais distintas. E uma das tarefas principais para a análise da pesquisa é sustentar a abertura para multiplicidade de sentidos e percepções, que se dá ao longo do processo. Do ponto de vista teórico, na Pesquisa Cartográfica se assume na coleta e análise, aspectos do cartografo aprendiz. "A investigação é cuidado ou cultivo de território existencial no qual o pesquisador e o pesquisado se encontram". Ao longo do processo de pesquisa, procura ter um olhar para a 
singularidade e não a generalidade dos dados (PASSOS, KASTRUP E TEDESCO, 2015).

Segundo Barbosa (2020), para efetivar a pesquisa cartográfica e seu tipo de análise, após as transcrições dos áudios gravados durante as entrevistas, deve-se submeter às mesmas a leituras sucessivas. Primeiro, para buscar apreender os múltiplos sentidos que cada entrevistado apresenta em sua fala sobre cada tema. O segundo, nas releituras das transcrições, observar as experiências vivenciadas e afetos expressos. Para o presente estudo, buscou-se seguir esta mesma metodologia.

\section{RESULTADOS}

O primeiro contato com a escola foi em 2018. A diretora recorreu a uma parceria com o Estágio de Psicologia Escolar na tentativa de transformar o ambiente da escola. Neste ano, a escola estava depredada, além disso, possuía um alto índice de violência entre a comunidade escolar. No início de 2019, o ambiente da escola estava completamente diferente. Carteiras e portas foram recolocadas, vidros trocados e as paredes haviam sido pintadas. Para este ano, a proposta do estágio era dar continuidade a um projeto já iniciado em $2018 \mathrm{com}$ as crianças e adolescentes da escola. Foi proposto a formação de grupos com os alunos do Ensino Fundamental, assim como grupos com os professores e familiares.

Nas supervisões os estagiários e pesquisadores foram preparados pelas supervisoras para a formarem os grupos. Foram realizados estudos sobre a violência e seus múltiplos aspectos, vivências sociodramáticas e reflexões cerca das estratégias adotadas pelos grupos de intervenção. Inicialmente para o trabalho com as famílias a pesquisadora e a estagiária que acompanhou a pesquisa criaram em conjunto com as supervisoras um projeto de intervenção chamado: "Cinema na escola". O projeto seria uma forma de aproximar a relação família escola, trabalhando com trechos de filmes e animações.

O sociodrama foi a metodologia de condução de grupo para criar um espaço de expressão, criatividade, espontaneidade e transformação para os pais e responsáveis dentro do ambiente escolar. Para trazer os pais para a escola, inicialmente se pensou na construção de vínculos. Portanto, a pesquisadora e a estagiária visitaram as famílias indicadas pela escola, tanto por serem parceiras quanto aquelas que tinham queixas ligadas a violência escolar, tema da pesquisa.

Todas as famílias dos alunos indicados foram visitadas pelo menos uma vez. Conforme foram ocorrendo as visitas, a pesquisadora e a estagiária tentavam se aproximar das famílias, retornando as visitas para levarem convites para o Cinema na Escola e para tentarem se vincular com o 
seu contexto, porém apenas uma família se mostrou aberta a participar do projeto e a conversar sobre a relação família e escola.

Além dos alunos indicados pela escola, também foi sugerido pela supervisora uma outra abordagem. Visitar mães indicadas pela escola. No total 5 mães foram indicadas pela diretora como parceiras e participativas. A pesquisadora e a estagiária fizeram visitas às casas e telefonaram para as mães na tentativa de formar vínculo, porém nenhuma se mostrou disposta a participar do projeto Cinema na Escola ou da pesquisa.

Observamos, que a falta de maior investimento e apoio no projeto por parte da escola, que no ano de 2019, passava por diversas mudanças de cunho governamentais dificultou a realização do projeto. A diretora se mostrava disposta a ajudar e a colaborar, no entanto notou-se que ela dispunha de pouco tempo e energia para outras questões, além das mudanças que a escola passava e as inúmeras queixas de violência.

Além disso, não se teve adesão dos pais e responsáveis dos dois grupos, tornando difícil viabilizar essa iniciativa de aproximação entre a relação família e escola, através do Cinema na Escola. Desse modo, passou-se a pensar em outro modo de intervir. A pesquisadora e a estagiária continuaram a visitar a casa da família escolhida para a pesquisa. Essa é a família de Maria (nome fictício) que teve três de seus filhos indicados pela escola por queixa de violência, Beto, Bruna e Bianca (nomes fictícios). A família foi acompanhada por cerca de cinco meses. Foram realizadas duas entrevistas com Maria e sua família.

Maria e sua família foram os únicos que se mostraram dispostos a participarem da pesquisa. Foi durante as visitas às casas para divulgação do projeto Cinema na Escola que a pesquisadora e a estagiária conheceram a mãe e sua família. Foram realizados sete encontros com a mãe, sendo que dois deles a pesquisadora se encontrou com a família reunida. Durante os cinco meses de visitas a casa de Maria, a pesquisadora participou da vida escolar dos três filhos indicados pela escola com queixa de violência. A mãe relatava a situação da relação família-escola em sua perspectiva, desabafando e expondo sentimentos e emoções. Além de visitar a casa de Maria era rotineiro a pesquisadora e a estagiária visitarem a escola para conversarem com a diretora sobre as estratégias de aproximação na relação família e escola. Nestas visitas foram acompanhadas diversas queixas de violência dentro da escola, muitas vezes a família de Maria era mencionada. Inicialmente a intervenção que era voltada para o projeto Cinema na Escola passou a ter um foco diferente, no qual a pesquisadora passou a compreender uma relação singular entre família-escola.

Para compreender essa relação família-escola foram realizadas entrevistas com a diretora e a família de Maria. Buscou-se criar três momentos durante a entrevista. O primeiro de interação e envolvimento entre a 
pesquisadora e os integrantes da pesquisa, que era uma preparação ou aquecimento. O segundo momento, que se explicava como funcionaria a entrevista, que ela seria gravada e depois transcrita pela pesquisadora. $O$ terceiro momento, após a permissão dos entrevistados, eles eram incentivados a discorrerem livremente sobre os temas.

Nas entrevistas realizadas com a família escolhida para a pesquisa e a diretora, utilizou-se a entrevista cartográfica. Segundo Tedesco, Sade e Caliman (2015) a cartografia "requer que a escuta e o olhar se ampliem, sigam para além do puro conteúdo da experiência vivida, do vivido da experiência relatada na entrevista". O pesquisador fica atento para perceber as pistas, as expressões faciais, a hesitação e o discurso que não é linear.

Esse olhar para a singularidade foi nascendo ao longo do estudo e suas mudanças. A parceria e os vínculos foram se estabelecendo ao longo de um processo. O Cinema na Escola não aconteceu como uma estratégia de intervenção e aproximação entre as famílias, contudo proporcionou a aproximação da pesquisadora com um contexto e uma relação família-escola singular. Durante o projeto observou-se dificuldades de relação entre escola e as famílias.

Ao entrarmos em contato com as entrevistadas e seus temas, percebeu-se que a situação de violência é vivenciada por ambas as partes, escola e família. A complexidade da relação está para além de cumprimento de metas, notas, comportamento, entre outras. O contexto vivenciado pela pesquisadora durante as visitas às casas de alunos indicados, a casa da família escolhida e à escola apresentou situações de violência institucional, no bairro, dentro da família e dentro da escola.

Notou-se na fala da diretora e ao longo da pesquisa as mudanças no ano de 2018 para 2019, porém uma dificuldade em sustentar a transformação.

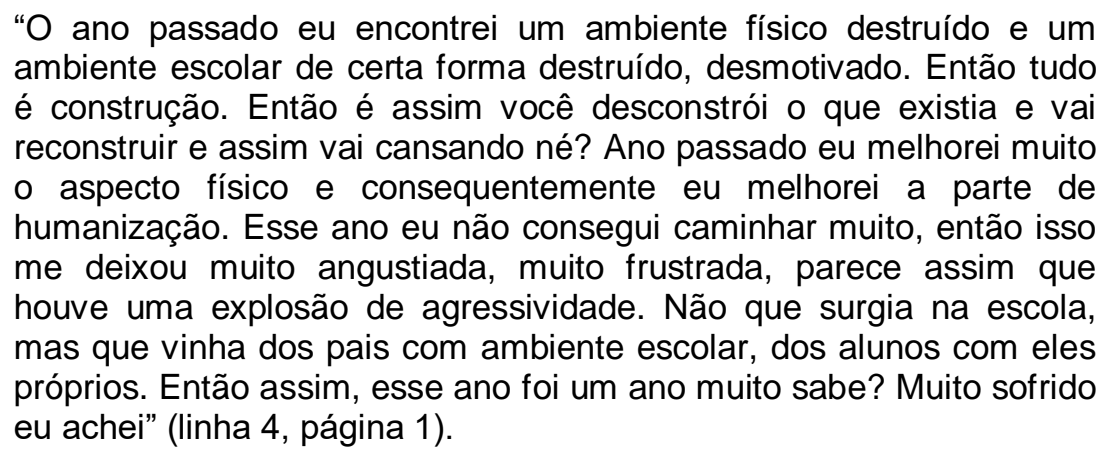

Além disso, observaram-se as tentativas de relação entre a escola e a família, a percepção sobre a necessidade de judicialização da relação, além dos conflitos recorrentes de violência na escola.

"Alunos que sofrem agressões em casa, uso de drogas na família, então assim é muito né? Um peso muito grande, porque eu tenho que 
olhar o pedagógico, eu tenho que olhar o aluno, eu tenho que respeitar as diferenças dele, mas ao mesmo tempo eu tenho que exigir uma postura" (linha 4, página 1).

Ainda, a diretora expôs o seu sofrimento e impotência frente a complexidade do seu trabalho, demonstrando o desejo de relação com as famílias e uma educação que deveria ser por amor. Apreende-se a busca por estar junto e próxima das famílias, entretanto as tentativas de aproximação são frustradas pela falta de energia, de tempo e dos incontáveis problemas de violência no contexto escolar.

\begin{abstract}
"A escola ela é formada por vários...tipo ela tem um lado pedagógico, o lado distrativo que está ligada ao burocrático, sim a questão da família e eu acho precisa muito conscientizar qual é a função da escola. O aluno saiu de casa com qual fundamento? O que ele veio fazer aqui? Acho que falta muito amor do professor. Não são todos os professores porque eu tenho professor que assume e veste a camisa. Mas tem muitas pessoas que tão muito, sabe? Para trabalhar educação você não pode trabalhar pelo valor que você ganha e sim pelo amor que você tem na profissão. De fazer o aluno um cidadão de bem. Então a escola tem que caminhar muito nessa parte. De conseguir levar todo mundo a ter um único olhar, sabe? Caminhar com uma única visão (linha 66, página 10) "Então eu falei eu quero o melhor para o filho de vocês. Eu tento fazer na escola o que eu gostaria que fosse feito para o meu filho. A gente não trabalha aqui só por conta de salário, que pelo salário eu já teria largado isso aqui há muito tempo. Então eu falei muito... é questão de amor, questão de amor as vidas, amor pelo o que faz. A gente não está aqui em vão (linha 16, página 4).
\end{abstract}

Quanto à família escolhida foi possível vivenciar com a mãe o seu contexto e seus enfrentamentos. A pesquisadora pode viver um vínculo com a Maria, escutando abertamente sua perspectiva sobre a relação com a escola, suas preocupações com os filhos e seus problemas já enfrentados na vida.

Apesar dos desencontros entre Maria e Camila (a diretora), observou-se que a mãe falou sobre as mudanças mencionadas pela diretora nos anos de 2018 e 2019 e reconhece a melhora na escola.

\begin{abstract}
"Mais nossa a escola ali, essa em si, no começo eu fiquei com medo eu ia na reunião, carteira não tinha, porta nas salas de aula, era um vandalismo total. Hoje, se você ver essa escola como ela era, faz o que 2 ou 3 anos atrás que eu voltei pra cá, nossa hoje eu tenho confiança de deixar os meus "fios" ir pra escola e ficar tranquila. Mas antes era preocupante" (página 4, linha 54).
\end{abstract}

No entanto em relação aos problemas de violência vivenciados pelos filhos, principalmente Beto, notou-se preocupação na fala da mãe e a dificuldade de comunicação entre a família e a escola.

\footnotetext{
"ah tava. Ai semana passada depois dessa suspensão eu fui lá e conversei com eles. Eu peguei e falei assim oh, toda vez que vocês me liga eu venho, eu compareço, só que eu vim aqui conversei, porque o menino pegou o caderno de desenho dele e não devolveu, o outro menino fica xingando, eles fica catando material dele e fica jogando na sala. Ai ela pegou e falou assim: "- Ah, mais ele não relata
} 
nada disso", ai eu então, diz ele que relata pra professora e a professora não ta resolvendo, ai eu falei na frente da professora, na frente da diretora e peguei e falei assim: eu, autorizei o meu filho o seguinte: a partir de hoje o que acontecer na sala de aula, se ele relatar a professora e ela não resolver, eu autorizo ele a sair da sala imediatamente e procurar a diretora, ou me ligar pra mim vim na hora. Assim quando ele dá "poblema" e eu venho na hora, quando ele tiver problema com alguém aqui eu também quero ser informada. Outra coisa que eu sempre falei, menino todo dia você tem que tá de olho, cê num tem que deixar pra me falar depois que ele fez 4 ou 5 vezes a mesma coisa. Então não deixa chegar no extremo. Ele fez alguma coisa hoje? Manda hoje pra mim! "(página 6, linha 76).

Buscando identificar o sentimento de Maria, que foi chamada pela escola diversas vezes para resolver problemas que os filhos se envolviam, a pesquisadora perguntou como ela se sentia com as ligações e convocações da escola.

"A gente sente mal. Sente mal, porque não é isso que você quer para o seu filho né? Entendeu? Cê luta, cê batalha, cê pega firme para tornar a pessoa de bem. Que nem eu sempre falo pra ele: - Você não precisa me amar, você não precisa ser meu amigo, eu to aqui para te fazer cê ser homem. De caráter, de conduta, responsável e ele me olha, ele para, ele pensa. Só que assim oh, né porque é meus filhos não, eles são uns meninos bons, eles são assim sabe... que nem as meninas é responsável. Que nem sábado o pai dele chamô ele pra ir trabalhar, ele foi e carregou lata de concreto, "e nossa pai..." meu marido contando, "que isso olha, minha mão" (página 7, linha 86).

Outro aspecto importante foi a entrevista que teve a participação de Beto, Bruna e Bianca atores escolares, que até então tinham sido mencionados pela mãe e diretora, mas não haviam sido escutados.

A pesquisadora pode ouvir os protagonistas das conversas com Maria e Camila. Pode-se entender a perspectiva dos conflitos de violência a partir de seus olhares e as suas percepções sobre a relação família e escola.

Bruna: "Ah depois daquela situação lá que a menina me agrediu... (página 6, linha 7) aí ela entrou e falou: "eu preciso conversar com você", aí eu falei: "então fala!". Aí ela começou a discutir comigo falar um monte de coisa... E começou a por a mão ni mim. Aí eu empurrei ela e ela me prensou na mesa apontou o dedo na minha cara e começou a falar um monte de coisas" (página 6, linha79). O professor não fez nada. Ele não tomou nenhuma atitude. Ficou parada olhando e não fez nada. Depois que a minha mãe foi lá na escola e conversou com todo mundo a situação nem foi mais da menina, foi com o diretor e foi com o professor, porque a diretora além focar toda culpa em mim até hoje fica me olhando com o rabo de olho sabe? Ela fica chamando mais atenção minha e eu não sei porque motivo" (página 7, linha 81).

Beto: "assim você só me chamava de macaco, essas coisas, eu contava com o professor e ele não fazia nada. (página 5, linha 63) a sala inteira. Eu falava professor eu posso ir na diretoria falar que tá fazendo bullying comigo? Aí ele falava não e eu ia assim mesmo. Não tava nem ai. Aí eu contava para a diretora e não adiantava de nada também (página 6, linha 65).

Bianca: "Bianca: "eu não gosto da relação escolar. Mas eu acho que tinha que mudar tudo" (página 12, linha 157) o respeito (página 12, 
linha 159) a maioria ali não tem respeito. Tem um menino na minha sala que você precisa de ver. Ele é super homofóbico, ele é homofobico demais da conta, não tem cabimento. Então eu acho que se trabalhasse o respeito com o próximo e todo o ser humano ia ser bom" (página 12, linha 161).

Em síntese, nesta relação família e escola, ambos se sentem impotentes, ambos são vítimas violência institucional. Não há culpados a serem apontados na escola ou na família, mas nota-se uma relação cheia de desencontros, falta de escuta, tentativas frustradas de aproximação e o desejo de Encontro ${ }^{1}$.

\section{DISCUSSÃO}

A pesquisa apresentou a relação de uma família e de uma escola em seu cotidiano. Durante o estudo notou-se algumas singularidades na relação, a dificuldade de ambas se escutarem, os encontros e desencontros entre as instituições, a judicialização da relação e o desejo de relação. Além disso, percebe-se que tanto a escola como a família são vítimas de violências.

Observou-se que a escola ainda possui um perfil de mãe tida como colaborativa e disponível. Como também, notamos que há uma classificação entre os tipos de família na escola, sendo que, a única a aceitar participar da pesquisa era vista como deficitária. Ribeiro (2006) buscou compreender a relação família e escola, tal como vem sendo vivenciada por pais de uma escola pública. Neste estudo, apontou aspectos semelhantes ao que encontramos, a família ainda é estereotipada dentro do ambiente escolar.

Outro aspecto da relação família e escola apontado por Ribeiro (2006) foi a queixa da escola, sobre os pais que mais precisam estar nas reuniões de pais serem ausentes. Este fator também apareceu na fala da diretora como um problema frequente, ela criou diversas estratégias entre elas as reuniões aos sábados e a judicialização para participação desses pais.

A partir desde apontamento, nota-se que a judicialização das relações escolares passou a fazer parte da escola quando os deveres não são cumpridos no universo, pois para a diretora foi a forma mais eficiente de aproximação entre a escola e a família. Chirispino e Chirispino (2008) abordaram a questão da judicialização, principalmente para situações de violência entre alunos, entre professor e aluno, obrigações de guarda e vigilância, danos morais, entre outros. A Judicialização foi considerada um fenômeno nas relações escolares, devido a sua frequência dentro do contexto escolar.

Outro ponto relevante sobre as dificuldades na relação família e escola, diz respeito ao predomínio de desencontros nesta parceria. O desejo

\footnotetext{
${ }^{1}$ O convite moreniano é uma espécie de convocação, é apelo para a sensibilidade do próximo. É convite para a vivência simultânea e "bi-empática", enfim télica. É apelo da espontaneidade (GONÇALVES, WOLFF E ALMEIDA, 1988).
} 
de relação de Camila e Maria, as tentativas frustradas de aproximação para resolução de conflitos e ambas as partes possuírem dificuldade de se escutarem, apresenta uma relação marcada por falhas principalmente na comunicação. Vidotti (2017) compreendeu a maneira como os professores e gestores percebem a relação entre família-escola e identificou diversas dificuldades que permeiam a relação família-escola, que contribuem para a criação de pré-julgamentos e generalizações frente aos problemas enfrentados no cotidiano escolar, assim como foi observado na relação de Camila e Maria.

Outro ponto relevante, mas sobre a potencialidade da relação família escola observada neste estudo foi que, tanto a Camila como a Maria buscam por uma relação próxima, ambas se preocupam com os conflitos vivenciados na escola. Vidotti (2017) apresentou que os professores e gestores demonstram reconhecer a influência que o contexto exerce no comportamento do aluno e como a família interage com a escola. Reconhecer as potencialidades da relação pode ser uma forma de estreitar a relação família e escola.

Considerou-se como potencialidade também, o fato da a escola ter aceitado participar dos diversos projetos oferecidos pelo estagio de psicologia escolar. Mesmo com as mudanças estabelecidas pelo calendário de atividades do Governo, a diretora fez questão de continuar com os projetos. Observa-se o desejo em manter as mudanças iniciadas em 2018. A escola se mostrou aberta a outras perspectivas e a vontade de transformação, contudo com dificuldades em sustentá-las.

Alguns lugares de sofrimento observados na pesquisa tanto pela escola como pela família, estão relacionados à situações de violência. A escola com queixas de violências diárias e um volume exorbitante de metas e prazos a serem cumpridos e a família enfrentando situações de racismo, bullying, agressões físicas, entre outras.

Em relação aos conflitos e situações de violência Abramovay (2015) abordou em seu estudo o programa de prevenção à violência nas escolas apontando as diversas situações de violências vivenciadas no contexto escolar. Além disso, caracteriza a violência como um fenômeno de muitas facetas.

Nas conversas com a diretora e com a mãe, situações assim eram cotidianas para ambas. Alguns dos impactos da violência foram observados como problemas visíveis, se apresentando no dia a dia da escola, como agressões verbais e físicas, incivilidades, desrespeito e ofensas, tal como observou também Abramovay (2015).

Uma violência evidente sofrida por um integrante da pesquisa, Beto, foi a discriminação por raça. O racismo apareceu mascarado, por meio de brincadeiras, como nas situações mencionadas por Beto que era chamado 
de "macaco" na escola. Estas violências possuem impactos profundos sobre a percepção do jovem sobre si mesmo. No entanto, para Abramovay (2015), a discriminação na escola não é apenas uma prática individual, são principalmente ações e omissões do sistema escolar.

Desse modo, observou-se que dentro do sistema escolar há diversos lugares de sofrimento, desencontros, desejos de relação, conflitos e a violências em seus múltiplos aspectos, bem como poucas mudanças experimentadas no universo escolar.

\section{CONSIDERAÇÕES FINAIS}

Em relação aos objetivos propostos neste estudo pode se compreender aspectos de uma relação família-escola em um contexto escolar público com queixas de violências em seu cotidiano. As visitas as casas dos alunos indicados pela escola, os encontros com as famílias participantes do estudo e os encontros com a diretora foram fundamentais para vivenciar 0 contexto escolar da relação foco da pesquisa.

Buscou-se proporcionar um espaço de escuta para as famílias em situação de violência por meio do Projeto Cinema na Escola, como um espaço de expressão, criação e espontaneidade, mas não houve adesão. As 28 famílias visitadas, tanto a de alunos indicados pela escola e como a de mães indicadas positivamente, não aderiram ao projeto.

Contudo, foi possível compreender a perspectiva de uma família indicada pela escola, cujos integrantes estavam envolvidos em queixa de violência. Foi possível também compreender a perspectiva da diretora e observar aspectos dessa relação família-escola.

Observou-se que ambas se sentem incompreendidas, não conseguem estabelecer diálogo, apesar de desejarem se aproximar. Os sofrimentos causados pelas mais diversas violências são visíveis tanto pelo prisma de Maria (mãe) como de Camila (diretora), sendo que ambas se sentem vítimas de violências. Observou-se ainda, uma tendência à judicialização da relação família-escola após tentativas frustradas de aproximação.

À pesquisa pôde dar voz aos atores escolares, tendo sido possível entender a percepção tanto da família como da diretora sobre a relação estabelecida, observando assim que o vínculo, a convivência e a relação não se mostram possíveis para nenhum dos lados. Predominou uma matriz de culpabilização, desencontros e convivência ruim. Sugerem-se que os gestores tenham mais condições de proporcionarem um espaço de reflexão dentro do ambiente escolar, rompendo com o padrão de violências na relação família-escola, que aponta para quem está certo e quem está errado. As mudanças em como se dá a relação família-escola pode ser um caminho possível para a transformação da convivência para além dos muros da escola. 
Sugerem-se que os atores escolares tenham espaço para refletirem sobre a relação estabelecida e distanciando do padrão quem está certo e quem está errado. $\mathrm{O}$ uso da violência para o estabelecimento da ordem parece predominar.

\section{REFERÊNCIAS}

ABRAMOVAY, M. e RUA, M. G. Violências nas escolas. Ed. Unesco, 2003.

ALMEIDA, W. C. Grupos: a Proposta do Psicodrama. Ed. Ágora, 1999.

ANTUNES, M. Psicodrama e Psicoterapia de Grupo. 2010. Disponível em: http://manoel-psicogrupos.blogspot.com/2010/09/psicodrama-e-psicoterapiade-grupo.html Acesso por último em: 20 de Maio de 2019.

ALBUQUERQUE, J. A. e AQUINO, F. de S. B. Psicologia Escolar e Relação Família-Escola: Um Levantamento da Literatura. Psico-USF. Campinas, v. 23, n.2, p. 307-318, 2018. Disponível em: <http://dx.doi.org/10.1590/141382712018230210>Acesso em: 15 março 2019.

BECHELLI, L. P. C.; SANTOS, M. A. Psicoterapia de grupo: como surgiu e evoluiu. Revista Latino-Americana Enfermagem. Ribeirão Preto, v. 12, n. 2, p. 242-249, 2004.

BARBOSA. N. P. Processos de produção de subjetividdae sobre a infância e práticas pedagógicas de professoras da Educação Infantil. 2020. (Tese de mestrado), Faculdade de Filosofia, Ciências e Letras de Ribeirão Preto/USP. 2020.

CHECHIA, V. A. e ANDRADE, A. S. O desempenho escolar dos filhos na percepção de pais de alunos com sucesso e insucesso escolar. Estud. Psicol, Natal. v.10, n.3, p. 431-440, 2005. Disponível em: < http://dx.doi.org/10.1590/S1413-294X2005000300012> Acesso em: 15 de Março 2019.

CESARINO, A. C. et.all. A Ėtica nos grupos. São Paulo: Agora,2002.

CONTRO, L. Veredas da pesquisa psicodramática: entre a pesquisa-ação crítica e a pesquisa-intervenção. Revista Brasileira de Psicodrama. São Paulo, v. 17, n. 2, p. 13-24, 2009.

DOVE, M. K., ZOROTOVICH, J. e GREGG, K. School Community Connectedness and Family Participation at School. World Journal of Education. v. 8, n.1, p.49-57, 2018. Disponível em: <https://doi.org/10.5430/wje.v8n1p49> Acesso em: 29 de Março 2019.

DESSEN, M. A e POLONIA, A. C. A Família e a Escola como contextos de desenvolvimento humano. Revista Paidéia. Ribeirão Preto-SP, v. 36, n. 17, p. 21-32, 2007. 
FERREIRA, L. P. et al. Sociodrama de famílias: um instrumento de potencialização da relação pais e filhos no contexto escolar. Revista Brasileira de Psicodrama. São Paulo, v. 25, n. 1, p. 108-114, 2017.

GUIMARÃES, E. Escolas, galeras e narcotráfico. Rio de Janeiro: UFRJ, 1998.

GONÇALVES, C. S; WOLFF, J. R. e ALMEIDA, W. C. Lições de Psicodrama: introdução ao pensamento de J. L. Moreno. São Paulo: Ágora, 1988.

JUNGES, L. A. S. e WAGNER, A. Os estudos sobre a Relação Família-Escola no Brasil: Uma revisão de literatura. Revista Quadrimestral. Porto Alegre, v. 39, n. 4, p. 114-124, 2016.

MARTINS, L. R. R. e PERES, V. L. A. A produção subjetiva da violência nas escolas: indicador de sentido para avaliação e desenvolvimento de políticas educacionais. Revista Psicopedagogia. São Paulo, v. 29, n. 90, p. 320-329, 2012.

MARTINS, E. e GERALDO, A. G. A Influência da Família no Processo de Escolarização e Superação do Preconceito Racial: um estudo com universitários negros. Revista psicol. polít. São Paulo, v. 13, n. 26, p. 55-73, 2013.

MALAQUIAS, Maria Célia. Teoria dos grupos e socioatria. In: Nery, Maria da Penha; CONCEIÇÃO, Maria Inês Ganfolfo. Intervenções Grupais: O psicodrama e seus métodos. São Paulo: Àgora, 2012, p. 17-36.

MESQUITA, Ana Maria Otoni. O psicodrama e as abordagens alternativas ao empirismo lógico como metodologia científica. Psicol. cienc. prof. Brasília, v. 20, n. 2, p. 32-37, 2000.

MINAYO, M. C. S. O desafio do conhecimento: Pesquisa qualitativa em saúde. 14. ed. São Paulo : Hucitec, 2014.

MINAYO, M. C. S. Pesquisa social: teoria, método e criatividade. Petrópolis: Vozes, Rio de Janeiro, 1993.

MUNHOZ, M. L. P. e SCARTRALHE, M. C. R. Família e escola na compreensão dos significados do processo escolar. Revista de psicopedagogia. São Paulo, v. 29, n. 88. p. 55-65, 2012.

PASSOS, E., KASTRUP, V. e TEDESCO, L. Pistas do método da cartografia: Pesquisa-intervenção e produção de subjetividade. Porto Alegre: Sulina, 2009.

PASSOS, E., KASTRUP, V. e TEDESCO, L. Pistas do método da cartografia: a experiência da pesquisa e o plano comum. Porto Alegre: Sulina, 2015.

RAMOS, A. L. L. Vínculo na prática educativa escolar: um estudo com base na ludicidade e no sociodrama. Revista Brasileira de Psicodrama. São Paulo, v. 19, n. 2, p.73-84, 2011. 
RIBEIRO, D. F. Desenvolvimento como liberdade e educação: a pesquisaintervenção sociodramática e a promoção da condição de agente. In: ZAMBAM, N. J.; KUJAWA, H. A. (Org.). Estudos sobre Amartya Sen: pesquisa e repercussão social. 1 ed. Erechim-RS: Deviant, 2018, v. 5, p. 99-124.

RIBEIRO, D. F. A implementação da gestão democrática na escola pública: uma proposta interventiva grupal com pais de alunos. In: IX Encontro de Pesquisadores do Uni-FACEF e II Fórum de Estudos Multidisciplinares, 2008, Franca - SP. IX Encontro de Pesquisadores do Uni-FACEF e II Fórum de Estudos Multidisciplinares. Franca - SP, 2008.

RIBEIRO, D. F. ANDRADE, A. S, SOARES, J. H. G. Os bastidores da relação entre escola pública e famílias populares: gestão democrática, participação comunitária e mobilização familiar para a escola. In: VIII Encontro de Pesquisadores do Uni-FACEF, 2007, Franca. Anais Artigos Completos ISSN 1981-6316, 2007.

RIBEIRO, D. F. ANDRADE, A. S. A relação família-escola sob a perspectiva de um estudo de caso etnográfico. In: V Seminário de Pesquisa do Programa de Pós-Graduação em Psicologia da FFCLRP-USP, 2002, Ribeirão Preto- SP. Livro de resumos do V Seminário de Pesquisa do Programa de Pós-Graduação em Psicologia da FFCLRP-USP, 2002.

RIBEIRO, D. F. Os bastidores da relação família-escola. 2004. Tese (Doutorado em Psicologia), Faculdade de Filosofia, Ciências e Letras de Ribeirão Preto/USP. 2004.

RIBEIRO, D. F. ANDRADE, A. S. A assimetria na relação entre família e escola pública. Paideia. Ribeirão Preto-SP, v. 16, n. 35, p. 385-394, 2006.

ROMANELLI, Geraldo. Família e Escola: arronjos diversos. Revista Pedagógica. Capecó, v. 18, n. 38, p. 78-96, 2016.

SILVERIO, V. R. Afirmando diferenças: montando o quebra cabeça da diversidade na escola. Ed. Papiros, 2013.

SCHMIDT, M. L. G. Algumas reflexões acerca da construção e contribuições da teoria socionômica. Psicol. Am. Lat. México, n. 11, 2007.

VIDOTTI. L. S. Percepções dos professores sobre a relação com as famílias dos alunos. 2017. (Tese de mestrado), Faculdade de Filosofia, Ciências e Letras de Ribeirão Preto/USP. 2017.

Tedesco, S. H., Sade, C. \& Caliman, L. V. A entrevista na pesquisa cartográfica: a experiência de dizer. IN: Passos, E., Kastrup, V., \& Tedesco, L. Pistas do método da cartografia: a experiência da pesquisa e plano comum. Porto Alegre: Sulina, 2015, cap. 4, p. 92-127 


\title{
A CONSOLIDAÇÃO DA AUTOESTIMA EM CRIANÇAS COM CICATRIZES CIRÚRGICAS, A PARTIR DA TERCEIRA INFÂNCIA
}

\author{
Mariana Felix Malta \\ mahfelix.malta@gmail.com \\ Sofia Muniz Alves Gracioli \\ sofiagracioli@yahoo.com.br
}

\section{INTRODUÇÃO}

O conceito prévio de autoestima seria uma análise subjetiva que cada indivíduo faz de si próprio, de modo que, todas as características, sejam elas físicas, morais ou comportamentais, estejam nessa avaliação. De todas as particularidades que envolvem a autoestima, a fisionomia é a mais significativa para o indivíduo, pois, é através desta que é construída as primeiras impressões sobre uma pessoa.

No campo da psicologia, há teóricos que enfatizam a formação da autoestima a partir do estágio de desenvolvimento caracterizado como terceira infância, visando explicar os aspectos que podem influenciar não só em sua construção, mas também nos fatores que contribuirão para que as pessoas possam desenvolver uma autoavaliação positiva de si mesma, nas outras fases de desenvolvimento.

Para que o indivíduo se satisfaça com a sua imagem exterior, existem alternativas a fim de proporcionar modificações para que isso aconteça. Porém, pode ocorrer mudanças das quais a pessoa não escolheria por vontade própria se deveria passar ou não por elas, por exemplo em cirurgias obrigatórias. Qualquer que seja essas mudanças, o procedimento pelo qual irão passar, deixará marcas pelo corpo, sejam elas permanentes ou não, como as cicatrizes. Nesse contexto, há cicatrizes que podem impossibilitar uma autoavaliação positiva do indivíduo, visto que, quando um corpo apresenta uma cicatriz, dependendo do lugar, pode ocasionar incômodos tanto para o portador, quanto para quem a vê.

A relevância deste artigo é a autoestima em uma perspectiva diferente, direcionando o foco para um contexto pouco abordado até então, as cicatrizes em crianças a partir da terceira infância.

O presente trabalho teve como objetivo revisar a consolidação da autoestima em crianças a partir da terceira infância com cicatrizes advindas de procedimentos não optativos, especificamente de cirurgias.

A metodologia a princípio foi uma revisão bibliográfica crítica com uso de artigos científicos e livros. 
Respectivamente, os tópicos abordados nesta revisão dissertam sobre aspectos gerais da terceira infância referindo-se a autoestima como parte essencial do desenvolvimento saudável das crianças. Posteriormente, foi apresentado como a autoestima concretiza após esta fase, levando em conta os desafios sociais relacionados aos portadores de cicatrizes cirúrgicas ainda na infância.

\section{A TERCEIRA INFÂNCIA EM UMA COMPREENSÃO COGNITIVISTA E PSICANALÍTICA}

O período que compreende em média, dos 6 aos 12 anos, é trazido por muitos autores no campo da psicologia como terceira infância, no qual está relacionado diretamente com a ida da criança à escola (PAPALIA; FELDMAN, 2013). Essa etapa acontece depois que a criança já adquiriu algumas habilidades cognitivas, motoras, sociais e de aprendizagem. Nas fases anteriores, as principais características desenvolvimentais estavam amplamente relacionadas com a capacidade motora da criança (aprender a andar, pegar, segurar...), e a aprendizagem através de símbolos - desenhos, objetos. Contudo, agora na terceira infância, a criança entra no período escolar, no qual irá não somente aprimorar suas habilidades adquiridas anteriormente, como também a experimentar oportunidades que serão cruciais para o seu desenvolvimento tanto afetivo quanto cognitivo.

Em uma compreensão cognitivista, Papalia e Feldman (2013), apresentam que, a ênfase causal que ocorre em todas as idades, advém da interação de fatores inatos e experiências, ou seja, o que causa as mudanças no desenvolvimento são as razões inatas que estimulam a prática. Nesse contexto, Jean Piaget (1896-1980) desenvolveu períodos de desenvolvimento mental, a fim de explicar como o ser humano constrói o conhecimento, acreditando que as crianças desencadeiam o desenvolvimento por mudanças qualitativas no pensamento (PAPALIA; FELDMAN, 2013). Em sua divisão, define as idades citadas anteriormente, como o período do operacionalconcreto. Moreira (2019) explica que na teoria de Piaget, é esperado que durante essa etapa, a criança desenvolva entre outras habilidades, o raciocínio lógico, atenuação do egocentrismo, capacidade de realizar operações mentais (anteriormente, centradas em aspectos físicos), e a compreensão de lógicas reversíveis, como por exemplo, a adição ser o inverso da subtração. Além disso, Piaget (1952) aborda nessa fase, a capacidade de seriação, no qual o indivíduo entre 7 e 8 anos, é capaz de classificar objetos em categorias de acordo com uma ou mais dimensões, como separar brinquedos pela cor, peso e quantidade.

De outro modo, a teoria freudiana trás aspectos do desenvolvimento psicossexual até a fase da adolescência, mas essa, não está vinculada aos aspectos biológicos genitais da criança, e sim no prazer em 
descobrir o próprio corpo. Em seus estudos, Freud (1905) determinou o período da terceira infância como o período de latência, em que a criança se descobrirá intelectual, social e emocionalmente. Ademais, o prazer da criança encontra-se nas interações sociais - esportes, passeios, brincadeiras correlacionando-as com o início do período escolar. Para Papalia e Feldman (2013), a ênfase causal dessa teoria psicanalítica, está nos fatores inatos que são transformados pela experiência. Isto é, destaca a importância dos pensamentos e motivações inconscientes que são representadas mentalmente através do estabelecimento de relações. Pode-se assim entender que, a divisão das fases do desenvolvimento psicossexual entre os 6 e 12 anos, está diretamente ligada a criança se auto descobrir a partir de sua integração em outros meios.

Dado o exposto, compreende-se que, na abordagem piagetiana, o desenvolvimento é centrado nas capacidades cognitivas em que ocorrerá avanços intelectuais significativos. Já Sigmund Freud, apresenta ênfase nos aspectos inatos que influenciam tanto no individual da criança - como ela irá se descobrir e se definir, como na sua sociabilidade, através da interação com o ambiente desconhecido. Além disso, é nítido interpretar que, a fase da terceira infância dentre outros marcos, caracteriza-se pelo início do período escolar, e consequentemente no estabelecimento de futuras relações com novas pessoas em um ambiente não explorado previamente.

\section{A CONSTRUÇÃO DA AUTOESTIMA}

Para que o conceito principal seja entendido, é necessário esclarecer a diferença de autoestima e autoconhecimento, pois são termos que muitas vezes são confundidos. Autoconhecimento é a compreensão que cada indivíduo tem de si próprio. Já a autoestima, é o engrandecimento do seu próprio valor. Em outras palavras, autoestima nada mais é do que uma análise individual que o sujeito faz de si mesmo. Ela é caracterizada por ser a união de juízos e valores que um sujeito atribui a aspectos de sua personalidade, habilidades e imagem pessoal (MUSSEN, 1995). Este conceito versa aspectos físicos e psicológicos que interferem na autoavaliação final, e que podem permanecer por um longo período de tempo. Nesse viés, existem teóricos na psicologia que explicam os possíveis fatores que contribuem para a formação e o desenvolvimento da autoestima.

O psicólogo mais conhecido nessa área foi o psicanalista Erik Erikson (1902-1994). Especializado em psicologia infantil, criou os Estágios de Desenvolvimento Psicossociais, no qual visa explicar que, em cada estágio o indivíduo deve enfrentar uma crise básica, para avançar socialmente. Em sua teoria, ele propõe que o período médio em que a autoestima começa a se desenvolver é dos 6 aos 12 anos, no estágio denominado Produtividade versus Inferioridade, onde expõe que o trabalho produtivo do indivíduo é fundamental 
para a formação da autoestima, envolvendo assim, a sua capacidade de realizar tarefas e obter aprovação. Por exemplo, uma criança que conseguiu completar uma atividade na escola e obteve aprovação da professora por tê-la cumprido, se sentirá motivada para realizar outras tarefas, e assim ficar satisfeita com a sua capacidade de realização. Nessa fase, Erikson (1982) explica que "a virtude que se desenvolve com a resolução dessa crise é a competência, uma visão do EU como capaz de dominar habilidades e completar tarefas".

Em continuidade, a ideia principal da teoria anterior é que, antes da criança alcançar esse estágio psicossocial do desenvolvimento, ela não será capaz de se autoavaliar de uma forma mais complexa, abstrata. Esta fase permite que a criança a partir dos 6 anos, iniciando a fase escolar, comece a se autoconhecer em comparação aos outros. Conhecido como terceira infância, essa etapa exige sobretudo, que o indivíduo adquira capacidade de formar sistemas representacionais, através da visão dimensional de que ele não atua no ambiente sozinho. Ou seja, a partir daí, a criança consegue aos poucos conhecer suas características e habilidades em função da inserção á um novo meio, por exemplo a escola, quando é capaz de perceber que tal amigo consegue terminar a atividade proposta primeiro.

No entanto, para Harter $(1996,1998)$ é possível que a criança antes dos 5 ou 6 anos, seja capaz de demonstrar através de seus comportamentos, que possue um breve entendimento sobre seu valor pessoal. Apresenta também, que a autopercepção positiva ou negativa, pode gerar influências nas questões socioemocionais durante os próximos anos. Entretanto, as crianças menores em questão, não firma necessariamente no que é real, porque tendem a aceitar 0 julgamento dos adultos, que normalmente dão retorno positivo sobre o que elas fazem, valorizando assim, as suas capacidades. Nesse critério, a autoestima no período da segunda infância (3 á 6 anos) propende a pequenas especificidades. Em outras palavras, a criança pode ter habilidades cognitivas de se definir, por exemplo se ela é boa ou má, mas não possui ainda interações com outros meios para que torne suas percepções mais realistas, capazes de moldar um senso de valor pessoal.

Retomando o contexto da autoestima, é entendível que essa auto interpretação comece a ser aplicada em cada indivíduo durante a infância, pois é nela que começamos a não avaliar somente nós mesmos, mas as outras pessoas que interagem no mesmo ambiente. Com isso, a formação da autoestima está associada a componentes cognitivos referentes aos pensamentos afetivos e sobre determinado objeto, que determinam as atitudes, seja elas positiva ou negativa, que $\mathrm{o}$ indivíduo tem com $\mathrm{O}$ objeto (ROSEMBERG; SCHOOLER; SCHOENBACH, 1995). Assim, começa a existir o julgamento subjetivo que cada um tem de si mesmo - o que o meu amigo faz 
que eu não faço, a aparência física do meu amigo não é a mesma que a minha - entre outros exemplos.

\subsection{O ALCANCE DA AUTOESTIMA EM CRIANÇAS COM CICATRIZES CIRÚRGICAS}

Todo processo cirúrgico no geral tem seus riscos e benefícios, porém, quando este não possui caráter optativo, o indivíduo é colocado automaticamente em um estado clinicamente não saudável para o seu desenvolvimento, tornando a cirurgia essencial ou mesmo em alguns casos, emergencial. Contudo, os resultados a partir do pós-operatório podem ser diversos, tanto em relação à saúde clínica quanto a emocional, e especificamente em crianças, esses efeitos podem ser vivenciados mais intensamente.

Precedentemente, compreende-se que a cirurgia é uma experiência que traz consigo exames incômodos, procedimentos anestésicos e possíveis dificuldades pós-operatórias como por exemplo, a dependência de aparelhos hospitalares para a recuperação do paciente (GARANHANI \& VALLE, 2012). Fora isso, é evidente que as cirurgias vão muito além do momento em que são efetuadas, provavelmente porque desde o recebimento da notícia sobre a necessidade de operar, o paciente passará por incertezas principalmente em relação aos resultados, e também acerca da invasibilidade que é esse tipo de procedimento. Em continuidade, a hospitalização do indivíduo também contribui para que as consequências sejam em sua maior parte benéficas ou não, tendo em vista que estas, influenciam diretamente na maneira como o paciente ao deixar o ambiente hospitalar, vivenciará seu dia a dia.

Agora, referindo-se particularizadamente as crianças, sua hospitalização representa uma situação diferente de todas já experimentadas, haja vista que sua rotina é modificada, ocorrendo assim, rupturas com o seu meio social, hábitos, costumes e outras atividades (CURSINO et.al, 2016). Destaca-se então, a modificação no contexto social que a demanda infantil encontrará como uma das principais alterações em suas vivências póscirúrgicas. Partindo desse princípio, a começar na terceira infância, a criança desenvolverá concepções a partir de sua interação em diversos meios de convivências, expondo-se assim, à situações que anteriormente não the causavam tanta representatividade quanto nessa fase, por isso a relevância do contexto social para o desenvolvimento infantojuvenil. Contudo, é possível que algumas crianças não sintam essa diferença de perspectiva em relação aos olhares externos se por exemplo, já estiver bem consigo mesma e com sua autoimagem. Entretanto, levando em consideração que é entre 6 e 12 anos que o indivíduo começa a desenvolver o senso de autoestima, é compreensível que uma criança portadora de uma ou mais cicatriz fique desconfortável ao se ver 
com marcas que as outras pessoas principalmente as da mesma faixa etária, não apresentam. Em conseguinte, pode-se despertar nas crianças sentimentos como inferioridade e atipicidade, visto que, ao perceber as mudanças na aparência do seu corpo entre antes e depois da cirurgia, há possibilidades de não se sentir bem e confortável consigo mesma.

Além dessas contingências posteriores à cirurgia, existem situações relacionadas ao preparo do momento em que a operação será de fato sucedida, por exemplo sentimentos como medo e incertezas que surgem como parte da adaptação a necessidade da cirurgia. Segundo Garanhani; Valle (2012), o medo revela-se como parte da experiência de submeter-se a uma cirurgia delatando uma falta de informação sendo o desconhecimento do que está acontecendo, um dos principais contribuintes nas dificuldades vividas pela criança hospitalizada. Diante do exposto, algumas medidas podem ser realizadas a fim de proporcionar a aceitação da cicatriz em favorecimento da autoestima das crianças. Dando-se exemplos, para Vasques; Bousso e Mendes (2011), faz-se necessário ouvir as crianças levando em consideração sua singularidade, em relação a sua real condição de saúde, a fim de compreender o modo como elas vivenciam os próprios aspectos clínicos. Não somente, para as criança que são submetidas à esses processos cirúrgicos recomenda-se que todas as orientações pertinentes sobre o seu quadro clínico abrangem primordialmente as pessoas significativas para a criança, e para isso, a família obtém papel fundamental para a adaptação sociocultural do indivíduo em questão, contribuindo assim para o equilíbrio emocional da mesma, e para o enfrentamento daquela situação adversativa (VERÍSSIMO, 1991; ANDRAUS et al. 2004) . Por fim, torna-se importante que os pais acompanhem o preparo emocional da criança em sua fase de socialização, antes do procedimento cirúrgico, porque ela validará as informações recebidas junto a eles, que são sua fonte de confiança e segurança (PALADINO; CARVALHO; ALMEIDA, 2014). Desse modo, é indispensável o apoio familiar a crianças especialmente da terceira infância, tanto no pré quanto no pós operatório, pois é no contexto familiar que se traçará seus principais vínculos iniciais de afeto, confiança e cuidado, para que assim posteriormente, a criança aos poucos consiga interagir em outros ambientes sociais, como na escola e áreas de lazer.

\section{A CONSOLIDAÇÃO DA AUTOESTIMA APÓS TERCEIRA INFÂNCIA}

Anteriormente, foi apresentado que a formação da autoestima inicia-se durante a infância, e que o instrumento fundamental para que isso aconteça, é a percepção que a criança desenvolve de si mesma, através da relação com outras pessoas que interagem em seu ambiente. Todavia, essas avaliações pessoais iniciadas no contexto infantil, não sustentam a autoestima em todas as idades, pois esta, sofre frequentemente influências adversativas. 
O psicólogo humanista Abraham Maslow (1908-1970) propõe em sua teoria - Teoria da Hierarquia das Necessidades Humanas - que possuímos uma escala de necessidades a serem supridas para que alcancemos a realização pessoal, a mais alta necessidade ambicionada pelos indivíduos. Segundo Silva (2012 apud CHIAVENATO, 2000) o criador dessa teoria organizou as necessidades humanas em níveis hierárquicos de acordo com a sua importância e influência, então, nas camadas bases estão as primordialidades mais simples e fáceis de serem conquistadas, como as fisiológicas - comer, dormir, vestir- e na mais elevada encontra-se a autorealização do potencial de cada sujeito, mostrando assim, a mais difícil de ser alcançada. Dentre esses extremos, existem as essencialidades de segurança emprego, saúde, família - e consequentemente as sociais, no qual abrange os vínculos afetivos construídos a partir de interações com os outros, por exemplo troca de amizade e relacionamentos amorosos. Entretanto, é importante salientar que as necessidades humanas não ocorrem em uma sequência ordenada, pois todas estão presentes durante o desenvolvimento do ser humano, permitindo assim, a alternância de prioridades conforme o padrão de vida do indivíduo. (KONDO, 1997). Apesar disso, a pirâmide dispõe-se assim:

Figura 1 - Pirâmide necessidades

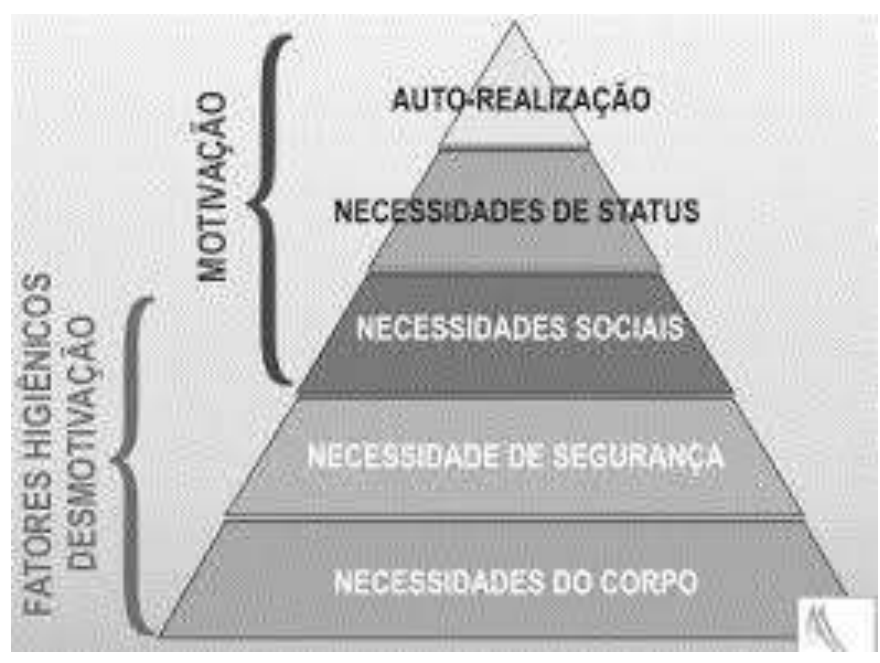

Fonte: Chiavenato (2000, p.254).

Dando continuidade, como apresentado acima, em um dos elementos que compõem a pirâmide está a estima, neste exemplo aparece como necessidades de status, na qual compreende as concepções pessoais a respeito das características intelectuais, sociais e principalmente, físicas de si próprio. Para que o indivíduo consiga atingir a estima, é indispensável ter motivações que o levem a esse objetivo, e muitas vezes, é o que falta para desenvolver uma estima saudável, reconhecendo não só o valor de si próprio, mas também a de ser reconhecido pela forma em que atua na sociedade. 
Essas motivações por sua vez, vêm exercendo o papel fundamental em todas as fases do desenvolvimento, começando ainda na infância. A criança que tem os dois primeiros níveis totalmente supridos, começa a perceber o que, e quem está ao seu redor fazendo com que sofra influências na sua maneira de pensar e agir sobre o mundo. Exemplificando, quando a criança não apresenta preocupações com as características relacionadas com sua fisiologia ou segurança, por exemplo, com o tempo mostrará interesse em realizar atividades sociais com professores, amigos, familiares, que proporcione reconhecimento por sua efetividade, por exemplo, ir bem na escola e obter a gratificação de seus responsáveis por isso, partindo da ideia de que a autoestima está diretamente relacionada com as respostas de outros indivíduos que também atuam naquele ambiente, sobre a pessoa em questão. Aqui, não importa somente a visão que cada indivíduo tem de si próprio, mas também e principalmente, como as pessoas interagem com ele.

Essas relações com o meio social no entanto, influencia em como o sujeito provará seu valor para a comunidade, bem como na forma em que lida com seus próprios sentimentos. Nesse viés, para que a autoestima seja consolidada, é necessário primeiramente que os requisitos anteriores mostrados na pirâmide, continuem ou comecem a ser logrados. Assim, analisando a relevância de cada necessidade apresentada nesta teoria, é possível compreender que, a autoestima se desenvolverá principalmente, se outras preocupações não ganharem destaque. Para simplificar, pensemos em uma mãe de família que precisa trabalhar incessantemente para colocar comida na mesa de seus filhos. Certamente, não sentirá necessidade de buscar por mudanças em sua aparência que julgue necessária, pois sua motivação estará ligada diretamente á proporcionar uma vida de qualidade à seus filhos. Por fim, a autoestima será alcançada quando outras essencialidades já estiverem sido supridas, caso o contrário, o indivíduo apresentaria dificuldades para esta ser consolidada.

\section{CICATRIZES CIRÚRGICAS: IMPRESSÕES, ESTIGMAS E DESAFIOS SOCIAIS}

Em uma delimitação prévia, as cicatrizes possuem por sua vez, diversos tipos, e estágios até que se chegue em uma aparência final. Contudo, o foco deste artigo não é exemplificar os processos de cicatrização em si, e sim contextualizar o impacto que um corpo marcado por estas carrega no cotidiano. Quando essas cicatrizes são advindas de procedimentos cirúrgicos que não possam ser adiados ou escolhidos pelo paciente, são em sua maioria incômodas, não apenas esteticamente, mas podendo ser até dolorosas de primeiro momento. Uma possível explicação para isso seria que toda experiência cirúrgica independente da faixa etária do operando, provoca constantes preocupações, medos, ansiedade, dúvidas que surgem a partir de 
quando são notificadas da necessidade da intervenção cirúrgica, dentre outros fatores (GARANHANI \& VALLE, 2012).

Direcionando o foco atual para as problemáticas sociais que decorrem a partir da reintegração coletiva da pessoa com cicatriz, é relevante dissertar sobre os estigmas internalizados da sociedade que estão diretamente relacionados às impressões externas dos indivíduos. A princípio, destaca-se a importância de compreender como as impressões sociais são pré estabelecidas nas pessoas e logo mais, como estas se veem a partir das concepções do que é ou não aceito em sua própria aparência. Em uma visão psicossocial, existe o gerenciamento de impressões, que nada mais é do que a busca pelo controle das opiniões externas acerca de si próprio - como gostaríamos que as pessoas vissem nosso corpo e nossos comportamentos. Segundo Carvalho e Grisci (2002), esse gerenciamento de impressões "pode ser definido como as várias maneiras pelas quais os indivíduos buscam controlar as impressões que os outros têm a seu respeito, no que se refere a comportamentos, valores e atributos pessoais visando atingir um determinado objetivo". Nesse contexto, para explicar a importância dada às opiniões externas, o sociólogo Goffman (2014) compara os relacionamentos sociais com uma peça teatral, pois para ele, o relacionamento social é resultado de uma troca de ação, oposição e de respostas conclusivas dramaticamente subjetivas. Ou seja, ele expõe que, todo relacionamento comum é montado como se fosse uma cena de teatro, no qual as pessoas apresentam a aparência que melhor se encaixa no contexto, mas nem sempre condizente com suas verdadeiras concepções. No caso de pessoas com cicatrizes, essa busca em manter as impressões dentro do que é padronizado pela comunidade, é ainda mais manipulada por seus portadores, pois pretendem se encaixar nos atributos que melhor será apresentável para os outros. Para Goffman (2014), "em sua qualidade de atores, os indivíduos se interessam em manter a impressão de que vivem a altura dos múltiplos padrões pelos quais eles e seus produtos (atitudes, aparências) são julgados". Então compreende-se que, no momento em que o portador de cicatriz percebe ser alvo de observações, é comum procure passar evidências positivas a seu respeito sobre suas qualidades, isso com o intuito de influenciar a maneira de ser tratado pelo observador.

Além disso, outro fator que interfere diretamente nas impressões externas é o valor que a mídia apresenta para um estilo de corpo bonito, saudável e acima de tudo, bem visto e melhor aceito na sociedade. Isso ocorre devido a pressão que a mídia e todo o seu padrão de beleza proposto exerce na autopercepção do indivíduo, o que interfere diretamente na consolidação da autoestima (BORBA \& MARIN, 2012). Porém, a mídia é relevante no cotidiano das pessoas porque estas têm relações cada vez mais efêmeras dando lugar de destaque para a aparência físicas dos outros, o que torna as impressões externas um importante aspecto de julgamento nos vínculos sociais. Nessa ideia, "o comportamento se estrutura no que é considerado mais belo ou 
menos belo" (BORBA \& MARIN, 2012). Assim, a imagem externa torna-se um valor social responsável por garantir sucesso ou fracasso, tanto nas relações interpessoais quanto intrapessoais, por exemplo no ambiente de trabalho (FERRAZ \& SERRALTA, 2007). Então, com toda essa pertinência dos meios de comunicação social exerce nas pessoas, caracteriza-se a consolidação de uma autoestima sólida um dos desafios que todos considerados fora do padrão de beleza aceito na comunidade terão de enfrentar, principalmente se o sujeito tiver marcas em seu corpo que não o deixará por um longo período, como é o caso das cicatrizes cirúrgicas.

Ademais, uma forte tendência da sociedade em julgar principalmente a aparência física das pessoas, é advinda dos estigmas internalizados pela coletividade. Esse processo de estigmatização é referente à desvalorização, perda de status e consequentemente, à discriminação de um indivíduo, que por sua vez é estimulada pela atribuição de estereótipos negativos com base em características físicas vistas socialmente inaceitáveis (LINK \& PHELAN, 2001; CORRIGAN \& WATSON, 2020). Tendo isso em vista, é compreensível que esse descrédito em pessoas tidas como diferente em sua aparência física, carregará esse peso de não se encaixar no que é tipicamente bem visto pelos seus contextos de socialização. Seguidamente, a internalização do estigma tem como uma de suas consequências, a concordância do indivíduo estigmatizado de sua real condição, passando a concordar com essas afrontas e aplicando os estereótipos negativos acerca de si próprio (CORRIGAN \& WATSON, 2002). Em outras palavras, a pessoa passa a acreditar na intolerância que o estereótipo diz respeito a ela, fazendo com que aceite a visão dos outros, encarando essa com verasticidade - se os outros vêem você de alguma forma, é porque você deve ser realmente o que dizem. Dado esse entendimento, é criado um círculo vicioso em que a internalização do estigma conduz a diminuição da autoestima prejudicando as relações sociais e afetivas ( VERHAEGHE; BRACKE; BRUYNOOGHE, 2008) . Por fim, é nítido que esses processos de estigmatização enraizados na sociedade impacta negativamente no indivíduo, por exemplo o portador de cicatriz, tanto em aspectos psicossociais quanto no desenvolvimento de uma autoestima sólida, em que exista o reconhecimento do seu próprio valor.

\section{CONSIDERAÇÕES FINAIS}

O presente artigo teve como objetivo geral, revisar inicialmente as características da terceira infância e sua relevância para a construção de uma autoestima saudável nas crianças. Já os específicos, consistiu em direcionar essa revisão para o contexto das cicatrizes cirúrgicas, estas advindas de procedimentos não optativos, e consequentemente, para as adversidades encontradas por parte do portador. Sendo assim, foi possível atingir os objetivos inicialmente traçados. 
No que diz respeito ao referencial teórico, foi pesquisado apesar das dificuldades em encontrar fontes teóricas sobre cicatrizes em pessoas a partir da terceira infância, informações relevantes sobre as questões que influenciam na consolidação da autoestima em portadores de cicatrizes cirúrgicas. No entanto, faz-se necessário maior demanda de pesquisas atuais nessa área infantil e hospitalar, visto que, não é um assunto com uma gama de trabalhos desenvolvidos a respeito.

Em suma, o artigo proporcionou ampliação do conhecimento acerca da construção da autoestima que inicia-se ainda na infância, em média dos 6 aos 12 anos, mais conhecida como terceira infância. Foi possível essa compreensão levando em consideração as ideias centrais dos teóricos citados e dos exemplos apresentados. Seguidamente, foi explanada algumas questõe que as crianças que passara um tempo hospitalizada devido o procedimento cirúrgico, possivelmente encontrará. Posteriormente, foi denotado sobre a consolidação da autoestima com base na teoria das necessidades humanas do psicólogo humanista Abraham Maslow. Finalmente, foi dissertado explicações em relação aos enfrentamentos vividos por pessoas que têm seu corpo marcado devido a algum procedimento não optativo levando em consideração as impressões sociais culturalmente construídas, o poder dos veículos de informações sobrecarregados de padrões de beleza mais aceitos, e as consequências dos estigmas internalizados da sociedade.

Como uma das principais problemáticas referentes a consolidação da autoestima em crianças com cicatrizes cirúrgicas a partir da terceira infância, além do impacto das mídias na vida cotidiana, encontra-se o processo de hospitalização como um forte determinante para o desenvolvimento de uma autoavaliação positiva de si próprio. Nesse viés, uma possível intervenção seria o melhor detalhamento do processo cirúrgico que a criança passará, sendo indispensável a presença de pessoas próximas à criança para que se sinta mais segura e confiante em relação a cirurgia. Não somente, para que a criança já tenha um conhecimento prévio das mudanças que seu corpo sofrerá após a cirurgia, é cabível que a equipe médica transmita informações relevantes sobre essas mudanças, por exemplo, mostrando através de imagens ou algum outro conteúdo lúdico - para o melhor entendimento da criança - como o seu corpo, especificamente o local da cirurgia ficará quando esta já estiver sido realizada.

Em encerramento, o artigo abordou temáticas pouca discutidas, não só em virtude dos procedimentos cirúrgicos, como também acerca da importância de iniciar o desenvolvimento saudável da autoestima nas crianças, a fim de que possa ser mais fácil de ser consolidada após essa fase, tendo em vista que há tempos, a aparência externa do indivíduo é cada vez mais valorizada e interpretada por terceiros, não levando em consideração sua singularidade moral e intelectual. 


\section{REFERÊNCIAS}

ALENCAR, J. S. A; GALLO, A. E. Psicologia do desenvolvimento da criança. 1ed. Paraná: Fernando Henrique Mendes et al. 2012. 91-97p. Disponível em: http://www.ficms.com.br/web/biblioteca/CESUMAR\%20\%20PSICOLOGIA\%20DO\%20DESENVOLVIMENTO\%20HUMANO.pdf. Acesso em 10 abril. 2020.

BORBA, T, J; THIVES, F. M. Uma reflexão sobre a influência da estética na autoestima, automotivação e bem estar do ser humano. Santa Catarina, 2012. Disponível em:

http://siaibib01.univali.br/pdf/Tamila\%20Josiane\%20Borba.pdf. Acesso em 24 abr. 2020.

CARDOSO, N. R; FIGUEIREDO, M. L; PRADO, P. F do; SOUZA, A. A. M. Vivenciando o processo cirúrgico: percepção e sentimentos da criança. Revista baiana de enfermagem. Bahia, v. 31, n 3, 2017. Disponível em https://portalseer.ufba.br/index.php/enfermagem/article/view/17648/15077. Acesso em 20 jun. 2020.

CHIAVENATO, Idalberto. Introdução à Teoria Geral da Administração. $2^{\underline{a}}$ ed. Revista e atualizada. Rio de Janeiro, 2000. 254 p.

FELICISSIMO, F. B et al. Estigma internalizado e autoestima: uma revisão sistemática da literatura. Psicologia: teoria e prática. São Paulo, v. 15 n 1 , abr. 2013. Disponível em http://pepsic.bvsalud.org/scielo.php?script=sci_arttext\&pid=S151636872013000100010. Acesso em 10 abr. 2020.

GARANHANI, M. L; VALLE, E. R. M do. O significado da experiência cirúrgica para criança.Cienc Cuid Saude. São Paulo, v. 10, n 5, 2012. Disponível em http://periodicos.uem.br/ojs/index.php/CiencCuidSaude/article/view/17084/pdf. Acesso em 21 jun. 2020.

MALEBRANCHE, H. SAMU, F. A teoria de Goffman e o gerenciamento de impressões. Revista húmus. Rio de Janeiro, v. 7, n 21, 2017. Disponível em http://www.periodicoseletronicos.ufma.br/index.php/revistahumus/article/view/6 949/4879. Acesso em 25 jun. 2020.

MATSUOKA, L. T; SILVA, J. J da. Os eventos e a hierarquia das necessidades humanas de Maslow: conjecturas na sociedade contemporânea.Colloquium Humanarum. São Paulo, v. 10, p. 633-639, jul-dez, 2013. Disponível em: http://www.unoeste.br/site/enepe/2013/suplementos/area/Humanarum/Psicologi a/Os\%20eventos\%20e\%20a\%20Hierarquia\%20das\%20Necessidades\%20Hum anas\% Relacionam-se com sentimentos humanos presentes na maior parte das pessoas, como a necessidade de amar e pertencer a um determinado grupo ou núcleo familiar. Fazem parte dessas necessidades, a troca de amizade, afeição, companheirismo e aceitação social. 20de\%20 Maslow\%20 
conjeturas\%20na\%20sociedade\%20 contempor\%C3\%A2nea.pdf. Acesso em 16 abr. 2020.

MOREIRA, A. M. Teorias de aprendizagem. 2ª ed. São Paulo: e.p.u, 2019. 97,98p.

NUNES, A. I. B. L; XAVIER, A. S. Psicologia do Desenvolvimento. 4ed. Fortaleza: EdUECE, 2015. Disponível em:

https://educapes.capes.gov.br/bitstream/capes/431892/2/Livro_Psicologia\%20d 0\%20Desenvolvimento.pdf. Acesso em 13 abril. 2020.

PAPALIA, D. E.; FELDMAN, R. D. Desenvolvimento humano. Tradução de Cristina Monteiro e Mauro de Campos Silva. $12^{\mathrm{a}}$ ed. Porto Alegre: Artmed, 2013. 285,286p.

ZATTONI, R. S. A autoestima em crianças da terceira infância e sua relação com o elogio no contexto educacional. Paraná, 2011. Disponível em: https://educere.bruc.com.br/CD2011/pdf/5262_3496.pdf. Acesso em 11 mar. 2020. 
A DOCILIZAÇÃO DOS CORPOS: repressão sexual e a potencialidade da masturbação e do orgasmo na emancipação feminina

Caio César de Paula caiocesardepaula1409@gmail.com

Letícia Sousa Victor leticiasousavictor@outlook.com

Yanca Araújo Polastrine yancapolastri@gmail.com

Sofia Muniz Alves Gracioli sofiagracioli@yahoo.com.br

\section{INTRODUÇÃO}

O presente estudo acadêmico tem como propósito elucidar sobre o tornar-se mulher, a repressão do gênero através do controle da sexualidade feminina, focar na potencialidade da masturbação e do orgasmo, não somente como fonte de prazer, mas como um elemento importante para saúde mental e um fator essencial para o empoderamento e emancipação do feminino. Atualmente a sexualidade ainda é um tabu para muitos, pouco se fala sobre 0 sexo, e com mais dificuldade se fala sobre a sexualidade da mulher, ressaltando que se faz necessário devido a questões históricas e sociais diferenciar a construção da sexualidade da mulher branca e da mulher negra.

Para dissertar sobre sexualidade feminina se faz necessário retratar temas anteriores a este, como por exemplo a construção social do que chamamos mulher, afinal como diria Beauvoir (1949) "Não se nasce mulher, torna-se mulher" ou seja, nasce um corpo, e se o mesmo segue determinadas características dos cromossomos XX, o nomeamos como um corpo feminino, e a partir desta designação é decidido qual lugar este corpo poderá habitar, e como este será construído, ser mulher, ou oposto, ser homem, não é inerente, ou somente, uma questão biológica, e sim também, uma questão cultural, portanto torna-se mulher.

O silêncio acerca da sexualidade feminina dá-se devido à ideia primordial de que o prazer sexual é pertencente ao gênero masculino, que são estimulados desde crianças a desenvolverem a libido para que se provem homens, enquanto na mulher, as vontades, não só carnais, devem ser reprimidas, portanto a função feminina seria, exclusivamente, procriar e servir prazer ao seu cônjuge. No mais, muito dessa docilização sobre os corpos femininos também se deve à religiosidade e suas interpretações bíblicas sobre a obediência que as mulheres são obrigadas a ter aos seus maridos, os "homens da casa". 
A emancipação financeira da mulher não basta para que ela possa finalmente não estar em um papel de obediência para com o masculino, existe então outras formas de dominação de gênero, como por exemplo o controle psicológico, a violência física, este estudo visa então discorrer sobre uma dessas formas, que é o adestramento da mulher através do controle sobre a sexualidade.

A edificação de ser mulher perpassa o que denominamos de docilização dos corpos, Foucault (2019) dirá que "É dócil um corpo que pode ser submetido, que pode ser utilizado, que pode ser transformado e aperfeiçoado" e a partir deste conceito que podemos fazer um paralelo sobre como a mulher se torna um corpo docilizado através do controle sobre sua sexualidade, um poder invisível, que garante assim que o feminino irá permanecer em um lugar de submissão ao masculino.

Apresentamos portanto a masturbação como uma forma de libertação deste corpo dócil, adestrado e submisso, apresentando artigos sobre a saúde psicológica da mulher que é dona do seu próprio prazer, e as consequências disto, quando ela se torna responsável pelo seu próprio gozo, ganha poder sobre si, poder esse que antes não Ihe pertencia, sendo assim, que pertencia a um "outro".

Neste trabalho delimitaremos a discussão somente sobre a mulher cisgênero, ou seja, aquela que se identifica com o gênero que lhe é proposto ao nascer, pois entendemos que, tanto a mulher cisgênero quanto a mulher transexual, são construções sociais, entretanto, a estruturação das mesmas perpassa caminhos diferentes, vale então para uma próxima pesquisa analisar e elucidar a sexualidade da mulher transexual e tudo o que daí a de vir.

Diante da escassa produção sobre o tema, não somente no ramo da psicologia, mas em um amplo aspecto de produção científica, se faz necessário a discussão sobre o corpo-submissão, às estratégias de manutenção deste corpo, a mulher que se masturba e a potencialidade de libertação através deste.

Buscamos então fazer uma revisão bibliográfica seguindo de alguns critérios, primeiramente revisar a literatura em um raio de tempo de sete anos, ou seja, artigos, livros, dentre outros publicados de dois mil e treze a dois mil e dezenove, publicados nas plataformas Google Acadêmico, scielo, e revistas de universidades, selecionando então resumos que continham palavras chaves, tais como, docilização, feminino, masturbação, e continham discussões acerca do mesmo. 


\section{A MULHER COMO CONSTRUÇÃO SOCIAL}

\subsection{A Construção Social De Gênero: a mulher branca}

A complexidade do papel mulher na nossa sociedade é alvo de diversos e recentes estudos, entender esse conceito e o símbolo feminino, requer primeiramente, uma retomada histórica do que pessoas nascidas com 0 cromossomo XX já representaram ao longo da história. A pessoa que nasce com uma vulva, será chamada de mulher, aquele que nasce com um pênis será denominado homem, essas nomenclaturas irão determinar os papéis que esses indivíduos vão ocupar, e como esses objetivos vão se desenvolver.

É a divisão social do trabalho, distribuição bastante estrita das
atividades atribuídas a cada um dos dois sexos, de seu local, seu
momento, seus instrumentos; é a estrutura do espaço, opondo o lugar
de assembleia ou de mercado, reservados aos homens, e a casa,
reservada às mulheres; ou, no interior desta, entre a parte masculina,
com o salão, e a parte feminina, com o estábulo, a água e os
vegetais; é a estrutura do tempo, a jornada, o ano agrário, ou o ciclo
de vida, com momentos de ruptura masculinos, e longos períodos de
gestação, femininos ( SANTOS apud BOURDIEU, 2012, p.18).

Perceber que quando colocamos na discussão do que é ser feminino e masculino as dimensões de tempo e espaço essas concepções mudam e, portanto, é perceber que o biológico não é determinante e não compreende todas as relações humanas, entretanto é através do biológico que a sociedade irá se organizar.

No matricentrismo, provavelmente, a ordem social era fluida e permissiva. As crianças ficavam com as mulheres, já que estas eram mais permanentes que os homens nos grupamentos humanos. Em geral, parece não ter havido chefes ou líderes, mas rodízio de poder. A despeito disso, a divisão sexual do trabalho variava de um tipo de sociedade para outro, sendo às vezes permissiva e em outras muito rígida. A transformação teria se dado quando da descoberta da função reprodutiva do homem e da criação de condições para o surgimento da propriedade privada, pela produção do excedente, apropriado pelos detentores dos meios de produção. Não se sabe com exatidão a época histórica em que isto possa ter ocorrido, mas estima-se que na era neolítica, há cerca de oito a dez milhões de anos. (FONSECA apud MURARO, 1989)

Entende-se que em algum momento da história era a mulher que ocupava papel central na organização humana, o homem neste período, não sabia que tinha participação no processo de reprodução, é a mulher, e só ela, que detém o poder de perpetuação da espécie, e portanto, diferente do papel de "sexo frágil", é o feminino que possui poder. Este poder do feminino, se concretizava na concepção do que era divino, nesta época histórica se cultivam as deusas, deusas que pariram o universo.

Entretanto quando homem percebe que também é uma parte determinante na geração de crianças, existe nele, a necessidade de garantir que esta criança é sua, assim garantindo que suas terras seriam passadas 
para os seus, é neste período que o corpo da mulher deve ser controlado, de forma física e psíquica ela deveria pertencer ao masculino, surgindo daí noções de propriedade privada, do homem como coletivo e da mulher como privado, um objeto de reprodução para o masculino.

A fêmea deve ser um corpo dócil ao macho, pronto para ser regido e manipulado, garantindo assim a hereditariedade dos seus filhos, a sexualidade feminina aqui deve ser controlada, para a manutenção deste controle, encontramos a concepções de santificação do feminino, a mulher que é cultuada é aquela pura e santa versos a mulher puta, que deve ser demonizada e punida, moralmente e fisicamente, ela deve manter-se casta, servil, obediente. a construção do instinto materno como inerente à mulher.

A submissão do feminino ao masculino foi um processo construído de forma gradual através de milhares de anos, que se modifica e ganha força através das culturas que transmutam, e das sociedades que nascem e se organizam também através desta, divisão entre os sexos parece estar "na ordem das coisas", como se diz por vezes para falar do que é normal, natural, a ponto de ser inevitável: ela está presente, ao mesmo tempo, em estado objetivado nas coisas, em todo o mundo social e, em estado incorporado, nos corpos e nos hábitos dos agentes (BOURDIEU,2012.p 17)

A dominação sobre o corpo feminino se faz portanto presente em todo o percorrer histórico, um momento que ilustra esta de forma transparente esta situação é a inquisição, que aconteceu na idade média, entre os séculos $\mathrm{XIV}, \mathrm{XV}, \mathrm{XVI}$, é nela que as chamadas bruxas serão queimadas em praças públicas, pontos importantes deste momento é perceber que serão as mulheres a serem queimadas, e quem são essas que morrem de forma brutal.

\begin{abstract}
Neste contexto, essencialmente teológico, a" maldição bíblica de eva" acompanharia mais do que nunca a mulher. Estigmatizando-a como responsável pela queda do homem e como tradução da perseguição implacável ao corpo da mulher. A raiz do medo da mulher, no homem, estava ligada aos segredos do parto, da cura e da fabricação de "mezinhas" (termo do qual se originou a palavra medicina). Ela ainda conhecia o segredo dos venenos, das poções e dos filtros (espécie de chá) que enfeitiçaram e matavam, sendo senhora da vida e da morte. Os homens medievais procuravam lutar contra esse saber-poder, estavam embutidos de crenças e mitos, temiam a sabedoria feminina porque desejam garantir sua soberania, partindo para uma caçada sangrenta nunca vista em nenhuma outra civilização (FREIRE, SOBRINHO, CONCEIÇÃO,2016).
\end{abstract}

A mulher então é um símbolo de novos tempos, é ela quem detém uma sabedoria capaz de salvar e matar, e quando a mesma adquire esse poder, cabe ao masculino levar a mulher ao lugar que ele the dá, o de submissão, é aqui que as mulheres sábias passam a ser designadas como bruxas, e toda aquela que questiona o papel que a igreja, o deus masculino, o homem Ihe dá, deve ser torturada e queimada. 
Outro momento histórico para se pensar a condição social feminina, e a construção do que é ocupar esse lugar é o movimento feminista contemporâneo, que inicia-se no século 19 na Inglaterra, é aqui que as discussões sobre os espaços determinados por gênero ganham pela primeira vez na história voz, ao ponto de que, outros ambientes possam ser ocupados, e que a mesma possa sair da dimensão do privado, conquistar o direito sobre 0 próprio corpo, e questionar o que é tido como normal e natural, buscando assim, o fazer-se mulher não mais a partir do olhar masculino.

\begin{abstract}
Um movimento social que surgiu na década de 60 a partir da noção de "mulher" enquanto indivíduo como valor, sujeito moral que passa a questionar os papéis sociais (baseados na diferença sexual) - que legitimam uma dominação masculina universal sobre a categoria mulher - e a reivindicar um espaço de atuação política. Vendo, portanto, a diferença biológica como a "base" da desigualdade, a mulher estaria "condenada" pelas sociedades a uma posição inferior devido à sua capacidade reprodutiva, já que esse "encargo natural" seria apropriado pelo homem confinando a mulher no espaço privado, sustentando uma dicotomia homem/espaço público x mulher/espaço privado que se legitimaria enquanto uma dicotomia hierárquica da desigualdade.(SOUZA, 2001).
\end{abstract}

Neste período pela primeira vez a mulher em nível mundial passa a conquistar direitos, tais que serão adquiridos através de muita luta e tempo, como por exemplo direito ao voto que só é conquistado pela primeira vez na Nova Zelândia, em 1883, no Brasil a mulher só pode voltar em 1928, de forma gradual a mulher branca vai conquistando outros espaços.

\title{
2.2. Mulher Negra
}

A luta pelo fim da misoginia é marcada na história por uma série de conquistas. Apesar dessa luta ainda não ter acabado, muito do que que já foi conquistado pelas mulheres se deve ao feminismo, um movimento filosófico, social e político que surgiu no século XIX, tendo como objetivo a igualdade entre os gêneros, e consequentemente a participação da mulher na sociedade. No entanto, enquanto as mulheres brancas buscavam equiparar direitos civis com os homens brancos, mulheres negras carregavam nas costas o peso da escravatura, ainda relegadas à posição de subordinadas, subordinação essa que não se limitava à figura masculina, pois a mulher negra também estava em posição servil perante à mulher branca.

Durante a Guerra Civil as mulheres brancas foram trabalhar fora de casa. Em 1870, embora $70 \%$ das mulheres trabalhadoras fossem domésticas, um quarto de toda a força de trabalho, excetuando-se a mão de obra rural, era constituída por mulheres. $\mathrm{Na}$ indústria de confecções, elas já tinham se tornado maioria, no entanto, segundo Angela Davis, as portas do movimento sufragista não se abriram para as mulheres negras 
$\mathrm{Na}$ condição de mulheres que sofriam com a combinação das restrições de sexo, raça e classe, elas tinham um poderoso argumento pelo direito ao voto. Mas o racismo operava de forma tão profunda no interior do movimento sufragista feminino que as portas nunca se abriram de fato às mulheres negras. (DAVIS, 2016)

Segundo Djamila Ribeiro "a invisibilidade da mulher negra dentro da pauta feminista faz com que ela não tenha seus problemas nem ao menos nomeados. E não se pensa em saídas emancipatórias para problemas que nem sequer foram ditos." (2018). A partir dessa percepção, a conscientização a respeito das diferenças de opressão contra as mulheres foi ganhando cada vez mais corpo com o surgimento do feminismo negro no Brasil no final da década de 1970.

Se o objetivo é a luta por uma sociedade sem hierarquia de gênero, existindo mulheres que, para além da opressão de gênero, sofrem outras opressões, como racismo, lesbofobia, transmisoginia, torna-se urgente incluir e pensar as intersecções como prioridade de ação, e não mais como assuntos secundários. (RIBEIRO, 2018)

O feminismo negro trata-se de um movimento de mulheres atuantes tanto na esfera da discussão de gênero quanto na luta antirracista. $O$ fato de que as mulheres negras nem sequer conquistaram igualdade em comparação com outros indivíduos do seu próprio gênero se deve a herança histórica dos 300 anos escravidão e o racismo estrutural incutido na sociedade desde 1444, quando os portugueses começaram a explorar da costa da África e a colonização das Américas.

Inseridos nesse contexto estão às mulheres negras escravizadas, que sem dúvida estavam colocadas em um nível social inferior, tanto por ser mulher, como por ser negra e, também escrava. Ser mulher, e ser escrava dentro de uma sociedade extremamente preconceituosa, opressora e sexista, é reunir todos os elementos favoráveis a exploração, tanto econômica quanto sexual, e também ser 0 alvo de humilhações da sociedade nos seus diferentes segmentos. (GIACOMINI 1988, p.26)

Em Mulheres, raça e classe, a filósofa Angela Davis aborda o fato de mulheres negras não serem tratadas como frágeis e castas, sempre tendo precisado realizar trabalhos que exigiam o uso da força. Ela inicia o livro com o capítulo "O legado da escravatura: Bases para uma nova natureza feminina", em que fala sobre como a mulher negra escravizada era tratada de modo a ofuscar uma "natureza feminina", uma vez que eram forçadas a desempenhar o mesmo trabalho dos homens negros escravizados. O que as diferenciavam dos homens, e essa é a diferença crucial, era o fato de terem seus corpos violados pelo estupro.

Essa outra construção de feminino contrasta diretamente com aquela que as mulheres brancas lutarão para derrubar: a da mulher frágil, submissa e dependente do homem. A mulher negra ter sido submetida a esse tipo de violência sistematicamente evidencia uma relação direta entre a colonização e a cultura do estupro. No Brasil, 
as mulheres negras tiveram essa mesma experiência. É importante ressaltar que a miscigenação muitas vezes louvada no país também foi fruto de estupros cometidos contra elas. Essa tentativa de romantização da miscigenação procura escamotear a violência. (RIBEIRO, 2018, p.78)

A abolição da escravatura no Brasil não foi resultado da benevolência do Império como muitos acreditam, essa conquista foi resultado do engajamento popular contra essa instituição, e a pressão popular sobre 0 Império foi o fator que fez com que a escravidão fosse abolida em 13 de maio de 1888.

Apesar da abolição, novas formas de poder foram estabelecidas na sociedade, deixando a escravidão vigorar em muitos âmbitos sociais, como no trabalho escravo contemporâneo onde o trabalhador obrigado a prestar um serviço, sem receber um pagamento ou receber um valor insuficiente para suas necessidades (as relações de trabalho costumam ser ilegais), ou através da marginalização de homens e mulheres negros, onde $72 \%$ da população das comunidades é composta por eles.

O reflexo atual da opressão que as mulheres negras enfrentam fica evidente na diferença dos salários, contratação, assédios, violência e condição social em comparação com as mulheres brancas. A violência obstétrica também é um marco na vida das mães negras e pobres. Negligenciadas nas filas do SUS, elas são colocadas em segundo plano para que mulheres brancas - consideradas mais frágeis e sensíveis - sejam priorizadas, independente da ordem de chegada.

As negras são mais de $60 \%$ das vítimas de feminicídio, exatamente porque não contam com assistência adequada e estão mais vulneráveis aos abusos das próprias autoridades.

Enquanto mulheres brancas lutam para que seus salários (média de $R \$ 797,00$ ) sejam equiparados aos salários dos homens brancos (média de $R \$ 1.278,00$ ), as mulheres negras recebem ainda menos (média de $R \$$ $436,00)$.

O Censo 2010 revelou que as mulheres negras são as que menos se casam, sendo a maioria na categoria de "celibato definitivo", ou seja, que nunca tiveram um cônjuge.

Os dados citados são apenas alguns exemplos das disparidades entre mulheres brancas e negras, mas são fundamentais para se compreender a necessidade de uma vertente específica dentro do feminismo. É preciso validar as diferenças para que seja possível eliminá-las. 


\section{O SEXO E O FEMININO}

"Era uma vez uma mulher

que via um futuro grandioso

para cada homem que tocava

um dia, ela se tocou"

Alice Ruiz

Ao percorrer a história verificamos que os discursos sobre 0 vivenciar o corpo, e a sexualidade foram temas polêmicos dentro das culturas normativas,_e difíceis de mensurar, principalmente sobre o corpo feminino, que aparecem relegados ao falo, ou descritos sob um olhar masculino, para mais, até onde os discursos culturais patriarcais se fazem na subjetividade da mulher. Ainda assim é na psicanálise que este tema parece ganhar espaço e teóricos que tentam abarcar todas essas dimensões.

O corpo feminino está cercado de tabus, para a psicanalista Corso (2016) por muitos séculos, perdurou a ideia de um sexo único, e a mulher seria um homem com órgãos sexuais internalizados, o que a tornava incompleta e inferior. No mundo burguês a mulher passa a ser sem corpo, santificada,_a rainha do lar.

Ou seja, as narrativas apontam que, ao longo do tempo, a mulher fora de todos, mas nunca dela mesma, ou é corpo, ou objeto, mas nunca subjetiva, nunca um eu pertencente a sua própria natureza.

Mas o corpo é em si mesmo uma construção, assim como o é a
miríade de "corpos" que constitui o domínio dos sujeitos com marcas
de gênero. Não se pode dizer que os corpos tenham uma existência
significável anterior á marca do seu gênero; e emerge então a
questão; em que medida pode o corpo vir a existir na(s) marca(s) do
gênero e por meio delas? Como conceber novamente o corpo, não
mais como um meio ou instrumento passivo á espera da capacidade
vivenciada de uma vontade caracteristicamente imaterial
(BUTLER,2019)

Este projeto busca então transcorrer o feminino, para além do corpo, tirar a mulher do lugar que lhe é relegado, Butler (2019) com certa dificuldade, a economia fantasmática de Platão priva virtualmente o feminino de uma morphe, uma forma, porque, como receptáculo, o feminino é uma nãocoisa permanente e, por isso, desprovido de vida e de forma, que não pode ser nomeado. E, portanto, dar forma, voz, autoridade a mulher a si, não somente ao corpo que the é seu, mas o vivenciar este, através da pesquisa, das entrevistas e questionários, vislumbrar as formas de libertação da não forma.

\section{MASTURBAÇÃO, ORGASMOS E A EMANCIPAÇÃO DO CORPO FEMININO}

Para iniciar a discussão sobre a vida sexual da mulher, propriamente dita, é necessário analisar a trajetória que foi incumbida ao prazer (ou a falta dele) de uma mulher cisgênero nos séculos passados. Enquanto os 
homens tinham pleno acesso à sexualidade dentro de bordéis, o mesmo conhecimento não era permitido às mulheres, que casavam virgens e eram proibidas de sentir prazer durante a relação sexual.

A sexualidade feminina era tão inexplorada que, até o século $X X$, o orgasmo feminino ainda era desconhecido. Nesse período, a medicina e a psicologia começaram a se aprofundar nesse estudo. Apesar disso, as mulheres continuavam a ser ensinadas a não discutir tais assuntos em espaços públicos, limitadas a expô-los, de maneira quase vergonhosa, dentro dos consultórios ginecológicos e psicológicos. Esses ensinamentos corroboram o controle dos corpos.

O corpo-objeto incumbido para a mulher ao longo das eras pelo patriarcado sujeita a repressão da própria mulher sobre o seu corpo, considerando-o indigno dos prazeres da carne. Assim, fixadas na ideia vendida pelo catolicismo da virgem Maria, as mulheres "serviam" aos seus maridos, envergonhadas de sua nudez e de seu corpo, sem acesso à métodos contraceptivos e sem direito ao aborto. Enquanto isso, as mulheres negras, em sua maioria, trabalhavam de domésticas, faxineiras, babás e, por conta do patriarcado e da construção do corpo-objeto, somado ao racismo e ao resquício do período colonial, eram estupradas por seus patrões.

Para além da vergonha mútua, há uma exigência que perdura até os dias de hoje sobre o hímen. A mulher deve casar casta, com o corpo puro, para então, satisfazer o seu marido e reproduzir. O casamento, ao preservar sua função reprodutiva, passou a ser um acontecimento divino, que vinculava 0 sexo à constituição e propagação da espécie humana. $O$ casal podia entregarse livremente um ao outro, sem, no entanto, impedir a reprodução. O prazer, podia acompanhar a atividade sexual do homem destinada à geração de filhos. Não é a busca do prazer que é condenada: é a busca 'apenas do prazer', em outras palavras, relações sexuais amputadas de sua virtude procriadora.

Com essa visão de corpo imaculado, casto, isento de prazer, puro e divino, como a virgem Maria, o controle sexual estende-se até mesmo à masturbação, as mulheres se sentem envergonhadas de seu próprio corpo, portanto tocar nele é uma afronta à Deus, a sociedade e a si mesma. A virgindade, definida na mulher cis pelo hímen, é imposta até o casamento, para que na noite de núpcias o homem rompa e ela sangre, como exemplo de sua castidade, portanto, a mulher transa pela primeira vez sem ter tocado no seu corpo, e mais ainda, sem ter tido orgasmo.

A emancipação do orgasmo feminino, da masturbação e do prazer vem junto do domínio do próprio corpo e do poder de escolha da mulher, pois se esta é capaz de dizer o que quer e o que gosta, o patriarcado perde os seus artifícios para controlá-la. 


\section{CONSIDERAÇÕES FINAIS}

Concluímos a partir deste estudo que os corpos denominados femininos são construídos para estarem em um lugar se submissão aos corpos ditos masculinos, subjetividades essas controladas através de uma cultura e valores patriarcais perpassados de gerações a gerações, que não se estendem somente a sexualidade feminina, mas a toda concepção de "ser mulher".

Todo um criar-se se baseia em estereótipos do que chamamos gênero, limitada portanto toda potencialidade humana de um sujeito através de concepções de como este deve ser e agir, segundo Sayão (2003) construções culturais provenientes dessa diferença evidenciam inúmeras desigualdades e hierarquias que se desenvolveram e vêm se acirrando ao longo da história humana, produzindo significados e testemunhando práticas de diferentes matizes.

Nesta revisão se fez necessário algumas distinções pois, ao elucidarmos 0 assunto percebemos que, não se basta falar sobre mulher, pois nossa cultura se subdivide ainda mais, e estratifica, segrega grupos dependendo se sua cor, classe ou gênero, sendo assim, devemos portanto sempre diferenciar, quem fala, e de quem se fala. Tanto mulheres brancas quanto mulheres negras lutam por emancipação da sexualidade, mas se distinguem quanto às repressões perpassadas pelas mesmas.

Mulheres brancas, portanto, encontram-se em um movimento de emancipação de si, do corpo que as aprisiona, não mais constroem um corpo para este outro, mas sim, vivenciam esse corpo para elas. Enquanto as mulheres negras também lutam pelo direito ao corpo, a serem donas de si, mas também para saírem do lugar de marginalização, da mulher sexualizada, que não é mulher e sim algo, um objeto a ser desfrutado e logo descartado,

A sexualidade, então, das duas são construídas de formas diferentes, tendo a mulher branca mais privilégios em detrimento da mulher negra, entretanto, para a libertação deste corpo, um ponto parece ser comum em ambas as construções, o tocar-se, o autoconhecimento sobre seu próprio prazer.

Conclui-se que a sexualidade da mulher antes controlada, ou seja, que anteriormente somente existia para ser vivido no âmbito privado, para prazer do masculino, como um ser incompleto e faltante, sem forma, agora ganha um outro olhar, a mulher passa a tocar-se, a tomar o poder de sentir prazer para si e não mais delegar essa função ao outro, e quando a mesma torna-se dona do seu próprio prazer, torna-se dona também de si, e do seu corpo, das suas escolhas, emancipação de um ser agora total e não mais um ser faltante 
REFERÊNCIAS

BOURDIEU, Pierre. A dominação masculina. 11. ed. Rio de Janeiro: Bertrand Brasil, 2012.

BUTLER.J. Corpos que importam: Os limites discursivos do "sexo".1. ed. São Paulo:n-1 edições. Nov.2019

BUTLER.J Problemas de gênero: O feminismo e subversão da identidade.18. ed. Rio de Janeiro: Civilização Brasileira. 2019

CORSO, D. Insustentável do corpo feminino. Café Filosófico, Campinas: Instituto CPFL, 2016.

DAVIS, Angela. Mulheres, raça e classe. Boitempo. São Paulo. 2016.

FONSECA, Rosa Maria Godoy Serpa da. A construção da identidade de mulheres e homens como processo histórico-social. Edisciplinas, USP. São Paulo.jun/2010. Disponível em:

$<$ https://edisciplinas.usp.br/pluginfile.php/169640/mod_resource/content/1/identi dade $>$ Acesso em 10 de set de 2020.

FREIRE, Mariza Scheffer; SOBRINHO, Vilma Pereira; CONCEIÇÃO, Gilmar Henrique Da. A Figura Feminina No Contexto Da Inquisição.Educere et Educare: Revista de Educação, v. 1, n. 1, p. 53-58, 2006.

SANTOS, Keila Meireles Dos. A Construção Social da Mulher. Portal Geledés.São Paulo. Out/2013. Disponível em: <https://www.geledes.org.br/aconstrucao-social-da-mulher/> Acesso em 02 maio de 2020

RIBEIRO, Djamila. Quem tem medo do feminismo negro? Companhia das Letras. São Paulo. 2018.

SILVA, Maria da Penha. Mulheres negras: sua participação histórica na sociedade escravista. Cadernos Imbondeiro. João Pessoa. 2010. 


\title{
A INFLUÊNCIA E AS CONSEQUÊNCIAS DE UM DIAGNÓSTICO DE PSICOPATIA NA VIDA DE UM INDIVÍDUO NA SOCIEDADE ATUAL
}

\author{
João Marcus Roque Cardoso \\ Mauricio Crivelenti Abrão \\ Mateus Lemos de Azevedo \\ Sofia Muniz Alves Gracioli
}

\section{INTRODUÇÃO}

A psicopatia é um distúrbio mental grave, onde o indivíduo apresenta comportamentos antissociais e amorais, sem demonstração de culpa ou remorso, sendo incapaz de amar, aprender com as experiências, incapaz de criar laços profundos com outros indivíduos e se mostrando extremamente egocêntrico.

Em convivência com a sociedade, a pessoa com psicopatia tem a tendência a causar danos para as outras pessoas ou ao bem-estar da sociedade geral. O diagnóstico de psicopatia é severo e implica em vários danos na vida do indivíduo em um meio comum, sua convivência passa a ser mal vista e sua patologia gera um preconceito á pessoa. Numa sociedade cheia de mitos e pouca informação, o baixo entendimento sobre tal caso gera uma resistência muito grande do meio com o indivíduo, e ao ser reconhecido com psicopatia, a vida do sujeito tende a sofrer graves mudanças, que foram demarcadas no presente artigo.

A relevância do presente artigo é que por ser um tema pouco discutido necessita de uma atenção especial, pois impacta a vida das pessoas de uma forma muito forte.

O objetivo deste artigo é analisar e elencar as dificuldades durante o tratamento e da convivência social que indivíduos psicopatas passam em seus dia-a-dia e como eles reagem as essas consequências.

A metodologia utilizada foi uma revisão bibliográfica crítica com uso de artigos científicos e livros a respeito do assunto.

\section{O CONCEITO DE PSICOPATIA: EVOLUÇÃO AOS DIAS ATUAIS}

O conceito de psicopatia foi desenvolvido e estudado através dos anos, até chegar na definição que temos hoje, sendo incluído no código penal. A etimologia da palavra tem origem do grego psykhé (mente) com pathos (sofrimento). Schnneider (1968) define personalidades psicóticas como "aqueles que sofrem com a sua anormalidade ou que assim fazem sofrer a sociedade".

Definido no dicionário online como uma "perturbação da personalidade que se manifesta essencialmente por comportamentos 
antissociais (passagens a ato), sem culpabilidade aparente" (PSICOPATIA, 2020 , s.p), o comportamento psicótico tem basicamente características a ausência de empatia ou culpa e características anti-sociais, além de ser perceptível nos atos cotidianos e dificilmente identificado por pessoas comuns.

Uma das características de indivíduos psicopatas é apresentar comportamentos antissociais, de acordo com o DSM-5 (2014), o "transtorno da personalidade antissocial é um padrão de desrespeito e violação dos direitos dos outros", e em alguns casos o indivíduo pode apresentar também um "transtorno da personalidade narcisista ou transtornos psicóticos". O transtorno de personalidade antissocial já foi visto de várias maneiras:

Esse padrão também já foi referido como psicopatia, sociopatia ou transtorno da personalidade dissocial. Visto que falsidade e manipulação são aspectos centrais do transtorno da personalidade antissocial, pode ser especialmente útil integrar informações adquiridas por meio de avaliações clínicas sistemáticas e informações coletadas de outras fontes colaterais (DSM-5, 2014, p. 659)

Psicopatas são pessoas aparentemente comuns, porém apresentam algumas características que desviam da norma, é possível apenas defini-los com base nas suas atitudes cotidianas. Filho (2009, p. 338) apud Checkley (1941/1976) enumera algumas características:

Charme superficial e boa inteligência; 2) Ausência de delírios e outros sinais de pensamento irracional; 3) Ausência de nervosismo e manifestações psiconeuróticas; 4) Não-confiabilidade; 5) Tendência à mentira e insinceridade; 6) Falta de remorso ou vergonha; 7) Comportamento antissocial inadequadamente motivado; 8) Juízo empobrecido e falha em aprender com a experiência; 9) Egocentrismo patológico e incapacidade para amar; 10) Pobreza generalizada em termos de reações afetivas; 11) Perda específica de insight; 12) Falta de reciprocidade nas relações interpessoais; 13) Comportamento fantasioso e nãoconvidativo sob influência de álcool e às vezes sem tal influência; 14) Ameaças de suicídio raramente levadas a cabo; 15) Vida sexual impessoal, trivial e pobremente integrada; 16) Falha em seguir um plano de vida. (FILHO apud CHECKLEY, 1941/1976, p. 338)

No sistema judiciário brasileiro, o indivíduo psicótico é tratado no Art. 26 do Código Penal - Decreto de Lei 2848/40 (BRASIL, 1940) como "inteiramente incapaz de entender o caráter ilícito do fato ou de determinar-se de acordo com esse entendimento", sendo assim, a pena definida para os delitos cometidos pode ser reduzido de um a dois terços, no caso do agente, em virtude da sua perturbação de saúde mental não era inteiramente capaz de entender o caráter ilícito do fato.

\section{COMO É REALIZADO E QUAIS SÃO AS DIFICULDADES PARA O TRATRAMENTO PARA A PSICOPATIA}

O tratamento na psicopatia é algo muito discutido, mas ao mesmo tempo têm-se poucas respostas a cerca desse processo. Muitas pessoas podem pensar que a psicoterapia seria uma saída para alavancar esse tratamento e possivelmente até uma suposta cura, mas segundo Hare (2013) a 
psicoterapia não seria muitas vezes uma forma de melhorar essa situação, muito pelo contrário, em determinadas situações a terapia pode piorar 0 indivíduo, pois é comprovado que o sujeito psicopata não se sente motivado em quase nenhuma situação e assim abandonam a terapia muito facilmente nas primeiras sessões. Muitos indivíduos com a psicopatia depois de fazerem terapia apontam um maior grau de violência quando são liberados, enquanto que os psicopatas que não passaram pelo processo da terapia se mostram um pouco menos violentos. Portanto é visto que a psicoterapia é muitas vezes erroneamente ligada a melhora de um psicopata, sendo que na maioria dos casos ela pode até piorar o comportamento dos sujeitos, sendo que os mesmo não sentem nenhum pouco de empatia ou qualquer outro sentimento que os faça mudar seu comportamento para melhor.

Morana (2006, s.p) diz o seguinte sobre o tratamento:

Os pacientes portadores de TP demandam excessiva atenção por parte da equipe profissional e muitos são considerados irritantes e de difícil manejo, contribuindo para dificuldades contra transferenciais que dificultam ainda mais a condução do tratamento. Existe alguma evidência sugerindo que pessoas que preenchem critérios plenos para psicopatia não são tratáveis por qualquer forma de terapia disponível na atualidade. O seu egocentrismo em geral e o desprezo pela psiquiatria em particular dificultam muito o seu tratamento.

Entende se então que além das dificuldades encontradas no sujeito psicopata(falta de empatia e de culpa) há as dificuldades externas que seriam a relação equipe $x$ psicopatas, que é muito deteriorada porque alguns profissionais da área da saúde tem a visão de que os psicopatas são irritantes e difíceis de lidar, dificultando mais esse processo de melhora.

Algo que dificulta no tratamento de psicopatia segundo Barbosa (2008) é que os psicopatas raramente procuram a terapia como uma forma de melhorar seus comportamentos, porque em geral quem procura a terapia é quem esta descontente e insatisfeita com sua situação atual, mas os psicopatas não, eles se sentem totalmente satisfeitos com tudo que acontecem em suas vidas, não tendo nenhuma tristeza, autoestima baixa, e nem mesmo depressão. Segundo Barbosa (2008) algo que seria mais eficaz nessas situações de psicopatia seria o uso das terapias biológicas, medicando o sujeito. Ou seja, o psicopata não tem vontade alguma de fazer terapia, e quando comparecem as sessões é obrigado por algum familiar, tudo isso porque ele se sente bem com seus comportamentos e seu estilo de vida, sem assumir nenhuma culpa ou angústias.

\section{COMO É O MÉTODO DE DIAGNÓSTICO DA PSICOPATIA}

Segundo a tese de Hilda Morana (2004), existem dois instrumentos padronizados que facilitam para identificar os psicopatas, os instrumentos padronizados são o PCL-R de Hare e a teste de Rorscharch, juntamente com a avaliação psiquiátrica. 
Segundo João Carlos Alchieri (2004) em sua tese as técnicas de tinta o teste de Rorscharch é um teste conhecido como manchas de tinta, sendo um instrumento que usa estímulos visuais pouco desenvolvidos possibilitando a comprovação da organização perceptual e a projeção dos aspectos internos do examinando.

Hare com seu teste concluiu um resultado interessante nas suas palavras:

Muitos estudos verificaram que os prisioneiros com altos escores que os prisioneiros com altos escores no PCL-R, portanto identificados como psicopatas, estão mais do que duas vezes propensos a reincidência criminal do que outros prisioneiros (HARE,1995, p.29)

A psicopatia é um distúrbio mental grave e de complexo diagnóstico esses instrumentos visam apenas a auxiliar o examinando se ele tem a probabilidade ou não de reincidência criminal de acordo com os resultados e as analises dos instrumentos.

Nas palavras de Morana:

A escala do Hare PCL-R - Psychopatic Checklist Revised - vem preencher essa dificuldade diagnóstica. Permite, através de um ponto de corte determinado, a identificação de características de personalidade compatíveis com 0 conceito de psicopatia, características essas entendidas como condições mórbidas que pressupõem comportamento antissocial destrutivo e elevada tendência à reincidência delitiva. Desta forma, a psicopatia inclui-se entre os transtornos antissociais da personalidade como forma mais grave de manifestação. Tal gravidade é entendida como menor possibilidade de reabilitação, dificuldade de ajuste à instituição prisional, reincidência em crime e violência. (MORANA, 2003, p. 35)

Ou seja, quanto maior grau de psicopatia mais complicado fica para o individuo viver em sociedade, de se adaptar a prisão, e sua repetição ao crime e violência voltará com mais facilidade.

Segundo Hare mesmo o ambiente sendo um fator que influencia ele esclarece:

Hare afirma, ainda, que os fatores sociais e a criação embora ajudem a modelar a "expressão" do transtorno, nada podem fazer quanto a incapacidade do indivíduo sentir empatia ou desenvolver uma consciência. Sua pesquisa atestou que, a qualidade de vida familiar se demonstra muito menos influente sobre a posterior criminalidade em infratores psicopatas do que em indivíduos não psicopatas. (HARE, 2013, p.181)

Por mais que no behaviorismo diz que o ambiente molda 0 comportamento, de acordo com as pesquisas de Hare o contexto familiar não influencia tanto a criminalidade pelos psicopatas.

Hare (1991) define que "O PCL-R é uma escala com destino a pontuação para qualificar a psicopatia em populações forenses masculinas, ele é um dos instrumentos mais utilizados em âmbito forense em vários países. 
"Ou seja, o PCL-R contribuiu muito a qualificar a psicopatia em âmbitos forenses.

O psicólogo Gacono comenta sobre os testes:

Em pesquisa realizada com o uso do Rorscharch e do PCL-R em população forense verificou que os que apresentaram altas pontuações no PCL-R evidenciaram refratariedade ao tratamento, apresentaram maior quantidade de registros por indisciplina e um elevado risco para reincidência, tanto em crimes violentos como não violentos. (GACONO, 1998, p.29)

Ou seja, no teste de Rorscharch e do PCL-R quantos mais elevados eram os resultados dos testes mais resistentes ao tratamento os indivíduos eram.

\section{CONSIDERAÇÕES FINAIS}

O objetivo geral do presente trabalho foi analisar e elencar as dificuldades no tratamento de indivíduos diagnosticados com psicopatia e na sua convivência em sociedade no dia-a-dia e como eles reagem as essas consequências, já os objetivos específicos foram definir o termo psicopatia e correlaciona-lo com as psicopatologias apresentadas pelo indivíduo, apresentar a visão jurídica do Brasil em relação à essas pessoas, descrever como é realizado o diagnóstico e tratamento e definir as dificuldades encontradas, sendo assim o artigo buscou englobar a maior parte de informações sobre 0 tema.

Acreditávamos em várias hipóteses durante o início do trabalho, sendo que algumas delas foram caindo, e com a pesquisa bibliográfica sendo executada, vimos que tais hipóteses na verdade possuíam outro significado. Como por exemplo, no começo do trabalho pensávamos que a psicoterapia era um forte aspecto que ajudaria durante o tratamento do indivíduo psicopata, mas através das nossas pesquisas chegamos ao resultado que, em alguns casos a terapia se torna um obstáculo e dificulta ainda mais tal processo. Outro exemplo de hipótese era que, o método de diagnóstico para a psicopatia era de fácil realização, e através das pesquisas realizadas vimos que tal processo é bem complexo e envolveu bem mais do que uma simples observação do sujeito em questão.

Vendo tais circunstâncias, pensamos que pode haver algumas saídas para que a situação seja amenizada ou pelo menos haja maior entendimento sobre 0 assunto e dessa forma possa haver um compreendimento melhor por parte das pessoas e assim o tema "psicopatia" tenha alguns de seus paradigmas quebrados.

Como prognóstico, digo que, com a aceitação do próprio indivíduo, sabendo que ele possui tal transtorno de personalidade, o tratamento ficaria mais fácil de ser realizado. Mas como a maioria dos sujeitos psicopatas não admitem e nem aceitam que possuem tal transtorno, o que indico seria melhoras nas relações sociais dessa pessoa, ou seja, o entorno dessa pessoa 
deveria ser mais trabalhado, para que eles aprendam a lidar com o indivíduo psicopata e possam encaminha-lo para melhores caminhos, aceitando suas dificuldades e ajudando-o a se relacionar melhor em sua sociedade.

Vejo também, que deve-se investir mais em ciência, ou seja, em pesquisas relacionadas a esse tema, para que todas as dificuldades encontradas atualmente durante o tratamento e na relação entre sujeitos psicopatas, seja um dia amenizada e possa haver um melhor entendimento sobre o assunto, quebrando assim alguns preconceitos existentes.

Durante a realização de tal artigo, encontramos algumas dificuldades que deixaram nosso trabalho um pouco mais complexo. A primeira seria a dificuldade de achar material, tal dificuldade deve-se a dois motivos: 0 primeiro é que por ser um tema de difícil entendimento e alta complexidade, em alguns momentos nos faltava materiais, e quando encontrávamos algum, era um pouco repetitivo. O segundo motivo foi por causa da pandemia do Corona Vírus, que nos impediu de fazermos pesquisas na biblioteca física da faculdade, fazendo com que a gente se dispusesse apenas de matérias onlines e livros que já possuíamos em mãos.

Tal dificuldade literária acarretou em termos que nos adaptar em relação a nossa busca de conteúdo, tendo que buscar nossas informações em revistas onlines, artigo onlines e em sites especializados no assunto.

Pensar em futuras pesquisas a partir da de vocês!!!

\section{REFERÊNCIAS}

AMERICAN PSYCHIATRIC ASSOCIATION. Manual diagnóstico e estatístico de transtornos: DSM-5; tradução: Maria Inês Corrêa Nascimento... et al.]; revisão técnica: Aristides Volpato Cordioli ... [et al.]. - 5. ed. - Dados eletrônicos. - Porto Alegre: Artmed, 2014. Disponível em: $<$ http://www.niip.com.br/wp-content/uploads/2018/06/Manual-Diagnosico-eEstatistico-de-Transtornos-Mentais-DSM-5-1-pdf.pdf>. Acesso em: 14 abr. 2020

ALCHIERI, C.J (2004). Técnicas de manchas de tinta. Tese de Doutorado, UFRN, Natal. Disponível em: <https://docero.com.br/doc/x18ecx>. Acesso em: 11 abr. 2020.

BITTENCOURT, M. I. G. F. Conceito de psicopatia: elementos para uma definição. Revista FGV, v. 33, n. 4, P. 20-34, 1981. Disponível em: <http://bibliotecadigital.fgv.br/ojs/index.php/abp/article/view/18612/17353>. Acesso em: 14 abr. 2020

BRASIL. Lei oㅜ 2848. Da Imputabilidade Pena. Brasília:Senado Federal, 2017. Disponível em:

$<$ https://www2.senado.leg.br/bdst/bitstream/handle/id/529748/codigo_penal_1e d.pdf>. Acesso em: 14 abr. 2020 
FILHO, N. H.; T, M. A. P.; DIAS, A. C. G.. Psicopatia: o construto e sua avaliação. Aval. psicol., dez 2009, vol.8, no.3, p.337-346. ISSN 1677-0471. Disponível em: <http://pepsic.bvsalud.org/pdf/avp/v8n3/v8n3a06.pdf>. Acesso em: 14 abr. 2020

HARE, Robert D. Sem consciência: o mundo perturbador dos psicopatas que vivem entre nós. Porto Alegre: Artmed, 2013.

MORANA, C.H. P (2003). Identificação do ponto de corte para a escala PCL-R. Tese de Doutorado, USP, São Paulo. Disponível em: $<$ https://www.teses.usp.br/teses/disponiveis/5/5142/tde-14022004211709/publico/HildaMorana.pdf>. Acesso em: 11 abr. 2020.

MORANA, C.H.P Transtorno de personalidade, psicopatia e serial killers. São Paulo,2006.Disponível em : http://www.scielo.br/scielo.php?script=sci arttext\&pid=S151644462006000600005. Acesso em: 13 abr. 2020

PSICOPATIA. Dicionário online de português, 28 abr. 2020. Disponível em < https://www.dicio.com.br /psicopatia/ >. Acesso em 28 abr. 2020.

SCHNNEIDER, K. Psicopatologia clínica. 1a.ed. São Paulo: Editora Mestre Jou; 1968.

SILVA, A. B B. Mentes perigosas: o psicopata mora ao lado. Rio de Janeiro: Objetiva, 2008. 


\title{
A PERSPECTIVA DA EQUIPE TÉCNICO-ADMINISTRATIVA DE UMA ESCOLA ESTADUAL ACERCA DA VIOLÊNCIA ESCOLAR: uma pesquisa etnográfica
}

\author{
Marina Neves Alves \\ marinanevesalves1@gmail.com \\ Daniela de Figueiredo Ribeiro \\ danifiribeiro@yahoo.com.br
}

\section{INTRODUÇÃO}

O presente artigo é proveniente de uma pesquisa realizada através do Programa Institucional de Bolsa de Iniciação Científica PIBIC, do Centro Universitário Municipal de Franca - Uni-FACEF e foi financiada pelo Concelho Nacional de Desenvolvimento Científico e Tecnológico (CNPq). O trabalho faz parte de um projeto de pesquisa da orientadora deste, cujo título é "A CONVIVÊNCIA ESCOLAR NOS ANOS FINAIS DO ENSINO FUNDAMENTAL PÚBLICO: MAPEAMENTO DAS DIFICULDADES E PROMOÇÃO DO DESENVOLVIMENTO COMO LIBERDADE", com o objetivo de mapear as variadas práticas de violência que ocorrem na escola e favorecer modos de convivência entre os atores escolares, favoráveis ao desenvolvimento como liberdade.

O fenômeno violência é encontrado em diversos cenários, incluindo o escolar, sendo considerado complexo e uma tarefa desafiadora por muitos pesquisadores. Segundo Modena (2016), a violência pode ser natural ou artificial, ou seja, natural por ser própria de todos os seres humanos. Artificial, geralmente é um excesso de força de uns sobre os outros, causando danos físicos, como ferimentos, tortura, morte ou danos psíquicos, como humilhações, ameaças e ofensas, assim como também define a Organização Mundial da Saúde (OMS, 2002), acrescentando a agressão contra si próprio, além de outra pessoa ou grupo ou comunidade. Modena (2016), ainda aponta que "dito de modo mais filosófico, a prática da violência expressa atos contrários à liberdade e à vontade de alguém e reside nisso sua dimensão moral e ética" (MODENA, 2016, p.8).

De acordo com Rosa (2004), o fenômeno violência, pode ser justificado, trazendo acusações à atenção pública, à falta de diálogo e falta de cidadania. Segundo Charlot (2002) a violência escolar pode ser classificada em três ações diretas, a primeira é a violência na escola, determinada como penetração de gangues, tráfico de drogas, desavenças entre alunos de fora para dentro da escola. A segunda, violência da escola, caracterizada como as deficiências estruturais e de má administração, o autoritarismo por parte dos gestores, o abuso do poder na relação professor e aluno. E a terceira, a violência à escola, quanto ao vandalismo, depredação do patrimônio público, 
falta de respeito com os profissionais da escola, a resistência dos estudantes a regras impostas pelo sistema de ensino que não há como argumentar.

Segundo Abramovay (2015), Ferro e Araújo (2015), é recorrente que nas escolas as agressões verbais, como insultos, palavrões, difamações sejam menosprezados comparando com outros tipos de violência, no entanto, salienta que são consideradas como porta de entrada para a violência física. A instituição escola, é constituída por vários cargos profissionais, a equipe responsável pela direção, coordenação, gerenciamento e mediação é denominada como equipe técnico-administrativa. Conforme Carreira (2005) é o grupo de pessoas que colaboram com o desenvolvimento administrativo desse contexto, além da mediação dos conflitos da comunidade escolar.

Neste sentido a equipe é afetada junto a toda escola pelos impactos da violência no ambiente de trabalho e na vida pessoal. Luck (2009) menciona as habilidades necessárias para a atuação dos cargos, sendo elas: garantir o funcionamento pleno da escola com o foco na formação dos alunos e promoção de aprendizagem, orientando os planos de trabalho e ações promovidas na escola, deve definir, atualizar e implementar a qualidade de ensino, proporcionar interação, coerência e consistência entre todas as dimensões do trabalho educacional, capacidade de articulação entre as dimensões da escola e por fim, uma visão abrangente de escola e educação, com o objetivo de promover uma boa qualidade.

Cunha (2009), discorre sobre a tríade violência, escola e equipe técnico-administrativa, esse grupo de pessoas que encontra-se em situações diversas, nas quais muitas vezes, precisam mediar e resolver alguns desentendimentos, conflitos, dialogar com a família, com os profissionais da escola e, em casos graves, precisam tomar medidas que competem a outros órgãos para resolver casos de violência na escola. Além dos impactos causados pela violência, os estudiosos encontraram como resultado de suas pesquisas programas e ações nas escolas com o objetivo de diminuir e/ou controlar o fenômeno, tendo a participação da sociedade e dos poderes públicos.

De acordo com Jones (2004), a finalidade dos programas de educação a fim de resolver conflitos, são a criação de ambientes seguros, reduzindo a violência entre os alunos e proporcionando um ambiente mais protegido e de confiança para que os estudantes possam compartilhar suas ideias e sentimentos. As medidas de prevenção realizadas nas escolas possuem menores custos se comparados com os investimentos em segurança e justiça criminal, sendo de grande valia (LEITÃO, 2010). Silva e Assis (2018) destacam a importância de incentivar o estabelecimento de relações democráticas, favorecer a convivência entre seus integrantes, além do respeito às diferenças. 
Na mesma direção, no estudo de Priotto (2008), algumas práticas educativas são vistas como podendo diminuir a violência, tais como: abrir a escola nos finais de semana, dialogar, estimular a reflexão e no último caso levar para a direção se houver desobediência. Ao realizar discussões, não focar no fato de origem, ouvir a todos, tentar solucionar os conflitos ainda em sala de aula, somente se persistir os comportamentos indesejáveis, encaminhar para o coordenador pedagógico. Outras práticas também deram resultado como: fazer acordos com os alunos sobre direitos e deveres, proporcionar momentos de práticas esportivas, projetos, palestras, eventos e atividades recreativas. Promover a participação da família na escola. A sala dos professores deve ser um espaço de descontração e de conversas diversificadas. Enfim, promover um ambiente de inclusão, saudável para todos que desfrutam dele. O presente trabalho tem como objetivo compreender os processos de violência que perpassam a escola sob a perspectiva da equipe técnico-administrativa no contexto escolar público, mapear formas de enfrentamento e possíveis modos de prevenção, novas formas de convivência, além de proporcionar reflexões sobre estes tópicos e compreender as relações humanas e a convivência no contexto escolar

\section{METODOLOGIA}

Este trabalho seguiu a metodologia qualitativa do tipo etnográfico. A sistemática surgiu através da teoria fenomenológica, que considera os aspectos particulares do comportamento humano, onde, para conhecer as atitudes é necessário aprofundar-se no universo do sujeito para entender seu real significado (ANDRÉ, 2011).

A etnografia significa, segundo André (2011), a tentativa de descrever a cultura do sujeito. O etnógrafo passa aos leitores os significados através das suas próprias experiências na realidade do outro. De acordo com Spradley (1979, apud ANDRÉ, 2011), esses significados são expressos pela linguagem, outros por meio das atitudes, utilizando sistemas complexos para organizar seu comportamento, compreender a si mesmo, os outros e dar sentido ao mundo que vivem.

Para que uma pesquisa seja considerada do tipo etnográfico educacional, sofre algumas alterações, pois alguns requisitos da etnografia não são necessários. Já as características como: observações participantes, onde o pesquisador interage com o ambiente, afetando-o e sendo afetado por ele, ao mesmo tempo que observa, sempre dando ênfase ao processo e não ao resultado são fundamentais. Da mesma forma é comum a realização de entrevistas de profundidade ou intensivas, com o objetivo de promover um aprofundamento sobre o tema em questão. Os dados obtidos são analisados de acordo com a análise de conteúdo (ANDRÉ, 2011). 
A pesquisa foi realizada em uma Escola Estadual do Estado de São Paulo, que apresentava queixas de violência, localizada em um bairro periférico e reconhecido como violento. A instituição de ensino atende em média 184 alunos que estão cursando no Ensino Fundamental II e 254 a média de alunos cursando o Ensino Médio, totalizando 438 alunos, e possui 66 funcionários. Participaram da pesquisa os integrantes da equipe técnicoadministrativa desta escola, sendo eles: uma diretora, uma vice diretora, um professor coordenador pedagógico, uma gerente de organização escolar e uma mediadora de conflitos.

Após ser aprovado pelo Comitê de Ética obtendo o CAAE: 08975119.6.0000.5384, a pesquisadora obteve o consentimento livre e esclarecido dos participantes para dar início a coleta de dados. O presente trabalho conta com a efetivação das disposições da resolução 466/12 do Ministério da Saúde sobre pesquisas envolvendo seres humanos.

A coleta de dados foi dividida em duas partes, na primeira foram realizadas oito observações participantes, com duração média de duas horas, sendo os dias e horários alternados de acordo com a disponibilidade de cada participante. Essa fase teve o objetivo de acompanhar o funcionamento da escola, a rotina de trabalho de cada integrante da equipe, a dinâmica do cotidiano escolar, além de mapear as situações de violência que ocorrem no contexto escolar. Foram realizados diários de campo como registro das observações.

$\mathrm{Na}$ segunda fase da coleta de dados, os integrantes da equipe técnico-administrativa passaram por uma entrevista individual semiestruturada, pautada em três eixos temáticos, sendo eles: "As relações humanas e convivência dentro da escola"; "As situações de violência no contexto escolar (aluno-aluno, aluno-professor, outros)" e "Programas de prevenção de violência escolar e promoção de novos modos de convivência". Foi entregue um primeiro cartão com o tema escrito para o entrevistado e ele refletiu sobre o assunto, escrevendo inicialmente palavras que the vieram à mente. Logo após a entrevistadora aprofundou a conversa a partir das palavras que o entrevistado escreveu. Em seguida, foi apresentado o segundo cartão e por fim, o terceiro, seguindo a mesma metodologia do primeiro. As entrevistas duraram em média uma hora e meia, foram gravadas e posteriormente transcritas.

Este procedimento metodológico vem sendo utilizado no Grupo de Estudo e Pesquisas "Produção de Subjetividades e Educação" - GEPSEd, da USP de Ribeirão Preto, coordenado pelo Prof. Dr. Antônio dos Santos Andrade, onde são feitos estudos que dão ênfase à produção de subjetividades nas instituições educacionais, como por exemplo os estudos de Barbosa (2020) e Ferreira (2019). 


\section{RESULTADOS}

\subsection{Observações Participantes}

A equipe é formada por Sônia ${ }^{1}$, diretora, formada em Matemática e Pedagogia, possui 45 anos de idade e está atuando na Educação há cerca de 21 anos. Nesta escola, como diretora, atua há 2 anos. Letícia, de 43 anos, também é formada em Matemática e Pedagogia, atua no cargo de Vice Direção há 2 anos e trabalha há 25 anos na área de Educação. $O$ cargo de Mediação de Conflitos é ocupado por Mara, de 54 anos, formada em Matemática, Economia e Psicopedagogia, com 6 anos como mediadora de conflitos e 20 anos de atuação em outras escolas. Viviane, ocupa o cargo de Gerente de Organização Escolar, tem 37 anos, é formada em Sistemas de Informações, está há 4 anos trabalhando nesta escola e há 6 anos na área de Educação. A instituição também conta como participante da equipe técnico-administrativa o cargo de Professor Coordenador Pedagógico, ocupado por César, de 51 anos, formado em Filosofia e Pedagogia, atuante há 1 ano na escola, além dos 26 anos em outras escolas, como professor.

A observação 1 aconteceu no período vespertino, durou uma hora e meia, teve como objetivo a apresentação da pesquisadora para a equipe técnico-administrativa junto com uma estagiária de psicologia do Uni-FACEF, para começar a entrar em contato com a escola. A observação 2, teve duração de uma hora, no período vespertino, onde a diretora e os demais assinaram a Carta de Anuência, e o TCLE. A observação 3 durou cerca de uma hora e meia, no período vespertino, com o objetivo de acompanhar a sala da diretoria. A observação 4, ocorreu no período matutino, com duas horas, a fim de acompanhar a diretora em turno diferente do anterior. A observação 5 teve duração de duas horas e meia, acompanhando a diretora e a vice-diretora no período da tarde. A observação 6 que durou duas horas, com o intuito de compreender o ofício da mediadora em vivência escolar foi realizada no período matutino. $\mathrm{Na}$ observação 7 foi acompanhada a Gerente de Organização Escolar, com duração de duas horas e quinze minutos, e por fim durante quatro horas e quinze minutos, na observação de número 8 foi possível observar a rotina do Professor Coordenador Pedagógico em seu trabalho.

Durante as observações, a pesquisadora notou a presença dos pais dentro da escola ao irem buscar seus filhos após a solicitação dos alunos para a direção, por motivos de saúde, como dores de cabeça ou se sentindo mal. Além de prestadores de serviços gerais, presos, em situações de pena alternativa, realizando pinturas no interior da instituição monitorados por agentes penitenciários.

1 Os nomes de todos os participantes são fictícios. 
Ficou evidente que toda a equipe é sobrecarregada de tarefas, de prazos para entregar documentos e são cobrados o tempo todo pelos seus superiores. Trabalham com muita atenção e cautela para que nada de errado aconteça, o que gera um sofrimento, estresse, ansiedade, nervosismo, dentre outros aspectos emocionais.

Há relatos vindos dos participantes de que a escola passou por grandes melhorias na estrutura física como pinturas, troca de carteiras para os alunos, reformas em geral. É também rodeada de câmeras, que segundo eles, foram essenciais para a diminuição da violência e indisciplina dos alunos. Esta ferramenta de monitoramento colaborou com o trabalho dos inspetores e/ou agentes escolares que possuem a função de controlar a movimentação de alunos no pátio e pelos corredores durante as aulas. Os inspetores estão disponíveis para auxiliarem os professores caso aconteça alguma situação violenta e este professor precise de ajuda, se algum aluno passar mal e precisar de assistência.

Mesmo com a mudança significativa na estrutura da escola, a localização influencia na presença de insetos e pragas, sendo necessário uma dedetização constante no interior e exterior do estabelecimento.

Outro aspecto importante observado foi o episódio em que um aluno, ao utilizar o banheiro, a descarga transbordou, o que gerou um grande constrangimento a ele, que sofreu com a exposição feita por seus colegas. $O$ aluno solicitou à direção que ligasse para que seus pais pudessem buscá-lo. A mediadora de conflitos tentou conversar sobre a situação, mas devido ao constrangimento ele preferiu não se pronunciar sobre o assunto.

Os participantes contaram sobre episódios de violências físicas e verbais que presenciaram na escola. Houve caso de um aluno que tentou atacar outro portando uma faca, após uma discussão. Outro caso, onde alguns pais lidam com a instituição de forma muito violenta. Relataram agressões verbais vindo dos pais, dizendo que se sentirem extremamente tristes com esse tipo de acontecimento. Falam que os sentimentos vão se acumulando e influenciando na vida particular da equipe, mesmo tentando manter o equilíbrio emocional, consideram uma tarefa difícil de lidar.

\subsection{Entrevista}

As entrevistas semiestruturadas, foram organizadas a partir de três eixos temáticos pré estabelecidos, sendo eixo I - As relações humanas e a convivência dentro da escola, eixo II As situações de violência no contexto escolar (aluno-aluno, aluno-professor, outros) e eixo III programas de prevenção da violência escolar e promoção de novos modos de convivência.

No eixo I foram abordados alguns tipos de relacionamento, primeiramente a relação da escola com os pais e responsáveis pelos alunos. 
Os participantes apontaram alguns fatos, como o não comparecimento quando há a necessidade de um diálogo entre família-escola para solucionar problemas, dificultando o processo de aprendizagem e de relacionamento, além de perceberem a falta de diálogo na relação entre pais e filhos, aspectos retratados em algumas falas do coordenador pedagógico e da vice diretora: "É, acontece muito da escola chamar os pais e o pai não vir, ou chamar, vir uma vez, segunda vez, terceira vez já não vir mais e o filho continua dando problema. Acontece muito do pai e a mãe trocarem de celular e não tá nem aí, não tem acesso telefônico, e não é pouco não, é muito, maioria da demanda. Não atualiza o telefone não tem contato, quebra o contato, dificulta o contato em relação aos próprios filhos"(César). "[...] Os pais não tem diálogo com os filhos, não sabem o que tá acontecendo e muitas vezes então a gente percebe uma falta de... Sabe? Uma ausência. [...] Então eu acho que mais difícil é isso, que o pai é ausente, mas ele quer ter razão" (Letícia).

Relatam que lidar com este público exige um maior equilíbrio emocional, pois a forma com que alguns pais lidam com as questões escolares de seus filhos na presença da equipe técnico-administrativa, professores, secretários, funcionários em geral tem como características a agressividade, como gritos e humilhações: "Esse fator violência é mais difícil, porque a gente tem que ter um equilíbrio emocional muito grande, né? Você tem que saber falar a palavra certa, no momento certo, tem que ser ponderada, porque você não pode se perder" (Letícia).

Dos sujeitos que encontram impasses no relacionamento com os pais, tem como exceção a mediadora de conflitos, que lida com eles desde 0 pré-escola, outro local de trabalho que atende a mesma comunidade, retratando em sua fala " $E$ assim, eu tenho uma facilidade porque eu dou aula na escola de cima, então eu já convivo. Os meninos que são meus lá, de quatro anos, eles tão vindo para cá, então lá a gente tem mais contato com a mãe por ser fácil, né? E assim, aí eu fui conhecendo a comunidade nesses seis anos que eu tô aqui, e assim, graças a Deus eu tenho uma relação muito boa, tá?" (Mara)

Outro tipo de relacionamento abordado do eixo I foi 0 relacionamento com os alunos. A equipe mostra-se compreensiva com a realidade que os alunos vivem, relatam que tentam investigar e conversar sobre a vida pessoal destes jovens, se enfrentam problemas em casa, se estão passando por algum momento turbulento, afim de entender o comportamento, às vezes, inadequado na escola. Alguns deles apresentam realidades que comovem a equipe, principalmente no aspecto social e com isto se cria um sentimento de solidariedade, amor e empatia aos alunos. Apontam que o diálogo é a ferramenta que interliga escola-aluno. Mara e Sônia ilustram estes momentos em suas falas: "[...] Então a primeira coisa quando eu cheguei aqui, eu me dispus a ajudar, entender os meninos, porque a vida deles não é fácil, sabe $o$, a... a convivência em casa, a estrutura familiar deles estão todas com 
muito conflito, muito desequilíbrio" (Mara). "Eu converso com os alunos, eu não só dou aula, eu vou circulando e vou dialogando né, "que que está acontecendo? Você tá triste hoje...", "Ah, professora é por causa disso, disso e disso", "Ué, o que que aconteceu, porque você tá agressivo? Você não é assim", "Ah, porque minha mãe fez isso, isso e isso". Aí na hora que você vai descobrir a história do menino você fala: "senhor!", né. Tem uma aluna que o pessoal falou, "como que você sabe de tudo isso?" Mas é porque converso" (Sônia).

Apesar da vida pessoal de cada um, assim como os funcionários, os alunos também são cobrados de prazos, em tirar notas boas, passarem de ano e formar-se dentro do tempo predeterminado pelo modelo educacional que vivemos no Brasil, de acordo com a idade e a série que estão inseridos. No entanto, segundo a equipe, alguns alunos não levam a sério a formação, reclamam do ensino aprendizagem e da quantidade de conteúdo. Neste aspecto, são leis que a escola deve cumprir e não há diálogo para discutir.

$O$ relacionamento entre a equipe foi 0 terceiro aspecto apresentado como resultado no eixo I das entrevistas. Segundo relatos, lidar com pensamentos e personalidades diferentes gera uma dificuldade em algumas situações, exigindo algumas habilidades para comunicação e resolução de desentendimentos. Há queixas da sobrecarga de tarefas que o sistema educacional promove, pois acaba distanciando o grupo, dificultando as tomadas de decisões. César expõe com clareza em sua fala neste aspecto: "Olha, o que eu sinto é que o sistema ele cria uma... uma situação que muitas vezes, é dificultadora do andar da carruagem, por quê? A direção ela é sobrecarregada de coisas, eu como coordenador sou sobrecarregado de coisas, professor mediador é sobrecarregado, a gerente de organização na secretaria, sobrecarregada de cronogramas e de tudo que tem que apresentar, esse excesso, talvez porque esse ano foi atípico, esse ano implantou o MMR, esse ano implantou avaliações externas que não existiam, esse ano implantou transição de currículo, esse ano mudou a mecânica de matricula escolar, esse ano mudou muita coisa. Talvez por causa dessa transição, o excesso burocrático distanciou um pouco, distanciou naturalmente a equipe, que precisou dar conta de fazer as coisas no tempo, no horário, na hora certa e entregar, porque é assim, é e-mail chegando com data pra entregar e e-mail chegando com data pra entregar.[...] Lógico que a gente conversa, lógico que a gente... para, pra tomar decisões, mas a gente não consegue ainda, criar uma rotina... suave, tranquila, nossa, pra isso, porque? Porque é incêndio o tempo inteiro, é verba chegando o tempo, e tem que canalizar a verba, se não canalizar a verba no tempo certo, perde a verba" (César).

Apesar disso, os conflitos são sempre resolvidos através do diálogo no dia-a-dia e reuniões e ainda, os participantes relatam que há momentos de descontração, confraternização e respeito entre eles. 
Por fim, contam suas expectativas e frustações relacionadas às relações dentro da escola, expõem o cansaço que encontram no final do ano letivo: ". Então eu estou assim, extremamente... Sabe? Consumida. [...] chegou o final do ano eu estou no meu limite" (Sônia). A sensação de estar em um ambiente desprotegido contra violência: "Ah, às vezes a gente se sente desprotegida né? Porque você nunca sabe a reação do... Do outro" (Viviane). Os sentimentos de ansiedade: "Ah tem dia que da uma ansiedade. [...] Vixe às vezes eu, eu, quando eu me vejo balançando a perna, quando eu vejo que eu tô apertando o dente, quando eu vejo... Que os músculos estão retraindo assim, ai eu sinto que eu estou... Tem que tentar dar uma relaxada" (Viviane). Decepção, tristeza e indignação com a educação nos dias de hoje: "Eu não me vejo fazendo outra coisa, mas ando decepcionada com as coisas que o... as... o rumo que a educação às vezes estão se levando, porque, talvez também, se perde muito tempo, não que isso não seja necessário, mas se perde muito tempo também olhando, preocupando com essa questão do relacionamento e a aprendizagem tá ficando um pouco de lado [...]" (Letícia).

No eixo II - As situações de violência no contexto escolar (alunoaluno, aluno-professor, outros), foram apresentados episódios de violência que ocorreram na escola: violência verbal, física e psicológica.

Foi considerado como mais dolorosa pelos participantes, a agressão verbal, envolvendo toda a comunidade, desde os professores, funcionários, entre pais e funcionários, entre pais e filhos dentro da escola que muitas vezes passam despercebidos: " $E$ eu falo pra eles que a violência não é só aquela que a gente agride. Pra gente tomar muito... Cuidado com aquilo que sai da boca, entendeu? Porque às vezes o que a gente fala pro outro machuca muito mais que você ir lá e dá um tapa, dá um empurrão, um soco". (Mara)

O bullying também foi citado por eles, sendo observado com maior frequência entre os estudantes: "É tipo bullying né... [...] Eu vejo muito assim, muito aluno com aluno". (Viviane) "Eu vou chamar a violência de agressividade. [...] A agressividade na maneira de lidar uns com os outros, em circunstâncias variadas. bullying existe? Existe. Mas a violência seria a intensidade da agressividade de trato que ocorre entre alunos, que pode estar mais acentuado que a gente chama de bullying". (César)

Vindo de alguns pais e responsáveis, a equipe sente que as palavras machucam, causando até consequências emocionais: "Ah, por exemplo a mãe da Sara. ela deu muito problema esse ano, ela gritava, gritava. Ela é uma mãe que grita, xinga, xinga, fala, fala, deixa o ambiente muito desequilibrado. E... e isso assim, foi muito ruim, a Letícia. em uma das situações, a vice, ela congelou aqui na minha frente, que ela atendeu, era a Patrícia mãe da Sara. Ela começou a gritar, a Letícia. me entregou o telefone. [...] Ela me entregou o telefone, mas ela já ficou congelada, parecendo que ela não conseguia mexer, a mãe gritou, gritou, e a Letícia. parou aqui e ficou assim 
assustada, ela não conseguia nem conversar, sabe, parece que ela ficou. E foi nesse dia que ela caiu em si, que ela estava com sintomas de síndrome do pânico. [...] Né, nesse dia ela caiu em si, ela chorou muito, ela... e nós tivemos várias situações, de pai com agressividade, chega gritando, grita, grita, grita, grita, grita, sabe?" (Sônia)

Sobre violência física, relatam episódios envolvendo os alunos, no entanto perceberam que acontece com menor frequência nos últimos anos. $O$ professor coordenador nomeia a violência de agressividade. A agressividade entre aluno e professor como indisciplina. Entre funcionários, como desentendimentos.

No eixo III - Programas de prevenção da violência e promoção de novos modos de convivência, a escola conta com o cargo de mediação de conflitos, ocupado por Mara, que utiliza como principal ferramenta o diálogo entre as partes conflituosas.

Os participantes destacam que todos são responsáveis por promover novos modos de convivência, mediar conflitos e prevenir a violência escolar. Utilizam também a conversa como recurso, em momentos diversos, salas de aulas, conversas informais, orientações. Consideram também, os eventos como festa junina, dia das crianças e momentos de lazer, ocasiões onde a taxa de violência diminui significativamente, nas palavras de Sônia: "Eventos, os alunos gostam muito. A festa junina, nós fizemos a festa das crianças. Então quando faz esses eventos, nossa, eles ficam em êxtase, abaixa bem o número da... da questão da violência, você vê que eles se sentem... é por exemplo, no dia da festa das crianças. Eles sentiram como se fosse aniversário deles". (Sônia)

Acontece frequentemente na escola, segundo relato dos participantes, programas como o Jovem Protagonista, um projeto social, em que um grupo de alunos voluntários ajuda com arrecadação de alimentos para a comunidade, promovendo aos alunos um sentimento de utilidade.

Existe também campanhas estruturadas como as questões do feminicídio, machismo, setembro amarelo, prevenção a saúde, entre outras. Ao mesmo tempo, os participantes sentem um desfalque por parte do governo com intervenções adequadas na escola, sentem que pessoas de fora da escola, como estagiários de cursos superiores realizam mais atividades do que a própria administração governamental: "Muito pouco programa de... o governo não... não vejo ele fazendo um... melhorias pra... pra ajudar a melhorar a violência da escola. [...] precisa de gente de fora pra tá ajudando mesmo a ter um pouco de prevenção, porque o governo ajuda muito pouco. Acho que vocês de fora fazem mais que o próprio governo" (Viviane). "O nosso grande problema do Brasil hoje é que os órgãos públicos parecem que não tem técnicos que façam intervenções adequadas em relação a isso. Não temos 
uma justiça com muito poder. Os três poderes na nação que ainda olha pra isso aqui de uma forma mais eficaz, né?" (César).

Queixam-se de que os alunos necessitam de um projeto que vise promover um futuro melhor, uma vida com metas e objetivos, proporcionando novas oportunidades. Apresentam ideias e sugestões de projetos que auxiliam na questão: Então, é... eu sempre... penso na minha cabeça que eu tenho que fazer um projeto de que vai se encaixar, não sei agora, um projeto de vida pra eles. "[...] Que eu acho que faltou um objetivo pra eles, que essa falta de objetivo, sabe? Essa falta de... sentir importante, eles, sabe? [...] De sentir uma pessoa importante, que quando a gente tem um objetivo, a gente tem que correr atrás dele, e isso depende do... eu procuro passar para eles do financeiro... [...] falar pra eles muito em moral, em ética, entendeu?" (Mara). "Se fosse pra eu montar um projeto eu montaria um projeto só com elemento piloto e começaria sempre com as series mais iniciais, por exemplo, e seria muito complexo, pegaria por enquanto, aqui na nossa realidade dessa escola aqui, $6{ }^{\circ} a n o$ que é, ainda é, uma faixa etária que, que, que, que demanda abertura né?

Então, então eu penso o seguinte ó, a melhor forma é você pegar o 6a ano que é ainda a faixa etária, que não é uma maravilha não, em termos assim, porque é uma ilusão você pensar também que se trabalhar com criança pequenininha e que tudo é fácil e vai transformar, pelo contrário, você vai pegar muitas complexidades pra lidar com aquilo ali entendeu? Por ser justamente criança. Muita, muita, muita, muita. Mas em contrapartida, é, tem menos vicio escolar, menos vicio de convivência, menos vicio de condução, certo? Menos nesse sentido. Então que eu faria? Focaria esses meninos nessa faixa etária e trabalharia, é, não de porteira fechada assim, trabalharia uma classe piloto e trabalharia uma classe piloto e uma, uma outra classe convencional para comparação, por elemento comparativo e pra análise, pegaria paridade de dois sextos anos no mesmo período, um com intervenção no programa, outro sem intervenção, pra avaliação contínua. E estabeleceria um método de abordagem, com toda aquela estrutura lá, o que se queria atingir, qual dimensão que você iria trabalhar, quais os efeitos que se iria concretamente obter, em quanto tempo. É assim que eu faria, assim, tô falando muito rusticamente" (César). "A mediação, já faz, desde o ano passado, só que vai passando. Eu quero formar um grupo de jovens também, pra na hora dos conflitos ele ajudar a tomar soluções. [...] Entendeu? Conversar com os alunos, pra eles mesmos se... se interagir e tá por dentro, né, pra tá ajudando se, se... né?" (Mara). "Conscientizados sobre oque que é patrimônio escolar. Quais são as consequências na depredação do ambiente. É... a questão da... do desacato, desacato aos funcionários públicos. Então, eles têm que ter uma noção, eu acho assim, que falta informação" (Sônia). 


\section{DISCUSSÃO}

A partir dos dados coletados nas observações participantes e nas entrevistas, observou-se que todos os integrantes da equipe técnicoadministrativa são sobrecarregados de tarefas vindas da Diretoria de Ensino, com prazos curtos e tarefas para serem cumpridas, com participações em reuniões, implementações de novas formas de administração escolar, o que resulta em desabafos sobre adoecimento psíquico e físico, sintomas de ansiedade, estresse e nervosismo. Parece um ciclo de cobranças, pois os alunos também precisam cumprir prazos, ter bons resultados e muitos não levam a sério a formação, reclamam e rebeldia contra o ensino aprendizagem e a quantidade de conteúdo. Neste aspecto, são leis que a escola deve cumprir e não há como fazer alterações.

Segundo Charlot (2002), a sobrecarga de tarefas corresponde a um desrespeito aos profissionais da educação que é uma das características da violência contra à escola, assim como o vandalismo, depredação do patrimônio público e a resistência dos estudantes a regras impostas pelo sistema de ensino, gerando a necessidade de construir medidas contra estes acontecimentos.

A instalação de câmeras para o monitoramento de violências contra à escola, e entre os alunos, professores e todos os atores escolares, foi adotada pela escola, sendo benéfica segundo os participantes da pesquisa, pois a taxa de violência, o uso de drogas dentro da escola obteve uma diminuição significativa após a instalação.

Mesmo com outras melhorias no ambiente físico, como pinturas, carteiras e lousas novas, os aspectos estruturais como os encanamentos dos banheiros geraram constrangimento e exposição em um dos alunos, como relatado em uma das observações participantes. $O$ ambiente que rodeia a escola contribui com a presença de insetos e pragas, como os escorpiões, sendo necessário uma dedetização constante no interior e exterior do estabelecimento, gerando perigo aos estudantes. Mesmo sem intenção, a escola age como reprodutora da violência, caracterizando uma outra ação direta estudada por Charlot (2002), a violência da escola causada por essas e outras deficiências na estrutura.

As violências que ocorrem na escola, Segundo Charlot (2002) é caracterizada como desavenças que ocorrem de fora para dentro da instituição, a penetração de gangues e tráfico de drogas. Considerando Abramovay (2015), Ferro e Araújo (2015), que falam que as agressões verbais, como insultos, palavrões e difamações, segundo os relatos nas entrevistas, juntamente das observações participantes, nota-se que violências físicas são presentes em casos de agressões e/ou tentativas delas, bem como a violência verbal, em xingamentos, insultos, humilhações, bullying entre alunos, entre 
professor-aluno, pais-professores, pais-equipe, equipe-alunos, validando os estudos de Charlot (2002), Abramovay (2015) e Ferro e Araújo (2015).

Ainda, Abramovay (2015) e Ferro e Araujo (2015) salientam que a violência verbal muitas vezes é menosprezada comparando com outros tipos de violência. Segundo os participantes desta pesquisa é tão habitual que pode até passar despercebido entre as pessoas no cotidiano. De acordo com os autores, as agressões verbais são consideradas como porta de entrada para outros tipos como a física. Ao mesmo tempo, os participantes queixam-se de cansaço e de sofrimento ao lidar com o público, exigindo um grande equilíbrio emocional.

Há algumas dificuldades nos relacionamentos entre as pessoas, como vimos durante a coleta de dados. Entre alunos, entre alunos e professores, entre equipe, entre pais e equipe, como a falta de diálogo entre toda a comunidade escolar ou a presença de forma agressiva, a falta de comprometimento ao cumprir seus ofícios, ao estudar, se dedicar fielmente a escola, gerando grandes impactos. O professor coordenador nomeia a violência de agressividade, a agressividade entre aluno e professor como indisciplina. entre funcionários, como desentendimentos.

A equipe técnico-administrativa, segundo relatos das entrevistas, tenta compreender a realidade dos alunos fora dos portões da escola, através de conversas informais, promovendo momentos de confiança para falar de sentimentos, compartilhar suas ideias, para verem os alunos também como pessoas que possuem outros papeis sociais, que não seja o de estudante. Ao fazerem esse exercício de uma escuta ativa, a equipe se solidariza com os aspectos da vida dos alunos que atendem, não justificando suas atitudes, mas compreendendo-os em seu contexto mais amplo.

Segundo Jones (2004), os programas de educação a fim de resolver conflitos criam possibilidades de ambientes seguros para que as crianças tenham confiança de expor a sua vida fora da escola, criando vínculos. Silva e Assis (2018) estudam sobre a importância de promover um ambiente que possibilite a convivência entre os integrantes, além de incentivar relações democráticas, o que possibilita a participação dos alunos e pais nas decisões da escola.

A escola conta com programas de prevenção a violência e modos de convivência: festas juninas, comemorações como o dia das crianças, tidas como ferramentas utilizadas pela escola. No estudo de Priotto (2008), abrir a escola nos finais de semana, dialogar, estimular a reflexão em casos de desentendimentos entre os alunos, não focar na origem do problema e sim na solução, também foram eficazes para abaixar o índice de violência na escola, assim como práticas esportivas, projetos, palestras, eventos e atividades recreativas promovendo um ambiente saudável para toda comunidade escolar. 


\section{CONSIDERAÇÕES FINAIS}

O objetivo do trabalho foi compreender a perspectiva da equipe técnico-administrativa acerca das violências escolares, mapear formas de como enfrentam este fenômeno. Com a análise dos resultados obtidos, foi possível observar que a violência escolar está presente em diversas situações no contexto e que esta causa impactos em muitos aspectos da vida pessoal e profissional dos integrantes da equipe. Compreende-se que a agressão verbal é a mais recorrente, tanto no relacionamento entre os estudantes, como com as famílias professores e funcionários, trazendo consequências mais dolorosas que até mesmo a agressão física, que ocorre com menor frequência.

Percebe-se a violência vinda dos órgãos superiores, causando uma rotina estressante e cansativa para a equipe, obstaculizando a comunicação e o trabalho como equipe. No entanto, os integrantes trouxeram formas de enfrentamento já utilizadas e ideias de possíveis caminhos para a mudança.

Aponta-se, ainda, que metodologia utilizada para a coleta de dados permitiu uma rica compreensão de como são as relações humanas e a convivência no contexto escolar. As vivências da pesquisadora nas observações e entrevistas promoveram um esclarecimento de como acontece o funcionamento escolar.

O conjunto metodológico também levou a equipe técnicoadministrativa a reflexões sobre as dificuldades que encontra no cotidiano, que podem passar despercebidas devido à grande quantidade de tarefas a cumprir. A pesquisa favoreceu um tempo para olharem e analisarem o contexto em que estão inseridos todos os dias.

No entanto, observa-se a necessidade de novas pesquisas com o intuito de aprofundar neste tema complexo e tão importante no contexto brasileiro, que é a violência escolar. Sugere-se que sejam realizadas investigações mais amplas que possam descrever o fenômeno e apontar soluções.

\section{REFERENCIAS}

ABRAMOVAY, M. Programa e Prevenção de Violência nas Escolas: Violências na Escolas. São Paulo: Flasco Brasil, 2015.

ANDRE. M. E. D. A. Etnografia da prática escolar. 17 ed. Campinas: Papirus. 2011.

CUNHA, E. O. A Gestão Escolar em um Contexto de Violência: a análise de um livro de ocorrências dos alunos e o olhar da equipe gestora em uma escola da rede. Gestão Educacional nos municípios: entraves e perspectivas, p. 311, 2009. 
CHARLOT, B. A violência na escola: como os sociólogos franceses abordam essa questão. Sociologias, Porto Alegre, n. 8, p.432-443, set/dez, 2002. Traduzido por Sônia Taborda. Disponível em: <http://www.scielo.br/pdf/soc/n8/n8a16.pdf>. Acesso em: 1 de nov. 2019. Descritores em Ciências da Saúde: DeCS. rev. e ampl. São Paulo: BIREME / OPAS / OMS, 2019. Disponível em: < http://decs.bvsalud.org >. Acesso em 11 de out. 2019.

FERRO, J. P.; ARAÚJO, E. L. Algumas reflexões sobre o fenômeno da violência escolar. INTERFACES DA EDUCAÇÃO, v. 1, n. 2, p. 69-78, 2015.

JONES, T. S. Conflict resolution education: the field, the findings, and the future. Conflict Resolution Quarterly, v. 22, p.233-267, 2004.

LEITÃO, C. Elaborando um projeto de intervenção local para enfrentar a violência na escola. In: ASSIS, Simone Gonçalves; CONSTANTINO, P; AVANCI, J. (Org.). Impactos da violência na escola: um diálogo com professores. Rio de Janeiro: Fiocruz, 2010. p 235-259.

LÜCK, E. Dimensões da gestão escolar e suas competências. 2. ed. Curitiba: Positivo, 2009. 142 p.

MODENA, M. R. (Org.). Conceitos e formas de violência. Caxias do Sul: Educs.p.176. 2016.

PRIOTTO, E. P. Violência escolar: políticas públicas e práticas educativas. In: Anais do III Congresso Ibero-americano sobre violência nas escolas, Curitiba: Campagnat. 2008. p. 11128-11141.

ROSA, E. M.; TASSARA, E. T. O. Violência, ética e direito: implicações para o reconhecimento da violência doméstica contra crianças. Psicol. cienc. prof., Brasília , v. 24, n. 3, p. 34-39, Set. 2004

SILVA, F. R.; ASSIS, S. G. Prevenção da violência escolar: uma revisão da literatura. Educação e Pesquisa, v. 44, 2018. 


\section{ADOLESCÊNCIA: um ser biopsicossocial}

Antônio Ancelmo Neto Barros antonio.anbarros@gmail.com

Sofia Muniz Alves Gracioli sofiagracioli@yahoo.com.br

\section{INTRODUÇÃO}

O ser humano é um ser biopsicossocial, ou seja, ele é composto por razões biológicas, psicológicas e sociais. Quando falamos sobre formação do ser, é muito importante destacarmos a adolescência, uma vez que nesse período o jovem está sofrendo grandes transformações biológicas, psicológicas e sociais e é exatamente quando ele está suscetível a uma série de influências e modificações.

De acordo com o senso comum, o período da adolescência é repleto de escolhas e mudanças. Todo ser humano passa por essa fase da vida em que $o$ indivíduo inicia a procura por autonomia naquilo que faz e consequentemente nas suas ações e escolhas. A adolescência é um período de transição da infância para a vida adulta e é um momento delicado para 0 ser, uma vez que, concomitantemente, existe uma crise pela busca da própria identidade (ERICKSON, 1976). Assim como diversas transformações que vão da parte biológica do indivíduo até a parte social. Desta forma, quando a fase da adolescência é levada em estudo as áreas libidinosas, as áreas físicas e sociais também são citadas (FONSECA, 2004).

A adolescência é um período de transição da infância para a vida adulta e isso acaba se tornando um momento delicado para o ser, pelo motivo que neste exato momento existe uma crise pela busca da própria identidade e por conta deste motivo e outros este período se torna importante para qualquer ser humano (ERICKSON, 1976).

Para Santrock (2014) os fatores biológicos, psíquicos e sociais se relacionam entre si e muitas vezes podem vir a causar problemas na adolescência e consequente em sua vida adulta, o que em alguns casos explica o motivo do adolescente poder ter algum problema com dependência química, problemas psicológicos ou sociais.

O objetivo geral desta pesquisa é explorar a fase da adolescência. O objetivo específico é estudar a fase do desenvolvimento humano na adolescência, explicar e explorar as questões biológicas, psíquicas e sociais que $o$ adolescente passa durante a etapa da puberdade.

O trabalho será realizado por meio de uma revisão bibliográfica crítica que tem como princípio buscar na literatura já existente informações sobre algum tema e por meio de comparações, realizar uma análise e uma 
discussão, com o objetivo de atingir o objetivo da pesquisa (RAUP e BEUREN, 2003). A pesquisa bibliográfica será feita com artigos científicos, revistas acadêmicas, livros e teses de mestrado e doutorado.

\section{PERÍODO DA ADOLESCÊNCIA}

A adolescência é um período de transição da infância para a vida adulta e isso acaba se tornando um momento delicado para o ser, pelo motivo que neste exato momento existe uma crise pela busca da própria identidade e por conta deste motivo e outros este período se torna importante para qualquer ser humano (ERICKSON, 1976).

Para Santrock (2014) os fatores biológicos, psíquicos e sociais se relacionam entre si e muitas vezes podem vir a causar problemas na adolescência e consequente em sua vida adulta, o que em alguns casos explica o motivo do adolescente poder ter algum problema com dependência química, problemas psicológicos ou sociais.

Naturalmente as mudanças biológicas na adolescência acontecem com todos os seres em todos os cantos do planeta, as questões físicas e biológicas, como o crescimento, mudança do corpo e uma sexualidade aflorada são mais evidentes, porém, não são apenas as questões físicas que marcam o período de transição da fase infantil para a fase adulta (SCHOENFERREIRA, AZNAR-FARIAS e SILVARES, 2010).

Contudo, segundo Lourenço e Queiroz (2010) o período da adolescência tem início por volta dos 10 anos de idade e seu ciclo se encerra aos 20 anos incompletos, porém, este período pode variar, sendo que para algumas pessoas a adolescência ou desenvolvimento puberal pode começar e terminar mais cedo ou mais tarde.

Salienta-se ainda que conforme Eisenstein (2005) o período da adolescência é repleto de impulsos que agem na área física, mental, social, emocional, sexual e psicológica do indivíduo e no empenho do adolescente em conquistar seus objetivos ou concretizar seus desejos que sofrem influências culturais do ambiente em que vive. O estágio da adolescência tem início quando os sinais da puberdade começam a aparecer e tem seu fim quando $o$ crescimento do indivíduo já finalizou e sua personalidade já se desenvolveu, a sua independência econômica também é algo a ser levado em consideração. (EISENSTEIN, 2005)

Em desacordo Melvin e Wolkmar (1993) relatam que a puberdade está mais ligada diretamente à idade física do ser, onde os homens possuem um tempo diferente das mulheres e que o período da adolescência está ligado à este período e que sofrem consequentemente uma influência.

A adolescência é reconhecida como uma fase do ciclo de vida em que $\mathrm{o}$ indivíduo passa por transições. $\mathrm{O}$ adolescente se torna, para 0 
senso comum, "o aborrecente", aquele que sabe apenas questionar e desafiar. Esta é uma fase de grandes mudanças, na qual surgem fatores e questões que repercutem sobre o jovem e sua família. (SANTOS, Larissa Medeiros Marinho Dos; 2005, p., p. 57)

Como Santos (2005) relata acima, perante o senso comum a adolescência também é marcada por um estigma de ser uma fase chata, onde o ser se torna questionador e gosta de ser desafiado e desafiar autoridades, incluindo a própria família que pode ser vista como um agente de autoridade dentro da sociedade e que exerce influência na maneira como o adolescente age logo este período cheio de transformações e dificuldades é chamado pelo senso comum como o período da "aborrecência", o que realmente faz sentido quando paramos para ver a visão da sociedade sobre o período da adolescência, porém, este artigo vai além do senso comum e como podemos ver até agora este período pode ser visto de várias formas, mas em todas elas a transformação está presente.

Ainda por cima conforme Palácios (1995) a adolescência é diferente para os meninos e meninas, onde nos meninos o início é marcado pelo crescimento dos pelos pubianos, testículos, do pênis e a voz começa a tomar um tom mais grave, os pelos na parte inferior das axilas começam a aparecer, juntamente com os pelos finos que começam a crescer na parte superior e inferior da boca e a produção de espermatozoides começa.

Já para as mulheres o início da puberdade é marcado pelo alargamento do quadril, crescimento dos seios e pelos na região pélvica, na região da genitália também a um crescimento, principalmente nos lábios e clitóris, os pelos nas axilas e pelo restante do corpo começam a crescer com maior rapidez e a primeira menstruação ocorre. (PALÁCIOS, 199

A puberdade é um período dinâmico do desenvolvimento marcado por rápidas alterações no tamanho e na composição corporal. Um dos principais fenômenos da puberdade é o pico de crescimento em estatura, acompanhado da maturação biológica (amadurecimento) dos órgãos sexuais e das funções musculares (metabólicas), além de importantes alterações na composição corporal, as quais apresentam importantes diferenças entre os gêneros. (RÉ, A.H.N; 2011)

Como citado acima à puberdade é um período transicional, onde é marcado pela metamorfose do corpo, principalmente em relação ao seu tamanho, seja em relação à altura ou tamanho de seus órgãos.

Acrescenta-se que a adolescência é dividida em duas partes, onde a primeira parte é caracterizada por um chamamento do próprio corpo, no qual o corpo demonstra alterações físicas e a segunda parte que seria marcado pela espera do outro, a espera pelo o que o outro irá pensar de mim e a sensação de só se viver a adolescência uma vez na vida (FERREIRA, 2016).

É válido lembrar também que assim como Miller (2015) citou, existe uma diferença entre adolescência e puberdade, onde a adolescência é 
algo relacionado meramente ao período da vida do ser, onde ele completa uma determinada idade, por outro lado a puberdade não necessariamente necessita vir juntamente com a adolescência, como por exemplo, as meninas costumam ser mais maduras e entrar na puberdade primeiro que homens.

No livro "Adolescência, família e drogas" onde Freitas (2002) conta o processo de transformação da visão do adolescente na sociedade, que no início do século XV era comum crianças serem enviadas para casas de terceiros e passarem a infância e a adolescência inteira dentro dessas casas com o objetivo de serem educadas a servir, o conceito de educação naquela época estava diretamente ligada a saber servir e essas crianças, chamadas de aprendizes, realizam atividades como limpar a casa, arrumar as camas, e juntamente com essas atividades era desenvolvido também alguma função profissional, porém era recorrente a vida profissional e pessoal serem confundidas e as relações eram afetas. Por conta desse afastamento da criança desde jovem para ir viver em outra casa, o relacionamento entre família/pais e criança/adolescente era afetado, assim tornando uma relação frágil e muitas vezes as crianças tinham uma relação muito mais forte com a casa que trabalhavam do que com seus pais, não era demonstrado nenhum afetividade entre pais e filhos, na era medieval era comum jovens de 14 anos acompanharem adultos em suas atividades para aprenderem e, por conseguinte acabavam acompanhando seus mestres em guerras (FREITAS, 2002).

Apenas depois do século XV que a educação de crianças e adolescentes começa a ser entendida como papel da escola e essas crianças e adolescentes começam a ser enviadas para as escolas e a visão que se tinha desses indivíduos começa a sofrer alterações, onde já é priorizado o ensinamento da moral e começa a se tentar manter a inocência na tentativa de afastarem as crianças das tentações do mundo, já que a religião era um agente muito influenciador na época. Esse exemplo da influência da religião mostra que a forma como a sociedade vê o adolescente e crianças influenciam diretamente em sua vida (FREITAS, 2002).

A puberdade é relatada por Freitas (2002) como um processo de luto, "Os lutos que os adolescentes deverão elaborar, pela perda do corpo, da identidade e dos pais da infância, serão denominados, no seu conjunto, de crise da adolescência.", onde o processo de saída da fase infantil para a fase da adolescência se torna confusa e dolorosa, onde é necessário entender que já não se é mais criança e pelo processo de crescimento a visão de como o jovem vê as relações no mundo se rompe.

Isso acontece pelo motivo que o adolescente nesta fase está em busca de construir sua identidade e por conta deste comportamento muitas vezes acabam contrariando as figuras paternas, por não se identificarem com determinadas atitudes de seus pais e percebem que o mundo vai além do que 
simplesmente ficar na visão de mundo dos pais (SANTOS, 2005).

Assim como Rocha, Tassitano e Santana (2002) relatam sobre o processo de transição da fase infantil para a adolescência:

\begin{abstract}
Ao tornarem-se adolescentes, esse indivíduos sentem necessidade de tornarem-se independentes de seus pais; tornarem-se seres com identidades próprias, vontades e projetos que os representam, mesmo que para isso tenham que contrariá-los. Alguns estudiosos afirmam que o fato de contrariar os pais faz parte do processo de construção da sua própria identidade. Sem precisar radicalizar nesse particular, acreditamos na busca de identidade, sem que para isso o adolescente tenha que romper com a família. [...] $\mathrm{Na}$ realidade, ao desenvolver 0 pensamento, a lógica e a crítica, o adolescente descobre que o mundo não pode mais ser visto através dos olhos dos pais na infância: um mundo harmonioso e colorido no qual, independente do que ocorresse, eles estariam protegidos.
\end{abstract}

É comum que na fase da adolescência vários paradigmas, como o dos pais estarem sempre corretos eventualmente seja quebrado, além do mais é de extrema importância para a construção da personalidade e identidade de qualquer pessoa a relação do adolescente com o conflito, onde está ligada diretamente a procura de sua identidade, porque podem acontecer em qualquer ambiente e momento, porquanto é costumeiro os conflitos com familiares e pessoas próximas.

Anjos e Duarte (2019)explicam que o período conflituoso da adolescência não tem como causa principal questões hormonais ou algo do tipo, mas sim questões cerebrais onde há uma maturação do órgão, contrariando alguns estudos que diziam que o cérebro é totalmente desenvolvido no final da infância, essa maturação do cérebro ainda na adolescência explicaria mudanças de humor repentinas, falta de coordenação motora e impulsividade por exemplo.

Em conformidade com Blakemore (2010) comportamentos como de se realizar decisões, organização, pensamento subjetivo e autocontrole está ligado com o desenvolvimento do córtex pré-frontal pois essa região do cérebro é responsável por funções de alto desempenho, outras mudanças do período da adolescência estão ligadas ao ambiente em que ele vive, relacionamentos que obtém, sentimentos e autoconhecimento.

Anjos e Duarte (2019) mencionam que "As exigências do meio social impostas ao adolescente, bem como as novas responsabilidades a ele confiadas, são fatores determinantes no desenvolvimento psíquico nessa idade." então as responsabilidades designadas para os adolescentes também contribuem para sua formação, já que é esperado dele uma maior maturidade para lidar com responsabilidades pelo motivo que ele está deixando de ser uma criança e totalmente dependente de sua família, para se tornam um adulto dono do próprio nariz que faz suas próprias escolhas.

Magro (2002) ressalta que a adolescência além de ser algo 
marcado por questões biológicas como a puberdade e idade, também possui influência de questões sociais e econômicas, isso por conta da era industrial, em que durante esse tempo o governo obrigava adolescentes a estudarem com o objetivo de se formarem como mão de obra qualificada para a indústria e assim gerar um desenvolvimento para o país, através da mão de obra ou auxiliar no desenvolvimento social. Porém um ponto é levantado por Magro (2002), que pelo fato do período da adolescência ser conturbado, um adolescente às vezes não consegue contribuir para a sociedade da forma esperada, assim não trazendo soluções ou ações significativas para o seu ambiente, isso faz com que por muitas vezes o adolescente não seja valorizado e acaba sendo deixado de lado pela política e sociedade, mas ao mesmo tempo é visto como o futuro da sociedade, o que acaba caindo em um paradoxo, já que por um lado é esperado muito dele, porém do outro lado não se tem incentivo ou empatia.

Coimbra (2005) completando o pensamento de Magro (2002) traz a ideia sobre como a era industrial e o capitalismo influencia na maneira de ser do adolescente, onde por conta das imposições capitalistas o adolescente desde novo começa a pensar se deseja ser bem sucedido, visto que ser bem sucedido para a sociedade é, possuir um emprego bem visto pela sociedade e bem remunerado, construir uma família e ter bens materiais ou prefere ser mal sucedido, desempregado e sem família. Sendo assim a era industrial faz com que o adolescente comece a pensar que a escolha é dele em ser bem ou mal sucedido em sua vida, assim gerando mais um conflito na vida do adolescente.

\section{CONSIDERAÇÕES FINAIS}

Dessa forma chegaram-se as considerações finais onde 0 objetivo geral desta pesquisa inicialmente era explorar a fase da adolescência. O objetivo específico era estudar a fase do desenvolvimento humano na adolescência, explicar e explorar as questões biológicas, psíquicas e sociais que 0 adolescente passa durante a etapa da puberdade.

A introdução do artigo tem como fundamento apresentar qual o objetivo da pesquisa e o qual o motivo existente para ir atrás de respostas, então através de alguns autores foi fundamentado o objetivo deste estudo e mostrado a importância da discussão deste tema. $O$ artigo tem como estrutura realizar um apanhado sobre o período da adolescência por diversas óticas, porém, sempre apoiando no ser biopsicossocial, logo é proferido o assunto adolescência passando pelos âmbitos biológicos, psicológicos e sociais, assim tentando entender de forma mais completa esse período. Este artigo serviu como uma espécie de introdução e base para o assunto adolescente que durante a pesquisa se demonstrou ser muito vasto e cheio de caminhos para estudo. 
Sendo assim diante ao referencial usado e estudado durante a execução deste artigo é explícito que o desenvolvimento do adolescente acontece nas três área que o ser humano é formado, as área biológicas, psíquicas e sociais, assim tornando a adolescência uma etapa muito conturbada, pelo motivo que o corpo esta passando por uma metamorfose muito grande.

A partir dos resultados alcançados pode se pensar em algumas soluções, como por exemplo, promover grupos de famílias com psicólogos ou profissionais da saúde mental com o objetivo de discutir a influência e o poder que a família exerce sobre o indivíduo, principalmente o adolescente, materiais e incentivo ao conhecimento deste período pode ser levado em consideração também, tendo em conta que com o conhecimento sobre o assunto acredito que a empatia da família e sociedade perante o adolescente seja maior, assim diminuindo a tensão que existe neste período conturbado para o ser humano.

Com base nessa pesquisa uma possibilidade para se dar continuidade ou ideia de novas pesquisas é realizar um estudo focando mais em estilos parentais e as diferentes maneiras que os estilos afetam os membros que compõem a família, outro tema que pode ser interessante também é realizar um apanhado histórico da família e como ela sofreu alterações durante o passar dos anos, além também de estudar como era 0 poder família em cada época.

\section{REFERÊNCIAS}

ANJOS, Ricardo Eleutério dos; DUARTE, Newton. 0 cérebro adolescente e o processo biológico historicamente condicionado: Contribuições da teoria histórico-cultural à educação escolar. 2019. Artigo (Doutorado) - FURB Universidade Federal de Blumenau, [S. I.], 2019. DOI http://dx.doi.org/10.7867/1809-0354.2019v14n2s1p622-642. Disponível em: https://bu.furb.br/ojs/index.php/atosdepesquisa/article/view/7171. Acesso em: 14 jan. 2020.

BLAKEMORE, S. J. The developing social brain: Implications for education. Neuron 65, March 25, 2010, Elsevier Inc. 744-747.

COIMBRA, C. C.; BOCCO, F.; NASCIMENTO, M. L. Subvertendo o conceito de adolescência. Arquivos Brasileiros de Psicologia, v. 57, n. 1, p. 2-11, 2005.

EISENSTEIN E. Adolescência: definiçoes, conceitos e critérios . Adolesc Saude. 2005;2(2):6-7

ERICKSON, E. Identidade, juventude e crise. Rio de Janeiro: Zahar ,1976. FERREIRA, Aurélio Buarque de Holanda.Dicionário Aurélio de Português Online.2016. Disponível em: https://dicionariodoaurelio.com/familia.

FONSECA, Helena. Abordagem sistêmica em saúde dos adolescentes e suas famílias. Adolesc Saude, 2004. 
FREITAS, L. Adolescência, Família e Drogas - A função paterna e a questão de limites, Rio de Janeiro, Mauad.2002.

LOURENÇO, B.; QUEIROZ, L. Crescimento e desenvolvimento puberal na adolescência. Revista de Medicina, v. 89, n. 2, p. 70-75, 19 jun. 2010.

MAGRO, Viviane Melo de Mendonça. Adolescentes como autores de si mesmos: cotidiano, educação e hip hop. Cafajeste. CEDES, Campinas, v. 22, n. 57, p. 63-75, agosto de 2002. Disponível em <http://www.scielo.br/scielo.php?script=sci_arttext\&pid=S0101$32622002000200005 \&$ Ing=en\&nrm=iso>. acesso em 20 de fevereiro de 2020.

Melvin, L., \& Wolkmar, F.R. (1993). Aspectos clínicos do desenvolvimento na infância e adolescência. 3ª ed). Porto Alegre: Artes Médicas.

PALÁCIOS, Jesús. FIERRO, Alfredo. Desenvolvimento da personalidade na adolescência: Desenvolvimento psicológico e educação: psicologia evolutiva. Porto Alegre: Artes médicas, 1995. V. 1.

RAUPP, Fabiano Maury; BEUREN, Ilse Maria. Metodologia da pesquisa aplicável às ciências sociais. In: Beuren, Ilsa Maria. Como elaborar trabalhos monográficos em contabilidade. Santa Catarina: Atlas, 2003. Cap. 3, p 76-97.

RE, A.H.N.. Crescimento, maturação e desenvolvimento na infância e adolescência: Implicações para o esporte. Motri., Vila Real , v. 7, n. 3, p. 55-67, jul. 2011. Disponível em <http://www.scielo.mec.pt/scielo.php?script=sci_arttext\&pid=S1646107X2011000300008\&lng=pt\&nrm=iso>. acessos em 17 fev. 2020.

ROCHA C.R.M, TASSINATO C.M.L.N, SANTANA J.S.S. O Acompanhamento do Adolescente na Família. Adolescer: Compreender, Atuar, Acolher. ABEn/Ministério da Saúde, 2002, p. 38-44.. Disponível em: www.abennacional.org.br/revista/cap2.2.html. Acessado em 19/02/2020.

SANTOS, Larissa Medeiros Marinho dos. O papel da família e dos pares na escolha profissional. Psicol. estud. Maringá, v. 10, n. 1, p. 57-66, abril de 2005. Disponível em <http://www.scielo.br/scielo.php?script=sci_arttext\&pid=S1413$73722005000100008 \& \operatorname{lng}=$ en\&nrm=iso $>$. acesso em 14 de fevereiro de 2020. https://doi.org/10.1590/S1413-73722005000100008 .

SANTROCK, John W. Adolescência. [S. I.]: AMGH Editora, 2104. ISBN $8580552419,9788580552416$.

SCHOEN-FERREIRA, Teresa Helena; AZNAR-FARIAS, Maria; SILVARES, Edwiges Ferreira de Mattos. Adolescência através dos séculos. Psic .: Teor. e Pesq. , Brasília, v. 26, n. 2, p. 227-234, junho de 2010. Disponível em $<$ http://www.scielo.br/scielo.php?script=sci_arttext\&pid=S0102$37722010000200004 \& \operatorname{lng}=$ en\&nrm=iso $>$. acesso em 14 de fevereiro de 2020. https://doi.org/10.1590/S0102-37722010000200004 . 


\section{ALZHEIMER: um estudo teórico acerca da doença e os malefícios que ela causa a memória}

Rafaella Orlando de Souza rafaellaorlandodesouza@gmail.com

Paulo de Tarso Oliveira paulotarso@facef.br

\section{INTRODUÇÃO}

Este artigo foi realizado a partir de um estudo apresentado como relatório final do programa de iniciação científica PIBIC/CNPq pelo Uni-FACEF (Centro Universitário Municipal de Franca) que teve como intuito desenvolver o estudo: "ALZHEIMER: Um estudo de caso da Memória Autobiográfica de um idoso institucionalizado". Este estudo foi uma continuidade da pesquisa anterior intitulada "Diferenças na qualidade de vida de idosos portadores Alzheimer com diferentes estimulações multiprofissionais em instituições de apoio". A experiência vivida anteriormente foi o maior motivador para que a pesquisadora desse seguimento no tema. A partir desses estudos foi criado o presente artigo com base nas pesquisas teóricas.

Gauer e Gomes (2008) explicam que a recordação de eventos pessoais passados constituem a memória autobiográfica, a síntese e a referência de nossas histórias de vida. A ação de evocar envolve várias habilidades cognitivas, desde as que permitem rever algo pessoal (caminho de casa) até as que se fazem necessárias para, por exemplo, escrever um livro de uma vida. Algumas pesquisas sobre essa memória têm-se dedicado a estudos com base na recordação de eventos pessoais específicos, marcantes, contextualizados no tempo e no espaço. A colocação desses autores, serve como um panorama geral para a construção do referencial teórico.

A pesquisa realizada foi delineada como estudo de caso exploratório, de abordagem qualitativa. Godoy (1995) explica que algumas propriedades ditas básicas identificam os estudos que são chamados "qualitativos". A partir desse aspecto, um elemento pode ser melhor compreendido no contexto em que acontece e do qual faz parte, devendo assim ser estudado sob ponto de vista que seja integrado. O pesquisador então vai a campo à procura de "captar" esse elemento em estudo a partir da visualização das pessoas nele envolvidas, considerando assim todos os pontos de vista relevantes. Assim, inúmeros tipos de informações são coletados e analisados para que se entenda a dinâmica desse elemento.

Com as informações recolhidas do estudo citado acima, foi realizado o presente artigo, que buscou atrelar as concepções da Doença de 
Alzheimer juntamente com os malefícios que esta causa à memória do paciente.

\section{A DOENÇA}

\subsection{O Alzheimer}

Para início de estudo foram pesquisados artigos que abordavam mais amplamente sobre o tema, e que disponibilizassem informações sobre a doença e alguns dados sobre o envelhecimento.

Segundo Fagundes et al. (2015) o Alzheimer foi identificado pela primeira vez há mais de 100 anos, porém é importante ressaltar que a pesquisa de seus sintomas, causas, fatores de risco e seu tratamento somente ganharam força nos últimos 30 anos. Apesar de muitos avanços no conhecimento da doença, as mudanças precisas no cérebro que desenvolvem a doença e a ordem em que tudo isso ocorre, em grande parte, ainda são desconhecidas. Em 2015 o número de pessoas que apresentam a situação em todo o mundo era estimado em 44 milhões e está previsto para dobrar até o ano de 2030 e mais que triplicar até 2050. Os autores ainda explicam mais à frente em seu estudo que segundo a Associação Brasileira de Alzheimer (ABRAZ) mais de 1 milhão e 300 mil pessoas só no Brasil, são portadoras da doença.

Para Cardoso et al. (2015) o envelhecimento da população apresenta-se devido a uma tendência mundial de diminuir a mortalidade e a fecundidade, aumentando assim o prolongamento de uma esperança de vida. Os habitantes idosos estiveram habitualmente relacionados a países desenvolvidos, porém esse paradigma mudou, pois nos últimos 40 anos 0 envelhecimento dessa população tem ocorrido também nos países que estão em desenvolvimento. Todo esse ocorrido acarretou mudanças no perfil epidemiológico, com uma predominância para as doenças crônicas que não são transmissíveis, que podem ou não limitar e comprometer a capacidade funcional e a qualidade de vida desse idoso, o que implica à necessidade de cuidadores. Os autores ainda acrescentam que o Alzheimer é a mais comum dentre as doenças crônicas que se destacam entre as demências. Ela refere-se a um acometimento que atinge o idoso e implica sua integridade física, mental e social, o que pode deixá-lo total ou parcialmente dependente de cuidados que se tornam cada vez mais complexos.

Smith (1999) aborda que a doença de Alzheimer foi caracterizada pelo neuropatologista alemão Alois Alzheimer (1907) onde ele cita que a mesma é uma patologia neurodegenerativa progressiva e irreversível de aparecimento insidioso, que origina a perda da memória e numerosos distúrbios cognitivos. 
Alvarez et al. (2002) esclarece em um estudo que a doença é cerebral degenerativa, como citado acima, e caracteriza-se por perdas progressivas da memória e de outras funções cognitivas, isso acarreta um prejuízo nas atividades de vida diária dos pacientes, e também podem afetar seu desempenho social e ocupacional.

Os autores anteriormente ainda citam que a instauração da doença se deve ao acúmulo de eventos que seriam genéticos e ambientais. Cada evento favorece com pequenos efeitos que se resultam, em conjunto, no estabelecimento do Alzheimer com diversos graus de severidade.

Encontra-se ainda em estudos, em especial no de Sereniki e Vital (2008) que em geral, a primeira particularidade é a deficiência da memória recente, pois as lembranças remotas são preservadas até certo estágio da doença. Os autores ainda explicam que além das dificuldades de atenção e fluência verbal, algumas outras funções cognitivas deterioram-se à medida que a patologia evolui, onde se observam prejuízos na capacidade de fazer cálculos, nas habilidades vísuoespaciais e na capacidade de usar objetos comuns e ferramentas. Já o grau de vigília e a lucidez do paciente não são afetados até a doença já estar muito avançada, nota-se isso também em relação à fraqueza motora (apesar de as contraturas musculares serem uma característica quase sempre observada nos estágios avançados da patologia).

Em uma citação relacionada, os autores acima também esclarecem que os sintomas anteriormente discutidos são sucessivamente acompanhados por distúrbios comportamentais, tais como: agressividade, alucinações, hiperatividade, irritabilidade e depressão. Os transtornos de humor afetam uma porcentagem relevante de pessoas que desenvolvem a doença de Alzheimer, em algum ponto da evolução da síndrome demencial.

\subsection{As Fases da Doença}

Alvarez et al. (2002) explica em um de seus estudos: "A DA pode ser dividida em três fases - leve, moderada e grave - de acordo com o nível de comprometimento cognitivo e o grau de dependência do indivíduo. " Os autores ainda citam que na fase mais leve da doença, o paciente mostra uma queda considerada significativa no desempenho de tarefas instrumentais da vida diária, porém o mesmo ainda é capaz de executar as atividades básicas do diaa-dia (mantém-se independente). Já na fase moderada, o comprometimento intelectual mostra-se maior e o paciente passa a requerer de maior assistência para a realização tanto das atividades instrumentais como para as atividades básicas (dia a dia). Na fase tida como grave esse paciente geralmente apresenta-se mais acamado, necessitando assim uma assistência integral, onde ele pode apresentar dificuldades de deglutição, sinais neurológicos e incontinência urinária e fecal. 
- Fase Inicial

Alvin e Coelho (2004) abordaram em um de seus estudos que todo o processo de cuidar na fase inicial do Alzheimer abrange sobretudo os cuidados que são focados na supervisão com atenção na prevenção de acidentes, pois a partir de dado momento o paciente não discerne mais as situações que o colocam ou não em risco ou perigo, ou seja, existe uma continuada presença de erros nas atividades cotidianas pois muitas vezes não sabem mais como fazê-las.

A partir do estudo de Araújo et al. (2010) citam que alguns danos dos estágios iniciais da doença gradualmente podem envolver outros comprometimentos cognitivos como: capacidade de julgamento, cálculo, capacidade de abstração e habilidades visuoespaciais. Também explicam que a afasia (distúrbio de linguagem que afeta a capacidade de comunicação da pessoa) pode desenvolver-se na fase intermediária, acarretando: dificuldade em nomear objetos ou escolher a palavra certa para expressar ideias, assim como apraxia(A apraxia é uma desordem neurológica que se caracteriza por provocar uma perda da capacidade em executar movimentos e gestos precisos).

Os autores Abreu, Barros e Forlenza (2005) exploram que em relação aos déficits de memória que são comuns na doença, verifica-se que nas fases iniciais da doença há a implicação da memória dita como episódica de longo prazo e da memória de curto prazo, onde a intensidade dos déficits relaciona-se com a gravidade de cada caso. Ainda expõem a necessidade de falar sobre a Memória Autobiográfica.

- Fase Intermediária

No site da ABRAz (Associação Brasileira de Alzheimer) explica que:

\begin{abstract}
$\mathrm{Na}$ fase moderada, são comuns dificuldades mais evidentes com atividades do dia a dia, com prejuízo de memória, com esquecimento de fatos mais importantes, nomes de pessoas próximas, incapacidade de viver sozinho, incapacidade de cozinhar e de cuidar da casa, de fazer compras, dependência importante de outras pessoas, necessidade de ajuda com a higiene pessoal e autocuidados, maior dificuldade para falar e se expressar com clareza, alterações de comportamento (agressividade, irritabilidade, inquietação), ideias sem sentido (desconfiança, ciúmes) e alucinações (ver pessoas, ouvir vozes de pessoas que não estão presentes).
\end{abstract}

Ainda citam que esse paciente, com o progredir da doença, as suas limitações ficam cada vez mais perceptíveis e graves, começam a ter dificuldades com a vida no dia-a-dia como: "pode ficar muito desmemoriada, especialmente com eventos recentes e nomes das pessoas; pode não gerenciar mais viver sozinha, sem problemas, é incapaz de cozinhar, limpar ou fazer compras; pode ficar extremamente dependente de um membro familiar e 
do cuidador; necessita de ajuda para a higiene pessoal; a dificuldade com a fala avança; apresenta problemas como perder-se e de ordem de comportamento, tais como repetição de perguntas, gritar, agarrar-se e distúrbios de sono; perde-se tanto em casa como fora de casa; pode ter alucinações (vendo ou ouvindo coisas que não existem)". (ABRAz [Associação Brasileira de Alzheimer]).

- Fase Avançada

Já na fase avançada/final, segundo novamente a ABRAz, esse é o estágio mais próximo de uma total dependência e da inatividade desse paciente, ou seja, os distúrbios de memória são muito sérios e o lado da doença que afeta a parte física torna-se mais nítido como: dificuldade para comer; incapacidade para comunicar-se; não reconhecer parentes, amigos e objetos familiares; dificuldade de entender o que acontece ao seu redor; incapacidade de encontrar o seu caminho de volta para a casa; dificuldade para caminhar; dificuldade na deglutição; incontinência urinária e fecal; manifestar comportamento inapropriado em público; dependência de uma cadeira de rodas ou cama.

Apesar de todas as fases descritas acima, a maioria dos sites, artigos e fontes utilizados explicam que apesar das repartições para melhor entendimento das fases, não se pode levar a mesma como verdade universal, uma vez que alguns pacientes podem ter sintomas mesclados em um mesmo período.

\section{MEMÓRIA NA DEMÊNCIA}

Em uma concepção geral sobre memória o autor Pinto (1999) explica que nos estudos da memória humana, os pesquisadores podem apresentar divergências evidenciadas sobre qual o modelo que se apresenta mais simboliza seu funcionamento, porém aceitam tranquilamente que a memória, distante de ser um sistema que seja único, mas sim um sistema composto por duas ou até mais estruturas ou componentes. Essas estruturas seriam a memória chamada de curto prazo $(\mathrm{MCP})$ e a memória nomeada de longo prazo (MLP).

O mesmo autor, citando outros dois estudos de Waugh e Norman (1965) e de Baddeley e Hitch (1974) explica que a MCP se relaciona ao processamento da informação corrente e tem sido intitulada por memória primária - ressaltando principalmente a capacidade limitada de armazenamento dela - e designa memória operatória, quando se refere as capacidades de armazenamento e processamento que são efetuadas simultaneamente. A memória de curto prazo dá-se por um sistema limitado de retenção e armazenamento temporário de informação. 
Pinto (1999) ainda descreveu a MLP pelo modelo de Tulving (1985), neste modelo mono-hierárquico e piramidal de memória é composto pela memória episódica, memória semântica e memória procedimental. A memória episódica está no topo da hierarquia e representa um subsistema da memória intitulada semântica, sendo que essa última depende da memória procedimental, a qual situa-se na base da hierarquia.

Para falar sobre memória no contexto da demência, inicialmente é necessário entender um pouco sobre como o nome demência surgiu. Prado et al. (2007, p. 44) discorre sobre o assunto:

$\mathrm{Na}$ idade muito avançada aumenta a incidência de doenças neurodegenerativas, dentre as quais as que se denominam demências (de: partícula privativa; mência: do latim mens, mente. Literalmente, "perda da mente"). As demências recebem esse nome porque comprometem de forma significativa a memória e também outras funções cognitivas, com intensidade suficiente para produzir perda funcional, incluindo até, eventualmente, a realização de atividades da vida diária ou o reconhecimento de pessoas e lugares do entorno habitual (o próprio filho, a própria casa) (Squire\& Kandel, 2000).

Ainda sobre os autores citados acima, eles explicam que não procede confundir a chamada "síndrome amnésica benigna" dos idosos que apresentam demências. Essa síndrome pode resultar em uma diminuição considerável do número total de hormônios e/ou da menor velocidade da corrente sanguínea regional do cérebro. Ela consiste em leves funções na evocação de memórias - principalmente nas recentes. É com frequência que os sujeitos não conseguem se recordar de algo ou alguém durante horas, até então que posteriormente a evocação surge e muitas vezes de surpresa.

Abreu, Forlenza e Barros (2005) explicam que a perda da memória complexifica a proximidade das pessoas em suas relações afetivas, sociais e familiares. A memória biográfica em si oferece o reconhecimento da identidade. Assim, o sujeito não evoca de fatos, de lugares e de pessoas, reconhece-se que a cada dia se têm menos da pessoa, a cada dia ela fica mais impossibilidade de se relacionar, de se cuidar, de planejar sua qualidade de vida, perde sua razão, autonomia e até mesmo a coerência. Tem-se a sensação que a essência e o próprio eu daquela pessoa se desvincula de suas funções cognitivas, o que garante apenas sua sobrevivência.

Os autores ainda explicam com base nos estudos de Izquierdo (2002) e também de Grossman et al. (1997) que a Doença de Alzheimer se caracteriza pelo déficit na memória episódica de longo termo - por conta de uma baixa performance na evocação - e também na memória nomeada de curto prazo - que pode estar relacionada com a gravidade do caso. É perceptível como esses pacientes desempenham a baixa atividade em lições ligadas a nomeação, fluência verbal e ao uso certo de sentenças e 
vocabulários - todos esses ligados na formação na memória semântica melhor definida como a representação mental de palavras, objetos e significação de ações para memória de longo prazo. Então, ações para a realização de atividades incluídas na vida cotidiana estariam comprometidas, seja para o esquecimento, seja ocasionada pelo déficit no próprio conceito da ação em si.

Os autores Lemos, Hazin e Falcão (2012) discorrem sobre a perda da capacidade de armazenar uma nova informação e alguns prejuízos acarretados:

A perda da capacidade de armazenar nova informação, ou de evocar experiências previamente armazenadas, implica em prejuízo de uma das principais funções da memória, ou seja, a construção e manutenção do senso de identidade (self), constituindo-se, portanto, em um dos declínios mais trágicos decorrentes da DA (Squire\& Kandel, 2003). De acordo com a compreensão do presente trabalho, a memória é um processo cognitivo complexo que possibilita ao sujeito o armazenamento de informações, abarcando conjunto de habilidades que permite, no caso da memória autobiográfica, a construção de uma história pessoal e de uma identidade (self) caracterizadas simultaneamente pela possibilidade de mudança e de estabilidade ao longo da vida.

\subsection{Memória de Curto Prazo}

Utilizando os estudos de Baddeley e Hitch (1974) os autores Parente et al. (1999) explicam que Baddeley e Hitch propuseram a substituição do termo "armazenador de curto prazo" pela nomenclatura "memória de trabalho". Para esses autores, essa memória dita como de trabalho é um sistema que constitui limitada capacidade e é voltada a uma manutenção temporária e também a manipulação de informação, que é realizada diante a realização de determinada tarefa - ex: a memória necessária para guardar um número de telefone até que se ache a caderneta para anotá-lo.

O autor acima ainda traz que essa memória é composta por três diferentes componentes (cada um com suas funções específicas): o executivo central (é amodal, ou seja, possui recursos atencionais e esse é o componente mais importante dessa memória - distribui a atenção para que diferentes atividades sejam realizadas), o circuito articulatório (é especializado na estocagem de informação verbal e se compõe de um estoque fonológico e de um processo de recapitulação articulatória - esse estoque recebe a informação que é verbal, apresenta auditivamente, transforma em códigos sonoros, transfere para a recapitulação articulatória e essa recapitulação repete essa informação até não precisar mais dela) e o registro visuo-espacial (as informações viso-espaciais são codificadas analogicamente, posteriormente elas podem ou não serem convertidas em um sistema fonológico e passar pelos processos listados acima). 


\subsection{Memória de Longo Prazo}

Bruna (n.c.) escreveu na página do site do Dr. Dráuzio Varella que a memória de longo prazo seria a que preserva de forma permanente a informação, permitindo assim com que ela seja tanto recuperada como evocada. Nesse tipo de memória estão armazenados todos os nossos dados tidos como autobiográficos e também todo nosso conhecimento adquirido, ou seja, a capacidade dessa memória é praticamente ilimitada.

Izquierdo (2011, apud Silva, 2018) retratam que quando uma informação persiste ao filtro rigoroso da memória de trabalho, ela passa a fazer parte do sistema incumbido pelo registro de MCP - memória de curto prazo que possibilita a evocação de informações, até mesmo quando elas estão em processo de consolidação. É importante ainda explicar segundo Kandel et al. (2014) que essas memórias de curto e de longo prazo se diferenciam em suas atividades bioquímicas, principalmente porque a composição da memória de longo prazo depende da produção de proteínas, já a formação da MCP não depende.

Os autores acima ainda abordam que a memória de longo prazo pode ser subdivida em memória implícita e memória explícita. A MI se resume nas memórias de capacidades ou habilidades motoras - os hábitos - enquanto que a ME guarda fatos, eventos ou conhecimento. Novamente Kandel et al. (2014, p. 1261) explicam que a memória nomeada como explícita é demasiada flexível, o que permite então uma associação de diversos fragmentos de informação sob múltiplas circunstâncias. A MI, no entanto, continua sobremodo dependente das condições originais sob as que se deram o aprendizado.

\subsection{Memória Autobiográfica}

Para uma breve introdução à memória autobiográfica, Pergher e Stein (2008) discorrem que alguns modelos teóricos propõem a explicar que essa memória é organizada hierarquicamente, tendo assim níveis mais específicos e níveis mais genéricos. No mais específico estão as lembranças de acontecimentos em particular (possuem uma localização temporal e espacial definidas - com duração inferior a apenas um dia). Uma lembrança "Minha festa de formatura da faculdade" se enquadra a um exemplo de memória autobiográfica específica. No nível citado como mais genérico, encontra-se as lembranças de períodos de vida e as lembranças de categorias de eventos. Essas lembranças de períodos de vida (memórias estendidas) são as que possuem início e final definidos (essas com duração superior a um dia). "As festas que fui no primeiro ano da faculdade" demonstram uma memória estendida, pois exemplifica um início e final definidos e também engloba um período superior a um dia. Já as lembranças chamadas de categorias de eventos (memórias categóricas) são as que se referem a um conjunto de eventos, não tendo assim nem início e nem final definidos - "quando vou a 
festas" pode ser conceituada como uma memória categórica, pois ela não faz ligação a um evento específico, nem informa sobre seu início ou fim.

Os autores Greenberg e Rubin (2003) identificam que a Memória dita como autobiográfica seria caracterizada por uma série de propriedades específicas o que justifica sua classificação como um sistema específico independente. A princípio - memória episódica - ela armazena informações autobiográficas relacionadas a datas de episódios ou eventos e as relações que são espaços-temporais existentes entre eles. Porém, essas memórias ultrapassam uma simples evocação de informações semânticas a respeito de si mesmo, pois ao sujeito recordá-las o mesmo tem consciência da vivência daquele específico evento como experiência própria, ao qual seria um estado mental que Tulving (1985) nomeou de consciência autonoética, que entra em oposição à consciência noética.

De acordo com Gauer e Gomes (2006) A memória autobiográfica refere-se à habilidade de relembrar conscientemente de experiências individuais vividas no passado. Ela abrange diversas capacidades cognitivas (desde a que permite lembrar um fato pessoal - caminho de casa ao trabalho até a de escrita de um livro sobre a própria vida), porém, a relembrança de eventos pessoais é o seu objetivo.

Os autores Abreu, Forlenza e Barros (2005) discorrem que essa memória oferece o reconhecimento da identidade. Com a falta da lembrança de fatos, lugares e de pessoas, pensa-se que a cada dia há uma parcela de perda dessa pessoa, ela fica impossibilitada de se relacionar, cuidar de si, planejar sua qualidade de vida, perde sua razão, autonomia e coerência. Ao decorrer da doença surge a impressão que o eu se desliga das funções cognitivas, assim esse indivíduo garante apenas sua sobrevivência.

\section{CONSIDERAÇÕES FINAIS}

As revisões bibliográficas foram realizadas a partir de artigos científicos dos sites Google Acadêmico e Scielo. Também foram utilizados alguns livros, nos quais foram feitas pesquisas na biblioteca do Uni-FACEF. Todo embasamento teórico utilizado está devidamente com sua referência ao final deste artigo.

A partir dos estudos de base teórica, se percebe muitos aspectos da Doença de Alzheimer. O mais característico é a perda de memória e a confusão mental. Aprofundando um pouco mais se observa que ao longo da evolução da doença a memória de curto prazo é altamente prejudicada, porém, a de longo prazo ainda se mantém em alguns aspectos ao longo do tempo.

Com base nos autores citados no estudo, a perda da memória dificulta e complexifica a proximidade desses indivíduos em suas relações afetivas, sociais e familiares. Esses pacientes tendem a esquecer os nomes 
dos familiares, quem eles são, onde está, ou seja, além da perda da memória também em casos mais agravados se percebe a confusão mental, o que torna o trajeto da doença mais difícil ainda.

Apesar da memória de curto prazo ser a mais afetada na doença visivelmente, ao longo do tempo também se percebe a dificuldade na evocação das memórias de longo prazo. Essas complicações implicam em prejuízos da função da construção e manutenção do senso de identidade, o que é um dos declínios mais temíveis da doença.

Em relação a memória autobiográfica, como as perdas ao longo do trajeto da doença são significativas, em um dado momento o indivíduo começa a se perder de si mesmo, não se reconhece mais no espelho, não se lembra de seu nome, se perde em fatos e vivências, ou seja, os primeiros níveis que ela atinge são os mais genéricos e aos poucos evolui para os mais específicos.

Conclui-se então a partir desse estudo que a Doença de Alzheimer tem sua maior característica na memória, que aos poucos se degenera por conseqüência da doença. A DA ainda não tem cura, porém, existem diversos tratamentos para a retardação de seus sintomas e muitas estratégias para que essa pessoa consiga levar uma boa vida apesar de todas as conseqüências.

Estudos assim são de suma importância para que mais informações sobre a Doença de Alzheimer sejam levadas a pessoas que convivem e cuidam de outras pessoas com essa doença. É importante a diferenciação da DA dos outros tipos de demência.

\section{REFERÊNCIAS}

ABREU, Izabella Dutra de; FORLENZA, Orestes Vicente; BARROS, Hélio Lauar de. Demência de Alzheimer: correlação entre memória e autonomia. Revista de Psiquiatria Clínica. Vol. 32, n. 3, p. 131-136, 2005. Disponível em: https://www.revistas.usp.br/acp/article/view/16324/18036 Acesso em: 04 de dezembro de 2019.

ALVAREZ, Ana Maria M.A; ANDRADE, Flávia C; AVILA, Renata; BOTTINO, Cássio M.C; BUSTAMANTE, Sonia, E.Z; CAMARGO, Cândida H.P;

CARVALHO, Isabel A.M; HOTOTIAN, Sérgio R; SAFFI, Fabiana; ZUKAUSKAS. Reabilitação Cognitiva em pacientes com doença de Alzheimer: Relato de trabalho em equipe multidisciplinar. Arquivos de Neuro-Psiquiatria. Vol. 60, n. 1,São Paulo, 2002. Disponível em:

http://www.scielo.br/scielo.php?script=sci arttext\&pid=S0004282X2002000100013 Acesso em: 04 de dezembro de 2019.

ALVIM, Neide Aparecida Titonelli; COELHO, Gleani da Silva. A dinâmica familiar, as fases do idoso com Alzheimer e os estágios vivenciados pela 
família na relação do cuidado no espaço domiciliar. Revista Brasileira de Enfermagem. Vol. 57 (5), Brasília, 2004. Disponível em: http://www.scielo.br/pdf/reben/v57n5/a05v57n5.pdf Acesso em: 04 de dezembro de 2019.

ARAÚJO, Cláudia Lysia de Oliveira; ONOFRE, Andréia de Almeida; SILVA, Edna Teodoro da; PENA, Maria Verônica Diniz. Qualidade de vida de idosos institucionalizados. Caderno Temático Kairós Gerontologia. Vol. 8, São Paulo, 2010. Disponível em: https://revistas.pucsp.br/kairos/article/view/6913/5005 Acesso em: 04 de dezembro de 2019.

BADDELEY, A. D.; Hitch, G. J. Working memory. In G. A. Bower (Ed.), The psychology of learning and motivation: Advances in research and theory.New York: Academic Press, 1974.

BRUNA, Maria Helena Varella. Memória. Dráuzio Varella, UOL. N.C. Disponível em: https://drauziovarella.uol.com.br/corpo-humano/memoria/ Acesso em: 16 de junho 2020.

CARDOSO, Veronica Barreto; et al. A doença de Alzheimer em idosos e as consequências para cuidadores domiciliares. Memorialidades. N. 23 e n. 24, 2015. Disponível em:

https://periodicos.uesc.br/index.php/memorialidades/article/view/1310 Acesso em: 04 de dezembro de 2019.

FAGUNDES, Valéria; et al. Envelhecimento, memória e Doença de Alzheimer. Ed iPUCRS: Porto Alegre, 2015. Disponível em: https://books.google.com.br/books?id=43lyCwAAQBAJ\&pg=PA4\&lpg=PA4\&dq =FAGUNDES,+Val\%C3\%A9ria;+et+al.+Envelhecimento,+mem\%C3\%B3ria+e+ Doen\%C3\%A7a+de+Alzheimer.+Ed+iPUCRS:+Porto+Alegre,+2015.\&source=b I\&ots=laF8zD9Rq9\&sig=ACfU3U25QZNK Ntl4Jz73NNPqNOV-VgFMQ\&hl=ptBR\&sa=X\&ved=2ahUKEwiQ9fCK0J3mAhWfH7kGHZwuC-

0Q6AEwAnoECAcQAQ\#v=onepage\&q=FAGUNDES\%2C\%20Val\%C3\%A9ria\% 3B\%20et\%20al.\%20Envelhecimento\%2C\%20mem\%C3\%B3ria\%20e\%20Doen \%C3\%A7a\%20de\%20Alzheimer.\%20Ed\%20iPUCRS\%3A\%20Porto\%20Alegre \%2C\%202015.\&f=false Acesso em: 04 de dezembro de 2019.

FALCÃO, Jorge Tarcísio de Rocha; HAZIN, Izabel; LEMOS, Caroline Araújo. Investigação da memória autobiográfica em idosos com Demência de Alzheimer nas fases leve e moderada. Red de Revistas Científicas da América Latina y El Caribe, Espanã y Portugal. Vol. 17 (1), 2012. Disponível em: http://www.scielo.br/pdf/epsic/v17n1/17.pdf Acesso em: 04 de dezembro de 2019.

GAUER, Gustavo; GOMES, Willian Barbosa. Recordação de Eventos Pessoais: Memória Autobiográfica, Consciência e Julgamento. Psicologia: Teoria e Pesquisa. Vol. 24, n 4. Brasília, 2008. Disponível em: http://www.ufrgs.br/museupsi/lafec/08.pdf Acesso em: 04 de dezembro de 2019. 
GAUER, Gustavo; GOMES, William B. A experiência de recordar em estudos da memória autobiográfica: aspectos fenomenais e cognitivos. Memorandum. 11Universidade Federal do Rio Grande do Sul, 2006. Disponível em: https://periodicos.ufmg.br/index.php/memorandum/article/view/6725/4298 Acesso em: 04 de dezembro de 2019.

GODOY, Arilda Schmidt. Pesquisa Qualitativa: tipos fundamentais. Revista de Administração de Empresas. Vol. 35, n. 3, p. 20-29, São Paulo, 1995. Disponível em: http://www.scielo.br/pdf/rae/v35n3/a04v35n3.pdf Acesso por último em: 02 de Julho de 2019.

GREENBERG, D. L.; RUBIN, D. C. The Neuropsychology of autobiographical memory. Cortex, 2003.

GROSSMAN, M; et al. Lexical Acquisition in Probable Alzheimer's Disease. Brain and Language. 1997.

IZQUIERDO, I. Memória. Cap. 2. São Paulo: Artmed, 2002.

IZQUIERDO, I. Memória. 2ed. Porto Alegre: Artmed, 2011.

PARENTE, Maria Alice de Mattos Pimenta; et al. Memória e compreensão da linguagem no envelhecimento. Estudos Interdisciplinares sobre o Envelhecimento. Porto Alegre, vol. 1, p. 57-76, 1999. Disponível em: https://www.seer.ufrgs.br/RevEnvelhecer/article/view/4651/2568 Acesso em: 16 de junho de 2020.

PERGHER, Giovanni Kuckartz; STEIN, Lilian Milnitsky. Recuperando memórias autobiográficas: avaliação da versão brasileira do Teste de Memória Autobiográfica. Revista PSICO. V. 39, n. 3, p.299-307, Porto Alegre, 2008. Disponível em: https://dialnet.unirioja.es/servlet/articulo?codigo=5161430 Acesso em: 06 de junho de 2020.

PINTO, Amâncio da Costa. Problemas de memória nos idosos: uma revisão. Psicologia Educação e Cultura. Vol. III, n. 2, p. 253-295. P.P.C.M.C.M: Colégio Internato dos Carvalhos, 1999. Disponível em: https://repositorioaberto.up.pt/bitstream/10216/18500/2/83735.pdf Acesso em: 16 de junho de 2020.

PRADO, Marco A.et al; Envelhecimento e memória: foco na doença de Alzheimer. Revista USP. N. 75, p. 42-49, São Paulo, 2007. Disponível em: http://www.revistas.usp.br/revusp/article/view/13619/15437 Acesso em: 04 de dezembro de 2019.

SERENIKI, Adriana; VITAL, Maria Aparecida Barbato Frazão. A doença de Alzheimer: aspectos fisiopatológicos e farmacológicos. Revista Psiquiatria. Vol. 30, n. 1, Porto Alegre, 2008. Disponível em: http://www.scielo.br/scielo.php?script=sci arttext\&pid=S010181082008000200002 Acesso em: 04 de dezembro de 2019. 
SILVA, Kleyfton Soares da. A NEUROCIÊNCIA COGNITIVA COMO BASE DA APRENDIZAGEM DE GEOMETRIA MOLECULAR: um estudo sobre atributos do funcionamento cerebral relacionados à memória de longo prazo. 2018. Dissertação (Mestrado em Ensino de Ciências e Matemática) Universidade Federal do Sergipe: São Cristóvão, SE, 2018. Acesso em: https://ri.ufs.br/handle/riufs/8229 Acesso em 16 de junho de 2020.

SMITH, Marília de Arruda Cardoso. Doença de Alzheimer. Revista Brasileira de Psiquiatria. Vol. 21, s. 2, São Paulo, 1999. Disponível em:

http://www.scielo.br/scielo.php?pid=S1516-

$44461999000600003 \&$ script=sci arttext\&tIng=es Acesso em: 01 de Junho de 2019.

TULVING, E. How many memory systems are there? American Psychologist, 40, 1985.

WAUGH, N. C.; NORMAN, D. A. Primary Memory. Psychological Review. 1965. 


\title{
APLICAÇÕES TEATRAIS NO DESENVOLVIMENTO PESSOAL DE PACIENTES COM TRANSTORNOS PSÍQUICOS
}

\author{
Sofia Rodrigues de França Roland \\ sofia.roland@gmail.com \\ Maria Cherubina de Lima Alves \\ mcherubina@facef.br
}

\section{INTRODUÇÃO}

A presente pesquisa tem como diretriz observar a história da doença mental no sujeito como algo processual, entendendo o adoecimento psíquico a partir do desenvolvimento do indivíduo enquanto ser humano, compreendendo a fase da infância como um marco, especialmente em relação ao desenvolvimento dos recursos de autoconhecimento da pessoa.

Quando a criança atinge seus sete anos, ela entra no estágio operacional concreto dando início à terceira infância (PIAGET apud MOREIRA, 2014). Assim, há o ingresso da criança na escola, onde ela terá seus primeiros contatos extrafamiliar. Sabemos que a educação muitas vezes não cumpre com seus objetivos e tende a limitar os pensamentos imagísticos e fantasiosos do indivíduo, forçando-o a se enquadrar em padrões de comportamentos préestabelecidos baseados em conceitos capitalistas de produtividade.

Nesse sentido, deixa-se de trabalhar a criatividade natural e introduz desde muito cedo as ideias de competição. A partir dessa repressão de impulsos vitais, o sujeito tende a coibir seu potencial criativo, ainda mais quando se trata de expressões pessoais. A partir dessas amarras sociais começam a ser desenvolvidas patologias psíquicas que comprometem as relações inter e intrapessoais.

Esse trabalho foi proposto como um estudo dos transtornos mentais, que tem crescido cada vez mais, com o foco em adultos, entendendo que a doença não é repentina e sim fruto de todas as vivências pessoais. A ideia de se trabalhar o teatro como ferramenta de aprimorar as relações intrapessoais surge do levantamento bibliográfico de autores que pontuam que ao trabalhar o corpo no teatro, o ator se depara com suas emaranhadas redes de afetos, possibilitando um autoconhecimento terapêutico.

O objetivo do estudo foi investigar de forma exploratória de que forma o teatro pode auxiliar no desenvolvimento pessoal dos pacientes com transtornos psíquicos e consequentemente nos seus processos terapêuticos. Os objetivos específicos são: compreender a história do teatro, passando pelo surgimento do psicodrama; ressignificar os transtornos psíquicos diferenciandoos de loucura; experenciar a prática de encontros teatrais com esse público 
específico proporcionando a eles um espaço livre para suas vivencias pessoais.

A justificativa para o tema escolhido veio diretamente do interesse pessoal da pesquisadora que propõe interligar a arte à psicologia acreditando ser uma importante junção multidisciplinar que beneficia até questões pessoais, sociais e até políticas, como a saúde pública. Além disso, sabe-se que a atuação no teatro e a pesquisa em psicologia mostram a existência de efeitos positivos na área da saúde mental tendo um grande potencial terapêutico. Neste cenário, e acreditando no potencial criativo de cada sujeito, considera-se que dinâmicas teatrais podem melhorar a relação intra e interpessoal em pessoas com transtornos psíquicos.

Quando à metodologia, esta pesquisa tem uma abordagem qualitativa, sendo caracterizada pelo estudo de caso. Segundo Yin (2005) o estudo de caso representa a estratégia preferida quando se colocam questões do tipo "como" e "por que", pois, permite investigar de forma que se preserve as características holísticas e significativas dos acontecimentos da vida real.

O estudo de caso foi realizado com um grupo de pacientes usuários do CAPS III - Florescer de Franca, participantes de um grupo teatral aberto, chamado de "Ação expressiva", oferecido semanalmente por uma profissional do teatro, de forma gratuita e aberta a todos os usuários do CAPS que estiverem interessados e possuírem indicações do médico responsável.

O grupo teatral já era oferecido aos pacientes como um grupo aberto, independente da presente pesquisa, assim os usuários podiam ter liberdade de participar quantas vezes desejarem. Nesse sentido, o critério de inclusão na amostra foi que eles participassem do grupo por pelo menos três meses consecutivos, pois considera-se a importância da periodicidade para que as oficinas possam ter efeito no processo de desenvolvimento dos pacientes.

Tanto a quantidade da amostra quando os procedimentos da pesquisa de campo precisaram ser alterados pelas recomendações de isolamento social, em função da pandemia da COVID 19. Assim, a pesquisa contou com nove participantes, acompanhando-os com observações de nove encontros (Oficinas Teatrais) e entrevistas individuais, semiestruturadas com cada um deles. Vale ressaltar que os nomes de todos os participantes foram substituídos por pseudônimos, preservando sua identidade.

As oficinas tiveram duração de uma hora semanal, e era realizada semanalmente, às sextas-feiras. O método dos encontros é parte de um estudo científico da atriz responsável (nomeada neste documento como D., para preservar sua identidade), sendo que a pesquisadora se limitou a participar, observando a dinâmica do grupo e, especificamente, a atuação dos participantes da pesquisa. 
Como instrumento foi usado um roteiro de entrevista semiestruturado para avaliar as condições dos participantes e suas opiniões a respeito das oficinas de ação expressiva. No primeiro momento foi feito 0 contato com os pacientes e explicação sobre a pesquisa e o convite voluntário a quem quisesse participar. Outro instrumento utilizado foi a observação com registros em diário de campo das oficinas teatrais, que foram acompanhadas pela pesquisadora, frequentemente, com todos os participantes já envolvidos.

Após as entrevistas, foi feita a análise dos dados a partir de categorias temáticas, que foram criadas com as temáticas mais relevantes da pesquisa de campo. Essas categorias seguiram os princípios básicos de agrupamento, sendo eles a formação a partir de classificações idênticas do tema, não contendo a exclusão de nenhum dado (MORAES, 1999).

Uma vez que a presente pesquisa envolveu o contato com seres humanos, foram ponderados os cuidados éticos necessários, tal como recomenda a Resolução no 466/12 do Conselho Nacional de Saúde (2012), sendo que o trabalho foi submetido e aprovado pelo Comitê de Ética em Pesquisa. Sendo assim, foi utilizado o Termo de Consentimento Livre e Esclarecido (TCLE) com cada um dos participantes a fim de garantir o respeito em relação aos participantes considerando sua dignidade e relativa autonomia. Como os usuários do CAPS III podem ser pessoas que precisam de autorização de responsáveis, foi adotado o critério de dois TCLEs: um para 0 usuário e outro para seu responsável - conforme recomendações éticas para pesquisas com pessoas que possam não ter autonomia para responder por si.

\section{UM NOVO OLHAR SOBRE O TEATRO}

Depois de um longo processo de evolução, o teatro adquire novas funções sociais (MAGALHÃES; ANDRADE, 2016). A facilitação do contato que a globalização proporciona torna as relações físicas, que eram inicialmente as principais, algo precário. Para Moreno (2003) o ser humano ainda está em um estágio embriônico de desenvolvimento quando comparado ao seu potencial espontâneo-criativo, ou seja, a comunicação direta e presencial está primitiva comparada à comunicação digital.

As maneiras de brincar se modificaram significativamente na última década, o desenvolvimento da criatividade está limitado de forma que a pessoa não precisa mais inventar brinquedos, criar brincadeiras, tudo está pronto para ocupar o tempo através de uma tela de televisão ou smartphone.

Além disso, outro fator importante é como tem sido conduzida a educação infantil dentro das escolas e contextos educacionais em geral. Por um lado, os adultos esperam pouco das crianças, limitando a possibilidade criativa, por outro, já se exige a responsabilidade de um vestibular em uma criança/adolescente de dez anos, esperando que desde cedo ela adquira 
consciência da importância de se dedicar as disciplinas escolares. Esse excesso de informação tem caracterizado a educação de uma maneira muito técnica perdendo a ludicidade necessária para a infância e adolescência.

Courtney (2010) propõe a investigação da imaginação dramática para um desenvolvimento educacional, e para alcançá-la, escreve sobre a diferenciação do teatro e do jogo dramático. $O$ teatro é a arte de representar perante uma plateia, já o jogo dramático é a ação de realizar jogos teatrais que contenham personificação e/ou identificação. Pensando nessa diferença, quando ele propõe a imaginação dramática está visando favorecer 0 desenvolvimento pessoal da criança.

Este trabalho pretende se estruturar a partir da importância do teatro, não como produtor de atores, mas como uma técnica teatral facilitadora para o autoconhecimento e desenvolvimento pessoal focando em pacientes com alguma doença psíquica.

Quando se trata da arte de praticar teatro refere-se a fazer do palco um laboratório de vida onde se pode trazer para a ação a vida que acontece no externo (real) e até a vida interna (imaginário) do sujeito, além de ser um investimento no potencial espontâneo criativo do indivíduo.

\section{OS TRANSTORNOS PSÍQUICOS}

Para desmistificar os transtornos psíquicos é necessário entendêlos. A palavra transtorno corresponde a uma anormalidade e significa que algo não está funcionando como deveria, e no caso dos transtornos psíquicos, a disfunção ocorre na mente. Há interpretações errôneas sobre os problemas mentais. Ainda é muito comum se escutar expressões tais como "ir ao psiquiatra é coisa de gente doida", concepções que podem ser interpretadas como reflexo da época que o modelo manicomial era utilizado de forma absolutamente agressiva e insalubre, onde pessoas com transtornos mentais iam buscar tratamento e acabavam sendo abandonados pelo resto de suas vidas.

Em 1852 o primeiro hospício brasileiro foi inaugurado, chamado de Hospício Dom Pedro II. Em 1978 começam os novos redirecionamentos no trabalho com pacientes em sofrimento psíquico, a partir do Movimento da Reforma Psiquiátrica e só em 1987 iniciou-se, de fato, a Luta Antimanicomial. Ou seja, são mais de cem anos propagando um modelo de assistência onde 0 foco era punição e controle (GUIMARÃES et al., 2013).

Desviat (2015) comenta que esse tipo de hospital atendia não só pessoas com problemas de saúde, mas também mendigos, pessoas sem trabalho, os criminosos, os rebeldes políticos, as prostitutas, alcoólatras, aqueles que eram considerados loucos, e até mulheres que haviam sido 
violadas. Todo esse público era aglomerado em hospícios conhecidos como asilos.

Millani e Valente (2008) ressaltam que a concepção de loucura nos tempos da Inquisição (século XII) como manifestação do sobrenatural, algo demoníaco e até satânico, classificada como ações de bruxaria. Já no século XVII surgem os primeiros estabelecimentos focados não em fornecer assistência médica, mas em exercer o controle social, sendo que a Igreja tinha a intenção de cuidar dos "loucos" como forma de caridade (MILLANI; VALENTE, 2008).

Foi após a Segunda Guerra Mundial, época em que a sociedade estava se reconstruindo, tempo de crescimento econômico e de maior tolerância e sensibilidade com o diferente e as minorias, que, profissionais e agentes culturais concluíram que deveriam transformar ou abolir aquilo que era considerado um hospital psiquiátrico (DESVIAT, 2015).

A verdade é que sempre existiram figuras que iam contra a maneira cruel de auxiliar aqueles que sofriam de adoecimento psíquico. Philippe Pinel (1745-1826) foi um desses que contribuiu com a mudança do paradigma da loucura, ele acreditava que ainda que a equipe técnica tivesse que manter uma postura firme em relação aos pacientes, esse contato precisava ser através de atitudes humanizas e que assim, obteriam mudanças significativas no comportamento do doente (PEREIRA, 2004).

Para Providello e Yasui (2013) outro autor importante é Foucault (1926-1984) que se nega a criar um novo conceito de loucura, pois para ele o importante é como se entende "o louco", o sujeito na sua loucura, e não a loucura isoladamente. Foucault (1975) entende que a loucura é caracterizada pela maneira em que a sociedade a vivência, não interessa a patologização ou o conceito propriamente dito, mas o que constrói a lógica da exclusão social do sujeito louco. Assim, expõe a bagagem cultural que a loucura carrega, desde a Idade Média, buscando descaracterizar essa imagem negativa. Ressaltando o histórico negativo dos transtornos psíquicos, Foucault (1975, p.16) pontua:

\footnotetext{
Quanto mais se encara como um todo a unidade do ser humano, mais se dissipa a realidade de uma doença que seria unidade específica; e também mais se impõe, para substituir a análise das formas naturais da doença, a descrição do indivíduo reagindo a sua situação, de modo patológico.
}

A interpretação sobre o que é loucura começa a se modificar quando a própria sociedade passa a manifestar interesses em mudanças no modelo de assistência, a partir de participações em Conferências de Saúde Municipais e Estaduais. Com isso os hospitais psiquiátricos passam a aderir às novas formas de gestão e são substituídos por redes de serviços abertos, como o Centro de Atenção Psicossocial (CAPS) que possui como política não atender e tratar os pacientes, mas sim acolher e envolvê-los em projetos sociais, culturais e de trabalho, dando uma nova perspectiva ao tratamento. 
Segundo o Manual de Orientações para Elaboração de Projetos de Construção, Reforma e Ampliação de CAPS (MINISTÉRIO DA SAÚDE, 2015), o intuito passa a ser auxiliar as pessoas com transtornos a se ressocializarem e conseguirem voltar para o mercado de trabalho, desenvolvendo estratégia de redução de danos.

Foucault (1975) acredita que a medicina passou a enxergar que os quadros clínicos não são uma coleção de fatos anormais, de monstros fisiológicos, mas são de certa forma desenvolvidos pelos mecanismos normais e pelas reações adaptativas do organismo ao contexto no qual ele está inserido.

Compreender um doente não é só colocar em pauta suas funções abolidas, ou seja, a doença não pode ser resumida a só essas perdas de consciência, ou apatia de tais funções.

\begin{abstract}
A doença não é então um déficit que atinge cegamente esta faculdade ou aquela; há no absurdo do mórbido uma lógica que é preciso saber ler; é a própria lógica de evolução normal. A doença não é uma essência contra a natureza, ela é a própria natureza, mas num processo invertido; a história natural da doença só tem que restabelecer o curso da história natural do organismo são (FOUCAULT, 1975, p.99).
\end{abstract}

Amarante (apud AUGUSTO et al., 2001) diz que a nova forma de enxergar a doença mental deixou de se ocupar totalmente da doença em si para ocupar-se do sujeito. $O$ tratamento e a instituição de cuidado deixam de se resumir apenas à prescrição de medicamentos para tornar-se uma ocupação do cotidiano. Augusto et al. (2001) propõem uma nova forma de cuidado, que não seja aquela de exclusão, supressão de sintomas e isolamento, mas que seja pautada na democracia e nos direitos do doente enquanto cidadão.

Mas, perante uma realidade compartilhada como verdade pela maioria das pessoas, transformar paradigmas não é um trabalho que se realiza facilmente, exige uma conscientização, em grande escala, de uma sociedade que se desenvolveu focada em uma produção desenfreada, e quanto mais se produz mais provoca a noção de existência. Só existe aquele que produz. E aquele que, por limitações físicas, mentais ou psíquicas, tem dificuldade em produzir, ele não tem função para sociedade. E o que se faz com quem não tem função?

\title{
4. A PSICOLOGIA DA ARTE
}

O teatro pode ser considerado como um fenômeno da sociedade pois, para Courtney (2010), a própria natureza teatral pressupõe a comunicação que é o processo social primário do ser humano. $O$ teatro pode ser considerado como uma tentativa de comunicação particularmente 
importante, que pode ser entre homem e homem, entre o dramaturgo e a comunidade, ou então, segundo a psicanálise, entre o inconsciente do artista ao inconsciente do público.

Praticar teatro, nesse contexto proposto pela pesquisa, não se fundamenta em decorar partituras textuais e corporais para se montar um espetáculo ao final do processo, mas sim em vivenciar a potencialidade da investigação pessoal que essa arte proporciona.

Nise da Silveira (1905-1999), aluna de Jung, foi uma importante figura dentro do tratamento de pacientes com sofrimento psíquico pois ela levou a arte em geral para dentro dos antigos manicômios visando possibilitar a manifestação do inconsciente daqueles pacientes.

Durante quase três décadas, Nise foi diretora do Setor de Terapia Ocupacional e Reabilitação do Centro Psiquiátrico Pedro II, e durante todo esse tempo ela pesquisou a eficácia desse método alternativo, comprovando a capacidade criativa que seus pacientes tinham. Segundo Castro e Lima (2007), ela desenvolveu cerca de dezessete núcleos de atividades - encadernação, costura, marcenaria, música, pintura, dança e teatro - que estimulassem a ampliação do relacionamento social e servissem como meio de expressão. Seu método foi baseado na compreensão, no diálogo e no afeto com seus pacientes.

Nise faleceu em 1999 e em sua homenagem o hospital Pedro II foi nomeado como Instituto Municipal Nise da Silveira. Em 2008 o médico e ator Vitor Pordeus deu início ao seu trabalho de coordenador do Núcleo de Cultura, Saúde e Ciência da Secretara Municipal de Saúde do Rio de Janeiro e a partir daí deu continuidade ao método de Nise. Ocupando alas abandonadas do hospital, Vitor, dá início ao Hotel e Spa da Loucura (SODRÉ, 2018).

Em uma entrevista com Sodré (2018), Vitor Pordeus relaciona a doença psíquica aos bloqueios de comunicação. Ele acredita que essa falta de comunicação com o outro faz com que o indivíduo se perca dele mesmo e consequentemente perde-se do outro, alcançando um lugar de negação do discurso e do afeto. O médico compreende a comunicação como aquilo que dá movimento a vida e, em referência ao educador Paulo Freire (1987), questiona a pedagogia da dependência, essa que faz com que a criança perca sua autonomia intelectual resultando numa base pronta de psicose em massa.

Nesse sentido que Nise e Vitor enxergaram que o sujeito com transtorno psíquico tem potencial para "falar", mas muitas vezes não se comunica por não ter condições de expressão: esse é o campo em que a arte pode (e precisa) exercer sua função. Para Silveira (1992) aqueles que são diagnosticados como psicóticos possuem maior capacidade de revelar imagens intensa e dramáticas que são fruto profundo do inconsciente. 
Pordeus (online) faz uma crítica de que esses, cuja capacidade criativa é inimaginável, são esquecidos dentro das grandes prisões químicas utilizadas de forma indiscriminada pelos serviços de "saúde" mental e isso se dá porque população sem "saúde mental" é mais fácil de ser controlada.

E é exatamente nesse exercício de comunicar através de sua criatividade que 0 ator encontra sua natureza, e a partir de então encontra 0 movimento eterno da vida. Atores, então, são todos aqueles que se propõem à prática do teatro, são atores dispostos a reflexão e não só a atuação em si.

Todo ser humano é ator. Não teríamos como existir caso contrário, pois somos contadores de histórias, contamos histórias o tempo inteiro uns para os outros. "Tudo que é dito é dito por um observador a outro observador que pode ser ele mesmo", e esse observador também é ator, construímos e vivemos essas narrativas culturalmente, explicando o mundo a nossa volta, ensinando os rituais do viver, contando histórias que nos ajudam a experimentar a eterna passagem do existir (PORDEUS, 2010, online).

Artaud (1987) pontua que o teatro existe para permitir que o conteúdo recalcado do sujeito, seja reativado. Teoria proposta por Freud (18561939) é explicada por Rodrigues et al. (2018) que diz que, como o psiquismo trabalha para evitar o desprazer, o recalque pode ser considerado como uma de suas estratégias para consegui-lo. O teatro seria então a porta de entrada, ou melhor, de saída desse conteúdo inconsciente, "[...] assim, esse movimento, essa força exercida para que o recalque permaneça, gera desprazer até o ponto em que ele seja superado, gerando prazer" (RODRIGUES et al., 2018, p.10).

\section{APRESENTAÇÃO E DISCUSSÃO DOS RESULTADOS}

Para contextualizar, foram entrevistados nove pacientes da instituição CAPS III Florescer - Franca que são participantes das Oficinas de Ação Expressiva, oferecidas pela própria instituição. Dentre estes sete são homens e duas mulheres, com faixa etária entre 22 e 59 anos, que serão referendados com pseudônimos, para preservar sua identidade.

A partir das entrevistas realizadas tem-se que oito integrantes nunca tiveram contato com teatro antes das oficinas oferecidas pelo CAPS, apenas um integrante teve aulas de teatro na sua adolescência. De uma maneira geral todos eles souberam das oficinas de ação expressiva por convite da própria profissional responsável ou por indicação dos técnicos de referência da instituição.

Os dados obtidos na pesquisa de campo foram organizados com base na identificação de categorias temáticas. Foram elaboradas quatro categorias, sendo elas: potencialidade terapêutica das vivências lúdicas; espontaneidade como estratégia de flexibilização do eu a partir de novas vivências; autoconhecimento e o corpo e sua potencialidade terapêutica. 


\title{
5.1. Potencialidade Terapêutica das Vivências Lúdicas
}

Esta categoria foi criada para possibilitar a discussão da potencialidade terapêutica mobilizada nos participantes da pesquisa ao vivenciar experiências lúdicas durante 0 tratamento desses pacientes, percebida durante a pesquisa.

A experiência do lúdico faz parte do desenvolvimento global da criança durante sua infância, representando mais do que uma brincadeira e um entretenimento (DALLABONA et al., 2004). A prática da ludicidade é um caminho para liberdade de ação, de expressão das pulsões interiores e de desenvolvimento psicossocial do ser humano. Winnicott (1975) afirma que é somente através do brincar que a criança ou o adulto pode ser criativo e utilizar da sua personalidade integral, podendo descobrir o seu eu (Self).

Foi possível notar, durante os encontros, que proporcionar a brincadeira, o jogo, a cena ou até mesmo dar espaço para reviver a infância de cada um através do diálogo, era para eles, uma possível visita ao seu "eu do passado". De acordo com os registros feitos pela autora no seu diário de campo, do último encontro no dia 13/03/2020, teve-se:

\begin{abstract}
Quando brincamos de pega-pega os participantes adoraram, riam demais e comentavam sobre o quão bom era voltar a ser criança. Quando nos sentamos em roda fomos discutir esse ser criança que muitas vezes deixamos para trás, e o que os pacientes falaram foi incrível! [...] A Cecilia contou sobre seus desenhos preferidos na infância, suas brincadeiras preferidas, e a saudade que sentia daquilo tudo. Cada um contou sobre seus desenhos, o que assistia na TV, suas memórias da infância... foi um momento nostalgia!
\end{abstract}

Os sujeitos nomeiam essas vivências de maneira explícita, entendendo que o brincar proporciona momentos de alívio psíquico, uma vez que permitem "ser criança de novo dentro" e, assim, se ressignificar dentro de uma patologia diagnosticada.

Foi perceptível que, ao utilizar de técnicas teatrais, o sujeito se lembrava de suas experiências passadas e demonstrava afeto por elas. As técnicas teatrais podem ser consideradas como formas de proporcionar jogos que liberem o potencial criativo do indivíduo de forma livre e espontânea, acionando o lúdico e dando a possibilidade de vivenciar aquelas lembranças da infância e reconhecer memórias reprimidas. Esses jogos foram tanto brincadeiras de infância, como pega-pega, queimada ou cirandas, quanto também jogos de improvisação, criação de personagem, personificação de objetos ou animais, etc.

O encontro com a criança interior, nada mais é do que, dar a esse público a possibilidade de se enxergar fora da loucura, de relembrar quem eram antes de um diagnóstico que os qualificam erroneamente. 
Enzo: As criancinhas que ficam perto de mim tá mais calma, porque no começo elas faziam arte. Mas não era eu, não sei como te explicar, não era eu que fazia as artes não, eu não me lembro de fazer [...] Como que eu vou por eles pra correr, eles ficam em cima de mim, me abraçando, que eu sinto eles tocando em mim, ai eu fico nisso, e eu gosto deles. Eu não gostava não, mas aí eles tá mais calminho, não tá fazendo aquelas arte feia, mais feia mesmo. Eles tão mais suave [sic].

Para essas pessoas que passam grande parte do seu tempo em sofrimento, e em contato com seus familiares que muitas vezes não tem condições de atender suas demandas psíquicas da melhor forma, ter um ambiente seguro para expressar é essencial. Poder expor a "loucura", transformá-la em arte ou jogo em um ambiente de acolhimento e confiança é um intensificador do desenvolvimento pessoal destes pacientes.

Outro exemplo, desta vez entendendo o lúdico como despertador do potencial criativo temos a resposta do Antônio à quarta pergunta "Você acredita que os encontros teatrais te auxiliam na sua vida pessoal?":

Antônio: Lá fora pode ajudar sim, de uma maneira assim de cantar uns parabéns pra você, tendeu? Por exemplo esses dias eu não tive muita ideia, muita criatividade de mandar um parabéns pra uma amiga minha, então na minha casa tem uma ducha desse tamanho assim ó, eu entrei lá, molhei e fiz o parabéns pra você [sic].

É um relato simples, mas, para um paciente portador de esquizofrenia, a capacidade de correlacionar o teatro com a sua criatividade ao cantar e dar parabéns à uma amiga é bastante significativo, pois assim ele está possibilitando seu aprimoramento criativo.

\subsection{A Espontaneidade Como Estratégia de Flexibilização do Eu a Partir de Novas Vivências}

Esta segunda categoria visa discutir a importância e os benefícios da espontaneidade além de entender qual é a relação do espontâneo com a timidez, e compreender o que isso resulta na flexibilidade da vivência do novo.

A espontaneidade, segundo a concepção de Moreno (2003), pode ser expressa de quatro maneiras distintas: qualidade dramática - a partir da repetição de ações criar algo novo; a criatividade - produção de novas experiências em seu próprio íntimo, a fim de criar novas obras de arte, invenções tecnológicas, novos ambientes sociais e além disso, poder criar uma nova criança interior; a originalidade - permissão para que a auto expressão encontre um fluxo livre liberando o sujeito da conserva cultural; e por fim, a adequação da resposta - bagagem espontânea suficiente para saber responder a novas situações de maneira adequada.

Partindo do princípio da originalidade na qual o sujeito vai evoluindo sua forma de expressão, Gael responde a terceira pergunta "Você 
acredita que o teatro possa ajudar no seu tratamento? Se sim, de que maneira?":

Gael: Ah, eu acho que sim. Acredito. Me ajuda legal sim.

Pesquisadora: E de que maneira?

Gael: Uai, no psicológico. Na cabeça. Tudo uai. Fica mais... como que se diz... assim, ajuda porque eu era muito fechado, muito tímido assim, e agora tô abrindo mais com as pessoas [sic]

O "se abrir mais com as pessoas" é exatamente uma maneira de se expressar que antes estava impedida, e para esse paciente, ter a oportunidade de se expressar nas oficinas pode abrir caminhos para melhor se relacionar na sua vida pessoal. No mesmo seguimento, Heitor responde a mesma pergunta da seguinte forma: "Eu acredito! Ah, a maneira assim... pra mim ser mais social, me relacionar com as pessoas de uma forma melhor [sic]."

Houve uma concordância entre os entrevistados em relação às respostas à essa pergunta pois a maioria citou o teatro como caminho para se expressar, se sentir melhor com as outras pessoas e/ou ser mais social.

Bento: $O$ teatro facilita a expressão, a arte facilita a expressão do seu eu, né, do seu self [...] é mais uma questão de expressão do self como o seu lugar no mundo, como liberdade do seu lugar no mundo, sua maneira de se expressar e que isso seja acolhido, ne? Então, o teatro ele faz isso, que suas ideias sejam acolhidas, né?

Para um indivíduo refém de um transtorno psíquico existem diversas amarras sociais e culturais que o aprisionam em seu mundo particular. Um exemplo disso é a fala da Íris à pergunta, "Você se sente confortável em expressar seus sentimentos para outras pessoas?", ela diz: "Não, eles falam que a gente é doida, né?". "Íris refere-se ao quanto essas pessoas permanecerem taxadas como "doidas", elas se prenderão em si mesmas dificultando esse fluxo livre para se expressar como proposto por Moreno (2003).

Em relação à bagagem espontânea a fim de alcançar novos meios de resposta às situações cotidianas, Bento ilustra:

Pesquisadora: Em uma escala de 0 a 10, sendo 0 ruim e 10 bom, qual o nível de melhora você tem sentindo no seu tratamento?

Bento: Vamo colocar aí... um oito. Eu tô bem assim, você tá vendo eu me comunicar com você, ne, comunicar na oficina, ficar tranquilo, falar essas coisas eram coisas que a princípio, quando eu cheguei aqui, eu não conseguia. Eu era uma pessoa que chegava totalmente mutilada aqui e isolada que nem um bicho, agora é um Bento normal, como antes.

Essa abertura que as vivências teatrais proporcionam contribui para o desenvolvimento pessoal desses pacientes, mas vai além disso, não é limitado apenas a uma categoria da vida deles, é perceptível em todos os ramos, no pessoal, social, psicológico e até comportamental, colaborando para forma como o sujeito reage ao seu cotidiano, como exposto pelo Bento anteriormente. 
Os pacientes revelam que nos grupos eles se sentem livres para falar e agir, exclusivamente por ser um ambiente acolhedor para eles.

Cecília: [...] na hora que a gente tá lá atuando, você não consegue lembrar de mais nada, você quer viver aquele momento, momento lá fora acabou, deixa para depois, é aquele momento acabou, mais nada.

Quando a Cecília pontua que o "momento lá fora acabou" dá-se para interpretar o que esse "lá fora" representa para ela, estar nas oficinas entregue aos exercícios porque "quer viver aquele momento" e não se preocupar com o que existe fora dali mostra a influência positiva de um ambiente que permite ao ser estar presente com sua real personalidade.

Durante as entrevistas, quando a pergunta "Você se sente confortável em expressar seus sentimentos para outras pessoas?" foi feita, apenas uma pessoas respondeu sim (Cecília), o restante apresentou ideias como "Não sou muito de entrar em contato do meu particular para outras pessoas" (Diogo) ou então "Eu sou assim, mais quieto" (Gael), "Criei uma certa introversão com a sociedade." (Bento), ou até mesmo o exemplo já citado anteriormente, "Eles falam que a gente é doente, né?" (Íris).

São discursos que trazem como base a timidez, insegurança, que expressam o desconforto ao se mostrar para o outro. A relação dessa timidez com a espontaneidade é estreita, isso mostra o quanto é difícil se libertar das amarras sociais e adquirir espontaneidade.

Francisco: Dependendo da pessoa eu não me sinto confortável.

Pesquisadora: E com que tipo de pessoa você se sentiria confortável?

Francisco: Com pessoas que passam confiança [...] pessoa sincera, que olha nos olhos, que interessa, que se importa contigo.

Francisco só se sente confortável em se expressar quando ele percebe que a pessoa com quem está conversando se importa com ele, se conecta visualmente com ele. O sentimento de desconforto possivelmente decorra de ambientes nos quais ele se sente julgado ao se expressar livremente.

Diante da pergunta "Você se sente confortável se estiver fazendo uma cena de teatro com espectadores? Por quê?", Francisco responde:

Hoje eu me senti. Hoje eu senti leve, me senti... eu mesmo! Sem impedimentos. Sem medos e sem impedimentos. [...] bom, eu vejo que... com o teatro, ele vai me ajudar muito, no meu processo de cura, e em outros também.

Isso demonstra o quanto o ambiente acolhedor e saudável se torna um caminho de possível cura psíquica. $\mathrm{O}$ ambiente em que o sujeito está, como Axia (2003) pontua, é um forte critério para se analisar a maneira como ele reage às situações, e isso é uma das possíveis contribuições da espontaneidade, já dito acima, o estudo e a prática de exercícios que 
estimulam a espontaneidade são grandes aliados a desenvolver no sujeito melhores condições de respostas às situações apresentadas pela vida.

A relação entre os pacientes em si junto com as profissionais que realizam a oficina se mostra diferente da relação com a autora da pesquisa, os pacientes estavam acostumados com a presença das meninas e por manterem um vínculo contínuo, o lugar de confiança é outro.

É a partir dos exercícios teatrais, que o sujeito vai se possibilitando vivenciar outros complexos saindo de um domínio apenas e se reconhecendo no outro, quando ele permite essa flexibilização do eu, se dispondo a criar um personagem com características diferentes da sua ele experimenta outras possibilidades de existir, além de poder diluir os traumas passados a partir da vivência do novo, ou ainda, ressignificar aquilo que representa uma cisão psíquica.

\subsection{Autoconhecimento}

O autoconhecimento é um dos mais importantes pontos para se pensar como benefício dos encontros de ação expressiva. Desenvolver habilidades de autoconhecimento é um processo extenso e muitas vezes de difícil acesso, sendo que poucas pessoas se conhecem, ou melhor, poucas pessoas permitem se conhecer, talvez por ser um ato muito individual e intenso.

Segundo Resende (2010, p.15), o processo de autoconhecimento se dá a partir da observação de si mesmo, da vida e das relações, "[...] é uma atitude perante a vida e, por que não dizer, uma arte". Ele complementa dizendo que o autoconhecimento não é uma atividade externa e muito menos técnica, não é possível adquirir essa ferramenta inserindo só informações e conhecimentos do mundo. Alcançar o conhecimento de si mesmo é permitir a consciência que floresça num fluxo livre, é se conhecer a partir da única fonte capaz de proporcionar essa descoberta: o eu.

A dificuldade do autoconhecimento é universal, mas se formos analisar dentro da realidade destes pacientes da pesquisa, esse processo se torna ainda mais complexo. É muito comum eles pontuarem uma ruptura com seu "eu do passado", antes do diagnóstico, e o "eu de agora", pós diagnóstico, e esse impasse ao se identificar nessa cisão. Assim, o conhecimento do diagnóstico parece ser como um marco na concepção de "eu" da pessoa com transtorno psíquico, sendo tão importante esse marco que a pessoa inclusive passa a se ver de forma diferente, como se fosse um outro "eu", o "eu de agora". Vale ressaltar que a pessoa é a mesma "antes" e "depois", mas o acréscimo de uma informação como esse altera de tal forma a autopercepção que a pessoa parece ser ver como alguém diferente. 
Diante da pergunta "Você acredita que o teatro possa ajudar no seu tratamento?" além de todos os pacientes terem respondido que sim, cada um com uma visão diferente sobre, sendo que Bento, ressalta:

\begin{abstract}
Então o teatro, o teatro, quando eu fiz ele no Arte Vidinha, ele já me ajudou nessa questão de sociabilização. Aqui ele já tá com um fundo mais terapêutico ainda, que é essa manifestação artística de ressocialização, então eu acredito que além disso de sociabilizar é uma maneira de autoconhecimento na parte terapêutica, o que as pessoas que têm transtorno mais buscam é o autoconhecimento, voltar às origens de si mesmo ne? Que é o que a $\mathrm{D}$. propõe em todos os trabalhos que ela faz e que é muito bom.
\end{abstract}

Essa busca pela origem de si, do se reconhecer dentro da "loucura" é um movimento necessário para o desenvolvimento destes pacientes. É importante que o sujeito tenha consciência de si para que seu processo terapêutico se realize de forma íntegra.

Silva (2012) postula que quanto mais o sujeito conhece sobre si mesmo, mais consciente de suas aspirações e limitações ele estará, e com isso poderá desenvolver melhor estratégia que possibilitem saber lidar com dificuldade comunicativas, de compreensão e resolução de problemas de maneira mais assertiva.

Os participantes dessa pesquisa, além de possuírem dificuldades no autoconhecimento, também apresentam complicações nas relações interpessoais. Para Silva (2012, p.24) "[...] o indivíduo, ao desenvolver uma conduta socialmente habilidosa, é capaz de promover interações de forma satisfatória ao nível social".

Torres e Torres (2006) valorizam as relações sociais pois quando em contato com os outros, eles nos acarretam sensações objetivas e subjetivas. "Diante do que sentimos, buscamos pensar para saber o que é" (TORRES; TORRES, 2006, p.7).

\footnotetext{
Pesquisadora: Você acredita que o teatro possa ajudar no seu tratamento? Se sim, de que maneira?

Heitor: Eu acredito! Ah, a maneira assim... pra mim ser mais social, me relacionar com as pessoas de uma forma melhor. [...]

Pesquisadora: Você acredita que os encontros teatrais te auxiliam na sua vida pessoal?

Heitor: Acredito... então, naquele esquema assim, né... na sociedade mesmo, nos meus relacionamentos. Tanto na área sentimental, quanto na área espiritual... em tudo!
}

As duas respostas do paciente Heitor exemplificam essa busca pela melhoria na qualidade dos relacionamentos que refletem diretamente nas suas áreas sentimentais e espirituais.

Diante da pergunta "Você se sente confortável em expressar seus sentimentos para outras pessoas?", Enzo responde com argumentos que vão além da confiança ao se expressar: 
Humm, não. Porque desde criancinha eu nasci assim, sabe? Apanhei muito dos meus irmãos, pra mim falar... pra falar pra mim que eu não sou homossexual, que eu sou homem, não sei o que, apanhava muito por causa disso [sic].

Essa resposta nos convida a pensar sobre a negação da identidade do eu, pois ele relata já na primeira frase da resposta que nasceu homossexual e que durante toda a infância apanhou muito para negá-la. Negar aquilo que se é por pressão e violência exterior vai transformando esse conteúdo reprimido, "não aceito", em partes da sombra, mesmo que inconscientemente.

Quando questionado sobre acreditar nos benefícios do teatro dentro do seu tratamento, Enzo responde que em partes ele acredita sim, porque foi a partir das oficinas que ele foi parando de se destruir por dentro. São inúmeras as maneiras de se suprimir, mas neste caso, podemos correlacionar a fala do paciente com aquela já discutida anteriormente, a negação da sua sexualidade, sem dúvidas esse pode ser um grande exemplo de se anular.

Assim, pudemos perceber nessa categoria que as oficinas de ação expressiva, como propiciadoras de um ambiente de acolhimento e liberdade de expressão, oferecem a possibilidade para que o indivíduo trabalhe seu processo de autoconhecimento, através de exercícios que estimulem o pensar em si e suas origens, reconstruir momentos dando novas perspectivas e experienciar novas realidades.

\subsection{Categoria o Corpo e Sua Potencialidade Terapêutica}

Esta categoria tem o objetivo de discutir como o corpo se comunica sem que seja necessário o uso de palavras. Entendendo o corpo como uma estrutura física que reage ao psíquico é indispensável proporcionar espaço para esse corpo se manifestar, assim como é importante expor aquilo que a psique elabora das suas experiências.

Várias teorias psicológicas, mais especificamente as teorias psicossomáticas, como a psicanálise, comportamental e a própria Psicologia Analítica (MELLO FILHO, 2002; RAMOS, 1994) também concebem que corpo e mente não estão separados em sua expressão. Ramos (1994) destaca para a importância de um olhar integrativo e total do ser humano, resgatando a noção de inseparabilidade psique-corpo e a possibilidade de se perceber no corpo "sinais" de questões que estão "escondidas" ou reprimidas na psique,

O fazer teatral não tem relação com nenhuma dessas teorias propriamente ditas, mas ao mesmo tempo, realizar os exercícios corporais que as técnicas teatrais propõem, certamente é um caminho para se liberar o corpo de amarras que o colocamos. Auto massagem, rolamentos, movimentos que 
são incomuns no dia a dia como experimentar o andar dos mais diversos animais ou então personificar algum objeto, são exemplo de diferentes formas de se trabalhar o corpo que foram feitos durante as oficinas. De acordo com o registro do último dia de pesquisa de campo, temos:

\begin{abstract}
Hoje foi dia de movimentar o corpo, fizemos vários exercícios corporais, dançamos em roda e brincamos de pega-pega (dentro das linhas da quadra). O dia estava bem quente, muito sol, abafado, 3 pacientes passaram mal (Antônio, Diogo e Íris), todos disseram que era por conta do calor e de termos girado bastante. D. comentou sobre isso, a gente paralisa tanto o corpo, os pacientes ficam tão dopados de remédio que quando movimentam um pouco o corpo, sentem-se mal. D. aconselha que é preciso se mexer mais, liberar o corpo dessa prisão em que colocamos ele.
\end{abstract}

De fato, pôr o corpo para se movimentar tanto pode ser incômodo no começo, tudo aquilo que é novidade gera estranheza, ainda mais quando se trata de liberar corpos que são pressionados por doses altas de medicamentos como esses da pesquisa. O remédio controla a mente e o corpo, limitando-o de grandes liberdades, e isso não é uma depreciação do tratamento medicamentoso em si, porque entende-se sua necessidade e capacidade de auxílio aos pacientes, mas trata-se de uma crítica construtiva a respeito das doses exacerbadas que anulam o indivíduo de sentimentos e vontades, enrijecendo seus corpos e adormecendo suas mentes.

Oliveira (apud BRÊDA et al., 2001) cita um estudo em um Centro de Saúde onde foi observado que a conduta mais frequente dos médicos em relação ao adoecimento psíquico, independente de qual fosse o problema, era receitar benzodiazepínicos. Benzodiazepínicos são medicamentos de que causam tolerância e dependência a curto prazo, além do que o uso contínuo provoca sérios efeitos colaterais como sonolência diurna, perda de memória e perda da função cognitiva (NORDON et al., 2009). O medicamento, ainda que indispensável na condição dos pacientes, prejudicam o desenvolvimento ativo ao longo do dia, como é exposto pela Cecília:

\footnotetext{
Pesquisadora: Em uma escala de 0 a 10, sendo 0 ruim e 10 bom, qual o nível de melhora você tem sentindo no seu tratamento?

Cecília: 7, porque ainda tem hora que eu sinto uns fracassos, e eu tô recente. Só que assim, em vista do que eu tava em casa, em casa eu dormia 24 horas por dia, aqui não, aqui eu faço as atividades, então por isso que eu coloquei 7 , porque aqui eu tô produzindo [sic].
}

Dar ao corpo a oportunidade de se exercitar traz qualidade à vida. Reble et al. (2012) compreendem que o corpo tem função central no reencontro do homem consigo mesmo, e atividades simples como alongamento podem ampliar o corpo, preenchendo novos espaços e aumentando a mobilidade, 0 que pode representar uma ação de luta e reconstrução de si.

Íris, quando questionada sobre acreditar no teatro como propiciador de melhoras no tratamento, respondeu: 
Pesquisadora: Existe alguma expectativa com os encontros teatrais? Se sim, qual?

Íris: Ah, lá me faz bem! Me faz bem! Eu espero assim, é... alívio no corpo. Igual hoje, eu tava pedindo remédio, não sei se é os rins ou se é essa veia, mas aí ó, melhorou (risos) [sic].

Outro exemplo é a fala de Antônio pontuando que a sua maior melhora dentro do tratamento é a sua flexibilidade. Os resultados das entrevistas demonstraram o reconhecimento dos pacientes em relação aos seus tratamentos, desde que entraram na instituição. Francisco, por exemplo, valoriza o tratamento entendendo que a continuidade dele pode ajudá-lo

íris responde a mesma pergunta dizendo que melhorou muito com as oficinas: "Melhorei...no número 10". À mesma pergunta, Diogo numera sua melhora em $99 \%$, Gael pontua em 10 e Enzo coloca em 8 sua melhora para as coisas boas, e 1 para aquilo que ele acha ruim "[...] é coisinha boba que eu não gosto de fazer que é horta, só isso."

Reconhecer e valorizar as melhoras do tratamento vai ajudando esses pacientes a retornarem às suas raízes, e relembrar quem eram - e ainda são, mas talvez escondidos por detrás de rótulos - antes do diagnóstico estabelecido. Além disso, perceber a melhora pode ser um fator que aumenta a autoestima e a possibilidade de acreditar no tratamento e persistir no mesmo.

\section{CONSIDERAÇÕES FINAIS}

Para responder ao objetivo geral deste estudo de investigar de que forma o teatro pode auxiliar no desenvolvimento pessoal dos pacientes com transtornos psíquicos e consequentemente nos seus processos terapêuticos, foram traçados dois caminhos, o primeiro uma retomada na literatura e segundo, uma pesquisa de campo para validar se os benefícios do teatro eram reais para o público em questão.

Com os estudos bibliográficos pôde-se concluir os objetivos específicos propostos, conhecendo mais profundamente a história do teatro; ressignificando os transtornos mentais, problematizando preconceitos arraigados no senso comum acerca da loucura e entendendo-os de maneira científica e; por fim, compreendendo aspectos relevantes sobre a relação entre arte e psicologia que possibilitam uma expressão humana significativa de forma indireta e não verbal.

A pesquisa de campo se mostrou pertinente para responder ao objetivo de pesquisa, de modo que a partir dos dados obtidos foi possível a elaboração de quatro categorias temáticas elucidando os êxitos e as dificuldades que um paciente tem durante seu processo de tratamento. As categorias foram: categoria potencialidade terapêutica das vivências lúdicas; categoria espontaneidade como estratégia de flexibilização do eu a partir de 
novas vivências; categoria autoconhecimento; categoria o corpo e sua potencialidade terapêutica

Utilizando-se de vivências lúdicas o sujeito pode estar desenvolvendo sua capacidade de expressão através de jogos e brincadeiras, que resultam em uma liberação psíquica e um alívio mental. Para os pacientes do estudo, a maioria relatou possuir dificuldade de conseguir se relacionar com outras pessoas - característica comum dos transtornos psíquicos. Segundo os relatos, os participantes pontuaram que se expressar e ser aceito era então um desafio considerável, mas, ao mesmo tempo, a maioria dos entrevistados consideram o teatro e as oficinas de ação expressiva um caminho facilitador para comunicação com o meio externo.

Ao experimentar o lúdico e se permitir ser espontâneo, o indivíduo está automaticamente dando a oportunidade ao seu "eu interior" de vivenciar diferentes práticas que estimulam a sua criatividade e originalidade. 0 ambiente teatral que foi estudado, foi capaz de gerar nesses pacientes sensações de acolhimento e confiança, dois aspectos indispensáveis para melhora na qualidade de vida destes sujeitos.

O autoconhecimento, aqui considerado como um dos mais importantes caminhos para o desenvolvimento pessoal de qualquer indivíduo, se torna ainda mais significativo quando se trata de pacientes com transtornos psíquicos. Eles mesmos pontuam uma cisão existente entre sua auto percepção nos momentos pré diagnóstico e pós diagnóstico, sendo que depois de serem diagnosticados passaram a ter um novo olhar sobre si mesmo, e na maioria das vezes, um olhar bastante preconceituoso. Além de possibilitar técnicas, as oficinas de teatro acompanhadas nessa pesquisa puderam proporcionar um ambiente propício para esse processo de autoconhecimento indispensável para aqueles que buscas um desenvolvimento pessoal dos pacientes.

De acordo com a última categoria estudada, foi comum entre os entrevistados que manifestar o corpo é um importante meio para também se alcançar alívio psíquico. Isto é, movimentar o corpo, esta estrutura física que representa uma importante parcela de quem somos e permitir que ela se expresse como sendo um animal, um objeto ou até pela dança pode promover a flexibilização do paciente, pois é possível que eles tenham a experiência de se desenrijecer do que é pressuposto pelo diagnóstico, alcançando também, alívio corporal.

As categorias delimitadas para melhor compreender os resultados, na verdade são complementares entre si e não categorias isoladas. Ao buscar métodos de autoconhecimento dentro das técnicas teatrais, é indispensável que disponha, por exemplo, de práticas que estimulem a criatividade e expressão. Confirmando o objetivo inicial, temos que as várias 
técnicas teatrais compõem um quadro extenso de possibilidades para se trabalhar as limitações que os transtornos mentais delimitam.

O jogo, a brincadeira, a movimentação, a criação de personagens, a personificação de objetos e animais e a expressão livre do corpo são os exemplos mais frequentes de exercícios utilizados dentro deste grupo durante o período de pesquisa de campo. O ambiente acolhedor é uma importante característica para que essas técnicas sejam desenvolvidas da melhor forma. Um ambiente livre de julgamentos, que saiba acolher as expressões da "loucura" e mais do que isso, saber fazer arte com cada criação, mostrar para o sujeito a possibilidade de que ele seja ator criador, dando autonomia para 0 indivíduo existir independente do seu diagnóstico.

É importante que grupos como esse possam ser disponibilizados em todo e qualquer ambiente terapêutico que trabalhe promovendo saúde mental. É necessário se expressar, se libertar das amarras pessoais e sociais que aprendemos a nos colocar.

Durante o processo da pesquisa de campo para este trabalho foi preciso ultrapassar algumas barreiras. Ao adentrar a um espaço público de saúde existem inúmeras burocracias que devem ser seguidas, por isso, o cronograma estipulado para esse trabalho não foi seguido como o esperado. $O$ CAPS III foi inaugurado recentemente na cidade de Franca, e durante 0 período da pesquisa coincidiu da instituição estar passando por momentos de modificações e melhorias da gestão e organização. Isso fez com que este trabalho atrasasse para se iniciar, e infelizmente, pouco tempo depois que foi possível iniciar entramos em um momento de isolamento social mundial, havendo que suspender os encontros.

Certamente tudo isso afetou e limitou a abrangência e o aprofundamento na averiguação dos resultados das oficinas teatrais para os participantes. Ainda que não tenha sido possível realizar como o esperado, certamente foi um trabalho de grande relevância, sendo possível alcançar resultados importantes na observação dos estudos de casos.

Os resultados dessa pesquisa corroboram com o de outras que ressaltam os benefícios e a potencialidade terapêutica das oficinas de teatro com pacientes diagnosticados com transtornos psiquiátrico. Fica como sugestão que novas pesquisas sejam realizadas com um público maior e em maior espaço de tempo, no mesmo serviço que investigamos, além de ser interessante estudar outros grupos também, como dependentes químicos por exemplo.

O teatro pode ser utilizado para diversas demandas já mencionadas ao longo deste trabalho, explorar ainda mais seus benefícios pode trazer cada vez mais melhorias para quem o usufrui. 


\section{REFERÊNCIAS}

ARTAUD, A. O teatro e seu duplo. Tradução Teixeira Coelho. 3. ed. São Paulo: Editora Max Limonad, 1987.

AUGUSTO, L.G.S. et al. O Cuidado ao portador de transtornos psíquicos na atenção básica de saúde. Ciênci. saúde coletiva. v.6, n.2, p.471-480, 2001. Disponível em: <https://www.scielo.br/scielo.php?pid=s141381232001000 200016\&script=sci_abstract\&tlng=pt>. Acesso em: 15 mai. de 2020 .

AXIA, G. A timidez: um dote precioso do patrimônio genético humano. Tradução Silva Debetto Cabral. São Paulo: Paulinas/Loyola, 2003.

BRÊDA, M. Z. et al. O cuidado ao portador de transtorno psíquico na atenção básica de saúde. Ciência \& Saúde Coletiva. São Paulo, v.6, n.2, 2001.

CASTRO, E. D.; LIMA, E.M.F.A. Resistência, inovação e clínica no pensar e no agir de Nise da Silveira. Interface (Botucatu), v.11, n.22, p.365-376, 2007. Disponível em <https://www.scielosp.org/article/icse/2007.v11n22/365-376/>. Acesso em 13 fev. de 2020.

COURTNEY, R. Jogo, teatro \& pensamento: as bases intelectuais do teatro na educação. Tradução Karen Astrid Muller e Silvana Garcia. São Paulo: Perspectiva, 2010.

DALLABONA, S. et al. O lúdico na educação infantil: jogar, brincar, uma forma de educar. Revista de divulgação técnico-científica do ICPG. v.1, n.4, 2004. Disponível em: <https://www.inesul.edu.br/professor/arquivos_alunos/ doc_1311627172.pdf>. Acesso em 03 jun. de 2020.

DESVIAT, M. A Reforma Psiquiátrica [online]. 2 ed. Tradução de Vera Ribeiro. Rio de Janeiro: Editora FIOCRUZ, 2015.

FOUCAULT, M. Doença mental e psicologia. Tradução Lilian Rose. Rio de Janeiro: Tempo Brasileiro, 1975.

FREIRE, P. Pedagogia do oprimido. 17. ed. Rio de Janeiro: Paz e Terra, 1987.

MAGALHÃES, S.; ANDRADE, R. Arte/Linguagem no século XXI: o teatro do oprimido como polifonia. Revista de estudos em Linguagem e Tecnologia, Rio de Janeiro, n.2. ano VII, 2016. Disponível em: <http://artefactum.rafrom.com.br/ index.php/artefactum/article/view/1318/646>. Acesso em 04 out. 2019.

MELLO FILHO, J. Concepção Psicossomática: visão atual. 9 ed. São Paulo: Casa do Psicólogo, 2002.

MILLANI, H.F.B; VALENTE, M.L.L; O Caminho da loucura e a transformação da assistência aos portadores de sofrimento mental. Revista Eletrônica Saúde Mental Álcool Drog, Ribeirão Preto, v.4. n.2, 2008. Disponível em: 
$<$ http://pepsic.bvsalud.org/scielo.php?script=sci_arttext\&pid=S1806-

$69762008000200009 \& \mid n g=p t \& n r m=i s o \& t l n g=p t>$. Acesso em: 30 nov. 2020.

MINISTÉRIO da Saúde. Centro de Atenção Psicossocial e Unidades de Acolhimento como lugares da atenção psicossocial nos territórios: orientações para elaboração de projetos de construção, reforma e ampliação de CAPS e de UA / Ministério da Saúde, Secretaria de Atenção à Saúde, Departamento de Atenção Especializada e Temática. Brasília : Ministério da Saúde, 2015. Disponível em: <http://bvsms.saude.gov.br/bvs/publicacoes/ centros_atencao_psicossocial_unidades_acolhimento.pdf>. Acesso em $04 \mathrm{fev}$. de 2020 .

MORAES, R. Análise de conteúdo. Revista Educação, Porto Alegre. v. 22, n. 37, p. 7-32, 1999. Disponível em: <http://pesquisaemeducacaoufrgs.pbworks. $\mathrm{com} / \mathrm{w} / \mathrm{file} / \mathrm{fetch} / 60815562 /$ Analise $\% 20 \mathrm{de} \% 20$ conte\%C3\%BAdo.pdf>. Acesso em abr. 2020.

MORENO, J.L. Psicodrama. 9. ed. São Paulo: Pensamento Cultrix, 2003.

NORDON, D. G. et al. Prescrição de benzodiazepínicos por clínicos gerais. Diagn Tratamento, Sorocaba, v.14, n.2, p.66-9, 2009. Disponível em: $<$ http://files.bvs.br/upload/S/1413-9979/2009/v14n2/a0004.pdf>. Acesso em: 29 fev. 2020.

PEREIRA, M. E. C. Pinel - a mania, o tratamento moral e os inícios da psiquiatria contemporânea. Rev. latinoam. psicopatol. fundam., São Paulo, v.7, n.3, p.113-116, 2004. Disponível em: <https://www.scielo.br/pdf/rlpf/v7n3/ 1415-4714-rlpf-7-3-0113.pdf>. Acesso em: 03 mai. 2020.

PORDEUS, V. et al. Teatro como método de cuidado em saúde mental: experiência do teatro de Dyonises. Disponível em: $<$ http://www.hcte.ufrj.br/downloads/sh/sh9/SH/trabalhos\%20posteres\%20compl etos/TEATRO-COMO.pdf>. Acesso em 02 mai.

Todo ser humano ator. Imanente Mente. Rio de Janeiro, 2010. Disponível em: <http://imanentemente.blogspot.com/2010/01/todo-ser-humanoe-ator.html?view=classic>. Acesso em 02 mai.

PROVIDELLO, G.G.D; YASUI, S. A loucura em Foucault: arte e loucura, loucura e desrazão. História, Ciências, Saúde-Manguinhos [online]. Rio de Janeiro, v.20, n.4, 2013. Disponível em: <https://www.scielo.br/scielo.php?pid=S0104-

59702013000401515\&script=sci_abstract\&tlng=pt>. Acesso em: 28 set. 2019.

RESENDE, M. Autoconhecimento. Brasília: Editora Teosófica, 2010.

RODRIGUES, C.E. et al. A metapsicologia do recalque. Psicanálise \& Barroco em revista. v.16, n.01, 2018. Disponível em: $<$ http://www.seer.unirio.br/ index.php/psicanalisebarroco/article/viewFile/7960/6893>. Acesso em: 15 mar. 2020. 
SILVA, A.J.G. Habilidades Sociais - uma ponte para o autoconhecimento. Mestrado em Educação Universidade do Minho. Portugal, 2012. Disponível em: <http://repositorium.sdum.uminho.pt/bitstream/1822/24218/1/Adriana\%20de\%2 0Jesus\%20Gon\%c3\%a7alves\%20da\%20Silva.pdf>. Acesso em: 02 jun. 2020.

SILVEIRA, N. O Mundo das Imagens. 2. reimpr. São Paulo: Ática, 1992.

SODRÉ, A. F. P. Hotel da loucura: um estudo de caso sobre arte, comunicação e saúde mental. Campina Grande, 2018. Monografia (Trabalho de Conclusão de Curso no Bacharelado em Comunicação Social). Universidade Federal de Campina Grande. Disponível em: https://www.academia.edu/37433985/Hotel

da_loucura_um_estudo_de_caso_sobre_arte_comunica\%C3\%A7\%C3\%A30_ e_sa\%C3\%BAde_mental.pdf $>$. Acesso em: 05 mai. 2020.

TORRES, C.; TORRES, R. A. Os Níveis do Pensar e a Consciência Humana. In: BIASE, F. D.(Org.). Dimensões da consciência. Rio de Janeiro: Qualitymark 2006. Disponível em:

http://files.efaconhecimento.webnode.com.br/200000004 70193710b8/ARTIGO\%20-\%20N\%C3\%ADveis\%20do\%20Pensar\%20e\%20 a\%20Consci\%C3\%AAncia\%20Humana.pdf>. Acesso em: 1 jun. 2020.

WINNICOTT, D.W. O brincar \& a realidade. Rio de Janeiro: Imago Editora, 1975. 


\section{AQUISIÇÃO DE ESTEREÓTIPOS DE GÊNERO NA INFÂNCIA: uma análise do relato materno}

lago Gonzales de Q. Silva iagogonq@gmail.com

Sofia Muniz Alves Gracioli sofiagracioli@yahoo.com.br

\section{INTRODUÇÃO}

Estereótipos sexuais são formados em um contexto cultural que estabelece padrões do masculino e do feminino por meio de processos educacionais no meio social e, dentre esses vários meios sociais, um deles é a família. Para estudar os estereótipos sexuais na família, foco desta pesquisa, partimos da discussão de gênero e papéis sexuais. Entendemos por gênero a relação que a sociedade, em diferentes culturas e momentos históricos, atribui às características estabelecidas para homens e mulheres, como sendo próprias de seres masculinos e femininos. Essas características se configuram em um padrão de conduta, que influenciará na formação de valores, crenças, traços de personalidade, comportamentos, habilidades, enfim, na representação do papel a ser desempenhado.

Pereira-Silva e Dessen (2003) afirmam que as interações estabelecidas no microssistema família são as que trazem as consequências mais importantes para o desenvolvimento saudável da criança, embora outros sistemas como a escola também tenham papel importante em seu desenvolvimento. $O$ indivíduo vivencia de forma particular o agora com aquilo que lhe pertence de sua história pessoal e familiar social (SIGOLO, 2004).

Dessa forma, a construção da criança é fortemente influenciada pelo meio social e familiar dela, sendo que a última é o primeiro contato social do ser, segundo modelo bioecológico pensado por Bronfenbrenner. Pais podem influenciar na construção das diferenças sexuais e na autopercepção caso tratem seus filhos e filhas de maneira diferente (SHAFFER; KIPP, 2012).

Carol Martin e Charles Halverson (1981) argumentam que a base do esquema de processamento dos estereótipos é o que eles chamam de "Schema". Schemas são teorias ingênuas que guiam a informação processada para estruturar experiências, regular comportamentos e prover bases para fazer inferências e interpretações (tradução nossa). Ou seja, os estereótipos de gênero guiam pensamentos, comportamentos e agem diretamente em como um indivíduo entende e interage com seu mundo interno e externo.

Ainda sobre o contexto familiar, Jacquelynne Eccles $e$ colaboradores (1990 apud SHAFFER; KIPP, 2012) realizaram uma série de estudos para tentar entender porque meninas apresentaram menor 
desempenho em matemática e em outra ciência, fazendo com que elas se afastassem dos curso que abordam tais matéria deixando-os com pouca representatividade feminina. Eles acreditam que as baixas expectativas dos pais em relação às filhas quanto à capacidade matemática se tornam profecias autorrealisáveis, isto é, os pais que esperam pouco desempenho de suas filhas com a matemática e outras ciências acabam não reforçando seus acertos, dando uma maior atenção aos comportamentos que condizem com suas expectativas, nesse caso, seus erros e dificuldades.

Todavia, se as características relativas ao gênero são, muitas vezes, fantasiadas e mascaradas pelo preconceito através dos estereótipos, isso quer dizer que, há uma construção do gênero, e se há construção, há desenvolvimento. E é sobre esse desenvolvimento da identidade de gênero e de seus estereótipos criados pela família que essa pesquisa se pautará.

Hoje, as lutas pela equidade de direitos reivindicados pelos movimentos feminista, LGBTQI+ entre outros grupos minoritários, trazem o assunto desigualdade de gênero a todo momento às notícias veiculadas nas grandes mídias. Resta-nos saber o quanto essas desigualdades podem ser explicadas por fatores biológicos condizentes à organização fisioanatômica e até cognitiva que nossos corpos possuem e o quanto delas são resultado de uma construção social iniciada principalmente no meio familiar e, o mais importante, que pode ser revertida.

O objetivo geral desta pesquisa foi investigar a construção do discurso, a partir do relato de mães de crianças de 4 a 6 anos em relação aos estereótipos de gênero na primeira infância.

Esta pesquisa é descritiva (COZBY, 2003; SPATA, 2005), utilizase de abordagem qualitativa para análise de dados e se justifica uma vez que, se identificados padrões rígidos de gênero na infância, propostas educativas poderão ser implementadas, visando prevenir a discriminação em relação aos padrões sexuais estabelecidos socialmente, isto é, aos estereótipos sexuais.

Participaram da pesquisa mães biológicas alfabetizadas cujas crianças de idade entre 4 e 6 anos estão frequentando as mesmas escolas infantis que aceitaram participar da pesquisa como mediadoras. A população esperada era de 50 mães, no entanto, apenas 14 destas mães aderiram a pesquisa, sendo 8 mães de filhos que frequentam escola pública e 6 mães com filhos matriculado em escolas particulares.

Nestas mães, foram aplicados questionários com a mediação das escolas em que seus filhos estudavam. O questionário é composto por 12 questões discursivas que foram usadas para analisar como o discurso das mães pode influenciar na aquisição de estereótipos de gênero nas crianças 


\section{HISTÓRIA E CONCEITOS}

$\mathrm{Na}$ atualidade, sem demasiado esforço, é de fácil percepção na sociedade uma confusão cultural entre os conceitos de gênero e sexo. Tanto a população mais idosa quanto os mais jovens ainda possuem dúvida a respeito da diferença entre ser homem e assumir uma identidade masculina. Este primeiro capítulo tem a intenção de sucintamente contar um pouco da história do gênero e conceituar termos como gênero, sexo, sexualidade, identidades de gênero e sexual, estereótipos de gênero e papéis sexuais.

A história por trás do termo gênero se remete aos primórdios das manifestações feministas iniciadas na Europa e nos Estados Unidos. A palavra gênero pertence a segunda onda de movimentações em prol à igualdade, ocorrida no final da década de 1960, na qual o movimento, além das preocupações sociais e políticas, passou também a construir uma base teórica que concretizasse seus ideais (LOURO, 2014). O objetivo primeiro da criação do expressão gender foi excluir a ideia de diferenças biológicas intrínsecas aos gêneros masculino e feminino escondida no uso de termos como sexo e diferença sexual, sendo que as pensadoras do termo desejavam acentuar através da linguagem que a ideia de diferenças baseadas no sexo são majoritariamente parte de uma construção social (SCOTT, 1995).

Uma comum associação quando o assunto é gênero é o pensamento que a construção da qual ele é formado se baseia única e exclusivamente na associações de papéis sexuais ao longo da vida de uma criança/adulto. Isso ocorre por exemplo no Referencial Curricular Nacional para a Educação Infantil, em seu volume 2 (BRASIL, 1999, p. 17-20) em que declara:

Assim, ser homem ou mulher varia conforme a cultura e o momento histórico, pois supõe, mais do que as características biológicas de um ou outro sexo, o desempenho de papéis atribuídos socialmente (BRASIL, 1999, p. 17-20).

A importância do gênero na vida de uma pessoa ultrapassa os limites do papéis sexuais, os quais segundo Louro (2014) compreendem-se em padrões ou regras que uma sociedade impõe sobre seus membros e que definem sua forma de se vestir, os locais que frequentam, modo de se relacionar, são através deles que um indivíduo deveria internalizar o que seria um comportamento tipicamente masculino ou feminino, devendo, portanto, se portar de acordo com o esperado socialmente para seu sexo.

Também é importante fazer-se um paralelo entre gênero e sexo, conceitos que também são comumente confundidos e usados como sinônimos pelo senso comum.

Sexo é categorizado por Bee e Boyd (2011, p. 279) como sendo "reservado para os aspectos biológicos da sexualidade". O dicionário Sacconi (2010, p. 1856) define sexo como " conjunto de características biológicas que 
diferenciam machos das fêmeas [...]". Esses conceitos evidenciam o viés biológico por trás do sexo. Essa características que acompanham o indivíduo desde a formação intrauterina, foram usadas durante séculos como uma generalização e uma "desculpa" para a dominação do sexo masculino sobre o feminino, como já discutido anteriormente.

Esse antigo pensamento ainda se faz presente na sociedade contemporânea através da errônea concepção de gênero como sinônimo de sexo. Essa ideia presente no sexo comumente nega os aspectos sociais da identidade de gênero e com isso, nega também sua possibilidade de mudança. A cristalização de uma personalidade característica para o homem e para a mulher são chamados estereótipos de gênero e são construções do senso comum.

Segundo o dicionário Cambridge Learner's Dictionary (2004), estereótipos são definidos como uma ideia fixa que pessoas tem sobre com o que um determinado tipo de pessoa se parece (tradução nossa), enquanto 0 dicionário Sacconi (2010, p. 865) define como "modelo estabelecido e aceito de comportamento, expressão ou outra manifestação; concepção, opinião, ideia ou imagem padronizada de forma convencional como verdadeira".

Os estereótipos de gênero se fazem presente quando 0 comportamento do papel sexual assumido com a criança não vai de encontro com o padrão esperado para o sexo ao qual pertence. Esse conflito identitário começa a ser formado na associação dos papéis escolhidos por uma criança por volta de 4 a 6 anos.

\section{AQUISIÇÃO DE PAPÉIS DE GÊNERO}

Grandes pensadores ao se perguntarem como os papéis sexuais são internalizados pelas crianças criaram pesquisas e, posteriormente, teorias sobre como crianças passam a se reconhecerem como do gênero masculino ou feminino, adotando, assim, características condizentes com suas escolhas. Neste artigo estão sintetizadas 6 delas, são elas: a Teoria Biológica, a Evolucionista, a Psicanalítica, a Cognitiva, a de Esquemas de Gênero e a de Aprendizagem Social.

Por uma similaridade nas atribuições de características de gênero em diversas tribos e culturas, alguns pesquisadores pensaram que esta pudesse ter um papel biológico. O primeiro aspecto trabalhado pela teoria biológica seria os hormônios presentes na corrente sanguínea antes e em torno da hora do nascimento que podem alterar o cérebro em desenvolvimento. Segundo Constantino et al. (1993) não há comprovações que os níveis de hormônio masculino testosterona esteja relacionado com a violência em crianças. No entanto, Auyeung et al. (2009) comprova em seu trabalho que em 
uma análise dos níveis mais altos de testosterona apresenta uma ligação com brincadeiras tipicamente masculinas em meninos.

Ao se pensar sobre a influência de aspectos biológicos na identidade de gênero precisa-se levar em conta dois elementos do biológico que influem para a identidade de gênero dos indivíduos (1) algumas diferenças entre homens e mulheres podem estar ligadas a hormônios e podem demonstrar a atuação hormonal na organização do cérebro (CAHILL, 2012). Consequentemente isso indica que (2) "a intensa exposição aos hormônios sexuais masculinos no período pré-natal pode influenciar nas atitudes, nas áreas de interesses e nas atividades dos indivíduos do sexo feminino" (SHAFFER; KIPP, 2012, p. 614).

Em suma, essa teoria nos faz lembrar que nem só de psiquismo é feito o homem. A parte biológica do contrução do comportamento humano fica bem clara, pois nesta teoria que leva em conta acima de tudo os processos hormonais que ocorrem internos ao olhar clínico e que podem influenciar nas preferências comportamentais dos indivíduos em relação ao gênero.

Estudiosos evolucionistas (por exemplo, BUSS, 1995, 2000; GEARY, 1999, 2005 apud SHAFFER; KIPP, 2012) afirmam que homens e mulheres por terem enfrentados diferentes pressões evolucionistas do meio ao longo da evolução da raça humana, o processo de seleção natural contribuiu para que diferenças fundamentais entre os sexos fossem criadas as quais segundo os autores estabelecem diferentes papéis de gênero ligados à sobrevivência da espécie para ambos os sexos. Assim se formou o que chamamos de teoria evolucionista.

Os homens e as mulheres, apesar de serem semelhantes psicologicamente em muitos quesitos, em alguns comportamentos e/ou habilidades há diferenças quando comparados os sexos; isso ocorre devido a situações que os primeiros homo sapiens viveram e que ficaram marcadas pela seleção natural em nossa história evolutiva através do genes. Como exemplo dessa diferença, podemos citar o melhor desempenho de homens em tarefas visual-espacial quando comparados a mulheres, essa habilidade foi conquistada através da necessidade de antecipar a trajetória da lança no momento da caça (BUSS apud SHAFFER; KIPP, 2012).

Essa teoria se pauta no aspecto histórico/evolucionista da raça humana levando em conta milhões de anos de adaptação natural que nossos corpos sofreram até que chegassem até o ponto que estão hoje. Ela se faz importante pois atrás do passado podemos vislumbrar o futuro, e mesmo que algumas dessas características genéticas herdadas de nossos antepassados possam estar mais uma vez sofrendo um processo de mudança, muitas delas ainda explicam porque alguns comportamentos se tornam estereótipos de gênero. 
Uma abordagem clássica que também vale a pena ser citada é a teoria psicanalítica sobre a masculinidade e feminilidade na criança. Hoje, por ser uma hipótese difícil de ser comprovada empiricamente, alguns autores preferem outras teorias. Freud (1996), postula que a emergência do gênero nas crianças está intimamente ligada ao complexo de Édipo e o complexo de castração tantos nas meninas como nos meninos. Segundo o autor, o complexo de castração precede o complexo de Édipo nas meninas e o procede nos meninos. Nas meninas, a ausência do pênis gera uma inveja deste órgão de seu pai que faz com que ela se identifique com ele. Ao mesmo tempo essa criança tem medo de ter seu clitóres dilacerado pela mãe, da qual mantém também um sentimento de ciúmes e apego materno. Essa menina, então, passa por um processo de identificação no qual imita comportamentos típicos da mãe para que possa conquistar o pai.

Esse processo gera, segundo Freud, as bases da identificação de gênero nas meninas. Nos meninos ocorre situação semelhante, no entanto, nestes a identificação ocorre com o pai com o qual disputa a atenção e o amor da mãe ao mesmo tempo que o teme por medo da castração. Freud diz que "[...] o complexo de castração sempre opera no sentido implícito em seu conteúdo: ele inibe ou limita a masculinidade e incentiva a feminilidade" (FREUD, 1996, p. 285).

A teoria Psicanalítica traz como contribuição o olhar para a família como principal meio formador da identidade de gênero da criança e no papel da representação de um modelo como importante para esse processo. Esse conceito de modelo será novamente trabalhado por Bandura na teoria da aprendizagem social.

Uma das abordagens mais conhecidas ao se falar da aquisição dos papéis de gênero são as teorias cognitivos-desenvolvimentais. Como o próprio nome diz essas teorias são fortemente baseadas na teoria piagetiana e tem como precursor Lawrence Kohlberg, o qual entendia que o processo crucial para a aquisição dos papéis de gênero seria o entendimento da criança do conceito de gênero (KOHLBERG; ULLIAN apud BEE; BOYD, 2011).

Segundo a teoria de Kohlberg, "o conhecimento do gênero precede o comportamento de gênero" (KOHLBERG apud PAPALIA E FELDMAN, 2013, p. 292). As crianças buscam comportamentos condizentes com o gênero ao qual pertence e os reproduzem pois os vêem como coerentes com o ser homem ou mulher, essa identificação é natural na criança e depende segundo Kohlberg da constância de gênero. Também chamada de constância da categoria sexual, se qualifica como a percepção que a criança tem que o gênero a qual pertence é uma característica constante em sua vida, quando adquirirem essa consciência aderem a atos típicos masculinos ou femininos (KOHLBERG apud PAPALIA; FELDMAN, 2013). 
A constância de gênero parece desenvolver-se em três etapas: identidade de gênero, estabilidade de gênero e consistência de gênero (MARTIN et al.; RUBLE;MARTIN; SZKRYBALO; RUBLE apud PAPALIA; FELDMAN, 2013). A identidade de gênero seria a consciência sobre o próprio gênero e ocorreria entre 2 e 3 anos. A estabilidade de gênero seria a noção mesmo que baseada em aspectos superficiais de que o gênero não muda. $E$ por fim a consistência de gênero seria quando as crianças percebem que mudanças de características externas como corte de cabelo, roupas ou comportamentos não afetarão seu gênero, fazendo com que criem menos estereótipos de gênero e sejam menos rígidas nos padrões sexuais (MARTIN et al. apud PAPALIA; FELDMAN, 2013).

Essa teoria está baseada nos processos cognitivos e foi de extrema importância para se pensar nos papéis sexuais como comportamentos dos quais o indivíduo entende e por algum motivo os reproduz, sendo um processo consciente e de caráter construtivista.

Carol Martin e Charles Halverson (apud BEE; BOYD, 2011) criaram uma teoria um pouco diferente sobre a tipificação de gênero. $O$ esquema de gênero ou teoria dos quadros sinópticos dos gêneros (SHAFFER; KIPP, 2012) começa a se desenvolver quando a criança tem aproximados 18 meses, idade em que ela percebe as diferenças entre os gêneros, sabe o seu próprio e pode rotular o masculino e o feminino com alguma consistência; o esquema de gênero estará completo na criança por volta dos 2 ou 3 anos (BEE; BOYD, 2011).

Segundo essa teoria, o fato de as crianças quererem determinar sua identidade básica faz com essas aprenda sobre os sexos e categorize essas informações em quadro sinópticos ou esquemas de gênero, isto é um conjunto de crenças e expectativas que possuem algum tipo de organização e permite à criança criar categorias para os diversos objetos em masculinos e femininos e que vão influenciar nos tipos de informações observadas, detalhadas e lembradas (SHAFFER; KIPP, 2012).

Primeiro essa criança irá categorizar o mundo segundo um esquema de grupo externo que irá lhe permitir categorizar alguns objetos, comportamentos e papéis como sendo de meninos e de meninas (SHAFFER; KIPP, 2012). Segundo Maccoby (1988 apud BEE; BOYD, 2011), o gênero é uma categoria que as crianças aprendem muito cedo e que parece funcionar como um ímã para nova informação.

Essas novas informações chegam de todas as maneiras. Os adultos, por exemplo, ensinam que o gênero é uma categoria importante e, assim incentivam direta ou indiretamente que as crianças criem esquemas de gênero que condizem com normas e crenças culturais (BEE; BOYD, 2011). 
Essa talvez seja uma das teorias mais bem aceitas e estudadas na atualidade pela sua contemporaneidade de dados e pela possibilidade de um estudo pautado no método científico. Essa teoria é muito importante, pois leva em conta tipos diferente de esquemas de gênero além dos tradicionais masculino e feminino, abarcando melhor a complexidade da espécie humana.

Segundo os teóricos da aprendizagem social, como Albert Bandura (1989) e Bussey e Bandura $(1992,1999)$, as crianças internalizam as identidades de gênero e preferências por papéis de gênero de duas maneiras. A primeira delas é por ensino direto no qual as crianças são reforçadas e encorajadas quando desenvolvem comportamentos que condizem com seu gênero e desencorajadas e/ou até punidas quando se apresentam comportamentos típicos do outro sexo. A segunda maneira é por meio da aprendizagem observacional em que as crianças imitam modelos do mesmo sexo que elas, repetindo o que veem.

Nessa teoria os pais têm um papel muito importante na determinação do papel de gênero de seus filhos. Conforme exemplificado por Fagot e Leinbach (1989) e Fagot, Leinbach e O'Boyle (1992)

Os pais que apresentam os padrões mais claros de reforço diferencial têm filhos que são relativamente rápidos em (1) se rotularem como meninos ou meninas, (2) desenvolverem fortes preferências por atividades e brinquedos típicos de seu gênero e (3) adquirirem compreensão dos estereótipos de gênero (apud SHAFFER; KIPP, 2012, p. 618-619).

Bee e Boyd (2011) apontam que em estudos experimentais comprovou-se que os pais, ao invés das mães, estão mais interessados na obtenção de gênero dos comportamentos lúdicos dos meninos. No entanto, ainda segundo as autoras, na maioria dos casos, os pais tratam meninos e meninas de modo semelhante.

Outro grupo de grande influência segundo a teoria da aprendizagem social são os pares. Os pares reforçam os comportamentos típicos de gênero mesmo quando os pais são menos habituados a fazer, reforçado, assim, a tipificação de gênero durante a infância (MARTIN; FABES, 2001).

Um outro modo pelo qual as crianças obtêm muitos dos seus interesses e atributos típicos de gênero, segundo Bandura (1989), é observando e reproduzindo comportamentos dos vários modelos, dos quais têm acesso e que possuem o mesmo sexo que ela.

John Masters e colaboradores (1979) descobriram em suas pesquisas que as crianças em idade escolar estão muito mais preocupadas com os comportamentos desempenhados pelos modelos elegidos por elas do que propriamente o sexo deste. 
Dessa forma, podemos concluir baseado nessas teorias que os pais possuem uma grande importância para a determinação dos papéis de gênero assumidos pelos seus filhos. Percebe-se que a família é o primeiro referencial das crianças para as teorias cognitivas e psicanalista e, por isso, desempenha um papel de grande peso para um desenvolvimento saudável de suas crianças.

\section{O PAPEL DOS PAIS NA CONSTRUÇÃO DA IDENTIDADE}

No início da vida, a primeira relação que nós temos é indiscutivelmente com nossas mães, passamos meses em ligação direta tanto fisiológica quanto psicologicamente. A maternidade segundo Moraes (2007) não é somente um laço biológico entre uma mulher e seu filho, e sim, um tipo de relação que exige tempo e cuidado dessa mãe em relação a seu bebê. Trata-se de uma longa relação de dependência.

Os primeiros anos de vida de uma criança até mesmo dentro do ventre de sua mãe são talvez os mais importantes de sua vida para sua formação mental. Esse pequeno ser está descobrindo uma gama de estratégias que serão usadas por ele durante sua interação com os estímulos do ambiente. No entanto, como já dito, esse começo é marcado pela dependência total deste bebê com seu/sua cuidador(a). É necessário, portanto que este(a) cuidador(a) desempenhe o papel de intermediário(a) dos estímulos do meio para a mente em formação do bebê.

A teoria do desenvolvimento infantil de Winnicott ajudou muito a entender as etapas mais primitivas do crescimento biopsicossocial do ser humano. Formado em pediatria e discípulo de Klein, Winnicott teve uma base teórica muito forte, a qual o ajudou a chegar à conclusão de que a maior parte dos problemas emocionais têm suas raízes nas etapas do desenvolvimento (MONTEIRO, 2003).

A base de sua teoria foi a díade mãe-bebê, desta forma a estrutura primária da saúde mental de qualquer homem são moldadas na primeira infância pela mãe ou cuidador(a) e também pelo meio na qual essa criança vive. Winnicott acreditava que toda mãe é capaz de cuidar devotamente de seu filho, isto é, fazer seu trabalho maternal (idem).

A qualidade das vivências da primeira infância da mãe interfere na qualidade da função materna exercida por ela. Se o meio que essa mulher teve na sua tênue infância foi desfavorável, ela terá problemas em produzir na fantasia uma criança viva e completa, dificultando sua relação com o bebê desde o início (MONTEIRO, 2003).

A função materna pautada no carinho e afeto, assim como é construída hoje, não é inata ao sexo feminino e sim uma parte da estruturação cultural do ser mãe em uma sociedade. De acordo com Badinter (apud SELL, 
2012, p.155) "a relação mãe e filho/a se desenvolve de acordo com as construções sociais e econômicas em que elas/eles vivem e, com isso a autora defende que o amor materno não é um sentimento inato nas mulheres" .

A impotência do recém nascido perante o meio, devido a sua imaturidade biológica, cognitiva e psíquica, torna-o totalmente dependente de um adulto para garantir sua subsistência (FRANÇA, 2017). Esse estado foi nomeado por Freud como "estado de desamparo" que causará feridas guardadas na memória todas as vezes que houver um acúmulo de excitação que não possa ser descarregado ou metabolizado (FRANÇA, 2017). Ainda segundo a autora,

[...] a experiência desse "estado de desamparo" influência, de modo decisivo, a estruturação do psiquismo do bebê, uma vez que este é destinado a se construir inteiramente na relação com o outrem, principalmente com a mãe - o que lhe confere uma função onipotente (FRANÇA, 2017, p.40).

Uma das funções mais importantes desempenhadas pelas mães ou cuidadores é o desenvolvimento de um apego seguro, teoria desenvolvida pelo psicanalista Edward Bowlby. Segundo Gomes e Bosa (2010, p.11) "ter apego ou estar apegado é ter alguém como base segura preferencial para explorar o ambiente". Ainda segundo as autoras a ideia central da teoria de Bowlby seria relacionar a qualidade do vínculo que se estabelece entre 0 cuidador e a criança cuidada com suas implicações para o desenvolvimento da auto-estima, da autoconfiança, da sociabilidade entre outros aspectos do desenvolvimento infantil (GOMES; BOSA, 2010).

A teoria do apego é importante para se pensar na desenvolvimento da identidade de gênero pois é através do vínculo formado que as crianças adquirem confiança suficiente para dar seus primeiros passos em direção ao social, no qual a maioria dos seus referenciais de papéis sexuais serão construídos. Logo, caso a criança apresente tipos inseguros de apego (evitativo e ambivalente) (PAPALIA; FELDMAN, 2013) ou desorientado (MAIN; SOLOMON, 1986 apud PAPALIA; FELDMAN, 2013), há grandes possibilidades de que em seus futuros relacionamentos esse padrões de apego vividos na infância voltem a acontecer.

Essa condição, vivida por crianças que viveram apegos nãoseguro, se torna fator de risco para que elas acabem não se sentindo protegidas o bastante para criar seus próprios esquemas de gênero e somente passem a repetir os que lhe são impostos pela sociedade e pela cultura predominante.

"O papel da paternidade é basicamente uma construção social (DOHERTY; KOUNESKI; ERICKSON, 1998 apud PAPALIA; FELDMAN, 2013, p. 217), sendo essa construção dependente de aspectos socioculturais. Segundo Berg e Wynne-Edwards (2001 apud PAPALIA; FELDMAN, 2013) pais que participam da gestação com a gestante tem níveis de testosterona mais 
baixos e níveis de estradiol mais altos, o que significa que seus corpos estão se preparando para a criação dos filhos.

Segundo Bustamante,

Ao revisar pesquisas que têm por foco a experiência dos homens em relação à paternidade, percebeu que há diferenças de percepção em função do país, da classe social e da idade dos pais. Segundo a autora, a paternidade é uma experiência que se constrói em vários níveis, nos quais os aspectos socioculturais estariam associados a ser provedor de recursos, respeito e autoridade e os aspectos estariam ligados ao relacionamento com a mãe das crianças. (ARPINI e CÚNICO, 2013, apud BUSTAMANTE, 2005, p. 33).

O envolvimento frequente e positivo de pais desde a primeira infância com seus filhos está ligado ao bem-estar e ao desenvolvimento físico, cognitivo e social da criança (CABRERA et al.; KELLEY et al.; SHANNON; TAMIS-LEMONDA; LONDON; CABRERA apud PAPALIA; FELDMAN, 2013). Segundo Papalia e Feldman (2013, p. 219) "Os pais tendem a pensar que bebês do sexo masculino e do sexo feminino são mais diferentes do que realmente são.". Ainda segundo as autoras os pais começam desde muito cedo a influenciar a personalidade de meninos e meninas (PAPALIA; FELDMAN, 2013). O pai, principalmente, promove a tipificação de gênero, processo em que a criança aprende qual papel esperado socialmente que ela reproduza baseado no seu sexo (BRONSTEIN, 1988 apud PAPALIA; FELDMAN, 2013).

Estas informações são muito importantes para se pensar no papel do homem - do pai - como parte determinante no desenvolvimento e estruturação das bases da personalidade das crianças na primeira infância. Entretanto essa discussão tem vindo a tona somente nos últimas décadas do século passado com o advento dos estudos feministas.

Segundo Costa (apud BENCZICK, 2011), a paternidade já foi definida pela figura de um pai antigo, o qual era proprietário de bens, escravos e filhos, disposto a exigir suas vantagens e seus direitos e a resguardar seu nome e sua honra. Gomes e Resende (apud BENCZICK, 2011), discorrem que o homem deparava-se com vicissitudes para diferenciar sua individualidade das funções de pai, dessa forma, ainda segundo os autores o pai

manteve-se protegido no silêncio, comprometedor de toda possibilidade de diálogo com a família, especialmente com os filhos. Foi sempre apoiado pela cultura que, sendo patriarcal reservou-lhe o lugar acima da trama doméstica constituída, sobretudo sobre pela mulher e pela criança. (GOMES; RESENDE apud BENCZICK, 2011, p. 68)

$\mathrm{O}$ afastamento entre o homem e os demais integrantes do seio familiar denúncia-se na tenuidade do laço estabelecido entre pai e filho, principalmente quando se trata de crianças do sexo masculino (BENCZICK, 2011). 
De acordo com Baumrind (1991) e Parke e Buriel (2006) (apud BENCZICK, 2011), as famílias desempenham importante papel como primeiro contexto de socialização no desenvolvimento do comportamento e no crescimento da criança. Baumrind propõe a existência de três estilos parentais: autoritário, autorizante e permissivo (BAUMRIND, 1967, 1971; DARLING e STEINBERG, 1993; PARKE e BURIEL, 2006 apud BENCZICK, 2011).

Nos estudos da autora, ela define o estilo autoritário como sendo aquele que apresenta valores baixos de afetividade e altos níveis de controle e restritividade. Os pais que se encaixam nessa categoria, ainda de acordo com a pesquisadora, exercem um domínio psicológico rígido, desencorajando a independência e a individualidade da criança e as trocas verbais entre eles. Estes pais ainda tendem a controlar e avaliar o comportamento e atitudes de suas crianças de modo que mantenham um padrão absoluto e tentam inspirar a criança valores tradicionais como obediência à autoridade (BAUMRIND, 1966, 1967, 1971 apud BENCZICK, 2011).

Este estilo parental limita 0 desenvolvimento independente de uma criança, isso acontece porque seus padrões de comportamento são apenas reflexos de um espelho criado por seus pais. Através de punições e regras severas, filhos de pais autoritários são educados através do medo tendo altas chances de desenvolver um apego inseguro, logo, isto dificulta com que estes confiem e criem laços com outras pessoas inclusive seus próprios filhos. Este comportamento gera um ciclo transferencial que só pode ser rompido pela boa vontade e maturidade psíquica.

No estilo autorizante, os pais mantêm uma relação de imposição firme, afetuosa, carinhosa e sempre atentos às necessidades da criança. Incentivam diálogos e promovem trocas abertas entre si e seus filhos e promovem a autonomia e a individualidade. Esses pais compartilham das decisões tomadas, pois percebem que seus filhos têm direitos e deveres, utilizam da razão para se orientar na tomada de decisões e têm uma atitude de confronto face aos problemas, mas sem exagerar nas punições (BENCZICK, 2011).

Por fim o estilo permissivo tem um comportamento tolerante e de aceitação diante aos desejos, impulsos e ações da criança, tentando sempre evitar situações de confronto e controle com seus filhos. São pais que exercem poucas punições, delegando aos seus filhos o completo controle sobre seus comportamentos e decisões, exigem também poucas regras de rotina (BAUMRIND, 1967 apud BENCZICK, 2011). "Tanto os pais com um estilo permissivo como os pais com um estilo autoritário fazem, segundo Baumrind, poucas exigências de maturidade e comunicam de modo ineficaz" (BAUMRIND, 1967 apud BENCZICK, 2011, p. 394).

O estilo parental permissivo é tão prejudicial para a identidade de gênero da criança quanto 0 estilo autoritário. Conforme a teoria de 
aprendizagem social discutida no capítulo dois desta pesquisa, os pais têm papel de grande importância para a delimitação dos papéis sexuais de seus filhos. As crianças filhos e filhas de pais do tipo permissivo negligente (principalmente) não podem contar com a regulação dos pais quanto a seus comportamentos, logo, a construção de suas identidades de gênero seria influenciadas exclusivamente pelo social. Isto novamente poderia ser um problema, se, essa influência for associada a um apego inseguro o qual está geralmente acompanha o estilo parental permissivo.

A liberdade e a segurança que um apego bem construído pela criança dão, quando complementadas por um estilo parental autoritativo, possibilitam que a construção de seus quadros sinópticos possa ser bem mais tranquila e saudável. o apoio oferecidos pelos pais que criaram uma base segura com seus filhos faz com que essa criança possa ter confiança em si mesma para desenvolver-se independente de uma sociedade e cultura préestabelecidas. Isto é importante para que comportamentos cristalizados pelas eras, todavia que não condizem mais com a atual realidade possam ser mudados e reestruturados.

\section{METODOLOGIA}

Esta pesquisa é descritiva (COZBY, 2003; SPATA, 2005), utilizase de abordagem qualitativa para análise de dados e se justifica uma vez que, se identificados padrões rígidos de gênero na infância, propostas educativas poderão ser adotadas, visando prevenir a discriminação em relação aos padrões sexuais estabelecidos socialmente, isto é aos estereótipos sexuais.

A pesquisa foi realizada na cidade de Franca-SP em duas escolas, uma pertencente a rede municipal e outra a rede particular de ensino.

Participaram da pesquisa mães biológicas alfabetizadas cujas crianças de idade entre 4 e 6 anos estão frequentando as mesmas escolas infantis que aceitaram participar da pesquisa como mediadoras. A população esperada era de 50 mães, no entanto, apenas 14 destas mães aderiram a pesquisa, sendo 8 mães de filhos que frequentam escola pública e 6 mães com filhos matriculado em escolas particulares.

Das 14 mães participantes $71,43 \%$ são casadas e $28,57 \%$ são solteiras, não há mães viúvas. A idade média da amostra de mães é de 34,7 anos sendo que a mais velha tem 41 anos e a mais nova 25 anos. Mães que completaram o ensino superior compõem $57,14 \%$ (8) da amostra, $21,43 \%$ (3) não completaram o ensino superior, 7,14\% (1) possui ensino médio completo, $7,14 \%$ (1) possui ensino médio incompleto e $7,14 \%$ (1) não respondeu a essa questão.

A média das idades das crianças é de 5,28 anos, sendo que 0 mais novo possui 4 anos e o mais velho 6 anos. 
O material utilizado para a coleta de dados foi um questionário baseado no encontrado no estudo de Reis (2008), o qual foi adaptado ao contexto atual e acrescido de uma pergunta necessária ao desenvolvimento do estudo (Apêndice $A$ ). Este questionário é composto por 12 questões abertas e busca investigar: a) identidade e formação de gênero; b) estereótipos sexuais; c) atitudes e posturas das mães frente à educação sexual dos filhos e d)definições de gênero, estereótipos de gênero e papéis sexuais. Para cada temática de investigação há uma sequência de perguntas visando englobar 0 maior número de respostas sobre o assunto. As questões 1, 2, 3 e 4 fazem referência às características do gênero; já as questões 5, 6 e 9 levantam as características da educação concedida a meninos e meninas, as questões 7, 8, 10 e 11 referem-se a brinquedos e brincadeiras de meninos e meninas e finalmente a questão 12 refere aos conteúdos prévios da mãe sobre conceitos como gênero, estereótipos de gênero e papéis sexuais . Nas questões abertas 10 a) e 11 a), apresentou-se uma prancha contendo fotos de brinquedos variados, totalizando 20 tipos, tidos como brinquedos tipicamente femininos e masculinos, elaborada pela pesquisadora e adaptado pelo autor do trabalho para que adeque ao contexto atual.

Após o projeto ter sido aprovado pelo comitê de Ética do Centro Universitário Municipal de Franca Uni-Facef, foram retomados os contatos com as escolas antes feitos para solicitação da pesquisa. Posteriormente ao agendamento das escolas, foram apresentados pelo pesquisador o termo de consentimentos livre e esclarecido (presente no Apêndice B) e o questionário (Apêndice A) à coordenadora ou psicóloga da instituição, as quais serviram de mediadoras entre as mães e o pesquisador. O questionário e o termo de livre esclarecimento foram entregue pelas crianças às mães. Aquelas que se interessaram e concordarem em participar do estudo tiveram uma semana para responder e entregar o questionário respondido à escola e que depois foi recolhido pelo pesquisador. Esse método de coleta foi escolhido por demanda das escolas e pela alta taxa de evasão dos pais na reunião bimestral. A realização da coleta de dados foi feitas nas escolas de educação infantil e ocorreu em 3 etapas:

a) Contato e agendamento com escola para a entrega dos questionários e termos de livre esclarecimento em branco;

b) Entrega do questionário às mães pela escola através das crianças para que pudesse ser respondido;

c) coleta dos questionários respondidos e dos termos assinados pelas mães umas semana depois.

O questionário foi cotado, as questões abertas foram transcritas na íntegra, sendo assim será utilizada a abordagem qualitativa, tendo para análise especialmente a de conteúdo proposta por Bardin (1977) adotada por (FRANCO, 2005; MINAYO, 2007). 
A pesquisa passou pelo Comitê de Ética em Pesquisa do Centro Universitário de Franca - Uni-Facef. Todos os cuidados éticos foram respeitados para preservar a identidade dos participantes. Ressalta-se que as mães das crianças na faixa etária entre 4 e 6 anos da escola receberam todas as informações referentes ao projeto: os objetivos e a atividade que foi realizada, procedimento, duração, ausência de ônus para a participação, possibilidade de desistência em qualquer momento e a garantia do sigilo das informações fornecidas, em caso de divulgação científica dos dados analisados. Depois de elucidadas todas as dúvidas, com o aceite, as mesmas assinaram um Termo de Consentimento Informado, autorizando a própria participação na pesquisa.

Como riscos, a pesquisa pode suscitar incômodos internos às participantes por se tratarem de questões pessoais a respeito da criação e educação de seus filhos e para tanto estes foram esclarecidos no Termo de Consentimento Informado.

\section{RESULTADO E DISCUSSÃO}

A análise das respostas dadas pelas mães nos questionário respondidos foram analisadas de acordo com a separação proposta pelo instrumento sobre as temáticas abordadas pelas questões, assim sendo a) identidade e formação de gênero (questões 1, 2, 3 e 4); b) estereótipos sexuais (questões 5, 6, 7 e 8); c) atitudes e posturas das mães frente à educação sexual dos filhos (questões 9, 10 e 11) d) definições de gênero, estereótipos de gênero e papéis sexuais (questão 12).

Na primeira categoria temática (questões 1, 2, 3 e 4) foi analisada a identidade e formação de gênero nas crianças. Perceberam-se a partir dessa categoria alguns aspectos importantes ligados a essa temática e que serão expostos a seguir.

A análise do primeiro desses aspectos demonstra que as características físicas e morais/valorativas foram as mais relacionadas ao feminino ou próprias da mulher (ambas com 6 menções) seguidas por características comportamentais (5 menções), estéticas/adereços (3 menções) e enfim, não sei (1 menção). Esses dados dão base para a necessidade da criação do termo "gênero", discutida no capítulo 1 , pois como proposto por Scott (1995), o objetivo inicial da criação do termo gender foi excluir a ideia de diferenças biológicas intrínsecas aos gêneros masculino e feminino encoberta no uso de palavras como sexo e diferença sexual, sendo que as pensadoras do termo desejavam acentuar através da linguagem que a ideia de diferenças baseadas no sexo são majoritariamente parte de uma construção social.

Ao se tratar do masculino, as respostas das mães giraram em torno principalmente em torno de características físicas (7 respostas), 
morais/valorativas (6 respostas) e "não sei" (3 respostas), seguidas por características comportamentais (1 resposta) e estéticas (nenhuma resposta). Esses dados vão de encontro com a literatura sobre os estereótipos do masculino na sociedade.

Shaffer e Kipp (2012) separam os papéis sexuais em duas categorias, papel instrumental e papel expressivo. O primeiro é atribuído aos homens que segundo os autores Ihes é esperado que sejam dominantes, independentes, determinados, competitivos e orientados por objetivos. Exceto pela característica dominante, as respostas coletadas das mães representam fidedignamente o proposto pela literatura, p. ex. "Enfrentam melhor as escolhas entre vida pessoal e profissional. São mais independentes e baseiam suas decisões quase sempre em si mesmos". - 1PA ou "Racionalidade, decisão, materialidade". - 6PA.

Pensando sobre as vantagens de ser homem ou mulher na sociedade pode-se perceber que o número de candidatas que responderam que existe uma diferença (individuais e sociais) é superior ao que acreditam que não existam vantagens ou que não quiseram responder a pergunta. $O$ número de candidatas que acreditam que as existam vantagens individuais é o mesmo que o que acreditam que existam vantagens sociais (6 candidatas), sendo seguido pelo de mães que não acreditam que haja vantagens em ser homem ou mulher ( 3 candidatas) e pelas que não responderam ( 1 candidata).

As respostas das participantes da pesquisa que acreditam em vantagens individuais giram em torno de características dos corpos masculino e feminino e de valores sociais atribuídos a cada um dos gêneros, p. ex. "Na minha opinião, a grande vantagem de ser homem é poder fazer xixi em pé". 2PA; "Mulher - poder engravidar e amamentar" [...] - 5PA; O homem é considerado valente, protetor. - 4PA e Vantagens de ser homem: andar sem camiseta. - 3PA. É interessante ressaltar que a predominância dos discursos individuais ocorreu nas repostas de mãe de filhos de escola particular com 5 das 6 mães defendendo vantagens individuais em seus discursos comparado a 1 de 8 mães de escola pública. Nesta última a prevalência foi de discursos voltados para vantagens sociais, os quais estavam presentes em 4 de 8 respostas.

Já a respeito das vantagens sociais a prevalência foi sobre a desigualdade salarial das mulheres em relação aos homens e a escolha de homens para ocuparem cargos de chefia. P. ex. [...] "Homem - preferência em postos de chefia e pretensões salariais". - 5PA; [...] "Porém para o homem os salários e oportunidades de emprego são melhores ainda em muitos estados". 1PU; "As mulheres tem mais preferencia em varios lugar e o Homem ganha mais do que a mulher no mercado de trabalho (injusto)". -8PU

Quanto às mães que responderam que não havia vantagens em ser homem ou mulher totalizam 3 e são divididas em 2 mães de alunos da rede 
pública e 1 da rede particular. P. ex. "Acredito que hoje não existe vantagem. São iguais". - 6PA; "Somos todos iguais; com a mesma capacidade". -4PU; "Não vejo vantagem nenhuma simplesmente temos que fazermos nosso papel de mulher honesta e guerreira e nunca desistir dos nossos sonhos". -5PU.

Sobre as desvantagens de ser homem ou mulher na sociedade, dois fatos chamaram a atenção. O primeiro diz respeito ao aumento de respostas, em relação a existência ou não de vantagens atribuídas a um dos sexos, dadas pelas mães em relação a não existência de desvantagens em ser homem ou mulher. A população na qual essa categoria de resposta está concentrada agora é dividida entre as mãe de escola pública e as de escolas particulares, sendo que ambas apresentam 2 respostas cada.

Outro fato que chama a atenção é a diferença entre a quantidade de desvantagens de ser homem para as de ser mulher apontadas pelas participantes. Enquanto a categoria masculina é preenchida por três menções, a categoria feminina é composta por 8 respostas correspondendo a aproximadamente $57,2 \%$ das respostas obtidas na pesquisa. Através deste dado, seria possível traçar um paralelo com a questão anterior na qual as vantagens de ser homem foram mencionadas 9 vezes sendo que a única mãe a não apresentar uma vantagem de ser um homem na pergunta 3 e depois uma desvantagem de ser mulher na pergunta 4 foi a mãe 2PA que na pergunta anterior respondeu Na minha opinião, a grande vantagem de ser homem é poder fazer xixi em pé. - 2PA e na 4 Não vejo desvantagens segregadas. $2 P A$.

$\mathrm{Na}$ segunda categoria temática, foram analisadas as questões 5 , 6,7 e 8 e relacionam-se com os estereótipos sexuais presentes nos discursos das mães que participaram da pesquisa. Sobre isso foi constatado que:

A maior parte das mães (8) acredita que não existam diferenças na criação de seus filhos e nem a necessidade de que a mesma ocorra. A população que compõe esse grupo está igualmente dividida entre mães de escola pública e mães de escola particular (4 mães em cada). Em seguida, a segunda maior coluna é composta por mães que acreditam que a educação de seus filhos deve ser diferente devido ao fator gênero, essas compõem 4 respostas e está dividida em 1 mãe de escola particular e 3 mães de escola pública. Por fim, duas mães não souberam responder a questão, sendo uma de escola particular e outra de escola pública.

$\mathrm{Na}$ visão das mãe que disseram que tinham mais dificuldades ou mais facilidades para educar um dos gêneros se comparado ao outro mães fica muito clara a formações de padrões comportamentais esperados aos sexos. Para Papalia e Feldman (2013, p.284), papéis sexuais "são os comportamentos, interesses, atitudes, habilidades e traços de personalidade que uma cultura considera apropriada para homens e mulheres". Quando essas mães dizem que é esperado de seus filhos, principalmente de suas 
filhas, ajam de uma determinada maneira predisposta socialmente, elas estão falando destes papéis sexuais.

Quanto à existência ou não de atividade proibidas para meninos ou meninas é importante ressaltar a quase absoluta resposta negativa. 12 de 14 mães responderam de forma negativa enquanto duas não quiseram ou puderam expor sua opinião por algum motivo. Esse número demonstra uma diferença dos resultados apresentados por Reis (2008), no qual, apesar de também haver um maior número de mães que não acreditavam na existência de brincadeiras proibidas a um dos gêneros, a discrepância entre os grupos foram de 6 mães (15 responderam que não e 9 responderam que sim).

As respostas mães se concentraram em torno de temáticas específicas tais como a independência de seus filhos quanto às brincadeiras que gostam, a separação social entre brincadeiras de meninos e meninas, funções características dos papéis de gênero masculino e feminino e a diferenciação dos termos gênero e sexo. Todos esses temas foram abordados pelas mãe na questão 6 e além dessas, houve também aquelas que mães que diferenciam sexo e gênero, mães que omitiram sua opinião e mães que demonstraram uma posição relativa perante a questão.

Através da questão 7 podemos traçar um linha de quais os tipos favoritos de brinquedos dos filhos da mães participantes e se os mesmo apresentam alguma tipologia sexual. $\mathrm{O}$ grupo de brincadeiras tipicamente femininas possui 3 mães presentes $(18,75 \%)$, o grupo de brincadeiras tipicamente masculinas não possuí nenhuma das respostas das mães, a categoria neutra é a que possui o maior número de participantes, sendo 11 mães $(68,75 \%)$ e a categoria não sei possui apenas uma mãe $(6,25 \%)$.

A primeira informação relevante a ser analisada sobre essa questão seria a grande quantidade de brincadeiras neutras que foram descritas pelas mães como sendo as favoritas de seus filhos. Foram alocadas na categoria neutra brincadeiras que não possuem relação direta com a excussão de papéis sexuais de nenhum dos sexos (ex: bonecas, casinha, carrinho, arminha, etc). Não houve discriminação entre as mães de escola pública e particular, das mães cujas respostas foram anexadas a essa categoria, 6 tem filhos em escolas particulares e 5 em escolas públicas. As brincadeiras mais citadas pelas mães foram "correr" respondido pela mãe 1PU e 2PU e "andar de bicicleta" respondido pelas mães 5PU e 6PU.

Quando questionado às mães se na opinião delas haveria brinquedos próprios para meninos e meninas e o porquê, a maioria das mães respondeu negativamente à pergunta mostrando avanço em relação à literatura já discutida na questão anterior, em que, a temática envolvendo papéis sexuais e a identidade de gênero eram discutidas somente pela elite que possuía acesso aos debates que estavam sendo realizados na europa (CARVALHO, 1993). 
O discurso presente nas respostas das mãe que foram contrárias a afirmação da pergunta, é semelhante, ressaltando a independência de escolha dos filhos e a não relação entre o tipo de brinquedo e o sexo e identidade de gênero da criança. Duas respostas deste grupo chamam atenção por seu conteúdo. São elas a da mãe 3PA "Não proibo nenhuma brincadeira ou brinquedo para meus filhos, mas nunca comprei boneca para eles" e da mãe 1PU "Não há brinquedos próprios mas há preferências e tudo depende do ambiente em que a criança vive".

Ambos discursos ressaltam a importância do ambiente para a criação de possibilidades de escolha para a criança. Mesmo que num primeiro momento a família seja o ambiente principal para a geração de estímulos para essa criança, com o passar do tempo os microambientes passam a caminhar rumo aos macros como a escola e por fim a sociedade (PEREIRA-SILVA; DESSEN, 2003).

A partir da questão 9 inicia-se a terceira categoria de análise das respostas chamada atitudes e posturas das mães frente à educação sexual dos filhos. Essa categoria corresponde às questões 9,10 e 11 e tem como objetivo analisar o comportamento das mães frente à educação sexual dos filhos.

A questão 9 se preocupou em averiguar a contribuição das mães para que seus filhos(as) pudessem se tornar homens e mulheres. $O$ importante a ser considerada na análise destes dados é a quase totalidade $(92,85 \%)$ de respostas afirmativas quanto à contribuição ou não para que os filhos(as) pudessem se tornar homens ou mulheres. Isso demonstra que essas mães acreditam ter papel ativo na criação de seus filhos, seja esse papel negativo ou positivo em relação a independência da criança. A única mãe que não aderiu a esse grupo foi a mãe 3PU que respondeu não sei a questão e que para tanto consideramos que ela não entende qual seu papel na criação e educação de seus filhos no que diz respeito a educação sexual e de gênero

Nas questões de número 10 e 11 foi perguntado às participantes qual presente elas dariam para um menino e uma menina (respectivamente às questões) da idade de seus/suas filhos(as). Para meninos, as mães participantes em sua maioria $(57,14 \%)$ se enquadravam na categoria de brinquedos neutra, suas respostas estão baseadas nos gostos da crianças, ao que a faixa etária gosta, brincadeiras que estimulem o desenvolvimento cognitivo e físico dessas crianças e por fim em brinquedos que seus filhos gostam.

No entanto, é importante ressaltar ainda sobre esse grupo que, mesmo justificando suas respostas com argumentos neutros, essas mães também evitaram escolher qualquer brinquedo que seja atribuído socialmente ao gênero feminino p. ex. bonecas, maquiagem. Contudo, não é possível afirmar se essa restrição nas escolhas é baseada no preconceito ou se é simplesmente resultado dele, isto é, através da aprendizagem observacional, 
os gosto dos filhos simplesmente repetem os papéis sexuais que veem e que são atribuídos a eles (BANDURA, 1989; BUSSEY; BANDURA, 1992, 1999).

Já no que diz respeito aos brinquedos escolhidos para as meninas, metade das mães participantes optou por bonecas ou brincadeiras que fazem relação ao serviço doméstico. Essas mães escolheram objetos que remetem ao comportamento estereotipado de feminino, isto é, segundo elas é de comum acordo que meninas cuidem da casa e de seus filhos, logo, é importante que as mesmas possam "treinar" tais comportamentos. Esse pensamento é correspondente ao presente na literatura em referir-se à expectativa de que mulheres sejam cooperativas, doces, maternais e sensíveis às necessidades dos outros (SHAFFER; KIPP, 2012). É esperado que mulheres cuidem da casa e gerem filhos, pois essa seria a razão de sua existência (SELL, 2012).

Por fim na última categoria temática composta pela análise da questão 12 que tinha como objetivo as definições de gênero, estereótipos de gênero e papéis sexuais que as mães possuíam.

De maneira geral, nos três termos a maior parte das mães não responderam apropriadamente à questão sendo a maior evasão de mãe da escola pública (2PU, 3PU, 4PU, 5PU e 6PU) em comparação às da rede particular (2PA e PA). É também importante destacar que dentre as três categorias a explicação de gênero foi a que apresentou mais erros (5) quando em relação às demais (ambas com 1). Já no diz respeito aos acertos, a definição de papéis sexuais lidera o ranking com 5 respostas certas, seguido por estereótipos de gênero com 4 e por último gênero com 3.

As respostas foram consideradas corretas quando iam de encontro com o exposto por Scott (1995) que afirma que o termo gênero foi criado para diferenciar as características adquiridas culturalmente as congênitas ligadas ao sexo. Esse termo, ainda segundo a autora, engloba as dimensões do masculino e do feminino enquanto o sexo engloba as definições de homem e mulher. Por fim, outro uso deste termo é delimitar as relações sociais entre os sexos, baseando-se inteiramente no social e nos ideais sobre os papéis adequados aos homens e às mulheres (SCOTT, 1995).

Já as respostas erradas foram consideradas assim, no maior número das vezes porque as mães confundiram os termos gênero e sexo. Essa confusão pode ser vista nas respostas das mães 3PA "Gênero é o sexo da pessoa [...]" e da mãe 7PU "Gênero = o qual nascemos. [...]". Nestes dois casos podemos perceber que o gênero que seria uma categoria fluida que é uma construção social ao longo da vida de uma pessoa, foi igualada ao sexo, que seria uma categoria na maior parte das vezes estável no indivíduo, isto é, é estabelecido pela presença do aparelho sexual/reprodutor. 
No que diz respeito ao termo papéis sexuais, as mães mostraramse mais confortáveis com seu uso o resultou no maior escore de respostas corretas dentre os três termos totalizando 5 respostas corretas. Neste grupo 0 critério avaliativo foi o enunciado por Papalia e Feldman (2013, p.284), "são os comportamentos, interesses, atitudes, habilidades e traços de personalidade que uma cultura considera apropriada para homens e mulheres".

O grupo de mães que responderam errado essa questão é composto pela mãe 3PA que respondeu '[...] Papéis sexuais - cada sexo tem seu papel na procriação [...]". Por essa respostas podemos pensar que talvez ela tenha confundido papéis sexuais com as funções reprodutivas se atendo totalmente ao funcionamento biológico e ignorando as funções esperadas dos sexos no contexto social.

O último termo da pergunta número 12 foi o de estereótipos de gênero. Essa categoria teve 4 respostas consideradas certas (1PA, 4PA, 5PA e $1 \mathrm{PU}$ ) e uma considerada parcialmente errada (7PU). O critério para a avaliação foi o enunciado pelos dicionários Cambridge Learner's Dictionary (2004) e Sacconi (2010, p. 865), os quais definem respectivamente estereótipo como uma ideia fixa que pessoas tem sobre com o que um determinado tipo de pessoa se parece (tradução nossa), e como "modelo estabelecido e aceito de comportamento, expressão ou outra manifestação; concepção, opinião, ideia ou imagem padronizada de forma convencional como verdadeira".

O que chama atenção nessas respostas relacionadas a esse termo é que mais da metade das participantes (8 mães) nem chegaram a responder a essa questão e das 14 participantes apenas 4 delas responderam corretamente, sendo apenas uma com filhos na escola pública. Estes dados coletados mostram como a difusão do conhecimento em relação ao gênero ainda está concentrada na elite, isto é, não é de fácil acesso ao coletivo. Isso está em acordo com o representado por Carvalho et al. (1993), a qual demonstra que a luta pela igualdade dos gêneros era restrita à elite cultural que detinha o monopólio do saber.

\section{CONSIDERAÇÕES FINAIS}

Então chegamos ao final dessa pesquisa e cabem aqui algumas considerações sobre o apresentado ao longo de mais de 90 páginas. O objetivo geral desta pesquisa era investigar a construção do discurso, a partir do relato de mães de crianças de 4 a 6 anos em relação aos estereótipos de gênero na primeira infância.

Esse objetivo foi concluído de forma honrosa, afinal através das respostas dadas pelas mães às 12 perguntas apresentadas a elas em formato de questionário, foi possível analisar suas falas e discursos, assim como, as ideias presentes neles. Foi possível também analisar, mesmo que brevemente, 
as raízes dos argumentos usados por essas mulheres para articularem suas falas.

Quanto aos objetivos específicos, foram traçados três deles ainda no projeto de pesquisa enviado à comissão avaliadora de pesquisa do Centro Universitário Municipal de Franca - Uni-Facef, são eles: Investigar a concepção sobre gênero de mães de crianças da primeira infância; entender sobre a criação de estereótipos por mães pelo seu relato sobre a educação de crianças, quando se trata de questões de gênero; explorar a percepção da mãe e o quanto pode impactar desenvolvimento de gênero das crianças.

Ao se tratar dos objetivos específicos, estes também foram concluídos e se encontram difundidos ao longo da pesquisa. Porém, é possível fazer uma pequena delimitação quanto a temática trabalhada no grupo de questões separados segundo proposto na metodologia deste trabalho. A investigação da concepção sobre gênero pelas mães pode ser encontrada com maior ênfase nas questões 1, 2, 3, 4 e 12. O entendimento sobre a criação de estereótipos pelas mães através do relato da educação dos filhos foi o tema das questões 5, 6 e 9 e por fim, a exploração da percepção das mães e seus impactos podem ser vistos na análise das questões 7, 8, 10 e 11.

As mães que participaram da pesquisa se mostraram em sua maioria inseridas nas discussões de gênero e sexualidade dos filhos, no entanto a própria voluntariedade da participação funcionou como um critério de exclusão, um filtro, para mães que não abordavam tão bem esse assunto. Isso fica claro, assim como também a permanência do tabu sobre a sexualidade e identidade de gênero infantis, através da comparação entre o número de questionários entregues e os que voltaram respondidos das escolas. Na escola pública foram entregues 20 questionários e voltaram 8 respondidos. Na escola particular foram entregues 40 questionários, dos quais somente 7 voltaram respondidos ( 1 desses questionários foi respondido pelo pai da criança, por isso foi descartado por não fazer parte do critério de exclusão da pesquisa).

Outro fato interessante a ser analisado é o questionário enviado a escola particular que voltou com a frase "não irei responder a esse questionário" escrita na primeira página. Essa necessidade de afirmar a não participação, nos faz pensar na relação desse comportamento dessa mãe com sua vontade de se manter o mais distante possível da temática, como se precisasse afirmar que não faria parte da polêmica que falar sobre gênero na infância geraria.

Dessa forma, apesar das participantes que tinham filhos ou filhas em escolas particulares se mostrarem bem esclarecidas na maioria das perguntas feitas às ela, o ambiente particular ainda é inundado pelo preconceito e pelos estereótipos sexuais. Por outro lado, as mães da rede pública que participaram da pesquisas superaram as expectativas direcionadas a elas antes da coleta de dado. 
Essas mães não só mostraram-se mais adeptas à pesquisa, como também seu discurso se aproxima muito das mães das escolas particulares que também participaram da pesquisa (salvo algumas exceções). Talvez essas diferença entre elas seja devido ao contexto protetivo que as mães de escola particular vivem em contraste ao contexto de risco em que vivem as mães de escola pública.

Muitos dos estereótipos sexuais ligados ao feminino estão relacionados à permanência das mulheres no serviço doméstico. Contudo, para muitas das participantes das escolas públicas, esse cenário não existe como uma realidade possível pois precisam gerar renda para manter suas famílias, das quais muitas são sua única mantenedora. Essa saída ao mercado de trabalho quebra o estereótipo pela vivência de algo diferente, no entanto, não é sempre que isso acontece podendo também essas mãe transferem a escolha que não tiveram para seus filhos, levando junto os estereótipos sofreu e agora os replica.

Ficou claro durante a análise da questão 9 que falava sobre a educação sexual dos filhos, que as mãe não conseguem sozinhas desempenhar o papel que Ihes foi atribuído pela sociedade. Os pais de maneira geral detém o dever do ensino sexual dos seus filhos, umas vez que, este foi tirado das incunbências das escolas por questões morais - que aparentemente são importante para a sociedade.

No entanto, isso de fato não acontece, ou acontece de forma insuficiente na maior parte das vezes. Esse dado precisa mudar o mais rápido possível. A rede mundial de computadores está aí para apresentar uma enxurrada de informações tanto benéficas como maléficas para 0 desenvolvimento das crianças, por isso é importante que estes tenham uma base segura de conhecimentos a respeito do seu corpo e sua identidade perante a sociedade.

A questão moral e de valores próprios de cada cultura e família são importantes, isso é inegável. O ponto que queremos chegar aqui é que além desses aprendizados existem outros que deveriam ser de conhecimento geral e, por tanto, deveriam ser universalizados nas escolas como uma maneira de garantir a prevenção da saúde física e psicológica das crianças.

Essa é uma solução que começaria o processo de mudança nas futuras gerações, mas e a geração das mães que já estão aqui? Para elas, seria muito importante que se criassem grupos de auxílio, ou melhor, que houvesse maior divulgação de grupos que existem que trabalham a questão da sexualidade e do gênero na infância com mães. Isso é justificável, pois através disso cria-se uma rede de apoio que fortalece os laços dessas mães com seus filhos de uma maneira saudável e garante que os estereótipos não se perpetuem por mais gerações. 
Neste trabalho, houve alguns empecilhos, dentre eles, o número de participantes que aderiram à pesquisa. Como já argumentado antes, isso está relacionado à concepção social sobre a sexualidade e a identidade de gênero na infância que ainda são vistas como tabus. O número esperado de mães no início da pesquisa era de 50 mães ( 25 da rede pública e 25 da rede particular), porém, o número de participantes obtidos foi de 14 mães (6 da rede particular e 8 da rede pública).

Outro desafio que fez com que a metodologia mudasse da inicialmente proposta (entrevistas semi estruturadas e questionário) para a realizada na coleta de dados (questionário), foi a disposição das escolas em serem mediadoras entre o pesquisador e as mãe. As escolas, ao serem contatadas pelo pesquisador, disseram que quase não havia aderência dos pais nas reuniões bimestrais, nas quais o pesquisador iria aplicar os questionários e as entrevistas, além disso, o tempo era muito precioso para os pais então a escola deveria ser o mais sucinta possível nesses encontros. Esses argumentos fizeram com que o pesquisador junto a orientadora mudasse a metodologia para que $o$ instrumento passasse a ser algo que os pais pudessem responder em casa.

Essa mudança pode ter prejudicado de certo modo a análise não verbal do discursos das mães que participaram da pesquisa, afinal na escrita e sem a observação do pesquisador, seria fácil para elas proferirem discursos que pensavam ser o certo a ser respondido e não o que realmente pensam sobre o tema. Esse foi um dos aspectos negativos dessa pesquisa que podem ser explorados em estudos futuros.

A literatura específica também se mostrou um problema para essa pesquisa. Há bastante conteúdo sobre gênero, principalmente sobre o feminino, sobre o Outro da sociedade. No entanto, o conteúdo sobre o gênero na infância ainda é muito escasso e desatualizado, dessa forma, faz-se necessário um maior investimento em pesquisas sobre essa temática em especial em um cenário nacional, visto que, todas as teorias sobre a aquisição de papéis sexuais são produções internacionais e o país possui ricos pensadores do gênero e da infância.

Para futuras pesquisas sugerimos a análise das crianças através das suas produções individuais e subjetivas como desenhos e brincadeiras e também sobre a importância do contexto escolar e dos pares para a manutenção e afirmação do gênero e também da sexualidade. Esses assuntos possuem bastante material bibliográfico não específico nas teorias psicanalíticas, em especial na ludoterapia de Klein e Winnicott. 


\section{REFERÊNCIAS}

AUYEUNG, B et al. Fetal testosterone predicts sexually differentiated childhood behavior in Girls and in Boys. Psychological Science, 20(2), 2009, 144-148.

BANDURA, Albert. Social cognitive theory. In: VASTA, R. (Ed.). Annals of child development. 6. ed. Greenwich: Jai Press, 1989. p. 1-60.

BARDIN, Laurence. Análise de conteúdo. Lisboa: Edições 70, 1977.

BENCZIK, Edyleine Bellini Peroni. A importância da figura paterna para o desenvolvimento infantil. Rev. psicopedag., São Paulo, v. 28, n. 85, p. 6775, 2011. Disponível em $<$ http://pepsic.bvsalud.org/scielo.php?script=sci_arttext\&pid=S010384862011000100007\&lng=pt\&nrm=iso>. acessos em 11 fev. 2020.

BEE, Helen; BOYD, Denise. A criança em desenvolvimento. 12. ed. Porto Alegre: Artmed, 2011. 567 p. Tradução: Cristina Monteiro.

BRASIL. Ministério da Educação. Secretaria de Educação Fundamental. Referencial Curricular Nacional para a Educação Infantil. v. 2, p.17-20. Brasília, 1998.

BUSSEY, Kay; BANDURA, Albert. Self-Regulatory Mechanisms Governing Gender Development. Child Development, [s.I.], v. 63, n. 5, p.1236-1250, out. 1992. JSTOR. http://dx.doi.org/10.2307/1131530.

BUSSEY, Kay; BANDURA, Albert. Social cognitive theory of gender development and differentiation. Psychological Review, [s.I.], v. 106, n. 4, p.676-713, 1999. American Psychological Association (APA). http://dx.doi.org/10.1037/0033-295x.106.4.676.

BUSTAMANTE, Vânia. Ser pai no subúrbio ferroviário de salvador: um estudo de caso com homens de camadas populares. Psicologia em Estudo, Maringá, v. 10, n. 3, p. 393-402, dez./2005. Disponível em:

https://repositorio.ufba.br/ri/bitstream/ri/3530/1/Ser\%20pai\%20no\%20suburbio \%20ferroviario\%20de\%20Salvador. Acesso em: 1 jul. 2020.

CAHILL, Larry. His Brain, Her Brain. Scientific American, [s.I.], v. 21, n. 2, p.411, 23 out. 2012. Springer Nature.

http://dx.doi.org/10.1038/scientificamericanbrain0512-4.

CAMBRIDGE UNIVERSITY PRESS. Cambridge Learner's Dictionary. 1. ed. Cambridge: Cambridge University Press, 2004. p. 1-780.

CARVALHO, Ana et al . Brincadeiras de menino, brincadeiras de menina.

Psicol. cienc. prof., Brasília, v. 13, n. 1-4, p. 30-33, 1993 . Available from $<$ http://www.scielo.br/scielo.php?script=sci_arttext\&pid=S1414-

$98931993000100006 \& \operatorname{lng}=$ en\&nrm $=$ iso $>$. access

on 01 June 2020. https://doi.org/10.1590/S1414-98931993000100006. 
CONSTANTINO, J. N.; GROSZ, D.; SAENGER, P.; CHANDLER, D. W.; NANDI, R.; EARLS, F. J; Testosterone and aggression in children. Journal of the Academy of Child and Adolescent Psychiatry, 32, 1993. p. 1217-1222.

COZBY, P. C.. Métodos de pesquisa em ciências do comportamento. São Paulo: Atlas, 2003.

FRANCO, M. A. S. Pedagogia da Pesquisa-Ação. Educação e Pesquisa, São Paulo, v. 31, n. 3, p. 483-502, dez./2005. Disponível em: scielo.br/pdf/ep/v31n3/a11v31n3.pdf. Acesso em: 1 jul. 2020. FRANÇA, Cassandra Pereira. Nem sapo, nem princesa: terror e fascínio pelo feminino. Terror e fascínio pelo feminino. São Paulo: Blucher, 2017. 192 p.

FREUD, S. (1925). Algumas consequências psíquicas da distinção anatômica entre os sexos. In: FREUD, S. Edição standard brasileira das obras psicológicas completas de Sigmund Freud. v. 19. Rio de Janeiro: Imago, 1996, p. 273-286.

GOMES, Vanessa Fonseca; BOSA, Cleonice Alves. Representações mentais de apego e percepção de práticas parentais por jovens adultas. Psicol. Reflex. Crit., Porto Alegre, v. 23, n. 1, p. 11-18, Apr. 2010. Available from $<$ http://www.scielo.br/scielo.php?script=sci_arttext\&pid=S0102$79722010000100003 \& \operatorname{lng}=$ en\&nrm=iso $>$. access on 04 Feb. 2020. http://dx.doi.org/10.1590/S0102-79722010000100003.

LOURO, Guacira Lopes; Gênero, sexualidade e educação: uma perspectiva pós estruturalista. 16. ed. Petrópolis, RJ: Vozes, 2014. p. 11-198.

MARTIN, Carol Lynn; HALVERSON, Charles F.; JR.. A Schematic Processing Model of Sex Typing and Stereotyping in Children. Child Development, [s. L.], v. 52, n. 4, p.1119-1134, dez. 1981.

MARTIN, Carol Lynn; FABES, Richard A.. The stability and consequences of young children's same-sex peer interactions. Developmental Psychology, [s.I.], v. 37, n. 3, p.431-446, 2001. American Psychological Association (APA). http://dx.doi.org/10.1037//0012-1649.37.3.431.

MASTERS, John C. et al. Modeling and Labeling as Integrated Determinants of Children's Sex-Typed Imitative Behavior. Child Development, [s.I.], v. 50, n. 2, p.364-371, jun. 1979. JSTOR. http://dx.doi.org/10.2307/1129411.

MONTEIRO, Mayla Cosmo. Um coração para dois: a relação mãe-bebê cardiopata. 2004. 99 f. Dissertação (Mestrado) - Curso de Psicologia Clínica, Departamento de Psicologia, Pontifícia Universidade Católica do Rio de Janeiro - Puc-rio, Rio de Janeiro, 2003. Disponível em: <https://www.maxwell.vrac.pucrio.br/colecao.php?strSecao=resultado\&nrSeq=4350@1>. Acesso em: 04 nov. 2019. 
PAPALIA, Diane E.; FELDMAN, Ruth Duskin. Desenvolvimento humano. 12. ed. Porto Alegre: AMGH, 2013. Tradução : Carla Filomena Marques Pinto Vercesi... [et al.].

PEREIRA-SILVA, N. L.; DESSEN, M. A.. Crianças com Síndrome de Down e suas interações familiares. Psicologia: Reflexão e Crítica, 2003, 16 (3), 503514.

REIS, Kellen Cristina Florentino. Infância, Gênero e Estereótipos sexuais: análise do relato de mães de crianças de 4 a 6 anos. 2008. 119 f. Dissertação (Mestrado) - Curso de Psicologia do Desenvolvimento e Aprendizagem, Universidade Estadual Paulista Júlio Mesquita Filho, Bauru, 2008.

SACCONI, Luiz Antonio; Grande Dicionário Sacconi: da língua portuguesa: comentado, crítico e enciclopédico. 1. ed. São Paulo: Nova Geração, 2010. p. 26-2087.

SCOTT, J; “Gênero: uma categoria útil de análise histórica”. Educação e Realidade. Vol. 20 (2), jul/dez. 1995.

SELL, Mariléia. "Minha mãe ficou amarga": expectativas de performances de maternidade negociadas na fala-em-interação. Rev. Estud.

Fem., Florianópolis, v. 20, n. 1, p. 153-172, Apr. 2012. Available from $<$ http://www.scielo.br/scielo.php?script=sci_arttext\&pid=S0104026X2012000100009\&lng =en\&nrm=iso $>$. access on 15 Jan. 2020. http://dx.doi.org/10.1590/S0104-026X2012000100009.

SHAFFER, David R.; KIPP, Katherine. Psicologia do desenvolvimento: infância e adolescência. 8. ed. São Paulo: Cengage Learning, 2012. 879 p. Tradução de: Marta Reyes Gil Passos.

SIGOLO, S. R. R. L. (2004). Favorecendo o desenvolvimento infantil: ênfase nas trocas interativas no contexto familiar. In E. G. Mendes, M. A. Almeida \& L. C. A. Williams (Orgs.). Temas em Educação Especial: avanços recentes (pp.189-195). São Carlos: Edufscar.

SPATA, Andrea. Métodos de pesquisa: ciência do comportamento e diversidade humana. 1. ed. Rio de Janeiro: LTC, 2005. p. 1-247. 
AS PRÁTICAS EDUCATIVAS PARENTAIS COM CRIANÇAS EM FASE PRÉESCOLAR: análise no contexto da cibercultura

Lara Junqueira Gomes larajunqueirag@gmail.com

Sofia Muniz Alves Gracioli sofiagracioli@yahoo.com.br

\section{INTRODUÇÃO}

O desenvolvimento tecnológico está cada vez mais transformando os comportamentos e os relacionamentos, impacta no meio social e determina um contexto em que se origina uma cultura digital, na qual a tecnologia é alicerce da manutenção de relações sociais.

Estabelece-se um cenário em que as crianças já se desenvolvem, apropriando-se e internalizando essa realidade, tendo experiência cada vez mais precoce com dispositivos digitais e acessibilidade à internet.

Para crianças entre três e cinco anos, o desenvolvimento de habilidades sociais está vinculado às práticas educativas parentais para compreensão de regras, valores e limites (MATURANO; SILVA, 2002). Assim, é necessário dar atenção ao gerenciamento, orientação, monitoramento e educação dos pais em relação aos seus filhos no que condiz ao contexto tecnológico.

O presente estudo tem como objetivo principal compreender as práticas educativas parentais e como estas podem impactar seus filhos com idades entre três e cinco anos inseridos em uma cibercultura. A amostra do estudo é de 39 mães, de duas escolas, sendo uma instituição de ensino particular e outra pública de uma cidade do interior do Estado de São Paulo.

As práticas parentais dessas mães foram avaliadas pela escala PAFAS - Parenting Skills and Family Relationships, sendo que perspectiva de Baurimd (1966) sobre os tipos de controles parentais estabelecidos é considerado no panorama conceitual das práticas parentais no primeiro capítulo, tendo como desdobramento a aspectos teóricos referente a mediação parental, que considera a gestão estratégica dos pais no monitoramento da acessibilidade da criança aos dispositivos digitais.

Ao considerar a teoria e os dados analisados, os resultados permitem estabelecer uma relação entre as práticas parentais e seu consequente impacto na acessibilidade digital de seus filhos, sendo a mediação parental aspecto importante de ser considerado nesse cenário.

Com a realização dessa pesquisa, pretende-se levantar as contribuições literárias sobre o tema, além de ser espaço para compreensão e 
busca de alternativas nesse contexto recente e desafiador de educar em uma cultura digital.

\section{PRÁTICAS PARENTAIS}

A primeira experiência social vivida por uma criança se estabelece no núcleo familiar, sendo uma "fase de vida em que absorverá intensamente o que the oferecerem" (LISBOA, 1997, p. 3). Estes se tornam referência e a influência no processo de desenvolvimento, além de atuarem como fonte de afeto e modelo de aprendizagem para seus filhos (LUBI, 2003).

Nomeado por Bandura (1977, p. 9) de "teoria da aprendizagem social", o comportamento é aprendido por meio da observação de modelos comportamentais, sendo que, contextualizando no núcleo familiar, o comportamento dos pais torna mais provável a ocorrência do mesmo comportamento em seus filhos estabelecendo, como denomina Saldaña, Del Pratte e Del Pratte (2002, p. 277), "uma cadeia de transmissão de regras de estilo de comportamentos de pais para filhos".

No contexto de educar, os pais optam por utilizar determinadas estratégias, conduzindo o comportamento de seus filhos para que se tornem autônomos, de forma responsável, como também deixando de reforçar aqueles comportamentos considerados socialmente inadequados (ALVARENGA, 2001).

Essa relação ganhou destaque principalmente com os estudos realizados por Baumrind (1966, p. 887) referentes aos tipos de controles parentais estabelecidos, classificados em: autoritativo, autoritário e permissivo.

No caso do perfil autoritário, se "tenta moldar [...] e controlar o comportamento e atitudes da criança de acordo com um padrão estabelecido de conduta"; já o autoritativo, "reforça sua própria perspectiva como adulto, mas reconhece os interesses individuais da criança", direcionando atividades de maneira democrática, com negociação e incentivo ao diálogo; por fim, os permissivos, "tendem a se comportar de forma não punitiva e afirmativa em relação aos impulsos, desejos e ações da criança", sendo este subdividido posteriormente por Maccoby e Martin (1983) como negligentes ou indulgentes, permitindo distinguir uma variação no nível de responsividade em determinado núcleo familiar (ANTONI, 2003), além disso,

\footnotetext{
Defendem que o estilo parental influencia o comportamento das crianças e que os do tipo negligente e indulgente estão geralmente associados a problemas no desenvolvimento dos filhos; enquanto que pais autoritativos - com alto padrão de exigência e alta responsividade - geram crianças mais competentes emocional e socialmente (WEBER, 2006, p. 408).
}

Darling e Steinberg (2004) revisam e desdobram o conceito, designando a correlação entre estilo parental e o contexto, com práticas 
baseadas também em suas crenças e valores. Os autores esclarecem também as diferenças entre "estilo" e "prática" parental:

\begin{abstract}
As práticas são estratégias com 0 objetivo de suprimir comportamentos considerados inadequados ou de incentivar a ocorrência de comportamentos adequados. [...] Já os estilos parentais constituem o conjunto de atitudes dos pais [...] os quais incluem as práticas parentais e outros aspectos da interação pais-filhos que possuem um objetivo definido, tais como: tom de voz, linguagem corporal, descuido, mudança de humor (DARLING, STEINBERG, 2004, p.323).
\end{abstract}

Harkness e Super (1992, p. 373), corroboram tais ideias por meio das etnoteorias parentais, em que correspondem a "conjuntos organizados de ideias que estão implícitos nas atividades da vida diária e nos julgamentos, escolhas e decisões que os pais tomam, funcionando como modelos ou roteiros para ações".

As etnoteorias parentais, somadas ao ambiente físico e social e aos cuidados e a criação daquela criança, estabelecem um nicho de desenvolvimento que atua como mediador da inserção da criança no ambiente cultural ao longo de seu crescimento (MACARINI et al, 2010).

De modo geral, os trabalhos que enfocam as influências dos pais afirmam que suas condutas impactam no desenvolvimento daquela criança, principalmente no que condiz à constituição da personalidade desta.

Algumas pesquisas realizadas por Baumrind (1966) e outros autores, como Dorbnbusch (1987), destacaram que filhos de pais autoritários costumam estabelecer habilidades escolares inferiores como também apresentam dificuldades em se relacionar com as pessoas (MONTANDON, 2005).

Por outro lado, Brazelton destaca:

Quando há relacionamentos seguros, empáticos, sustentadores, as crianças aprendem a ser íntimas e empáticas e eventualmente a comunicar seus sentimentos, refletir sobre seus próprios desejos e desenvolver seus próprios relacionamentos com seus iguais e com os adultos (2002, p. 4).

Somado a esse conceito, Patterson, Reid e Dishion (2002) declaram que práticas parentais positivas podem evitar o surgimento ou permanência na dificuldade de interação entre pais e filhos, enquanto práticas negativas podem aumentar a ocorrência de conflitos familiares e, consequentemente, desencadear problemas internalizantes e externalizantes em seus filhos (MOSMANN; TRINDADE, 2016).

Conforme Gomide (2003, p. 21), pode-se concluir que "as práticas educativas [...] poderão tanto desenvolver comportamentos pró-sociais, como anti-sociais, dependendo da frequência e intensidade que o casal parental utilize determinadas estratégias educativas", atuando como fatores de risco ou 
de proteção no contexto de desenvolvimento de seus filhos (CECCONELLO et al, 2003).

Responsabilidade e papel importante da educação parental que, segundo Rauber e Scheibe (2014), atualmente se tem como cenário comum os pais não darem a devida importância a seu papel de referência e exemplo para suas crianças:

\begin{abstract}
As famílias estão cada vez mais despreocupadas com o que transmitem para as crianças, o que prejudica significativamente todo um processo de desenvolvimento infantil. A formação do "eu" é fortemente atingida por fatores externos diversos como: novelas impróprias, jogos violentos, acessos livres a internet e por demais recursos tecnológicos existentes. Os pais estão se esquecendo da importância de transmitir bons exemplos (2014, p. 2).
\end{abstract}

Desta forma, o temperamento da criança está relacionado a características das práticas educativas dos pais, em que fatores como a reciprocidade, sincronia e responsividade na relação estabelecida entre pais e filhos diz respeito à perspectiva transicional no desenvolvimento da criança (SAMEROFF, 2000).

Abordando alguns fatores epidemiológicos, Besnard et al (2009) desenvolveram estudo comparativo entre práticas parentais de mães e pais de crianças, levando em consideração a variável de problemas de comportamento, e chegaram à conclusão de que as mães se mostraram mais disponíveis para seus filhos, enquanto os pais de crianças com problemas de comportamento se envolviam menos, além de utilizar práticas mais hostis na educação da mesma.

Ao considerar aspectos socioeconômicos, Linhares (2015) enfatiza ser fator que inclui marcadores individuais condizentes a educação e a ocupação profissional relacionados à renda familiar, sendo que o nível socioeconômico impacta no desenvolvimento da criança e as competências parentais (MACANA; COMIN, 2015).

Foram desenvolvidos dois modelos para compreender esse contexto: o Modelo de Estresse Familiar, em que analisa a relação de dificuldades financeiras com as relações conjugais e relações entre pais e filhos e o Modelo de Investimento, em que enfatiza que recursos econômicos levam ao aumento de investimentos que pais fazem no desenvolvimento de seus filhos (CONGER, 2010).

A sensibilidade materna é considerada crucial para o desenvolvimento da autonomia, competência social e adaptação emocional, atuando juntamente com a formação da segurança de apego da criança (LEEKERS; CROCKENBERG, 2006).

Os achados da literatura majoritariamente destacam o vínculo entre as práticas parentais adotadas e o comportamento manifestado por seu 
filho ao longo do desenvolvimento. No contexto atual, também é importante agregar a tais práticas a mediação parental, levando em consideração os hábitos e condutas concernentes a precoce acessibilidade tecnológica, junto ao conteúdo e ao tempo de acesso instituídos nessa circunstância.

\section{MEDIAÇÃO PARENTAL}

A questão da educação e a influência dos pais no comportamento de seus filhos têm alta relevância em um contexto da conectividade e socialização virtual das crianças, já que se enquadra em um cenário de risco a crimes cibernéticos como cyberbullying, invasão de privacidade e pedofilia (LIVINGSTONE; HELSPER, 2008; YOUN, 2008).

Conforme Vygotsky (1998, p. 61), "[...] todo cultural é social. Justamente a cultura é um produto da vida social e da atividade social do ser humano, por isso a própria abordagem do problema do desenvolvimento cultural da conduta nos leva diretamente ao plano social do desenvolvimento".

No contexto social atual, está instaurada a cibercultura que pode ser estabelecida como um conjunto de técnicas de atitudes e valores que caminham paralelamente ao crescimento do mundo virtual. Ou seja, indivíduos inseridos nesse contexto integram essa cultura, que delineia aspectos mentais e práticos dessa sociedade (LÉVY, 1999; SANTAELLA, 2003).

Segundo Lévy,

A cibercultura é a expressão da aspiração de construção de um laço social, que não seria fundado nem sobre links territoriais, nem sobre relações institucionais, nem sobre relações de poder, mas sobre a reunião de centros de interesses comuns, sobre o jogo, sobre o compartilhamento do saber, sobre a aprendizagem colaborativa, sobre processos abertos de colaboração (1999, p. 130).

Embasados nas perspectivas teóricas sobre cultura e cibercultura, pode se estabelecer que a criança já se apropriou e internalizou alguns conhecimentos sobre a "cultura digital"; afinal, essa criança se encontra em um meio social no qual o "encontro com a tecnologia é inevitável e se dá cada vez mais cedo, porque as crianças tendem a seguir e se interessar pelos hábitos dos pais" (JOTTA, 2019, online).

A acessibilidade de crianças à internet tem relação com 0 gerenciamento, orientação, monitoramento e educação dos pais em relação aos seus filhos. Mesmo consistindo em um movimento sócio cultural da atualidade, a exploração e utilização da tecnologia por crianças não é um processo homogêneo, sendo que "diferenciam-nas padrões de práticas e de representações”, segundo Almeida (2011, p. 9).

Na definição de Maidel (2015, p. 295), "entende-se a mediação parental como um processo pelo qual os pais influenciam, com suas condutas, 
valorizações e verbalizações nas modalidades de uso e significações que os filhos têm a respeito das mídias". Dessa forma, o termo contextualiza tanto a gestão parental no que condiz à restrição na relação estabelecida pela criança com a mídia, como também contempla as estratégias de monitoramento aplicadas por eles nesse contexto.

Assim, o processo educacional dos pais no contexto da conectividade, engloba também a responsabilidade de regulação das tecnologias e seus respectivos conteúdos acessados pelas crianças (HERRING, 2008).

Entretanto, é importante que nesse processo, os pais também observem o próprio comportamento nos meios digitais. A aprendizagem observacional sociocognitiva apresenta teorias em que é possível notar a semelhança, quase sempre significativa, no comportamento de pais e filhos (FRIEDMAN, 1999).

Uma pesquisa realizada pela ONG americana Common Sense Media corrobora esta informação, destacando que "a maioria das crianças $(56 \%)$ com pais que se sentem viciados também se sente viciadas, criando lares onde toda a família tem mais chances de ter esse sentimento" (KNORR, 2019, online).

Portanto, o contato com o digital se torna inevitável em contexto sociocultural atual, entretanto, é crucial que os pais dialoguem, acompanhem e imponham limites à acessibilidade tecnológica de seus filhos pré-escolares, como também atuem como modelo no destaque da relevância do mundo offline também. Isso porque o uso inadequado pode gerar prejuízos em fase primordial para o desenvolvimento da personalidade daquela criança.

\section{METODOLOGIA}

Para compreender as práticas educativas parentais adotadas, foi realizada uma pesquisa de campo para que se faça um comparativo entre mães com filhos entre dois e cinco anos, matriculados em instituições públicas e particulares, visando a consecução do objetivo de investigar se há divergência nas Práticas Parentais exercidas em algum desses contextos educacionais

A coleta de dados foi realizada através da aplicação da escala PAFAS (Parenting...) para compreensão das práticas educativas parentais. Este estudo foi realizado em duas instituições: uma de ensino infantil particular e outra de ensino infantil municipal, localizada na cidade de Franca, no interior do Estado de São Paulo.

Atrelado aos objetivos desta pesquisa, a amostra total almejada era de quarenta participantes (mães), sendo vinte delas com filhos 
matriculados na instituição municipal e vinte com filhos matriculados na instituição particular.

Foi possível contar com a participação de vinte mães do contexto municipal e dezenove mães inseridas no contexto particular, totalizando uma perda amostral de apenas uma participante e tendo uma amostra composta por 39 mães, com filhos na faixa etária de três a cinco anos de idade, matriculados nas respectivas instituições de ensino.

Todas as trinta e nove mães participantes foram informadas sobre o objetivo do estudo, além de assinarem o Termo de Consentimento Livre e Esclarecido - TCLE, que se encontra nos ANEXOS, sendo todo o processo de desenvolvimento da pesquisa sustentado pela resolução 466, de 12 de dezembro de 2012.

A escala PAFAS foi traduzida e adaptada para a Língua Portuguesa, do Brasil, com autorização do autor, por Linhares, Gracioli e Leonetti (2015). O PAFAS investiga as práticas parentais, levando em consideração também o ajustamento parental e familiar nesse contexto. Consiste em uma escala de fácil administração, rápida e confiável que pode contribuir na avaliação de aspectos da parentalidade, tais como as práticas parentais e o ajustamento familiar na população brasileira em populações nãoclínicas. Os participantes devem selecionar um número, por meio de uma escala Likert que varia de 0 a 3, que corresponda a veracidade da informação apresentada em relação ao que foi praticado ao longo das últimas quatro semanas, conforme sinalizado na Figura 1.

Figura 1 - Escala Likert | Parenting Skills and Family Relationships (PAFAS)

\begin{tabular}{c|c|c|c}
\hline 0 & 1 & 2 & 3 \\
\hline $\begin{array}{c}\text { Nem um } \\
\text { pouco }\end{array}$ & $\begin{array}{c}\text { Um pouco ou } \\
\text { algum tempo }\end{array}$ & $\begin{array}{c}\text { Bastante ou uma } \\
\text { boa parte do tempo }\end{array}$ & $\begin{array}{c}\text { Muito ou a maior } \\
\text { parte do tempo }\end{array}$ \\
\hline
\end{tabular}

Fonte: Linhares, Gracioli e Leonetti (2015)

A versão original apresenta ao todo 40 itens, contendo duas escalas: a Parentalidade e o Ajustamento Familiar. Para o presente estudo, foi utilizada a versão do instrumento adaptada e validada para o Brasil por Santana e Leonetti (2018). Na Figura 2 é apresentada a interpretação do PAFAS adaptado em língua portuguesa:

Figura 2 - Interpretação da escala PAFAS - adaptação para o Brasil

\begin{tabular}{c|c|c|c}
\hline $\begin{array}{c}\text { Subescalas de } \\
\text { PAFAS }\end{array}$ & Itens & $\begin{array}{c}\text { Variação do } \\
\text { escore }\end{array}$ & Interpretação \\
\hline
\end{tabular}




\begin{tabular}{l|l|c|l}
\hline \multicolumn{3}{|c|}{ Parentalidade } \\
$\begin{array}{l}\text { Consistência } \\
\text { parental }\end{array}$ & $3 ; 8 ; 17$ & $0-9$ & $\begin{array}{l}\text { Escores mais altos } \\
\text { indicam menor nível de } \\
\text { consistência }\end{array}$ \\
\hline $\begin{array}{l}\text { Práticas } \\
\text { coercitivas }\end{array}$ & $9 ; 12 ; 14 ; 19$ & $0-12$ & $\begin{array}{l}\text { Escores mais altos } \\
\text { indicam mais práticas } \\
\text { coercitivas }\end{array}$ \\
\hline $\begin{array}{l}\text { Encorajamento } \\
\text { parental }\end{array}$ & $10 ; 13 ; 22$ & $0-9$ & $\begin{array}{l}\text { Escores mais altos } \\
\text { indicam melhor nível de } \\
\text { incentivo positivo }\end{array}$ \\
\hline $\begin{array}{l}\text { Relacionamento } \\
\text { pais e filhos }\end{array}$ & $20 ; 24 ; 25 ; 28$ & $0-12$ & $\begin{array}{l}\text { Escores mais altos } \\
\text { indicam melhor } \\
\text { relacionamento pai-filho }\end{array}$ \\
\hline $\begin{array}{l}\text { Ajustamento } \\
\text { Ajustamento } \\
\text { parental }\end{array}$ & $30 ; 31 ; 32$ & $0-9$ & $\begin{array}{l}\text { Escores mais altos } \\
\text { indicam melhor adaptação } \\
\text { dos pais }\end{array}$ \\
\hline $\begin{array}{l}\text { Ajustamento } \\
\text { familiar }\end{array}$ & $34 ; 37 ; 38$ & $\begin{array}{l}\text { Escores mais altos } \\
\text { indicam melhores } \\
\text { relacionamentos familiares }\end{array}$ \\
\hline
\end{tabular}

Fonte: Gracioli (2018)

Em ambos os cenários, a amostragem foi aleatória simples sendo que, após a reunião em que a pesquisadora explicou o intuito da pesquisa, os pais interessados em participar foram selecionados aleatoriamente, sendo detalhado a eles as instruções e demonstrações dos instrumentos e, em seguida, receberam os documentos (termo de consentimento e escala) para participação da pesquisa em mãos, tendo como prazo máximo de devolução dos instrumentos preenchidos um período de até uma semana.

\section{RESULTADOS E DISCUSSÃO}

Foram analisadas as práticas educativas maternas, levando em consideração as percepções das mães através da aplicação da escala de práticas parentais (PAFAS) e apresentadas na tabela 5. 
Tabela 1 - Escala de práticas parentais (PAFAS)

\begin{tabular}{|c|c|c|c|c|}
\hline $\begin{array}{l}\text { Práticas Parentais } \\
\text { Dimensões }\end{array}$ & $\begin{array}{l}\text { Amostra Total } \\
(n=39)\end{array}$ & $\begin{array}{c}\text { Escola } \\
\text { particular }(n= \\
19)\end{array}$ & $\begin{array}{l}\text { Escola } \\
\text { pública } \\
(n=20)\end{array}$ & \\
\hline & $\begin{array}{c}\text { Média } \\
\text { (DP; min-max) }\end{array}$ & $\begin{array}{c}\text { Média } \\
\text { (DP; min-max) }\end{array}$ & $\begin{array}{c}\text { Média } \\
\text { (DP; min-max) }\end{array}$ & $\begin{array}{l}\text { Valor } \\
\text { de } p\end{array}$ \\
\hline \multicolumn{5}{|l|}{ Parentalidade } \\
\hline $\begin{array}{l}\text { Consistência parental } \\
(-)\end{array}$ & $\begin{array}{l}2,05 \\
( \pm 1,582 ; 0-8)\end{array}$ & $\begin{array}{l}2,26 \\
( \pm 1,91 ; 0-8)\end{array}$ & $\begin{array}{l}1,85 \\
( \pm 1,226 ; 0-4)\end{array}$ & 0,332 \\
\hline Práticas coercitivas (-) & $\begin{array}{l}5,03 \\
( \pm 2,444 ; 1-10)\end{array}$ & $\begin{array}{l}4,05 \\
( \pm 1,58 ; 1-6)\end{array}$ & $\begin{array}{l}5,95 \\
( \pm 2,781 ; 1-10)\end{array}$ & 0,031 \\
\hline $\begin{array}{l}\text { Encorajamento } \\
\text { parental }(+)\end{array}$ & $\begin{array}{l}8,28 \\
( \pm 0,887 ; 6-9)\end{array}$ & $\begin{array}{l}8,11 \\
( \pm 0,937 ; 6-9)\end{array}$ & $\begin{array}{l}8,45 \\
( \pm 0,826 ; 7-9)\end{array}$ & 0,367 \\
\hline $\begin{array}{l}\text { Relacionamento entre } \\
\text { pais e filhos }(+)\end{array}$ & $\begin{array}{l}11,23 \\
( \pm 1,012 ; 9-12)\end{array}$ & $\begin{array}{l}11,26 \\
( \pm 0,991 ; 9-12)\end{array}$ & $\begin{array}{l}11,2 \\
( \pm 1,056 ; 9-12)\end{array}$ & 0,700 \\
\hline \multicolumn{5}{|l|}{ Ajustamento familiar } \\
\hline $\begin{array}{l}\text { Ajustamento parental } \\
(+)\end{array}$ & $\begin{array}{l}5,90 \\
( \pm 1,021 ; 4-8)\end{array}$ & $\begin{array}{l}5,74 \\
( \pm 1,046 ; 4-7)\end{array}$ & $\begin{array}{l}6,05 \\
( \pm 0,999 ; 4-8)\end{array}$ & 0,153 \\
\hline $\begin{array}{l}\text { Ajustamento familiar } \\
(+)\end{array}$ & $\begin{array}{l}5,56 \\
( \pm 1,465 ; 2-9)\end{array}$ & $\begin{array}{l}5,53 \\
( \pm 1,389 ; 4-9)\end{array}$ & $\begin{array}{l}5,6 \\
( \pm 1,569 ; 2-8)\end{array}$ & 0,063 \\
\hline
\end{tabular}

Conforme os dados apresentados na tabela 5, considerando aspectos relativos a parentalidade, a escala média da amostra total referente a consistência parental é 2, indicando um nível alto e positivo de consistência.

A referida subescala abrange as respostas educativas dos pais diante de um comportamento negativo de seus filhos ("Eu dou ao meu/minha filho/filha o que ele/ela quer quando ele/ela ficam com raiva ou chateado (a)"), sendo majoritário o número de mães do atual estudo que não cedem em situações como essa. A evidência de consistência nas práticas educativas representa um fator de proteção no que condiz a problemas de comportamento dos filhos (BOLSONI-SILVA; DEL PRETTE, 2002; PATTERSON, 2002).

Já as práticas coercitivas apontaram uma média em torno de 5 , aspecto este que consta 12 como escore máximo, podendo-se constatar que 
os índices apresentados foram baixos, indicando menos práticas coercitivas das mães, de forma geral.

Esse tópico está associado ao uso de força, ameaças e punição por parte dos pais ("Eu dou uma palmada no meu/minha filho/filha quando ele/ela se comporta mal"), na qual a maioria das mães, tanto de contexto público quanto particular, apresenta baixos índices de uso dessas técnicas como forma educativa.

As práticas coercitivas fazem com que o comportamento da criança se respalde nas respostas punitivas de seus pais, sendo assim, 0 controle desses comportamentos tende a depender de intervenções externas por não conseguir compreender as consequências de suas ações, sendo estratégia que não beneficia o entendimento de regras sociais e padrões morais (HOFFMAN, 1994).

Referente ao encorajamento parental, relativo aos estímulos de tomada de decisões, foi resultante uma média ao redor de 8 , um escore alto que indica melhor nível de incentivo positivo dessas mães. A escala de relacionamento entre pais e filhos apresentou 11 como escore médio da amostra total, sendo possível interpretar que há um bom relacionamento paisfilhos de modo geral.

Essa é uma característica do estilo parental autoritativo, em que a criança tem espaço para manifestar seu ponto de vista, o que pode desenvolver um reconhecimento das qualidades e aspectos positivos da criança (VIEIRA, 2010).

Sobre as dimensões relativas ao ajustamento familiar, o ajustamento parental, que leva em consideração os sentimentos vivenciado pelos pais ("eu sinto-me feliz") aponta uma média por volta de 5-6, como o escore máximo nesse aspecto é de 9 , pode-se considerar que está havendo um aumento positivo no aspecto sentimental dos pais.

Por fim, o ajustamento familiar em si apresenta escore médio de 5 , considerado moderado no que condiz aos relacionamentos familiares. $O$ ajustamento familiar diz respeito sobre os padrões de comportamento referente às necessidades e papéis familiares, sendo que o ajustamento psicológico dos pais costuma ser associado a melhores índices de funcionamento familiar (BEAVERS; HAMPSON, 2000; BASTOS; ALICE, 2013).

Fazendo um comparativo dos dois cenários estudantis, representados pelo fator $p$, que constam na Tabela 5 , a diferença significativa fica para o aspecto de práticas coercitivas, sendo que os escores foram um pouco mais altos no cenário público do que no privado, indicando haver mais práticas coercitivas por parte das mães de ensino público.

Mesmo que em um panorama geral ambos os contextos apresentaram índices abaixo da média para práticas coercitivas, sinalizando 
uma média de 5,03 em que o valor máximo era 12, as mães do cenário público tiveram uma média de 5,95, quase totalizando a metade (6) dessa máxima, sendo aspecto importante de ser acompanhado.

Isso porque consiste em uma prática parental negativa, caracterizada pela aplicação direta de força e poder dos pais, sendo que a alta exposição a disciplina coercitiva pode ocasionar em uma tendência da criança a repetir esse padrão de atitudes em outros contextos, podendo estimular e acentuar os problemas de externalização como agressividade, insegurança e medo ao longo de seu desenvolvimento (CATANIA, 1999; GOMIDE, 2003; GRANIC; PATTERSON, 2006; SALVADOR; WEBBER, 2005).

Os pais com menor conhecimento de estratégias de disciplina para o desenvolvimento saudável de seus filhos têm uma tendência a apostar mais em punições coercitivas. Essas práticas consistem em uma das estratégias características do estilo parental autoritário, em que há uma tendência a buscar obediência enfatizando a autoridade e ordem, utilizando a punição como controle comportamental. Associado ao contexto digital, esses pais definem regras e limites rígidos de uso, sem estabelecer um diálogo sobre o que consomem online e os riscos do mundo digital. (BAUMRIND, 1966; HASLAMB, 2017; MENDONÇA, 2016).

Conforme os resultados desse estudo, as mães de forma geral, de ambos os contextos educacionais, demonstram condições de proteção no desenvolvimento de seus filhos, apresentando uma predominância na prática parental positiva.

As práticas educativas parentais influenciam o desenvolvimento socioemocional de seus filhos. A partir de achados na literatura, é destacado a importância das práticas positivas que se respaldam em um envolvimento parental e um controle assertivo, priorizando diálogos pacíficos, estando associadas a competência social daquela criança, além de ser respaldado por uma confiança de que os problemas possam ser abordados no contexto familiar sem ser de modo aversivo (ALVARENGA; PICCININI, 2009; CONGER AT AL, 2009; MONDIN, 2006).

Desta forma, as estratégias educativas adotadas pelos pais como controle e supervisão parental, além do suporte parental e expressões de afeto, podem consistir como fator preditor no comportamento das crianças tanto no contexto offline, como também no âmbito digital, aspecto característico da cibercultura.

\section{CONSIDERAÇÕES FINAIS}

Compreender as práticas educativas parentais em que o contexto cultural é pautado pela acessibilidade digital foi a problemática levantada pela pesquisadora do presente estudo, visando estabelecer um comparativo entre 
mães com filhos matriculados em instituição pública e particular, para compreender se há divergências nesses aspectos.

A partir do objetivo proposto, referente as práticas educativas parentais e a mediação dos filhos em relação ao uso da internet, chegou-se as considerações de que as práticas parentais são majoritariamente positivas, em ambos os contextos, tanto de mães com filhos inseridos no contexto de ensino público como também no particular, sendo relevante destacar os altos escores médios referentes ao relacionamento de pais e filhos, como também no que condiz ao encorajamento parental.

Entretanto, apesar de ambos os grupos apresentarem índices abaixo da média no que concerne às práticas coercitivas, aspecto negativo atribuído as estratégias de práticas parentais, este foi o fator que apresentou maior divergência entre os contextos, sendo que o cenário de mães com filhos matriculados no ensino público $(5,95)$ apresentaram escores superior ao de ensino particular $(4,05)$, aspecto que merece atenção para que não haja progressão e não se torne predominante a longo prazo.

Não atribuir orientação educacional referente ao uso de aparelhos eletrônicos, e esses serem realizados de forma negligente, impacta diretamente nos riscos para com o desenvolvimento de seu filho, já que o adulto é responsável por fazer uma curadoria da interação da criança com o mundo externo.

Dessa forma, é importante conscientizar esses pais sobre a importância de uma mediação ativa em cenário digital, como também sobre os dados referentes a tempo e conteúdo de acesso e consequências a curto e longo prazo desse cenário para o desenvolvimento desses filhos, colocando em pauta o papel da parentalidade, e a função deles no posicionamento e educação de seus filhos referente ao âmbito virtual.

As mães demonstraram interesse em participar da pesquisa de campo sobre o tema, principalmente por ser algo que é desafiador e ainda confuso nas estratégias de práticas parentais, o que pode ter impactado positivamente na efetividade do estudo como um todo.

É um tema recente e ao longo dos estudos realizados, a pesquisadora considerou que a partir dos assuntos levantados, as pesquisas com crianças de $1^{\underline{a}}$ a $3^{a}$ infância considerando a acessibilidade digital devem ser priorizados, sendo importante aprofundar sobre as reações emocionais na ausência do dispositivo eletrônico, para que haja melhor prognóstico no desenvolvimento da personalidade de crianças a longo prazo nesse novo contexto virtual.

Além disso, uma futura pesquisa pode aprofundar em instrumentos e discussões referentes ao aspecto de mediação parental, estratégia específica referente a acessibilidade digital dos filhos. Os impactos 
das estratégias parentais como também as consequências diante de um cenário de conectividade prolongado propiciam férteis possibilidades de estudo e investigação.

\section{REFERÊNCIAS}

ALMEIDA, A. N. D; ALVES, N. D. A; DELICADO, Ana. As crianças e a internet em Portugal: Perfis de uso. Sociologia: Problemas e práticas, Local, Volume, Número, p. 9-30, dez./2005. Disponível em:

https://journals.openedition.org/spp/74?lang=pt. Acesso em: 13 ago. 2019.

ALVARENGA, Patrícia; PICCININI, Cesar. Práticas Educativas Maternas e Problemas de Comportamento em Pré-Escolares. 2001. 11 f. Dissertação (Mestrado) - Curso de Psicologia, Ufrs, Porto Alegre, 2001. Disponível em: <http://www.educadores.diaadia.pr.gov.br/arquivos/File/2010/veiculos_de_com unicacao/PRC/VOL14N3/7832.PDF>. Acesso em: 01 jul. 2019.

ANTONI, C. D. et al. PRÁTICAS EDUCATIVAS, ESTILOS PARENTAIS E ABUSO Fí́SICO NO CONTEXTO FAMILIAR. Psicologia em Estudo, Maringá, v. 8,2003 , p. $45-54$.

BANDURA, Albert; Social Learning Theory. Nova York : General Learning Press, 1971. p. 1-46.

BAUMRIND, D. Effects of authoritative parental control on child behavior. Child Development, Chicago, v. 37, p. 887-907, 1966.

BESNARD, T. et al. Parental practices of mothers and fathers and problem behaviour in preschool children: Differences and similarities. Revue de Psychoéducation, v. 38, n. 1, p. 15-43, 2009.

BRAZELTON, T. B., \& GREENSPAN, S. I. As necessidades essenciais das crianças. Porto Alegre: Artmed, 2002.

CECCONELLO, A. M. Resiliência e vulnerabilidade em famílias em situação de risco. Tese de Doutorado, Universidade Federal do Rio Grande do Sul, Porto Alegre, 2003

CONGER, R. D., Conger, K. J., \& MARTIM, M. J. Socioeconomic status, family processes, and individual development. Journal of Marriage and Family, v 72 n.3, 685-704, 2010.

DARLING, N.; STEINBERG, L. Parenting style as a context: an integrative model. Psychological Bulletin, v. 113, p. 487-496, 1993.

DEL PRETTE, A., \& DEL PRETTE, Z. A. P. Psicologia das relações interpessoais: Vivências para o trabalho em grupo. Petrópolis: Vozes, 2002 DORNBUSCH, S. M. et al. The relation of parenting style to adolescent school performance. Child Development, p. 1244-1257, 1987. 
FRIEDMAN, Howard S.; SCHUSTACK, Miriam W.; Teorias da Personalidade: Da teoria clássica à pesquisa moderna. 2. ed. Pearson, 1999. p. 252 GOMIDE, P.I.C. Estilos Parentais e comportamento anti-social. In A. Del Prette \& Z. Del Prette (Orgs.). Habilidades sociais, desenvolvimento e aprendizagem: questões conceituais, avaliação e intervenção. Campinas: Alínea, p. 21-60 2003.

GRACIOLI, S. M. A. Práticas educativas maternas, temperamento e problemas de comportamento em crianças na idade pré-escolar. Ribeirão Preto, 2018.

HARKNESS, S.; SUPER, C. M. Parental ethnotheories in action. In: SIGEL, I. E.; MCGILLICUDDY-DELISE, A.; GOODNOW, J. J. (Org.) Parental belief systems:The psychology consequences for children. Hillsdale/ Hove: Lawrence Erlbaum, p. 373-391, 1992.

HELSPER, Ellen J. et al. Country classification: opportunities, risks, harm and parental mediation. The London School of economics and political science, Londres, jun./2013. Disponível em:

http://eprints.Ise.ac.uk/52023/1/Helsper_Country_classification_opportunities_2 013.pdf. Acesso em: 17 mar. 2020.

HERRING, Susan. Questioning the generational divide. In: D. Buckingham (org.), Youth, Identity and Digital Media, Cambridge, MA, The MIT Press, p. 71 92, 2008.

JOTTA, Andrea. In: TECNOLOGIA UOL. Pais devem fiscalizar celular e tablet de crianças . Disponível em:

https://noticiasdatv.uol.com.br/noticia/tecnologia/pais-devem-fiscalizar-celular-etablet-de-criancas-alerta-especialista-5137?cpid=txt. Acesso em: 7 nov. 2019.

LÉVY, Pierre; Cibercultura 1. ed. São Paulo: Editora 34, 1999. p. 130 LINHARES, M. B. M. Família e desenvolvimento na primeira infância: Processos de autorregulação, resiliência e socialização de crianças pequenas. In G. A. Pluciennik, M. C. Lazzari, \& M. F. Chicaro (Orgs.), Fundamentos da família como promotora do desenvolvimento infantil: Parentalidade em foco. São Paulo, SP: Fundação Maria Cecília Souto Vidigal, 2015, pp. 70-82.

LISBOA, M. D. Ser quando crescer: A formação da identidade ocupacional. In R. S. Levenfus, D. H. Soares-Lucchiari, I. C. Silva, M. D. Lisboa, M. C. Lassance \& M. Knobel (Eds.), Psico-dinâmica da escolha profissional: Aspectos clínicos e pedagógicos. Porto Alegre, RS: Artes Médicas, 1997

LIVINGSTONE, S., HELSPER, E. J. Parental mediation and children's Internet use. Journal of Broadcasting \& Electronic Media, v 52, n 11, p. 581599, 2008.

LUBI, A. P. L. Estilo parental e comportamento socialmente habilidoso da criança com pares. In M. Z. Brandão, F. C. S. Conte, F. S. Brandão, Y. K. Ingberman, C. B. Moura, \& V. M. Silva, et al. (Org.). Sobre comportamento e 
cognição Vol. 11: A história, os avanços, a seleção por conseqüências em ação. Santo André: Esetec, 2003, pp. 536-541.

MACARINI, Samira Mafioletti et al. Etnoteorias parentais: um estudo com mães residentes no interior e na capital de Santa Catarina. Psicologia: Reflexão e Crítica, Porto Alegre, v. 23, n. 1, 2010. Disponível em:

https://www.scielo.br/scielo.php?script=sci_arttext\&pid=S0102-

$79722010000100006 \&$ Ing=pt\&nrm=iso. Acesso em: 5 nov. 2019.

MACCOBY, E.; MARTIN, J. Socialization in the context of the family:

Parent-child interaction. In P. Mussen (Ed.), Handbook of child psychology: Vol.4. Socialization, personality, and social development v 4, p. 1-101. New York: John Wiley, 1983.

MAIDEL, Simone; VIEIRA, Mauro Luis. Mediação parental do uso da internet pelas crianças. Psicologia em Revista, Belo Horizonte, v. 21, n. 2, p. 293-313, dez./2015. Disponível em:

http://pepsic.bvsalud.org/pdf/per/v21n2/v21n2a06.pdf. Acesso em: 24 out. 2019.

MONTANDON, CLÉOPÂTRE. AS PRÁTICAS EDUCATIVAS PARENTAIS E A EXPERIÊNCIA DAS CRIANÇAS. Educ. Soc., Campinas, v. 26, n. 91, p. 485507, jun./2005. Disponível em:

https://www.scielo.br/pdf/es/v26n91/a10v2691.pdf. Acesso em: 8 out. 2019.

TERRES, Michele Trindade; MOSMANN, Clarisse Pereira. Conflitos Familiares e Práticas Educativas Parentais como Preditores de Dependência de Internet. Psico-USF, Campinas, v. 21, n. 3, p. 623-633, jun./2016. Disponível em: https://www.scielo.br/scielo.php?pid=S141382712016000300623\&script=sci_abstract\&tlng=pt. Acesso em: 8 out. 2019.

PATTERSON, Gerald e cols. Antisocial boys: Comportamento anti-social. Santo André, SP: ESETec, 2002.

RAUBER, Mariane; SCHEIBE, Rosileica Webler. A formação da personalidade da criança na perspectiva dos pais p. 1-22, dez./2017. Disponível em: https://docplayer.com.br/50634674-A-formacao-dapersonalidade-da-crianca-na-perspectiva-dos-pais.html. Acesso em: 12 nov. 2019.

SAMEROFF, A. J., \& FIESE B. H. Transactional regulation: The developmental ecology of early intervention. In J. P. Shonkoff \& S. J. Meisels (Eds.), Handbook of early childhood intervention. New York, NY: Cambridge University Press, 2 ed, p. 135-159, 2000.

SANTAELLA, Lúcia. Da cultura das mídias à cibercultura: 0 advento do póshumano. FAMECOS: subtítulo da revista, Porto Alegre, Volume, n. 22, p. 23-33, dez./2003. 
VIGOTSKI, Lev Semenovich. A formação social da mente: o desenvolvimento dos processos psicológicos superiores. 6 ed. - São Paulo: Martins Fontes, 1998.

WEBER, Lidia N. D. et al. CONTINUIDADE DOS ESTILOS PARENTAIS ATRAVÉS DAS GERAÇÕES: TRANSMISSÃO INTERGERACIONAL DE ESTILOS PARENTAIS. Paidéia, v. 16, n. 35, p. 407-414, 2006. Disponível em: http://lidiaweber.com.br/Artigos/2006/2006Continuidadedosestilosparentaisatrav esdasgeracoes.pdf. Acesso em: 3 mar. 2020.

\section{APÊNDICE}

\section{Apêndice A - Termo de Consentimento Livre e Esclarecido}

\section{Prezado(a),}

Você está sendo convidado(a) a participar, como voluntário(a), da pesquisa "As práticas educativas parentais e a vulnerabilidade em relação aos crimes cibernéticos: impactos no desenvolvimento da personalidade de crianças na fase pré-escolar" conduzida por Lara Junqueira Gomes, aluna do curso de Psicologia do Centro Universitário Municipal de Franca Uni-FACEF e supervisionada pela Professora Doutora Sofia Muniz Alves Gracioli.

Você foi selecionado(a) por ser mãe de filho(a) com faixa etária correspondente a 3 a 5 anos. A qualquer momento, você poderá desistir de participar e retirar seu consentimento. Sua recusa, desistência ou retirada de consentimento não te acarretará prejuízos

Os dados desta pesquisa serão analisados e apresentados ao Centro Universitário de Franca (Uni-FACEF) como requisito do Trabalho de Iniciação Científica, os resultados podem ser divulgados em congressos e artigos científicos, contudo os nomes de identificação dos mesmos serão substituídos por nomes fictícios, a fim de preservar o sigilo ético.

Caso você decida participar desta pesquisa voluntariamente, é importante destacar que esta não possui nenhum tipo de risco ao participante. Sua participação não é remunerada e não te implicará em gastos. Esta pesquisa é sigilosa, sendo seus dados confidenciais, assim como sua identidade, de maneira nenhuma os resultados individuais serão divulgados, visando assegurar o sigilo de sua participação. Em caso de publicação desta pesquisa, o colaborador declara-se desde já ciente.

Sua participação nesta pesquisa consistirá em responder uma escala (PAFAS) que consiste em investigar aspectos da parentalidade, como também um questionário, concedendo à pesquisadora as análises destes dados. A participação será realizada em uma sessão de mais ou menos un hora, marcadas previamente entre os colaboradores e a pesquisadora.

A presente pesquisa não oferece nenhum risco ao participante e tem como benefício aprofundamento científico da temática em questão, além 
de ajudar na reflexão do impacto da acessibilidade à internet para o desenvolvimento da Personalidade de crianças entre 3 e 5 anos. Caso você concorde em participar desta pesquisa, assine ao final deste documento, que possui duas vias, sendo uma delas sua, e a outra, da pesquisadora responsável. Seguem os contatos da mesma ao fim documento, onde você poderá tirar suas dúvidas sobre o projeto e sua participação nele, agora ou a qualquer momento. Após estes esclarecimentos, solicita-se seu consentimento de forma livre para que participe desta pesquisa. Portanto preencha, em caso de assentimento, os itens que se seguem:

$\mathrm{Eu}$,

portador(a) do RG ํ․ — ciente das informações acima mencionadas, autorizo minha participação na pesquisa "As práticas educativas parentais e a vulnerabilidade em relação aos crimes cibernéticos: impactos no desenvolvimento da personalidade de crianças na fase préescolar" conduzida por Lara Junqueira Gomes, como forma de contribuição ao progresso científico.

Assinatura

Orientadora

Professora Doutora Sofia Muniz Alves Gracioli

Contato: sofiagracioli@yahoo.com.br Cel.: (16) 99222-9897

Pesquisadora

Lara Junqueira Gomes

Contato: larajunqueirag@gmail.com Cel.: (16) 99227-8391.

Declaro que entendi os objetivos, riscos e benefícios de minha participação na pesquisa, e que concordo em participar.

Franca, SP , de de

*Elaborado de acordo com a Resolução no196/96 do conselho nacional de saúde, decreto no93933 de 1987

\section{ANEXOS}

ESCALA PAFAS

Escala de Parentalidade e Ajustamento Familiar

Parenting and Family Adjustment Scale (PAFAS)

NOME:

IDADE:

Por favor, leia cada afirmação e assinale com um círculo o número da escala que mostra até que ponto cada afirmação é verdadeira, considerando as últimas 4 semanas. 
Não há respostas certas ou erradas. Não gaste muito tempo com cada afirmação.

Até que ponto cada afirmação é verdade?

$\begin{array}{llll}\text { Nem } & \text { Um } & \begin{array}{l}\text { Bastante } \\ \text { (uma }\end{array} & \begin{array}{l}\text { Muito } \\ \text { (a }\end{array} \\ \text { um } & \begin{array}{l}\text { pouco } \\ \text { pouco }\end{array} & \begin{array}{l}\text { (algum } \\ \text { boa }\end{array} & \begin{array}{l}\text { maior } \\ \text { temporte do }\end{array} \\ \begin{array}{lll}\text { parte } \\ \text { tempo) }\end{array} & \begin{array}{l}\text { do } \\ \text { tempo) }\end{array}\end{array}$

\begin{tabular}{|c|c|c|c|c|}
\hline $\begin{array}{l}\text { 1. Eu faço meu/minha filho/filha se desculpar } \\
\text { pelo seu mau comportamento. }\end{array}$ & 0 & 1 & 2 & 3 \\
\hline $\begin{array}{l}\text { 2. Eu digo para meu/minha filho/filha parar } \\
\text { assim que observo seu mau comportamento. }\end{array}$ & 0 & 1 & 2 & 3 \\
\hline $\begin{array}{l}\text { 3. Se meu/minha filho/filha não faz o que peço, } \\
\text { eu desisto e eu mesma faço. }\end{array}$ & 0 & 1 & 2 & 3 \\
\hline $\begin{array}{lccc}4 . & \text { Eu ignoro intencionalmente } & \text { pequenos } \\
\text { maus comportamentos do meu/minha filho/filha. }\end{array}$ & 0 & 1 & 2 & 3 \\
\hline $\begin{array}{l}\text { 5. Eu dou uma guloseima, uma recompensa } \\
\text { ou uma atividade divertida quando meu/minha filho/filha } \\
\text { se comporta bem. }\end{array}$ & 0 & 1 & 2 & 3 \\
\hline 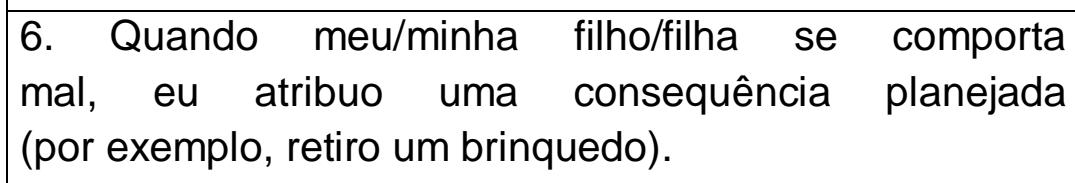 & 0 & 1 & 2 & 3 \\
\hline $\begin{array}{l}\text { 7. Quando meu/minha filho/filha se comporta mal eu } \\
\text { mando o/a dar um tempo (por exemplo, sentar-se } \\
\text { sozinho(a) em um lugar tranquilo). }\end{array}$ & 0 & 1 & 2 & 3 \\
\hline & $\begin{array}{l}\text { Nem } \\
\text { um } \\
\text { pouco }\end{array}$ & $\begin{array}{l}\text { Um } \\
\text { pouco } \\
\text { (algum } \\
\text { tempo) }\end{array}$ & $\begin{array}{l}\text { Bastante } \\
\text { (uma } \\
\text { boa } \\
\text { parte do } \\
\text { tempo) }\end{array}$ & \begin{tabular}{|l} 
Muito \\
(a \\
maior \\
parte \\
do \\
tempo)
\end{tabular} \\
\hline
\end{tabular}


8. Quando meu/minha filho/filha se comporta mal, eu ameaço (por exemplo, desligar a televisão), mas não cumpro.

9. Eu grito ou fico brava com meu/minha filho/filha quando ele/ela se comporta mal.

10. Eu elogio meu/minha filho/filha quando ele/ela se comporta bem.

11. Eu repreendo meu/minha filho/filha ou tenho uma longa conversa para explicar por que 0 seu comportamento não é aceitável.

12. Eu tento fazer meu/minha filho/filha se sentir mal (por exemplo, culpado ou envergonhado) por se 0 comportar mal, para lhe ensinar uma lição.

13. Eu dou atenção ao meu/minha filho/filha como um abraço, uma piscada de olho, um sorriso 0 ou um beijo, quando ele/ela se comporta bem.

14. Eu dou uma palmada no meu/minha filho/filha quando ele/ela se comporta mal.

15. Eu discuto com meu/minha filho/filha sobre seu comportamento e atitude.

16. Eu lido com o mau comportamento do meu/minha filho/filha da mesma maneira, o tempo todo.

17. Eu dou ao meu/minha filho/filha o que ele/ela quer quando ele/ela ficam com raiva ou chateado (a).

18. Eu brinco e leio livros com o/a meu/minha filho/filha.

19. Eu fico irritado com o/a meu/minha filho/filha.

20. Eu converso com o/a meu/minha filho/filha.

\begin{tabular}{|l|l|l|l|}
\hline 0 & 1 & 2 & 3 \\
\hline 0 & 1 & 2 & 3 \\
\hline 0 & 1 & 2 & 3 \\
\hline 0 & 1 & 2 & 3 \\
\hline 0 & 1 & 2 & 3 \\
\hline 0 & 1 & 2 & 3 \\
\hline 0 & 1 & 2 & 3 \\
\hline 0 & 1 & 2 & 3 \\
\hline 0 & 1 & 2 & 3 \\
\hline 0 & 1 & 2 & 3 \\
\hline 0 & 1 & 2 & 3 \\
\hline
\end{tabular}




\begin{tabular}{|c|c|c|c|c|}
\hline $\begin{array}{l}21 . \text { Eu encorajo meu/minha filho/filha a praticar } \\
\text { atividades } \\
\text { fícirac }\end{array}$ & 0 & 1 & 2 & 3 \\
\hline & $\begin{array}{l}\text { Nem } \\
\text { um } \\
\text { pouco }\end{array}$ & $\begin{array}{l}\text { Um } \\
\text { pouco } \\
\text { (algum } \\
\text { tempo) }\end{array}$ & $\begin{array}{l}\text { Bastante } \\
\text { (uma } \\
\text { boa } \\
\text { parte do } \\
\text { tempo) }\end{array}$ & \begin{tabular}{|l|} 
Muito \\
(a \\
maior \\
parte \\
do \\
tempo)
\end{tabular} \\
\hline $\begin{array}{l}\text { 23. Eu preocupo-me com o futuro do/da meu/minha } \\
\text { filho/filha. }\end{array}$ & 0 & 1 & 2 & 3 \\
\hline 24. Eu sou orgulhosa do/da meu/minha filho/filha. & 0 & 1 & 2 & 3 \\
\hline $\begin{array}{l}\text { 25.Eu gosto de passar o tempo com meu/minha } \\
\text { filho/filha. }\end{array}$ & 0 & 1 & 2 & 3 \\
\hline $\begin{array}{l}\text { 26. Eu ensino meu/minha filho/filha a fazer as coisas } \\
\text { sozinho(a). }\end{array}$ & 0 & 1 & 2 & 3 \\
\hline 27. Eu faço refeições com meu/minha filho/filha. & 0 & 1 & 2 & 3 \\
\hline $\begin{array}{l}\text { 28. Eu tenho um bom relacionamento com meu/minha } \\
\text { filho/filha. }\end{array}$ & 0 & 1 & 2 & 3 \\
\hline 29.Eu sinto-me estressado ou preocupado. & 0 & 1 & 2 & 3 \\
\hline 30. Eu sinto-me feliz. & 0 & 1 & 2 & 3 \\
\hline 31. Eu sinto-me triste ou deprimido. & 0 & 1 & 2 & 3 \\
\hline 32. Eu sinto-me satisfeito com a minha vida & 0 & 1 & 2 & 3 \\
\hline $\begin{array}{l}\text { 33. Eu lido com as demandas emocionais de ser } \\
\text { mãe/pai. }\end{array}$ & 0 & 1 & 2 & 3 \\
\hline $\begin{array}{|llllr|}34 . \quad \text { Eu trabalho como uma equipe com meu } \\
\text { companheiro } \\
\text { criação dos filhos. }\end{array}$ & 0 & 1 & 2 & 3 \\
\hline $\begin{array}{l}\text { 35. Eu discordo do meu companheiro na criação dos } \\
\text { filhos. }\end{array}$ & 0 & 1 & 2 & 3 \\
\hline $\begin{array}{l}\text { 36. Eu tenho um bom relacionamento com meu } \\
\text { companheiro. }\end{array}$ & 0 & 1 & 2 & 3 \\
\hline
\end{tabular}


Un:-FA

\begin{tabular}{|l|l|l|l|l|}
$\begin{array}{l}\text { 37. Os membros da nossa família ajudam e apoiam uns } \\
\text { aos } \\
\text { outros. }\end{array}$ & 0 & 1 & 2 & 3 \\
\hline $\begin{array}{l}\text { 38.Os membros da nossa família se dão bem uns } \\
\text { com os outros. }\end{array}$ & 0 & 1 & 2 & 3 \\
\hline $\begin{array}{l}\text { 39.Os membros da nossa família brigam ou discutem. } \\
\begin{array}{l}\text { 40.Os membros da nossa família criticam ou colocam os } \\
\text { outros para baixo. }\end{array}\end{array}$ 0 & 1 & 2 & 3 \\
\hline
\end{tabular}




\title{
COMO A MÍDIA IMPACTA NA NEGAÇÃO DO ENVELHECIMENTO HUMANO NOS DIAS ATUAIS
}

\author{
Juliana Presotto Pereira Netto \\ jprepen@gmail.com \\ Lucas Moreira de Oliveira \\ lucas_moreira_oliveira@outlook.com \\ Sofia Muniz Alves Gracioli \\ sofiagracioli@yahoo.com.br
}

\section{INTRODUÇÃO}

O tema "Envelhecimento Humano" comporta grande complexidade, uma vez que o próprio conceito de idoso é variável, envolvendo aspectos cronológicos, biológicos, socioeconômicos, entre outros. Sendo assim, optou-se por tratar de uma das vertentes desse processo, qual seja: como a mídia que promete juventude impacta na negação do envelhecimento humano.

Partiu-se do fundamento de que envelhecer é um processo, na opinião de alguns iniciado a partir do próprio nascimento e que perpassa toda a vida do indivíduo, mas para outros melhor localizado a partir de algo em torno dos 50 anos de idade, considerando os dias atuais. Ocorre que faz parte do senso comum a noção da velhice como uma fase de limitações, dificuldades e proximidade da morte e, por consequência, percebe-se uma intensa negação do envelhecimento por parte daqueles que dele se aproximam. Sendo assim, a questão que ora se coloca é em que medida a mídia em geral - aqui compreendidas propagandas, notícias, postagens nas redes sociais, internet, TV, rádio, etc. - cujo conteúdo promete uma juventude prolongada (e, por vezes "eterna"), impacta nessa negação.

Esse artigo aborda, portanto, o conceito de envelhecimento em uma rápida revisão histórica até os dias atuais, e busca subsídios para entender a negação presente nesse processo, a falta de aceitação das pessoas em geral e o desejo da "eterna juventude" como se essa fosse garantia de uma vida de fato melhor. Em seguida, foca na mídia falada e escrita, incluindo as redes sociais mais comuns, investigando como ela impacta de um modo global, gerando informação de que remédios, alimentação, cosméticos, entre outros, garantiriam a realização do desejo de não envelhecer.

Justifica-se a pesquisa pois a longevidade humana tem aumentado cada vez mais e pesquisas das indústrias de cosméticos, treinos físicos, academias, intervenções cirúrgicas, suplementos alimentares, etc., vêm para melhorar os aspectos físicos dos indivíduos, mas a mente e o psicológico 
dessas pessoas muitas vezes não estão preparados para as mudanças que acompanham o processo como um todo.

O mundo moderno exige que as pessoas sejam jovens e saudáveis e a mídia, em grande parte a serviço da indústria e em outros momentos na "onda" das redes sociais, defende e propaga essa ideia, a qual muitos aderem sem, ao menos, ponderar seus desdobramentos. Assim, idosos negam a idade e julgam serem capazes das mesmas proezas (muitas vezes físicas) que os jovens. Por outro lado, aqueles que rejeitam a necessidade de ser/parecer sempre jovens, por vezes também exageram e assumem uma postura extremada de que não são aptos a mais nada, ainda que isso também não seja verdade. Em meio a esse conflito, destaca-se o papel do psicólogo enquanto profissional indicado a colaborar para que as pessoas possam ponderar esses pontos de vista e entender o momento atual.

O objetivo desse artigo então é investigar a negação do envelhecimento e o impacto da mídia - que reflete a cultura do momento nesse processo. Em que medida as pessoas aderem às ideias apresentadas, propagandas e propostas? Como a psicologia pode contribuir para incentivar a reflexão e o desenvolvimento de percepções singulares, que reflitam a realidade de cada um e não apenas reproduzam uma visão geral e estereotipada? Por que as pessoas nessa situação, de envelhecimento, agem como agem ao invés de, por exemplo, priorizar suas experiências pessoais e seu amadurecimento enquanto seres únicos e dotados de vontade própria?

A metodologia adotada consiste em uma revisão bibliográfica crítica acerca do tema aqui abordado, com especial ênfase na área da psicologia, mas transitando também pela publicidade e propaganda, com algumas nuances da economia. Foram consultadas, em especial, as bases

Scielo e revistas de universidades. Fundamentado em livros e artigos científicos, o levantamento das informações atualmente disponíveis sobre a influência da mídia na negação do processo de envelhecimento deverá fornecer evidências e criar hipóteses para estudos futuros e o contínuo aprofundamento da pesquisa.

\section{ENVELHECIMENTO E VELHICE: conceitos que se complementam}

Tão simples quanto pensar em processo e consequência, os conceitos de envelhecimento e velhice não coincidem, mas se complementam: ou seja, o primeiro é causa, é processo que culmina no segundo. Apesar disso, é frequente na vivência diária que as pessoas tomem uma coisa pela outra, sem pensar na diferença substancial: idosos poder-se-á ser ou não um dia, conforme o momento da morte de cada um; envelhecer, no entanto, é um imperativo que se aplica a tudo e todos que estão vivos hoje. 
Nesse sentido, em uma visão ainda mais extrema, seria possível pensar que desde o momento do nascimento o ser vivo começa a "envelhecer", considerando que vai ficando mais perto da morte. No entanto, a literatura costuma demarcar algo em torno de 40 ou 50 anos como início do processo. Trindade e Bruns (2007, p. 41) depois de ressaltarem que o envelhecimento comporta alterações biopsíquicas e sociais, destacam que "essas alterações alcançam o organismo como um todo e seus sinais começam a ser perceptíveis por volta dos 40 anos". Já Giglio (2007, p. 76) comenta que não há uma idade cronológica "certa" para o envelhecimento começar, "mas que usualmente pensamos que se inicia entre os quarenta e cinquenta anos".

A partir de então, é consenso reconhecer que o envelhecimento é um processo multifatorial, de difícil conceituação, tendo em vista que comporta diversas abordagens não necessariamente coincidentes, dentre elas biológica, cronológica, social, cognitiva, cultural, psicológica, e até funcional.

A distinção entre idosos jovens, idosos velhos e idosos mais velhos pode auxiliar no entendimento de que o envelhecimento não é algo determinado pela idade cronológica, mas é consequência das experiências passadas, da forma como se vive e se administra a própria vida no presente e de expectativas futuras; é, portanto, uma integração entre as vivências pessoais e o contexto social e cultural em determinada época, e nele estão envolvidos diferentes aspectos: biológico, cronológico, psicológico e social (SCHNEIDER; IRIGARAY, 2008).

É evidente, portanto, que definir a velhice - estado ou condição de ser velho, idoso - também enfrenta o mesmo problema, porque significaria determinar um ponto, um limite, a partir do qual a pessoa atinge uma situação diferente da que tinha até então: passa a ser idoso. Isso, de fato, não ocorre, daí porque prefere-se falar em processo, o que traz a ideia de uma ação continuada, prolongada no tempo.

Apesar disso, a legislação dos diferentes países precisa ter uma definição clara a esse respeito, quando trata de questões referentes ao idoso e ao envelhecimento. A lei não pode ser individual, conforme a circunstância de cada um, e assim convencionou-se definir como idoso, na maior parte das nações, as pessoas de 60 a 65 anos de idade (países "em desenvolvimento" e países "desenvolvidos", respectivamente), seguindo uma diretriz da Organização Mundial da Saúde (OMS, 2015). No Brasil, o art. 1ํ do Estatuo do Idoso, Lei n. 10.741/03, define como idosas "as pessoas com idade igual ou superior a 60 anos" (BRASIL, 2003).

Em qualquer dos casos, por certo, o mais relevante é reconhecer que o envelhecimento deve se dar com a preservação da qualidade de vida daquele que transita para a sua última etapa de desenvolvimento psicossocial. Daí decorrem outros conceitos como, por exemplo, o de envelhecimento ativo, definido como "processo de otimização das oportunidades de saúde, 
participação e segurança, com o objetivo de melhorar a qualidade de vida à medida que as pessoas ficam mais velhas" (OMS, 2005, p. 13).

Esse conceito, incentiva que as pessoas idosas percebam seu potencial para o bem-estar físico, mental e social, bem como reconheçam suas necessidades, desejos e capacidades, o que, em suma, demonstra claramente que o envelhecimento comporta tanto desafios quanto oportunidades em diversas áreas e cenários. Ou seja, é um processo natural, inexorável, que pode (e deve) sim ser visto por uma perspectiva positiva, porém, não há que se falar em "escolha" quanto a sua ocorrência ou não. Mas há escolhas, no plural, quanto ao "como" envelhecer e quanto à idade psicológica do indivíduo, a qual é

definida pelos padrões de comportamento adquiridos e mantidos ao longo da vida e tem uma influência direta na forma como as pessoas envelhecem. $O$ envelhecimento é resultado de uma construção que o indivíduo fez durante toda a vida. A autoeficácia, que é a crença do indivíduo na capacidade de exercer controle sobre a própria vida, está relacionada às escolhas pessoais de comportamento durante 0 processo de envelhecimento e à preparação para a aposentadoria. Saber superar as adversidades determina o nível de adaptação a mudanças e a crises próprias do processo de envelhecimento (SCHNEIDER; IRIGARAY, 2008).

Assim, aqueles que aceitam e se preparam para a velhice, tendem a se adaptar às mudanças inerentes a esse processo e conseguir uma melhor condição de vida a partir dos 60 anos. Nesse sentido, a velhice não assombra, mas se conquista. $O$ que, no atual cenário, pode ser entendido como medida de substancial sabedoria no Brasil, já considerado um "país envelhecido". ${ }^{2}$

Segundo o Instituto Brasileiro de Geografia e Estatística - IBGE, em 2000 a população idosa com mais de 60 anos era de 14,5 milhões de pessoas, um aumento de $35,5 \%$ ante os 10,7 milhões em 1991. Hoje, este número ultrapassa os 29 milhões e a expectativa é que, até 2060, este número suba para 73 milhões com 60 anos ou mais, o que representa um aumento de $160 \%$. A OMS considera um país envelhecido quando $14 \%$ da sua população possui mais de 65 anos (SOCIEDADE, 2019).

É válido ainda lembrar que o processo de envelhecimento no Brasil tem se dado de maneira bastante acentuada, muito mais rápida que em países europeus, o que, naturalmente, intensifica as preocupações e a necessidade de estudos voltados não apenas para os aspectos individuais, mas também para as políticas públicas necessárias nessa área.

\footnotetext{
${ }^{2}$ Afirmativa calculada com base nos números disponíveis no site do IBGE, que afirmam que a população do Brasil está hoje (22.06.2020) em 211.683.288 de habitantes. $<$ https://www.ibge.gov.br/apps/populacao/projecao/box popclock.php>.
} 


\section{O MECANISMO DA NEGAÇÃO E SUA UTILIZAÇÃO DIANTE DO PROCESSO DE ENVELHECIMENTO}

Quando trazido para o nível da subjetividade, o processo de envelhecimento descrito comporta diferentes possibilidades em termos de aceitação. Há aqueles que lidam bem e serenamente com ele, mas há também casos de pessoas que sofrem com a simples possibilidade de enfrentar o que ele pode representar, em especial em termos de perdas e diminuição de capacidades, autonomia, etc., como já foi falado.

Essa atitude decorre de uma situação de ansiedade, em geral descrita como uma experiência emocional negativa intensa, a qual pode surgir tanto de medos realistas (como, por exemplo, você se deparar com um cão raivoso), mas também de impulsos irracionais que ameaçam tornar-se incontroláveis, conhecida então como ansiedade neurótica (FELDMAN, 2015, p. 389) ou simplesmente ansiedade potencial.

Para lidar com isso, reduzindo o desconforto que ela causa, os indivíduos são capazes de distorcer a realidade, ocultando a fonte de ansiedade de si mesmos, por meio dos chamados "mecanismos de defesa", pensados e descritos originalmente por Freud e estudados também por diversos outros autores, ainda que com outra nomenclatura (por exemplo: "atenção seletiva", para Sullivan ou "modelo de autodefesa", para Rogers) (HALL; LINDZEY; CAMPBELL, 2007, p. 142).

Os mecanismos de defesa são diversos e, em geral, utilizamos vários deles ao mesmo tempo. Via de regra (e essa é uma de suas características), operam inconscientemente. Seu elenco pode variar, mas alguns mais conhecidos são: repressão, negação, formação reativa, projeção, regressão, racionalização, deslocamento e sublimação. Esse artigo foca na negação, conforme será exposto a seguir.

Segundo D'Agord (2006) a negação está presente na obra freudiana em dois sentidos: em um diz respeito ao não dos contrários e dos opostos, e em outro (o qual se aplica ao caso em tela), a negação aparece como constitutiva do que é negado. Assim, envolve uma acepção de verdade proposicional ou seja: na negação está subentendida uma verdade, a qual é reconhecida inconscientemente, porém não é admitida.

No caso do envelhecimento então, há o reconhecimento da existência desse processo que, embora lento, é inexorável, mas opta-se por deixar no inconsciente a percepção de que ninguém, nem mesmo a própria pessoa, escapa dessa verdade, a não ser em caso de morte prematura. Assim, nega-se que esteja acontecendo comigo: o envelhecimento é um processo que existe sim, mas com os outros (como se isso fosse possível).

Sabe-se que, em alguns casos, a negação pode até ser considerada saudável, no sentido de minimizar o intolerável, dando um tempo à 
mente para elaborar a ideia e se adaptar à realidade; mas, desde que isso seja temporário, provisório. Quando passa a ser um comportamento duradouro, contínuo, há grandes possibilidades de que esconda um problema com o qual não se deseja confrontar, nesse caso a necessidade de aceitar e aprender a lidar com os atributos do envelhecimento.

E por que tanta dificuldade? Como visto no tópico anterior, há toda uma suposição construída em torno do processo de envelhecimento, de que o idoso é necessariamente alguém sem saúde, sem autonomia, sem beleza, sem razão de viver, o que, em suma, conduz à perda de sentido da vida. Como destacam Salzedas e Bruns (2007, p. 18):

Os traços estigmatizadores da velhice estão ligados a valores depreciativos culturalmente construídos. Em nossa sociedade pós moderna o idoso é cada vez menos valorizado - com a exaltação do jovem, daquilo que é novo -, e a experiência vivida parece ter importância secundária. Além disso, observamos uma preocupação exacerbada com o corpo, o que, muitas vezes, nos impede de aceitar seu declínio natural (...).

É também nesse sentido, que a "a negação da velhice aparece nos codinomes melhor idade, segunda adolescência, adulto maior, criados pela ideologia do velamento da velhice" (SALZEDAS; BRUNS, 2007, p. 17).

Ocorre que:

a. tais assertivas referentes aos traços estigmatizadores não são verdadeiras em todos os casos. Por exemplo, a senilidade, como destacam Schneider e Irigaray (2008),

não é um componente normal do envelhecimento. Desta forma, o idoso não perde a capacidade de raciocínio e a idade não leva ao declínio das funções intelectuais, uma vez que a presença de patologias, e não a idade em si, está envolvida na maior parte dos problemas que interferem nas habilidades cognitivas dos idosos;

b. ainda quando o envelhecimento culmina com esses fatos indesejados (a senilidade, no exemplo acima), algum poeta já disse que, muito mais importante do que chegar ao destino é o caminho, ou seja: não se sabe como será a velhice, mas enquanto ela não chega, é possível desfrutar do período que a antecede e investir nele para que transcorra da melhor forma possível, conforme comentado no tópico anterior; e

c. finalmente, mesmo que também o caminho não agrade a princípio, as coisas valem mais por como são vistas, do que por como elas efetivamente são. Assim, o envelhecimento não é um castigo para quem é incapaz de se cuidar ou não consegue se adequar aos padrões de consumo em geral apresentados como capazes de estagnar esse processo. Não é opção ou a falta dela, mas sim é algo natural, cuja aceitação pressupõe maturidade psicológica para viver, tão bem quanto possível, mais uma etapa da vida. 


\title{
4. O IMPACTO DA MÍDIA NA NEGAÇÃO DO ENVELHECIMENTO
}

Entende-se a mídia como uma maneira de veicular informações de diversos gêneros, por diversas formas. Conforme o Dicionário on line (MÍDIA, 2020), a própria etimologia da expressão remete a isso.

\begin{abstract}
Mídia: meio através do qual as informações são divulgadas; os meios de comunicação. Reunião dos veículos e meios utilizados numa campanha publicitária. Seção da agência publicitária que faz a seleção dos meios de comunicação (rádio, televisão etc.) e aconselha a melhor programação para divulgar uma mensagem, para alcançar o público-alvo.
\end{abstract}

Em decorrência desse conceito, é possível também conceber a mídia como um instrumento milenar, congregando desde a mera gravura rupestre até o meio mais avançado de tecnologia informativa, tendo por objetivo transmitir uma informação sem a necessidade da presença do interlocutor e com a maior fidelidade ao que foi dito, o que se poderia se deturpar quando a mensagem é apenas oral.

Miranda (2007, p.11) também retrata esse cenário, abordando mais especificamente a escrita e destacando sua importância, o que pode ser percebido quando se recorda que a possibilidade de registro dos fatos dividiu a própria história entre antes (pré-história) e depois do seu aparecimento. Ressalta ainda que a escrita, "inventada pelos sumérios, em aproximadamente 3.500 a.C., possibilitou ao homem transmitir [informações] de forma segura e sem alterações de conteúdo, o que geralmente acontecia na transmissão oral".

Com o passar do tempo a humanidade evoluiu e os meios de comunicação evoluíram junto dela. Se antigamente uma informação levava muito tempo para ser construída e alcançar um destino, hoje isso acontece em momentos. Se na Idade Média um livro demorava anos para ser confeccionado e podia ser destruído facilmente (pois via de regra não havia muitas cópias), hoje a informação se propaga de forma viral. Mas o relevante é que, desde sempre, o objetivo da comunicação se mantem: transmitir informação (causando impacto sócio histórico, entre outros, nesse trânsito).

Enquanto ferramenta, a mídia toma a forma que seu usuário lhe dá e embora seu cerne tenha se mantido desde os primórdios dos tempos, suas relações sofreram alterações e hoje um de seus braços (muito provavelmente o direito) é constituído pelas relações de marketing.

Considerando que a sociedade contemporânea se caracteriza por relações fluidas, imodéstia e empáfia, não é de se surpreender que as mídias tomem a mesma forma, encaixando-se nesse novo modelo social efêmero. Umberto Eco, ao dissertar sobre as novas tecnologias, afirmou:

As mídias sociais deram o direito à fala a legiões de imbecis que, anteriormente, falavam só no bar, depois de uma taça de vinho, sem 
causar dano à coletividade. Diziam imediatamente a eles para calar a boca, enquanto agora eles têm o mesmo direito à fala que um ganhador do Prêmio Nobel. O drama da internet é que ela promoveu o idiota da aldeia a portador da verdade (SEIS, 2016).

Ideias como essa demonstram como a vulgarização da mídia tornou-se comum, e em algum momento, ela se desgarrou da mera ideia de veicular informação e se transformou também em uma maneira de vender, ou seja: um veículo comercial.

Vive-se hoje um tempo singular, no qual os meios de comunicação como jornal, rádio e televisão vêm perdendo espaço, antes hegemônico, como disseminadores de notícias, informações e cultura e, paulatinamente, têm sido substituídos por outras mídias, digitais. Se há pouco mais de dez anos era raro haver em uma residência um único computador com escasso acesso à internet discada, hoje não é incomum que cada integrante da família possua mais de um meio de acesso, como notebook e smartphone. Os carros têm GPS de fábrica e a internet é versátil e acessível em quase qualquer lugar, a quase qualquer pessoa.

Os cookies, arquivos de internet que armazenam temporariamente o que o internauta está visitando na rede, captam informação das áreas de interesse do usuário e essas informações são vendidas para empresas. Com base nessas informações, propagandas sobre seus objetos de desejo surgem "milagrosamente" em suas telas.

Em paralelo, como visto nos tópicos anteriores, esse também é um momento no qual se verifica o envelhecimento da população e, de alguma forma, essas duas informações conflitam. Afinal, o idoso tradicionalmente era visto na mídia consumista com algum desdém: ainda que fosse uma classe com poder financeiro e aquisitivo, existia com um número pequeno de pessoas, insuficiente para chamar atenção. Não era sem razão, portanto, que no início desse século, Daibert (2003) destacava a necessidade do idoso passar a ser visto como um fato econômico sério, para a publicidade valorizá-lo e dar a ele 0 espaço merecido na mídia.

Ocorre que a realidade concernente à quantidade de idosos vem sofrendo drástica alteração, com o aumento crescente de seu número em nossa sociedade, e então a questão que se coloca é: a mídia consumista respeita essa classe de consumidor?

A conclusão é subjetiva e eventualmente tendenciosa, pois ao entender-se como respeito a venda daquilo que o consumidor final deseja, a resposta será sim. De outra sorte, ao refletir-se sobre o desejo ser real ou incutido, a resposta por vezes será não.

Vive-se hoje em um mundo estético, no qual a "liquidez" das relações apontada por Bauman e traduzida livremente por "vazio das relações", 
é um conceito muito difundido. Em sua obra "Vida para consumo", esse autor aponta, de maneira didática, a ideia fim da mídia consumista:

[...] que o destino final de toda mercadoria colocada à venda é ser consumida por compradores; que os compradores desejarão obter mercadorias para consumo se, e apenas se, consumi-las for algo que prometa satisfazer seus desejos; que o preço que o potencial consumidor em busca de satisfação está preparado para pagar pelas mercadorias em oferta dependerá da credibilidade dessa promessa e da intensidade desses desejos (BAUMAN, 2008, p. 18).

A mídia consumista contemporânea sugestiona no sentido de que é preciso ser ousado, é preciso fazer sua juventude durar de forma perene, e consequentemente, convence essa fatia de mercado - os idosos, de que a mídia não precisa se adaptar a eles, mas sim o contrário: que eles precisam se adaptar ao mercado. Para esse fim, vende a ideia de juvenilização do idoso na cultura do consumo.

A velhice, antes vista como sinônimo de perdas na maioria das vezes ou, quando muito e sob a égide de um ponto de vista positivo, vista como idade de retenção de conhecimento e sabedoria, foi deturpada. Tratou-se um conceito biológico (o envelhecer) como fruto de um delírio psíquico, com intuito de dizer que "a velhice só existe na cabeça daquele que se limita".

Os idosos da cultura de consumo, considerados saudáveis e bem sucedidos, tendem a aderir aos estilos de vida e à parafernália de técnicas de manutenção corporal veiculados pela mídia. Assim, assistimos à emergência de novos estereótipos (MATOS, 2014, p. 494).

Embora haja uma minoria que lute pela ideia de envelhecer de maneira produtiva e saudável, com direitos e garantias que sejam condizentes com essa fase da vida, ela não prevalece para essa mídia cujo objetivo é, como visto na citação de Bauman, meramente a circulação de mercadoria e não outro. Ocorre que essa ideia exclusiva de consumo, que é vendida e bem vendida, fere de morte o próprio conceito de idoso, já que o que se vende é a suposição (inviável) de uma juventude eterna. Nesse sentido, também a colocação de Barbosa (2004, p. 11):

Estilo de vida e identidade tornaram-se, portanto, opcionais. Independentemente da posição social, idade e renda "posso ser quem eu escolher". Assim, estilo de vida no contexto da cultura do consumo, sinaliza para a individualidade, auto expressão, estilo pessoal e autoconsciente.

Destaca-se nesse contexto, a necessidade de que o idoso consiga se encontrar no cenário atual e construir sua própria identidade, independentemente dos interesses midiáticos e econômicos já referidos, bem como dessa imposição de uma juventude oportunista e fictícia, uma vez que biológica e organicamente, conforme demonstrado em tópico anterior desse trabalho, o envelhecimento é um processo que até pode ser parcialmente retardado, mas nunca detido. 


\section{A CONTRIBUIÇÃO DA PSICOLOGIA PARA COMPREENSÃO DO IMPACTO DA MÍDIA NA NEGAÇÃO DO ENVELHECIMENTO}

Basicamente, é possível pensar no envolvimento da psicologia nesse cenário, a partir de dois pontos de vista. Um, enquanto psicoterapia individual ou mesmo grupal, em que um psicólogo poderia cuidar dos sentimentos, pensamentos e crenças daquele que envelhece, buscando entender suas causas e consequências e analisar o que pode ser mudado para que a pessoa viva melhor, com menos cobranças, menos afeta a suprir expectativas dos outros, mais voltada para a qualidade de vida segundo seus próprios valores e não tão suscetível à influência da mídia.

Em uma segunda perspectiva, adotada aqui, cabe refletir sobre 0 conceito de psicologia social proposto por Feldman (2015, p. 528), cujo âmbito trata, entre outras coisas, de responder perguntas tipo: Como podemos convencer as pessoas a modificar suas atitudes ou a adotar novas ideias e valores? Como somos influenciados pelo que os outros fazem e pensam? Em suma, ele afirma que psicologia social é o "estudo científico acerca de como os pensamentos, sentimentos e ações das pessoas são afetados pelos outros" (ibid). No caso, dentro da proposta desse artigo, entenda-se "outros" como a mídia em geral (conforme exposto no tópico 4) e o objetivo do atual tópico como entender um pouco mais porque as pessoas se deixam influenciar nesse e em outros contextos.

Entende-se persuasão como o processo de mudança de atitudes, o que pode ocorrer de maneira mais fácil, conforme:

a) a fonte da mensagem transmitida: comunicadores que são física e socialmente mais atraentes têm maiores possibilidades de produzir uma mudança mais significativa. São os chamados "comunicadores de atitudes", tanto mais eficazes quanto maior seu conhecimento e a credibilidade que emanam;

b) mensagens que apresentam dois lados de um problema, em tese demonstrando porque um argumento é mais válido que o outro, que foi refutado, também tem maior chance de sucesso;

c) análise das características do público alvo: conforme o gênero, idade, níveis de inteligência, apresentação em contexto público ou privado, a mensagem tem mais ou menos chance de ser aceita.

Além disso, a receptividade de uma mensagem também está relacionada ao tipo de processamento da informação que é utilizado. Processamentos pela rota central são mais indicados para um público sensível à lógica, mérito e força de um argumento, ou seja: "deve ser acionada quando existir probabilidade alta de ocorrência de elaboração cognitiva". Já aqueles de rota periférica adequam-se melhor a pessoas influenciáveis por quem está transmitindo a mensagem ou o apelo emocional dos argumentos, ou seja, "permitem a uma pessoa avaliar um assunto ou produto sem se engajar em 
raciocínios profundos relacionados com o tema abordado, mas apenas por meio de argumentos circunstanciais ou indiretos" (ANDRADE, MAZZON, 2011, p. 5).

Diante de tantas variáveis, uma agência de publicidade precisa conhecer muito bem seu público alvo e analisar a melhor maneira de apresentar um produto ou serviço, para que tenha o sucesso almejado. Nesse contexto uma das mídias mais estudadas hoje em dia é a dos anúncios on line para, por exemplo, entender quais os fatores que levam os possíveis consumidores a clicar sobre algumas mensagens em detrimento de outras. Certamente um dos aspectos de maior peso refere-se à influência social, "processo pelo qual grupos sociais e indivíduos exercem pressão sobre um indivíduo, seja deliberadamente, seja não intencionalmente" (FELDMAN, 2015, p. 541). Quando tal pressão conduz ao chamado "pensamento de grupo" a motivação de seus membros para atingir um consenso é tão significativa, que eles acabam perdendo a capacidade de avaliar criticamente pontos de vista alternativos.

Tudo isso, em grande parte, é o que acontece com os "envelhescentes" que teimam em fazer parte de um grupo de "hipoteticamente jovens, saudáveis e felizes", os quais, muitas vezes, se perdem no consumismo para aparentar uma realidade que não é originalmente a sua. Isso significa que o mal não está em praticar certas atividades, usar certos produtos, uma vez que o idoso de hoje é bem diverso daquele de décadas atrás. $O$ problema instala-se quando ele precisa disso para se sentir incluído em determinado grupo ou, ainda pior, para negar um processo que, conforme já foi dito repetidas vezes, é natural e inexorável: o envelhecimento.

Assim, o desafio da publicidade hoje, bem como da psicologia que a orienta, é trabalhar com a grande diversidade existente: um idoso que pula de paraquedas, o outro que aprecia fazer um bolo para os netos no final de semana, e ainda aquele que não assumindo sua condição participa de algo que não quer, apenas para fazer parte de um grupo e não se sentir "tão inútil ou tão desatualizado". Cada um tem sua liberdade, mas o temerário em termos de saúde mental é, lembrando um comercial emblemático da década de 90 , tornar-se o "tio sukita" - aquele personagem que, sendo mais velho, tenta paquerar uma mocinha, sem nenhum sucesso, por simples negação da sua realidade.

\section{CONSIDERAÇÕES FINAIS}

Partindo-se do pressuposto de que o objetivo desse trabalho foi investigar a negação do envelhecimento e o impacto da mídia nesse processo, questionando em que medida as pessoas aderem às ideias por ela 
disseminadas e como a psicologia atua nesse contexto, apresentam-se as considerações finais como segue.

Processo multifatorial, com aspectos de alterações biológica, cronológica, social, cognitiva, cultural, psicológica e até funcional, o envelhecimento culmina na velhice que é, portanto, um construto de ordem individualizada, embora a legislação a defina como algo em torno dos 60,65 anos de idade.

Por essa ocasião, considera-se um idoso como alguém que desfruta de qualidade de vida quando, entre outras coisas, percebe seu potencial para o bem-estar físico, mental e social, bem como reconhece suas necessidades, desejos e capacidades. Além disso, é fundamental que lide serenamente com a velhice, e não veja apenas os riscos que ela pode representar, em especial em termos de perdas e diminuição de capacidades, autonomia, etc.

Quando não o faz, muitas vezes o indivíduo é capaz de distorcer a realidade, ocultando de si próprio a fonte de ansiedade recorrente, por meio dos chamados "mecanismos de defesa", dentre eles a negação. Dessa forma, o idoso que era visto na mídia com algum desdém, passa a ser por ela valorizado quando se converte em consumidor voraz de produtos e serviços que prometem uma juventude eterna.

Se por um lado esse fato demonstra como a vulgarização da mídia tornou-se comum quando, em algum momento, ela minimizou a ideia de veicular informação e se transformou em um veículo comercial, por outro denota também um equívoco conceitual sobre a velhice, a qual não é opção ou a falta dela, mas sim algo natural, cuja aceitação pressupõe maturidade psicológica para viver, tão bem quanto possível, mais uma etapa da vida.

Em sentido contrário, observou-se pela pesquisa que a mídia consumista contemporânea sugestiona no sentido de que é preciso ser ousado, fazer sua juventude durar de forma perene, e consequentemente, convence essa fatia de mercado - os idosos, de que a mídia não precisa se adaptar a eles, mas sim o contrário: que eles precisam se adaptar ao mercado. Para esse fim, vende a ideia de juvenilização do idoso na cultura do consumo.

Tratou-se um conceito biológico (o envelhecer) como fruto de um delírio psíquico, com intuito de dizer que "a velhice só existe na cabeça daquele que se limita", o que fere de morte o próprio conceito de idoso, já que o que se vende é a suposição (inviável) de uma juventude eterna. Contrário senso, o envelhecimento é um processo que até pode ser parcialmente retardado, mas nunca detido.

Nesse cenário, a psicologia aparece na esfera da terapia individual ou coletiva, ou ainda enquanto instância de auxílio para reflexão sobre mudanças de atitude e adoção de novas ideias e valores, por influência 
do pensamento e ideias de outrem sobre nós, ainda que esse "outro" seja distante e virtual, como a mídia.

Percebeu-se que há "envelhescentes" que teimam em fazer parte de um grupo de hipoteticamente jovens, saudáveis e felizes, os quais, muitas vezes, se perdem no consumismo para aparentar uma realidade que não é originalmente a sua. Por outro lado, há aqueles que lidam bem com o processo de envelhecimento e assumem sua condição, usufruindo de seus aspectos positivos.

Resta então, como desafio da publicidade hoje, bem como da psicologia que a orienta, trabalhar com a diversidade existente, buscando ressaltar a esfera de liberdade de cada um, mas sem que isso comprometa a sanidade e o equilíbrio de saúde mental daquele que envelhece. Essas possibilidades abrem diversos caminhos para novas pesquisas, as quais poderão, por exemplo, a partir do levantamento e análise de casos concretos, aferir em que medida e com que intensidade essas escolhas são feitas, bem como a que consequências elas conduzem.

\section{REFERÊNCIAS}

ANDRADE, Josmar; MAZZON, José Afonso. Os caminhos da persuasão: um estudo sobre o uso de rotas centrais e periféricas em anúncios impressos publicados entre 1968 e 2008. GP Publicidade e Propaganda - XXXIV Congresso Brasileiro de Ciências da Comunicação. Recife, 02-06 set. 2011. Disponível em: <http://intercom.org.br/papers/nacionais/2011/resumos/R62648-1.pdf>. Acesso em 22 jun. 2020.

BARBOSA, Lívia. Sociedade de consumo. Rio de Janeiro: Zahar, 2004.

BAUMAN, Zigmunt. Vida para consumo: a transformação das pessoas em mercadoria. Rio de Janeiro: Zahar, 2008.

BRASIL. Lei n. 10.741, de 01 de outubro de 2003. Estatuto do idoso. Disponível em: <http://www.planalto.gov.br/ccivil 03/LEIS/2003/L10.741.htm>. Acesso em 17 abr. 2020.

D’AGORD, Marta. A negação lógica e a lógica do sujeito. Ágora: estudos em teoria psicanalítica. v. 9, n. 2. Rio de Janeiro, jul.-dec. 2006. Disponível em: $<$ http://www.scielo.br/scielo.php?script=sci arttext\&pid=S151614982006000200006\#nt05>. Acesso em 09.04.2020.

DEBERT, Guita Grin. O velho na propaganda. Cadernos Pagu. Campinas, n. 21. Disponível em:

$<$ https://www.scielo.br/scielo.php?script=sci arttext\&pid=S0104-

83332003000200007>. Acesso em 21 abr. 2020. 
FELDMAN, Robert S. Introdução à psicologia. 10. ed. Porto Alegre: AMGH, 2015.

GIGLIO, Zula Garcia. A criatividade e os caminhos: em busca do mapa no processo de envelhecimento. In: BRUNS, Maria Alves de T.; DEL-MASSO, Maria Cândida S. Envelhecimento humano: diferentes perspectivas. Campinas: Alínea, 2007. cap. 5, p. 73-89.

HALL, Calvin S.; LINDZEY, Gardner; CAMPBELL, John B. Teorias da personalidade. 4. ed. Porto Alegre: Artmed, 2007.

MATOS, Cássio Luiz Aragão. A juvenilização do idoso na cultura de consumo: construção de identidades e culto ao corpo. $18^{\circ}$ Redor, Recife, 2014. Disponível em:

$<$ http://www.ufpb.br/evento/index.php/18redor/18redor/paper/viewFile/1933/657 >. Acesso em 22 abr. 2020.

MÍDIA. Dicionário on line. Disponível em: <https://www.dicio.com.br/midias/>>. Acesso em 29 abr. 2020.

MIRANDA, Gustavo Lima de. A história da evolução da mídia no Brasil e mundo. Monografia (Comunicação social com ênfase em publicidade e propaganda). Centro Universitário de Brasília - UniCEUB, Brasília, 2007. Disponível em:

$<$ https://repositorio.uniceub.br/jspui/bitstream/123456789/1265/2/20266495.pdf >. Acesso em 29 abr., 2020.

PAPALIA, Diane E.; FELDMAN, Ruth Duskin. Desenvolvimento humano. Tradução de Cristina Monteiro e Mauro de Campos Silva. 12. ed. Porto Alegre: AMGH, 2013.

OMS - Organização Mundial da Saúde. Envelhecimento ativo: uma política de saúde. Brasília, 2005. Disponível em:

$<$ http://bvsms.saude.gov.br/bvs/publicacoes/envelhecimento ativo.pdf $>$.

Acesso em 28 abr. 2020.

. Relatório mundial de envelhecimento e saúde (resumo).

Genebra, 2015. Disponível em: <https://sbgg.org.br/wp-

content/uploads/2015/10/OMS-ENVELHECIMENTO-2015-port.pdf > $>$. Acesso

em 30 abr. 2020.

SALZEDAS, Patrícia L.; BRUNS, Maria Alves de T. O corpo em transformação: a silenciosa passagem pelo tempo. In: BRUNS, Maria Alves de T.; DEL-

MASSO, Maria Cândida S. Envelhecimento humano: diferentes perspectivas. Campinas: Alínea, 2007. cap. 1, p. 13-33.

SCHNEIDER, Rodolfo Herberto; IRIGARAY, Tatiana Quarti. O envelhecimento na atualidade: aspectos cronológicos, biológicos, psicológicos e sociais.

Estudos de Psicologia, Campinas, v. 25, n. 4, p. 585-593, dez. 2008. 
Disponível em <http://www.scielo.br/scielo.php?script=sci_arttext\&pid=S0103166X2008000400013\&lng=en\&nrm=iso>. Acesso em 04 mar. 2020.

SEIS ideias memoráveis do escritor Umberto Eco sobre redes sociais e tecnologia. Época. 2016. Disponível em:

$<$ http://epoca.globo.com/vida/noticia/2016/02/5-frases-memoraveis-do-escritorumberto-eco-sobre-redes-sociais-e-tecnologia.html>. Acesso em: 29 abril. 2020.

SOCIEDADE brasileira de geriatria e gerontologia. OMS divulga metas para 2019: desafios impactam a vida de idosos. jan., 2019. Disponível em: $<$ https://sbgg.org.br/oms-divulga-metas-para-2019-desafios-impactam-a-vidade-idosos/>. Acesso em 30 abr. 2020.

STACHESKI, Denise Regina; MASSI, Gisele Aparecida Athayde. Índices sociais de valor: mass media, linguagem e envelhecimento. Interface: comunicação, saúde, educação, v.15, n.37, p. 425-436, abr.jjun. 2011. Disponível em: <http://www.scielo.br/scielo.php?script=sci_arttext\&pid=S1414$32832011000200008 \&$ lang=pt>. Acesso em 04 mar. 2020.

TRINDADE, Ellika; BRUNS, Maria Alves de Toledo. Meia idade masculina: significados do envelhecimento. In: BRUNS, Maria Alves de T.; DEL-MASSO, Maria Cândida S. Envelhecimento humano: diferentes perspectivas.

Campinas: Alínea, 2007. cap. 3, p. 35-52. 


\title{
COMPREENDENDO O TRANSTORNO DA CONDUTA: uma análise sobre o caso de Mary Bell
}

Caio César de Paula caiocesardepaula1409@gmail.com

Julia Lopes Rodrigues jlopesrod17@gmail.com

Sofia Muniz Alves Gracioli sofiagracioli@yahoo.com

\section{INTRODUÇÃO}

A psicopatologia é a área do conhecimento que tem como objetivo estudar os estados psíquicos que causam sofrimento mental. Nessa abordagem, existem diversos transtornos conhecidos e classificados, o que facilita a compreensão da área da saúde psicológica e também para a autocompreensão do sujeito e de sua família a respeito de determinado transtorno. Dentre as doenças mentais compreendidas, o transtorno da conduta está relacionado a um padrão persistente de violação dos direitos básicos de outras pessoas, assim como o descumprimento de normas, regras e até mesmo leis.

Segundo Bordin e Offord (2000), o transtorno da conduta se caracteriza pela apresentação de comportamentos socialmente inadequados, podendo até transgredir as leis do Estado. Sendo comum no sexo masculino e em crianças cima dos dez anos. Nessa condição, a pessoa está isenta de sentimentos como culpa, remorso, empatia, valores morais culturais.

\begin{abstract}
Há de se considerar que o adolescente que apresenta condutas e comportamentos motores característicos do transtorno de conduta social, sob o ponto de vista moral, não se angustia com o que faz e com o julgamento alheio, por se encontrar em uma temporalidade permeada por uma condição moral diferente da vivenciada pelos outros que estão em relação com ele. Logo, o mesmo vivencia uma moralidade individual que se apresenta socialmente por uma escala de valores morais e éticos. (CODEA; BERESFORD, 2004, n.p.).
\end{abstract}

$\mathrm{Na}$ contemporaneidade, o transtorno da conduta vem sido discutido, no cenário psiquiátrico internacional, principalmente em relação às ações preventivas, que demonstram ineficácia no cenário brasileiro, pois o foco está mais em conter o sujeito, do que compreendê-lo. A necessidade de investigação sobre o transtorno da conduta, e especificamente, em crianças que cometeram crimes é algo de extrema importância, visto que, no cenário brasileiro não é incomum crianças ou adolescentes infringirem a lei.

O objetivo do presente trabalho foi pesquisar e enfatizar os impactos que o transtorno da conduta evoca em diversos jovens, abordando as 
consequências tanto para o sujeito, quanto para o social e também uma análise específica sobre crianças que cometeram crimes, enfatizando como a área judicial age sobre crianças criminosas e se há apoio da área da saúde sobre essas crianças, pois se trata de um transtorno.

Para investigar e esclarecer o tema exposto realizou-se uma revisão bibliográfica crítica com uso de artigos científicos e livros com a finalidade de procurar relatos verdadeiros sobre crianças criminosas e como a sociedade enquadrará essas crianças. Trata-se de um tema que pode interessar aos pesquisadores brasileiros, devido à vasta demanda de cuidados em saúde mental na faixa etária infanto-juvenil, juntamente com as discussões em torno da formulação da política de saúde voltada para essa população, ainda mais no contexto do Brasil, em que é comum crianças apresentarem comportamentos não esperados para idade, e principalmente comportamentos criminosos.

\section{DELIBERAÇÕES SOBRE TRANSTORNO DE CONDUTA}

Entende-se como comportamento antissocial quando há o desrespeito aos direitos alheios, violações de normas morais, ou legais. (HENRIQUES, 2014). O DSM-V utiliza o termo PDC (Problemas de Conduta), englobando o transtorno de oposição desafiante (TOD) e o transtorno da conduta (TC) (DSM-V, 2014).

Os PDC possuem comportamentos de violência e criminalidade (MURRAY et al., 2013). Alguns estudos mostram que a delinquência juvenil está interligada ao fator de risco para TC e TOD. (MURRAY e FARRINGTON, 2010).

Os PDC desemprenham papel crítico em comportamentos posteriores de violência e criminalidade (MURRAY et al., 2013; PICKLES e HILL, 2006). Estudos apontam como preditores de delinquência juvenil coincidem com fatores de risco do Transtorno da Conduta e do Transtorno de Oposição Desafiante, como anteriormente mencionados: impulsividade, baixo QI, pouca escolaridade, negligente e/ou insuficiente educação infantil, abuso, conflito com pais, famílias disruptivas, pais antissociais, influência dos pares, fatores socioeconômicos, problemas escolares e na comunidade (MURRAY e FARRINGTON, 2010).

A identificação precoce de PDC é de extremamente importante para a gestão de políticas públicas de prevenção de saúde mental, principalmente para grupos que estão em situações adversativas em um contexto repleto de fatores de risco (OMS, 2001). 


\subsection{Critérios Diagnósticos}

O DSM-V compreende o transtorno da conduta como um padrão de comportamento repetitivo e persistente no qual são violados direitos básicos de outras pessoas ou normas e regras sociais relevantes e apropriadas para a idade. É necessária, em um período de 12 meses, a presença de pelo menos três dos 15 critérios seguintes, de qualquer uma das categorias adiante, com ao menos um critério presente nos últimos seis meses.

\section{Em relação a: Agressão a Pessoas e Animais}

1. Frequentemente provoca, ameaça ou intimida os outros. 2. Frequentemente inicia brigas físicas. 3. Usou alguma arma que pode causar danos físicos graves a outros.4. Foi fisicamente cruel com pessoas. 5. Foi fisicamente cruel com animais. 6 . Roubou durante 0 confronto com uma vítima.7. Forçou alguém a atividade sexual. (DSM-V, p. 470).

Em relação a: Destruição de Propriedade

Os critérios são: "8. Envolveu-se deliberadamente na provocação de incêndios com a intenção de causar danos graves. 9. Destruiu deliberadamente propriedade de outras pessoas." (DSM-V, 2014, p. 470).

Em relação a: Falsidade ou Furto

Os critérios são: "10. Invadiu a casa, edifício ou carro de outra pessoa.11. Frequentemente mente para obter bens materiais, favores, ou para evitar obrigações.12. Furtou itens de valores consideráveis sem confrontar a vítima." (DSM-V, 2014, p. 470).

Em relação a: Violação Graves de Regras

13. Frequentemente ficou fora de casa à noite, apesar da proibição dos pais, com início antes dos 13 anos.14. Fugiu de casa, passando a noite fora, pelo menos duas vezes enquanto morando com os pais ou lar substituto, ou uma vez sem retornar por um longo período.15. Com frequência falta às aulas, com início antes dos 13 anos. (DSM-V, 2014, p. 470).

É necessário compreender também se a perturbação comportamental causa prejuízos no funcionamento social, acadêmico ou profissional, e também se o indivíduo tem mais de 18 anos, os critérios para transtorno de personalidade antissocial não são preenchidos. (DSM-V, 2014).

O transtorno da conduta possuí alguns subtipos em relação ao início, em que o Tipo com início na infância é para indivíduos que apresentem pelo menos um sintoma do transtorno antes dos 10 anos. Após os 10 anos é classificado como Tipo com início na adolescência. Há também o Início não 
especificado, em que não há informações se houveram sintomas antes ou depois dos 10 anos.

Também é necessário especificar se ocorre o que é denominado como "Emoções pró-sociais limitadas", em que o sujeito deve apresentar pelo menos duas das seguintes características: Ausência de remorso ou culpa, Insensível - falta de empatia, despreocupado com o desempenho, Afeto superficial ou deficiente. Lembrando que no período de pelo menos 12 meses e em múltiplos relacionamentos e ambientes. (DSM-V, 2014).

Quanto à gravidade, o transtorno da conduta pode ser leve, moderada ou grave, dependendo das ações que comete. Entende-se como grave ações como sexo forçado, crueldade física, uso de armas, roubo com confronto à vítima, entre outros. (DSM-V, 2014).

\subsection{Prevalência}

Ainda de acordo com o DSM-V (2014), a prevalência na população varia de 2 a mais de $10 \%$ (com $4 \%$ de mediana). As taxas de prevalência aumentam da infância para a adolescência e são presentes mais no sexo masculino. Poucas crianças com transtorno da conduta recebem tratamento.

As pesquisas apontam altas taxas de transtorno de conduta em crianças e adolescentes brasileiros, sendo em média de 3,6\%. Importante ressaltar que o nível socioeconômico baixo, o sexo masculino, a baixa escolaridade da mãe, e problemas de saúde mental materno juntamente com a violência estão entre os fatores de risco mais identificados na literatura nacional e internacional (BORDIN, CURTO, DUARTE, PERES, NASCIMENTO e PAULA, 2009; MURRAY et al., 2013; PAULA, ZAYAT, YASSUTAKE e NAKAMURA, 2015).

\subsection{Desenvolvimento e Curso}

O DSM-V (2014) compreende que o transtorno da conduta pode ocorrer nos anos pré-escolares e o transtorno de oposição desafiante atua como precursor comum ao transtorno de conduta. O transtorno da conduta pode ser diagnosticado em adultos, porém os sintomas surgem na infância e adolescência, sendo raríssimos à aparição de sintomas aos 16 anos a diante.

Indivíduos com transtorno de conduta leve, e com sintomas no início na adolescência, tem uma melhor tendência à remissão na vida adulta, conseguindo se adequar ao social e ao profissional. Porém, o mesmo dificilmente ocorre com sujeitos com transtorno de conduta grave, principalmente se os sintomas são na infância, levando ao comportamento criminal, uso de substâncias, transtornos de humor, ansiedade, de estresse 
pós-traumático, psicóticos, do controle de impulsos, de sintomas somáticos, entre outros. (DSM-V, 2014).

\subsection{Fatores de Risco e Prognóstico}

O DSM-V (2014) lista dentre os fatores de risco, o comportamento temperamental de difícil controle e inteligência abaixo da média, assim como fatores ambientais, como, por exemplo, a negligência parental, abuso físico e sexual, disciplina agressiva, família excessivamente grande e criminalidade na família. Há também fatores genéticos e fisiológicos, sendo mais frequente em sujeitos cujos pais possuem transtorno por uso de álcool graves, depressivos, bipolares ou esquizofrenia, e com pais com TDAH ou transtorno de conduta.

Outros fatores de risco relevantes são:

Impulsividade, baixo QI, escolaridade baixa ou falta de escolaridade, abuso, divergências com os pais, famílias disruptivas, pais antissociais, influência da família ou de qualquer parentesco, fatores socioeconômicos, o contexto social do sujeito. (MURRAY e FARRINGTON, 2010).

Portanto, fica evidente a relação do contexto familiar e social, para o surgimento de possíveis PDC, contudo, a sociedade foca primeiramente em julgar o sujeito pelos seus atos, e puni-lo, geralmente o afastando do convívio social, por meio de encarceramento, sem o apoio psicológico, o sujeito com TC irá prosseguir seu desenvolvimento com os mesmos sintomas, podendo até elevá-los, por isso se faz necessário a atuação da área da saúde juntamente com a área judicial.

\subsection{Diagnóstico Diferencial}

O DSM-V (2014) diferencia o transtorno da conduta de outros transtornos, por exemplo, o transtorno de oposição desafiante está relacionado mais com conflitos sobre figuras de autoridade, sendo menos graves que 0 transtorno de conduta, no qual pode ocorrer até violência contra figuras de autoridade.

Em relação ao transtorno de déficit de atenção/hiperatividade, não é comum crianças com TDAH cometerem violações às normas e regras, e principalmente leis, por isso a diferenciação, mesmo crianças com TDAH apresentarem um comportamento mais hiperativo, não se iguala aos comportamentos de uma criança com transtorno de conduta. O transtorno depressivo e bipolar também apresenta irritabilidade, agitação, mas estão interligados ao humor e raramente ocasionarão nas consequências vistas no transtorno da conduta. $O$ transtorno explosivo intermitente também envolve altas taxas de agressividade, porém com foco em obtenção de algo e os 
critérios diagnósticos não incluem os sintomas não agressivos presentes no transtorno da conduta. (DSM-V, 2014).

\subsection{Comorbidades}

O DSM-V (2014) aborda que as comorbidades mais frequentes juntos ao transtorno de conduta são o TDAH e o transtorno de oposição desafiante. Há relação também como o transtorno de conduta e pessoas com algumas características de transtorno de personalidade antissocial, é comum sujeitos com transtorno de conduta serem diagnosticados com o transtorno de personalidade antissocial (vulgarmente chamado de psicopata), após os 18 anos.

\subsection{Tratamentos}

Há 3 principais formas de tratamento, sendo elas: fármacos para tratamento de comorbidades, psicoterapia e, ocasionalmente, acomodação em um centro residencial.

O tratamento das comorbidades com fármacos ou psicoterapia pode melhorar a autoestima e o autocontrole e, essencialmente, melhorar o transtorno de conduta. Os fármacos podem incluir estimulantes, estabilizadores do humor e antipsicóticos atípicos, especialmente o uso a curto prazo de risperidona. (ELIA, 2017).

Outros aspectos que devem ser levados em consideração no tratamento é o evitamento de moralização e advertências bruscas, pois são ineficazes. A psicoterapia individual, incluindo terapia cognitiva e modificação do comportamento é uma excelente escolha também. Crianças e adolescentes com distúrbios graves devem ser acomodados em centros de residência onde o comportamento deles possa ser trabalhado da melhor maneira, afastando-os do ambiente estressor que possa contribuir para os sintomas.

\section{CRIANÇAS QUE COMETERAM ASSASSINATOS EM SÉRIE: O CASO DE MARY BELL}

Muitos casos de assassinos em série são divulgados nas sociedades e estudados por aqueles que se interessam no assunto, como o de Jeffrey Dahmer, Ted Bunty, Albert Fish, Francisco de Assis Pereira (Maníaco do Parque) e Pedro Rodrigues Filho (Pedrinho Matador), que são famosos entre o ramo dos serial killers e fazem jus ao que denominamos de psicopatia especificamente transtorno de personalidade antissocial. Convém ressaltar que esses indivíduos são adultos e, por isso, recebem a caracterização da doença mental descrita acima. Porém, não somente os maiores de idade cometem 
crimes agressivos e violentos, e diversos relatos de crianças homicidas são também exemplificados na área forense.

O transtorno de conduta é caracterizado por porte agressivo, não agressivo, defraudação e furto, permeado por comportamentos persistentes que violam direitos básicos dos outros, normas ou regras sociais. Indivíduos com essa psicopatologia demonstram pouca empatia, são agressivos, isentos de culpa ou remorso e, principalmente, possuem início dos sintomas na infância ou adolescência. Além disso, de acordo com Bordin e Offord (2000):

\begin{abstract}
São fatores associados a comportamento antissocial na infância: ser do sexo masculino, receber cuidados maternos e paternos inadequados, viver em meio à discórdia conjugal, ser criado por pais agressivos e violentos, ter mãe com problemas de saúde mental, residir em áreas urbanas e ter nível socioeconômico baixo. Fatores individuais, familiares e sociais estão implicados no desenvolvimento e na persistência do comportamento antissocial [...] (BORDIN; OFFORD, 2000, n.p.).
\end{abstract}

Em Porque as Crianças Matam: a história de Mary Bell (2019), a autora retrata as vivências da criança. Bell nasceu em 26 de maio de 1957 em Newcastle upon Tyne, Reino Unido, filha de Betty McCrickett. Foi criada em um ambiente hostil e matou, em um intervalo de nove semanas, dois garotos de 3 a 4 anos.

A menina foi criada por sua mãe e, posteriormente, por seu padrasto, e desconhecia seu pai biológico. No nascimento da criança, relata-se que Betty gritava, aos prantos, para que os médicos tirassem a recém-nascida de perto dela, chamando-a de "coisa". O padrasto de Mary era um traficante, e ensinava a ela que as autoridades eram inimigas, sendo o parente mais próximo de Mary. Betty era prostituta e possuía perturbações mentais, o que ocasionou em diversas tentativas de doar ou matar Mary e a oferecer o corpo da criança para sua clientela, incentivando os abusos sexuais pedofílicos que a garota sofria. Mary, apresentando sintomas dos abusos, possuía incontinência urinaria o que gerava maus tratos por parte de sua mãe.

Acompanhada de Norma Bell (sem parentesco), as duas possuíam rancores por seus ambientes familiares e, portanto, eram inseparáveis, por sua amizade ser sustentada principalmente pelo sofrimento vivido por ambas. Juntas, invadiram escolas e deixaram bilhetes confessando os crimes: em 25 de maio de 1968, um garoto de quatro anos e dois meses, chamado Martin Brown saiu de sua casa para passear. Um tempo após comprar um pirulito em uma vendinha do bairro, seu corpo foi achado por garotos que procuram lenha nas casas abandonadas do local. Ele estava deitado de barriga para cima, com sangue misturado com saliva, sem sinais de luta. Foram achados também vidros vazios de comprimidos, o que sugestionou envenenamento. Nove semanas depois, em 29 de julho de 1968, o corpo de Brian Howe, de apenas três anos, foi encontrado com pequenas feridas feitas 
por objetos pontiagudos, em sua barriga estava marcada a letra "M" e, ligeiramente, um "N" e, em seu pescoço, leves marcas de mão.

Por conta das inconsistências de seus relatos, Mary e Norma foram levadas a julgamento. Durante o julgamento, as crianças não pareciam possuir consciência da gravidade de seus atos. $\mathrm{Na}$ época, a mídia sensacionalista divulgou notícias de como Mary era "inerentemente má", uma "semente ruim" ou até mesmo o "anticristo".

A garota principal não possuía noções de que a morte era permanente, e, por isso, questionava sua longevidade. Mary, dias após assassinar Martin, foi até sua casa e perguntou pelo garoto, pois queria conversar com ele. No livro escrito por Gitta (2019), Mary explicita o que a levou a pensar dessa maneira: conta que tinha um cachorro da qual amava muito e que, em determinado momento, o animal acabou morrendo. Mas, logo depois, o padrasto apareceu com outro cachorro idêntico, o que gerou, na menina, ideias de que a morte seria "dormir por mais tempo". Em conformidade com Codea e Beresford (2004), que citam Kohlberg (1992):

\begin{abstract}
Para Köhlberg (1992) tal adolescente está no nível pré-convencional do desenvolvimento moral humano, embora pela faixa etária devesse estar saindo do nível convencional para o pós-convencional. Ele não consegue se articular com o social compreendendo as regras e percebendo que do mesmo ele faz parte, construindo e definindo seus valores morais a partir de suas carências, identificando-se com um projeto para tornar-se adulto. [...] O nível pré-convencional implica em uma postura heterônoma. $\mathrm{O}$ adolescente tem seu comportamento sob uma perspectiva egocêntrica, não considerando as diferenças interpessoais e os interesses alheios. Reage fisicamente às considerações verbais e não tem discernimento sobre a influência da autoridade alheia em sua vida devido à noção equivocada de limite individual e social. Isto porque, desenvolve um individualismo que 0 dificulta perceber que todos os outros também têm seus interesses, 0 que gera conflito, pois o correto se torna relativo. (CODEA, BERESFORD, 2004, n.p. apud KOHLBERG, 1992, n.p.).
\end{abstract}

Mary Bell e Norma Bell foram julgadas em tribunais de adultos, sem que os delegados ali possuíssem noção das experiencias traumáticas das duas, nem como se comunicavam a partir de suas fantasias, como expõe Ximenes, Oliveira e Assis (2009):

No âmbito da família (especialmente quando se trata de crianças e adolescentes), agressões físicas graves, abuso sexual, tortura, ameaças à vida da pessoa ou de alguém próximo podem ser considerados como eventos ameaçadores, desencadeando o quadro de TEPT. [...] O transtorno de estresse pós-traumático (TEPT) é um dos problemas de saúde mental mais associado à vitimização por violência. Atinge crianças, adolescentes e adultos após experiência pessoal, testemunho ou conhecimento de eventos que põem em risco à vida ou integridade física, própria ou de outros. [...] A Associação de Psiquiatria Americana (APA) caracteriza TEPT pelo surgimento de sintomas após a exposição a um evento traumático que cause medo intenso, impotência ou terror, envolvendo morte, ferimentos, agressões reais; ou ameaças à integridade física da pessoa ou de outros. O estressor é considerado como ameaçador à vida. [...] Para 
caracterizar TEPT, os sintomas devem causar sofrimento e prejuízo significativo em áreas importantes da vida e estar ocorrendo há mais de um mês. (XIMENES; OLIVEIRA; ASSIS, 2009, n.p.).

Norma Bell foi absolvida do caso, já Mary, com apenas 11 anos, foi julgada e condenada à prisão perpétua, onde cumpriu 12 anos da pena.

\section{DESTINAÇÕES E PROPÓSITOS DO DIREITO}

Após ser liberada de sua pena, Mary Bell participou de uma pesquisa realizada por Gitta Sereny (releitura realizada em 2019) em que relata os acontecidos da época. De acordo com os esclarecidos, o julgamento penal de Mary foi baseado nas notícias sensacionalistas do período, que difundiam a ideia de que Bell era má por natureza, o anticristo. Além disso, a criança foi julgada em um tribunal de adultos, de caráter retribucionista, uma das fases do julgamento de crianças e adolescentes ao longo da história:

A primeira fase, que se estendeu desde o surgimento dos códigos penais de caráter nitidamente retribucionistas do século XIX até o código de 1919, foi caracterizada pela responsabilização penal indiferenciada entre menores de 18 anos e adultos. (SIMONE, 2010, p. 12).

A audiência e os jurados do caso não tinham conhecimento dos traumas que Bell havia vivenciado, e de como esses episódios teriam influenciado na postulação de sua personalidade e seus comportamentos. Por isso, não levaram em conta a veracidade e a importância do estado do fenômeno mental da menina, julgando-a por homicídio culposo com responsabilidade atenuante, pegando prisão perpétua. Ressalta-se: 0 homicídio culposo ocorre quando um sujeito tira a vida de outro sem intenção, por negligência ou imperícia por parte do autor. A culpa é inconsciente, e o individuo não possuía a real intenção do crime. A responsabilidade atenuante se dá quando o ato é amenizado, como em confissões voluntárias do agente, buscando reduzir o impacto da punição do crime. Bell relata, no livro, os horrores que viveu na prisão, como tortura e isolamentos prolongados.

De 1969 a 1973, Mary Bell foi alojada em uma instituição chamada Red Bank, uma "escola de recuperação", que possuía como intenção de que esses lares comunitários se adentrassem na comunidade e que as crianças parassem de ser institucionalizadas, mas consideradas humanas, 0 que realmente são. A atmosfera criada na instituição era voltada para o afeto e o amor, tentando ajudar as crianças na compreensão de seus estados psíquicos - ainda que, em partes, falha, devido à isenção de profissionalismo psicológico.

A partir da Constituição Federal de 1988 e do ECA, as crianças e adolescentes brasileiros passaram a ser vistos como cidadãos, aos quais se deve garantir direitos fundamentais (vida, educação, saúde, escola, respeito, dentre outros), o que antes era negligenciado pelos instrumentos jurídicos que tratavam, quase que restritamente, dos 
deveres dessa parcela da população. Porém, vale salientar que o ECA não é um estatuto elaborado para acolher e desresponsabilizar os jovens de seus atos. (MONTE et al, 2011, n.p.).

O Estatuto da Criança e do Adolescente busca, especialmente, acabar com concepções generalistas e, assim, atentar-se às condições de desenvolvimento desses sujeitos, suas situações de risco e vivências diversas, tornando o menor infrator passível de responder por seus atos através de parâmetros socioeducativos - mas que não despenalizem o sujeito.

\begin{abstract}
Dessa forma, o adolescente autor de ato infracional é passível de responder pelo seu ato através do cumprimento de medidas socioeducativas, as quais podem ser dos seguintes tipos: (1) advertência, (2) obrigação de reparar o dano, (3) prestação de serviços à comunidade, (4) liberdade assistida, (5) inserção em regime de semiliberdade e (6) internação em estabelecimento socioeducativo. Ressalta-se que a aplicação de medidas socioeducativas referentes aos adolescentes que cometem atos infracionais deve seguir algumas orientações, tais como a obrigatoriedade de escolarização e profissionalização, bem como a garantia de atendimento personalizado, respeitando a identidade e singularidade dos adolescentes. Quando o ato infracional tiver sido cometido por crianças, serão aplicadas medidas de proteção como, por exemplo, matrícula e frequência obrigatórias em estabelecimento oficial de ensino. Especialmente no caso das instituições de internamento, as orientações do ECA e do SINASE buscam afastar a imagem dessas instituições dos presídios ou das antigas FEBEMs, nas quais o tratamento as aproximava das chamadas "Instituições Totais", que se caracterizam pelo tratamento despersonalizado, padronizado e pela falta de mobilidade e poder de contratualidade dos usuários do serviço (Goffman, 1974). Ou seja, nessas instituições, o tratamento dispensado para todos os casos ignora os aspectos individuais de cada sujeito. (MONTE et al, 2011, n.p.).
\end{abstract}

Entretanto, em 1973, após meses de batalha contra o estado, Mary Bell foi transferida para uma prisão. A garota relata como esse fato foi de total negatividade para ela, visto que é obrigada a deixar um lar que the transmitia segurança para voltar para a detenção que a humilhava e martirizava. Ela, por outro lado, explicita que preferiria ir para qualquer lugar a voltar para casa (GITTA, 2019).

Embora haja dificuldades financeiras e estruturais, o ideário da punição e do castigo como bases pedagógicas para a ressocialização de crianças e adolescentes autores de ato infracional ainda parece se configurar como o maior obstáculo a um trabalho comprometido com a formação autônoma desses jovens. Em muitas instituições de ressocialização, os adolescentes são considerados delinquentes, que, por sua "natureza ruim", são irrecuperáveis e altamente perigosos. Desconsidera-se, portanto, que eles são indivíduos cujo desenvolvimento sofre forte influência das desigualdades e injustiças sociais a que são submetidos, assim como do tipo de relação interpessoal prevalente nos locais em que eles cumprem medidas socioeducativas. (MONTE et al, 2011, n.p.). 
Em maio de 1980, Bell foi liberada da prisão, após ficar dos 11 aos 23 anos encarcerada. Desde então, Mary nunca fez mal a nenhum outro ser, comprovando sua redenção.

\section{CONSIDERAÇÕES FINAIS}

Concluímos que o transtorno da conduta vivenciado pela criança abordada no presente artigo científico exemplifica a ideologia de que, na maioria dos casos, as patologias se desenvolvem após a experimentação de traumas que não conseguem ser assimilados por seu fenômeno mental, visto vez que Mary sofreu abusos e violências durante toda sua infância. Vale lembrar que nem toda pessoa que passa por um evento traumático vai, necessariamente, desenvolver o transtorno em questão.

Acerca do tratamento psicoterápico, deve-se sempre tratar os sujeitos de acordo com suas demandas, voltando-se para fármacos, psicoterapia e, caso necessário, acomodação em um centro residencial, como também é importante a análise de seu contexto ambiental, para que sejam essencialmente abordados e remanejados de forma adequada e positiva.

O transtorno de conduta é um transtorno complexo, e deve ser tratado especialmente em suas fases iniciais, a fim de prevenir possíveis agravamentos. Em casos de descuidados, a doença pode resultar no que chamamos de transtorno de personalidade antissocial, datado a partir da idade adulta. Por isso, a prevenção breve deve ser priorizada.

Por fim, destacamos a possibilidade de aprofundamento no tema sobre a penalização e as noções de direito em um próximo trabalho, em que poderia ser estabelecida uma investigação minuciosa sobre o destino penal de crianças que cometem crimes graves, como assassinato. A importância de se trabalhar o pressuposto é buscar a desvinculação das bases diretrizes do Direito - que implica diretamente na sociedade em que está habituado - com a ideologia de que crianças são nada mais que miniaturas de adultos e que, isentas de contexto e fatores internos, são inerentemente más e sombrias, como foi julgado erroneamente no caso de Mary Bell.

\section{REFERÊNCIAS}

AMERICAN PSYCHIATRIC ASSOCIATION. DSM-V: Manual diagnóstico e estatístico de transtornos mentais. Trad. Maria Inês Corrêa Nascimento; 5.ed. Porto Alegre: Artmed, 2014.

BORDIN, I.A.S.; OFFORD, D.R. Transtorno da conduta e comportamento antissocial. Rev. Bras. Psiquiatr., v.22, supl.2, p.12-5, 2000. 
BORDIN, Isabel; DUARTE, Cristiane; PERES, Clovis; NASCIMENTO, Rosimeire; CURTO, Bartira, PAULA, Cristiane Silvestre. Severe physical punishment: risk of mental health problems for poor urban children in Brazil. Bull World Health Organ-Vol. 87, no 5, pp. 336-344, 2009.

CODEA, Janaina de Souza Marinho Teles; BERESFORD, Heron. O adolescente com transtorno de conduta: um estudo filosófico no âmbito da psicologia educacional e esportiva. Psicol. esc. educ. Campinas, v.8, n.1, p. 67-74, $2004 . \quad$ Disponível em: $<$ http://pepsic.bvsalud.org/scielo.php?script=sci_arttext\&pid=S1413$85572004000100008 \&$ Ing=pt\&nrm=iso $>$. Acesso em: 21 de setembro de 2020.

ELIA, Josephine. Distúrbios de conduta. Manual MSD Versão para Profissionais da Saúde, 2017. Disponível em: https://www.msdmanuals.com/pt-br/profissional/pediatria/transtornos-mentaisem-crian\%C3\%A7as-e-adolescentes/dist\%C3\%BArbios-deconduta?query=Transtorno\%20de\%20conduta. Acesso em: 21 set. 2020.

GITTA, Sereny. Porque Crianças Matam: a história de Mary Bell. Belo Horizonte: Editora Vestígio, 2019.

HENRIQUES, Brigite Micaela. Comportamento antissocial na infância e adolescência-revista INFAD de Psicología-Vol 4 (1), 2014.

MURRAY, Joseph; ANSELMI, Luciana; GALLO, Erika Alejandra Giraldo; FLEITLICH-BILYK, Bacy; BORDIN, Isabel. Epidemiology of childhood conduct problems in Brazil: systematic review and meta-analysis-social Psychiatry and Psychiatric Epidemiology-Vol 48, nำ10, pp. 1527-1538, 2013.

MURRAY, Joseph; FARRINGTON, David. Risk Factors for Conduct Disorder and Delinquency: Key Findings from Longitudinal Studies. The Canadian Journal of Psychiatry-Vol. 55, no10, pp. 633-642, 2010.

MONTE, Franciela Félix de Carvalho et al. Adolescentes autores de atos infracionais: psicologia moral e legislação. Psicol. Soc. Florianópolis, v. 23, n. 1, p. 125-134, 2011. Disponível em: <http://www.scielo.br/scielo.php?script=sci_arttext\&pid=S0102-

$71822011000100014 \&$ Ing=en\&nrm=iso $>$. Acesso em: 21 de setembro de 2020.

PAULA, Cristiane de Paula; ZAYAT, Suzana Pessoa Guerra; YASSUTAKE, Maysa; NAKAMURA, Eunice. Estudos sobre preditores de problemas de saúde mental na infância: uma revisão sistemática da literatura sobre estudos epidemiológicos longitudinais In: XXXIII CONGRESSO BRASILEIRO DE PSIQUIATRIA, 2015, FLORIANÓPOLIS. Anais: XXXIII Congresso Brasileiro de Psiquiatria. Associação Brasileira de Psiquiatria, 2015. v.1. p.1-1.

SAÚDE, Organização Mundial da. Saúde mental: nova concepção, nova esperança. Rio de janeiro: OMS, 2001. 
SILVA, Luna Rodrigues Freitas. Transtorno da conduta: uma oportunidade para a prevenção em saúde mental? Botucatu: Interface, v. 15, n. 36, p. 165173, $2011 . \quad$ Disponível <http://www.scielo.br/scielo.php?script=sci_arttext\&pid=S1414-

32832011000100013\&lng=en\&nrm=iso>. Acesso em: 21 de setembro de 2020.

SIMONE, Luiz Otávio Campos. Adolescente em conflito com a lei: da criminologia clássica à justiça restaurativa. Florianópolis: Unisul, 2010. Disponível em: https://www.riuni.unisul.br/bitstream/handle/12345/671/101738_Luiz.pdf?seque nce $=1$ \&isAllowed=y. Acesso em: 21 de setembro de 2020 .

VILHENA, Karime; PAULA, Cristiane Silvestre de. Problemas de conduta: prevalência, fatores de risco/proteção; impacto na vida escolar e adulta. Cad. Pós-Grad. Distúrb. Desenvolv., São Paulo, v. 17, n. 1, p. 39-52, jun. 2017. Disponível em <http://pepsic.bvsalud.org/scielo.php?script=sci_arttext\&pid=S1519$03072017000100005 \&$ Ing=pt\&nrm=iso>. Acesso em 21 set. 2020.

XIMENES, Liana Furtado; OLIVEIRA, Raquel de Vasconcelos Carvalhães de; ASSIS, Simone Gonçalves de. Violência e transtorno de estresse póstraumático na infância. Ciênc. saúde coletiva, Rio de Janeiro, v. 14, n. 2, p. 417-433, 2009 . Disponível
<http://www.scielo.br/scielo.php?script=sci arttext\&pid=S1413$81232009000200011 \& \operatorname{lng}=$ en\&nrm=iso $>$. Acesso em 21 de setembro de 2020. 
HÁBITOS E PADRÕES DE COMPORTAMENTO: zona de conforto

Ana Laura Pacheco

Júlia Moraes

Rayssa Lima

Sofia Muniz Aves Gracioli

\section{INTRODUÇÃO}

O conceito de hábito pode ser definido como uma forma permanente ou frequente de comportar se. Ele é a repetição de um ato que se torna regra. $O$ hábito nos dá mais segurança por sentirmos em um terreno conhecido, e assim nos faz sentir na zona de conforto. Significa adquirir um comportamento de maneira natural até o ponto de tornar-se um comportamento espontâneo.

A zona de conforto é o conjunto de todos os hábitos que adquirimos durante a vida, e que nos mostra uma maneira única de comportamento nos impedindo, assim, de conhecer novas maneiras de viver. Para sair da zona de conforto é preciso adquirir novos hábitos, mesmo que no início isso seja desconfortável, uma hora se torna prazeroso, e espontâneo.

A relevância do presente trabalho explora se os indivíduos têm preparação para lidar com o autoconhecimento de seus hábitos diários e padrões de comportamentos.

O objetivo deste trabalho foi explorar o autoconhecimento e o aspecto de padrões de comportamentos diários relacionados a zona de conforto.

A metodologia a princípio foi um levantamento de artigos científico, teses e livros para o corpo teórico do presente trabalho. $O$ trabalho teve como base as teorias de Frederic Skinner e Carl Rogers, e teve como principal inspiração o livro "o poder do hábito" escrito por Charles Duhigg.

\section{COMO SÃO CRIADOS OS HÁBITOS}

Diante de todas as tarefas encontradas no dia a dia do ser humano, pode-se dizer que grande parte delas são feitas por hábitos, mais precisamente, compõem $40 \%$ de toda rotina, conforme pesquisa da Universidade Duke, dos Estados Unidos. Seria como se por nove horas no dia, a pessoa não refletisse sobre o que faz, apenas faz. Um hábito pode não ser percebido a menos que seja interferido por algo que the interrompa (e.g., dirigir para trabalhar, como faz há anos, e receber multa por excesso de velocidade por não ter percebido que a velocidade da via foi reduzida). Esses tipos de situações podem indicar a presença de um hábito em curso, o qual impede as 
mudanças desejadas ou a captação de novas informações que podem ser uteis para saúde ou segurança do sujeito.

O hábito é um comportamento aprendido que, após ser repetido várias vezes em um contexto estável, tornou-se automático, isto é, com pouca ou nenhuma deliberação do indivíduo (VERPLANKEN; AARTS, 1999). A literatura evidencia a existência do hábito em diversas situações no nosso cotidiano: no uso do transporte, como carro e bicicleta (GARDNER, 2009), na alimentação saudável, como comer frutos do mar (HONKANEN, OLSEN, \& VERPLANKEN, 2005), na realização de atividade física (VERPLANKEN \& MELKEVIK, 2008) e no ato de poupar dinheiro (LOIBL, KRAYBILL, \& DEMAY, 2011).

Quando um hábito surge, o cérebro para de tomar decisões sobre o comportamento já "automatizado", porém, o mesmo não consegue diferenciar entre hábitos bons e ruins, pois é da natureza do ser humano a tendência de fazer sempre o que é mais fácil, rápido e agradável. "Os hábitos, dizem os cientistas, surgem porque o cérebro está o tempo todo procurando maneiras de poupar esforço." (DUHIGG, 2012). Por conta disso, os hábitos nunca desaparecem, e os maus hábitos estão sempre latentes, esperando as deixas e recompensas certas.

Para que haja maior controle sobre os hábitos instaurados em uma rotina, é necessário que haja um entendimento sobre como o cérebro cria 0 hábito, o qual é formado por uma sequência de três etapas. Primeiro há uma deixa, um estímulo que manda o seu cérebro entrar em modo automático e indica qual hábito ele deve usar em uma respectiva situação. Depois há uma rotina, que pode ser física, mental ou emocional. E finalmente, há uma recompensa, que ajuda o cérebro a saber se vale a pena memorizar este específico ciclo para o futuro. Ao longo do tempo, o processo - deixa, rotina, recompensa - se torna cada vez mais automático. A deixa e a recompensa entrelaçam-se até que surja um senso de antecipação e desejo, se tornando assim um padrão neurológico: nasce o hábito.

No que se refere aos padrões de comportamento, Albert, Bagalin e De Quadros (2008) chamam a atenção para dois aspectos essenciais à formação de hábitos: os fatores culturais e os fatores relacionados à classe social que pertencem. O primeiro seria os costumes, crenças e comportamentos institucionalizados que impactam na formação e personalidade do indivíduo, enquanto o segundo refere-se à percepção do indivíduo tanto de si quanto de indivíduos pertencentes a outras classes sociais. Assim posto, ambos os aspectos "influenciam a maneira como as pessoas definem situações e como respondem a elas" (ALBERT; BAGALIN; DE QUADROS, 2008, p.12).

Portanto, segundo os teóricos citados acima, podemos perceber que 0 hábito nunca desaparece totalmente, pois precisamos deles para que em nossa rotina algumas coisas possam ser feitas com mais facilidade e rapidez. 
Deixando de forma explicita que seja qual for o hábito, ele influenciará na qualidade de vida e até no futuro como um todo.

\section{A IMPORTÂNCIA DO AUTOCONHECIMENTO}

O autoconhecimento permite que o indivíduo questione e reflita sobre suas ações diárias. Com o autoconhecimento é possível compreender padrões comportamentais, os quais não são percebidos, pois se tornaram automáticos. Todos os hábitos são aprendidos desde a nossa infância. Segundo Skinner, o ambiente é a razão principal para que um determinado comportamento aconteça, e enfatiza que ter um controle sobre o ambiente é necessário, como citado por ele em seu "livro sobre o behaviorismo":

Nosso conhecimento cada vez maior do controle exercido pelo meio ambiente torna possível examinar o efeito do mundo dentro da pele a natureza do autoconhecimento. Possibilita também interpretar uma ampla gama de expressões mentalistas (SKINNER, 2002. p.19)

Ao identificar essas práticas habituais o indivíduo tem o poder de decidir quais hábitos manter e quais não manter. Ainda assim, a pessoa poderá fazer uma auto avaliação, e entender os motivos pelo quais as situações se repetem e as motivações que ela recebe para continuar esse padrão.

Segundo Moreira e Medeiro (2007), o reforço é definido como estímulos que aumentam a frequência de dado comportamento, e complementa afirmando que existem diferentes respostas para conseguir uma recompensa. Então, ao interpretar e reconhecer os reforços de determinada atitude facilmente identifica-se o motivo para manter o comportamento.

Carl Rogers defende em sua teoria de que o indivíduo tem capacidade de se perceber e de se autoavaliar, como mencionado por ele em seu livro "psicoterapia e relações humanas":

[...]capacidade de conhecimento reflexivo; isto é, a capacidade, não somente de saber, mas de saber que se sabe. O conhecimento reflexivo torna possível a auto-avaliação e a autocorreção operações fundamentais da capacidade em questão[...] (ROGERS; KINGET, 1977. p.40)

Dessa forma, observa-se que todo indivíduo tem capacidade de se perceber e reconhecer suas vontades e direcionar seus hábitos, através de uma autoavaliação e autocorreção de seus costumes.

Rogers apresenta em sua obra, uma noção do "eu" (self), que é definida como:

[...]uma estrutura perceptual, isto é, um conjunto organizado e mutável de percepções relativas ao próprio indivíduo. Como exemplo destas percepções citemos: as características, atributos, qualidades e defeitos, capacidades e limites, valores e relações que o indivíduo reconhece como descritivos de si mesmo e que percebe como constituindo sua identidade[...] (ROGERS; KINGET, 1977, p.44) 
Carl Rogers (apud FADIMAN; FRAGER, 2004. p. 359), em sua teoria defende a existência de um self real e o self ideal. O self real é uma visão real sobre si mesmo, ou seja, o que de fato a pessoa é. Já o self ideal é aquilo que o indivíduo busca ser, como ele imagina ser, ou seja, o que os outros pensam dele, o comportamento que a sociedade espera que ele tenha. Rogers (1977) destaca que quando o self real é muito diferente do self ideal e pessoa sente um desconforto e insatisfação:

[...] Sob certos aspectos seu comportamento é regido pela tendência atualizante e, sob outros aspectos, pela tendência à atualização do eu. Como resultado o comportamento parece incompreensível e a personalidade fica desequilibrada. O comportamento neurótico é uma manifestação deste estado de desacordo. Este tipo de comportamento se conforma ora com a imagem do eu, ora com as exigências do organismo. De modo que o neurótico é incapaz de se compreender a si mesmo, pois, verifica que, por um lado, faz as coisas que não quer fazer e que, por outro abstém-se de fazer aquelas que desejaria fazer. (ROGERS; KINGET, 1977. p.169)

Assim nota-se, que ao sentir o desconforto e insatisfação causado pelo self, a pessoa desenvolve um desequilíbrio emocional, evitando assim, 0 desenvolvimento pessoal e conclui que ao se aceitar como realmente é (self real), e não como a sociedade quer se ele seja (self ideal), o indivíduo alcança sua saúde mental e a partir de então consegue seu desenvolvimento pessoal. Com isso, é notável a importância de se conhecer e reconhecer como os outros veem.

Em seu livro Silva e Vieira refletem sobre as crenças e valores que são adquiridas através de experiências "Nossa convicções definem tanto o que somos quanto o que fazemos" (SILVA E VIEIRA, 2018. p.152). Os autores, ainda, definem crenças como sendo "toda a programação mental adquirida como aprendizagem durante a vida" e valores como "tudo aquilo que damos importância". Os princípios impostos pelo grupo social podem atrapalhar no autoconhecimento da pessoa gerando assim obstáculos para sua autoavaliação, e sem a autoavaliação o indivíduo se limita diante de determinados comportamentos.

Segundo Platão (apud SILVA E VIEIRA, 2019. p.154), o mito da caverna mostra os indivíduos se libertando de suas crenças limitantes (mundo das ilusões) e conhecendo outra maneira de viver (mundo real). Ao sair do mundo das ilusões, as pessoas se sentiram libertas e puderam vivenciar novas experiências, sem os medos e crenças de antes. Os autores Silva e Vieira, ainda explicam que "o indivíduo vivencia uma experiência que, por sua vez, gera determinada crença. E essa crença que vai moldar e definir certos valores" (SILVA E VIEIRA, 2019. p.160). Com isso percebe-se que as crenças e valores são formados pelas experiências da pessoa. As crenças influenciam nas escolhas e vontades, gerando comportamentos necessários para alcançar os objetivos desejados. 


\title{
4. A INFLUÊNCIA DOS HÁBITOS PARA O SUCESSO NO DESENVOLVIMENTO PESSOAL
}

O desenvolvimento pessoal visa a potencialização de habilidades para a conquista de objetivos e obtenção de sucesso, para isso é preciso do auto conhecimento, ou seja, a pessoa precisa se auto conhecer para saber o que precisa para conquistar seus objetivos e alcançar o sucesso, seja ele pessoal ou profissional.

Para a obtenção de um desenvolvimento pessoal antes de tudo é preciso de um objetivo bem definido, e foco nesse objetivo, outro ponto importante e é automotivação, o esforço, e o autoquestionamento, a pessoa deve se questionar do que precisa ser feito para ser alcançado o objetivo esperado.

\begin{abstract}
Se você tem um hábito ruim, ele está sempre ali à espreita, esperando as deixas e recompensas certas. Isso explica por que é tão difícil criar o hábito de fazer exercícios, por exemplo, ou de mudar nossa alimentação. Uma vez que adquirimos uma rotina de sentar-se no sofá em vez de sair para correr, ou de fazer um lanchinho sempre que passamos por uma caixa de donuts, esses padrões continuam para sempre dentro das nossas cabeças (Charles Duhigg)
\end{abstract}

Outro fator importante é a criação de hábitos ligado sempre ao seu objetivo. O ser humano é um ser de costumes, e com isso qualquer ação repetida várias vezes se torna facilmente um hábito, sendo percebido ou não pelo indivíduo. Por exemplo para uma criança é um desafio abandonar a chupeta e deixar para trás o hábito de chapa-la que já se tornou uma ação espontânea.

Por isso o hábito tem grande poder dentro do indivíduo, qualquer ação se torna um hábito quando reproduzida diversas vezes. Então percebe se que qualquer ação pode ser acrescentada, modificada ou extinta, tudo depende do esforço para a formação de um hábito, é onde se dá o início do desenvolvimento pessoal, quando o indivíduo percebe a necessidade da modificação de seus hábitos para a obtenção de sucesso. A mudança pode não ser rápida, além de nem sempre ser fácil. Mas, com tempo e esforço, quase qualquer hábito pode ser reformado. (Charles Duhigg, autor do livro "O Poder do Hábito").

Portanto para obtenção do desenvolvimento pessoal, é preciso de foco, esforço, determinação, e acima de tudo a criação de bons hábitos, que não passam de repetições de uma ação, até que se tornem um costume, e vire algo rotineiro, eles devem ser sempre relacionados com as suas metas, sejam elas pessoais ou profissionais, a mudança dos hábitos é sempre uma boa opção para quem almeja mudanças em suas vidas. 


\section{CONSIDERAÇÕES FINAIS}

A partir do estudo, constata- se que os hábitos são formados por uma série de crenças, costumes e padrões repetitivos de comportamentos, que são aprendidos por meio de experiências e estímulos 0 qual são proporcionados pelo meio. Com isso, notou-se que para reconhecer um hábito é necessário um processo de auto- conhecimento, onde após a pessoa realizar esta etapa, acontece o processo de auto- avaliação, o qual o sujeito identifica seus costumes, e com isso, espera- se que procure novos objetivos e novas maneiras de se relacionar socialmente.

Os hábitos são comportamentos que geram uma recompensa e sensação de bem-estar ao indivíduo, sendo assim gerados pela impulsividade, portanto não planejados, porém este hábito não acontece somente quando há gratificações, sendo executados também em momentos indesejados, levando a consequências hostilizadas, e é neste momento que o indivíduo tem de trabalhar as técnicas de auto controle, ou seja, controlar suas impulsividades, para conseguir resultados recompensadores.

Esta pesquisa bibliográfica teve como base as teorias de Burrhus Frederic Skinner e Carl Rogers, e como principal fonte teórica o livro "O poder do hábito" escrito por Charles Duhigg. Em seu livro, Charles observa a importância da auto- motivação e dos reforços para mudar um hábito e destaca que padrões comportamentais não podem ser eliminados, mas podem ser supridos por hábitos que melhorem o desenvolvimento pessoal do próprio indivíduo.

Este artigo tem como objetivo ajudar pessoas que não consigam pensar em formas de criar novos hábitos, entretanto é importante entender que as mudanças não serão repentinas, serão mudanças de longo prazo, isso é possível através de duas etapas, a primeira seria a razão para que aquele hábito acabe, a segunda etapa seria as estratégias para manter um novo hábito.

Observa-se que não são todos os comportamentos que conseguimos mudar, pois alguns são padrões fixos de ação, sendo ensinados desde quando nascemos, envolvendo crenças, experiencias passadas de outras pessoas, até mesmo sendo biológicas como o reflexo ao colocar a mão em algo quente e logo em seguida tirar por exemplo. Personalidade, crenças, sentimentos e motivação/intenção, juntos podem assumir um caráter não consciente, sendo como uma aprendizagem preparada.

No presente artigo evidenciou- se as crenças, as quais a própria pessoa desenvolve e cria limitação para alcançar seus objetivos. Essas crenças podem ser causadas pelas experiências do indivíduo ou podem decorrer pelas expectativas do outro. Em ambas as situações é preciso que 0 sujeito faça uma autoavaliação e busque entender a real causa de sua 
limitação. Com isso percebe- se que o auto- conhecimento proporciona a criação de um novo modo de vida, o qual possibilita a saída da zona de conforto, encontrando uma forma diferente de compreender o âmbito onde está inserido.

Está temática procurou desenvolver uma reflexão no leitor, sobre seu modelo de vida, investigando um novo jeito de alcançar suas metas e se desenvolver pessoalmente. Entenda-se portanto, que os indivíduos que apresentam padrões comportamentais, não percebem suas atitudes, consequentemente, para alcançar seus objetivos, apenas reproduzem o que a sociedade acredita ser qualificado para ele. Por isso, é importante que as pessoas reflitam sobre seus comportamentos e questionem sua maneira de viver, a reflexão é um processo necessário para o indivíduo descobrir seus próprios desejos, objetivos e melhorar sua qualidade de vida.

\section{REFERENCIAS}

ALBERT, C. E.; BAGOLIN, I. P.; DE QUADROS, M. P.. Aportes da Economia Institucional e da Psicologia: hábitos e costumes na construção da escolha do agente econômico. Revista Cadernos de Economia, v. 12, n. 22, p. 7-22, 2008.

DUHIGG, C. O Poder do Hábito - Por que fazemos o que fazemos na vida e nos negócios. Objetiva. 2012.

Gardner, B. (2009). Modelling motivation and habit in stable travel mode contexts. Transportation Research Part F, 12(1), 68-76.

Honkanen, P., Olsen, S. O., \& Verplanken, B. (2005). Intention to consume seafood-The importance of habit. Appetite, 45,161-168.

Loibl, C., Kraybill, D. S., \& DeMay, S. W. (2011). Accounting for the role of habit in regular saving. Journal of Economic Psychology, 32, 581-592.

Verplanken, B., \& Aarts, H. (1999). Habit, attitude, and planned behaviour: Is habit an empty construct or an interesting case of goal-directed automaticity European Review of Social Psychology, 10(1), 101-134

Verplanken, B., \& Melkevik, O. (2008). Predicting habit: The case of physical exercise. Psychology of Sport and Exercise, 9, 15-26.

SILVA, A. D. et al. O Organismo e o Self: Congruência e Incongruência. Slide Share, 2017. Disponível em:

$<$ https://pt.slideshare.net/DanielaPoncianoOlive/teorias-da-personalidade-carlrogers\#: :text=\%EF\%83\%98\%20A\%20extens\%C3\%A30\%20da\%20diferen\%C 3\%A7a,um\%20obst\%C3\%A1 culo\%20ao\%20desenvolvimento\%20pessoal.\&tex $\mathrm{t}=\% \mathrm{EF} \% 83 \% 98 \% 20 \mathrm{~A} \% 20$ aceita\%C3\%A7\%C3\%A30\%20de\%20si,um\%20sinal $\% 20$ de $\% 20$ sa\%C3\%BAde\%20mental> 
FADMAN, J; FRAGER, R. Personalidade e Crescimento Pessoal, $5^{\circ}$ ed, Porto Alegre: Artmed, 2004.

VIEIRA, P; SILVA D. Decifre e Influencie Pessoas, São Paulo: Gente, 2018.

ROGERS, C. R; KINGET, G. M. Psicoloterapia e Relações Humanas. Tradução de Maria Luisa Bizzotto, $2^{\circ}$ ed, Belo Horizonte: Interlivros, 1977. 


\section{MULHERES DA ATUALIDADE E ARQUÉTIPOS DAS DEUSAS}

Anna Laura de Abreu Sampaio annaabreusampaio@gmail.com

Gabriela Maia de Almeida bi31maia@gmail.com

Isabella dos Santos Machado isabelladsmachado@gmail.com

Nathália Bosco Mendes da Silva nathaliabosco@gmail.com

Maria Cherubina de Lima Alves mcherubina@facef.br

Rafaella Orlando de Souza rafaellaorlandodesouza@gmail.com

Tayná Gonçalves Morais tayna_g.morais@hotmail.com

\section{INTRODUÇÃO}

Existem diversos fatores psicológicos de acordo com Carl Gustav Jung, mas o presente artigo irá focalizar no conceito de arquétipos. Essa noção tem origem em suas obras entre o período do ano de 1909 a 1912, quando começou a se distanciar da teoria de Freud por não compreender a premissa de sua teoria. Assim, após um sonho, começou a acreditar na importância de uma imagem-guia para construir a estrutura psíquica.

Ao trabalhar com uma de suas pacientes e com suas respectivas fantasias, começou a unir mitos, contos e histórias antigas para interpretar tais imagens e percebeu que havia muitas semelhanças entre o passado e presente, o que ocasionou na busca de um sentido para tal fato. Para tanto, Jung integra essas relações com a existência de um coletivo inconsciente, ou seja, elementos passados de gerações sem haver uma apreensão consciente sobre eles. Com isso, Jung criou sua teoria dos arquétipos, reconhecendo a existência de modelos arcaicos psicológicos.

Essa ideia é usada atualmente nas psicoterapias com abordagem junguiana, mas sempre levando em consideração as diversidades contidas em cada caso analisado. O modo que o paciente leva sua vida pode coincidir com histórias anteriores, ajudando 0 analista a criar ferramentas para 0 desenvolvimento do processo, entretanto, não significa que o final irá se repetir da mesma forma. Portanto, essa teoria serve como um guia de prevenção a 
condições indesejadas, como também de expansão para ambos na relação terapêutica, colaborando no desempenho da individuação.

Este artigo tem como objetivo discutir três arquétipos de deusas gregas, sendo Ártemis, Atenas e Afrodite, explicando um pouco da trajetória de cada uma e relacionando-as com mulheres contemporâneas. As mulheres escolhidas para análise são Billie Jean King, Oprah Winfrey e Beyoncé, cada qual com suas diferenças e vivências de vida. Para finalizar, será feito uma reflexão sobre as semelhanças e diferenças entre o curso dos arquétipos com as devidas pessoas escolhidas como referências.

Como metodologia, foi feito um estudo teórico por meio de livros, artigos científicos, revistas e sites, juntamente com supervisões semanais sobre o tema realizadas entre estudantes de psicologia e um supervisor com o intuito de aprimorar o aprendizado dessa área.

\section{ARQUÉTIPOS DAS DEUSAS E A MULHER CONTEMPORÂNEA}

Bolen (1990) aponta que todas as deusas são padrões potenciais na psique das mulheres. No entanto, cada mulher em sua singularidade, têm um padrão de deusa ativado, energizado ou desenvolvido e outros não. Os arquétipos ativados significam que, ele age em nós, pode ser considerado como uma estrutura que vai tomando forma e sendo reconhecida à medida que se desenvolve.

Este desenvolvimento pode ser compreendido a partir de uma predisposição inerente, por exemplo a dos bebês. Eles já nascem com traços de personalidade (ativos, teimosos, calmos, curiosos, capazes de passar 0 tempo sozinhos, sociáveis) que acompanham alguns arquétipos de deusa mais do que outros. Segundo Bolen (1990) uma criança com dois ou três anos já pode apresentar características típicas de algumas deusas.

Outro fator que é considerado um precursor no desenvolvimento de arquétipos de algumas deusas é o ambiente familiar. As expectativas dos pais contribuem para alimentar o padrão ativado. Entende-se que o movimento da família reforça as qualidades de deusas já aparentes nas crianças, por exemplo, os pais que esperam que as filhas sejam "o braço direito da mãe, amor e graça", são qualidades de deusas Perséfone e Deméter (BOLEN, 1990).

Ainda sobre esta temática, é relevante apontar o efeito da cultura sobre esses arquétipos. Como a cultura se manifesta mantendo o papel de algumas deusas nas mulheres, faz-se presente estereótipos de mulheres com imagens positivas e negativas dos arquétipos das deusas. Em uma sociedade patriarcal os papeis aceitáveis são os de jovem (Perséfone), da esposa (Hera) e da mãe (Deméter). A deusa Afrodite, nesta sociedade é considerada 
"prostituta ou sedutora". Neste contexto, observa-se uma distorção da sexualidade desse arquétipo. (BOLEN, 1990)

A autora ainda aponta que as vidas das mulheres foram modeladas por papeis permitidos e imagens idealizadas da época. Estereótipos que favorecem alguns padrões de deusas. Nota-se que em algumas culturas a mulher ainda tem a expressão de independência, inteligência ou sexualidade reprimidas (BOLEN, 1990).

\section{APRESENTANDO BREVEMENTE AS DEUSAS: ÁRTEMIS, ATENAS E AFRODITE}

De acordo com Bolen (1990) as deusas Ártemis e Atenas são as deusas virgens enquanto Afrodite é a deusa alquímica. Ártemis que também é conhecida como Diana na mitologia romana, era considerada a deusa da caça e da lua, representando assim uma personificação do espírito feminino independente. Nos mitos Ártemis sempre aparece agindo de forma eficaz em prol daqueles que pediam por ajuda, contudo também punia de forma rápida aqueles que a ofendiam. Bolen (1990, p. 50) aponta que "o arquétipo que ela representa possibilita a uma mulher procurar seus próprios objetivos num terreno de sua própria escolha".

Sendo outra deusa virgem Atenas, conforme foi apontando pela autora citada acima, é a deusa grega da sabedoria e das artes. $\mathrm{O}$ arquétipo de Atenas é representado por pessoas que possuem grande capacidade para elaborar estratégias e soluções práticas, sendo assim mulheres de mente lógica se destacam por possuírem esse tipo de arquétipo.

O conceito de Atenas como arquétipo do pensamento lógico desafia a premissa junguiana de que o pensar é realizado por uma mulher através de seu animus masculino, que se presume ser diferente do seu "ego" feminino. Quando a mulher reconhece o modo intenso com que sua mente trabalha como uma qualidade feminina relacionada com Atenas, ela pode desenvolver uma autoimagem positiva, ao invés de se amedrontar de estar masculinizada, isto é, imprópria (BOLEN, 1990, p.71).

Bolen (1990) realiza a divisão da deusa Afrodite como deusa alquímica e destaca que essa deusa precisa de uma categoria própria, pois Afrodite passa sozinha em sua jornada por um processo de poder e transformação. Afrodite como arquétipo governa os prazeres do amor e da beleza, sensualidade das mulheres e sexualidade, se tornando uma força para a personalidade feminina e se mostrando sendo um arquétipo instintivo. De acordo com Bolen (1990, p.187) "Afrodite impele as mulheres a preencherem funções criativas e procriativas". 


\section{ANALISANDO FIGURAS FEMININAS A PARTIR DOS ARQUÉTIPOS DAS DEUSAS}

A fim de ilustrar os aspectos dos arquétipos das deusas, foram selecionadas três figuras femininas reconhecidas, e será feita uma análise que propicie investigar quais aspectos de suas personalidades tem relação com os arquétipos das deusas.

\subsection{Billie Jean King e a Deusa Ártemis}

Billie Jean King é reconhecida como uma das maiores atletas de todos os tempos, e uma das melhores tenistas do mundo. Ficou conhecida não apenas pela sua qualidade esportista, mas principalmente por suas lutas de igualdade.

Analisando sua biografia, é notável que o movimento de independência sempre se fez presente, e a busca pelos seus próprios caminhos é marcante. Desde criança (BILLIE JEAN KING ENTERPRISES, 2017), quando decidiu que queria jogar tênis, buscou por si própria as oportunidades para realizar seu sonho. Essas características qualificam a presença de Ártemis, e como aponta Bolen (1990, p.53), é usual que os atributos dessa deusa apareçam cedo.

Bolen (1990, p. 50), indica que Ártemis representa um arquétipo que "possibilita a uma mulher procurar seus próprios objetivos num terreno de sua própria escolha". Enquanto deusa virgem, representante da caça e da lua, Ártemis personifica o papel da independência feminina.

Em sua biografia (BILLIE JEAN KING ENTERPRISES, 2017), é explicitado que Billie falava desde criança que seria a número um do mundo, e se mantinha focada em sempre ser a melhor. Sentiu na pele as diferenças em ser uma tenista mulher na época de 1955, com ainda 14 anos, quando foi excluída de uma fotografia de um jogo de tênis simplesmente por não estar usando a saia (uniforme comum das tenistas na época), mas sim um short no lugar.

Com o tempo, foi ganhando seu espaço e cada vez mais reconhecimento pela sua qualidade como tenista. Quando se profissionalizou, atingiu patamares nunca alcançados por mulheres, e se tornou a primeira atleta mulher a ganhar em torno de $\$ 100,000$ dólares de prêmio em dinheiro. Considerando que Ártemis é a deusa da caça, seu arquétipo possibilita às mulheres esse aspecto de 'arqueira com meta-direcionada', que se mantém focada em alcançar seu alvo. Esse aspecto é extremamente presente na personalidade Billie, e pode ter sido de grande auxílio para atingir suas metas.

Ela sempre se incomodou pelo fato de que mesmo tendo se tornado a primeira no mundo do tênis, sequer faturava a mesma quantia dos

SAMPAIO, Anna Laura de Abreu; ALMEIDA, Gabriela Maia de; MACHADO, Isabella dos Santos; SILVA, Nathália Bosco Mendes da; ALVES, Maria Cherubina de Lima;

SOUZA, Rafaella Orlando de; MORAIS, Tayná Gonçalves; 
atletas homens. Todos os episódios de 'rebaixamento' enfrentados por ser mulher, tanto por ela como por suas colegas do esporte, foram importantes para que Billie Jean assumisse o papel de defensora da igualdade de gêneros. O movimento de desejo de evitar 0 mal às mulheres, tão presente no movimento feminista, também se relaciona com a deusa Ártemis, uma vez que ela era protetora das jovens.

A ferocidade da deusa Ártemis permite à mulher a sensação de firmeza a respeito de suas causas e princípios. Isso é explícito quando Billie confronta a organização de um dos maiores torneios de tênis, o U.S. Open, exigindo que os prêmios deveriam ser iguais para homens e mulheres. (BILLIE JEAN KING ENTERPRISES, 2017)

A campanha por pagamentos iguais entre esportistas ganhou uma audiência global quando Billie derrotou Bobby Riggs na chamada "Batalha dos Sexos". Bobby havia proclamado que as mulheres não só não podiam jogar melhor que os homens, como valiam menos. Toda essa força, determinação e luta são características claras de um arquétipo de Ártemis ativado. (BILLIE JEAN KING ENTERPRISES, 2017)

\begin{abstract}
Eles jogaram um contra o outro em uma partida histórica chamada Batalha dos Sexos. Trinta mil pessoas no estádio e cinquenta milhões de telespectadores viram Billie Jean derrotar Riggs em sets consecutivos. O US Open enfim aceitou as exigências das jogadoras, tornando-se o primeiro grande torneio a oferecer prêmios iguais a homens e mulheres. Graças a Billie Jean, hoje o tênis é um dos poucos esportes em que atletas homens e mulheres alcançaram salários iguais. (CAVALLO e FAVILLI, 2018, p. 37)
\end{abstract}

Outro aspecto interessante da vida de Billie que corrobora para a ilustração do arquétipo de Ártemis, se refere ao seu relacionamento com seus pais. Bolen (1990, p. 54) indica que a filha com esse arquétipo para que possa desenvolver-se da melhor forma, pode precisar de mãe e pai que a aceita e apoia. Problemas podem surgir quando há críticas ou rejeições por parte dos pais. Durante a infância e juventude de Billie, seus pais foram apoiadores para que ela se tornasse uma tenista de sucesso, afinal, toda a família era composta por atletas. No entanto, grandes problemas de relacionamento surgiram quando Billie se assumiu homossexual. Ela se viu sem apoio familiar para esse assunto, e acabou se afastando de seus pais nesse período. (BILLIE JEAN KING ENTERPRISES, 2017)

A quebra de paradigmas, a luta por igualdade e justiça, o respeito e proteção às mulheres, a independência são fatores que acompanham a trajetória dessa tenista, e que exemplificam um funcionamento com o arquétipo de Ártemis.

\title{
4.2. Beyoncé e a Deusa Afrodite
}

Beyoncé, nascida em 4 de setembro de 1981, nos Estados Unidos, hoje é a estrela pop mais influente do mundo, sendo cantora, 
compositora e empresária. Ela tinha seis anos quando seu pai começou a vender ingressos para as pessoas vê-la cantando e dançando. Sua mãe a apoiou fazendo fantasias para sua banda com as amigas, nascendo o grupo "Destiny's Child". Ela era a rainha do grupo, motivada e interessada em aprender sobre todos os aspectos do negócio da música.

Seu pai de início era seu empresário, porém, a própria tomou frente e passou a controlar seus negócios e sua carreira. Se inspirava em Madonna, desejando ser uma potência e conquistando essa posição.

Em suas músicas, cantou sobre liberdade, amor, independência e dor (pessoal quanto à injustiça social). Inspirou mulheres negras a se orgulharem de suas origens, cultura e estilo único.

Beyoncé, pode ser comparada com a deusa Afrodite, que segundo Friedrich (1978 apud BOLEN, 1990), é conhecida como a deusa do amor e da beleza, deusa alquímica, simbolizando o poder transformativo e criativo do amor. Era chamada pelos romanos de Vênus. Sua beleza física, de rosto e corpo, seus cabelos dourados, olhos brilhantes e bonitos seios chamavam atenção, um arquétipo entrelaçado com Beyoncé, uma dimensão da feminilidade principalmente em seus últimos álbuns, utilizando a sensualidade. É reconhecida também pela sua atratividade, um carisma pessoal, magnetismo/eletricidade que combinado com as características físicas fazem, determinam uma mulher Afrodite, podendo compreender um dos motivos para que a cantora seja tão querida e atrativa.

De acordo com Friedrich (1978 apud BOLEN, 1990), o arquétipo de Afrodite governa o prazer do amor e da beleza, da sexualidade e sensualidade das mulheres. Também impele ao preenchimento de funções em relação à criatividade e procriação, se fazendo presente em suas diversas performances da cantora, shows, roupas e danças.

Uma Afrodite adolescente, na faculdade, segundo Friedrich (1978 apud BOLEN, 1990), focará em aspectos sociais, principalmente. No trabalho, será encontrada principalmente em música, arte, escrita, dança ou drama, por não gostar de tarefas repetitivas e preferir as que causam variedade e intensidade. Se interessa pelo trabalho. Com isso, temos toda a carreira percorrida por Beyonce, como dito anteriormente, é a estrela do pop mais influente da música, sendo cantora, compositora e empresária, sempre motivada em aprender e tomando frente dos negócios. No âmbito social, inspira muitas pessoas e principalmente mulheres com representatividade da feminilidade e maternidade da mulher negra.

$\mathrm{Na}$ atual sociedade, o poder de uma mulher grávida raramente é celebrado. Beyoncé chamou atenção para essa necessidade, particularmente por ser uma mulher negra, mostrando vários aspectos para relacionar com a Deusa Afrodite em quesitos de sensualidade e procriação. 


\subsection{Oprah Winfrey e a Deusa Atena}

Ao analisar a vida de Oprah Winfrey, conseguimos identificar claramente o arquétipo da deusa Atena - é a deusa da sabedoria, das artes, estrategista e 'filha do pai' - sendo assim, ao olharmos para a trajetória de Oprah podemos ressaltar as principais características desse arquétipo, principalmente referindo-se a sua carreira profissional. Adiante será elencado aspectos relevantes e marcantes da vida desta figura segundo sua biografia.

Nascida em 29 de janeiro de 1954, filha de mãe solteira, foi criada na fazenda de sua avó, sendo ensinada desde muito cedo a ler, recitava poemas e versículos da Bíblia nas igrejas locais e apesar das dificuldades do ambiente físico em que vivia tinha o apoio de sua avó. Aos seis anos de idade mudou-se com sua mãe para Milwaukee que havia encontrado um emprego como doméstica e essa mudança foi um marco em sua vida, com a ausência da mãe para o trabalho, Oprah foi molestada várias vezes por parentes e outros visitantes do sexo masculino, esses abusos perduraram por anos, ocorrendo dos nove aos treze anos de idade da garota (ACADEMY OF ACHIEVEMENT, 2018).

Observa-se aspectos de Atena nesse primeiro momento de vida de Oprah quando se verifica a compreensão do mundo a partir de uma orientação realista da sua condição de vida, na qual logo cedo apresenta padrões adultos em uma jovem adolescente, realizando decisões importantes de vida a partir da razão e não da emoção. (BOLEN, 1990)

De acordo com a Academy of Achievement (2018) após viver esse momento traumático, encontra-se sozinha e fora de casa aos 14 anos. Nesse período em que se depara estar por conta própria inicia uma vida sexual promíscua, logo engravida e dá a luz a um menino que morreu logo na infância, depois desse fato vai para Nashville morar com seu pai. Nessa fase da vida em que passa a morar com seu pai, vive uma vida de regras e exigências, Vernon Winfrey se mostrava rigoroso e queria que sua filha tirasse o melhor proveito da vida, exigia que Oprah lesse livros e escrevesse relatório a cada semana e com isso ela se tornou uma estudante de honra, ganhou prêmios por oratória e recitação dramática.

A figura de Oprah também corresponde aos atributos de 'filha do pai' do arquétipo de Atena, dessa forma observa-se que "Atenas representa a mulher que tende naturalmente aos homens poderosos que têm autoridade, responsabilidade e poder, homens que se ajustam ao arquétipo do pai patriarcal ou do "homem patrão" (BOLEN, 1990, p. 73). Da mesma forma consegue-se atribuir a Oprah essas mesmas características quando se torna uma filha dedicada aos estudos perante a disciplina do pai.

O mesmo site afirma que aos 17 anos de idade Oprah após ganhar um concurso de beleza, começou a trabalhar no ar na WVOL - uma 
estação de rádio - também ganhou uma bolsa de estudos na Tennessee State University. Contudo com a carreira de radiodifusora já estava decolando ela deixa a escola e assina com uma emissora de televisão local para ser repórter e âncora. A carreira de Oprah vai se transformando até alcançar um sucesso avassalador.

\begin{abstract}
Em 1976, ela se mudou para Baltimore para se juntar ao WJZ-TV News como uma co-âncora. Lá, ela co-organizou seu primeiro talk show, People Are Talking, enquanto continua a servir como âncora e repórter. Ela havia encontrado um nicho que se encaixava perfeitamente em sua personalidade extrovertida e empática, e as palavras logo se espalharam para outras cidades. Em janeiro de 1984, ela foi convidada para Chicago para apresentar um programa matutino de meia hora pela WLS-TV. Em menos de um ano, ela transformou AM Chicago no show mais quente da cidade. $O$ formato foi logo expandido para uma hora e, em setembro de 1985, foi renomeado para The Oprah Winfrey Show. (ACADEMY OF ACHIEVEMENT, 2018, p. online)
\end{abstract}

Bolen (1990) consolida que a jovem tipo Atena é considerada extrovertida, tem grande capacidade de observação, tendem a ser populares e buscam planejar o futuro. Quando consideram cursar uma faculdade, mas não possuem recursos financeiros, de maneira geral encontram um modo de conseguir uma bolsa de estudos ou ajuda financeira para conquistar tal realização.

A mesma autora alega que caso a garota tipo Atena tenha que optar por um trabalho ao invés de sua escolaridade, essa busca assumir empregos que apresentem boas oportunidades. A trajetória de Oprah consegue confirmar essas características apresentadas pelo arquétipo e demostrar de maneira clara como Atena age no seu estilo de vida.

Aponta Academy of Achievement (2018) que um ano depois de ser renomeado o programa de Oprah começou a ser transmitido nacionalmente e logo já se tornou o programa número um, rendendo várias premiações do Emmy Awards. Oprah também fez algumas atuações cinematográficas ganhando até indicações ao Oscar e um Globo de Ouro na categoria de Melhor Atriz Coadjuvante. Reconhecendo seu amor pela atuação e entretenimento de qualidade à produção, decide criar a sua própria produtora, a Harpo Productions, Inc. Com o início da sua proporia produtora, logo adquiriu a propriedade e as responsabilidades sobre o seu talk show, o que fez de Oprah a primeira mulher da história a produzir e possuir o seu próprio talk show. Atualmente a Harpo produz filmes e conteúdo televisivo, além da publicação de revistas e Internet.

Os interesses comerciais de Oprah Winfrey se estenderam muito além de sua própria produtora. Ela é uma das parceiras da Oxygen Media, Inc., um canal a cabo e rede interativa que apresenta programação projetada principalmente para mulheres. Com seu sucesso, ela também se tornou uma das filantropas mais generosas do mundo. Em 2000, a Angel Network da Oprah começou a oferecer 
um prêmio "Use Your Life" de US \$ 100.000 para pessoas que estão usando suas próprias vidas para melhorar a vida de outras pessoas. Ela agora publica duas revistas: $O$, The Oprah Magazine e $O$ at Home. O lançamento de sua primeira revista foi a start-up de maior sucesso na história da indústria. Quando a Forbes Ao publicar sua lista de bilionários americanos em 2003, divulgou que Oprah Winfrey foi a primeira mulher afro-americana a se tornar bilionária (ACADEMY OF ACHIEVEMENT, 2018, p. online)

Observando mais fielmente para a caminhada profissional de Oprah percebe-se que ela é uma mulher dedicada e focada naquilo que deseja alcançar e utilizou do pensamento lógico e estratégico para concretizar seus sonhos. O lado de artesã de Atena também se faz presente na vida de Oprah quando está admite o papel de atriz, acentuando o seu lado artístico e comercial.

A mulher tipo Atenas pretende fazer alguma coisa de si própria. Trabalha arduamente em direção àquele fim, aceita a realidade tal como ela é e se adapta. Portanto, os anos de idade adulta lhe são usualmente produtivos. No mundo do poder e da realização, seu uso da estratégia e do pensamento lógico mostra parentesco com Atenas [...]. Como artista, a mulher tipo Atenas faz objetos funcionais que agradam esteticamente. Também tem tino comercial e, portanto, Ihe interessa mostrar e vender seu trabalho, tanto quanto fazê-lo. Maneja bem as mãos e, qualquer que seja sua habilidade, orgulha-se de dominar a habilidade requerida e do acabamento de seu produto. Pode fazer com prazer variações do mesmo objeto (BOLEN, 1990, p. 77-78).

Oprah Winfrey se tornou a mulher mais bem paga na televisão e é uma influência mundial. Sua história e conquistas cativam pessoas de todo o mundo e sua produtora e programa ainda tratam de questões sociais importantes, além de produzirem conteúdos sobre valores espirituais, de vida saudavél e auto-ajuda, Oprah se tornou um nome de referência mundial.

A vida de Oprah Winfrey mostra variados aspectos e características que relaciona-se com o arquétipo da deusa Atena, sendo uma mulher focada nos objetivos e desejos que teve para sua vida, alcançou uma posição social muito privilegiada em comparação aquilo que tinha no início de sua vida, passou por vários obstáculos financeiros e emocionais e hoje busca contribuir para a sociedade sendo uma das maiores filantropas da atualidade.

\section{CONSIDERAÇÕES FINAIS}

É possível perceber ao longo do artigo a posição dos arquétipos no funcionamento de cada indivíduo. Após um sonho, Jung começou a acreditar na importância de uma imagem-guia para a construção de uma estrutura psíquica. Apesar de existirem inúmeras considerações sobre os arquétipos e como na teoria a pessoa poderia ser, é importante ressaltar que é preciso levar em consideração a individualidade de cada caso que se é analisado. 
Em relação à mulher foi possível entender que todas as deusas podem ser consideradas como padrões potenciais na psique das mulheres, contudo, como citado anteriormente, é necessário que seja observado a singularidade de cada mulher, que pode ter um padrão de alguma deusa ativado, energizado ou desenvolvido e outros não.

O desenvolvimento dessas deusas pode ocorrer já desde 0 nascimento, relacionado a uma predisposição inerente, mas até mesmo o ambiente familiar pode ter interferência nesses aspectos.

Foram escolhidas para as análises mulheres contemporâneas, cujo exemplo de vida se apresentam coletivamente com um simbolismo forte, que realmente chamam atenção por posturas e atitudes. Essa escolha também se instituiu por se tratar de figuras públicas. Assim, é possível relacionar claramente os arquétipos que estão ativados e um pouco do funcionamento dessas figuras.

Conclui-se então que o objetivo inicialmente do artigo era realmente esse, apresentar 0 arquétipo dessas deusas Ártemis, Atenas e Afrodite relacionando cada uma às mulheres Billie Jean King, Oprah Winfrey e Beyoncé, para que assim fosse percebido suas características, mas sempre levando em conta o individual de cada uma delas em questão. Estudos assim são importantes para que fique claro essas comparações e assim facilitar a compreensão desses arquétipos relacionando-os com a vida real.

\section{REFERÊNCIAS}

ACADEMY OF ACHIEVEMENT. OPRAH WINFREY BIOGRAPHY. ACADEMY OF ACHIEVEMENT, 24 ago. 2018. Disponivel em: $<$ https://achievement.org/achiever/oprah-winfrey/\#biography>. Acesso em: 03 jul. 2020.

BILLIE JEAN KING ENTERPRISES. BJK Biography. Billie Jean King, 2017. Disponivel em: <https://www.billiejeanking.com/biography/>. Acesso em: 3 Julho 2020.

BOLEN, J. S. As deusas e a mulher: nova psicologia das mulheres. Tradução de Maria Lydia Remédio. São Paulo: Paulus, 1990.

CAVALLO, F.; FAVILLI, E. História de ninar para garotas rebeldes 2.

Tradução de Carla Bitelli ; Flávia Yacubian e Zé Oliboni. ed. 1. ed. São Paulo: V\&R Editoras, 2018.

JAMES, ; HALL, M. D. A experiência Junguiana: análise e individuação. São Paulo: eDITORA cULTRIX, 1986.

STEIN , M. Jung o mapa da alma: uma introdução. São Paulo: Editora Cultrix, 1995. 
MÚSICAS BRASILEIRAS ATUAIS: um retrato do machismo na cultura

Camila de Figueiredo Ramos

figueiredoramoscamila@gmail.com

Maria Cherubina de Lima Alves

mcherubina@facef.br

\section{INTRODUÇÃO}

Segundo Sarti (1988), a partir de 1970 o feminismo passa a ficar em ascensão no Brasil, mas as mulheres sempre estiveram, de alguma forma, em busca da igualdade de gênero em todos os aspectos.

Levando em consideração que antes de 1932, no Brasil, as mulheres não eram consideradas cidadãs e não tinham direito ao voto, é possível notar que alguns avanços já foram alcançados como, por exemplo, o direito ao voto, ao trabalho e a equidade de salário (que nem sempre acontece. Historicamente, essa desigualdade de gênero deixou marcas na sociedade. $O$ machismo acabou se enraizando e muitas mulheres sofrem com isso todos os dias.

A relação entre o sexo feminino e masculino "[...] não é de complementariedade, e sim de domínio e submissão, de coerção e existência" (ALVES; PITANGUY, 1985, p.15). O feminismo surgiu para desconstruir 0 sexismo social, para "[...] repensar e recriar a identidade de sexo sob uma ótica onde o indivíduo [...] não tenha que se adaptar a modelos hierarquizados [...]" (ALVES; PITANGUY, 1985, p.9) e para promover uma visibilidade positiva das mulheres perante todos.

Principalmente em virtude das crenças religiosas que envolvem o cristianismo, por muito tempo as mulheres foram submissas aos homens, servindo apenas como objeto de satisfação e prazer. Essas características foram carregadas pela sociedade por centenas de anos, e ainda atualmente traços dessa submissão aparecem indiretamente em músicas, novelas, filmes, bem como na vida cotidiana.

Allport (1966) afirmava que diversos autores (FADIMAN; FRAGER, 1939) consideravam a cultura como fator decisivo para o desenvolvimento da personalidade do indivíduo. Para eles, o indivíduo só vai se desenvolver social e psiquicamente a partir da cultura na qual está inserido. Assim, considerando o enfoque deste estudo, um indivíduo imerso em uma cultura machista tende a reproduzir inconscientemente tais comportamentos.

A cultura pode ser também fator condicionante em relação à visão de mundo do ser humano. Até mesmo fatores relacionados à fisiologia humana podem sofrer interferência cultural, como expressões faciais em virtude de risos, brigas, entre outras. Ademais, esses fatores culturais são os precursores de diversos tipos de discriminação pois, quando inseridos em um determinado 
conjunto social, o homem desenvolve suas características de acordo com o padrão daquele grupo, ao passo que tudo que não se encontre nesse padrão, é considerado errado por esse grupo (LARAIA, 2005). Logo, quando comportamentos machistas são naturalizados, o estranho, na nossa cultura, é fugir desse padrão, e é em virtude disso que as mulheres lutam há tanto tempo pela igualdade de gênero.

O objetivo da pesquisa é identificar a percepção que homens e mulheres tem a respeito de conteúdos machistas presentes nas músicas brasileiras mais populares. Essa ideia parte do pressuposto de que esses elementos machistas presentes no inconsciente coletivo alimentam uma visão específica do feminino na qual a mulher é colocada em posição de inferioridade em relação ao homem, o que influencia no desenvolvimento da personalidade e na disseminação do machismo, com justificativa cultural.

Os objetivos específicos são: discutir as especificidades e diferenças entre machismo, feminismo e sexismo e como eles se apresentam nas manifestações culturais; analisar a música como expressão cultural e representante de conteúdos arquetípicos; apresentar o referencial teórico que possibilite a compreensão de como conteúdos presentes em músicas famosas podem afetar no desenvolvimento da personalidade dos indivíduos dessa sociedade.

Nesse sentido, as perguntas norteadoras da pesquisa são: 0 conteúdo das músicas brasileiras de maior sucesso na contemporaneidade pode ser considerado machista? E em caso positivo, deve-se responder como esse conteúdo é percebido e expressado por homens e mulheres dessa sociedade?

Observa-se a influência midiática, principalmente no meio de convivência dos jovens, que tendem a querer viver aquilo que é visto na televisão, na internet, e o que é ouvido nas rádios. Dessa forma, assim como novelas, as músicas influenciam seu comportamento, bem como o processo de desenvolvimento da personalidade.

Sendo assim, a base metodológica escolhida foi a qualitativa, a fim de explorar através da pesquisa de campo, através de entrevistas com homens e mulheres, as percepções de expressões machistas presentes no conteúdo de uma música considerada de sucesso no momento do desenvolvimento da pesquisa. A análise da pesquisa de campo também será de cunho qualitativo, organizada em categorias temáticas definidas a partir do conteúdo acessado nas entrevistas com os participantes, tendo em vista que o propósito da investigação é identificar ideais de um pequeno grupo de pessoas. Todos estes aspectos serão subsidiados com referencial teórico vasto envolvendo livros e artigos. 


\section{HISTÓRIA DA MULHER NO BRASIL: comportamentos machistas desde a colonização}

De certo que o machismo não é um conceito que surgiu recentemente, muito pelo contrário, ainda no século XIX, a mulher era considerada como alguém que precisava ser completamente submissa ao homem com quem havia se casado - frequentemente na adolescência, por volta dos 15 anos - com sua existência baseada basicamente na vida doméstica (BESSE, 1999). Essa cultura chegou ao Brasil com os portugueses, depois da colonização e evangelização dos índios.

Entretanto, anterior a todos esses acontecimentos "[...] a mulher estava condenada, por definição, a pagar eternamente pelo erro de Eva [...]" (ARAÚJO apud DEL PRIORI; BASSANEZI, 2000, p. 46), pois esta havia acabado com a oportunidade da permanência da humanidade no paraíso. Em uma sociedade onde a prevalência religiosa é o cristianismo, disseminou-se a ideia de que a mulher devia ser controlada a todo tempo, para que não cometesse nenhum pecado. Segundo Araújo (apud DEL PRIORI; BASSANEZI, 2000), em meados do século XVIII é possível encontrar literatura que "comprovasse" o fato de a mulher ainda carregar o pecado de Eva consigo. Segunda tal literatura, a mulher não tinha responsabilidade ou força suficiente para ficar sozinha, e se o fizesse, cometeria atrocidades e pecados, assim como fez Eva ao comer o fruto proibido no paraíso.

Toda literatura voltada ao público feminino, nessa época, falava sobre como ser uma boa esposa, como ser uma mulher digna para um bom casamento. Ainda falavam sobre a importância de ser recatada e pura, e como devia se dedicar apenas aos afazeres da casa, sem nunca almejar independência financeira. O não cumprimento desses requisitos antes e depois do casamento, fazia com que a sociedade subjugasse as mulheres, além de elas também serem condenadas pela igreja (DEL PRIORI; BASSANEZI, 2000).

Como se todas essas características já não mostrassem submissão, as mulheres também eram ensinadas a não esperar nada do marido, e caso fosse decepcionada, deveria agir normalmente e perdoar independentemente do que fosse. Se o casamento acabasse por qualquer motivo, a culpa era inteiramente da mulher. Além de submetidas a alcançar todas as expectativas da igreja, das famílias e dos maridos, as mulheres ainda precisavam ser autoconfiantes e belas, prezando sempre pelo cuidado estético para apresentarem-se bem aos maridos (FIGUEIREDO apud DEL PRIORI; BASSANEZI, 2000).

As mulheres que não se encaixavam em todas as regras citadas anteriormente, sem campo de trabalho, viam-se obrigadas a se venderem. Quando jovens ou escravas, eram vendidas por seus próprios pais ou "senhores". A mulher, nesses casos, era literalmente vendida como um objeto de prazer (FIGUEIREDO apud DEL PRIORI; BASSANEZI, 2000).

A prostituição, então, fez com que a diferenciação entre a mulher 
"digna" e a "indigna" ficasse ainda mais explícita. Roupas mais coloridas, abuso de acessórios, vestidos de seda, independentemente de quem estivesse usando, era visto como insinuação, provocação, e as mulheres que se vestiam assim, normalmente jamais encontrariam um marido. Não ser casada também era algo negativo para as mulheres (FIGUEIREDO apud DEL PRIORI; BASSANEZI, 2000).

A relação sexual devia acontecer apenas com o objetivo de procriação ou satisfação do homem, e mesmo durante a relação, a mulher devia se comportar como esposa, e não como "amante", sem demonstrar prazer, desejo, e nada que a igreja pudesse considerar pecado. "Passava a ser direito do marido exigir o pagamento da dívida através da violência e coerção física" (FIGUEIREDO apud DEL PRIORI; BASSANEZI, 2000, p. 175). A "dívida" conjugal era justamente "cobrada", pelo marido, através do ato sexual.

No caso das esposas e noivas, elas ainda eram consideradas "objetos" de valor político, social e econômico, que deveria manter o nome e as tradições da família. Para manter esse lugar de poder na sociedade e serem "bem casadas", os pais ofereciam as filhas à família que tinha interesse em fazer aliança - um valor simbólico ao noivo, chamado "dote" (DEL PRIORI; BASSANEZI, 2000).

Depois da proclamação da república, por volta de 1890 a mudança estrutural da sociedade fez com que algumas adaptações sociais fossem estabelecidas, com relação à aspectos afetivos e até mesmo sexuais. A medicina tinha alcançado um avanço significativo, bem como a psiquiatria. Então, no final do século XIX e início do século XX, começaram a surgir os primeiros casos de "histeria", definida como possível doença mental que acometia somente mulheres. Dizia-se que a histeria era reflexo de desejos sexuais reprimidos, que faziam com que as mulheres pecassem e então elas acabavam enlouquecendo.

Nesse momento da história da mulher no Brasil, aquela que sentisse desejo e buscasse o prazer era, não apenas pecadora, mas perversa e psiquicamente perturbada. A chamada histeria era o exemplo de uma disfunção cerebral relacionada às características definidas como representação do feminino (sentimentos, emoções, cuidado). Tudo isso tinha início no útero, portanto, apenas mulheres eram acometidas por tal doença (ROUDINESCO, 2003).

Nesse período, a condição social da camada popular da tornava impossível manter a estrutura clássica da família, na qual o homem é, sozinho, o responsável pelas despesas da casa. A mulher passou a trabalhar fora também, e isso fez com que os homens se sentissem inferiores. Como resultado, a agressão física contra a mulher era a resposta para qualquer problema; era uma forma de demonstrar poder, levando em consideração que o homem não tinha mais o papel de chefe da família.

Fica evidente na construção social da mulher no Brasil, os traços de fraqueza e submissão, criando uma ideia de hierarquia, na qual o homem 
sempre está acima da mulher. Segundo Alves e Pitanguy (1985, p.9), "[...] o feminismo busca repensar e recriar a identidade de sexo onde o indivíduo [...] não tenha que adaptar-se a modelos hierarquizados [...]", ou seja, o feminismo busca a igualdade genuína dos gêneros, onde nenhum indivíduo será subjugado por ser homem ou mulher (negro, branco, pardo, rico, pobre - 0 feminismo caminha junto com outras lutas em virtude de direitos).

Todos os estereótipos colocados na mulher geraram expectativas em relação aos "papeis sociais" que tem que exercer, tais como o de ser mãe, ser esposa, cuidar da casa, etc. são características do arquétipo que representa o feminino. Um arquétipo nada mais é que "[...] imagens primordiais que nunca são representações de acontecimentos físicos, mas produtos espontâneos do fator anímico" (JUNG, 2002 p.70).

Os arquétipos, os conceitos de anima e animus são empíricos, e não concretos, mas, de acordo com a teoria junguiana, são definitivos para o desenvolvimento de uma sociedade, e surgem a partir dos ideais desta. Nesse sentido, a anima pode ser caracterizada por características presentes no homem que indicam para a fragilidade e sensualidade feminina, ao que ele pode responder, na vida concreta, com o ciúme e a violência voltados à mulher com quem ele se relaciona. $\mathrm{E}$ as mulheres, por sua vez, podem ter animus com características julgadoras, críticas, violentas e que drenam sua potência e autoconfiança, representando características machistas nelas mesmas que explicariam sua submissão a homens com essas características.

\section{CULTURA E SOCIEDADE}

O mundo é composto por seres vivos de diversas espécies. O ser humano se diferencia dos outros seres vivos por ser social, cultural e civilizado. Dessa forma, a cultura é um reflexo da sociedade que a desenvolve. O ser humano se desenvolve a partir da sociedade em que vive, e a cultura dessa sociedade se desenvolve no reflexo do ser humano. Tudo que a cultura representa, está diretamente relacionado ao homem, bem como os pensamentos, atitudes e criações deste, são expressões da cultura na qual ele está inserido (SOUZA: PEREIRA, 2014)

Caminhando também nesse sentido de psicologia das massas e comportamentos grupais, Jung (2000) traz o conceito de inconsciente coletivo. Indo para um caminho um pouco diferente de Freud, o pensamento junguiano entende que todo indivíduo de determinada sociedade leva consigo aspectos idênticos a outrem, porém esses aspectos estão inseridos no indivíduo, e para quem os vivencia, é quase que imperceptível.

O inconsciente coletivo diz respeito aos comportamentos de determinado grupo ou sociedade, representando a camada do inconsciente em comum entre todos os homens, como comportamento inato: "[...] é uma parte 
da psique que pode distinguir-se de um inconsciente pessoal pelo fato de que não deve sua existência a experiência pessoal, não sendo, portanto, uma aquisição pessoal" (JUNG, 2000, p. 53).

As massas tendem a ter sentimentos extremos e simplistas, ou seja, quando acreditam em algo tendem a defender isso de todas as formas, com todas as forças, e negar o oposto: ou amam ou odeiam qualquer conteúdo que têm contato (LE BON, 1985). Sendo assim, de forma geral, a sociedade tende a ter pensamentos parecidos e permanentes, sendo qualquer mudança extrema, quase que uma revolução.

Considerando o fato de que a sociedade atual, em termos nacionais, é inteiramente patriarcal, a dominação masculina é uma forte característica, a qual vemos seu reflexo em diferentes expressões culturais, dentre elas, a música.

\subsection{Músicas De Teor Machista Como Reflexo Da Cultura}

Uma das diversas formas de expressão cultural é a música, presente na vida das pessoas de diferentes classes sociais, crenças, ambientes. As músicas, em especial no Brasil, surgiram, inicialmente, com as poesias líricas, que eram poemas cantados (AGUIAR, 1998). Essas poesias representavam a época referente a sua escrita, descrevendo traços socioculturais de forma implícita, com o propósito de fazer arte. Os escritores e declamadores dessas poesias eram chamados de trovadores.

No início do século $X X$, surgiram as rádios, então a música e a poesia foram se distanciando, de certa forma, e passaram a existir de forma independente, ainda que os focos principais que as duas tratassem fossem 0 amor e o sentimentalismo (AGUIAR, 1998).

Ao chegar como sucessos nas rádios, muitas vezes aconteciam apresentações das músicas preferidas ao vivo, como pequenos shows, que eram abertos ao público. A plateia era majoritariamente feminina, com mulheres provenientes das classes mais baixas da sociedade, mulheres pobres. Essas mulheres que acompanhavam seus ídolos receberam o nome de "macacas de auditório", representando o distanciamento dos artistas em relação ao seu público, e a fama inalcançável que todas essas pessoas também almejavam (AGUIAR, 1998).

Como dito no capítulo anterior, o século XX no Brasil a sociedade tinha comportamento machista em virtude do desenvolvimento patriarcal, trazido pelos europeus na colonização, sendo assim, o conteúdo das músicas não era diferente. Ainda no início do século $X X$, quando as mulheres começaram a trabalhar fora $e$ as agressões domésticas como nova representação de poder ganharam ainda mais força, as primeiras músicas começaram a fazer certo sucesso na rádio. 
A música é uma expressão dos ideais culturais de uma sociedade, e sua criação depende também do momento social no qual determinado grupo se encontra, bem como seu modus operandi.

\section{METODOLOGIA DE PESQUISA}

Este trabalho foi desenvolvido utilizando o método de pesquisa qualitativa, através da revisão bibliográfica, da entrevista e da análise vinculando a teoria ao que será recolhido a partir desta. Segundo Minayo (1994), este método possibilita o aprofundamento no mundo dos significados das ações e relações humanas.

Torna-se importante ressaltar que uma pesquisa que utiliza 0 método qualitativo não se torna menos "científica" do que a quantitativa. $O$ qualitativo não é apenas um modo para atender a demandas que não podem ser alcançadas de outra forma, mas sim traz a finalidade de "[...] criar um modelo de entendimento profundo de ligações entre elementos, isto é, de falar de uma ordem que é invisível ao olhar comum", como menciona Turato (2005, p.509). Na presente pesquisa, foram apresentados argumentos teóricos e exemplos atuais de como a cultura ainda dissemina machismo inconscientemente, através de diversos veículos de informação e mídia.

A partir da abordagem qualitativa, essa pesquisa é caracterizada como exploratória, pois segundo Piovesan e Temporini (1995, online):

[...] apóia-se em determinados princípios bastante difundidos: 1) a aprendizagem melhor se realiza quando parte do conhecido; 2) devese buscar sempre ampliar o conhecimento e 3) esperar respostas racionais pressupõe formulação de perguntas também racionais.

Para tanto, a pesquisadora coletou dados teóricos e empíricos sobre cada um dos temas apresentados, construindo informações suficientes para que as análises posteriores possam ser subsidiadas por esses dados e utilizando das mesmas para a construção do atual projeto de pesquisa.

O projeto original desta pesquisa foi encaminhado ao Comitê de Ética em Pesquisa envolvendo Seres Humanos, garantindo o atendimento das exigências éticas e científicas da Resolução oㅡ 466, de 12 de dezembro de 2012, do Conselho Nacional de Saúde (CNS) que define as diretrizes básicas de pesquisas científicas que envolvem seres humanos. Foi assegurado que 0 integrante tem a opção de desistir de sua participação a qualquer momento, podendo ainda receber quaisquer esclarecimentos sobre a pesquisa a qualquer etapa da mesma. A pesquisa de campo só foi iniciada após a aprovação do projeto por este Comitê, que teve o Parecer favorável (CAAE: 29703920.2.0000.5384).

Posteriormente, os primeiros processos da pesquisa de campo tiveram início: para a amostra de pesquisa, definiu-se um total de doze participantes, sendo seis mulheres - três participantes de coletivos feministas e 
três não participantes - e seis homens - três apoiadores das causas feministas e outros três neutros a respeito. Foi decidido que tanto os homens quanto as mulheres da amostra deveram ter de dezoito a trinta anos pelo motivo de a música apresentar conteúdo censurável, o que não seria adequado para menores de idade. Além disso, pensou-se no limite de trinta anos para que a amostra faça parte do público contemporâneo consumidor da plataforma Spotify ${ }^{3}$.

Para conseguir o contato inicial com os participantes voluntários, foi necessária a adaptação da metodologia de pesquisa em virtude do isolamento social devido a pandemia que surgiu durante a pesquisa. Respeitando as recomendações da Organização Mundial da Saúde, todo o processo de contato e entrevista foi feito via internet, por meio de redes sociais como Facebook (apenas para o convite de potenciais participantes), Zoom, Skype e Whatsapp (os últimos 3 foram oferecidos para ser usados para a entrevista, conforme a preferência do participante), se adaptando com a realidade de cada participante.

Para tanto a pesquisadora buscou um dos coletivos feministas da cidade de Franca- SP com maior número de integrantes, por meio da rede social Facebook, perguntando a respeito do interesse de mulheres e homens em participar da pesquisa. Nesse espaço, seis pessoas foram selecionadas (três homens e três mulheres).

Para compor o grupo de participantes que não fizesse parte de movimentos feministas, a pesquisadora divulgou o convite por meio das suas próprias redes sociais (grupos de WhatsApp e de Facebook da faculdade). Porém, para esse grupo a pesquisadora se confrontou com uma resistência das mulheres em participar, não obtendo retorno e nem o consentimento de nenhuma delas para participar da pesquisa.

Como o tempo destinado para a pesquisa de campo finalizou antes de que a pesquisadora conseguisse voluntárias desse grupo, a pesquisa de campo precisou de ser encerrada e contou apenas com os 6 participantes ( 3 mulheres e 3 homens) do grupo dos movimentos feministas e 3 participantes (homens) que não participam de nenhum movimento feminista. Todos os participantes tinham entre vinte e trinta anos, e cursavam o ensino superior ou já haviam graduado.

Antes do início da entrevista, foram enviadas instruções para o participante para garantir ao máximo a segurança e o sigilo da pesquisa. Para os interessados, foi enviado remotamente (por e-mail ou pelo próprio WhatsApp, conforme a preferência do participante) um Termo de Compromisso Livre e Esclarecido, contendo todas as informações necessárias sobre a pesquisa, os aspectos éticos e o contato da pesquisadora e orientadora em

\footnotetext{
${ }^{3}$ A plataforma digital Spotify é a mais utilizada, por pessoas de todas as idades, para ouvir músicas de todas as épocas. É um aplicativo gratuito no qual todas as pessoas, que possuem notebook/computador ou celular, podem usufruir. O próprio aplicativo computa a quantidade de vezes que cada música foi tocada e cria as playlists, como a "50 mais tocadas no Brasil".
} 
caso de dúvidas futuras. Os participantes assinaram o seu TCLE e devolveram à pesquisadora escaneado, por vias digitais.

Os riscos dessa pesquisa são mínimos, e foi esclarecido a cada participante que ele poderia sentir-se desconfortável ao ouvir a música e interpretá-la, mas teria a liberdade de não responder ou interromper a entrevista em qualquer momento, sem nenhum prejuízo para seu atendimento. Além disso a pesquisadora assegurou a garantia do sigilo, da privacidade e da identidade dos participantes.

As entrevistas foram realizadas por meio de chamada de áudio ou vídeo, por meio do recurso de preferência do participante (WhatsApp, Zoom, Skype), onde foi marcado um horário individual com cada um dos participantes. O primeiro passo foi relembrar o participante a respeito do conteúdo da pesquisa. Em seguida, a pesquisadora apresentará a música Quando a vontade bater, do MC PK, por meio de áudio e compartilhamento de tela com a letra da música.

A música foi selecionada por fazer parte do veículo analisado, o midiático musical, e foi retirada da lista "cinquenta mais tocadas no Brasil" da plataforma musical Spotify no mês de setembro de 2019, na intenção de ilustrar a concepção das mulheres perante a sociedade nos dias atuais. A música selecionada (Quando a vontade bater, do MC PK) foi a que ocupava o topo da lista de mais tocadas no momento da elaboração do projeto, no mês de setembro de 2019.

$\mathrm{Na}$ pesquisa de campo, inicialmente foi apresentada a música "Quando a vontade bater", do MC PK, sendo que cada participante pôde ouvir a música até o final do primeiro refrão (depois disso a letra se repete) e teve acesso a letra completa. Depois de apresentar a música ao participante, foram feitas algumas perguntas (que pode interromper a participação a qualquer momento, caso desista).

\section{ANÁLISE E DISCUSSÃO DOS RESULTADOS}

As entrevistas foram gravadas perante autorização dos participantes, transcritas e assim foi feita uma análise do conteúdo através da elaboração de categorias temáticas representativas dos principais conteúdos acessados. A análise teve o objetivo de verificar pontos em que os conteúdos se assemelham ou se diferem entre si e com a literatura encontrada.

Os resultados foram apresentados em forma de categorias temáticas, a serem elaboradas a posteriori, a partir dos conteúdos identificados nas entrevistas como relevantes para apreensão qualitativa do objeto investigado (ANDRÉ; LÜDKE, 1986). 
As categorias temáticas são: mulher como objeto de desejo e submissão perante a música apresentada, relação do conteúdo da música com a cultura brasileira e desigualdade de gênero.

As transcrições foram indicadas com $\mathrm{H}$ para representar o que foi dito por homens e M para representar o que foi dito por mulheres. Quando a transcrição pertencer ao grupo de participantes feministas e apoiadores da causa, na frente de cada letra ( $\mathrm{H}$ ou $M)$, aparece a letra $F(H F$ e MF).

\subsection{Mulher Como Objeto De Desejo E Submissão Perante A Música Apresentada}

Está categoria discutirá a objetificação feminina, ou seja, a coisificação, o colocar a mulher em posição de objeto.

Em resposta à música "Quando a vontade bater", do MC PK, de todos os nove participantes (seis do sexo masculino e três do sexo masculino) apenas um deles afirmou que nunca tinha ouvido a música. Isso comprova a afirmação de que é uma música bem popular entre a faixa etária estudada.

Segundo os participantes, os relatos, de forma geral foi de que tinham ouvido a música principalmente em festas:

"Eu conheço essa música, já tinha ouvido ela. Ela é bem famosa, na internet, em qualquer rolê aleatório, toca bastante ela é bem difundida (HF)".

Após ter ouvido a música e acompanhado a letra, os participantes foram questionados a respeito das temáticas presentes na música. Nesse momento, a maioria das respostas indicava que a letra era muito explícita, que colocava a mulher como objeto do homem, entretanto, todos os participantes afirmam gostar da batida e do ritmo da música (conhecido como funk). Seguem alguns exemplos:

"Então, é, é estranho falar sobre isso. Assim, eu acho o beat dela legal, agradável, mas é uma letra que assim, acho que você vê que é uma coisa, tipo, uma conotação sexual muito explicita, só que não é fácil falar sobre isso, não é uma coisa, por exemplo, que você usa de linguagens para você falar sobre algo, é uma coisa muito direta. (HF)"

"Eu acho que, bom, a gente tem uma linguagem muito explícita em relação ao sexo, mas a gente não pode descartar a cultura do funk que tem muito isso, só que a mulher parece um ser passivo [...] Então acho que tem muito essa coisa da objetificação da mulher, entendeu. Tem funk que a gente ouve que tem a linguagem explicita, tem palavrão, fala de sexo, mas não precisa de colocar a mulher em um lugar passivo. Isso que me incomoda (MF)"

"E como se hora que ele quisesse ela estaria ali pra fazer tudo o que quiser com ela, como se fosse o objeto dele $(H)$ ".

Ao analisar as respostas anteriores é possível perceber que todas elas têm relação com atos sexuais e a passividade. Quando se coloca a mulher como ser passivo e sem desejo, é como ignorar a sua humanidade e seus sentimentos como ser humano, o que pode ser considerado objetificação. A 
objetificação feminina se dá quando a mulher é banalizada, tratada como um material, um objeto que pode estar relacionado à publicidade, às questões sexuais e sociais (BIRMAN, 1999).

A ideia reforçada culturalmente de que a mulher é passiva em relação ao homem, também usa a anatomia dos órgãos sexuais de cada um como argumento. $O$ fato de o pênis ser 'para fora' e "aquele que penetra" e a vagina 'para dentro' e "aquela que é penetrada", traz essa conotação de que o corpo da mulher, passivo, seria um objeto de prazer, pois para que o homem se satisfaça não é necessário que a mulher faça nada além de consentir com a relação. Nesse sentido, muito além da submissão, é possível identificar a objetificação feminina (FROMM, 1965).

Porém foi comprovado teoricamente que as diferenças biológicas entre o homem e a mulher não servem para reforçar esse tipo de comportamento, e que apesar das diferenças, as capacidades de ambos os sexos são equivalentes. Além da biologia, a sociologia e a antropologia apresentam também argumentos que refutam essa justificativa orgânica para a dominação masculina, mostrando com base em estudos que a vivência masculina não deferência da feminina, mudando apenas de indivíduo para indivíduo independente do sexo biológico (FROMM, 1965).

Outro fato interessante de ser discutido está na questão de consumir músicas sem se atentar ao que essa ela diz. Isso significa que tudo está tão rígido estruturalmente que as pessoas, de forma geral, não desenvolvem senso crítico para com aspectos socioculturais que acabam passando despercebidos, como por exemplo as músicas, novelas, filmes etc. (LE BON, 1985).

Os participantes da pesquisa de todos os grupos (feministas e não feministas) demonstraram em suas respostas traços de submissão feminina na vida cotidiana em algum momento:

"Mulheres recebem menos, como elas são tratadas, como elas são sempre objetificadas, tipo uma menina posta um semi-nude o pessoal fica sexualizando, igual a Mc Melody que é uma criança, que o pessoal 'Nossa que não sei o que'. Como a mulher é minimizada na sociedade, como ela é tratada (HF)"

A diferença salarial existente entre homens e mulheres foi algo que apareceu apenas uma vez, e foi dita por um participante do sexo masculino. É interessante pontuar essa fala pois ela mostra a tomada de consciência em relação a outros aspectos relacionados ao machismo que vão além da hipersexualização feminina, e logo depois é citada pelo mesmo participante. O exemplo dado por ele mostra que a sexualização do corpo feminino começa ainda na infância e é perpetuada pela mídia.

"O que me incomoda é essa representação da mulher, essa passividade, que muitas vezes a gente tem também no sertanejo, que a gente tem até em algumas músicas populares, que a mulher é aquele serzinho, que você vai pegar, que não tem vontade (MF)". 
Analisando as frases citadas acima, fica bem claro para quem presta atenção na letra a mensagem que ela passa: submissão e objetificação feminina. Essa objetificação é algo estrutural, que existe na sociedade desde sempre e por isso, acaba passando despercebida (BORDIEU, 2002).

Segundo Fromm (1965):

$\mathrm{Na}$ Psicologia moderna, Freud tornou-se o representante mais destacado do ponto de vista dos românticos. Enquanto o argumento destes fora elaborado em linguagem filosófica, o de Freud se baseava na observação científica dos pacientes pela Psicanálise. Supunha Ele que as diferenças anatômicas entre os sexos era a causa de diferenças de caráter inalteráveis. "A anatomia é a sua desgraça", diz ele da mulher, parafraseando uma afirmação de Napoleão (p. 89).

A dominação do masculino em relação ao feminino aparece não só nas atividades cotidianas como também no ato sexual. Tradicionalmente, existem sempre opostos: acima e abaixo, ativo e passivo, para fora e para dentro, e a partir disso é possível perceber que o homem, com justificativa anatômica, ocupa o lugar de dominação (dentro das ambiguidades) e a mulher de submissão. A passividade é acompanhada de objetificação, visto que a mulher, nessa concepção, é apenas aquela que dá prazer ao homem (BORDIEU, 2002).

\subsection{Relação Do Conteúdo Da Música Com A Cultura Brasileira}

A segunda categoria tem como objetivo relacionar o conteúdo da música com aspectos socioculturais presentes na cultura brasileira, sendo eles identificados de forma consciente ou não pelos participantes.

Os participantes foram questionados sobre a relação da cultura popular brasileira com a música que Ihes foi apresentada, no intuito de que fosse possível investigar a relação da cultura com o machismo. As respostas tiveram o conteúdo parecido, sendo que os participantes, de forma geral, afirmaram reconhecer a relação dessas duas áreas:

"Assim, eu acho que não só o conteúdo das músicas, mas toda a objetificação por volta dela, nos clipes, eu acho que tipo, se você for parar para ver, se for analisar mesmo, você fica tipo, mano, para que eu estou ouvindo uma coisa dessas? [...] É uma coisa que eu acho que tipo, às vezes você não presta atenção, mas como está ouvindo isso todo dia, você meio que assimila isso né, e se torna uma coisa cotidiana influenciado com a música e você nem percebe. Vira uma coisa estrutural (HF)".

"Sim. Mesmo que indiretamente, mesmo que essas pessoas não percebem, sim. Porque se essa música é tocada em uma festa, e, o funk ele já é uma, adoro funk, eu amo funk, quando eu bebo eu danço mesmo, sou muito contra esse discurso de que funk não é cultura, funk é cultura sim, representa 
muita gente, mas se nós, mulheres, estamos em uma festa e dançamos essa música, de um jeito ou de outro, essa música manda uma mensagem que reforça essa objetificação que já é muito forte e que na minha opinião precisa ser descontruída (MF)".

Foi possível identificar nas falas dos participantes, de forma geral, que aspectos culturais são influenciados pela música e o contrário também. $O$ desenvolvimento social decorre das vivências e experiências de determinada sociedade. $O$ sujeito tende a representar aquilo que foi aprendido em casa, pelos ensinamentos dos pais e passado de geração para geração. Sendo assim, a cultura machista desenvolvida ao decorrer dos anos acaba se enraizando e se tornando algo estrutural (CASTAÑEDA, 2006).

\subsection{Desigualdade De Gênero}

Nessa categoria, buscou-se apresentar falas dos participantes que comprovassem a desigualdade de gênero, subsidiando esses comentários com aspectos teóricos. Em um terceiro momento, durante a entrevista, os participantes foram questionados sobre as concepções individuais em relação a mulher, para que a pesquisadora pudesse abordar o sentido de 'ser mulher' na sociedade atual.

A prevalência das respostas foi em relação de ser uma pergunta muito ampla e, como resultado, complicada de responder. Entretanto, os participantes desenvolveram alguma resposta:

"Filosófico isso hein!? Caramba! Na minha visão, bom, fica difícil falar isso porque, querendo ou não você é muito influenciado pelo meio, né. E a gente é do interior, do meio do nada, minha família veio da roça, então a gente tem uma visão de a mulher fazer atividades domésticas, apesar que no momento eu estava lavando as louças. Geralmente essa opinião que a gente costuma ter. Como eu vou ficando mais velho, evoluindo como pessoa, eu tento ir tendo uma visão diferente, de igualdade sabe? Porque são só pessoas, eu tento não diferenciar por gênero (HF)".

"Caramba. Porque existem tantas mulheres, existem de tantas formas, mas, nossa, eu acho que é difícil sem um recorte assim, mas é, dentro do feminismo, resistência, sabe? E de um modo geral a gente já foi, já foi não, né, ainda é oprimida em muitos contextos e tudo mais, mas não pelo nosso gênero, mas por uma cultura totalmente desnecessária, enfim (MF)".

"Bastante complexo, né? Eu posso te falar um monte de coisas sobre isso, mas eu penso em família, sabe? O que vem na minha cabeça em princípio. Acho que não tem nem a ver com o tema, mas fala em mulher eu penso em uma de família, em uma esposa $(H)$ ". 
"Mulher eu penso na minha mãe, que é um exemplo de mulher de família, recatada, que cuida do marido e dos filhos e da casa $(H)$ ".

"É uma pergunta complicada pois cada pessoa pode relacionar a mulher a diferentes aspectos. Eu, por exemplo, não costumo fazer diferenciação entre os sexos, considero todos seres humanos com sua individualidade, mas em casa não funciona bem assim. Meus avós são muito religiosos, e acreditam que a mulher está diretamente relacionada com a família, que é cuidar da casa, cuidar dos filhos, cuidar do marido. Eu não concordo com essa afirmação, mas a maioria das pessoas da minha família acreditam nisso (MF)".

De acordo com as respostas anteriores, percebe-se que algumas das explicações do que é ser mulher são baseadas em conceitos bíblicos, especialmente as respostas de homens que não se consideram apoiadores da causa feminista. Para o cristianismo, os prazeres carnais eram considerados pecado, e tudo que envolvesse coisas do tipo. Sendo assim, a relação sexual entre homem e mulher só devia ser praticada no intuito de reprodução. Em virtude disso, a mulher é constantemente relacionada com a maternidade e 0 cuidado com a família, e aquela que descumpre essas expectativas é julgada e considerada pecadora (BIRMAN, 1999).

Um dos participantes afirma ter gostado do ritmo da música, porém não ter gostado da letra. De nove participantes apenas um afirmou que, além de ter ouvido a música anteriormente, já havia analisado a letra e desgostado. É um ponto interessante a ser destacado pois mostra que, ao menos algumas pessoas, possivelmente já estão buscando desenvolver senso crítico em relação ao machismo estrutural.

Logo após a reflexão do que é ser mulher, os participantes foram indagados ao contrário: qual a concepção de cada um em relação ao "ser homem". As respostas condisseram bastante com o que cada participante havia dito em relação a mulher:

"Quando fala em homem a primeira coisa que vem é trabalho duro, sinceramente. Isso é a primeira coisa que me vem na cabeça $(H)$ ".

"Eu acho que existem subtipos dentro dos homens, por exemplo, eu tenho amigos que são caras muito conscientes da questão da mulher, mas eu também conheço caras que, vão ao meu grupo de leituras que é de mulheres que são super machistas e se incomodam com o tanto de mulher tendo voz, pensando 'aqui não é seu lugar, não é sua vez de falar'. Eu acho que ainda é muito difícil para o homem sair desse lugar de privilégio que o machismo coloca ele. (MF)". 
Fica explícita a diferenciação feita em relação da posição da mulher e do homem na sociedade, voltando a deixar explicita a ideia de que 0 homem é forte e deve trabalhar pesado para sustentar a mulher e mãe de seus filhos. Tudo isso em virtude a estrutura social na qual a sociedade se desenvolveu (DEL PRIORI; BASSANEZI, 2000).

As visões expressas nas falas dos participantes demostram a polarização homem $X$ mulher, indicando uma contradição entre querer ver $\mathrm{e}$ buscar a semelhança entre eles, bem como a igualdade de condições, mas assumir, na fala e no olhar para a criação que tem, dentro de si, valores e ideias de que são diferentes. Além disso, as falas pontuam que são questões que, apesar de sabermos que não favorecem a mulher, estão arraigadas na subjetividade e na cultura. Esses aspectos dicotômicos entre os sexos tomaram força na ascensão do cristianismo, quando a bíblia afirma que o homem foi criado a imagem e semelhança de Deus, e a mulher foi criada depois, como punição (FROMM, 1965).

\section{CONCLUSÃO}

O objetivo da pesquisa foi discutir a percepção que homens e mulheres tem a respeito de conteúdos machistas presentes em músicas brasileiras. Partindo do pressuposto de que elementos machistas presentes no inconsciente coletivo alimentam uma visão específica do feminino na qual a mulher é colocada em posição de inferioridade em relação ao homem, esses elementos influenciam no desenvolvimento da personalidade individual e na disseminação do machismo, e ainda podem ser justificados como cultura.

O machismo no Brasil, foi algo de fato construído culturalmente, principalmente após a ascensão do cristianismo, quando as pessoas passam a justificar falar e atos machistas com frases bíblicas. Essa naturalização de hábitos considerados machistas acaba refletindo em toda a cultura daquela sociedade, nos meios de comunicação, inclusive as músicas. Não se pode afirmar que toda a música existente contém conteúdo machista, mas é possível perceber a prevalência de tal conteúdo em alguns gêneros, no caso estudado, o funk.

O interessante ao levantar discussões por volta desse aspecto é que se torna nítido o papel da indústria do entretenimento na disseminação de ideias, sejam essas machistas, não machistas, positivas ou negativas. A mídia contribui diretamente no desenvolvimento sociocultural de quem a consome, pois na maior parte das vezes mostra determinados conteúdos como importantes e exemplifica com famosos consumindo esse conteúdo, incentivando a população a fazer o mesmo.

Muitos jovens e adolescentes que estão em fase de desenvolvimento, ouvem alguma música, assistem algo na televisão e acabam representando aquilo que foi dito, simplesmente por estar na moda entre todos. No caso do machismo, se tornou algo tão estrutural que acaba passando 
despercebido pelas pessoas, que não são incentivas a desenvolver senso crítico sobre $o$ assunto. As músicas tocam, as pessoas ouvem e reproduzem, sem nem colocar atenção no que ela diz. Esse conteúdo fica no inconsciente dessas pessoas e elas acabam o reproduzindo, as vezes na forma de frases cotidianas, como "isso é coisa de home/mulher".

Conteúdos machistas não são reproduzidos apenas por homens, justamente por ser algo naturalizado. Mulheres não feministas, ao lerem o tema da pesquisa não aceitaram participar, afirmando que "não seria uma pesquisa parcial", por acreditar que discussões acerca do machismo são apenas problematização de problemas inexistentes. Viver em uma sociedade que a mulher é inferior ao homem faz com que muitas mulheres também acreditem nessa "verdade", por isso muitas nem aceitam esse tipo de questionamento. É como se ficasse explicito que a mulher não pode ter voz, nem vontades, e muito menos questionar sobre os seus próprios direitos.

Outras pesquisas que continuem a investigação acerca das produções culturais e sua influência na perpetuação e/ou na ruptura de estereótipos são recomendadas, visando o aprofundamento da compreensão e das reflexões acerca dessa temática.

\section{REFERÊNCIAS}

AGUIAR, Joaquim. A poesia da canção. 2. ed. São Paulo: Scipione LTDA, 1998.

ALLPORT, Gordon W. Personalidade: padrões e desenvolvimento. São Paulo: Herder, 1996.

ALVES, Branca Moreira; PITANGUY, Jacqueline. O que é feminismo. São Paulo: Abril Cultural / Brasiliense, 1985.

BESSE, Susan K. Modernizando a desigualdade: reestruturação da ideologia de gênero no Brasil 1914-1940. São Paulo: Editora da Universidade de São Paulo, 1999.

BIRMAN, Joel. Cartografias do feminino. São Paulo: Editora 34, 1999.

BORDIEU, Pierre. A dominação masculina. 2. ed. Rio de Janeiro: Bertand Brasil, 2002.

CASTAÑEDA, Maria. 0 machismo invisível. São Paulo: A Girafa, 2006.

DEL PRIORI, Marry; BASSANEZI, Carla. História das mulheres no Brasil. 3. ed. São Paulo: Contexto, 2000.

FADIMAN, James; FRAGER, Robert. Teorias da Personalidade. São Paulo: HARBRA, 1986.

FREUD, Sigmund. O mal-estar na cultura. Porto Alegre: LPM, 2010. 
FROMM, Eric. O dogma de cristo: e outros ensaios sobre religião, psicologia e cultura. E. ed. Rio de Janeiro: Zahar, 1965.

JUNG, Carl Gustav. Obra completa de Jung 9/1: Os arquétipos e o inconsciente coletivo. Petrópolis, RJ: Editora Vozes, 2011.

LARAIA, Roque de Barros. Cultura: um conceito antropológico. 18. Ed. Rio de Janeiro: Jorge Zahar, 2005.

LE BON, Gustav. Psicologia das multidões. Lisboa: Edições Roger Delraux, 1980.

LÜDKE, Menga; ANDRÉ, Marli E. D. A. Pesquisa em educação: abordagens qualitativas. São Paulo: EPU, 1986.

MINAYO, Maria C. de S. (Org.). Pesquisa social: teoria, método e criatividade. 21. ed. Petrópolis, RJ: Vozes, 1994.

MORAES, Roque; GALIAZZI, Maria do C. Análise Textual Discursiva. ljuí: Unijuí, 2005.

PIOVESAN, Armando; TEMPORINI, Edméa R. Pesquisa exploratória: procedimento metodológico para o estudo de fatores humanos no campo da saúde pública. Revista De Saúde Pública, v.29, n.4, p.318-325, 1995. Disponível em: <https://doi.org/10.1590/S0034-89101995000400010>. Acesso em 04 jul. 2020.

PK. Quando a vontade bater. Rio de Janeiro: MDSProduções, 2020. Disponível em: <https://www.letras.mus.br/pk/quando-a-vontade-bater/>. Acesso em 09 mar. 2020.

ROUDINESCO, Elisabeth. A família em desordem. Rio de Janeiro: Zahar, 2003.

SARTI, Cynthia. Feminismo no Brasil: uma trajetória particular. Cad. Pesq., São Paulo, n.64, p.38-47, fev., 1988. Disponível em: $<$ http://publicacoes.fcc.org.br/ ojs/index.php/cp/article/view/1182/1188>. Acesso em 04 jun. 2020.

TURATO, Egberto R. Métodos qualitativos e quantitativos na área da saúde: definições, diferenças e seus objetos de pesquisa. Revista de Saúde Pública, v.39, n.6, p.507-514, 2005. 


\section{O CORPO NA PSICANÁLISE: genealogia do conceito e crítica a partir de uma perspectiva de gênero}

Manoela Pacheco Chagas

Sofia Muniz Alves Gracioli

\section{INTRODUÇÃO}

A discussão acerca da corporeidade coloca em relação corpo ${ }^{4}$ e sujeito ${ }^{5}$ a partir do contexto e da sobreposição do vivido e do pensado através do sentido. A compreensão construída sobre os fenômenos cotidianos por um indivíduo, passa pela mediação do outro e se concretiza nas capacidades perceptivas do sujeito. Ao levar em consideração o impacto da imagem corporal, as fronteiras do corpo não se restringem ao sujeito em si. Durante muito tempo, os limites do corpo foram descritos como fronteiras materiais, mas a partir de novas óticas dentro das ciências humanas, enxerga-se o corpo como um elemento relacional que transpõem as barreiras anatômicas.

A relação entre sujeito e seu corpo se faz por um processo social e individual no qual traços e características corpóreas afetam o entendimento do sujeito a partir de seu corpo. As relações e sentimentos vividos que são produto do sujeito, ao mesmo tempo que são experienciados por ele, elucida uma relação que por muito tempo foi invisibilizada na filosofia ocidental e na psicanálise: a relação bidirecional entre sujeito e corpo. O enfoque do presente artigo é analisar especificamente a relação entre sujeitos com seu corpo e com outros corpos, para entender como foi tecida a visão corpo e mente ao longo da história ocidental e qual o encaixe a psicanálise faz a partir do que já foi construído e o que é trazido de novo pelas humanidades.

A literatura conta com uma extensa discussão que tange o tema do corpo, mas existe uma lacuna quanto aos reflexos psicológicos da corporeidade, o que justifica a pertinência de análise crítica destas categorias.

O presente artigo buscou realizar uma discussão acerca da relação entre corpo e sujeito, para compreender qual é o entendimento dos elementos pela psicanálise e a relação dos processos criados por eles. Para isso, foi utilizada a metodologia de revisão bibliográfica crítica, visando explorar

\footnotetext{
${ }^{4}$ Corpo, no conceito deste artigo, significa não somente a esfera biológica do homem, o ego psíquico ou um sujeito influente no ambiente, mas o local onde as três esferas se tangem, como um ser biológico, em que o ego reside no mundo e existe em detrimento da relação das três esferas, biológica, psicológica e social.

${ }^{5}$ Sujeito, no contexto deste artigo, remete a individualidade psíquica. Estrutura psíquica, na fragmentação freudiana de id, ego e superego; inconsciente, subconsciente e consciente. Onde se dão os reflexos do vivido pelo corpo em todos as esferas, para um recorte psicológico da análise de corpo.
} 
os levantamentos já feitos através de uma genealogia do conceito de corpo aos moldes foucaultianos, traçar correlações com a visão psicanalítica de corpo em "Estudos sobre a Histeria" e discutir a partir do trabalho de Simone de Beauvoir como acontecem a relação de corpo e sujeito em um recorte de gênero.

\section{HISTÓRIA DO PENSAMENTO SOBRE O CORPO}

Observando as expressões atuais referente aos aspectos corpóreos do ser humano, torna-se imprescindível a reflexão sobre aspectos históricos do desdobramento sobre o tema. O presente tópico relaciona dois conceitos: o corpo e a história, para que posteriormente caiba a construção de um pensamento sobre a relação entre sujeito e corpo. Antes de adentrarmos nas visões de diferentes pontos de vistas e momentos históricos, é importante ressaltar que foram escolhidos os discursos mais influentes para a psicanálise, que para onde se encaminhará o trabalho desse artigo, mas que existem outras inúmeras perspectivas, que não foram abordadas por não terem a oportunidade de serem as visões mais citadas e acessadas na psicologia ocidental.

A discussão acerca do corpo trazidas pela psicologia, tem seu cerne na filosofia greco-romana, com platão e aristóteles e se desdobra na idade-média, para as concepções cristãs que ainda compõem visões de corpo até hoje. Em contraponto a perspectiva negacionista do corpo $^{6}$ da mentalidade medieval, o renascimento se inicia com a predominância do culto ao prazer carnal com o hedonismo e progride para a acentuada dessacralização do corpo, que se afirma no antropocentrismo.

Os primeiros registros da discussão ocidental a respeito das propriedades corpóreas foram traçados pelos filósofos greco-romanos. Platão (428-347 a.C.) relaciona a existência do corpo a uma subordinação à alma; esses dois elementos se contrapõe, no sentido de que a alma é colocada como perfeita, eterna e imutável e já o corpo representa uma dimensão inferior por ser imperfeito e mortal e realizador de trabalhos não prestigiosos, em relação ao trabalho intelectual da alma (DUMONT e PRETO, 2005). Assim, suas ideias teceram os pressupostos para a teologia cristã em várias dimensões, incluindo o entendimento da corporeidade humana, através da filosofia platônico-cristã, que teve como principal representante Santo Agostinho (DE OLIVEIRA 2017).

Santo Agostinho (354-430 d.C.) coloca que o homem faz sua existência possível pela relação das substâncias alma e corpo. No qual a primeira é de natureza espiritual, criação divina mais perfeita do que o segundo (NUNES COSTA, 2018). O corpo para Santo Agostinho é instrumento

\footnotetext{
${ }^{6}$ como renúncia às necessidades primárias do corpo, principalmente relacionados aos pecados capitais, que culminam na "ascese".
} 
pecaminoso, o que desenvolve junto a filosofia cristã, a noção de que os prazeres corporais devem ser abdicados, já que pecaminosos, em prol dos princípios cristãos.

Outro filósofo grego, que as ideias permeiam os pensamentos dos dias atuais, foi Aristóteles (384-322 a.C.). O filósofo também constrói a ideia de corpo à partir da sua relação com a alma, mas em contraponto à cisão antagônica dos elementos tratada por Platão, ratifica que o corpo é instrumento para a alma racional e que o homem é uma unidade substancial dos dois componentes, que ao se relacionarem concebem o intelecto (DUMONT e PRETO, 2005). O homem é uma conciliação essencial de alma e de corpo, em que a primeira realiza as finalidades de forma em relação à matéria, que é constituída pelo segundo.

A idade média carregou a visão da teologia cristã e com isso a ideia de que o corpo era fruto da bênção e glorificação, o corpo sacro. Mas por ser produção divina, deveria ser mantido intacto o máximo possível, havendo a estimulação de práticas de "ginástica espiritual" que abordava a realização de procedimentos negacionistas dos prazeres humanos como jejum, penitência e mortificação.

Mesmo tendo vivido na idade média, Santo Tomás de Aquino (1225-1274) coloca a relação corpórea de maneira distinta a aristotélica, de modo a unir corpo e alma em um só composto substancial. Apesar de não suspender a dualidade psicofísica entre material e mental, o filósofo coloca 0 corpo em uma valoração ascendente e equiparada a da alma e realça que a alma deve sua existência ao corpo, ao passo que os dois elementos se relacionam de maneira interdependente (COSTA, 2015).

A modernidade é caracterizada em si pelo contraste à secularização da época medieval e assim, a visão de corpo acompanha a ânsia pela libertação do "sujeito cosmológico". A designação do corpo se revela em características científicas como animale traz crescente dessacralização do corpo e assim, o antropocentrismo emerge, em sobreposição ao teocentrismo. Assim, o distanciamento do dualismo radical cartesiano psico-físico do corpo tem ascensão e Baruch Spinoza (1632-1677) coloca o corpo como estabelecido por relações com outros corpos e em sua possibilidade de afetar e ser afetado de maneira harmoniosa, um corpo se regenera na presença de outros e dispõe de maior capacidade vital (CHAUÍ, 1995). Além disso, a crença filosófica-moral do hedonismo também surge com o distanciamento do pensamento estrito secular, considerando o prazer como bem supremo da vida humana.

As grandes navegações, colonizações e grandes invenções mudaram a vida na idade moderna, afetando os relacionamos entre corpos e do sujeito com o próprio corpo. O pensamento cartesiano realça, ao mesmo tempo que trás novas esferas para o dualismo psicofísico. Tomando como 
alegoria do pensamento moderno a frase "Penso, logo existo", de René Descartes (1596-1650), a racionalidade pode ser entendida como único elemento caracterizador do homem e a alma como razão pura a qual está separada do corpo físico, propondo que o raciocínio deve ser feito de forma desconectada das emoções, assim como também considerava Immanuel Kant (1724-1804) posteriormente (TOMAZ e GIUGLIANO 1997).

As teorias biológicas de Charles Darwin (1809-1882) e JeanBaptiste de Lamarck (1744-1829) caminham pelo mesmo trajeto da herança deixada por Kant e Descartes. Com a emergência das ciências duras, a razão defendida pelos lluministas do século XVII e XVIII ganha mais força, secularizando o corpo ao mesmo tempo em que aumentam a cisão entre corpo e mente. Ao reiterar a criação do homem como não divina, os autores contribuem para a secularização do corpo em retomada a cisão cristã, mas em substituição à alma, aqui ganha lugar a razão. Em perspectiva estritamente biológica, os autores colocam o corpo humano como produto de uma evolução genética, indicado por contexto seletivo (DUMONT e PRETO, 2005) e tem grande grande impacto a concepção de corpo na idade contemporânea, Darwin e Lamarck trazem a ideia da teoria da evolução orgânica e estão presentes na maioria massiva dos livros de biologia do ensino básico de todo o mundo (ALMEIDA e FALCÃO, 2010). Entanto, a compreensão biológica compreende certa noção de corpo como condição de fábrica, já que cada partícula, célula, tecido e órgão é responsável por uma função específica que contribui para o bom funcionamento do todo.

Já com a Revolução Industrial e a ascensão do capitalismo, o corpo é diminuído a condição de máquina. Visto como destinado ao trabalho, o funcionamento corpóreo propõe-se a um ajustamento para que a produção material seja maximizada, influindo Karl Marx (1818-1883) a colocar a relação com o trabalho e sua a divisão social como imprescindível para entender 0 corpo. $O$ autor propõe que o corpo é definido nas relações mercado-capital se portando como objeto, quando a dinâmica de oferta e demanda obriga o trabalhador a vender sua força de trabalho e se atribuir um valor, o tornando mercadoria (JUNIOR, 2009).

Já com uma ótica diferente dentro das discussões contemporâneas da corporeidade, Michel Foucault (1926-1984) traz a perspectiva da disciplinarização dos corpos. O filósofo francês é um dos mais influentes da contemporaneidade, principalmente para os estudos das ciências humanas nos diálogos sobre poder, estado e também sobre a disciplinarização dos corpos. Em uma de suas obras mais emblemáticas, "Vigiar e Punir", Foucault (2014) trabalha os espaços de punição e domesticação dos corpos e aponta que ao decorrer dos séculos XVII e XVIII surgem técnicas de controle para "corpos dóceis", que estão prontos para serem domesticados.

O momento histórico das disciplinas é o momento em que nasce uma arte do corpo humano, que visa não unicamente o aumento de suas 
habilidades, nem tampouco aprofundar sua sujeição, mas a formação de uma relação que no mesmo mecanismo o torna tanto mais obediente quanto é mais útil, e inversamente. Forma-se então uma política das coerções que são um trabalho sobre o corpo, uma manipulação calculada de seus elementos, de seus gestos, de seus comportamentos. O corpo humano entra numa maquinaria de poder que o esquadrinha, o desarticula e o recompõe. Uma "anatomia política", que é também igualmente uma "mecânica do poder", está nascendo; ela define como se pode ter domínio sobre o corpo dos outros, não simplesmente para que façam o que se quer, mas para que operem como se quer, com as técnicas, segundo a rapidez e a eficácia que se determina. (FOUCAULT, 2014, p. 135)

A análise do autor parte da relação poder-corpo e como a disciplina fabrica corpos dóceis, moldados para aumentar suas forças econômicas, tornando-se mais útil, e para diminuir as forças políticas, tornando-se obediente. $O$ almejo pelos corpos úteis e dóceis partem das políticas de coerção sobre o corpo praticadas pelas técnicas de instituições disciplinares, tornando indissociável a consideração dos espaços disciplinares para o entendimento da corporeidade, na primeira forma de poder posta pelo filósofo (FOUCAULT, 2014, p. 135 - 136).

Após a análise do corpo dentro da lógica disciplinar, Foucault faz uma leitura da lógica biopolítica, concretizada no biopoder a partir das "regulações de população demográfica, a estimativa da relação entre recursos e habitantes, a tabulação das riquezas e de sua circulação e das suas vidas como duração provável" que controlam os corpos pelo poder soberano de distribuir o "indireito" de vida e morte (2017, P. 151).

Concretamente, esse poder sobre a vida desenvolveu-se a partir do século XVII, em duas formas principais; que não são antitéticas e constituem, ao contrário, dois pólos de desenvolvimento interligados por todo um feixe intermediário de relações. Um dos polos, o primeiro a ser formado, ao que parece, centrou-se no corpo como máquina: no seu adestramento, na ampliação de suas aptidões, na extorsão de suas forças, no crescimento paralelo de sua utilidade e docilidade, na sua integração em sistemas de controle eficazes e econômicos - tudo isso assegurado por procedimentos de poder que caracterizam as disciplinas: anátomo-política do corpo humano.O segundo, que se formou pouco mais tarde, por volta da metade do século XVIII, centrou-se no corpo-espécie, no corpo transpassado pela mecânica do ser vivo e como suporte dos processos biológicos: a proliferação, os nascimentos e a mortalidade, o nível de saúde, a duração da vida, a longevidade, com todas as condições que podem fazê-lo variar; tais processos são assumidos mediante toda uma série de intervenções e controles reguladores: uma biopolítica da população (FOUCAULT, 2017, P. 149 - 150, grifo do autor).

Então, a função mais elevada do poder não se caracteriza mais no assentimento para matar, mas no investimento sobre a vida, de cima para baixo.

Através da genealogia do conceito de corpo aqui trazido, fica claro que o lugar filosófico que a categoria de corpo ocupou nos trajetos da história 
do pensamento ocidental foi muito marcada por uma centralidade metafísica da alma, da razão, do mundo imanente, categorias construídas e olhadas em oposição ao corpo. Ou são percebidas de maneira relacional a um outro conceito específico, como o trabalho em Marx e o poder em Foucault.

A compreensão relacional do corpo é feita por uma ótica causal, que localiza o corpo como produto dentro do encadeamento estabelecido, 0 que determina a influência de um objeto em outro como unidirecional. É importante entender a operação de causalidade descrita para entendimento do corpo, assim como as condições sócio-históricas que produziram a noção de corpo para imaginar uma relação dialética que valorize o corpo como espaço de produção de relações e subjetividades.

No próximo tópico será disposto o entendimento de corpo dentro da psicanálise, a partir da obra que é o ponto de partida da teoria freudiana, "Estudos sobre a histeria", que revelam suas noções básicas sobre o conceito explorado no artigo e também será proposta uma discussão de gênero sobre corpo e subjetivação através do trabalho de Simone de Beauvoir.

\section{A COMPREENSÃO DE CORPO PELA PSICANÁLISE}

As ciências humanas se encontram em um contexto em que marcadores sociais se tornam cada vez evidentes como questões epistemológicas, assim como suas consequências psicológicas; com isso, o entendimento de corpo deve abranger tais questões e a transposição do vivido para o pensado e sentido no sujeito precisam aparecer no pensamento psicanalítico contemporâneo. A psicanálise enxerga o corpo como produto dos processos psíquicos e para entender tal visão será feita uma análise da posição histórico-social do surgimento da psicanálise e um comentário sobre o entendimento de corpo na obra "Estudos sobre a histeria"

A visão de homem pela psicanálise é condicionada por seu momento histórico. Para entender a percepção que a teoria tem do corpo, é preciso fazer uma leitura do processo sócio-histórico de sua construção com Sigmund Freud. Na teoria Freudiana, o corpo tem encaixe na compreensão sobre o ser humano, intimamente relacionado com o pensamento da época.

Freud inicia a construção de suas ideias no final do século XIX e início do século XX, sobretudo em Viena, grande espaço cultural, científico e econômico da época, integrado por vastos pensamentos cosmopolitas. A cidade era o centro do Império austro-húngaro, que já estava desde os últimos cinco anos do século XIX em desintegração social e política e teve seu fim em 1918. Neste período de virada do século, as ideias de refinados intelectuais em juventude se voltavam para as preocupações do indivíduo em uma sociedade em desintegração.

Tal pensamento se constrói pela confrontação às ideias da 
geração anterior, seus pais, agentes liberais que haviam criado Viena até então, com foco no homem racional. Esse era centrado em construir a boa sociedade a partir do domínio sobre a natureza amparado pela comunidade científica, além de dominar, reproduzir e conduzir as próximas gerações a correta conduta moral. Pelo descontento com as condutas que se mantiveram como vestígios da monarquia, a posição da nova juventude era o de contrapor a conformidade disciplinada aos padrões de bom gosto e da ação de bons costumes (WINOGRAD e KLAUTAU, 2014).

Assim, no século $X X$, o homem racional tão enaltecido durante 0 século anterior, dá lugar ao chamado homem psicológico. Como visível também no trabalho de Gustav Klimt e Egon Schiele, esse homem era repleto dos sentimentos humanos privados antes ocultados ferrenhamente pela Viena de XIX, mas que agora quer expressar os desejos que se fizeram reprimidos.

As criações freudianas e o desenvolvimento da teoria psicanalítica se dão em consonância com a perspectiva descrita acima, o enfoque na libertação dos traços humanos viscerais, está presente também na forma de apresentar a estrutura humana de Freud, como pode se perceber em suas ideias de inconsciente e os somatização de desejos não expostos do ser.

Freud realizou sua formação acadêmica na Universidade de Viena como médico em momento de renovação da ciência neurológica. As doenças psíquicas ainda eram pouco ou quase nada exploradas, tampouco os aspectos psíquicos eram considerados como biológicos pela comunidade científica. As colocações positivistas exigiam comprovação material, como elucida Freud (1996, p. 215), "eles não sabiam o que fazer do fator psíquico e não podiam entendê-lo. Deixavam-no aos filósofos, aos místicos e - aos charlatães: e consideravam não científico ter qualquer coisa a ver com ele".

O autor expande seu trabalho de pesquisa a princípio para a busca das causas de uma doença enigmática até então, a histeria. Sua primeira publicação, escrita com Breuer, "Estudos sobre a Histeria" (1996) é o livro amplamente considerado como 0 ponto de partida das ideias psicanalistas. Nesta primeira grande obra já fica claro a visão da teoria sobre a dimensão corpórea e seu papel. O corpo é retratado pela psicanálise como limite, de maneira que é entendido como a barreira fisiológica em que se inferem as psicopatologias em forma de sintomas.

Os estudos que chegaram a histeria se iniciaram pelo interesse de Breuer e Freud em casos de sintomas físicos não explicados inicialmente pela análise fisiológica médica, os quais foram descobertos como tendo causas psicológicas. Ou seja, a histeria se revela em sintomas físicos ligados a causas psíquicas.

Nossas experiências [...] têm demonstrado que os mais variados sintomas, que são ostensivamente espontâneos e, como se poderia dizer, produtos idiopáticos da histeria, estão tão estritamente 
relacionados com o trauma desencadeador quanto os fenômenos a que acabamos de aludir [ataques histéricos em que o paciente alucina o mesmo evento que provocou o primeiro deles] e que exibem a conexão causal de maneira bem clara. Os sintomas cujo rastro pudemos seguir até os referidos fatores desencadeadores deste tipo abrangem nevralgias e anestesias de naturezas muito diversas, muitas das quais haviam persistido durante anos, contraturas e paralisias, ataques histéricos e convulsões epileptóides, que os observadores consideravam como epilepsia verdadeira, petit mal e perturbações da ordem dos tiques, vômitos crônicos e anorexia, levados até o extremo de rejeição de todos os alimentos, várias formas de perturbação da visão, alucinações visuais constantemente recorrentes, etc (FREUD; BREUER, 1996, P. 20).

Foram percebidos como perturbações sensoriais e motoras, dores ou disfunções corporais que não tinham causa fisiológica e Freud e Breuer os rastrearam, na época utilizando a hipnose, como a somatização do sofrimento intrapsíquico histérico. $O$ corpo aqui aparece apenas como espaço de aparição do sintoma, que sucede o trauma, em um sistema de causa e consequência em que o corpo é espaço de aparição da última, em analogia estritamente unidirecional.

A partir da análise da histeria muito foi revelado sobre os acontecimentos psíquicos e como estes acometem o corpo. A interpretação de Freud, e posteriormente de toda a comunidade psicanalítica, foi de que 0 sofrimento poderia ser uma anomalia que acomete a parte fisiológica humana, ao se manifestar na dimensão corpórea.

O corpo na psicanálise se inscreve como um resultante das combinações entre as esferas do real, simbólico e imaginário. Entende-se a corporeidade como um litoral psicossomático, como orquestrado no livro "A pele como litoral: fenômeno psicossomático e psicanálise" (Aragão, Ramirez, Assadi e Dunker, 2011).

Muito foi descoberto e discutido pela psicanálise sobre como o estado psíquico acomete o corpo, mas como e mesmo se o processo inverso acontece não é algo esclarecido pelos escritos Freudianos. Como a construção simbólica de determinado corpo no interior da estrutura social perpetra a dinâmica psíquica? Como a diferença transformada em desigualdade afeta os processos de subjetivação? Como a linguagem se transforma ao encarar corpos diferentes e como isso se reflete na psique de cada sujeito? Como a relação de causa (psíquica) e efeito (corporal) se dobra?

\section{A COMPREENSÃO DE CORPO A PARTIR DE UMA PERSPECTIVA DE GÊNERO}

Neste tópico será feita uma discussão de gênero sobre o corpo e subjetivação através do trabalho de Simone de Beauvoir que ratifica a importância de considerar a volta da relação causal proposta pela psicanálise 
que enxerga o corpo apenas como produto, para que se possa entender os reflexos do corpo inserido em uma estrutura, em especial aqueles que vivem com marcadores sociais da diferença.

Na sociedade, tradicionalmente os indivíduos são categorizados a partir do corpo em estrutura binária: feminino e masculino. Tal colocação aparece associada a papéis e comportamentos que, se seguidas ou desviadas, certamente afetam a dinâmica psíquica do indivíduo..

Para compreender a construção simbólica do feminino, neste artigo, será feita utilização da divisão colocada por Simone de Beauvoir quanto ao corpo segundo organismo, que se polariza estruturalmente como feminino e masculino (BEAUVOIR, 2009). Tais "categorias" não se encontram em essências fundamentais que as distinguem separadamente uma da outra, a existência da mulher como sujeito em estrutura acontece por meio da posição que esse corpo tem em relação ao homem e a masculinidade, sendo interpretada como o outro, que só existe a partir do lugar que exerce para o sujeito primeiro, o homem. A interpretação social do papel do corpo feminino se deu por meio de uma situação de submissão e inferioridade em relação ao homem, em processo dialético opressor.

Desde a infância a menina já se desenvolve a partir de um tratamento e linguagem que conduzem a colocação de si em posição de não detentora do poder, não possuinte da sabedoria e não atuante na construção da cultura. A menina é educada para tornar-se mulher, sua posição é designada a gerência e cuidado da existência masculina, para que o homem possa concretizar seus desejos.
A formação da menina não a encaminha para o destino masculino privilegiado; ela não possui um pênis, a ela Ihe dão uma boneca, que corresponde a seu duplo separado de si mesma, a presença física que ela pode ostentar simbolizando o destino feminino. (BEAUVOIR, 2009, p.371) Com todas essas características especificamente masculinas e femininas, o discernimento entre masculino como superioridade e feminino como inferioridade já ocorre na infância. Com a ampliação do universo da criança essa diferença só é confirmada, no ambiente familiar a criança observa que é o pai quem tem autoridade sobre todos, e fora da família, na sociedade ocidental em geral, seja na história, na literatura, nas canções, nas lendas e na religião cristã (BEAUVOIR, 2009, p.385), aprendem que foi o homem quem fez tudo (OLIVA, 2014).

Durante a puberdade, no processo de tornar-se adulta, a menina passa a ser encarada como objeto, sendo removida da situação de criançasujeito. O corpo ideal da adolescente é objetificado pelo olhar masculino, mais do que em qualquer outro momento do corpo feminino. Ao ser colocada em lugar de corpo objeto, a mulher é distanciada da condição de sujeito, colocada em perspectiva passiva e perde sua agência e autonomia.

Na vida adulta o papel imanente da mulher é o de esposa, mãe e cuidadora. Durante seu período de escrita, Beauvoir descreve que maternidade 
era vigorosamente disposta como inerente à essência feminina, em que ser mãe se torna como a única maneira coerente de realização pessoal (OLIVA, 2014), além do dever de gerir o espaço de convivência e nutrição tanto física quanto psíquica para os demais componentes da família.

A capacidade que o corpo da mulher tem de procriar não a realiza, nem justifica a sua existência, ela não transcende a sua situação de fêmea humana, ela continua a pretender afirmar-se por meio do seu corpo, como a sociedade já sugere que ela faça, e continua presa na imanência. O reconhecimento que ela pode ganhar como mãe na sociedade decorre do serviço que ela presta à espécie, e por assumir o papel de mãe, porém continua situada como o Outro (OLIVA, 2014).

Ao caminhar para o envelhecimento o corpo objetificado da mulher juvenil se esvai naturalmente, mas é cobrado que ele se mantenha e que haja uma luta para a conservação da juventude corporal. É estabelecida uma luta contra a velhice e o destino natural do corpo, o que a submete a alienação ao processo de envelhecimento.

Diante da situação social em que se encontra a diretividade do desenvolvimento da menina-mulher-idosa, existem desvios e coerências traçados por cada mulher. Seguir a trilha social a que estão submetidas acarreta em não encontro com seus verdadeiros desejos, já negar este caminho é se colocar como desviante de seu lugar em sociedade.

A questão levantada aqui não é para a reflexão de se as mulheres estão ou não seguindo as diretrizes as que são impostas, mas reiterar de que a simbologia do corpo feminino está sujeito a normatividade delimitante e que a vivência condizente ou discrepante com os caminho normativo precisa ser levado em consideração para se pensar como isso afeta a subjetivação do indivíduo na dobra do pensamento psicanalítico de relação de causas psíquicas e consequências corporais.

\section{CONSIDERAÇÕES FINAIS}

Como elucida Simone de Beauvoir, o corpo é sujeito de experiência. $O$ mundo não trata a todos com neutralidade, a vivência de cada sujeito em um espaço se estabelece conforme é tida a compreensão do corpo deste pelos demais e por si próprio. Por isso, é necessário não só entender o corpo como local passivo que recebe inscrições do estabelecimento psíquico do sujeito.

As descobertas psicanalíticas sobre a somatização histérica foram grandes passos para a compreensão da dinâmica humana e como o corpo se estabelece como litoral psicossomático, mas não é a única relação que se estabelece nessa dinâmica tão peculiar que envolve o indivíduo como um todo, atravessando todas as esferas constituintes da filosofia ocidental: biológica, psíquica e social, sendo produto e produtor do ambiente no qual se encontra. 
Os entendimentos históricos de corpo que tangem o tempo todo a condição humana são também cruciais para que entendamos não só a construção da noção corpórea pela teoria psicanalítica, mas também como chegamos na compreensão contemporânea coletiva que foi construída em uma teia relacional de ideias e conceitos.

O trabalho de Simone de Beauvoir trazido para a construção do último tópico é uma das teorias que deixam clara a necessidade de se construir a dobra relacional discutida nesse artigo dentro da teoria psicanalítica.

Por fim, é preciso pontuar que no presente artigo foi marcada a relação do sujeito e seu corpo e, conforme o assunto foi explorado, abrem-se portas para um terceiro elemento, crucial para o desenvolvimento pleno da proposição que este trabalho buscou realizar: os outros corpos com o qual o corpo-sujeito se correlaciona. A questão não foi abordada por escassez de tempo e espaço, mas preparou-se o terreno para que em outro momento esse terceiro elemento relacional, necessário para compreender os processos de subjetivação, possa ser parte constituinte da equação psicanalítica e assim compreender plenamente os processos de subjetivação.

\section{REFERÊNCIAS}

ALMEIDA, A. V.; FALCÃO, J. T. R.. As teorias de Lamarck e Darwin nos livros didáticos de Biologia no Brasil. Ciênc. educ. (Bauru), Bauru, v. 16, n. 3, p. 649-665, 2010 . Disponível em <http://www.scielo.br/scielo.php?script=sci_arttext\&pid=S151673132010000300010\&lng=en\&nrm=iso>. acesso em 21 Abr. 2020.

BEAUVOIR, S. O Segundo Sexo. Trad. Sérgio Milliet. 2. ed. Rio de Janeiro : Nova Fronteira, 2009. 2v.

CHAUÍ, M. Espinosa: uma filosofia da liberdade. São Paulo: Editora Moderna, 1995.

COSTA, Vani Maria de Melo. Corpo e história. Revista ECOS. v. 10, n. 1 , 2015.

DE OLIVEIRA, G. V. A relação entre cristianismo e platonismo nos séc. I-II. UNITAS-Revista Eletrônica de Teologia e Ciências das Religiões, v. 5, n. 1, p. 153-170, 2017. Disponível em <http://revista.faculdadeunida.com.br/index.php/unitas/article/view/376/439>. acesso em 27 Abr. 2020.

DUMONT, A.; PRETO, E. L. O. A visão filosófica do corpo. Escritos educ., Ibirité, v. 4, n. 2, p. 7-11, dez. 2005 . Disponível em $<$ http://pepsic.bvsalud.org/scielo.php?script=sci_arttext\&pid=S167798432005000200002\&lng=pt\&nrm=iso>. acessos em 10 abr. 2020. 
FOUCAULT, M. Vigiar e Punir: nascimento da prisão. Tradução de Raquel Ramalhete. 42. ed. Petrópolis: Editora Vozes, 2014.

FOUCAULT, M. História da sexualidade I: a vontade de saber. Tradução de Maria Thereza da Costa Albuquerque. 6. ed. São Paulo: Editora Paz e Terra, 2017.

FREUD, S.; BREUER J. Estudos sobre a histeria (1895). In: Salomão J (trad.). Obras psicológicas completas de Sigmund Freud. Rio de Janeiro: Imago, 1996.

JUNIOR, C. H. Do corpo-motor ao corpo-informação: corporeidade e trabalho no capitalismo. Revista Brasileira de Ciências do Esporte, v. 30, n. 2, p. 107122, 2009. Disponível em

<https://www.redalyc.org/pdf/4013/401338537008.pdf> acesso em 09 abril 2020.

NUNES COSTA, M. R. A relação corpo-alma no homem, segundo Santo Agostinho : dualismo ou unidade substancial?. Enrahonar : quaderns de filosofia, Núm. Supplement Issue, p. 185-204, 2018. Disponível em <https://ddd.uab.cat/record/199219> acesso em 13 abril 2020.

OLIVA, J. O Outro a partir da corporeidade: a importância do corpo na situação da mulher em O Segundo Sexo de Simone de Beauvoir. Sapere Aude, v. 5, n. 9, p. 267-286, 2014.

Disponível em <http://periodicos.pucminas.br/index.php/SapereAude/article/view/7559> acesso em 02 de junho de 2020

TOMAZ, C.; GIUGLIANO, L. G. A razão das emoções: um ensaio sobre "O erro de Descartes". Estud. psicol. (Natal), Natal, v. 2, n. 2, p. 407-411, Dez. 1997 . Disponível em <http://www.scielo.br/scielo.php?script=sci_arttext\&pid=S1413-

294X1997000200013\&Ing=en\&nrm=iso > acesso em 21 abril 2020.

WINOGRAD, Monah; KLAUTAU, Perla. Vienna, Austria: notes on the context of the emergence of psychoanalysis. Tempo psicanalítico, v. 46, n. 2, p. 197213, 2014. Disponível em <http://pepsic.bvsalud.org/scielo.php?script=sci_arttext\&pid=S0101$48382014000200002 \&$ Ing=pt\&nrm=iso\&tlng=pt $>$ acesso em 20 de junho de 2020. 


\section{O NARCISISMO E O RELACIONAMENTO ABUSIVO: UMA ASSOCIAÇÃO}

\section{Anna Claudia Reis Carvalho}

Gabriela dos Reis Nascimento Delfino

Marina Vanini Pinheiro

Sofia Muniz Alves Gracioli

\section{INTRODUÇÃO}

O Transtorno de Personalidade Narcisista é caracterizado por sentimentos exagerados de autoimportância, egocentrismo, arrogância, falta de empatia, necessidade de admiração, entre outros. As pessoas que possuem esse transtorno pensam só em si mesmo, mas na verdade nunca se reconhecem realmente. Afinal, há uma negação de seus próprios sentimentos.

O narcisista quando em uma relação amorosa pode fazer de seu parceiro submisso e inferior, o que pode se tornar um relacionamento abusivo. Este que consiste em uma relação que tem abuso físico, e como nesse caso, emocional, visto que estes são incapazes de se importarem com os sentimentos alheios. A pessoa que tem o trasntorno recorre ao poder ou a coerção para ter acesso aos seus objetivos, portanto muitas vezes desiste das esperanças de um relacionamento. Em busca de admiração, estabelece relações em que o outro é sempre o errado, o inadequado e incapaz. O que pode levar a traumas psicológicos ao parceiro, que ira sempre se sentir indigno do amor dele.

A relevância do presente trabalho é que o relacionamento abusivo é extremante discutido e vivenciado nos dias atuais. A Personalidade Narcisista, que pode ser uma das causas deste tipo de relacionamento, não esta muito em pauta. Portanto, precisa ser melhor evidenciado para que as vítimas sejam capazes de reconhecer que estão convivendo com um narcisista.

O objetivo deste artigo foi explorar o Transtorno de Personalidade Narcisista e sua relação com relacionamentos abusivos.

A metodologia a princípio foi uma revisão bibliográfica crítica com uso de artigos científicos e livros.

$\mathrm{O}$ presente estudo foi dividido em três tópicos. O primeiro é "O indivíduo com Transtorno de Personalidade Narcisista e suas relações", aqui é colocado em pauta as características do narcisista, suas relações, 0 diagnóstico, os tipos e até mesmo o mito que deu origem ao nome do transtorno.

Já no segundo tópico "O relacionamento abusivo nos dias atuais e suas consequências" é mostrado as variadas formas de relacionamentos abusivos, conceitos como o ciclo do relacionamento abusivo e dados sobre 
agressão contra mulher, principalmente no Brasil, até chegar nas consequências dessa relação.

E por fim, o terceiro tópico "O narcisismo associado ao relacionamento abusivo", evidência as características do Narcisista dentro de um relacionamento, o seu comportamento, e como isso pode acarretar em um relacionamento abusivo.

\section{O INDIVÍDUO COM TRANSTORNO DE PERSONALIDADE NARCISISTA E SUAS RELAÇÕES}

Narciso foi um famoso adolescente que se apaixonou de sua própria imagem refletida na água de uma fonte, essa contemplação despertou uma nostalgia amorosa, que ele se lançou à água, procurando unir-se à sua própria sombra. Esse é o mito grego que deu nome ao Transtorno. Segundo os autores Barret, Glueck, Jeliffe, Myerson e Wittels (1941), a ideia de namorar-se de si próprio está ligada a lenda de Narciso, a ideia de um espelho que nos aflige em virtude de uma ansiedade jamais satisfeita.

O Transtorno da personalidade narcisista, segundo o DSM-V (APA. 2014), tem como característica essencial um padrão difuso de grandiosidade, necessidade de admiração e falta de empatia. Surge no início da vida adulta, e está presente em vários contextos, pelos quais é dado o diagnóstico, sendo eles:

1. Tem uma sensação grandiosa da própria importância ( $p$. ex. exagera conquistas e talentos, espera ser reconhecido como superior sem que tenha as conquistas correspondentes);

2. É preocupado com fantasias de sucesso ilimitado, poder, brilho, beleza ou amor ideal;

3. Acredita ser "especial" e único e que pode ser somente compreendido por, ou associado a outras pessoas (ou instituições) especiais ou com condição elevada;

4. Demanda admiração excessiva;

5.Apresenta um sentimento de possuir direitos (i.e., expectativas irracionais de tratamento especialmente favorável ou que estejam automaticamente de acordo com as próprias expectativas);

6. É explorador em relações interpessoais (i.e., tira vantagem de outros para atingir os próprios fins);

7. Carece de empatia: reluta em reconhecer ou identificar-se com os sentimentos e as necessidades dos outros;

8. É frequentemente invejoso em relação aos outros ou acredita que os outros o invejam; 
insolentes.

9. Demonstra comportamentos ou atitudes arrogantes e

Sigmund Freud destaca dois tipos de personalidade narcisista. $\mathrm{O}$ narcisismo primário ou original são os que as crianças em fase oral possuem. O mundo exterior ainda não chama a atenção, e seus desejos são sempre supridos. O seio materno, o dedo polegar e outros objetos que podem levar a boca já trazem a sua satisfação. As crianças, portanto, são classificadas como auto-erótica. Como é explicado por Oliveira em seu artigo Narcisismo: Desenvolvimento e Estruturação Narcísica:

O narcisismo primário, portanto refere-se a um investimento libidinal sobre uma imagem do eu. [...] O narcisismo é condição de formação do eu. Inicialmente o eu é o objeto privilegiado de investimento, armazenador de toda a libido disponível no chamado narcisismo primário. Posteriormente, o investimento libidinal passa a incidir sobre objetos (representações-objeto), o que corresponde à transformação da libido narcísica em objetal. (OLIVEIRA, 2016, p. 06-07)

Quando o ego é descoberto, após a idade embriagadora, é possível ver um refletir da libido dirigido para os objetos. A energia da libido não utilizada, por conta da falta ou da negação da satisfação, reflui ao interior, o que leva ao narcisismo secundário, que é um tanto quanto perigoso, e em seu grau mais desenvolvido se torna uma enfermidade. Como dito por Fernandes (2002, p. 27): "O narcisismo secundário designaria um retorno da libido ao ego após ter investido objetos externos."

Uma pessoa com personalidade narcisista se diferencia de uma pessoa egoísta, pelo fato do narcisista não querer se servir do mundo exterior. Quanto mais o indivíduo é narcisista mais o mundo exterior não existe para ele. Diferentemente do egoísta, que necessita do mundo exterior e de seus objetos, como é explicado pelos autores Barret, Glueck, Jeliffe, Myerson e Wittels no livro: Sexo e Psicanálise, 1941.

Como explica Dan Kiley (1986), o indivíduo narcisista se sente como se fosse colocado dentro de uma sala cheia de espelhos, e primeiramente ele faz apenas uma autocrítica natural. Com um pouco mais de tempo na sala, ele passa a enxergar defeitos nele, os espelhos começam a mostrar suas inseguranças. As falhas do caráter ficam em evidência, assim como as físicas. E então, para se defender, o indivíduo constrói fantasias opostas ao que estava vendo, dominando a situação. As inseguranças cedem lugar às maravilhas. A pessoa se torna prisioneira da perfeição, afinal, compensa as grandes imperfeições ficando nesta sala. Quanto mais habituada a pessoa estiver de mentir para si própria em relação a suas fraquezas, mais hostil e incansáveis serão os espelhos.

Como citado por Lowen (1983, p.07): "Narcisistas estão mais preocupados com o modo como se apresentam do que com o que sentem. De 
fato, eles negam quaisquer sentimentos que contradigam a imagem que procuram apresentar."

Segundo o DSM-V (APA, 2014), outras características do indivíduo narcisista são comportamentos arrogantes, egocêntricos, insolentes e esnobes, o que dificulta suas relações pessoais. Eles podem se sentir como únicos e reais merecedores de conquistas, admirações e privilégios, e podem desvalorizar grosseiramente a contribuição dos outros.

De acordo os teóricos acima citados, podemos perceber que um indivíduo com o Transtorno de Personalidade Narcisista possui uma excessiva necessidade de admiração, além de serem egocêntricos e não se preocuparem com os sentimentos alheios, colocando-se sempre em primeiro lugar. Essas características são, na verdade, uma forma de negação dos seus próprios sentimentos. Como consequência destas, muitos encontram dificuldades de se relacionar com um narcisista.

\section{O RELACIONAMENTO ABUSIVO NOS DIAS ATUAIS E SUAS CONSEQUÊNCIAS.}

O relacionamento abusivo é um termo que vem sendo bastante discutido nos dias atuais. Este é definido por uma relação que tenha abuso físico ou emocional. É tratado como abuso situações onde se encontram uso incorreto e excessivo de poderes, o mesmo pode ter forma de violência física, psicológica, sexual e financeira.

Uma das violências é o abusivo emocional que, segundo a secretaria Especial de Políticas para as Mulheres (2005), vai além de ameaças, ela também se manifesta por atos como intimidar a vítima, diminuí-la, provocar confusões mentais, fazer com que ela se sinta culpada, xingá-la, humilhá-la, desvalorizá-la, controlar seus movimentos, fazer chantagens, isolá-la de amigos e parentes, retê-la ou tirar dinheiro da mesma.

De acordo com Atlas da Violência (2019), no Brasil 4.936 mulheres foram assassinadas em 2017, maior número em dez anos. O Mapa da Violência (2015) coloca o Brasil como o $5^{\circ}$ país de um grupo de 83 países que mais tem violência contra a mulher. No gráfico a seguir é possível perceber a evolução das taxas de homicídio de mulheres (por 100 mil) no Brasil entre 1980 e 2013. 
Grafíco 1 - 1 Evolução das taxas de homicídio de mulheres (por 100 mil). Brasil. 1980/2013

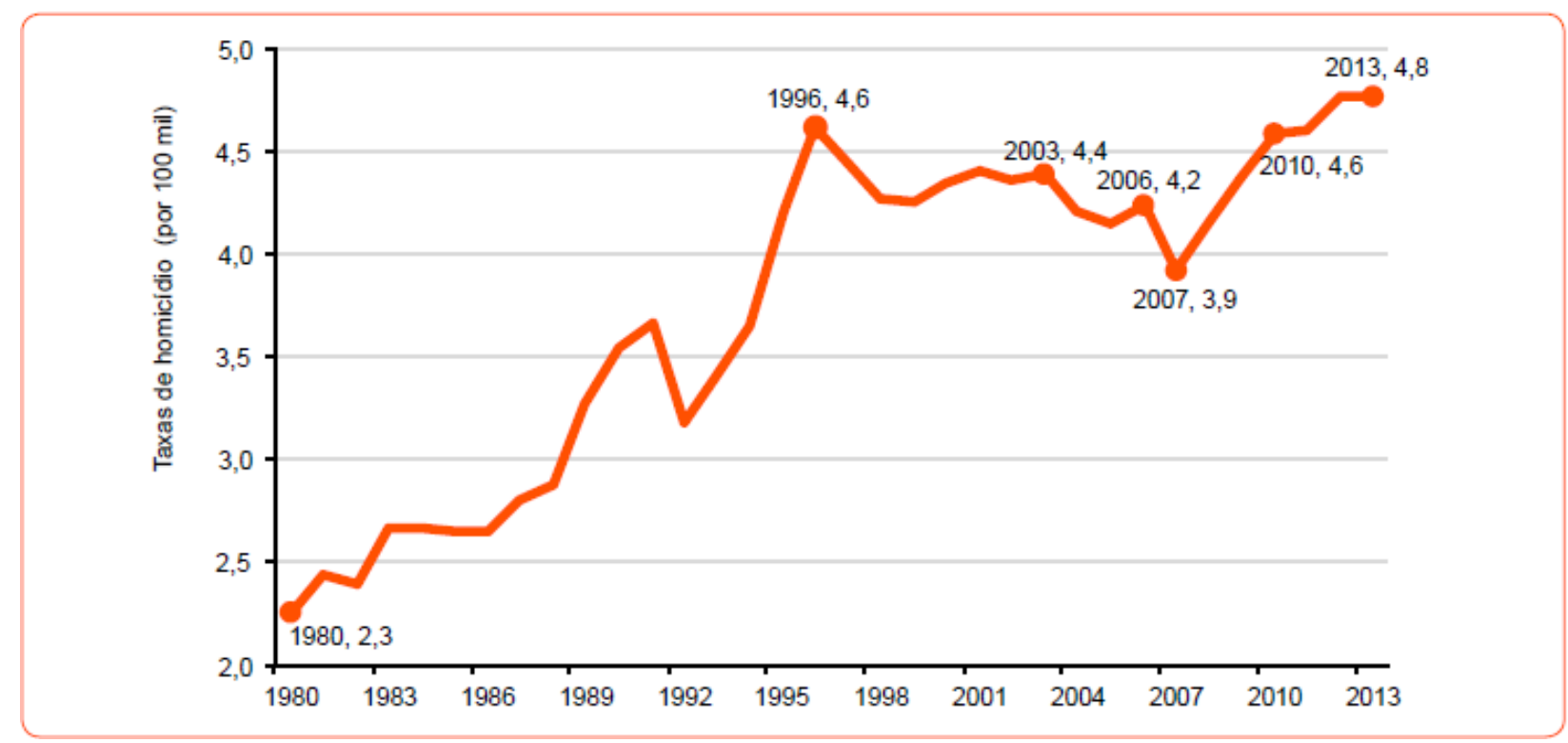

Fonte: WAISELFISZ, 2015, p.12.

Entre os meses de janeiro e outubro de 2015 foi realizado um balanço dos atendimentos registrados pelo Ligue 180 e segundo a Secretaria de Políticas para as Mulheres, das 63.090 denúncias de violência contra a mulher, $49.82 \%$ referiam-se à violência física, $30.40 \%$ à violência psicológica, $7.33 \%$ à violência moral, $4.86 \%$ à violência sexual, $2.19 \%$ à violência patrimonial, $1.76 \%$ à cárcere privado e $0.53 \%$ à violência envolvendo tráfico. Esses atendimentos também revelaram que $77,83 \%$ das vítimas possuem filhos/as e que $80,42 \%$ desses/as filhos/as presenciaram ou sofreram a violência.

Como disse Souza (2019) o parceiro, em um relacionamento abusivo, geralmente tenta controlar sua parceira por meio da destruição da sua autoestima e, consequentemente, a segurança da mesma. Os abusos aos quais a mulher é submetida vão a tornando cada vez mais enfraquecida, fazendo com que a mesma vá perdendo sua resiliência.

A violência se inicia com microviolências, que podem ser morais e verbais e, em seguida, evoluem para agressões físicas, de forma que a violência tende a ser naturalizada, de acordo com Hirigoyen (2006). Em vários depoimentos as vítimas falam que o início do relacionamento é perfeito, 0 abusador a trata da melhor forma possível, e aos poucos, começa a se mostrar uma pessoa diferente, e passa a dizer coisas que a humilha, diminui, mas sempre de uma forma leve. Com o tempo essas agressões passam a ser mais evidentes e mais graves. 
Como descrito na cartilha de Enfrentamento a Violência contra a Mulher (2005), existe um ciclo do relacionamento abusivo. A primeira fase, há uma construção da tensão no relacionamento que vai acontecer através de agressões verbais como gritos, xingamentos, ameaças até explodir para a segunda fase. Esta que é denominada de explosão da violência, é nessa etapa que acontecem espancamentos, murros, chutes, e as agressões atingem níveis elevados, esse segundo momento é considerado de curta duração porque, consequentemente, 0 agressor entra na terceira fase, onde se instala 0 arrependimento. Esta fase, nomeada lua de mel, o agressor se arrepende e sente remorso de todo o mal que causou, com medo de perder a companheira, que acaba por perdoar. Esse ciclo é uma série de ações comuns entre agressores.

Em Brasil (2005) diz que tanto o homem quanto a mulher podem ser violentos e praticar agressões físicas ou verbais. Isso porque podem ter dificuldades de expressar os sentimentos de maneira respeitosa e civilizada. Nesses casos, a relação de amor acaba se transformando numa espécie de ringue de lutas. Entretanto, segundo a Política Nacional de Enfrentamento à Violência contra as Mulheres (2011), os homens tendem a ser vítimas nos espaços públicos, já as mulheres são atingidas cotidianamente dentro de seus próprios lares, geralmente, por seus companheiros e familiares.

Segundo Balone e Ortolani (2003), além de destruir milhares de vidas, essa violência pode provocar danos físicos, depressão e comportamentos suicidas. Como disse Adeodato et. al. (2005) isto pode causar sentimentos como a solidão, desamparo, irritação, tristeza, ansiedade, distúrbios e sociais entre outros.

Levando em conta as considerações dos autores citados, o relacionamento abusivo acontece tanto fisicamente, quanto emocionalmente. Esses trazem prejuízos, danos e traumas a vítima. Para tenta prevenir vivenciar esse tipo de relacionamento é de extrema importância que todos saibam identificar as vertentes do mesmo, e que fiquem atentos as características de seus parceiros.

\section{O NARCISISMO ASSOCIADO A RELAÇÃO ABUSIVA.}

Uma pessoa com Transtorno de Personalidade Narcisista possui características como o egocentrismo, sentimento de grandiosidade, falta de empatia, necessidade de admiração, entre outras. Isso em um relacionamento amoroso pode resultar em atitudes abusivas por parte do narcisista, por esse motivo faz-se necessário a associação dos dois termos citados anteriormente.

Por apresentar essas características é possível observar que o narcisista se preocupa apenas com ele mesmo, e que sua aproximação a outras pessoas tem como objetivo satisfazer suas próprias necessidades. 
Afinal, como foi evidenciado por Holmes (2005, p.40) "Se aproximam dos outros não com um fim em si, mas como um meio para fins egoístas".

Confirmando a afirmação de Holmes, Noé (2002) compara o Transtorno com um cativeiro, no qual o narcisista está preso, buscando sempre a confirmação de sua auto-imagem nas relações com o outro. Essa relação se torna então, utilitarista, tendo sua vida baseada em uma ilusão.

Os narcisistas são incapazes de se importarem com os sentimentos do outro. Isso não quer dizer que eles não querem amar e ser amado, entretanto, segundo Lowen (1989), eles não podem, e essa é a sua grande tragédia. Por isso, Holmes (2002) diz que às vezes ele perde as esperanças de reciprocidade em seus relacionamentos e acaba recorrendo ao poder ou a coerção para alcançar seus objetivos, levando assim o abuso para dentro de sua relação.

Esse abuso praticado pelo narcisista é baseado em enfoques psicológicos, aos quais o abusador se sobressai, julgando-se superior a vítima e manifestando-se de diversas formas. Como citado por Echeburúa e Corral (1998) estão inclusos nesta agressão as críticas, humilhações, posturas e gestos ameaçadores, imposições, restrições, condutas destrutivas e violentas.

Outra característica da pessoa com Transtorno de Personalidade Narcisista que influencia negativamente em suas relações é o sentimento de grandiosidade, junto a negação de seus próprios sentimentos. Segundo Noé (2002), o narcisista sem um círculo de admiradores é incapaz de viver, pois precisa que confirmem e reforcem a sua imagem interior grandiosa.

Segundo Araújo (2005), essa dependência de admiração faz com esse sujeito se torne carente e aprisionado ao olhar do outro, o que o leva a querer ser um ideal de Eu perfeito. Porém isso não se concretiza, visto que uma de suas principais características é o egocentrismo, logo ele só é capaz de amar a si próprio. Nesse sentido, Noé (2002, p. 52) afirma que "a pessoa narcisista sofre, porque ela é incapaz de amar".

Esses indivíduos vivem aprisionados em seus próprios cativeiros em busca da perfeição, temendo sempre a derrota, por isso Lasch (1979) afirma que eles nunca conseguem se desprender da humilhação e do fracasso e no desespero buscam sustento na terapia. O que é explicado por Noé em seu artigo Homo Narcissicus:

Sob as condições atuais isto significa passar por um processo de reaprendizagem social e psicológica. A identidade social, psicológica e religiosa precisa passar por um processo de decomposição para que se torne possível sua recomposição em uma nova consciência, agora relacional. Em outro trabalho apontavam para a conveniência do recurso a jogos e dramatizações no contexto de pequenos grupos para facilitar este processo." (NOÉ, 2002, p.55) 
É notável que as características de uma pessoa com Transtorno de Personalidade Narcisista podem resultar em pontos negativos quando em um relacionamento. Analisando os aspectos do relacionamento abusivo é possível identificar que essas características podem, muitas vezes, levar o Narcisista a ser o autor de abusos psicológicos. Por isso, o Transtorno deve ser melhor evidenciado para que as vítimas desse abuso possam reconhecer que estão se relacionando com um narcisista.

\section{CONSIDERAÇÕES FINAIS}

A presente pesquisa explorou o Transtorno de Personalidade Narcisista e seus aspectos com o objetivo de associá-lo ao relacionamento abusivo, assunto que está em pauta nos dias atuais. Este percurso nos levou a percepções de que as características do narcisista se assemelham com as que são encontradas em um relacionamento abusivo.

Em um primeiro momento foi introduzido o conceito de Transtorno de Personalidade Narcisista e a partir disso concluímos que é algo caracterizado por sentimentos de egocentrismo, de auto importância e de falta de empatia. Além de relacioná-las com a negação de seus próprios sentimentos. Logo após, foi apresentado a conceituação, tipos, dados e estatísticas a respeito do relacionamento abusivo. E por fim associamos os dois conceitos a fim de identificá-los quando apresentados juntos.

Portanto, ao realizar um levantamento bibliográfico buscamos compreender o Transtorno e então colocá-lo em evidência para que possa ser identificado quando em um relacionamento abusivo.

O objetivo do presente trabalho foi alcançado levando em consideração as duas temáticas e a associação que pode ser feita entre elas através de estudos bibliográficos.

Uma vez contextualizado o relacionamento abusivo, é possível realizar campanhas de prevenção e identificação do mesmo, e também incentivar o acompanhamento psicológico para as vítimas. Além de estratégias, como a denúncia anônima ao ligar para o "180", e a conscientização da população referente ao assunto.

Quanto ao narcisista, é necessário passar por um processo de reaprendizagem social e psicológica, através da psicoterapia e tratamentos psiquiátricos.

Para finalizar, reconhecemos que novas pesquisas devem ser realizadas para que haja novas informações sobre e para colocar em evidências os dois assuntos tratados. Incentivamos também que sejam feitas pesquisas de campo com intuito de coletar dados a respeito. 


\section{REFERENCIAS}

ADEODATO, V. G., CARVALHO, R. R., SIQUEIRA, V. R., SOUZA, F. G. M., 2005. Qualidade de vida e depressão em mulheres vítimas de seus parceiros. Revista Saúde Pública.

ASSOCIAÇÃO AMERICANA DE PSIQUIATRIA. Manual diagnóstico e estatístico de transtornos mentais. $5^{\mathrm{a}}$ ed. Porto Alegre: Artes Médicas. Disponível em: http://www.niip.com.br/wp-content/uploads/2018/06/ManualDiagnosico-e-Estatistico-de-Transtornos-Mentais-DSM-5-1-pdf.pdf. Acesso em: 23 mar. 2020.

BALLONE, G. J., ORTOLANI, I. V. Violência Doméstica, 2003. Disponível em: http://www.psiqweb.med.br. Acesso em: 23 mar. 2020.

BRASIL, Secretaria de Políticas para as Mulheres Presidência da República. Política Nacional de Enfrentamento à Violência contra as Mulheres. Brasília, 2011. Disponível em: https://www12.senado.leg.br/institucional/omv/entenda-a-violencia/pdfs/politicanacional-de-enfrentamento-a-violencia-contra-as-mulheres.

Acesso em: 08 abr.2020.

BRASIL. Secretaria Especial de Políticas para as Mulheres. Enfrentando a Violência contra a Mulher. Brasília, 2005. Disponível em: https://www12.senado.leg.br/institucional/omv/entenda-aviolencia/pdfs/enfrentando-a-violencia-contra-a-mulher-orientacoes-praticaspara-profissionais-e-voluntarios. Acesso em: 07 abr. 2020.

CERQUEIRA, D; LIMA DE S, R; BUENO, S; NEME, C; et al. Atlas da Violência. Brasília: Rio de Janeiro: São Paulo, 2019.Disponivel em: http://www.ipea.gov.br/portal/images/stories/PDFs/relatorio_institucional/19 0605_atlas_da_violencia_2019.pdf. Acesso em: 27 abr.2020.

ECHEBURÚA, E.; CORRAL, P. Manual de violência familiar. Madrid, 1998 Siglo XXI.

FERNANDES, E B. Narcisismo. Departamento de psicologia. São Carlos.2002.

Disponível em: http://www.ufscar.br/ bdsepsi/77a.pdf. Acesso em: 08 abr.2020.

HIRIGOYEN, M. (2006). A Violência no Casal: da coação psicológica à agressão física. Trad. Maria Helena Kühner. Rio de Janeiro: Bertrand Brasil.

HOLMES, J. Conceito da Psicanálise: Narcisismo. Tradução de Carlos Mendes Rosa. Rio de Janeiro: Relume Dumará: Ediouro; São Paulo: Segmento-Duetto, 2005.

KILEY, D. Síndrome de Peter Pan (18.ed.). São Paulo: Melhoramentos, 1986.

LASCH, C. A Cultura do Narcisismo: a vida americana numa era de esperanças em declínio. New York: Werner, 1979. 
LOWEN, A. Narcisismo: A negação do verdadeiro self. Tradução de Álvaro CAbral. São Paulo: Summus Editora Ltda, 1983. Disponível em: https://books. google.com.br/books?hl=ptBR\&lr=\&id=z 46DwAAQBAJ\&oi=fnd\&p q=PT4\&dq=info:ybsr8sltrAJ:scholar.google.com/\&ots=KhNDsGRTV4\&sig=daNy 0GV1ETLQGL9nyYr8OtVeEDY\#v=onepage\&q\&f=false. Acesso em: 07 abr. 2020

NOÉ, S. V. Homo Narcissicus. Numen: revista de estudos e pesquisa da religião. Juiz de fora, v. 5, n.1, p. 41-59, 2002. Disponível em: <https://periodicos.ufjf.br/index.php/numen/article/view/21687>. Acesso em: 20 mai. 2020.

OLIVEIRA, M. Narcisismo: Desenvolvimento e Estruturação Narcísica. São Paulo,2016.

SOUZA, S. A. Relacionamentos Abusivos: Consequências Psicológicas em mulheres que o vivenciam. $17^{\circ}$ Congresso de Iniciação Científica da FASB, 2019, Barreiras - Ba.

Disponível em:< http://www.fasb.edu.br/revista/index.php/cic/article/view/492/> Acesso em: 08 abr.2020.

WAISELFISZ. J.J. Mapa da Violência 2015: Homicídio de Mulheres no Brasil.1 ed. Brasília-DF,2015. Disponível em:

http://www.onumulheres.org.br/wpcontent/uploads/2016/04/MapaViolencia 2015 mulheres.pdf. Acesso em: 08 abr. 2020

WITTLES, F; et al. O sexo e a psicanálise. São Paulo: editora Piratininga, 1941. 


\section{O PAPEL DOS AVÓS: importância desta relação para o desenvolvimento dos avós e dos netos}

Isabella Riqueti Garcia

Sofia Muniz Alves Gracioli

\section{INTRODUÇÃO}

As relações familiares possuem diversas configurações e sistematizações, existindo entre elas, independente da presença do fato consanguíneo, um convívio entre gerações nas mais diversas tenras ou longevas idades. Logo, o convívio entre avós e seus netos, como será o tema abordado neste trabalho, apresenta-se como alvo de estudo para uma melhor compreensão acerca desta relação, suas peculiaridades e singularidades.

Faz-se importante observar a presença e a interação entre fatores sociais, históricos e psicológicos coabitando nestas relações. As influências externas e internas se mostram como variáveis de tamanha importância para o grau de funcionalidade dessas convivências.

Assim, essa revisão tem como objetivo abordar como é experienciada a relação entre avós e netos, o estabelecimento de vínculos e as vantagens e desafios desenvolvidas ao longo dessa construção para ambos as duas partes. Ao fim, é apresentado uma seleção de filmes, livros e documentários que relatam a temática aqui presente, demonstrando como a relação entre avós e netos estão presentes nas artes e sempre fora alvo de pesquisa e estudo.

A metodologia utilizada foi uma revisão bibliográfica, com uso de artigos e textos disponíveis nas plataformas de pesquisa Scielo, Lilacs, Pubmed, google acadêmico e alguns livros.

\section{ENQUADRAMENTO TEÓRICO}

A relação entre avós e netos é indiscutivelmente um encontro de gerações, onde se cruzam vários tempos sociais, individuais e familiares, um espaço para partilha de memórias, lições, experiências, emoções e mais. $O$ tempo social, nomeadamente a história da sociedade e da comunidade, está relacionado com o fato de que grupos de pessoas que nasceram e viveram em períodos distintos diferem em vários aspectos, sendo as diferenças como segue: alteração nos papéis de gênero, melhora no nível de educação, maior acesso a bens e serviços, diversificação nas relações familiares, etc. (Carter \& McGoldrick, 1995, citados por Sousa, 2006). O tempo individual representa o desenvolvimento de cada pessoa em termos de idade e características 
pessoais (cognitivos, afetivos, motores, sociais) e inclui também a relação com outros sistemas na comunidade. Finalmente, o tempo familiar envolve os processos de evolução, mudança, desenvolvimento e continuidade na família. Neste sentido, devem, portanto, ser consideradas três gerações com diferentes tempos de vida social, individual e familiar: avós, pais e netos (Sousa, 2006).

É preciso destacar a diferença nas vivências dos avós e os netos. Há avós que viveram tempos intensos de mudança, por exemplo, passaram por acontecimentos políticos marcantes que alteraram drasticamente a sua vida. Desta maneira os avós tornam-se uma memória viva do passado e reviver os acontecimentos passados permite-lhes ver 0 mundo através de "olhos novos". Por um lado, os acontecimentos desagradáveis podem ser revividos de outra forma, atribuindo-lhes um significado menos negativo no momento de contar as histórias e por outro lado, as questões e observações dos netos permitem a continuidade das experiências dos avós (Sousa, 2006). O encontro entre avós e netos é uma oportunidade de valores, crenças e atitudes a serem revistas, repensadas e resignificadas, numa dimensão dialógica, em que elementos histórico-culturais e pessoais interagem de forma sistêmica.

A velhice evidentemente faz parte das diferenças nas vivências, sendo que ela é muito próxima dos avós e muito mais distante para os netos. Neste sentido, o encontro entre avós e netos é uma oportunidade para desenvolver atitudes positivas acerca do envelhecimento sendo benéfico para ambos, tanto para os avós quanto para os netos (Sousa, 2006).

A criação de vínculo entre os avós e os netos é essencial para ter uma relação adequada e saudável. O relacionamento com os netos baseia-se em trocas expressivas, voluntárias e está envolvido num clima de amizade, carinho e compreensão. O compartilhamento de vivências é fundamental: por um lado, os avós transmitem conhecimentos aos netos e, por outro, os netos ensinam algo aos avós, ou seja, é uma relação de cuidados e aprendizagem recíproca. Desta maneira, os avós cuidam dos netos enquanto estes são menores e os netos poderão cuidar dos avós quando estes chegarem uma fase da vida de maior debilidade. (Sousa, 2006).

Muito se discute acerca do envelhecimento e dos diversos papéis sociais que o mesmo propõe para o sujeito, em especial o tornar-se avós. Historicamente, associa-se aos avós aqueles que exercem a função de "mimar" as crianças e "estragá-las com mimos", no qual os pais, são aqueles que as educam. Contudo, a partir de estudos empíricos e em contato com a realidade contextual deste sujeito, observa-se que não é verdade. Logo, há avós jovens e ativos que são capazes de proporcionar à criança muitos conhecimentos e experiências de aprendizagem, sendo capazes de as educar, compreender e cuidar. 
Neste sentido, é apontado por Rabello e Passos (2008) e Silva (2012) que o papel social nomeado "ser avô" é uma aprendizagem que se inicia de maneira prematura, visto que é desenvolvida através de uma aprendizagem diária e de forma singular, executado de forma ativa a partir da descoberta da gravidez em conjunto com o nascimento do primeiro neto. Contudo, observa-se que tal atribuição não é definida de maneira concreta e fixa, visto que as maneiras como os pais vivenciam essa realidade são diversas. Logo, essa nova função depende diretamente com o contexto sociocultural que o sujeito está inserido juntamente com as vontades dos filhos e das situações familiares particulares como o divórcio e/ou recasamento.

Neste contexto Papalia (2013), aponta que o papel dos avós na atualidade se difere em outros aspectos desenvolvidos antigamente, devido à complexidade de contextos e variáveis estabelecidas na dinâmica familiar que o sujeito se insere e que consequentemente estará sujeita a corresponder com as seguintes exigências propostas pelo meio. Ademais, o nascimento do primeiro neto pode ser em si o momento para se reinventar como avó ou avô, é de grande construção que é feito esse papel, e assumi-lo também depende de processos diários de entendimento e assimilação com as novas demandas familiares.

Desta forma, não há apenas um único "modo de ser avó ou avô", considerando que este papel acontece com a mistura de características singulares de cada sujeito, simultaneamente com as suas expectativas em relação a mudança social dentro da rede familiar e das novas situações que enfrentarão.

Existem muitas definições acerca das maneiras de exercer avosidade. Os avôs/avós podem escolher desempenhar este papel de formas diferentes. Neste trabalho vamos mencionar os estilos de ser avó/avô, estabelecidos por Neugarten e Weinstein (1968, citados por Sousa, 2006). Assim, os avós podem ter um dos seguintes cinco estilos: formal, divertido, substitutivo, autoritário ou distante.

Os avós formais comportam-se de acordo com o que thes parece ser o seu papel, mantendo clara a diferença em relação ao papel parental e separando-se da tarefa de criar o neto e abstendo-se de dar aconselhamento. Nos avós divertidos predomina a atitude lúdica e informal onde avós e netos são companheiros de brincadeira, com ênfase na satisfação mútua. Os avós com estilo substitutivo são aqueles que assumem todas as responsabilidades parentais educativas por causa da ausência dos pais (nos casos de morte, emigração ou negligência). Deste modo os avós tornam-se pais dos netos. Os autoritários adotam um estilo que é também praticado pelos pais da criança por causa dos pais terem sido colocados numa posição de subordinação face aos próprios pais deles. Os distantes são aqueles avós que mantêm contacto 
com os netos apenas em ocasiões especiais, p. ex. aniversários, festas, etc. (Sousa, 2006).

Além disso, de acordo com Lima (2007) o significado de ser avô se difere de pessoa para pessoa e está diretamente relacionada com os estilos de interação, sendo ele, mais formal - caracterizado por descontração, divertimento e confiança - e mais distante, voltada para a substituição dos pais. As mesmas autoras complementam que ser avô é ter um papel fundamental na vida do neto, o que faz com que se sinta útil e com valor como idoso, onde é encarado como sábio.

Nesta perspectiva são atribuídas características que se assemelham para os netos e avós. Considera-se os avós aqueles que transmitem memórias e tradições familiares, bem como os valores e conhecimentos, que os auxiliam na construção de sua identidade (neto). Sendo assim, os avós são confidentes e uma fonte de importante afeto, provedores de atenção, segurança e estabilidade, prestando apoio direto e indireto à criança. Além disso, a relação entre avós e netos é uma oportunidade para os avós quebrarem as normas de comportamento adequadas à idade: brincar com os netos neste caso é uma atividade socialmente adequada e aceitável e permite aos avós fazerem algo desejado mas desadequado noutras ocasiões, num contexto adequado (Sousa, 2006).

Em contrapartida, para os avós, os netos são um estímulo físico e intelectual que lhes dá um sentimento de continuidade e uma fonte de amor. Os netos e netas possuem a chance de aprender com seus avós e avôs o que fora de uma época passada, ensinamentos válidos para atualmente e até mesmo momentos de partilha e de diversão entre si, inegavelmente, substanciais por si só.

Conforme Moragas (1997), as flexibilidades implicadas no papel de ser avô/avó e neto/neta, na sociedade contemporânea, são recentes em que os avós têm uma conduta mais livre do que os pais, devido pouca definição da sociedade ainda pela especificidade do que os avós devem ou não fazer. Logo, a singularidade desses papéis representa as inúmeras possibilidades que os avós e avôs podem assumir diante de seus netos e netas.

Os papéis que os avós assumem são multidimensionais tanto na sociedade quanto na família (Oliveira \& Pinho, 2013). Kivnick (1982, citado por Sousa, 2006) por exemplo especifica cinco funções educativas dos avós:

1. Mimar, o que não é sinónimo de deseducar ou estragar os netos. Consiste em aproveitar o tempo e a disponibilidade para realizar tarefas de que os netos gostam, sem contrariar os pais e deixar os netos fazer o que os pais não deixam

2. Promover o desenvolvimento dos netos. 
3. Funcionar como fonte de sabedoria, sendo um recurso importante para o neto.

4. Experimentar um sentimento de continuidade pessoal, sabendo que as recordações permanecerão e que a descendência dará continuidade à família.

5. Reviver experiências educativas anteriores através da relação com os netos.

O valor da relação entre avós (ôs) e seus netos (as) é tida em referência do aprendizado qualitativo que os mais novos podem adquirir com os mais velhos. Afirma Lima (2007) que, os idosos transmitem para as gerações mais novas os valores humanísticos e a herança histórica da família, o que contribui para a formação dos jovens [...].

No convívio dito diário ou esporadicamente, netos e seus avós possuem a oportunidade de compartilharem entre si perspectivas e ensinamentos referentes aos seus conhecimentos pessoais, que estão impregnados de valores e visões advindos de sua faixa etária e época de vivência.

Assim, Gonçalves (2015) argumenta que, importa, assim, compreender em que medida a presença de netos na vida dos avós influencia estes últimos na seleção e adoção de hábitos e estilos de vida que incrementem a sua qualidade de vida.

Sendo assim, deve-se analisar a realidade contextual que os avós e avôs vivem com seus netos e netas, e buscar compreender a dinâmica associada da vivência entre eles. A saber que, esta relação que é familiar mas também é social, pode possuir aspectos positivos e negativos para ambos.

No lado positivo pode ser mencionado que a relação avós-netos é menos complicada do que a relação pais-filhos: há menos responsabilidades e obrigações e, portanto, menos conflitos. Este laço para os avós constitui a concretização do desejo de continuidade e permite também que eles vejam os seus filhos serem pais: quando observarem que os filhos assumem o papel parental adequado, os avós sentem-se orgulhosos de ter sido eles mesmos bons pais (Sousa, 2006).

Segundo Papalia (2013), os avós podem ser fontes de orientação, companhias para brincar, vínculos com o passado e símbolos de continuidade familiar. Eles expressam generatividade, um desejo de transcender a mortalidade investindo eles próprios nas vidas das futuras gerações. $O$ encontro entre avós e netos apresenta-se também como um terreno fértil para mudanças em concepções estereotipadas, promovendo promoção de melhores condições de saúde, qualidade de vida e desenvolvimento para ambos. Existe uma troca incessante de conhecimentos: recordações e sabedoria por parte dos avós e, por exemplo, conhecimento 
das novas tecnologias e novos valores mais ajustados ao tempo atual por parte dos netos.

Assim, a presença dos avós e avôs para os membros mais novos da família, contribuem para representar uma forte figura de apoio porém sem demandar a complexidade da díade pais-filhos. Com a proximidade entre duas gerações tão distintas, a diversão lúdica e o legado passado para os netos e netas contribuem para a formação ímpar de indivíduos que possuem disponíveis para si o contato com os idosos. Como se nota para os avós uma volta à dimensão do brincar, eles podem desfrutar da companhia dos netos para realizar atividades que ora sentem falta, ora não puderam ter com seus filhos. Além disso, para os netos é uma vantagem enorme que os avós tenham mais tempo para brincar, passear, etc., enquanto os pais voltam sua atenção com o emprego, frequentemente voltam do trabalho cansados e irritados e geralmente dispõem de menos tempo (Sousa, 2006).

Outra vantagem está relacionada com a tendência dos casais atuais terem filhos mais tarde, o que causa que a diferença de idades intergeracional seja maior, ou seja, há mais avós e menos netos. Isto permite que os avós possam dar mais atenção individual aos netos, o que antes não era possível, já que no passada existiam menos avós para mais netos (Sousa, 2006).

Uma melhoria significativa de hoje em dia é o aumento da esperança e qualidade de vida: a maioria das pessoas torna-se avós aos 5060 anos, o que possibilita que avós e netos convivam mais tempo. Como consequência, a geração atual de netos torna-se a primeira que pode esperar conhecer os quatro avós, existindo cada vez mais casos de netos que conseguem conhecer ainda os bisavós (Sousa, 2006).

Entretanto, em alguns casos, a relação de avós com seus netos pode não se mostrar proveitosa e digna como é concebida para a maioria. A convivência domiciliar entre avós e netos pode, então, apresentar aspectos negativos para os idosos. Algumas barreiras surgem à medida que justamente existe a vivência entre uma população mais nova e moderna com outra que por vezes preserva os modos de viver e de pensar que se relacionam com sua história. Como aponta Papalia (2013), a diferença de idade pode tornar-se uma barreira, e ambas as gerações podem sentir-se privadas de seus papéis tradicionais. Consequentemente, pode-se surgir conflitos quanto a união entre as idades e os desafios emergentes da modernidade, como por exemplo, o advento da tecnologia, das novas formas de expressão advindas da cultura e as diferentes prioridades que os indivíduos consomem para si. Alguns estudos apontam que há uma queda na qualidade da saúde física e emocional, alterações na vida social e familiar, sobrecarga financeira e estresse. 
Outros desafios para o estabelecimento de uma relação forte e saudável entre netos e avós podem ser as discordâncias entre pais e avós em relação às crenças e comportamentos educativos face às crianças. É importante, portanto, manter relações equilibradas (Sousa, 2006).

Ademais, caso a relação se mostra fragilizada, pode vir a ser combustível para possíveis mudanças. Com a reconsideração dos motivos que levam os indivíduos a terem disfuncionalidades entre si, a desejar um cotidiano repleto adaptações a visar o bem-estar da família e do convívio de netos e avós.

Em conclusão, pode-se dizer que a cooperação, solidariedade e reciprocidade entre gerações é de extremo valor para os idosos e seus netos, uma vez que os idosos ganham o sentido de generatividade, e os netos possuem a chance de se conectarem com diferentes pontos de vistas e combaterem os estereótipos acerca da fase idosa da vida.

\section{CONSIDERAÇÕES FINAIS}

Confluindo com o tema discorrido ao longo do trabalho sobre a importância dos avós e avôs na vida de seus netos (as) e gerações futuras, é de grande evidência que esta participação tem como princípio enriquecer o conhecimento dos indivíduos vindouros, transmitir conhecimentos acerca da herança familiar e da qualitativa companhia provida pelos mais velhos.

Logo, ao abordamos os múltiplos benefícios que a relação entre uma geração mais antiga e outra mais nova podem gerar, tanto para uma quanto para a outra, focamos na geração de avós e avôs que encaram o embate da sétima das oito crises cunhadas por Erik Erikson (1902-1994) para designar estágios do desenvolvimento psicossocial dos seres humanos, o de generatividade $x$ estagnação. Em cada crise, o ser deve "resolvê-lo", causando um desfecho positivo ou negativo.

Logo, é comum que se dediquem à transmissão de valores e de moral. A motivação trazida pela generatividade, a criação, o movimento de vida gerado é capaz de influenciar prazerosamente na auto estima do sujeito. $O$ sentido de vida então, torna-se unicamente, ajudar o próximo, deixar sua marca no mundo para que possa ser sentido e experimento.

Segundo Rabello e Passos (2008), nesta fase, o indivíduo tem a preocupação com tudo o que pode ser gerado, desde filhos até idéias e produtos. Ele se dedica à geração e ao cuidado com o que gerou, o que é muito visível na transmissão dos valores sociais de pai para filho.

Assim, os avós em sua grande maioria sentem o desejo inerente de se manterem próximos em várias áreas das vidas - sejam elas, escolares, sociais e cotidianos - de seus netos e outros indivíduos mais novos em relação 
à eles. Com o intuito de acrescer os laços familiares e de nutrir o conhecimento proporcionado, prosseguindo assim, a continuidade de conhecimentos e tradições.

Portanto, por mais que as pessoas ainda assumam uma postura estereotipada acerca da percepção dos avós, é importante ressaltar a singularidade de cada um, que é dependente da região em que vive, momento histórico e social. Sendo esses últimos os maiores influenciadores em sua personalidade, e na forma que encaram o papel social de ser avó ou avô.

\section{REFERÊNCIAS}

GONÇALVES, S. S. O. (2015). E os netos?: estragam os avós?: perceção de avós e pais sobre o impacto dos netos na qualidade de vida dos avós.

LIMA, C. R. (2007). Programas intergeracionais: um estudo sobre as atividades que aproximam as diversas gerações. Campinas/SP. Dissertação de Mestrado em Gerontologia, Faculdade de Educação da Universidade Estadual de Campinas.

MORAGAS, R. M. (1997). Gerontologia social: envelhecimento e qualidade de vida. Paulinas

OLIVEIRA, P. M. P. D., Mariano, M. R., Rebouças, C. B. D. A., \& Pagliuca, L. M. F. (2012). Uso do filme como estratégia de ensino-aprendizagem sobre pessoas com deficiência: percepção de alunos de enfermagem. Escola Anna Nery, 16(2), 297-305.

OLIVEIRA, P. M.P.M, Monaliza R.. R, Cristiana,A. \& Pagliuca, L. M. F.. (2012). Uso do filme como estratégia de ensino-aprendizagem sobre pessoas com deficiência: percepção de alunos de enfermagem. Escola Anna Nery, 16(2), 297-305.

OLIVEIRA, A. R. V., \& PINHO, D. L. M. (2013). Relações entre avós e seus netos adolescentes: uma revisão integrativa. Revista Brasileira de Geriatria e Gerontologia, 16(3), 633-642.

PAIS, V. A. G. (2013). 0 papel dos avós: como percebem os avós a sua importância na educação dos netos (Doctoral dissertation, Dissertação (Mestrado em Enfermagem de Saúde do Idoso e Geriatria)-Universidade de Enfermagem de Coimbra, Coimbro).

PAPALIA, D. E., Feldman, R. D. (2013). Desenvolvimento Humano. Porto Alegre: Artmed.

RABELLO, E., \& Passos, J. S. (2008). Erikson e a teoria psicossocial do desenvolvimento. Consultado no dia 09 de abril de 2020. 
SILVA, A. M. (2012). A colaboração dos avós na educação dos netos. Interfaces Científicas-Educação,1(1),67-75.

https://periodicos.set.edu.br/index.php/educacao/article/viewFile/176/87

SOUSA, L. (2006). Avós e netos: uma relação afectiva, uma relação de afectos. Povos e Culturas, Universidade Católica Portuguesa, (10), 39-50.

\section{APÊNDICE A}

Encontra-se aqui, um espaço de sugestão e exposição de filmes, livros, documentários, blogs, entrevistas e outros sites de entretenimento que aborda o tema de nosso trabalho. De forma singela e carinhosa, demonstro o contentamento em encontrar materiais atuais condizentes com um trabalho igualmente urgente e moderno.

\section{Livros}

"Serei sempre o teu abrigo" é uma obra escrita por Valter Hugo Mãe, premiado escritor português famoso por sua escrita poética que retrata laços familiares especialmente entre netos (as) e seus avós e avôs - e responsável por demonstrar o poder e a singularidade destas mesmas relações.

\section{Sugestões de Mídias Sociais:}

\section{Instagram:}

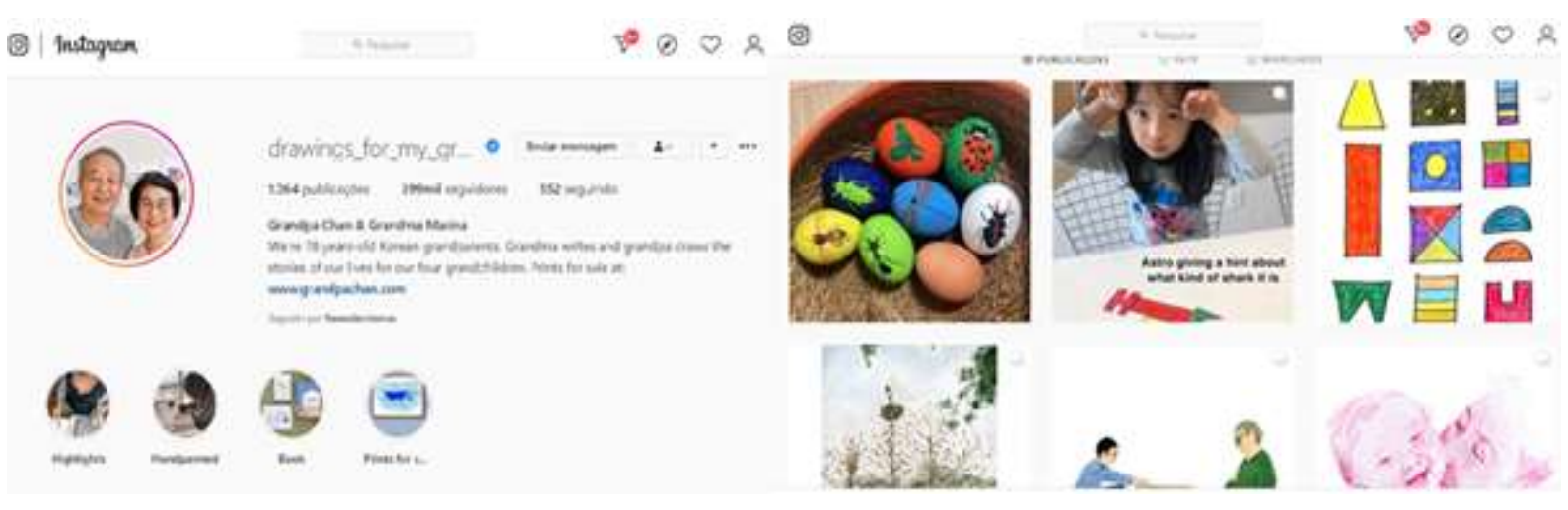

Fonte: @drawings_for_my_grandchildren

\section{Reportagens:}

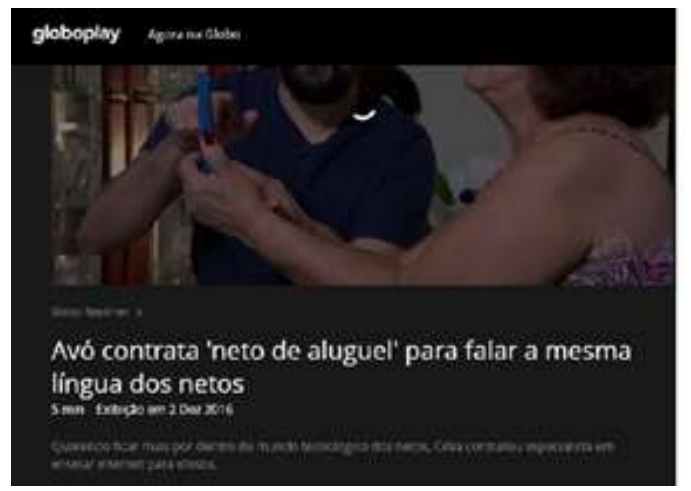

Neto de aluguel: jovem decide acompanhar idosos no dia a dia auvcogeres 01200:27.1000 


\section{Documentários:}

"What's Happening to Grandpa?" - Maria Shriver

O documentário "O que está acontecendo com vovô?" relata histórias de cinco crianças de diferentes faixa etária que apresentam um aspecto em comum: convivem com avós com Alzheimer e em conjunto com os pais, tentam compreender como se passa e manifesta a doença. O curta foi produzido pela rede de televisão $\mathrm{HBO}$, trazendo depoimentos tocantes das aprendizagens adquiridas e de sentimentos despertados pelas crianças e seus familiares.

\section{Filmes:}

\section{Moana - Um mar de Aventuras:}

Neta da chefe da aldeia, Moana se inspira e segue os conselhos e aprendizados da sábia vovó Tala. Incentivando a primogênita a buscar seus sonhos, a senhora mesmo após o falecimento, continua cuidando e incentivando a pequena a seguir seus objetivos.

\section{A Solidão dos Avós:}

Este curta metragem desenvolvido por Laura Stewart descreve a história de um senhor que vive sozinho, passando os dias em companhia do fantasma e da solidão. Para refletir sobre abandono na velhice.

\section{Up: Altas Aventuras:}

Carl Fredrickson, não tem netos, no entanto passa a descobrir os sentimentos de um avô quando solicita a ajuda de Russell para homenagear a sua amada, vivenciando grandes aventuras e aprendizagens juntos.

\section{Pequena Miss Sunshine:}

Vovô Hoover é um avô fora dos padrões que cativa a todos com sua sensibilidade e idéias malucas. Após ser expulso do Lar de Longa Permanência por uso de drogas, ensina sua neta atrapalhada uma coreografia para que ela possa concorrer e ganhar o concurso de beleza Miss Sunshine.

\section{A Era do Gelo 4:}

Este filme pertencente à uma famosa franquia de animação, conta a história de Sid, que abandonado pela família quando menor, reencontra sua avó após um tempo, tendo a oportunidade de conhecer melhor a sua história e fortalecendo os laços afetivos com seus ancestrais. 


\title{
O SILÊNCIO E A NEGAÇÃO DO ABUSO SEXUAL INFANTIL INTRAFAMILIAR
}

\author{
Caio César de Paula \\ caiocesardepaula1409@gmail.com \\ Maria Cherubina de Lima Alves \\ mcherubina@gmail.com
}

\section{INTRODUÇÃO}

A discussão sobre o abuso sexual está cada vez mais vindo à tona e deixando de ser um tabu social, contudo, os números de casos de abuso sexual, em específico os infantis e intrafamiliares, vem crescendo cada vez mais. O silêncio não só das vítimas, mas também da família, é algo comum, consequência do abuso, e encontrar voz para romper este silêncio requer muito mais do que possamos imaginar.

O abuso sexual infantil no âmbito familiar é tão comum nas famílias que passou a ser considerado como problema de saúde pública. A violência sexual, se caracteriza por atos praticados com finalidade sexual que, por serem lesivos ao corpo e a mente do sujeito violado (crianças e adolescentes), desrespeitam os direitos e as garantias individuais como liberdade, respeito e dignidade previstos na Lei ํo 8.069/90 - Estatuto da Criança e do Adolescente (BRASIL, 1990).

Ao se analisar os dados estatísticos fornecidos pelo Anuário Brasileiro de Segurança Pública que apontam 66.041 casos se abuso sexuais em 2018, o maior número já registrado no país. Lembrando que $53,85 \%$ desse total tinham até 13 anos de idade. Diversas pesquisas apontam que 0 abuso sexual no espaço doméstico e familiar tem maior predominância do homem como agressor e da mulher como vítima (AZEVEDO; GUERRA, 1988; COHEN, 1993; SAFFIOTI, 1997). De acordo com a pesquisa realizada por Saffioti (1997) no Município de São Paulo sobre abuso incestuoso: 71, \% dos agressores eram pais biológicos e $11,1 \%$ padrastos. Logo, pai e padrastos representam $82,6 \%$ do total de abusos sexuais (SAFFIOTI, 1997).

A necessidade de investigação das consequências do abuso sexual infantil intrafamiliar se deve ao fato de ser algo extremamente comum na sociedade, ainda mais devido aos dados estatísticos que estimam que três crianças ou adolescentes são abusadas sexualmente a cada hora no Brasil. Importante ressaltar também que a grande maioria das pessoas que foram abusadas sexualmente, no contexto familiar, dificilmente irão relatar, ou conseguir se quer comprovar o ato de abuso sexual. Infelizmente grande parte dos abusados se mantém no silêncio ou negam a si próprios que sofreram abuso sexual, enquanto carrega diversas adversidades psicológicas frutos do abuso. 
O objetivo do presente trabalho foi pesquisar e enfatizar os impactos sobre 0 abuso sexual infantil intrafamiliar, abordando as consequências, barreiras e desnorteamentos quanto para questões ligadas à saúde mental destes indivíduos.

Para investigar e esclarecer o tema exposto, realizou-se uma revisão bibliográfica crítica com uso de artigos científicos e livros com a finalidade de procurar as consequências sobre o abuso sexual infantil intrafamiliar e as barreiras que impedem os direitos do abusado.

Esse artigo foi elaborado a partir do projeto de Iniciação Científica que será desenvolvido no período de setembro de 2020 até julho de 2021 com fomento do Programa de Iniciação Cientifica do Uni-FACEF.

\section{COMPREENDENDO A VIOLÊNCIA}

Qualquer ato não consentindo é um tipo de violência, invadir o corpo de outra pessoa sem a sua permissão é uma violência extremamente comum, principalmente no Brasil, o estupro é uma das violências mais noticiadas, assim como a violência doméstica, contudo, a divulgação é em massa, porém os dados só aumentam.

Segundo Chauí (1985), a violência vai além de uma simples violação aos direitos do próprio corpo, mas sim demonstra a assimetria numa relação hierárquica de desigualdade com finalidade de dominação, exploração e opressão, que se mantém a partir do silêncio e passividade.

Há, infelizmente, diversos tipos de violação sexual, para compreender o abuso sexual é necessário saber diferenciar os tipos existentes. Primeiramente a violência sexual, é caracterizada por atos praticados com finalidade sexual que, por violarem o corpo da criança ou adolescente, desrespeitam os direitos e as garantias individuais como liberdade, respeito e dignidade previstos na Lei oㅡ 8.069/90 - Estatuto da Criança e do Adolescente (BRASIL, 1990, Artigos 7ํㅜ 15, 16, 17 e 19).

Enquanto a violência sexual:

A violência sexual caracteriza-se: [...] por um ato ou jogo sexual, em uma relação heterossexual ou homossexual, entre um ou mais adultos e uma criança ou adolescente, tendo por finalidade estimular sexualmente esta criança ou adolescente, ou utilizá-la para obter uma estimulação sexual sobre sua pessoa ou de outra pessoa (AZEVEDO; GUERRA, 1998, p.33).

Na violência sexual, é necessário compreender duas questões, a exploração sexual, caracterizada pela relação com finalidade econômica pelo comércio do corpo/sexo, seja por pornografia, prostituição ou tráfico humano. E o abuso sexual se caracteriza como qualquer ação de interesse sexual de um 
ou mais adultos em relação a uma pessoa, podendo ocorrer tanto no âmbito intrafamiliar ou extrafamiliar.

A principal forma de abuso sexual infantil é realizada através de incesto, pois em nossa cultura, o incesto é uma das formas de abuso sexual mais frequente e o que mais gera consequências pejorativas às vítimas.

O abuso sexual infantil é considerado, pela Organização Mundial da Saúde (OMS), como um dos maiores problemas de saúde pública. Estudos realizados em diferentes partes do mundo mostram dados estatísticos preocupantes em que $7-36 \%$ das meninas e $3-29 \%$ dos meninos sofreram abuso sexual. Lembrando que grande parte das vítimas não conseguem denunciar, ou ao menos compreendem que foram abusadas.

\begin{abstract}
Abuso sexual infantil é o envolvimento de uma criança em atividade sexual que ele ou ela não compreende completamente, é incapaz de consentir, ou para a qual, em função de seu desenvolvimento, a criança não está preparada e não pode consentir, ou que viole as leis ou tabus da sociedade. $O$ abuso sexual infantil é evidenciado por estas atividades entre uma criança e um adulto ou outra criança, que, em razão da idade ou do desenvolvimento, está em uma relação de responsabilidade, confiança ou poder (WORLD HEALTH ORGANIZATION, 1999, p. 7).
\end{abstract}

Portanto o abuso sexual pode ser realizado de diversas maneiras e ocorre principalmente na infância e no contexto familiar, o que dificulta as pesquisas sobre o tema, e principalmente, as denúncias e buscas pelos direitos das vítimas. O abuso sexual é comum na família, contudo, diversos fatores impedem a erradicação do mesmo.

\title{
3. SILÊNCIO E NEGAÇÃO
}

Quando temos acesso à divulgação de alguma notícia sobre alguma criança vítima de abuso sexual, provavelmente, é algum caso extremo, e que a mídia vê como uma oportunidade de ganhar visualizações. Mas e os casos de abuso sexual que não deixam marcas? Grande parte dos abusos sexuais praticados em crianças não é perceptível, pois é frequentemente praticado sem o uso da força física e não deixa marcas visíveis, dificultando ainda mais a comprovação. Lembrando que o abuso sexual infantil pode ocorrer com ou sem penetração e até em atos sem o contato sexual como o voyeurismo e o exibicionismo. (AZEVEDO; GUERRA, 1989; THOMAS; ECKENRODE; GARBARINO, 1997).

O abuso sexual supõe uma disfunção em três níveis: o poder exercido pelo grande (forte) sobre o pequeno (fraco); a confiança que o pequeno (dependente) tem no grande (protetor); e o uso delinquente da sexualidade, ou seja, o atentado ao direito que todo indivíduo tem de propriedade sobre seu corpo (GABEL, 1997, p.10)

Os impactos do abuso sexual para o abusado segundo Day et al. (2003 apud FLORENTINO, 2015), são: medo do agressor e de pessoas do 
sexo do agressor; queixas sintomáticas; sintomas psicóticos; isolamento social e sentimentos de estigmatização; quadros fóbico-ansiosos, obsessivocompulsivo, depressão; distúrbios do sono, aprendizagem e alimentação; sentimento de rejeição, confusão, humilhação, vergonha e medo; e secularização excessiva, como atividades masturbatórias compulsivas.

Essas consequências são potencializadas ainda mais quando 0 abuso é realizado no ambiente familiar, que "normalmente" representa um local confiável e seguro para os seus membros mas que, nesses casos, se torna um espaço de insegurança, medo, desconfiança, conflitos e de incertezas entre 0 que é certo e errado (FURNISS, 1993).

Os sintomas construídos durante uma experiência traumática afetam não somente os pensamentos do indivíduo, mas a sua memória, o estado de consciência e todo o campo de ação, de iniciativa e de objetividade na vida. Muitas vítimas criam uma área de proteção em volta de si que as impede de continuar com a vida normal. Uma vítima de violência física, seja ela estupro ou pancadas, evita sair de casa, tem medo de andar sozinha, rejeita sexo ou qualquer contato físico (SILVA, 2000, p. 32).

O silêncio e a negação vêm como consequência do abuso sexual, principalmente devido a manipulação que o abusador faz em relação à vítima. E mesmo quando a criança consegue relatar, a própria família em si nega e não crê na criança. Geralmente, as crianças e adolescentes vítimas de abusos sexuais no contexto familiar são também vítimas de negligência, abusos emocionais e físicos. (DE ANTONI; KOLLER, 2000, HABIGZANG; CAMINHA, 2004, KOLLER, 1999).

Com relação à vítima, pode-se afirmar que o silenciamento diante de uma situação que the viola, oprime, envergonha e, muitas vezes, desumaniza, constitui uma reação natural à situação vivenciada, posto tratar-se de um "cidadão em condições especiais de desenvolvimento", submetido a uma relação assimétrica de poder (física e/ou psicológica) que, muitas vezes, se estende para além do controle e domínio da vítima propriamente dita (CUNHA; SILVA; GIOVANETTI, 2008, p. 283).

O abuso sexual infantil intrafamiliar não é um tema fácil, mas é de extrema necessidade, a família faz parte da nossa socialização primária, é o ambiente que será responsável por grande parte dos aprendizados e ensinamentos que adquirimos e replicamos, e uma criança que cresce em um contexto onde abuso sexual é comum, tem uma probabilidade maior de crer que faz parte da normalidade familiar cometer abusos sexuais.

\section{A COMPROVAÇÃO DO ABUSO SEXUAL}

Os profissionais da área de saúde concordam que identificar situações de abuso sexual infantil é um desafio, pois a maioria dos casos envolve crianças muito pequenas, que tem a comunicação verbal limitada 
(FRIEDRICH, 2001). Principalmente no contexto intrafamiliar, a criança não sabe identificar ou diferenciar especificamente o que foi o abuso sexual.

\begin{abstract}
A violência sexual contra crianças e adolescentes segundo Vaz (2001), ocorre, muitas vezes, no seio familiar ou em locais próximos, como vizinhança ou casa de parentes. A violência na maior parte dos casos não é denunciada e há a omissão de parentes ou conhecidos quanto ao crime cometido. Tal violência deixa "feridas afetivas" na criança que não são cicatrizadas, uma vez que o ato é praticado por alguém que a criança confia (ROMARO; CAPITÃO, 2007, p. 157).
\end{abstract}

O relato da vítima é primordial, contudo, quem responderá pelo abuso sexual cometido em bebês ou crianças que não possuem comunicação formada? É bem provável que uma criança com capacidade de relatar o abuso sexual, provavelmente, foi abusada desde do primórdio de sua vida.

A perícia psicológica deve incluir entrevistas com os responsáveis e com a vítima, e obviamente que o abusador contestará as acusações, e tentará manipular o contexto, demonstrando ser uma excelente pessoa.

Observa-se que o pacto de silêncio que se estabelece nos casos de abuso sexual contra crianças é um entrave para que este seja impedido e os agressores punidos. A falta de punição e a recorrência do ato sexual violento podem, muitas vezes, levar a criança à morte ou deixar graves sequelas físicas e psíquicas (ROMARO; CAPITÃO, 2007, p. 171).

O psicólogo adquire um papel de julgador nesses casos, focando no grau de incongruência entre as necessidades da criança e as habilidades parentais despendidas (ROVINSKI, 2007). Cabe ao psicólogo destacar e analisar os aspectos psicológicos das pessoas envolvidas e o principal objetivo da perícia psicológica é auxiliar o juiz na tomada de uma decisão, garantindo, consequentemente, os direitos e o bem-estar da criança e/ou adolescente (SILVA, 2003).

Ou seja, já é extremamente complicado para o abusado, compreender que foi abusado, ou conseguir relatar o abuso, e quando consegue, a família, na maioria das vezes, não irá atrás dos direitos ou simplesmente não acreditará. $E$ isso independe de testemunhas, visto que há diversos abusos sexuais em que há testemunhas, contudo, silenciam e negam o que estão vendo. E mesmo se a vítima com a ajuda de alguém, conseguir ir atrás de seus direitos, se não houver comprovação, de nada adiantará a denúncia.

\title{
5. CONSEQUÊNCIAS DO ABUSO SEXUAL
}

Ao se falar sobre abuso sexual, pode-se afirmar que o abuso sexual e suas consequências sobre a saúde da vítima abusada "[...] são primeiramente uma violação dos direitos humanos, não escolhendo cor, raça, credo, etnia, sexo e idade para acontecer" (CUNHA; SILVA; GIOVANETTI, 
2008 , p. 245). Há casos de abuso sexual relatados com qualquer tipo de pessoas, mas é notório nos dados estatísticos que mulheres e crianças são as principais vítimas.

A maioria dos pesquisadores concorda que o abuso sexual infantil é facilitador para 0 aparecimento de psicopatologias graves, prejudicando a evolução psicológica, afetiva e social da vítima. Os efeitos do abuso na infância podem se manifestar de várias maneiras, em qualquer idade da vida (ROMARO; CAPITÃO, 2007, p. 151).

Além de facilitar o aparecimento de psicopatologias, é extremamente comum uma pessoa que comete o abuso sexual, ter sido abusada sexualmente, principalmente, em homens. A pesquisa ainda é escassa em relação a este ciclo de abusos sexual.

O que se observa na literatura existente é a concordância entre os especialistas em reconhecer que a criança vítima de abuso e de violência sexual corre o risco de uma psicopatologia grave, que perturba sua evolução psicológica, afetiva e sexual (ROMARO; CAPITÃO, 2007, p. 144).

De acordo com Furniss (1993), as consequências do abuso sexual variam de acordo com a idade da criança, quando houve o início da violência, a duração e a quantidade de vezes em que houve o abuso, o grau da violência, a diferença de idade e o vínculo entre o abusador e a vítima.

As diversas formas de violência ou abuso afetam a saúde mental da criança ou do adolescente, visto este se encontrar em um processo de desenvolvimento psíquico e físico, produzindo efeitos danosos em seu desempenho escolar, em sua adaptação social, em seu desenvolvimento orgânico. Vários estudos relacionam a violência doméstica com o desenvolvimento de transtornos de personalidade, transtorno de ansiedade, transtornos de humor, comportamentos agressivos, dificuldades na esfera sexual, doenças psicossomáticas, transtorno de pânico, entre outros prejuízos, além de abalar a autoestima, por meio da identificação com o agressor, um comportamento agressivo (ROMARO; CAPITÃO, 2007, p. 121).

O comportamento sexual inadequado para a idade é um sintoma característico de crianças sexualmente abusadas. Geralmente a criança apresentará brincadeiras de cunho sexual, e até mesmo atos sexuais como masturbação, ou comportamento sedutor. Exemplificando com o relato:

Paul, de cinco anos, foi rapidamente confiado a uma família adotiva, com apoio do Estado, depois que foi sodomizado por seu padrasto; a mãe adotiva não quis mais acolhê-lo depois de tê-lo surpreendido com seu filho de três anos, reproduzindo com um objeto o que ele havia sofrido. Descobrimos, às vezes, reações em cadeia: Cécile, de seis anos, foi denunciado por um vizinho, de dez anos, ao qual ele pediu que se despisse. Nesse momento, tomou-se conhecimento de que tinha sido obrigada a praticar uma relação em um adolescente de catorze anos, ele próprio vítima de um professor. Enfermeiros e professoras de cursos maternais descrevem o mal-estar por que passam diante de crianças que procuram contato erótico e lhes pedem carícias genitais. Essas provocações, muito frequentes depois de um abuso sexual, farão com que as pessoas achem que a criança 
é perversa e que mente quando denuncia aquilo que the aconteceu (GABEL, 1997, p. 69).

Nos adolescentes é comum a agressão sexual sobre outras crianças, principalmente em meninos que sofreram agressões sexuais na infância, enquanto nas meninas é comum a manifestação de sedução, e em casos extremos as vítimas de abuso sexual tem tendência a ninfomania e até mesmo prostituição (GABEL, 1997).

Logo, as consequências do abuso sexual vão desde de problemas psicológicos a comportamentos sexuais precoces, além de diversas outras adversidades, contudo, uma das observações é a vítima de abuso sexual ser o próximo abusador. Ou seja, a construção de um ciclo de abusos sexuais, e isso ocorre principalmente na família em que há uma geração de abusados e/ou abusadores perpetuando em uma cultura que não quer perceber o abuso sexual, pois prefere negá-lo.

\section{PERFIL DOS AGRESSORES}

O tema abuso sexual infantil é comumente relacionado com a pedofilia, contudo, é necessário compreender que a pedofilia não necessariamente está relacionada com o abuso sexual.

\subsection{Pedofilia}

De acordo com o DSM-V a Pedofilia é um transtorno parafílico, em que o sujeito possui fantasias, desejos, impulsos ou comportamentos intensos ou sexualmente excitantes envolvendo adolescentes pré-púberes ou jovens. Um dos critérios diagnósticos é o indivíduo ter 16 anos e ser pelo menos 5 anos mais velho que a criança alvo das fantasias ou comportamentos.

A maioria dos pedófilos é homem e a preferência é pelo sexo oposto, mas também ocorrem com o mesmo sexo, em proporção 2:1. Geralmente, o adulto é conhecido da criança e pode ser membro da família, ou uma figura de autoridade.

Importante compreender que Pedofilia não é sinônimo de violência sexual, por isso, ninguém é punido por ser pedófilo, mas sim, quando prática algum tipo de abuso sexual. Logo, a violência sexual não necessariamente é cometida por pedófilos.

\subsection{Contexto do Agressor}

É importante também compreender o contexto do abusador, segundo González (2006), de acordo com a teoria da aprendizagem social, muitos abusadores aprenderam o uso da violência em sua adolescência, 
incluindo maus tratos na infância e vitimização sexual em grande parte do contexto de vida do abusador. Vale lembrar que há diversas teorias afirmando que, para que o abuso ocorra, é necessário que se tenha motivação para abusar, que pode ser fruto de experiências próprias traumáticas ou de pessoas adultas próximas (GONZÁLEZ; MARTíNEZ; LEYTON; BARDI, 2004). Essas informações corroboram para a importância de entender a problemática da violência sexual como um processo cíclico.

Diversas pesquisas mostram que alguns abusadores sexuais foram vítimas de abuso sexual quando crianças, e que, a cada oito crianças abusadas, uma repetirá o comportamento na idade adulta. Segundo Ray Wyre (1996 apud SANDERSON, 2005, p. 55), "[...] para entender porque algumas vítimas passam a praticar abusos, é preciso prestar atenção ao tipo de abusador, à relação formada com a criança e à experiência da criança com o abuso".

Miller (1997) diz que as vítimas irão repetir as atrocidades que sofreram, pois não conseguem vivenciar, de forma consciente, os danos que Ihe foram causados na infância. Negando a sua história, gerando uma vida com situações sem resolução e uma infância reprimida.

Logo, a partir do momento em que a pessoa aceita e compreende a sua vivência infantil, em que foi abusada, terá menos necessidade de violar outra criança. Ou seja, descobrir o próprio passado é fundamental para que não se transfira toda dor e ódio à inocentes (MILLER, 1997).

Portanto, a pessoa que comete o abuso sexual, também possuí um contexto e possivelmente há diversas explicações para a ocorrência do ato, contudo, apesar de explicar tais argumentos não justificam o abuso, por isso as penas criminais ainda serão mantidas sobre o agressor, mas conjuntamente com o apoio psicológico, pois como visto na teoria os agressores sexuais provavelmente foram agredidos sexualmente na infância, e merecem, assim como quem é abusado, todo o suporte psicológico, desde que aceite e queira receber ajuda.

\section{CONSIDERAÇÕES FINAIS}

A partir deste artigo é possível concluir que o abuso sexual possui diversas vertentes e ramificações em seu entorno, pois ao analisar de maneira teórica, nota-se o vasto caminho que o abuso sexual percorre. Especificamente falando do abuso sexual infantil intrafamiliar, nota-se a dificuldade que as famílias têm em compreender o abuso, geralmente silenciando ou negando o mesmo.

Ainda mais se tratando de crianças abusadas pelos próprios parentes, e principalmente, pelos próprios pais. A família faz parte da nossa socialização primária, é o ambiente que será responsável por grande parte dos 
aprendizados e ensinamentos que adquirimos e replicamos. O contexto familiar é de extrema importância para a formação da identidade do sujeito, não é à toa que existem diversas pesquisas sobre a influência da família na formação da personalidade.

O abuso sexual infantil intrafamiliar é complexo e difícil de se enfrentar, pois a família não tem a base para lidar com essa problemática, 0 que faz com que o ciclo de abusos sexuais infantis na família se reinicie nas próximas gerações. Acarretando em uma insegurança familiar, diversos problemas psicológicos, e abalos na construção da personalidade.

Uma geração que cresce em um contexto onde o abuso sexual é comum e sem impedimentos, sempre continuará perpetuando diversos outros abusos sexuais, por isso se faz necessário uma maior atenção, principalmente na escola e na família, pois provavelmente há uma criança que sofre de abuso sexual, contudo, não tem para quem falar, ou não sabe que está sendo abusada.

Quando se fala sobre ensino sexual, não é para ensinar crianças a terem relações sexuais, mas sim, para a criança compreender o que é uma violação do seu corpo, como reagir e como se precaver de ser uma futura vítima.

A cultura brasileira precisa, urgentemente, tratar o abuso sexual com outros olhos, pois é nítido a alta taxa de abusos sexuais, e não é incomum ter na família alguém que já abusou ou foi abusado sexualmente.

Portanto, se tem uma cultura do abuso sexual e ela é fortalecida com o silêncio e negação dos demais à respeito do tema, sendo que deveria ser ao contrário, as pessoas precisam ter maiores conhecimentos sobre os direitos do próprio corpo, como analisar se está presente de um contexto de abuso sexual e, principalmente, o que fazer diante de uma situação dessas.

Realizar este artigo foi árduo, pois ler as consequências de quem sofre o abuso sexual, especificamente na infância, não é uma leitura agradável, muito menos fácil, contudo, extremamente necessária, visto que os casos de abuso sexual infantil vem crescendo cada vez mais, e principalmente no contexto atual atingido pela pandemia, em que todos estão em casa, suponho que os índices de abuso sexual tenham aumentado ainda mais.

Ao longo deste ano (2020) estarei realizando uma pesquisa de campo sobre "O ciclo de abuso sexual infantil na família e a normalização da pedofilia", com o financiamento do Programa de Iniciação Científica do UniFACEF, e ter escrito este artigo de revisão contribuiu diretamente com a pesquisa em andamento.

O tema abuso sexual é um tema que precisa, urgentemente, de pesquisas e principalmente de pesquisas de campo, investigações e compreensões sobre o mesmo, por mais que seja um tema delicado de se 
tratar, é algo que está presente e comumente é visto em famílias, portanto, é uma questão de saúde pública e bem estar social continuar pesquisando sobre o abuso sexual, ninguém em hipótese alguma merece ter seu corpo violado por outra pessoa.

\section{REFERÊNCIAS}

AMAZARRAY, M. R.; KOLLER, S. H. Alguns aspectos observados no desenvolvimento de crianças vítimas de abuso sexual. Psicol. Reflex. Crit., Porto Alegre, v. 11, n. 3, p. 559-578, 1998. Disponível em $<$ http://www.scielo.br/scielo.php?script=sci_arttext\&pid=S0102-

$79721998000300014 \&$ Ing=en\&nrm=iso $>$.Acesso em 19 set. 2020.

AMERICAN PSYCHIATRIC ASSOCIATION. DSM-V: Manual diagnóstico e estatístico de transtornos mentais. Trad. Maria Inês Corrêa Nascimento; 5.ed. Porto Alegre: Artmed, 2014.

AZEVEDO, M. A.; GUERRA, V. N. Pele de asno não é só estória... um estudo sobre a vitimização sexual de crianças e adolescentes em família. São Paulo: Editora Roca, 1988.

BRASIL. Presidência da República. Casa Civil. Subchefia para Assuntos Jurídicos. Lei no 8.069, de 13 de julho de 1990. Dispõe sobre o Estatuto da Criança e do Adolescente e dá outras providências. 1990. Disponível em: $<$ http://www4.planalto.gov.br/legislacao >. Acesso em: 18 set. 2020.

CHAUÍ, M. Participando do debate sobre mulher e violência. In: CAVALCANTI, M. L. V. C.; FRANCHETTO, B.; HEILBORN, M. L. (Orgs.) Perspectivas Antropológicas da mulher. Zahar: Rio de Janeiro, 1985.

CUNHA, E. P.; SILVA, E. M.; GIOVANETTI, A. C. Enfrentamento à violência sexual infanto-juvenil: expansão do PAIR em Minas Gerais. Belo Horizonte: UFMG, 2008.

DAY, V. P. et al. Violência doméstica e suas diferentes manifestações. Revista de Psiquiatria do Rio Grande do Sul, Porto Alegre, v. 25, suppl. 1, p. 09-21, 2003.

FLORENTINO, Bruno Ricardo Bérgamo. As possíveis consequências do abuso sexual praticado contra crianças e adolescentes. Fractal, Rev. Psicol., Rio de Janeiro, v. 27, n. 2, p. 139-144, ago. 2015. Disponível em <http://www.scielo.br/scielo.php?script=sci_arttext\&pid=S1984-

02922015000200139\&lng=pt\&nrm=iso >. Acesso em 18 set. 2020.

FÓRUM BRASILEIRO DE SEGURANÇA PÚBLICA - FBSP. Anuário Brasileiro de Segurança Pública. Edição XII. São Paulo, 2018.

FURNISS, T. Abuso Sexual da Criança: uma abordagem multidisciplinar. Porto Alegre: Artes Médicas, 1993. 
GABEL, M. Crianças vítimas de abuso sexual. trad. GOLDFEDER, S.; GOMES, M. C. C. São Paulo: Summus Editorial, 1997. Disponível em: $<$ https://www.scielo.br/scielo.php?script=sci_arttext\&pid=S1413-

$73722002000200002 \#$ end $d^{\wedge}$. Acesso em 19 set. 2020.

GONZÁLEZ, E.; MARTINEZ, V.; LEYTON, C.; BARDI, A. Características de los abusadores sexuales. Revista Sogia, v. 11, n. 1, p. 6-14. 2004. Disponível em: <https://d1wqtxts1 xzle7.cloudfront.net/33130738/XI1abusadores.pdf?13939223 $42=\&$ response-content-

disposition=inline\%3B+filename\%3DCaracteristicas_de_los_abusadores_sexua I.pdf\&Expires $=1594154915$ \&Signature $=$ LcBWqShcpsoNdxnVZS6uR5FpH1kFx HltQJWcgRqBCcVA1 eD2YvdKMKtUjgd4fAetwDGTnrXhx3QXTa5FZAUGCC5z $\sim$ GSsD V 1nAvuQnsARyK85dLX82kuze-

c1Se6uGTHDrTXT9jc3S8LU5L9bF7G45 96ZgHPSZxf4hvlSizm7oKlj6zbFklK I RCQyVSvmkENR8Cpbq9HF3GPn5ymPjCki7eg 1b7OWVYWIQcUFcaUuT0bU h2jGrzVGmiLT xD2j2CnoqopfyAfwrZgc5Gh0YtBs1rHxqVRrhTumttPBG2Cr4iP 2mx7mw5p 5AlyGo-AzcB1otclohoD9KuRFSUw_ \&Key-PairId=APKAJLOHF5GGSLRBV4ZA>. Acesso em: 20 set. 2020.

GONZÁLEZ, P. Delincuentes Sexuales. Dissertação de Mestrado, Universidad de Aconcagua, 2006.

HABIGZANG, L. F. et al. Abuso sexual infantil e dinâmica familiar: aspectos observados em processos jurídicos. Psic.: Teor. e Pesq., Brasília, v. 21, n. 3, p. 341-348, dez. 2005.2 Disponível em<http://www.scielo.br/scielo.php?script=sci_arttext\&pid=S0102-

$37722005000300011 \&$ Ing=pt\&nrm=iso>. Acesso em 19 set. 2020

JESUS, Núbia Angélica de. O círculo vicioso da violência sexual: do ofendido ao ofensor. Psicol. cienc. prof., Brasília, v. 26, n. 4, p. 672683, dez. 2006.2 Disponível em $<$ http://pepsic.bvsalud.org/scielo.php?script=sci_arttext\&pid=S141498932006000400013\&lng=pt\&nrm=iso >. Acesso em: 21 set. 2020.

MILLER, A. O Drama da Criança bem Dotada. Summus: São Paulo, 1997.

ROVINSKI, S. Fundamentos da perícia psicológica forense. Vetor: São Paulo, 2007.

ROMARO, R. A; CAPITÃO, C. G. As faces da violência: aproximações, pesquisas, reflexões. São Paulo: Vetor, 2007.

SAFFIOTI, H. I. B. No Fio da Navalha: Violência Contra Crianças e Adolescentes no Brasil Atual. Quem Mandou Nascer Mulher? São Paulo: Editora Rosa dos Tempos, 1997.

SANDERSON, C. Abuso Sexual em Crianças. M. Books: São Paulo, 2005. 
SCHAEFER, L. S.; ROSSETTO, S.; KRISTENSEN, C. H. Perícia psicológica no abuso sexual de crianças e adolescentes. Psic.: Teor. e Pesq., Brasília, v. 28, n. 2, p. 227-234, jun. 2012 Disponível em: $<$ http://www.scielo.br/scielo.php?script=sci_arttext\&pid=S0102-

$37722012000200011 \&$ Ing=en\&nrm=iso $>$. Acesso em 19 set. 2020.

SILVA, D. M. P. Psicologia Jurídica no Processo Civil Brasileiro. Casa do Psicólogo: São Paulo, 2003.

SILVA, I. R. Abuso e trauma. Vetor: São Paulo, 2000.

WORLD HEALTH ORGANIZATION. Guidelines for medico-legal care for victims of sexual violence, 2003.

Prevention. Geneva, 1999. 


\title{
PERCEPÇÕES DE ADOLESCENTES SOBRE A INFLUÊNCIA PARENTAL NA ESCOLHA PROFISSIONAL
}

\author{
Alany Alves Borges \\ alany.ab@hotmail.com \\ Maria Luísa Casillo Jardim Maran \\ mluisajmaran@gmail.com
}

\section{INTRODUÇÃO}

O ser humano, ao longo da vida, vivencia a necessidade de realizar diversas escolhas e o sentimento de dúvida é muito presente em todas as fases. Durante a adolescência a escolha profissional se mostra uma tarefa desafiadora ao adolescente, pois esta fase é repleta de questionamentos e instabilidade.

É um momento fundamental no processo de construção da identidade e ocorrem muitas transformações no desenvolvimento biológico, psíquico, nas relações socioculturais e familiares. Discute-se que há diversos fatores que influenciam na escolha profissional, um deles é o núcleo familiar. Desta forma, é notável a relevância do suporte emocional e das devidas orientações aos adolescentes (e aos pais) durante essa transição para a vida adulta.

Sendo assim, a Orientação Profissional pode contribuir justamente para que o adolescente possa tomar uma decisão de forma que ele identifique as suas aptidões, habilidades e motivações, aumentando o conhecimento de si e daquilo que pode favorecer ou impedir uma escolha adequada e autônoma.

$\mathrm{Na}$ literatura da área discute-se que a família é um fator de influência importante sobre a escolha profissional, pois o vínculo estabelecido entre pais e filhos, geralmente, contribui para que o jovem almeje a aprovação da família frente à decisão tomada. Há pais que apresentam condições psíquicas mais favoráveis para acolher uma decisão diferente daquela esperada, no entanto, este momento também pode ser permeado por conflitos e distanciamentos. Sendo assim, é importante cuidar desse vínculo e de suas influências para auxiliar o jovem na tomada de decisão e no enfretamento dos dilemas da adolescência.

Diante dessas considerações, buscou-se conhecer de que maneira a dinâmica familiar influencia na escolha profissional de adolescentes. Para tanto, participaram do estudo quatro adolescentes, todos com 17 anos de idade, cursando o terceiro ano do ensino médio. Realizou-se uma entrevista online, a partir de um roteiro semiestruturado, buscando abordar os temas da adolescência, escolha profissional e influência parental. Os dados obtidos 
foram submetidos à análise qualitativa (MINAYO, 2001), elaborando-se três categorias de análise: Vivência da adolescência e construção da identidade; Escolha profissional; Relação entre pais e filhos e participação dos pais na escolha profissional.

\section{ADOLESCÊNCIA E PUBERDADE: DESAFIOS DO DESENVOLVIMENTO}

De acordo com Outeiral (1994), a definição da palavra adolescência (adolescer) provém do latim, 'ad' que corresponde a: 'a, para', enquanto 'olescer', tem como significado a palavra crescer. Outrossim, a palavra carrega o significado do desenvolvimento corporal e psíquico e também do adoecer como parte das angústias e dores vivenciadas devido às grandes mudanças dessa fase.

A Organização Mundial da Saúde (OMS, 2018) define a adolescência em uma faixa etária entre os 10 anos de idade aos 19 anos, dividindo-a em duas categorias: dos dez aos dezesseis anos e a outra fase dos dezesseis aos dezenove. No Brasil, o Estatuto da Criança e do Adolescente (ECA, 1990) de acordo com a lei no 8069/90, define a adolescência entre os doze e os dezoito anos de idade. Em contraponto, Campos (2012) afirma que estabelecer uma idade estática para a adolescência pode ser equivocado, pois cada um vivenciará esse período da vida de forma particularizada.

De acordo com Hanke e Oliveira (2017), a Psicanálise aborda a adolescência como uma das fases da vida e observa que uma pessoa pode apresentar comportamentos de uma idade inferior ou superior a sua, assim, não é interessante relacionar o sujeito a sua idade cronológica, pois não se trata de considerar apenas o tempo físico e as mudanças corporais, mas também o desenvolvimento do psiquismo do indivíduo. Freud (1905) define o início da puberdade após o período da latência, não definindo uma idade préestabelecida. No estudo "Três ensaios sobre a teoria da sexualidade", a primeira fase do desenvolvimento humano se caracteriza pelo autoerotismo, no período de latência, a pulsão sexual é satisfeita por meio da sublimação e ocorre uma intensa repressão dos impulsos sexuais. Ao sair do período de latência e ingressar na fase genital, o sujeito ingressa na puberdade, momento no qual a energia sexual é muito voltada ao outro, com o estabelecimento de relações genitais.

Para Freud (1905) a adolescência está muito relacionada ao Complexo de Édipo, ocorrendo nessa fase uma reedição das vivências anteriores. O indivíduo precisa romper a fantasia incestuosa com os pais e, com isso, acontece uma ruptura com os pais idealizados na infância, direcionando a energia sexual a outros objetos externos. Desta maneira, ele vivencia um maior contato com o real e uma diferenciação entre o eu e o outro. 
Devido às mudanças da puberdade, os conteúdos psíquicos que, anteriormente, eram recalcados, vem à tona.

Para Lourenço e Queiroz (2010) a puberdade é um fator importante na transição da infância para a vida adulta, como parte do processo de adolescer, porém, não representa a totalidade da fase, e nem são sinônimos, pois o termo puberdade se restringe às mudanças biológicas e físicas que ocorrem no homem e na mulher, tais como: mudanças nos órgãos reprodutores, capacidade reprodutiva, crescimento dos pelos nas genitálias e no sexo feminino acontece o desenvolvimento mamário e a menarca. Segundo Levisky (2009) a adolescência é um fenômeno psicossocial, enquanto que a puberdade se refere a modificações biológicas, no entanto, são processos interligados.

A adolescência se caracteriza como metamorfose, sendo um importante momento do desenvolvimento humano, tanto do ponto de vista biológico, quanto psicológico e social. A cultura gera grande influência sobre a vivência da adolescência, com suas convenções, valores, leis e afins (LEVISKY, 2009). Desta forma, os parâmetros para designar a adolescência e seu significado em determinada cultura abrange vastas influências do contexto no qual o jovem está inserido.

Segundo Soares (2002), é na adolescência que o processo de formação de identidade, do conhecer a si mesmo e das indagações acerca de si e do mundo são mais presentes. A escolha da profissão começa a ser mais questionada neste momento e é também influenciada por aspectos do contexto no qual se encontra o adolescente, tais como: renda, família, meio político, educacional, social, entre outros. Desta forma, o adolescente, inserido numa cultura e contexto social, precisa de orientações das pessoas que estão próximas para que, desta forma, consiga se construir subjetivamente de maneira mais estável (BARRETO; RABELO, 2015).

Segundo as afirmações de Erikson (1976) acerca do desenvolvimento psicossocial e também do desenvolvimento da personalidade, o jovem enfrenta a crise da identidade versus a confusão de papéis. Nesse período, é importante o adolescente compreender sua singularidade e a busca pela própria identidade, sendo capaz de experimentar novos papéis, novas situações. Nessa visão, o teórico também aborda a conceituação da possível crise de identidade, as habilidades que foram adquiridas na terceira infância e a aplicabilidade em uma identidade ocupacional. Na crise, como propriamente $\mathrm{o}$ nome diz, podem surgir conflitos, sobre os quais os adolescentes podem ter dificuldades em encontrar soluções. Todavia, quando isso ocorre de uma forma satisfatória, os adolescentes conseguem adquirir a virtude da lealdade e fidelidade. Sendo assim, a fidelidade permite que o adolescente crie uma união com pessoas, grupos, ideologias através da identificação. Os adolescentes 
começam a passar menos tempo no ambiente familiar para vivenciarem novas relações externas.

Anjos (2017) descreve a adolescência em dois períodos (ou atividades). Inicialmente estabelece-se o "código de companheirismo" no campo afetivo, 0 que envolve a confiança e o respeito dos pares. $O$ adolescente vivencia diversas identificações, com professores, artistas e ainda com os pais. Acontece, em parte, a reprodução de suas inter-relações com os amigos da mesma faixa etária e essa reprodução é utilizada como um parâmetro de comportamento que pode definir um estilo de vida. Já no segundo período, o adolescente se volta mais para as escolhas referentes à vida adulta, como escolha profissional, inserção na vida profissional e no mundo do trabalho.

Ao levar em consideração os aspectos da adolescência, assim como suas dificuldades e o processo de escolha profissional, a orientação profissional como pratica psicológica pode contribuir para a construção das identidades pessoal e profissional e não somente para a decisão por uma profissão.

\section{PAIS E FILHOS: INFLUÊNCIA PARENTAL NA ESCOLHA PROFISSIONAL}

O adolescente passa por grandes mudanças físicas e psíquicas, as quais são influenciadas pelo contexto e este pode auxiliá-lo no seu processo de desenvolvimento. Segundo Reichert (2012), ao tratar da relação familiar, é visto que no mundo contemporâneo ocorreram diversas mudanças e, por conseguinte, isso ocasiona alterações na dinâmica familiar, uma vez que a relação primária continua sendo essencial para o desenvolvimento da pessoa. No entanto, durante a adolescência, pais e filhos fazem ajustes em suas relações.

Para o adolescente, diversos aspectos podem influenciar sua escolha profissional, como o ambiente social, econômico, religioso, familiar, entre outros elementos. Em relação à influência parental, ela pode contribuir positivamente ou negativamente, o que depende da relação e da dinâmica que os pais e os filhos tem uns com os outros. Cada núcleo familiar possui suas autenticidades e particularidades, então é necessário conhecer como é o funcionamento da família do jovem que está prestes a realizar uma escolha profissional.

Em relação à projeção dos pais, Soares (2002) aborda sobre como muitos pais tendem a, de certa forma, realizar suas próprias vontades através dos filhos. Outoral (1994) também pontua como muitos pais encontram nos filhos uma forma de extensão e de realização de desejos não realizados. 
Negam o filho como um ser singular, com vontades próprias de realização, pois existe um filho fantasiado e idealizado, desde o início de vida do bebê.

Segundo Bohoslavsky (1998), o adolescente ou jovem não é o único que passa por dificuldades, pois a indecisão dos filhos acerca da profissão pode interferir muito sobre os próprios pais. Quando se trata da expectativa dos pais sobre os filhos, Andreani (2004) apud Santos (2005) aborda que 0 adolescente se sente cobrado, o que pode gerar muita ansiedade. Na dinâmica familiar, o apoio entre pais e filhos é muito importante, de maneira a buscarem formas de resolver os conflitos sofridos durante essa fase.

$O$ ato do filho, ao escolher sua área de atuação, desperta nos pais as escolhas de suas próprias vidas. Pode ocorrer uma expectativa de que 0 filho possa realizar aquilo que os pais gostariam, possivelmente, como forma de elaborar situações conflitivas. Para Silva (1996), os pais podem depositar no filho, de forma inconsciente, os desejos do contexto familiar.

Outeiral (1994) afirma que é fundamental deixar o adolescente construir sua autonomia e isto não é sinônimo de quebrar os laços da relação parental, mas sim de deixar o jovem se desprender do vínculo infantilizado. Este marco é difícil para ambos os lados, tanto dos filhos, quanto dos pais, pois, para isso, os pais terão que ser compreensivos sobre o momento de vida do adolescente, momento de afastamento para tornar-se mais independente. Assim, o adolescente inicia sua independência e adquire uma imagem positiva e real dos pais. Contudo, o autor destaca que "esta aceitação não sugere evidentemente falta de colocação de limites" (OUTEIRAL, 1994, p. 17). Sendo assim, os pais precisam buscar formas de equilibrar o cumprimento de ordem e obediência de seus filhos, mantendo bons laços familiares de forma afetiva.

É visto que cada núcleo familiar apresenta um tipo de estilo parental, de acordo com Reichert (2012), pois cada indivíduo possui valores, pensamentos e comportamentos diferentes e isso interfere na forma como esse pai/mãe vai se portar na educação de seus filhos. Alguns estudos apontam que, consequentemente, isso pode influenciar na vida do adolescente e na sua autonomia.

Em relação à influência dos pais no enfoque da escolha profissional, Levenfus (1997) aborda que, nesse contexto, podem aparecer diferentes influências e dinâmicas familiares, tais como: sonhos e desejos dos pais colocados sobre o filho; pressão dentro da família para a decisão de carreira; influência ativa e comportamentos dos pais contra a vontade do filho; desaprovações e imposições, com domínio sobre os filhos; idealização dos pais sobre os filhos.

Outras situações que ocorrem são de apoio para que o filho faça sua própria escolha, enquanto outros mantêm uma posição isenta. Há pais que 
se mantêm indiferentes e há casos de homogeneidade profissional dentro do núcleo familiar, de forma que muitos adolescentes podem se sentir influenciados a seguirem a mesma profissão, mesmo não tendo vontade ou aptidões para a mesma. Por fim, há também os adolescentes/jovens que não se sentem influenciados pelos pais.

Escolher uma profissão remete o adolescente a muitas dúvidas, ao questionamento do que fazer, embora muitos adolescentes realizem a escolha de uma profissão sem pensarem e pesquisarem sobre seus gostos e competências. Pesquisas realizadas chegaram a dados de que a indecisão voltada à profissão pode ocasionar neuroses como ansiedade, comportamentos impulsivos e até mesmo depressão, de acordo com Levenfus (2016).

Muitos autores não diferenciam a Orientação vocacional e profissional, porém, alguns fazem uma diferenciação entre as duas. A primeira está baseada em alcançar o autoconhecimento do jovem, conhecimento da própria realidade e assim tomar decisões com maior autonomia (MULLER, 1998). A Orientação profissional, por outro lado, foca em gerar conhecimento sobre as diferentes profissões e sobre o mercado de trabalho (LEVENFUS, 2016). Essas duas modalidades caminham no sentido de auxiliar a pessoa em um importante momento de escolha profissional, tendo em vista todos os complexos fatores que estão envolvidos com tal escolha, tornando-se uma decisão desafiadora em muitos casos.

A partir do exposto, entende-se assim que o propósito deste tipo de orientação é o de "auxiliar terapeuticamente alguém a encontrar um direcionamento para a sua vida, por meio do reconhecimento de uma identidade profissional, a partir do conhecimento de seu mundo interno e do mundo ocupacional" (VASCONCELOS apud LEVENFUS, 1997, p.228). Levando em conta os diversos fatores que podem estar relacionados com a questão da escolha, a orientação profissional/vocacional busca trazer um esclarecimento pessoal e profissional para que esta escolha seja feita com maior autonomia e segurança.

A Orientação Profissional, dentro da Psicologia, irá auxiliar para que, de forma pertinente e salubre, sejam feitas reflexões sobre uma boa escolha profissional. Sendo assim, o intuito da Orientação Vocacional/Profissional é contribuir para o indivíduo e para o contexto social. Bohoslavsky (1998) afirma que a Orientação Profissional contribuirá para os jovens em seus enfrentamentos e análise pessoal. Por conseguinte, irá auxiliálo a enfrentar os problemas que dificultam sua escolha profissional. $O$ autor contextualiza que aquele que vê na Orientação Profissional uma forma de auxílio no processo de decisão, demostra preocupação consigo mesmo e, assim, busca ajuda de um orientador. Nessa fase, o pensamento é que o futuro 
não remete apenas ao que realizará, mas também ao que o definirá como pessoa.

Apesar de ser uma questão importante na fase da adolescência, adultos também vivenciam a indecisão, sendo que a escolha de uma carreira será a primeira de muitas outras, pois o medo e a incerteza estão presentes durante toda a vida.

\section{MÉTODO}

Esse artigo retrata um estudo qualitativo, realizado com quatro adolescentes de 17 anos, que cursavam o terceiro ano do Ensino Médio, três deles provenientes da rede particular de ensino e um da rede pública.

Buscou-se compreender a percepção dos adolescentes sobre suas vivências durante o período da adolescência e seu processo de escolha profissional, com o intuito de compreender possíveis influências parentais no processo de escolha profissional. Através da construção de um referencial teórico pertinente ao tema explorado na pesquisa, bem como uma metodologia condizente com os objetivos propostos, foram realizadas entrevistas semiestruturadas para a coleta de dados e, posteriormente, uma análise qualitativa dos dados obtidos, baseada em Minayo (2001).

\subsection{Participantes}

Considerando os objetivos propostos, o trabalho foi realizado com quatro adolescentes de 17 anos. Os participantes deveriam cursar o terceiro ano do ensino médio, na faixa etária entre 16 a 18 anos de idade, residentes na cidade de Franca-SP.

A pesquisa foi feita com três adolescentes provenientes de escola particular e um de escola pública. Foram entrevistados três adolescentes do sexo masculino e uma jovem do sexo feminino, conforme apresentado na Tabela 1.

Tabela 1 - Identificação dos adolescentes $(n=4)$

\begin{tabular}{l|l|l|l|l|l}
\hline \multicolumn{1}{c|}{ NOME } & IDADE & SEXO & $\begin{array}{c}\text { ESTADO } \\
\text { CIVIL }\end{array}$ & $\begin{array}{c}\text { GRAU ESCOLAR } \\
\text { (Ensino Médio) }\end{array}$ & \multicolumn{1}{c}{$\begin{array}{c}\text { ESCOLHA } \\
\text { PROFISSIONAL }\end{array}$} \\
\hline LAURÊNCIO & 17 & $\mathrm{M}$ & Solteiro & $3^{\circ}$ ano & $\begin{array}{l}\text { Engenharia } \\
\text { mecatrônica }\end{array}$ \\
\hline CHARLIE & 17 & $\mathrm{M}$ & Solteiro & $3^{\circ}$ ano & Psicologia \\
\hline BRENO & 17 & $\mathrm{M}$ & Solteiro & $3^{\circ}$ ano & $\begin{array}{l}\text { Engenharia } \\
\text { mecatrônica }\end{array}$ \\
\hline LORENA & 17 & $\mathrm{~F}$ & Solteira & $3^{\circ}$ ano & $\begin{array}{l}\text { Relações } \\
\text { Internacionais, } \\
\text { Direito, História }\end{array}$ \\
\hline
\end{tabular}


* Nomes fictícios

Foi solicitado aos adolescentes que escolhessem nomes fictícios para que os mesmos fossem identificados no trabalho, em função na necessidade de sigilo de suas identidades. Cada adolescente escolheu o nome de acordo com alguma vivência ou afinidade. Laurêncio escolheu o nome do número 103 da tabela periódica, já Charlie escolheu o nome do seu cachorro, Breno escolheu um nome que acha bonito e Lorena disse que esse nome foi a segunda opção de seus pais enquanto aguardavam seu nascimento.

Dentre os participantes, três deles estão decididos sobre a escolha profissional, sendo todos do sexo masculino, enquanto que a adolescente afirma não estar totalmente decidida sobre a profissão escolhida.

\subsection{Instrumentos}

Para alcançar os objetivos pretendidos, para a realização da coleta dos dados, foi utilizado um roteiro de entrevista semiestruturado. Atendendo-se aos cuidados éticos necessários para a realização de pesquisa com seres humanos, foram elaborados um Termo de Consentimento Livre e Esclarecido (TCLE) assinado pelos responsáveis dos adolescentes, autorizando a participação dos mesmos, bem como um Termo de Assentimento a ser assinado pelos adolescentes.

\subsection{Procedimentos de coleta e de análise dos dados}

A pesquisa foi aprovada pelo Comitê de Ética em Pesquisa com seres humanos do Centro Universitário Municipal de Franca, parecer oㅜ 3.699.205, atendendo-se às exigências éticas da Resolução no 466/2012 sobre pesquisa com seres humanos.

Inicialmente a pesquisadora assistente entrou em contato telefônico com os adolescentes e seus responsáveis, informando sobre os objetivos da pesquisa e forma de coleta dos dados, verificando a possibilidade de colaboração. Em função da necessidade de isolamento social, os Termos de Consentimento Livre e Esclarecido e de Assentimento foram enviados por email e, após assinados pelos responsáveis e pelos adolescentes, respectivamente, foram digitalizados e enviados para a pesquisadora assistente.

A coleta dos dados ocorreu com o uso de um roteiro de entrevista semiestruturado, que abordava os temas contemplados na pesquisa. Agendouse uma data e horário conveniente para o colaborador e todas as entrevistas foram realizadas pelo aplicativo Skype, gravadas, com o consentimento dos participantes, com preservação do sigilo dos dados obtidos. 
Os relatos dos participantes, coletados através das entrevistas, foram analisados a partir de uma abordagem qualitativa, baseada na proposta de Minayo (2001), realizando-se uma discussão com a literatura referente ao tema abordado nesta pesquisa. Ao compreender as vivências dos participantes e associá-las à literatura da área, objetivou-se realizar uma discussão integrada e enriquecedora acerca do tema em estudo.

Minayo (2001) afirma que para a operacionalização de sua proposta é necessário seguir três passos: o primeiro é a ordenação dos dados, ou seja, o mapeamento de todos os dados obtidos no trabalho de campo, nos quais estão inscritos a transcrição de gravações, a releitura do material, a organização dos relatos e dos dados. O segundo passo é a classificação dos dados e, através de uma leitura exaustiva e repetida dos textos, são estabelecidas interrogações para identificação do que surge de importante. Com base no que é percebido como relevante são elaboradas as categorias específicas. O último passo consiste na análise final, que é o momento em que se procura estabelecer a articulação entre os dados e os referenciais teóricos da pesquisa, baseados em seus objetivos, promovendo a relação entre 0 concreto e o abstrato, o geral e o particular, a teoria e a prática.

Os dados obtidos por meio da análise das entrevistas evidenciaram informações de suma importância no que concerne à escolha profissional e influências parentais. Os aspectos a serem discutidos permitem que sejam realizadas interrelações entre os objetivos do trabalho, os dados obtidos e a literatura científica acerca da escolha profissional.

Com a análise qualitativa das entrevistas foram elaboradas as seguintes categorias temáticas: Vivência da adolescência e construção de identidade; Escolha profissional; Relação pais e filhos e participação dos pais na escolha profissional.

\section{RESULTADOS}

\subsection{Vivência da adolescência e construção da identidade}

Os quatro participantes entrevistados relataram como foi e está sendo vivenciar a fase da adolescência e abordaram sobre o processo de construção da identidade, sobre a necessidade de pensar por si próprio e adquirir mais autonomia de escolha, assim como expressaram preocupações relacionadas a questões sociais.

De acordo com Outoral (1994), o adolescer se constitui como importante fase para a construção da identidade e nessa fase ocorrem muitas modificações, inicialmente, as mudanças corporais, visíveis, com o início da puberdade. Posteriormente, as modificações se estendem para um aspecto social, com o desenvolvimento de maior responsabilidade social e aquisição de 
certa maturidade. Nesse momento costumam ocorrer conflitos entre as gerações (adolescentes $X$ pais) e surge o desejo de independência, a percepção sobre desejos sexuais e orientação sexual. E, por fim, o jovem se depara com a necessidade de escolha de uma profissão e busca pela satisfação financeira no futuro.

Pode ser observado, nas falas dos participantes, como vivenciam a adolescência.

\begin{abstract}
"Sinto que fiquei mais independente a partir do primeiro colegial, assim, a partir que entrei no colegial eu acho que mudou um pouco, aí eu comecei a andar mais a pé que antes eu dependia muito dos meus pais para ir para todos os lugares, acho que foi uma coisa bem natural, ao longo da minha formação mesmo, adquirindo maturidade, acho que isso" (Laurêncio).

“(...) Acho uma fase muito complicada porque a gente começa a ver o mundo com os nossos próprios olhos, né, começa enxergar as coisas como elas são realmente, mas é uma fase para você se conhecer, criar sua identidade." (Charlie).

“(...) Eu acho que a relação social, com os outros assim, e meio introspectiva, de parar pra pensar nas coisas (...) foi o que eu comecei a refletir mais." (Breno).

"Difícil, mas bom ao mesmo tempo (...) uma parte boa desse período é que eu formei minhas próprias opiniões, e eu tô me descobrindo mais quem eu sou o que eu gosto de fazer (...)" (Lorena).
\end{abstract}

Outro aspecto abordado durante as entrevistas diz respeito a observações e modificações importantes na adolescência, em especial, sobre as relações sociais, vínculo com amigos e relações amorosas, como relatado pelos jovens Charlie e Breno. Houve relato sobre a vivência de rejeição em um relacionamento amoroso homoafetivo e a aceitação sobre a orientação sexual, momentos considerados importantes para o amadurecimento.

“(...) Uma coisa muito importante que se destacou muito na minha adolescência é o termo social, amizade, uma coisa assim foi essencial e que formou o que eu sou hoje às amizades é que tem conflitos que você meio que aprende com eles envolve várias coisas, e na escola que trouxe essas amizades, então é muito importante ressaltar mesmo esse ponto, acho que é isso. (...). Charlie aborda que o processo da autoaceitação como homossexual foi muito difícil nessa fase da vida: "O mais difícil para mim foi a aceitação, a minha aceitação, que pra mim entender que eu não gosto de pessoas de outro sexo e que eu sou assim, de me aceitar daquele jeito sabe, isso que foi mais difícil pra mim (...) acho que o que me pegou mais, que eu sofria muito, foi de aceitar a rejeição da pessoa que eu gostava, e misturou com essa questão de aceitação." (Charlie).

Para Breno, o que mais mudou foram as relações sociais, mas diferentemente de Charlie, ele sentiu que houve um distanciamento maior dos amigos e da família durante este período, tendo modificações em suas relações interpessoais. 
Eu acho que a relação social, com os outros assim, e meio introspectiva, de parar pra pensar nas coisas (...) foi o que eu comecei a refletir mais. (Breno).

O participante aborda um momento no qual o distanciamento com os amigos e vivenciar o luto de um familiar próximo fez com que vivenciasse um período de tristeza durante aproximadamente dois meses.

"Quando eu vejo a galera falando de depressão, parecia uma depressão só que a diferença é que foi muito rápido" (Breno)

Rassial (1999) apresenta que o período da adolescência apresenta modificações em diferentes áreas. Um marco popular dessa fase é a experiência da puberdade, o que pode fazer com que esse momento pareça com algo negativo e, de certa forma, catastrófico, quando as mudanças do corpo geram sentimentos de incômodo. Porém, há questões relacionadas a mudanças nas relações sociais e com o mundo externo. Sendo assim, trata-se de um momento no qual o jovem se depara com as modificações em si mesmo e nas relações sociais, porventura, com dificuldades para elaborar muitas mudanças rápidas e num curto período de tempo. Em alguns momentos, o indivíduo pode optar por manter-se mais solitário como forma de se proteger de tantas demandas.

É na adolescência que as temáticas envolvendo cultura e o meio social aparecem de forma mais evidente, devido ao fato de que nesse período o sujeito está mais exposto à cultura de massa e aos conteúdos presentes nas mesmas. Portanto, este é um ponto necessário para que adolescente busque integrar aspectos presentes em seu meio social à construção de si como um ser autêntico (MORIN 2005). Como observado nos relatos dos adolescentes, os mesmos compreendem que essa fase é um momento no qual acontece maior compreensão do meio social, até mesmo dos aspectos envolvendo a política, ideologia e assuntos correlacionados. É através do mundo externo que o indivíduo se organiza internamente, ou seja, o ser humano depende do contexto para a formação de sua subjetividade. Portanto, o adolescente se encontra em constante estimulação e mudança, como relatado pelos adolescentes, buscando aproximar-se de assuntos do âmbito social e cultural, assim como em relação às relações familiares, de amizade e no campo amoroso.

Tendo em vista que a adolescência não é apenas um marco de modificações biológicas, é importante abordar sobre a construção social da adolescência, pois esta não pode ser vista como uma transformação apenas do ponto de vista biológico, mas também uma construção pelo homem moderno, que implica na inclusão de escolhas referentes à vida adulta. (BOCK et al. 1995)

Como foi abordado, a adolescência, para muitos, pode ser momento de grandes confusões e confrontos. Os jovens participantes desta 
pesquisa abordaram sobre esse sofrimento, o único adolescente que afirmou não ter passado por dificuldades nesse momento foi o Laurêncio. Ao ser perguntado sobre sua experiência ele relata como: "Tranquilo". Porém, disse ser uma pessoa mais reservada e de poucas palavras, o que pode ter gerado uma menor verbalização sobre como vivenciou a adolescência.

De acordo com Levisky (2009) os aspectos negativos que podem ser vivenciados na adolescência dizem respeito a vivências de estresse, questões conflitivas, autoestima fragilizada, entre outros. Neste sentido, o trauma representa para $o$ adolescente $o$ sentimento de algo aparentemente difícil de tolerar, o que pode estar relacionado ao contexto, mas também a seus próprios conteúdos inconscientes, conforma afirma o autor.

\begin{abstract}
O trauma e a dor mental estão presentes quando o insuportável afeta a espontaneidade e autonomia do sujeito, condições muito valorizadas no mundo da pós modernidade. As manifestações da dor psíquica e de seus efeitos traumáticos inconscientes são mutáveis e dependem das construções das subjetividades. (FRANCO JÚNIOR apud LEVISKY, 2009, p. 212)
\end{abstract}

Todos estão sujeitos a essas dificuldades, independentemente da cultura e do contexto, devido a pressões para a entrada na vida adulta, o que ocasiona vicissitudes no plano emocional e físico. A relação entre a cultura e as mudanças fisiológicas, como o início da puberdade, se tornam cada vez mais conflitantes, principalmente para aqueles que passaram por fixações no desenvolvimento infantil. Para um bom amadurecimento do adolescente, é essencial que sejam desenvolvidas saudáveis estruturas psíquicas para que 0 adolescente lide com esse período do desenvolvimento. Avesso a isso, quando o adolescente não possui um bom suporte, desde o início da vida, pode vivenciar maiores dificuldades para solucionar situações conflitivas do seu mundo interno e externo (LEVISKY, 2009).

Portanto, a vivência da adolescência está atrelada à construção da identidade e suas interrelações com o contexto social e estabelecimento de relações significativas, bem como a aspectos relacionados ao funcionamento psíquico do adolescente.

\title{
5.2. Escolha Profissional
}

Ao realizar a análise das escolhas profissionais dos jovens participantes da pesquisa, observou-se que as mesmas estão relacionadas a alguns aspectos. Os adolescentes relacionam a escolha profissional a maior facilidade e interesse às áreas de exatas, humanas e biológicas. Além do mais, os adolescentes buscam profissões que possibilitem uma boa qualidade de vida, todavia, foi visto que os adolescentes conhecem, superficialmente, o mundo do trabalho e carreira e pretendem conhecer mais quando já estiverem 
na faculdade. Cada adolescente abordou como foi o processo de realizar a escolha.

De acordo com Bock et al. (1995) o processo de decisão de escolha profissional abrange diversos fatores do contexto no qual 0 adolescente está inserido, tais como: relações com os pares, com a família e crenças nos âmbitos religioso, político e familiar. Ao tratar-se do núcleo familiar, esse contexto é um meio de interferência e influi na escolha e tomada de decisão profissional. Sendo assim, o adolescente, ao se deparar com a necessidade de escolher uma carreira, precisa conscientizar-se sobre seus valores, desejos e aptidões para a realização da escolha e identificar as influências sociais sobre ela, como concepções dos pais sobre a melhor escolha ser seguida e identificações com os pais.

De acordo com Bohoslavsky (1998), a escolha do adolescente parte através de três esferas institucionais: da ordem familiar; ordem da educação e, por fim, da ordem de produção. As escolhas do indivíduo estão relacionadas com sua visão sobre si mesmo, sua relação com o Outro e visão sobre seu próprio futuro. Para a realização da escolha o adolescente utiliza dos mecanismos inconscientes de identificações: "A identificação se estabelece com o grupo como uma totalidade, seu status e papel dentro do mesmo, as pessoas que o constituem, seus sistemas e valores" (BOHOSLAVISKY, 1998, p. 34). Sendo assim, a escolha do adolescente se forma através das identificações proporcionadas pelo mundo externo e aquilo que o indivíduo atribui para si mesmo - de forma subjetiva.

"Eu sempre gostei da área de exatas, sempre fui da área de exatas e sempre tive certeza que era a área que eu queria (...) E aí eu tô pensando agora em tentar engenharia mecatrônica, que é uma alternativa, que tá muito relacionada nessa área de física e matemática, e eu acho que posso ter oportunidade para fazer o que eu gosto que é relacionado com astrofísica, astronomia, física moderna e esses negócios assim." (Laurêncio)

"Eu tinha 15, 16 anos também que eu comecei a me apaixonar por essa área sabe, da psicologia. E até hoje eu tenho muita vontade (...) Eu descobri que eu queria cursar psicologia, foi uma fase que eu tava muito triste, eu tava fazendo terapia, eu tinha vários transtornos e tudo mais, e comecei a pesquisar mais os trabalhos dos psicólogos, dos psiquiatras, e eu achei muito interessante essa área sabe, não pra lidar com seus próprios problemas, mas sim para lidar com os problema de outras pessoas, ajudar outras pessoas." (Charlie)

"Na verdade tenho a bastante tempo, eu penso em fazer engenharia mecatrônica agora, mas antes eu pensava na engenharia física (...) foi bem simples, eu tava ainda no oitavo ano, na verdade no oitavo ano eu já comecei a pensar o que eu queria fazer, aí eu já sabia que eu era de exatas e que eu queria mexer alguma coisa como computador, essas coisas, aí eu pensava em fazer ciências da computação, essas coisas." (Breno) 
Entre os adolescentes participantes, somente Lorena apresentou mais dificuldade em definir o curso e se sente confusa sobre a escolha, essa indefinição gera à adolescente conflitos internos e ansiedades, o que está muito relacionado com imposição do pai sobre o curso a ser feito na universidade.

\begin{abstract}
"Agora eu tenho 3 cursos em mente, relações internacionais, direito e história, então eu penso... depende o curso que eu fosse fazer se eu fizesse relações internacionais eu gostaria de ir para Brasília, estudar na UnB, ou se fosse direito ou história ou na USP ou na PUC (...) minha área eu tenho certeza que é humanas mas minha dúvida mesmo era R.I ou direito, mas agora eu também tô com dúvida história (...) se eu fizesse direito eu podia fazer história junto, dependendo da faculdade, e isso me anima um pouco de querer fazer direito (...) conhecer culturas diferentes e poder ajudar pessoas em situações de vulnerabilidade, e aí eu comecei a relacionar relações internacionais com isso, e procurar mais sobre o curso e foi aí, no primeiro colegial única opção que eu pensava era R.I mesmo...eu tô bem perdida então eu gostaria de uma orientação sincera, sem ninguém falar: " isso é o melhor pra você fazer, sem parcialidade sabe." (Lorena
\end{abstract}

De acordo com Leite (2018) a escolha profissional desperta nos adolescentes seu ideal de futuro, por isso a escolha profissional pode ser vivenciada de uma forma tão conflituosa, como observado em Lorena. Escolher o que cursar na universidade, com o que trabalhar, faz com que o indivíduo trabalhe conjuntamente com suas relações interpessoais e mundo interno. Escolher uma profissão está vinculado ao que é possível realizar enquanto atividade de trabalho, mas também a quem se pretende ser ou não ser, uma vez que a identidade pessoal, identidade ocupacional, profissional e social estão integradas nessa escolha. Dentre os participantes, Lorena apresentou maior demanda para realizar um processo de Orientação Profissional, vale ressaltar que a pesquisadora fez indicação para buscar auxílio, já que a jovem relatou desejo de realizar uma orientação sincera e imparcial.

A orientação profissional visa trabalhar questões conscientes e inconscientes, tais como: autoconhecimento - propõe ajudar o adolescente a identificar seus valores, habilidades e interesses pessoais e aptidões; busca de informações sobre o mundo do trabalho, carreira, mercado de trabalho, bem como informações sobre os cursos relacionados à profissão escolhida. Buscase ainda auxiliar o adolescente a identificar as possíveis influências sociais que podem afetar o processo de escolha (LEITE, 2018).

Em seguida, será abordado possíveis influências das relações parentais na escolha profissional.

\title{
5.3. Participação Dos Pais Na Escolha Profissional
}

Essa categoria apresenta o principal tema da pesquisa, buscando-se verificar o funcionamento das relações entre pais e filhos e sua 
participação na escolha profissional do adolescente e possíveis influências. adolescente Breno identificou que durante este período ele sentiu um distanciamento na relação parental:

"Ah eu acho que foi meio que natural, aquela questão de ser mais eu, sabe, não sei explicar". (Breno).

Mas em contraponto, ao ser questionado sobre suas identificações com seus pais, o adolescente disse:

"O que eu mais me identifico? Eu acho que tudo, eu sou tudo o que eles fizeram, eu não sou muito nada fora da curva".

A ideia de sair da cidade onde reside também parece uma boa ideia e ele sente apoio dos pais para isso. Disse: "Acho que eu tenho que viver uma vida mais sozinho também, sabe, a ideia de bater as asas", analogia feita referindo-se a ter uma vida com responsabilidade sobre si mesmo e maior liberdade.

No caso do participante Charlie, o que impedia uma relação mais próxima entre si e seu pai foi o processo de contar a eles sobre sua orientação sexual, então antes ele considera que isso causava um certo distanciamento:

"Era uma coisa que me impedia... era um obstáculo várias coisas, e muita coisa a gente não pode falar né, sim e era muito difícil conseguir ter minha vida mantendo isso em segredo, era um obstáculo várias coisas, e muitas coisas a gente não pode falar né, sim, e era muito difícil conseguir ter minha vida mantendo isso em segredo, eu fui para terapia para lidar com os problemas que eu tava sentindo de aceitar a rejeição, tipo assim, eles chegaram a questionar se eu tinha certeza que eu era homossexual e eu não sentia atração pelo sexo oposto e eu disse que realmente não tinha mudança, como mudar e eles aceitaram sabe."

Esse adolescente relata que após a fase de sua autoaceitação sobre sua orientação sexual e de ter contado aos pais, sua relação com eles passou ser mais próxima.

"Passou a ser muito mais maduro, a gente começa a conversar por coisas mais sérias, principalmente depois dessa fase da aceitação do que eu sou, a gente virou amigos sabe, melhores amigos, eu conto tudo pra eles, e sei lá, tinha uma barreira entre a gente antes disso sabe, entre criança e adolescente, e essa barreira foi quebrada, e agora somos super próximos"

O adolescente Laurêncio não relatou tantas informações sobre a relação com os pais, mas fala que aos 17 anos a relação é de proximidade e de amizade:

"A gente vive uma relação muito boa, quando eu fico bravo por sei lá... alguma coisa é coisa boba, e lógico eu já penso: 'Não tem porque eu ficar assim é uma coisa muito banal' e logo já volto ao normal (...) nunca senti falta (...) mas sempre tiveram aqui, me apoiando (...) Eu vejo minha relação com meus pai como amizade mesmo." (Laurêncio) 
Lorena apresentou uma questão mais conflitiva relacionada ao pai, pois a adolescente afirma o quanto encontrar seu pai remete à insegurança e ansiedade devido a escolha de carreira, seu pai possui dificuldades em aceitar que a adolescente possui outro interesse de curso.

\begin{abstract}
"Meu pai detesta a opção de relações internacionais, ele acha que eu tenho que fazer direito e que essa é a minha única opção, ou engenharia ou medicina, muito ruim, porque é meu pai então eu dou muito valor ao que ele pensa e querendo ou não eu escuto muito ele, porque eu admiro muito ele, então vale muito a opinião dele pra mim, tanto é que antes a minha única opção de curso possível era R.I, aí quando eu falei pra ele, ele: 'Não, como assim você vai fazer relações internacionais, isso não vai te dar base nenhuma, você vai ficar desempregada' contando que é o pior curso que eu poderia fazer e, assim, eu fiquei um pouco mal com isso, e durante o ano passado que eu tava no segundo, ele ficou falando o ano inteiro que eu deveria fazer direito, que era um curso que me daria boas bases, um leque muito amplo de opções na carreira que eu fosse seguir, então assim, eu fiquei realmente com dúvida, sabe, antes eu nem pensava em direito, ano passado eu pensava."
\end{abstract}

Neste sentido, a adolescente tentou buscar formas de alinhar seu pensamento com a ideia proposta pelo pai, como forma de agrada-lo e evitar decepções da parte dele.

"Tá se meu pai vai me obrigar a fazer direito, eu posso fazer direito primeiro e depois ir pra área de relações internacionais, direito internacional ou até mesmo R.I ou a faculdade".

Outro ponto a ser apresentado referente à adolescente Lorena é que a tentativa de agradar o pai não está apenas relacionada à escolha profissional, mas também em outros aspectos, como observado na seguinte fala:

"Eu ficava escutando ali pra agradar ele, no que ele é, tentando agradar meu pai".

Em contrapartida, ao perguntá-la sobre se consegue conversar com a mãe sobre o assunto da profissão, Lorena disse:

"É, consigo, e ela acha que eu deveria fazer o que eu quero mesmo."

Embora a adolescente afirme que a mãe não emite uma opinião, não sente amparo da mesma e acaba ficando confusa sobre as divergências dos pais nesse sentido.

"Eu até conversei com ela essa semana porque eu tive uma crise de ansiedade muito forte sobre essas questões, eu tava muito angustiada, muito angustiada, toda vez que eu pensava em o que eu ia fazer e 'tals', e eu falei pra ela, mas ela falou que... não sei o que ela fala... que eu tenho que fazer o que eu quero mesmo, não tem uma orientação muito profunda. Até porque ela falou que só fez medicina porque na época era o único curso possível sabe." (Lorena)

A adolescente relata que a mãe só fez Medicina, pois o avô também era médico e que essa era a única possibilidade possível a ser feita, 
então a adolescente observa que isso faz com que a mãe não verbalize opiniões sobre o que seria melhor a ser feito. Parece que a permissividade da mãe dificulta o processo de escolha e se sente muito sozinha, pois também não consegue conversar com a mãe sobre outros assuntos.

Leite (2018) aborda que se o indivíduo possui pouco autoconhecimento, mais dúvidas sobre a escolha profissional são sujeitas a acontecer e, por conseguinte, maiores influências externas, entre elas, a submissão perante as ideias dos pais, que, muitas vezes, podem ser mais verbalizadas ou expressas de modo subliminar.

Dentro dessa influência parental, os filhos são dependentes de como esse contexto familiar está estruturado, o que está relacionado às condições de apoio que os pais concedem, seja no âmbito social (financeiro) e de afeto. A influência se dá na presença ou não do suporte que os pais dão aos adolescentes, ao incentivo e à possibilidade maior ou menor de aquisição de autonomia. Apesar do contexto familiar ser um fator forte de atuação na escolha, é necessário observar quais outros aspectos também contribuem nesse direcionamento de decisão de carreira, como a escola e amigos (CARVALHO; TAVEIRA, 2009).

Para Bohoslavsky (1998), a ordem institucional familiar pode ser de pais como referência positiva ou negativa na vida do adolescente e ambos influenciam para o processo de decisão do adolescente, pois a relação primária possui papel expressivo na vida do jovem. Essas influências partem de conteúdos egóicos dos pais, vontades pessoais e experiências de vida.

No caso de Lorena, isso ocorre em uma constante verbalização do pai ao desagrado pela opção do curso de Relações Internacionais, de forma autoritária. Essa constante repetição de indignação do pai faz com que a adolescente se sinta confusa sobre a profissão a seguir.

De acordo com Almeida e Pinho (2008) o adolescente pode conseguir identificar a influência sobre a escolha através da própria linguagem que compreende de seus pais, pois há diversas formas de influência, seja de forma velada ou mais expressiva. Como o adolescente ainda está em processo de formação de identidade, é necessário que os pais cumpram uma função de suporte e acolhimento.

Os adolescentes precisam de seus pais, é necessária a função parental. De acordo com Alberti (2004), essa relação é necessária até como forma de fazer uma separação, mesmo que isso aparente ser antagônico. Se um adolescente não tem esse vínculo ou seus pais por perto, ele não consegue nem ter essa opção. Para a autora, a adolescência envolve a elaboração de escolhas. Essas escolhas são integradas a partir de toda a vivência do adolescente, de suas relações interpessoais e do contexto inserido. (ALBERTI, 2004) 
Apesar dos outros adolescentes relatarem que não vivenciavam influência familiar, Breno, durante a entrevista, afirmou que não sofria influência dos pais, mas depois ao ser perguntado sobre seu pai ter o influenciado a dar continuidade à administração da fazenda da família, ele afirmou que foi influenciado:

"Sim, bastante. Porque meu pai fez agronomia e ele sempre quis que nós quatro fizesse agronomia porque é um curso que ele gosta bastante"

Todavia, a influência para realizar agronomia existiu desde a infância, até pelo próprio contato com a fazenda e o desejo dos pais para 0 adolescente seguir a mesma profissão. Por estar mais decidido sobre o que fazer, o adolescente afirma:

"Quando eu entrei na pré-adolescência com uns 11/12 anos, as minhas irmãs estavam saindo de casa e indo fazer economia, que já não é. Então essa discussão foi mais um problema delas, mas eu não tive que passar por si, e quando eu tinha que passar eu já tinha meio que escolhido e já era tarde demais pra qualquer coisa sabe, porque já tinha escolhido".

Foi observado que apesar dos pais manterem o incentivo sobre Engenharia Agronômica, quando o adolescente decidiu sobre Engenharia Mecatrônica ou Física não houve uma imposição sobre o curso de Agronomia. Porém, o adolescente afirma que, futuramente, ele acabará indo trabalhar na fazenda, mas ele não observa isso como uma imposição dos pais.

O adolescente Laurêncio aponta que possui muito apoio dos pais e sente a relação como uma amizade, tem o suporte dos pais, assim como a autonomia que sentiu durante a fase de escolha possibilitou que a mesma tenha sido realizada mais facilmente.

No caso dos estudantes Laurêncio e Charlie, abordaram que os pais não conhecem sobre as áreas que desejam seguir, mas que em alguns momentos conversaram indicando aos adolescentes a seguirem uma área diferente:

“(...)Ele fala: 'Filho eu não sei o que te falar porque eu não conheço essa área' e ele fala que se fosse para ele escolher o que eu fosse fazer, ele fala para eu fazer medicina, porque é o que ele acha que vai me dar seguro assim, segurança na vida, mas eu não gosto dessa área, e ele respeita isso de boa." (Laurêncio).

"Mesmo depois que eu tomei minha decisão e tal, minha mãe conversou comigo, a minha tia que veio falar pra minha mãe que eu deveria cursar até esqueci o nome do curso, mas que trabalha com raio x (...) aí minha mãe veio falar comigo, veio conversar falar sobre os pontos positivos mas eu falei que não me interessava e que eu queria psicologia, e mais tarde minha mãe veio perguntar se eu tinha certeza que era isso que eu queria (...) ela não sabia se eu daria certo nesse ramo sendo psicólogo (...) não me influenciou porque eu já tava maduro e decidido o suficiente pra ela me influenciar." (Charlie) 
"Não foi algo que eles me moldaram, que me influenciaram, acho que foi totalmente livre essa decisão, e saiu de dentro de mim mesmo, da minha vontade" (Charlie)

É visto que os adolescentes Breno, Charlie e Laurêncio definem que não sofreram grandes influências na escolha profissional por se sentirem decididos e maduros sobre a escolha. No caso da participante Lorena, a adolescente sentiu uma imposição vinda do pai sobre o curso de direito, esse fator, trouxe ainda maiores dúvidas sobre qual faculdade seria melhor para realizar.

Embora os fatores sociais, econômicos, interpessoais, identificação de aptidões e desejos são elementos importantes na realização de uma escolha profissional, a literatura aponta que a relação familiar, sendo a relação primária do indivíduo, tem uma parcela de influência significativa durante esse processo, de forma indireta ou não, positiva ou negativa. Em alguns casos o adolescente sente a influência de forma negativa, como algo impositivo.

Levenfus (2016) aborda que o vínculo familiar e a relação entre os pais e os filhos contribuem em como o adolescente se sente preparado para realizar uma escolha em sua vida, isso pode ser ocorrer em um aspecto bom ou ruim, isso dependerá do funcionamento da dinâmica familiar e a forma que está estruturada, se o adolescente possui um suporte familiar, isso pode favorecer em uma escolha mais elaborada.

\section{CONSIDERAÇÕES FINAIS}

Este trabalho partiu de questionamentos a respeito do grau de influência que a família tem sobre a escolha profissional do indivíduo, como esta é percebida, aspectos positivos e negativos. Foi realizada uma revisão da literatura acerca do tema em estudo e realização de uma pesquisa qualitativa, com quatro adolescentes de 17 anos de idade, cursando o terceiro ano do ensino médio da cidade de Franca- SP.

Ampliou-se o entendimento sobre a vivência da adolescência, o período de decisão profissional, como os pais participam da vida dos filhos nesse momento e influências sobre a escolha profissional.

Pode-se observar que a escolha de uma profissão não é uma tarefa fácil e que $o$ adolescente apresenta a necessidade de respaldo familiar e, algumas vezes, profissional, para engendrar uma escolha, permeada por incertezas, medos e ambivalências.

É evidente que estudar a adolescência e a relação parental é importante para a compreensão do processo de tomada de decisão, o que poderá contribuir para a prática em Orientação Profissional. Faz-se necessária a continuidade das pesquisas que tratem do mesmo tema, o que poderá 
auxiliar na realização de escolhas autônomas e conscientes por parte dos adolescentes.

\section{REFERÊNCIAS}

ALBERTI. Sônia. O Adolescente e o Outro. Rio de Janeiro. Jorge Zahar editor. 2004.

ALMEIDA, M. E. G. G.. PINHO, L. V Adolescência, família e escolhas: implicações na orientação profissional. Psicologia e clínica., Rio de Janeiro, v. 20, n. 2, p. 173184, 2008. Disponível em: http://pepsic.bvsalud.org/scielo.php?script=sci_arttext\&pid=\$010356652008000 200013\&lng=pt\&nrm=iso. Acesso em: 12 nov. 2019.

ANJOS, R. E. D. O desenvolvimento da personalidade na adolescência e a educação escolar: aportes teóricos da psicologia histórico-cultural e da pedagogia histórico-crítica. Araraquara/SP. 2017.

BARRETO, Maria José; RABELO, Aline Andrade. A família e o papel desafiador dos pais de adolescentes na contemporaneidade. Pensando famílias. 2015, vol.19, n.2, pp. 34-42. Disponível em:

BRASIL. Lei № 8.069 de 13 de julho de 1990. Casa civil. Brasília-DF. Disponível em: <http://www.planalto.gov.br/ccivil_03/leis//8069.htm>. Acesso em: 09 mai. 2019.

BRASIL. Proteger e Cuidar da Saúde de Adolescentes na Atenção Básica. Brasília-DF, 2018.2 Disponível em: http://bvsms.saude.gov.br/bvs/publicacoes/proteger_cuidar_adolescentes_aten cao_basica_2ed.pdf>. Acesso em: 20 de out. 2019.

BOCK, C. M, et al. A escolha profissional em questão. São Paulo: Casa do Psicólogo, 1995.

BOHOSLAVKSY, Rodolfo. Orientação vocacional: A estratégia Clínica. São Paulo: Martins Fontes, 1998.

CAMPOS, Dinah. Psicologia da adolescência. 24 ed. Petrópolis: Editora Vozes, 2012. $181 \mathrm{p}$.

CARVALHO, Marisa; TAVEIRA, M. D. C. Influência de pais nas escolhas de carreira dos filhos: visão de diferentes atores. Revista Brasileira de Orientação Profissional, São Paulo, v. 10, n. 2, p. 33-41, 2009. Disponível em: http://pepsic.bvsalud.org/scielo.php?script=sci_arttext\&pid=S167933902009000200005. Acesso em: 11 jul. 2019.

CONSELHO NACIONAL DA SAÚDE. Resolução ํำ 466, de 12 de dezembro de 2012. 
<http://conselho.saude.gov.br/resolucoes/2012/reso466.pdf>. Acesso em: 18 mai. 2019.

ERIKSON, E. H. Identidade, Juventude e Crise. Rio de Janeiro: Zahar editores, 1976.

FREUD. S. Três ensaios sobre a sexualidade. Rio de Janeiro: Imago, 1905.

HANKE, Bruno Curcino, OLIVEIRA, H. M. D; Adolescer na contemporaneidade: Uma crise dentro da crise. Ágora, Rio de Janeiro, v. 20, n. 2, p. 295-310, ago./2017. Disponível em: $<$ https://www.redalyc.org/jatsRepo/3765/376554416001/376554416001.pdf>. Acesso em: 15 de maio de 2020.

LEITE, Maria. Série o que fazer? Orientação profissional. São Paulo: Blucher, 2018.

LEVENFUS, Roseane Schotgues. Orientação vocacional e de carreira em contextos clínicos e educativos. Porto Alegre: Artmed, 2016.

LEVENFUS, Roseane. Orientação vocacional ocupacional: à luz da psicanálise. In: Artes Médicas, 1997. Psicodinâmica da escolha profissional. Porto Alegre:

LEVISKY, David. Adolescência: Reflexões Psicanalíticas. 3 ed. Itatiba: Casapsi, 2009.

LOURENÇO B, Queiroz LB. Crescimento e desenvolvimento puberal na adolescência. Revista de Medicina, ed. Vol. 89, São Paulo abr.-jun 2010; Disponível em: <https://www.revistas.usp.br/revistadc/article/view/46276>. Acesso em: 20 de Maio de 2020.

MINAYO. M. C. Z. Pesquisa social: Teoria método e criatividade. Petrópolis RJ: Editora vozes; 2001.

MORIN E. Cultura de Massas no Século XX. v. 1: Neurose. Rio de Janeiro: Forense Universitária;2005.

MULLER, M. Orientação Vocacional: Contribuições clínicas e educacionais. Porto Alegre: Artes Médicas, 1998.

OUTORAL, José. Adolescer: Estudos sobre adolescência. Porto Alegre: Artes médicas, 1994.

RASSIAL. J-J. O Adolescente e o Psicanalista. Rio de Janeiro: Companhia de Freud;1999. 
REICHERT, Claudete Bonatto. Autonomia na adolescência e sua relação com os estilos parentais. PUCRS Biblioteca Digital de Teses e Dissertações, Porto Alegre, v. 11, n. 2, p. 3-6, dez./2012. Disponível em: <http://tede2.pucrs.br/tede2/handle/tede/667>. Acesso em: 20 nov. 2019.

SANTOS, L. M. M. D. O papel da família e dos pares na escolha profissional. Psicologia em estudo, Maringá, v. 10, n. 1, p. 57-77, abr./2005. Disponível em: $<$ https://docplayer.com.br/1113163-O-papel-da-familia-e-dos-pares-na-escolhaprofissional-1-the-parents-and-peers-role-in-vocational-choice.html>. Acesso em: 29 nov. 2019.

SILVA, L. B. de C. A escolha da profissão: uma abordagem psicossocial. São Paulo: Unimarco Editora, 1996.

SOARES, Dulce Helena. A escolha profissional: Do Jovem ao Adulto. São Paulo: Summus, 2002. 
PESQUISA ETNOGRÁFICA COM ALUNOS DOS ANOS FINAIS DO ENSINO FUNDAMENTAL: perspectivas acerca das violências no contexto escolar

Livia Aquino Alves

Daniela de Figueiredo Ribeiro

\section{INTRODUÇÃO}

A violência escolar tem sido um problema apontado por diversos autores (ABRAMOVAY, 2015; ABRAMOWICZ, LEVCOVITZ, 2005; AVANCI, PESCE, FERREIRA, 2010; BISPO, LIMA, 2014; CRUZ, MACIEL, 2018; DAHLBERG, KRUG, 2007; FERREIRA, PEREIRA, 2014; KAPPEL, GONTIJO, MEDEIROS, MONTEIRO, 2014; LIBARDI, CASTRO, 2014; NJAINE, MINAYO, 2003; SILVA, RISTUM, 2010; SPOSITO, 1998; ROCHA, 2000). A partir da queixa do fenômeno em um contexto público de educação nos anos finais do Ensino Fundamental, foi proposta esta pesquisa com a finalidade de compreender e mapear as violências presentes, verificando como os alunos a percebem, tendo em vista a compreensão acerca das diferentes situações de violência, levantar aspectos das relações aluno-aluno e professor-aluno e favorecer reflexões que se referem aos modos de convivência nesse contexto.

A violência, segundo a OMS (Organização Mundial da Saúde), se configura na prática

[...] intencional da força física ou do poder, de modo real ou em ameaça, auto-inflingida, interpessoal ou coletiva, que resulte ou tenha alta probabilidade de resultar lesão, óbito, dano psicológico, deficiência de desenvolvimento ou privação e o ato violento pode ser de natureza física, sexual, psicológica ou negligência (OMS, 2002, p. 5).

Além disso, a violência é resultante da relação entre os níveis individuais, relacionais, comunitários e sociais. Por isso, o enfrentamento do fenômeno no contexto escolar "além de considerar dados sobre sua magnitude, também perpassa pela compreensão do contexto social que a produziu" (KAPPEL; GONTIJO; MEDEIROS; MONTEIRO, 2014, p. 2).

$O$ fato de que a violência tem definido diferentes situações no contexto escolar "contribui para o agigantamento do conceito e alimenta a sensação de que a violência alcança lentamente todas as esferas, camadas, instituições e relações interpessoais" (LIBARDI; CASTRO, 2014, p. 2). Deste modo, a escola "possui seus próprios mecanismos de exclusão e seleção social" (ABRAMOVAY, 2015, p. 8), auxiliando a perpetuação da violência e colaborando com sua propagação. Abramoway (2015) aponta que os excluídos são aqueles que não entram nos padrões, não respondendo às expectativas relacionadas ao aprendizado, ao comportamento e, ainda, nas relações com os integrantes da escola. 
O protagonismo e a autoria na violência, de acordo com Cruz e Maciel (2018), revelam a falta destes no exercício do cotidiano escolar. Assim, é possível discernir que "a violência não é uma ruptura com o meio e sim uma reprodução continuada do modelo social de interação predominante na escola e na vida social" (CRUZ; MACIEL, 2018, p. 9). Ainda por meio desta afirmação, considerando Abramowicz e Levcovitz (2005), as produções educacionais que retratam o cotidiano da escola são diversas, em que crianças que não atuam ou estejam em um padrão estabelecido socialmente estão excluídas, evidenciando um modo de funcionamento de uma instituição que, influenciada pelo funcionamento de uma sociedade, atua mantendo "a necessidade de sentar, calar e copiar para aprender, a valorização de determinado jeito de ser, de brincar, de falar e de pensar" (ABRAMOWICZ; LEVCOVITZ, 2005, p. 74), considerando que todas as formas de violência, exclusões, discriminações, relações de poder, contradições, conflitos de interesse presentes nas escolas são reflexo de um reprodução existente na sociedade, conforme afirmam Bispo e Lima (2014).

A relação dos alunos com seus superiores está menos preocupada com uma relação de diálogo e se constitui da atenção à disciplina, segundo Ferreira e Pereira (2017). Assim sendo, um espaço para existência da participação destes no contexto escolar não é favorecido. Assim, é possível compreender que a participação dos estudantes em situações de violência está atrelada a questões que estes não definem o funcionamento da escola e não afetam as decisões tomadas por aqueles que detém o poder.

Compreender a violência só é possível, segundo Silva e Ristum (2010), vivenciando-a no contexto em que ela acontece. Além disso, de acordo com Abramoway todos os membros escolares, independente dos papéis que atuam, podem ser potenciais vítimas e agressores.

Tendo em vista os estudantes, a fase da adolescência, assim como a infância, é de contínuo e intenso processo de desenvolvimento e maturação, segundo Avanci, Pesce e Ferreira (2010). Assim, as experiências vividas nessa etapa deixam marcas importantes no indivíduo, mesmo que possam ser reconstruídas ou reparadas. No entanto, no contexto escolar, estes "não reconhecem alternativas atribuídas à importância da escola em suas vidas" (SPOSITO, 1998, p. 72), levando em consideração que são, na maioria das vezes, atores da violência escolar.

Bispo e Lima (2014) afirmam o fato da escola ser alvo das ferramentas institucionais de controle daqueles jovens considerados perigosos. No entanto, embora haja um empreendimento de controle operado pela escola, alguns dos alunos implementam recursos de resistências a estes mecanismos institucionais vigentes no contexto sistemático, "encontrando saídas alternativas, cumplicidades subversivas ou paralelas à hierarquia burocrática. Tentam escapar à vigilância, desafiam os mecanismos de punição e burlam as 
normas estabelecidas" (BISPO; LIMA, 2014, p. 5). E, ainda segundo os autores, a escola exclui e segrega sistematicamente todos os que expressam comportamento discordante, implicando ao aluno punições e vigilância contínua.

Levando em consideração Njaine e Minayo (2003), foi constatado que o contexto de violência está além da responsabilidade de um só. Assim, segundo Bispo e Lima (2018), vê-se uma necessária ampliação de recursos democráticos no contexto escolar, onde todos os atores escolares tenham a possibilidade de serem respeitados e ouvidos em sua condição humana.

Desta forma, de acordo Bispo e Lima (2014), considerando que não seja apenas uma instituição disciplinar, a instituição escolar precisa definir o favorecimento do acordo entre os diversos contextos sociais, culturais e subjetivos, além de um espaço de transformação social e criação, se comprometendo com a formação de sujeitos reflexivos e críticos. "Para tanto, ao invés de estratégias pautadas em modelos universais, deve-se elaborar projetos de intervenção que incluam as especificidades" (BISPO; LIMA, 2014, p. 7). Então, ainda segundo os autores, se torna relevante admitir que, buscando formas diversas de laços sociais, os jovens são marcados pela multiplicidade, horizontalidade, descentralização e fragilidade. Por este lado, a instituição não deve estar alheia às modificações sociais e não pode continuar pautada no reforço do controle e na centralização do poder das práticas educacionais, pois são estes aspectos que acarretam o aumento do fenômeno.

Portanto, compreendendo que a "criação surge da transgressão, do conflito, presente em todo grupo social" (BISPO; LIMA, 2014, p. 8), é nos remetida à ideia de que é papel da escola dar abertura a espaços que caibam a palavra e a promoção de estruturação de um sentido singular aos estudantes, mesmo que dentro de um âmbito coletivo, segundo Bispo e Lima (2014).

Por fim, considerando Dahlberg e Krug (2007, p. 1164), ainda que "a violência tenha estado sempre presente, a humanidade não deve aceita-la como um aspecto inevitável da condição humana" pois, ainda segundo as autoras, junto à violência existem outros fatores como sistemas filosóficos, comunitários, legais ou até religiosos que se desenvolveram com a finalidade de limitá-la ou preveni-la.

\section{METODOLOGIA}

Este estudo caracteriza-se como qualitativo de cunho etnográfico, a compreensão acerca dos comportamentos, crenças, práticas, hábitos e valores que existem em um ambiente sociológico (ANDRÉ, 1995).

A pesquisa contou com participantes estudantes do Ensino fundamental de uma escola pública dos $6^{\circ}, 7^{\circ}$ e $8^{\circ}$ anos do período da tarde. Foram realizadas seis observações participantes, sendo duas delas em cada 
sala, com duração de em média cinco horas cada, pautadas em um roteiro previamente estabelecido com a finalidade de que informações sobre a data e duração, série dos alunos, contexto onde aconteceram as situações de violência, práticas observadas e os estudantes envolvidos nas ocorrências fossem registradas. Posteriormente, seis alunos foram convidados para participar de uma entrevista individual semiestruturada e uma entrevista grupal, considerando o envolvimento destes em situações de violência, tanto como agressor quanto como vítima. Foram realizadas seis entrevistas individuais semiestruturadas, também contando com um roteiro onde os dados coletados se referiram ao sentimento dos alunos antes de irem à escola, enquanto estão na escola e como se sentem quando vão embora da escola, o que os chateia na escola e como gostariam de ser tratados na hora da chateação, o que os deixam felizes na escola e como gostariam de ser tratados quando estão felizes, o que os deixam com raiva na escola e como gostariam de ser tratados quando estão com raiva, se alguém os agride o que fazer e se veem alguém sendo agredidos o que fazem, tendo em vista que com cada participante foi realizada uma entrevista, e uma entrevista em grupo focal com três dos participantes, considerando que os seis foram convidados, onde cada um escolhendo duas das figuras apresentadas, representando situações de violências que ocorrem na escola, discorreram suas perspectivas no que se referem às situações de violência escolar, qual o sentimento trazido por estas aos participantes, exemplos de como elas ocorrem, qual o papel de atuação destes estudantes nas ocorrências dessas situações, como lidam com elas e possíveis modificações na efetivação das mesmas.

Os dados coletados foram analisados segundo os moldes sugeridos por Minayo para Análise de Conteúdo (2007) e a pesquisa foi aprovada pelo Comitê de Ética em pesquisa com seres humanos (CAAE no 08975119.6.0000.5384).

\section{RESULTADOS}

\subsection{Obsevações Participates}

A partir das observações participantes realizadas, foram identificadas ocorrências de violências em diversos níveis, considerando as agressões relacionais (aluno-aluno/professor-aluno/equipe técnico administrativa-aluno) e pela maneira como estas ocorrem, verbal ou fisicamente.

Quanto a relação aluno-aluno, foi percebido pela pesquisadora que um aluno não tinha interação nenhuma com a sala e algumas alunas ficam muito sozinhas o tempo todo, sem se relacionarem com outros grupos e/ou pessoas. Um aluno ficava o tempo todo querendo se enturmar, sendo ignorado, xingado e excluído. 
Sendo a segunda violência observada que mais obteve destaque, a violência verbal na relação aluno-aluno foi exposta a partir das ocorrências de violência em que os estudantes, verbalmente se dirigiram uns aos outros com palavras que puderam causar desconforto.

A violência que ocorre a nível físico na relação aluno-aluno também foi observada. Este tipo de violência pode resultar em danos físicos à vítima e uma das falas que se enquadraram nesta categoria foi: "Eu dei um tapa na cara dele".

A agressão verbal na relação professor-aluno apareceu algumas vezes, assim como a agressão verbal vinda por meio de um membro da equipe técnico-administrativa, considerando a fala de uma professora direcionada a um aluno: "Eu não "tô" te dando opção" e a fala de alerta do coordenador: "Estou passando para avisar que estou chegando. Fiquem espertos".

Outra violência a ser considerada é a auto-inflingida que, durante as observações realizadas, apareceu uma vez e, apesar de não ter sido concretizada, o comentário não obteve nenhuma reação: "Acordei com vontade de morrer", um aluno disse.

Tendo em vista a negligência como um ato de violência que, não necessariamente, causa sofrimento ou morte, as situações a seguir, percebidas nas observações participantes, discorrem situações que poderão gerar consequências futuras às vítimas no que diz respeito à possíveis prejuízos a eles e ao contexto em que vivem: uma professora perguntou: "O que é Radiciação?" e um aluno respondeu: "a gente vai ligar o rádio", os demais alunos zombaram e a professora não fez nada; em outra situação, uma professora informou que a redação solicitada anteriormente não seria usada: "Aquelas lá, vocês esquecem", neste caso os alunos já haviam produzido a atividade e esta não seria usada, nem considerada para nota; num outro momento um aluno disse: "eu não consigo fazer resumo de 15 a 20 linhas", a professora respondeu: "1" Não é resumo..." e não concluiu a fala, ignorando os dizeres do estudante e mudando de assunto; com a dúvida de um aluno sobre como se escreve uma palavra, a professora respondeu com desdém: "Escreve do jeito que você quiser".

\subsection{Entrevistas Individuais Semiestruturadas}

Nas entrevistas individuais, como sentimentos presentes antes de ir na escola, os estudantes responderam: "normal", "eu me sinto bem", "empolgada", considerando que algumas respostas foram repetidas. Tendo em vista os participantes enquanto estão na escola, os sentimentos levantados por duas estudantes foram: "[...] só tem as vezes assim que é "mei" chato" [...] "Por que tem uma professora que eu não vou meio com a cara da professora. Eu não gosto dela, é por isso que "nóis" levou suspensão, por causa dela, aí eu 
não vou muito com a cara dela" e "Às vezes nervosa, porque os meninos me "estressa" e as vezes triste, por que os meninos faz muito bullying". Os demais participantes responderam que se sentiam bem na escola. Relacionado a quando vão embora da escola, os estudantes expressaram em suas respostas se sentir livre ao ir embora da escola, poder brincar quando se vai embora da escola e ter sensação de alívio, constatada pela fala: "Ah, por que eu acabei de sair da escola e por que eu "tô" longe dos menino que fica fazendo graça". Levando em conta o que os chateia o bullying foi resposta de dois estudantes, além de: "quando os alunos fica fazendo graça", "eles [professores] corrigir uns e não corrigir os outros", "quando os professores levanta a voz pra gritar comigo" e "[...] quando tem alguma professora [...] que pega no meu pé". Nos momentos de chateação, os participantes relataram que gostariam de ser tratados: "igualmente os outros. Igual", "bem, né?! Bem", "bem" [...] "Fazesse" eu feliz", "[...] com tipo educação" "deixa eu no canto, quieto" e "eu gosto de ficar longe de todo mundo, quando eu "tô" chateada". No que se refere ao que os deixam felizes, as respostas foram: "estudar", "quando brinca, quando vai estudar com o professor, na aula de educação física...", "a felicidade dos outros. Ver os outros bem", "meus "colega", "as minhas "amiga" e meus "amigo"' e "A comida e os "professor" também". Nestes casos, gostariam de ser tratados: "bem", “...normal", "como amigo", “...também com educação" e "eu tento deixar os outros feliz também". Neste quesito houve uma participante que não soube responder como gostaria de ser tratada na hora da felicidade. Não houveram falta de respostas em nenhuma outra categoria ou subcategoria. Considerando, agora, o que os deixam com raiva, as respostas foram: "o bullying", "os "amigo" falso", "quando a menina inventa rolo e não aguenta e joga a culpa no outro", "a mesma professora que fica..." [...] "que fica pegando no meu pé..." e "os "menino"' [...] "e os professor". Além delas, um participante respondeu: "Nada. Mais, nada" [...] "Nada" e na continuação da entrevista, ainda nesta categoria, se esquivou. Sobre como gostariam de ser tratados, disseram: "com ajuda" [...] "Dos professores, orientador", "bem, educado", "isolado", "ai, que queria que eles falasse a verdade e levava a culpa", "é, também com educação..." e "longe de todo mundo pra não falar coisa que não deve".

Ainda por meio das entrevistas individuais, foram levantados aspectos sobre quando alguém o agride o que se faz, sendo eles: falar para a diretora/ ir à diretoria, agredir ou deixar quieto dependendo de quem comete a agressão, chorar e bater, ficar brava, se afastar, bater ou falar para os professores. Levando em conta o que se faz quando vê outra pessoa sendo agredida, as respostas foram: faço nada, falo pra parar, chama o inspetor, ajuda, separa, entra no meio, chama os coordenadores mas não intromete e dependendo da situação fala para a diretoria ou separa. Na categoria sobre o bullying, considerando que dois participantes o sofreram, um deles não teve nenhum exemplo para relatar e contou que quem pratica bullying com ele é de 
sua sala, relatou que se chateia e que ficou com raiva com o fenômeno e que este aconteceu no recreio, principalmente, e na troca de professores, quando a sala ficou sem nenhuma pessoa de autoridade. A outra participante disse que, em relação ao bullying, se sentiu triste e é algo que acontece com frequência. Sobre o que pode ser feito, um entrevistado disse que solicitaria ajuda aos orientadores e professores ao ser questionado sobre como gostaria ser tratado. Para isso, ele disse que esperaria que os professores e orientadores, considerando a relação professor-aluno e equipe técnico-administrativa-aluno, olhassem para as pessoas, para o que está acontecendo, para as coisas e, ainda, sugeriu a suspensão para quem pratica o bullying. Tendo em vista, por fim, a busca de ajuda de superiores um estudante contou que foi na diretoria para falar o que aconteceu e que, quando fez isso, levou suspensão, relatou que o outro aluno que estava envolvido na mesma situação não levou suspensão como ele e que, por isso, sentiu ódio e teve vontade de bater no colega. Outro participante relatou que uma vez buscou a ajuda da diretora e que foi normal, disse que recebeu instruções para não repetir o comportamento. Por fim, uma outra estudante contou que quando falou com a diretora ou com os professores as situações se resolveram com diálogo.

\subsection{Entrevista Em Grupo Focal}

$\mathrm{Na}$ entrevista em grupo focal os estudantes, ao serem questionados sobre como aconteceram as situações de violência representadas pela figura escolhida, começaram a rir. Com a intervenção da pesquisadora e o questionamento de como eles atuam nesses momentos, os participantes responderam: "eu olho", "também olho" concordou outra, "mentira. Todo mundo zoa..." discordou o outro. A primeira participante, então, complementou: "uns fica rindo" e o outro concluiu: "uma hora eu zoo, outra hora eu rio... uma hora eu fico quieto", explicando que em cada situação agia de uma maneira. Ao final, foi solicitado aos participantes que eles encontrassem uma solução para estas situações. Desta forma, uma estudante respondeu: "Conversar não adianta", e seu colega disse: "Cada um tem que fazer sua parte". Assim, a primeira estudante retornou: "A pessoa que tem que sentir na pele o que é ser zoado e não gostar, pra parar". Outro participante, assim, afirmou: "Se a pessoa tivesse no lugar da outra, ela não ia gostar. Então não faça com o outro o que você não gostaria que fizesse a você". Os três participantes foram incitados, a partir disto, a encontrarem uma só solução em conjunto para as situações discutidas. Um participante começou: "Cada um faz sua parte e para de zoar um ao outro" [...] "Vamos supor, cada um fica no seu canto e para de zoar um ao outro". Então, as outras estudantes concordam com a solução final. 


\section{DISCUSSÃO}

A discussão do trabalho foi realizada em três eixos teóricos, sendo eles: a naturalização da violência, a violência institucional e suas decorrências e soluções cotidianas para situações de violência, considerando os resultados obtidos a partir da realização das observações participantes, das entrevistas individuais e, ainda, por meio da entrevista em grupo focal.

A naturalização da violência foi percebida nas observações participantes e nas entrevistas: individual e em grupo focal, de acordo com as situações trazidas pelos participantes, tendo em vista a concepção de que a violência abarca as diversas formas, níveis e intensidades em que o fenômeno acontece, segundo a OMS (2002).

Este aspecto pôde ser notado a partir da entrevista em grupo focal, quando um participante, se referindo às violências, contou que estas ocorrência em todo lugar, na sala e fora da escola, e que lida normalmente com elas. Segundo Libardi e Castro (2014), a violência tem sido conceituada de modo que diga respeito às diversas situações entre os adolescentes $\mathrm{e}$, a partir disto, há uma contribuição no que se diz respeito ao aumento do conceito, alimentando a impressão de que o fenômeno tem alcançado as mais diversas camadas, esferas, instituições e, ainda, as relações pessoais.

Ainda partindo da conceituação de Libardi e Castro (2014), os estudantes partilham de vivências rotineiras e para fazer parte de um grupo deve-se agir em conformidade com o cotidiano de relações sofríveis ali estabelecidas. Os autores observaram que o medo de se contrapor esconde 0 medo do não pertencimento, que é maior. Deste modo, naturalizando a violência aceitam, sem contestar. Nesta pesquisa os dados revelam situações que vão no mesmo sentido, considerando a reprodução de violência nas relações.

$\mathrm{Na}$ atual pesquisa, da mesma forma, os professores se mostraram indiferentes na maioria das situações de violência verificadas nas observações participantes, mostrando desinformação e naturalização da violência. Elas não geraram comoção nem por parte dos alunos, nem pelos professores e, ainda, não foram percebidas pela equipe técnico-administrativa.

Bispo e Lima (2014) consideram a educação como mecanismo da formação humana, acontecendo a partir da ligação do desejo de aprender e do desejo de ensinar, considerando que a transmissão pressupõe o inesperado, 0 imprevisto, o ineducável, apontando que a escola está em crise devido ao aumento das violências neste contexto e a evidência pelo desinteresse na aprendizagem. A naturalização da violência se fez presente neste aspecto quando, em meio às aulas registradas a partir das observações participantes, ocorreram situações onde todos os tipos de violência estiveram presentes, inclusive nas práticas consideradas brincadeiras. 
Considerando a violência institucional e suas decorrências, foram constatadas variadas situações que se referem à violência institucional e suas decorrências, situações que dizem respeito às relações de poder existentes no âmbito escolar e aos sentimentos dos estudantes diante destas relações.

Nas observações participantes foram evidenciadas situações que se referem à violência institucional, tendo em vista a relação professor-aluno e equipe técnico-administrativa-aluno, relacionada às ameaças, sendo estas posturas refletidas nas reproduções do fenômeno na relação aluno-aluno.

Abramovay (2015) afirma que a violência institui à escola uma preocupação por se tratar de uma instituição que tem privilégios na formação dos alunos e, ainda, por ser um lugar para socialização, além do aprender. Apesar disso, a autora revela que a escola detém mecanismos próprios de seleção social e exclusão, em vários casos, auxiliando a violência e sua propagação, sendo os excluídos aqueles que não estão nos padrões estabelecidos. Desta maneira, a escola não é mais um território neutro e as discriminações ocorridas nela são omissões e ações, principalmente, do sistema escolar que possivelmente contribuem com prejuízos na aprendizagem, o que influencia de forma negativa o processo de construção de identidade destes estudantes. Portanto, são potenciais agressores e vítimas qualquer membro da escola.

Segundo Rocha (2000), a instituição escola privilegia a subjetividade mecânica por meio dos elementos da comunidade, das regras, símbolos ou signos, sendo encarada como produtora de um raciocínio que homogeneíza e se fortifica sendo fábrica de uma socialização padronizada. Assim, na maior parte das instituições, tem sido consideravelmente difícil a transformação da realidade que desestimula, onde o tédio é traduzido na sensação de impotência da criação, sendo impossibilitada a produção de forças que mobilizam a construção de práticas e caminhos que sejam fecundos e gratificantes.

Em outras situações, observou-se que os alunos também reproduzem a violência institucional, ou resistem a ela. Em determinada situação a professora explicou uma atividade e os alunos não prestaram atenção, conversando com os colegas paralelamente; em outra aula, ainda, a proposta era de que os alunos copiassem um texto, fizessem a leitura do mesmo e, assim, respondessem duas questões de interpretação. Neste caso, alguns alunos fizeram, outros não, desconsiderando-a.

Njaine e Minayo (2003) apontam a luta que diz respeito à afirmação da identidade dos próprios alunos, que são afetadas pela agressividade e que não são reconhecidas pelos professores. Portanto, a desatenção acerca da violência na escola, principalmente a violência verbal, e nas relações estabelecidas nesta, geram sua perpetuação. Ela acontece em vários níveis relacionais: entre os pares, na relação professor-aluno, equipe 
técnico administrativa-aluno e, ainda, nas relações fora da escola, no contexto em que o jovem se insere.

Por fim, soluções cotidianas para situações de violência foram relatadas nas três fases da pesquisa. Nas observações participantes os alunos mencionaram a vigilância e a disciplina como possíveis soluções, considerando a suspensão ou "chamar a polícia". Já os professores citaram o conselho tutelar.

Segundo Ferreira e Pereira (2017), as relações de diálogo são a menor preocupação da relação dos alunos com seus superiores, dando espaço para relações que se constituem da atenção à disciplina, não favorecendo um espaço para a participação e existência dos estudantes no âmbito escolar. Desta forma, é possível concluir que a atuação destes não está atrelada à questões que determinam o funcionamento da instituição, não afetando as decisões que são restritas àqueles que detém todo o poder.

Deste modo, reproduzindo os mecanismos institucionais e não exercendo espaço dentro do ambiente escolar, foram levantadas, ainda, soluções pautadas na punição, considerando um aluno que contou que levou suspensão ao brigar com um colega e relatou como sua mãe reagiu, sendo a privação uma solução comumente encontrada para lidar com a violência e revidar a violência.

De acordo com Bispo e Lima (2014), a escola utiliza de seu poder para disciplinar e ter controle social. Entretanto, enquanto produz corpos submissos e dóceis, provoca comportamentos de rompimento com a submissão às ordens impostas. Os autores destacaram a função dupla que possui a ordem simbólica que diz respeito à violência, onde de um lado há uma função estabilizadora e pacificadora nos mecanismos de educação padronizados e, por outro, há uma função que é violenta e visa o constrangimento dos indivíduos para que estes se adequem às normas. Entretanto, mesmo que estejam presentes iniciativas de controle operadas pela escola, alguns estudantes são capazes de implementar recursos de persistência que não se enquadrem nos mecanismos institucionais, desvendando alternativas, cumplicidades paralelas à hierarquia que é burocrática e subversivas, na tentativa de escapar da vigilância, desafiando os procedimentos de punição e, ainda, burlando as regras estabelecidas.

Ainda, foram levantadas situações relacionadas à culpabilização, considerando relatos onde a solução seria a mudança de comportamento da vítima ou professores homens na sala de aula.

No entanto Sposito (1998) afirma que a violência nega a probabilidade de uma relação social que se constitui pelo uso da palavra, pela comunicação, pelo conflito e pelo diálogo e que, em sua própria definição, rompe diversos níveis de significação, tendo em vista que os limites entre 
reconhecer, ou não, o ato como violento, implica condições culturais e históricas diversas. A violência escolar se trata da violência urbana que adentra o âmbito escolar. Então, com a finalidade de que atribuições novas se ampliem, há a necessidade da superação e entendimento de práticas agressivas que dizem respeito à compreensão dos caminhos que possibilitem uma ação socializadora e, então, a tolerância, o respeito às diferenças e os direitos evidenciados, ideias centrais da democracia, se tornarão possíveis.

A partir disso, foram levantadas soluções para violência pautadas em tratar o outro como gostaria de ser tratado, tratar bem, com respeito e educação, fazendo-o feliz também, foram levantadas considerando, ainda, pedir ajuda aos professores e orientadores e, ainda, por outro lado, soluções mais dialógicas surgiram na entrevista em grupo focal.

Deste modo, a partir de um espaço democrático vivenciado na entrevista em grupo focal, soluções cotidianas para situações de violência foram levantadas pautadas em limites definidos pelo respeito e tolerância às diferenças.

\section{CONSIDERAÇÕES FINAIS}

Considerando os anos finais do Ensino Fundamental, as violências escolares estão presentes nas relações entre os estudantes e seus pares, entre eles e seus professores e em sua relação com a equipe técnicoadministrativa, considerando a compreensão e o mapeamento das violências presentes no contexto escolar, visando verificar como os alunos a percebem, compreendendo as diferentes situações ocorrentes. Ainda nesta pesquisa, foram levantados aspectos das relações aluno-aluno, professor-aluno e, ainda, equipe técnico-administrativa-aluno, favorecendo reflexões acerca de novos modos de convivência na escola.

O fenômeno de dá, além disso, por intensidades e níveis que se diferem, no que se diz respeito às violências verbais, físicas, auto-inflingidas e negligência.

Neste trabalho foram levantadas questões relativas à violência, enquanto fenômeno que se efetiva em níveis e intensidades diferentes; à escola, considerando-a uma amostra da sociedade; à violência institucional e grupal, presentes nas relações professor-aluno, equipe técnico administrativaaluno e aluno-aluno; ao contexto social e a violência, sendo fatores que se correlacionam no âmbito escolar; ao estudante adolescente, tendo em vista a etapa de vida em que os estudantes vivenciam e sua atuação na escola; e ao enfrentamento das violências, no que se refere às possibilidades existentes para transformação da realidade escolar.

As violências mapeadas foram as violências físicas e verbais, auto-inflingidas e negligência. Os estudantes mostraram, diante do tema, 
naturalização, tendo em vista a maneira como são vistas as situações observadas, sendo muitas vezes consideradas brincadeiras. Além disso, foram percebidas decorrências da violência institucional em todas as relações, sendo elas: aluno-aluno, professor-aluno e equipe técnico-administrativa-aluno.

Como soluções cotidianas para violência foram encontradas pelos estudantes: punição, revidar a violência, vigilância, culpabilização, disciplina, questões acerca do gênero, além de considerar a ajuda de algum superior.

Em contrapartida, trouxeram também soluções pautadas em tratar o outro como gostaria de ser tratado, tratar bem, com respeito e educação fazendo-o feliz soluções cotidianas foram levantadas por meio das entrevistas individuais e entrevista em grupo focal, onde experenciando um espaço democrático se estabeleceu um espaço de respeito e tolerância às diferenças.

Conclui-se, deste modo, que os estudantes agem e percebem a violência de forma natural, apesar de não se sentirem bem em determinadas situações, além de sentirem e reproduzirem a violência institucional, ou resistirem a ela. Reproduções dos modos dominantes na sociedade são reproduções trazidas como soluções para violência dentro da escola, como punir e culpar. Por outro lado, são apontadas saídas ligadas a se colocar no lugar do outro e respeitando as diferenças, implicando novos modos de convivência.

Verifica-se, por fim, a importância da reflexão acerca dos valores que norteiam os modos de convívio grupal e social, considerando os dados evidenciados nesta pesquisa e os novos modos de convivência suscitados a partir de espaços mais democráticos.

\section{REFERÊNCIAS}

ABRAMOVAY, M. Violência nas escolas. Programa de prevenção à violência nas escolas, p. 1-21, [20--?], disponível em:

http://flacso.org.br/files/2015/08/Violencias-nas-Escolas.pdf

ABRAMOWICZ, A.; LEVCOVITZ, D. "Tal infância. Qual criança?" In: ABRAMOWICZ, A. SILVÉRIO, V. R. (orgs). Afirmando diferenças: montando o quebra-cabeça da diversidade na escola. Campinas: Papirus, 2005.

ANDRE, M. E. D. A. Etnografia da prática escolar. Papirus, 17 ed., Campinas, 1995, p. 27-30.

AVANCI, J. Q.; PESCE, R. P.; FERREIRA, A.L. Reflexões sobre Promoção da Saúde e Prevenção da Violência na Escola. In: ASSIS, S. G.; CONSTANTINO, P.; AVANCI, J. Q. (Orgs). Impactos da violência na escola: um diálogo com professores [online]. Rio de Janeiro: Ministério da Educação/Editora FIOCRUZ, 2010. 
BISPO, F. S.; LIMA, N. L. de. A violência no contexto escolar: uma leitura interdisciplinar. Educ. ver., Belo Horizonte, v. 30, n. 2, abr.jun. 2014

CRUZ, F. M, L.; MACIEL, M. A. 'Excluir', 'Xingar', 'Bater': sentidos de violência na escola segundo estudantes da Paraíba. Psicol. Esc. Educ., Maringá, v. 22, n. 2, mai./ago. 2018.

DAHLBERG, L. L.; KRUG, E.G. Violência: um problema global de saúde pública. Ciência \& Saúde Coletiva, 2007, p. 1164-1165.

FERREIRA, M. F. T.; PEREIRA, A. S. GESTÃO ESCOLAR E PARTICIPAÇÃO: a percepção dos alunos. Revista de Iniciação Científica, Criciúma, v. 15, n. 2, 2017. Fractal, Ver. Psicol., Rio de Janeiro, v. 26, n 3, p. 1-12, set./dez. 2014.

KAPPEL, V. B.; GONTIJO, D. T.; MEDEIROS, M.; MONTEIRO, E. M. L. M. Enfrentamento da violência no ambiente escolar na perspectiva dos diferentes autores. Interface (Botucatu), Botucatu, v. 18, o 51, p. 1-11, Out./Dez. 2014.

LIBARDI, S. S.; CASTRO, L. R. Violências "sutis": jovens e grupos de pares na escola. Fractal, Ver. Psicol., Rio de Janeiro, v. 26, n 3, p. 1-12, set./dez. 2014

NJAINE, K.; MINAYO, M. C. S. Violência na escola: identificando pistas para a prevenção. Interface (Botucatu), Botucatu, v. 7, no 13, p. 1-11, Ago. 2003.

Organização Mundial da Saúde (WHO). World Report on Violence and Health. Geneva: World Health Organization Press; 2002, p. 5 e 32.

ROCHA, M. L. Educação em tempos de tédio: um desafio à micropolítica. In:

SILVA, J. O.; RISTUM, M. A violência escolar no contexto de privação de liberdade. Psicol. cienc. prof., Brasília, v. 30, no 2, p. 1-11, 2010.

SPOSITO, M. P. A instituição escolar e a violência. Cadernos de Pesquisa. Fundação Carlos Chagas, 58-75, 1998.

TANAMACHI E.; PROENÇA, M. (Orgs.). Psicologia e Educação: desafios teóricos-práticos. São Paulo: Casa do Psicólogo, 2000. 
PESQUISA-INTERVENÇÃO SOCIODRAMÁTICA COM PROFESSORES: as violências na escola

\author{
Rebeca Silva Moreti \\ rebeca_moreti@hotmail.com \\ Daniela de Figueiredo Ribeiro \\ ribares@facef.br
}

\title{
1. INTRODUÇÃO
}

Como o ambiente escolar passa por um momento crítico em relação as formas saudáveis de convivência (RAMOS, 2011), é importante que sejam resgatados na educação uma "relação com o conhecimento, com o outro e com o mundo construída no acolhimento, respeito e diálogo", propiciando o crescimento de todos participantes do processo educativo. Contudo, a presença da violência no ambiente escolar impede que ele cumpra com seu papel social primordial, que é fornecer aos indivíduos a sua preparação para a atuação social na existência e nas relações subjetivas (SILVA; CASTRO, p.2, 2008). Ela é tida como um sintoma social (ARREGUY; COUTINHO, 2015) e tem sido vista como um grave problema enfrentado pela educação (ARAÚJO, 2002).

Compreende-se então o importante papel do professor diante desta realidade e como este influencia na formação de seus alunos enquanto cidadãos (RAMOS, 2018). Assim, o professor exerce um papel importante como uma tentativa humanizada fundamental no enfrentamento da violência (NUNES; VIOTTO, 2018). Nesta perspectiva, utilizou-se o sociodrama criado por Jacob Levy Moreno como ferramenta para condução de grupos com os professores da atual pesquisa, buscando compreender busca compreender os modos de convivência escolar e as violências vivenciadas na escola na perspectiva dos docentes. Entende-se que a atuação com professores a partir de um acolhimento humanizado pode contribuir para um ambiente de trabalho motivante e que favorece a criatividade (SANTOS et al. 2016). A utilização do sociodrama na intervenção grupal contribui para a tomada de consciência e a reflexão sobre a prática docente, embora ainda pouco explorado na educação (ALTARUGIO; CAPECCHI, 2016).

Abramovay (2005) trata sobre o conceito de violência como sendo amplo, dinâmico e mutável. Seus significados são influenciados de acordo com o momento histórico, o contexto cultural e diversos fatores que lhe atribuem um caráter dinâmico, próprio dos fenômenos sociais, sendo que ao mesmo tempo em que se trata a violência como uma questão de visibilidade, em outros momentos é tratada de forma naturalizada. "A violência é ressignificada segundo tempos, lugares, relações e percepções, e não se dá somente em atos e práticas materiais" (ABRAMOVAY, 2005, p. 54). 
Diante disso, tem-se chegado à conclusão de que se trata de um fenômeno biopsicossocial que se manifesta na vida em sociedade (MINAYO, 1994). Segundo a autora, a violência não pode ser tratada de forma fatalista, pois "é sempre um caminho possível em contraposição à tolerância, ao diálogo, ao reconhecimento e à civilização" (MINAYO, 1994, p.7).

Frente às conceituações sobre a violência, diversos autores afirmam em seus trabalhos a visão de Sposito, como sendo "todo ato que implica a ruptura de um nexo social pelo uso da força. Nega-se, assim, a possibilidade da relação social que se instala pela comunicação, pelo uso da palavra, pelo diálogo e pelo conflito" (1998, apud RISTUM; BASTOS, 2001, p.22). Quando não se lida com o conflito através de um espaço para comunicação, toda oportunidade de se estabelecer uma relação social através do uso da palavra é rejeitada. O uso da violência seria como um "enclausuramento do gesto e da palavra" (SANTOS, 2001, p.107).

Levando em consideração que a escola é um dos principais grupos sociais no qual o indivíduo está inserido, entende-se que esta instituição não está isenta do problema das violências enfrentadas em sociedade. Segundo Araújo (2002, p.43) "não há dúvida de que a violência presente nas escolas tem sido um dos problemas sérios enfrentados pela Educação".

Esta, por sua vez, é caracterizada por alguns autores como um reflexo da sociedade, um lócus da violência. Esta afirmação é confirmada em Aquino (1998), a qual exprime a ideia de que a escola é marcada pela reprodução de outros contextos institucionais, sendo eles a política, a economia e a família. Contudo, essa instituição não somente reproduz forças exógenas a ela, pois "algo de novo se produz nos interstícios do cotidiano escolar, por meio da (re)apropriação de tais vetores de força por parte de seus atores" (AQUINO, 1998, p.10).

A escola não apenas reproduz as violências correntes na sociedade, mas produz formas próprias, de diversas ordens, tipos e escalas, que se refletem no dia a dia. Assim, recusa-se a tese de que a instituição não reflete somente um estado de violência generalizado que teria origem fora dela (ABRAMOVAY, 2003, p.9).

"Insiste-se que a violência em meio escolar pode expressar modalidades de ação que nasce no ambiente pedagógico, o que significa que este não funciona apenas como uma caixa de ressonância da violência social" (ABRAMOVAY, 2005, p. 66). A partir dessa perspectiva, compreende-se que a escola também é produtora de sua própria violência, permitindo assim a compreensão das nuances deste fenômeno. Só assim é possível pensar em uma outra proposta de escola, tendo em vista propagação de uma cultura contra violências (ABRAMOVAY, 2005).

Em uma pesquisa da UNESCO coordenada por Abramovay (2005), a autora coloca em questão a ideia de que a escola não tem atuado como uma instituição que propague a democracia e a inclusão, pois na prática 
tem-se observado um movimento de propagação das desigualdades. Dessa forma, "a escola deixa de cumprir a missão central atribuída a ela neste início de século XXI, que é a de atuar como promotora dos indivíduos e das sociedades" (ABRAMOVAY, 2004).

Enquanto instituição de escolarização formal, a escola deve ser
defendida, os processos de desenvolvimento do indivíduo que nela
ocorrerem devem ser estudados, e as melhorias, buscadas, a fim de
que desenvolvamos indivíduos felizes, justos, críticos e
transformadores, que possam retornar à sociedade o desejo e os
meios para a construção de uma sociedade mais igualitária
(PEREIRA;WILLIAMS, 2010, p.47).

Nunes e Viotto (2018) tratam a violência escolar como sendo um fenômeno multideterminado em suas origens e manifestações. Segundo uma pesquisa realizada pela UNESCO, a violência na escola pode ser designada de três maneiras: violência contra a pessoa e o patrimônio, as incivilidades e a violência simbólica. Debarbieux (1999 apud SANTOS, 2001, p.109) traz uma categorização das violências semelhantes, pois afirma que três tipos de violências escolares: "a violência penal, dos crimes e delitos; as incivilidades, tendo assim denominado os conflitos de civilidades, e o sentimento de insegurança". Os participantes da violência escolar podem assumir diferentes papéis neste contexto, visto que podem ser os autores dos comportamentos violentos, podem ser os alvos da violência ou testemunhas desses atos e suas consequências (PEREIRA; WILLIAMS, 2010, p.49).

Por incivilidade, Almeida e Holanda (2016) definem não por atos físicos, mas por "pequenas violências" "que comprometem a chamada conduta socialmente desejável, ou seja, a interação civilizada dos alunos com seus colegas e professores" (LA TAILLE; VINHA, 2013 apud ALMEIDA; HOLANDA, 2016, p.2). Por sua vez, estes atos geram respostas como o desgaste, 0 cansaço, o ressentimento e o acanhamento, se tornando cada vez mais difícil a convivência daqueles que estão inseridos neste contexto.

"Assim, a ruptura dessa conduta traz ao professor um desgaste tanto emocional quanto físico e aos alunos o comprometimento do seu processo de aprendizagem, além de sua evolução na relação social" (ALMEIDA; HOLANDA, 2016, p.2). Nesta perspectiva, Castro (2010) se refere as incivilidades ocorridas entre alunos e professores como sendo as mais prejudiciais, visto que há um desencontro entre aqueles que precisam de cuidados, e seus cuidadores.

Visto que a educação tem uma finalidade política e social, um de seus objetivos é desenvolver, capacitar e oferecer condições aos professores para desenvolverem seu pensamento crítico diante dos problemas sociais. Dessa maneira, o combate a violência demanda que haja um trabalho conjunto e uma reformulação das práticas desenvolvidas neste ambiente, com a finalidade de analisar como o "trabalho pedagógico pode contribuir no 
enfrentamento desta situação, seja por meio de medidas preventivas, projetos, propostas ou outras alternativas" (SILVA, M. p.8, 2004).

Nesta perspectiva, considera-se o importante papel que os professores desempenham diante desta realidade, além da importância de compreender como eles pensam e atuam diante deste fenômeno. Segundo Severo e Franco (2011), quando se refere ao papel docente frente a violência escolar, é necessário que sejam considerados alguns aspectos como a valorização do profissional da educação e a formação docente.

Para Ramos (2018), além de ser mediador da aprendizagem, o professor também influencia na formação dos alunos enquanto cidadãos. No ambiente escolar, as relações positivas entre os professores e os alunos têm se mostrado como um "fator protetivo importante para o desenvolvimento do comportamento agressivo" (LUIZZI, 2006, p. 11).

Diante dos diversos caminhos que podem ser pensados para oferecer melhores condições de convivência a alunos e professores, visando as condições para o pleno desenvolvimento destes, há um ponto que deve ser valorizado: "a importância do papel do educador, não apenas diante de comportamentos inadequados, como também diante da possibilidade de tornarse um agente transformador no desenvolvimento de seu aluno" (SEVERO; FRANCO, 2011, p.589).

O indivíduo está em processo de construção e autoconstrução e a função básica do processo educativo é a humanização. Nesta concepção, o professor tem um papel de vital importância, porque é na escola que a formação do sujeito se efetiva e mesmo que a educação esteja determinada por esta sociedade, ela possui uma responsabilidade crucial no processo de edificação e transformação desta sociedade (SEVERO; FRANCO, 2011, p.594).

Neste sentido, o presente artigo trata-se de uma pesquisaintervenção sociodramática com professores de uma escola pública da cidade de Franca, a qual busca compreender os modos de convivência escolar e as violências vivenciadas na escola na perspectiva dos professores. O diferencial da metodologia proposta é que ela "Propicia a leitura dos grupos e da rede de relações, numa perspectiva de educação pela e para a ação" (RAMOS, 2011). A pesquisa teve como objetivos promover um ambiente de reflexão e de novos modos de convivência aos professores; levantar concepções e vivências dos professores a respeito das violências no contexto escolar e verificar como os professores pensam sobre o modo de convivência na escola.

\section{METODOLOGIA}

Este trabalho foi realizado a partir de uma pesquisa-intervenção de natureza qualitativa. A pesquisa foi realizada em uma Escola Estadual localizada na periferia de uma cidade do interior do estado de São Paulo, onde 
foram realizadas intervenções grupais com 20 professores que participam das reuniões de ATPC (Aula de Trabalho Pedagógico Coletivo). Os trabalhos grupais ocorreram mensalmente nas últimas segundas e terças-feiras do mês, durante as reuniões de ATPC com duração de duas horas em média, conforme já acordado com a escola. Os professores foram divididos em dois grupos de intervenção, sendo o primeiro grupo os professores que participavam das reuniões de ATPC às segundas-feiras, e o segundo grupo com os professores que participavam das reuniões de APTC às terças-feiras. $O$ processo de intervenção grupal foi realizado em dois encontros com o primeiro grupo de professores e três encontros com o segundo grupo de professores, conforme a disponibilidade oferecida pela escola. Inicialmente foram propostos três encontros com cada grupo, porém devido a incompatibilidade de datas e horários foram realizados apenas dois encontros com o primeiro grupo.

A equipe que conduziu as intervenções grupais contou com a supervisora de estágio dando todo o suporte necessário durante as supervisões e 4 estagiárias de Psicologia Escolar do $4^{\circ}$ e $5^{\circ}$ ano de Psicologia do Uni-Facef, colaboradoras da pesquisa, as quais assinaram um termo consentindo a participação na mesma, além de cumprir os passos propostos na metodologia deste trabalho. O critério de inclusão dos professores foi 0 assentimento quanto ao estudo e a assinatura do Termo de Compromisso Livre e Esclarecido. O projeto de pesquisa foi encaminhado e aprovado pelo Comitê de Ética em Pesquisa do Uni-FACEF com o seguinte número de aceitação: 08975119.6.0000.5384 (CAAE).

A pesquisa intervenção constitui-se como uma ferramenta de transformação além de possibilitar a prática de um novo pensar e de fazer educação (ROCHA e AGUIAR, 2003). A pesquisa-intervenção adota uma nova relação entre sujeito e objeto, teoria e prática, pois "rompe-se a barreira entre sujeito que conhece e objeto a ser conhecido" (ROSSI e PASSOS, p.21, 2014). Segundo Rocha e Aguiar (2003), por um lado ela traz uma nova dimensão na formação dos profissionais de Psicologia concebendo uma dimensão social, histórica e política e, por outro, elabora novas formas de atuação do psicólogo nas instituições, percebendo as situações como circunstâncias sociais, influenciadas por diversas condições. A pesquisa-intervenção introduz uma nova articulação entre teoria e prática e desenvolve as ciências sociais "através de ações concretas na realidade, refletindo criticamente e avaliando seus resultados" (ROCHA e AGUIAR, p.2, 2003).

Como metodologia para condução dos grupos desta pesquisa foi proposto o Sociodrama, capaz de gerar uma tomada de consciência do grupo a partir dos temas a serem abordados. "No sociodrama educativo, a proposta é escolher temas que possam gerar discussão, de maneira a fomentar 0 crescimento da consciência crítica dos participantes" (GRANDE, 2009, p. 71).

Segundo Grande (p.70, 2009), "Na prática, o sociodrama é uma dramatização do que as pessoas vivem, uma representação curta das coisas 
que acontecem na vida em grupo." Este método quando utilizado com professores propicia a articulação de respostas criativas perante as situações problemáticas vivenciadas pelo docente no cotidiano escolar, além disso favorece a reflexão e a participação efetiva de todos os envolvidos no processo.

A pesquisa psicodramática, ao se deixar conduzir pela emergência de um tema protagônico, vai comungar com a pesquisa intervenção quando esta se guia pelo surgimento natural de um analisador (CONTRO, 2009 p.10).

Um dos instrumentos dentro desta abordagem que foi utilizado com o grupo é chamado de Jogo Dramático, que proporciona ao sujeito exteriorizar de forma livre as criações do seu mundo interno, através de atividades corporais ou artísticas. Assim, ele proporciona uma proximidade de conflitos vividos pelos participantes do grupo, o que possibilita mudança, tomada de consciência e crescimento pessoal (MOTTA, 1995).

Os jogos dramáticos seguem as seguintes etapas: aquecimento, 0 jogo dramático propriamente dito através da dramatização e por último o compartilhar. $\mathrm{O}$ aquecimento consiste em alguma atividade para preparar $\mathrm{O}$ grupo, na qual consiste em aliviar a tensão e proporcionar um ambiente favorável para a liberação da espontaneidade. O Jogo Dramático que vem após o aquecimento, é uma proposta para trabalhar o conflito grupal através do teatro da espontaneidade. Por último, a etapa do compartilhar consiste na elaboração daquilo que foi experenciado pelo grupo através da palavra, aparecendo neste momento as aprendizagens e as dificuldades encontradas pelo grupo.

Os temas abordados durante as sessões realizadas foram: convivência grupal, os conflitos do cotidiano, violências entre alunos, violências vivenciadas pelos professores, modos de enfretamento da violência e novas formas de comunicação.

As sessões realizadas foram registradas em Folha de Registro estruturada que continham as seguintes informações a serem preenchidas após cada encontro: data; duração; número de participantes; aquecimento inespecífico, aquecimento específico; desenvolvimento; compartilhar; palavras do compartilhar; configuração sociométrica (como o grupo se dividiu em cada encontro); modos de convivência; práticas de violência e observações. Desse modo, todos os envolvidos na coleta de dados informaram e registraram adequadamente as situações vividas, os fatos, reflexões e resultados observados durante as intervenções. Esses documentos de pesquisa e as respostas dos questionários passaram por Análise de Conteúdo, segundo os moldes propostos por Minayo (2007). A partir das sessões grupais, os conteúdos que foram mais frequentes foram divididos em cinco categorias, as quais serão abordadas nos resultados e discussão do artigo. 


\section{RESULTADOS E DISCUSSÃO}

Os participantes da pesquisa foram divididos em dois grupos de acordo com os horários de ATPC que estavam inseridos. Em ambos os grupos a pesquisadora responsável estava presente no momento do encontro, que ocorreu mensalmente, às últimas segundas e terças-feiras de cada mês. A seguir serão apresentados os resultados co-construídos nas sessões de grupo organizadas em cinco categorias, que serão discutidas segundo a literatura da área.

\subsection{O Professor Diante Da Violência Aluno-Aluno}

Observou-se que os modos de convivência violentos entre alunos que mais apareceram nas sessões grupais (dramatizações e discursos dos professores) foi a exclusão e o isolamento, os quais serão abordados como incivilidades. Estas, por sua vez, podem ser tratadas como uma inversão de valores, pois vão na contramão de um posicionamento necessário para a vida social (ALMEIDA; HOLANDA, 2016). Já no primeiro encontro, os professores do primeiro grupo trouxeram uma cena de dois alunos sentados na sala de aula fazendo atividades, quando uma aluna que estava distante tenta se aproximar deles. Contudo, essa aluna é vítima da exclusão pois os alunos não permitem que essa aproximação aconteça, permanecendo isolada.

Em relação ao primeiro encontro do segundo grupo, os professores representaram uma cena na qual cinco alunos estavam brincando em roda, quando uma aluna tenta entrar na brincadeira, mas não é aceita. Os alunos verbalizam que essa aluna não sabe brincar, dizendo para que ela fique de fora.

No segundo encontro deste grupo, uma professora se recordou de uma situação vivida onde uma aluna recebe um bilhete de outras alunas com calúnias a seu respeito, como por exemplo que esta aluna não sabe se vestir, é brega e feia. O ato da incivilidade, segundo Garcia (2006 apud ALMEIDA; HOLANDA, 2016, p.5), "está ligado à transgressão de esquemas da vida social, ou do que se espera do outro como pessoa humana, como quando uma criança ofende a um colega com injurias." Castro (2010) recorre a obra de Norbert Elias (1939) para melhor compreensão sobre o conceito de incivilidades.

O conceito de incivilidade refere-se a um tipo de agressividade miúda, caracterizada pela quebra de regras de boa convivência - desordens, empurrões, ofensas, grosserias, humilhações - envolvendo ataques cotidianos e repetidos ao direito de cada um (ELIAS, N. 1939 apud CASTRO, R. 2010, p.106).

Observa-se que essas situações são recorrentes no cotidiano escolar e podem ser tão danosas ou até mesmo piores que outras práticas de violência. Por sua vez, essas práticas interferem negativamente no processo de aprendizagem, causam desgaste e cansaço em todos os envolvidos neste 
contexto, prejudicam as relações estabelecidas, entristecem, acanham e ferem as crianças, além de provocar um mal-estar entre os educadores (CASTRO, 2010). De acordo com a fala dos professores durante as sessões grupais, essas situações de violência são "corriqueiras" no ambiente escolar, sendo vistas de forma "banalizada", em função de se tornarem tão comuns. Dessa forma, a banalização neste contexto passa a ser empregada estrategicamente, a fim de sustentar o consenso entre os atores escolares.

(...) Ela desempenha um papel relevante na preservação dos discursos de emancipação. Esta estratégia identifica o mal e, em vez de nomeá-lo, buscando a conexão que os une, o banaliza. $\mathrm{E}$ banalizar significa destituir o sujeito de qualquer insígnia ou importância relativa ao seu papel social; banalizar é embranquecer (NOLASCO, 2001, p. 116 apud ABRAMOVAY, 2005, p.75).

\subsection{O Professor Diante Do Sofrimento Dos Alunos}

Diante do sofrimento dos alunos, no primeiro encontro do segundo grupo os professores trouxeram a falta de recursos dos alunos em lidar sozinhos com as situações de violência. Nas encenações onde os professores se colocaram no papel de alunos, somente foi possível encontrar uma saída quando o educador intervia nos conflitos gerados na sala de aula. Dessa forma, é fundamental olhar para o papel do professor como uma proposta humanizada no combate a violência (Ramos 2018; Gomes e Lira, 2018; Nunes e Viotto, 2018).

Contudo, os educadores se encontram numa posição problemática diante deste contexto. Além da demanda de cumprir com a proposta pedagógica curricular, possuem um desafio ainda maior de encontrar meios para lidar com a violência na sala de aula. Em alguns momentos os professores não sabem como lidar com esse quadro (ALMEIDA; HOLANDA, 2016).

Como se pode notar, os educadores quase sempre acabam padecendo de uma espécie de sentimento de "mãos atadas" quando confrontados com situações atípicas em relação ao plácido ideário pedagógico. Entretanto, o cotidiano escolar é pródigo em eventos alheios a esse ideário-padrão (AQUINO, 1998, p.9).

Esta demanda é confirmada pelos professores participantes desta pesquisa, pois no primeiro encontro do segundo grupo os professores trouxeram no compartilhar o medo de intervir nas questões de violência e a falta de recursos para lidar com essas situações. "Esse desafio leva o educador a se portar com passividade e esse quadro é perigoso e preocupante, pois é claro que o professor também sofre com esse cenário" (ALMEIDA; HOLANDA, 2016, p.5).

Outra característica abordada pelos professores durante as sessões foi o contexto no qual seus alunos estão inseridos, o qual pode se apresentar muito 'vulnerável, ou de condições precárias'. Uma professora disse 'depois de entender a história deles, a gente acaba ficando com dó. A vó de um deles morreu e o pai está preso'. Outra professora ainda disse 'Muitos meninos 
aqui não têm o que comer. Muitos deles chegam cheirando a fogão a lenha'. Essas falas são corroboradas por Castro (2010) quando aborda que não havendo uma estrutura familiar continente para a criança, é possível que seja gerada uma lacuna no seu processo de desenvolvimento.

Por isso, acredito que a agressividade corriqueira observada nas instituições de ensino não esteja dissociada dos índices de vulnerabilidade social das nossas crianças e adolescentes, nem sempre acolhidos e acompanhados em suas necessidades de constância, disponibilidade ou empatia (CASTRO, 2010, p.5).

Diante deste cenário, destaca-se a importância de não adotar um posicionamento de culpabilização da família, visto que há toda uma rede ampla envolvida no desenvolvimento de um indivíduo. Assim, o intuito foi somente abordar sua importância na vida do sujeito. Para Castro (2010), nota-se a carência de uma política eficaz voltada aos cuidados sociais às famílias. Dessa forma, "(...) a escola recebe, cada vez mais, um público fragilizado, que anseia por uma atenção e sensibilidade para a qual a instituição não está preparada" (CASTRO, 2010, p.6).

\subsection{O Professor Diante Das Agressões Vividas}

Já na primeira intervenção, a qual teve como tema central a violência entre alunos, o primeiro grupo de professores trouxe o reflexo das violências vividas no cotidiano escolar marcado pelo mal-estar gerado neste contexto (ABRAMOVAY, 2005). Um dos professores coloca sua dificuldade em lidar com o que nomeia de 'líder da violência', completando sua fala com 'muitas vezes não tenho força para lidar com isso'. A partir dessas falas, é possível considerar a presença de um quadro de fragilidade entre os professores, o qual tem sido reconhecido nos estudos a respeito da violência escolar. Também na primeira intervenção com o segundo grupo, os professores manifestaram sentir medo de intervir em situações de violência. Segundo Almeida e Holanda (2016, p.3) "As sensações de medo e de insegurança já enraizaram em nossas escolas".

Percebe-se que a violência gera uma ruptura daquilo que se almeja pela escola enquanto uma instituição democrática. Como consequência desse fenômeno, é gerado um desgaste tanto emocional quanto físico nos professores (ALMEIDA; HOLANDA, 2016). Esse aspecto é revelado na maneira como os docentes da atual pesquisa chegam nos encontros. Muitas vezes notou-se um clima grupal de agitação, ansiedade, cansaço e uma demanda grande de poder se expressar, sendo este o único espaço possível para que isso ocorresse. Essa não abertura para um espaço de comunicação é vista como uma violência simbólica, pois enclausura a palavra dos que estão sujeitos ao ambiente escolar, sem, no entanto, utilizar de um mecanismo de opressão explícito (ABRAMOVAY, 2005).

Esbarra-se nestes tipos de situações com o que se denomina de violência institucional. Na primeira sessão do segundo grupo, os professores se 
queixaram da falta de respaldo da escola para enfrentar as violências, afirmando se sentirem sozinhos neste cenário. Esse tipo de violência se ampara na inadequação de fatores presentes no cotidiano escolar:

(...) como o sistema de normas e regras muitas vezes autoritárias; as formas de convivência; o projeto político pedagógico; os recursos didáticos disponíveis e a qualidade da educação - em relação às características, expectativas e demandas dos alunos, o que gera uma tensão no relacionamento entre os atores sociais que convivem na escola (ABRAMOVAY, 2005, p.72).

Visto a forma com que a violência institucional afeta os professores, também se faz presente na realidade dos alunos. Estes, por sua vez, são submetidos a um conjunto de padrões, de normas e de regras os quais não levam em consideração as diversidades presentes no contexto escolar (ABRAMOVAY, 2005), acarretando forças contrárias neste ambiente as quais contribuem no entendimento de alguns comportamentos relacionados a indisciplina dos alunos, aspecto tão presente no discurso dos professores.

Observou-se que na maioria das sessões grupais os professores destacaram a questão da indisciplina em sala de aula, marcada pelas falas: 'Tenho dez alunos, só dois abrem o caderno'; 'Na sexta-feira quando voltamos para ver o filme, tinha uma aluna terrível. Toda hora ela mexia no notebook em que o filme estava ligado, colocava pra frente e pra trás. Depois de muito pedir, eu tirei o braço dela, e ela começou a gritar, me acusando de ter batido nela'.

Além disso, a encenação realizada pelo segundo grupo no segundo encontro foi também relacionada a indisciplina, onde duas alunas estão fazendo uma atividade, uma terceira aluna tenta copiar de modo que as três começam a brigar em sala de aula, sem que a professora consiga apaziguar a situação. No momento do compartilhar desta sessão grupal, os professores trouxeram a dificuldade de resolver esses conflitos: 'Enquanto nós estamos resolvendo este conflito pequeno, os outros quarenta alunos estão pegando fogo dentro da sala de aula'; 'Nós somente apagamos fogo, não temos tempo para resolver todos os problemas'. Na sessão seguinte do grupo dois, os professores trouxeram uma cena que ocorreu no espaço da sala de aula. Enquanto a professora estava tentando prosseguir sua aula, um aluno ficava em pé querendo sair da sala atrapalhando o restante da turma, fazendo com que os outros alunos começassem a brigar com este que estava em pé.

Furlan e Peri (2011) delineiam a questão da disciplina na escola a partir de uma visão aprofundada sobre este fenômeno, utilizando como referência a teoria de Foucault sobre corpos docilizados, a qual pode ser entendida como um adestramento de corpos. "A disciplina é um tipo de poder, torna os indivíduos meros objetos e, ao mesmo tempo, instrumentos do seu próprio exercício" (FURLAN; PERI, 2011, p.2392). São três os instrumentos responsáveis pelo sucesso do poder disciplinar: "o olhar hierárquico, a sanção normalizadora e sua combinação num procedimento que the é específico, 0 exame" (FOUCAULT, 2009b, p. 164 apud FURLAN; PERI, 2011, p.2392). Dessa forma, não é necessário que a violência seja marcada no corpo, pois o 
indivíduo apreensivo em ser punido passa se auto controlar, evidenciando aqui o que se refere a violência psicológica (FURLAN; PERI, 2011, p.2392). É possível então compreender que as manifestações de indisciplina no contexto escolar são brechas encontradas pelos alunos para ir na contramão daquilo que lhes é imposto.

A instituição escola se revela um ambiente inflexível no que diz respeito a participação de educandos e educadores em seus processos pedagógicos, em suas decisões e na elaboração de conteúdos (FURLAN; PERI, 2011). Se instaura neste ambiente uma relação vertical marcada pelo silêncio daqueles que não podem se colocar enquanto sujeitos reflexivos. Abandona-se o direto à palavra, restando somente o dever de executar. Dessa maneira, a crítica colocada tem a finalidade de expor como este modelo afeta negativamente, causando sofrimento em todos os envolvidos no ambiente escolar, inclusive nos professores.

\subsection{Modos Habituais De Reação À Violência}

Os principais modos habituais de reação a violência que apareceram para sanar ou resolver algum conflito na sala de aula foram o uso de gritos e ameaças de encaminhar o aluno para a diretoria. Notou-se que com esses modos cristalizados de reação a violência, os professores não são capazes de resolver os conflitos em sala de aula.

Sem o protagonismo, sem o poder de interferência em seu meio, resultado do exercício estável de tomada de consciência e de reflexividade, (...) assistiremos à paralisação do professor diante dos desafios da docência. Nesse estado, o professor é passivo, é minimizado, limitado às circunstâncias que lhe são impostas, o que o levaria a emitir sempre as mesmas respostas frente a velhos problemas. (ALTARUGIO; CAPECCHI, 2016. P.33).

É possível observar este aspecto na cena representada na primeira sessão do grupo 1 , onde a professora tenta resolver o conflito de exclusão na sala de aula por meio de gritos com os alunos, diz que vai mandar o aluno para diretoria e dá um tapa em sua mesa; na cena do segundo encontro do grupo 2 a professora que entra na cena de indisciplina também tenta resolver através de gritos e ameaça de mandar para a diretoria. De acordo com um dos professores participantes da pesquisa, só foi possível controlar a sala 'colocando ordem e gritando com os alunos.'

Diante da perspectiva sobre o papel do professor e sua influência na vida dos educandos, entende-se que os conflitos nesta relação podem ser prejudiciais e funcionar como um fator de estresse para a criança (LUIZZI, 2007). De fato, na tentativa dos educadores em conter a violência escolar e os problemas de comportamentos dos alunos, acaba por gerar respostas inapropriadas por parte destes. Segundo Almeida e Holanda (2016) não é atípico que os professores se coloquem de maneira hostil e autoritária, utilizando de formas coercitivas no tratamento com os alunos, a fim de manter 
a disciplina. Contudo, "A educação punitiva gera sentimentos de ressentimento e revanche e pode assim contribuir para a violência no contexto escolar (LUIZZI, L. 2007, p.14)". Além disso, esse aspecto contribui não só para a coerção dos alunos, mas também no desgaste emocional dos professores.

Essa condição é observada nas cenas durante a dramatização onde o professor intervém em uma situação de indisciplina através de atos coercitivos, como gritos e ameaças. Estas reações, por sua vez, não são capazes de solucionar o problema em questão, somente trouxeram sentimentos de raiva e coerção nos professores que estavam no papel de alunos na dramatização. Diante disso, "por não saber agir na prevenção, considerando a ocorrência de um evento, o profissional em educação não sabe tão pouco diagnosticá-lo, logo não se sabe como proceder com o tratamento" (ALMEIDA E HOLANDA, 2016, p.7).

Se faz necessário destacar nesta categoria que o caminho da culpabilização dos professores não é a resposta para o tema da violência, pois em vista deste cenário hostil são mobilizados "fortes sentimentos entre os educadores, deixando-os perdidos, atônitos, desvitalizados, descrentes" (CASTRO, 2010, p.107). Contudo, não há dúvidas de que é preciso colocar em questão a relação estabelecida entre educandos e educadores, e a reflexão do papel de professor é um caminho humanizado no combate da violência. Visto que a correlação positiva entre o professor e seu educando contribui na melhoria do desenvolvimento social e interpessoal da criança, e consequentemente na atenuação da violência escolar (LUIZZI, 2007), é fundamental olhar para essa relação de uma forma mais elaborada. Portanto, a partir do momento que os professores passam a perceber como seus comportamentos e suas respostas afetam a vida de seus educandos, é possível se estabelecer um melhor relacionamento entre esse par, cessando desta maneira com os sentimentos de passividade e desamparo (LUIZZI, 2007).

\subsection{Novos Modos Co-construídos De Intervenção Nas Situações De Violência}

O sociodrama aplicado na área da educação se respalda nas experiências cotidianas vivenciadas pelos atores escolares, dos seus papéis e objetiva uma melhor compreensão e composição desses papéis no ambiente escolar (BORSATO; ANDRADE, 2000). A utilização do sociodrama com o grupo de professores teve como objetivo o resgate da espontaneidade e a criatividade na resolução dos conflitos relacionados à violência, a fim de buscar, criar e co-construir através do encontro grupal novas respostas diante dos mesmos problemas. Por sua vez, a espontaneidade é caracterizada como uma "resposta do indivíduo a uma nova situação ou a nova resposta a uma antiga situação" (MORENO, 2009, p. 101 apud ALTARUGIO; CAPECCHI, 2016, p.223). 
No primeiro encontro com o grupo 1 de professores, após aparecerem na dramatização os modos habituais de reação a violência em sala de aula, uma última professora interviu na cena de exclusão entre alunos, chamando o aluno que estava praticando o ato de exclusão para conversar fora daquele ambiente. Neste momento o diálogo entre o aluno e o professor se mostrou uma prática positiva pois despertou uma atitude diferente do aluno frente a situação experenciada. A prática da comunicação, sem que o aluno seja exposto, se mostrou benéfica no cotidiano escolar, além de ser o único modo em que se conseguiu alcançar uma resolução para o conflito instaurado na sala. Assim, o aluno passou a se comportar de maneira diferente. O diálogo também se mostrou uma prática positiva no desfecho da dramatização do segundo encontro do grupo 2, onde a cena dramatizada girava em torno de uma briga entre alunas na sala de aula.

No primeiro encontro com o grupo 2 de professores, a dramatização girou em torno de uma aluna que queria participar da brincadeira de um grupo, porém os alunos deste grupo não permitiram que ela entrasse, alegando que ela não sabia brincar. Para encontrar um novo caminho nesta cena de exclusão, uma professora entra na cena propondo para o grupo encontrar uma nova brincadeira que todos saibam brincar, pedindo para que a aluna excluída sugerisse uma. Neste momento encontrou-se a saída para o conflito instaurado.

Numa situação de jogo ou de improviso, a partir de uma situação fictícia, o sujeito coloca muito de si e o caráter lúdico da mesma permite criar situações insólitas na qual o sujeito toma consciência de como se trabalha com o outro, toma decisões, avalia riscos, além de revelar fenômenos menos cognitivos, como medo, dependência, etc (PERRENOUD, 2001 apud ALTARUGIO; CAPECCHI, 2012, p.223).

Já no último encontro do grupo 2, no momento da dramatização a professora propôs para que os professores que estavam no papel de alunos se sentassem em círculo e sugeriu uma atividade diferente sobre o halloween. Neste momento, os professores que estavam no papel de alunos a escutam e verbalizam estarem menos entediados. No "jogo de papéis" é possível vivenciar as situações conflituosas que aparecem diante do papel do educador, e através disso alcançar uma melhor compreensão, se preparando para novas situações que possam surgir (BORSATO; ANDRADE, 2000).

Dessa forma, é possível verificar que as sessões sociodramáticas rompem com aquilo que Moreno chamou de conserva cultural, pois são capazes de alcançar um novo saber a partir da espontaneidade e da criatividade (BORSATO; ANDRADE, 2000). Segundo Altarugio e Cappecchi (2012, p.36), é durante a dramatização, que os indivíduos têm a oportunidade de modificar a realidade vivenciada na cena, encontrando novas saídas para ela. 
É na dramatização, momento central do psicodrama, que os indivíduos têm a oportunidade de, atuando em espaços e tempos imaginários, modificar as cenas, construir novos significados e criar e experimentar coletivamente soluções novas para situações vividas (ALTARUGIO; CAPPECCHI, 2012, p.36).

No compartilhar do último encontro do grupo 2, as professoras contaram sobre algumas experiências diferentes que tentaram realizar, como colocar os alunos em círculo, propor uma atividade diferente que foi relacionada com a proposta pedagógica, promover jogos e debates sobre a matéria estudada, além de manter uma boa comunicação com os alunos, abrindo espaço para que eles possam se expressar também.

Nota-se que adotar medidas que não vão ao encontro com o padrão estabelecido pelo modelo tradicional são benéficas no que diz respeito a expressão das singularidades de cada aluno, na criação de um espaço que permite trabalhar as diferenças e assim tirar os alunos da mesmice do dia-adia. Visto que os alunos se portam de maneira diferente diante de uma nova proposta, é possível que sejam agregadas experiências positivas para eles e para os educadores, e consequentemente um efeito positivo diante do problema da violência.

O desenvolvimento de um professor reflexivo não se limita a resolução dos conflitos a respeito da prática didático-pedagógica dentro da sala de aula, mas espera constituir professores com pensamento crítico que exerçam seu papel de cidadãos inseridos em uma instituição - a escola - onde irão atuar como "mediadores e intérpretes ativos de culturas, valores, de conhecimentos prestes a se transformar" (PERRENOUD, 2002, p. 189 apud ALTARUGIO; CAPECCHI, 2016, p.32).

\section{CONSIDERAÇÕES FINAIS}

Através dos encontros grupais foi possível proporcionar um espaço de reflexão aos professores, visto que estes se mostraram participativos durante os encontros, além de trazerem concepções importantes e vivências pessoais sobre a manifestação da violência. Um espaço de troca de experiências entre os próprios professores se mostrou benéfico, pois foram capazes de colocar suas dificuldades e escutar sugestões criativas. No momento em que os professores experimentaram diferentes papéis na dramatização foi possível constatar que eles encontraram novas saídas para os conflitos vivenciados no cotidiano escolar, relacionados à violência.

Verificou-se que através da proposta metodológica deste estudo, foi possível experenciar, por meio da ação, que os modos habituais de reação a violência, principalmente os atos punitivos e repressores como gritos, ameaças e encaminhamentos dos alunos não são eficazes na resolução dos conflitos e não geram respostas positivas nos alunos, visto que sanar a agressividade utilizando de recursos agressivos só desperta uma resposta 
negativa. Neste sentido, os encontros grupais sociodramáticos propiciaram a expressão da espontaneidade e da criatividade dos professores, os quais trouxeram novas respostas frente aos conflitos cotidianos.

Visto a importância da escola na vida do indivíduo, como lócus de fomentação do pensamento, de desenvolvimento do cidadão e da propagação de ações que valorizam as diferenças, é preciso compreender que estamos vivenciando uma crise profunda e multidimensional diante do cenário da violência escolar, a qual afeta todas as relações de uma sociedade. É preciso visualizar a violência na escola como uma oportunidade de "corrigir os erros, buscar novas soluções, usar a criatividade, rever os modelos, buscando compreender a totalidade do fenômeno" (SEVERO; FRANCO, 2011, p.593).

Eis o desafio da educação e por conseguinte dos educadores. Desse modo, se faz necessário evidenciar a relevância de uma pesquisa intervenção em psicologia escolar, a qual atua segundo uma perspectiva de construção de um novo saber.

\section{REFERÊNCIAS}

ALMEIDA, E.A.B; HOLANDA, M.J.B. Atos de Incivilidade: um comportamento cada vez mais frequente no ambiente escolar. 2016.

ALTARUGIO, Maisa Helena; CAPECCHI, Maria Candida Varone de Morais. Sociodrama pedagógico: uma proposta para a tomada de consciência e reflexão docente. Alexandria: Revista de Educação em Ciência e Tecnologia, Florianópolis, v. 9, n. 1, p. 31-55, maio 2016. Disponível em: $<$ https://periodicos.ufsc.br/index.php/alexandria/article/view/19825153.2016v9n1p31>.

AQUINO, J.G. A violência escolar e a crise da autoridade docente. Cadernos Cedes, 1998.

BORSATO, C.R; ANDRADE, A.S. Assessoria a Professores de 1aㅡ A $4^{\text {a }}$ Séries Visando o Desenvolvimento do Profissional Reflexivo a Partir dos Princípios do Psicodrama Pedagógico. Dissertação. São Paulo: FEBRAP, Revista Brasileira de Psicodrama, 8(2): 69-82, 2000.

CASTRO, R. Incivilidades: a violência invisível nas escolas. POLÊM!CA, v. 9 , n. 2, p. $105-113$, abril/junho 2010.

CONTRO, Luiz. Veredas da pesquisa psicodramática: entre a pesquisa-ação crítica e a pesquisa-intervenção. Rev. bras. Psicodrama, São Paulo, v. 17, n. 2, p.13-24, 2009. Disponível em $<$ http://pepsic.bvsalud.org/scielo.php?script=sci_arttext\&pid=S0104$53932009000200002 \& \operatorname{lng}=\mathrm{pt \& nrm}=$ iso $>$.

FURLAN, M.B; PERI, M. Michel Foucault: corpos dóceis e disciplinados nas instituições escolares. 2011. 
GRANDE, Carolina. O trabalho e o afeto: prazer e sofrimento no trabalho dos professores da escola pública de Brasília. Brasília, 2009. Disponível em http://repositorio.unb.br/bitstream/10482/4836/1/2009_CarolinaGrande.pdf

LIRA, Adriana; GOMES, Candido Alberto. Violence in schools: what are the lessons for teacher education? Ensaio: aval.pol.públ.Educ, Rio de Janeiro , v. 26, n.100, p.759-779, 2018. Disponível em http://www.scielo.br/scielo.php?script=sci_arttext\&pid=S010440362018000300759\&lng=pt\&nrm=iso

LUIZZI, Luciana. Prevenção de comportamentos agressivos entre préescolares: uma proposta de capacitação para professores. Dissertação. São Carlos: UFScar, 2006.

MOTTA, J. (org). O Jogo no Psicodrama. 2. ed. São Paulo: Ágora, 1995.

NUNES, R.; VIOTTO Filho. Reflexões teórico-críticas para uma práxis científica educativa de enfrentamento da violência na escola. Colloquium Humanarum. p.10-21, 2018.Disponível em http://journal.unoeste.br/index.php/ch/article/view/2535.

PEREIRA, A.C; WILLIAMS, C.A.L. Reflexões sobre o conceito de violência escolar e a busca por uma definição abrangente. Temas em Psicologia, vol. 18, núm. 1, 2010, pp. 45-55.

RAMOS, Antonia Lucia Leite. Vínculo na prática educativa escolar: um estudo com base na ludicidade e no sociodrama. Rev. bras. Psicodrama. São Paulo, v.19, n.2, p.73-84, 2011. Disponível em <http://pepsic.bvsalud.org/scielo.php?script=sci_arttext\&pid=S0104$53932011000200007 \&$ lng=pt\&nrm=iso $>$.

RAMOS, A. A violência nas escolas: um desafio para o professor. Eventos Pedagógicos, 2018. Disponível em <http://sinop.unemat.br/projetos/revista/index.php/eventos/article/view/3332>.

ROCHA, Marisa Lopes da; AGUIAR, Katia Faria de. Pesquisa-intervenção e a produção de novas análises. Psicol. cienc. Prof, Brasília, v. 23, n. 4, p. 6473, 2003. Disponível em $<$ http://www.scielo.br/scielo.php?script=sci_arttext\&pid=S141498932003000400010\&lng=pt\&nrm=iso.

ROSSI, André; PASSOS, Eduardo. Análise institucional: revisão conceitual e nuances da pesquisa-intervenção no Brasil. Rev. Epos, Rio de Janeiro, v. 5, n. 1, p.156-181, 2014. Disponível em $<$ http://pepsic.bvsalud.org/scielo.php?script=sci_arttext\&pid=S2178700X2014000100009\&lng=pt\&nrm=iso>.

SANTOS, Manoel Antônio et al. Grupo operativo com professores do ensino fundamental: integrando o pensar, o sentir e o agir. Rev. SPAGESP, Ribeirão Preto, v.17, n.1, p.39-50, 2016. Disponível em 
$<$ http://pepsic.bvsalud.org/scielo.php?script=sci_arttext\&pid=S1677$29702016000100005 \&$ lng $=$ pt\&nrm=iso $>$.

SILVA, Joelma Oliveira da; RISTUM, Marilena. A violência escolar no contexto de privação de liberdade. Psicol. cienc. prof., Brasília, v. 30, n. 2, p. 232-247, 2010. Disponível em

$<$ http://www.scielo.br/scielo.php?script=sci_arttext\&pid=S1414-

$98932010000200002 \&$ lng $=$ pt\&nrm=iso $>$.

SILVA, Hermínia Helena; CASTRO, Leonardo Villella de. Formação docente e violência na escola. Psicol. Educ, São Paulo, n. 26, p. 47-66, jun. 2008.

Disponível em

$<$ http://pepsic.bvsalud.org/scielo.php?script=sci_arttext\&pid=S1414-

$69752008000100004 \&$ lng $=$ pt\&nrm=iso $>$. 


\title{
RELAÇAO MATERNA EM GAROTAS ANORÉXICAS: análise fílmica
}

\author{
Irma Helena Ferreira Benate Bomfim \\ irma@benate.com.br \\ Aline de Paula Rodrigues \\ Alinedpr97@yahoo.com.br
}

\section{INTRODUÇÃO}

A alimentação pode ser considerada uma das ferramentas principais que atua na construção do vínculo na relação materna. De acordo com Winnicott (1982) a alimentação vincula-se com aspectos emocionais que devem ser respeitados na compreensão do ato de amamentar e nas dificuldades em relação a esse processo.

De acordo com Giard (1998), as delegações sobre alimentação infantil, como amamentar, preparar alimentos a partir de receitas, faziam parte do ritual de integração da criança à socialização. $O$ ato de alimentar a criança foi aprendido devido aos diálogos, na experiência e vivência das mulheres, transmitida de mãe para filha, de avó para neta.

De acordo com o DSM-V (2013), a anorexia consiste em uma restrita ingestão calórica em relação às necessidades básicas, um medo intenso de ganhar peso ou engordar, forte ausência de reconhecimento do baixo peso corporal. Transtorno alimentar, em especial a anorexia, dá-se na grande maioria em mulheres, jovens adultas ou adolescentes.

A anorexia é considerada um transtorno do comportamento alimentar que surge consideravelmente nas estatísticas em meninas adolescentes. Apresenta características diagnósticas gravíssimas como citadas a cima e consiste em um processo psicopatológico que sofre influência direta de fatores biopsicossociais (CORDÁS, 2004).

Segundo Fonseca e Rena (2008) o período da adolescência é um marco em relação às mudanças inevitáveis que acontecem simultaneamente. Em decorrência disso, o corpo muda e a percepção de si mesmo automaticamente é modificada. Nessa fase, inicia-se a formação de uma identidade, dos valores sociais, se faz necessário enquadrar-se, o que resulta em atitudes como restrição alimentar, ocasionando consequências gravíssimas.

De acordo com Mannoni (1971) emagrecer pode ter como finalidade delirante de diminuir a proporção da figura materna interna, podendo assim ser livre para o nascimento de seu sujeito desejante. Miranda (2007) cita que o emagrecer presente na anorexia é uma forma de dramatização executada no corpo, a fim de demonstrar o desejo de fazer a mãe e seus 
conteúdos sumirem internamente dela. A maneira com é estabelecida e manejada a relação mãe-bebê, ou seja, a capacidade de cuidado e a organização mental influenciam fortemente na formação da estrutura da personalidade da criança.

Segundo Vighietti (2001) a pessoa diagnosticada com anorexia não é preparada para a experiência de separação de sua mãe que é uma particularidade da fase da adolescência, pois com a falta de liberdade inviabiliza um desenvolvimento autônomo da jovem. Acarretando em consequências graves ao desejarem tentativas de se separarem das mães.

Como cita Busse (2004), não resta às pacientes outra saída, a não ser tentar obter o controle do próprio corpo, na tentativa de ter o domínio de si, ou seja, ocorre uma transferência para o peso e para o comer todas as ansiedades e problemas psicológicos. Ainda para Busse (2004), o sintoma anoréxico consiste em uma tentativa frustrada da menina de estabelecer uma demarcação entre ela e a mãe.

\section{HISTÓRIA DA ANOREXIA}

A anorexia foi à primeira doença citada dentro dos principais transtornos do comportamento alimentar. Descrita no século XIX, também é considerada a pioneira a ser corretamente classificada e apresentar critérios atuantes reconhecidos já no ano de 1970.

A doença remete a ausência de orexis, apetite, que apresenta um comportamento com considerável privação alimentar que é imposta para atingir um peso e uma forma corporal exageradamente magra segundo padrões adotados devido à distorção da imagem corporal.

O termo anorexia declaradamente não é o mais apropriado de acordo com a psicopatologia, porque não há uma perda verídica de apetite, ao menos no período inicial da doença. $O$ termo alemão pubertaetsmagersuch, que significa "busca da magreza por adolescentes", se torna mais propício em relação aos sintomas de negação do apetite e controle obsessivo encontrado no transtorno.

Historicamente, a patologia anoréxica é considerada como manifestação de alguma inconstância psicológica primária, e desde o século XIX está associada à histeria. As primeiras referências a esse estado, apareceram nos antigos textos latinos a.C e foi relacionado ao termo fastidium, que significava aversão à comida, enjoo ou falta de desejo.

Os primeiros relatos de restrições alimentares severas aparecem na Idade Média, apresentando relação com uma conduta religiosa de privação. Já a intitulação propriamente dita de "anorexia nervosa" foi apresentada por William Gull em 1873, que se referiu a particularidade da doença que aflige em 
grande maioria mulheres jovens e apresenta características como emagrecimento intenso, da qual "falta de apetite" é consequência de um estado mental mórbido.

Para Gull, a anorexia nervosa, ou apepsia hysterica, revelava um quadro similar a uma patologia gástrica, mas com fundamentos histéricos importantes. Acreditava que o tratamento ideal seria a alimentação forçada, em espaços constantes de tempo, evidenciando que o desejo da paciente não deveria ser respeitado visando segurança, pois os jejuns poderiam levar ao óbito.

Habermas (1986) relata o primeiro caso consideravelmente sugestivo de anorexia nervosa em uma serva do ano de 895. Após estar recuperada de uma doença irreconhecível, a jovem Friderada virou vítima de um apetite voraz e descontrolado. Na tentativa de cessá-lo, refugiou-se em um convento onde com o tempo foi limitando sua alimentação até vivenciar os jejuns. Ainda nos estágios iniciais da doença a jovem conseguia manter suas tarefas conventuais, mas velozmente seu quadro deteriorou-se até levá-la a óbito com caso grave de desnutrição.

No século XIII, jovens conhecidas como "santas anoréxicas" realizavam rigorosos jejuns na tentativa de conectar-se espiritualmente com Deus. Esse quadro apresentava alto nível de perfeccionismo, auto insuficiência, rigidez, insatisfação pessoal e distorções cognitivas, igualmente os quadros de anorexia atuais.

Cordás (2004) relata o caso de Santa Maria Madalena de Pazzi na Revista de Psiquiatria Clínica. Nascida em Florença, ingressa no convento Carmelita de Santa Maria dos Anjos em 1582. Em meio de 1584, adoece em estado de "arrebatamento" e antes de completara vinte anos de idade, acredita estar guiada por Deus, passando a restringir sua alimentação a pão e água, alimentando-se normalmente, porém em pequena quantidade apenas aos domingos. Quando forçada a comer por suas superioras, passa a provocar vômito, considerando a comida uma tentação diabólica, fazendo da alimentação restrita uma punição e um caminho para a purificação dos pecados.

Aos vinte e cinco anos, Maria falece e o caso passa a ser visto como exemplo de crucificação, sofrimentos físicos auto impostos e jejuns intermináveis, visando atingir perfeitamente seu destino místico.

O jejum autossuficiente não é considerado de ordem obrigatória de um transtorno alimentar. $\mathrm{Na}$ antiguidade consta que vários povos praticavam o jejum voluntário como prática religiosa e contemplavam na privação alimentar um modelo de purificação. Segundo Vandereycken (1994), no Egito Antigo, quem desejava ser iniciado nos mistérios de Isis e Oriris deveria ficar de sete a 40 dias sem alimentar-se. Entre gregos e romanos, 0 
jejum sucedia antes da consulta com os oráculos, e os profetas do Velho Testamento abdicavam da comida como forma de preparo para religião e revelações divinas.

Desde os anos 80, tornou-se evidencia na literatura a definição de dois subtipos clínicos da anorexia nervosa, o restritivo e o purgativo.

De acordo com o DSM V a anorexia nervosa consiste em um transtorno alimentar com alta restrição de consumo calórico, medo excessivo de ganhar peso ou engordar e perturbação em perceber e vivenciar seu próprio corpo.

De acordo com a Classificação Internacional de Doenças (CID 10), a anorexia nervosa consiste em um transtorno personalizado por perda de peso intencional, induzida e mantida pelo paciente. O transtorno é mais comum em mulheres adolescentes ou jovens, mas pode afetar homens adolescentes e jovens, como também uma criança prestes a entrar na puberdade. Os sintomas são restrição alimentar, prática excessiva de exercícios físicos, vômitos induzidos e uso de laxantes, anorexígenos e diuréticos. Segundo Freitas (2004), a anorexia e a bulimia apresentam sintomas similares, apesar de terem diagnósticos diferenciais bem definidos.

Atualmente, a anorexia nervosa apropria-se do sexo feminino em cerca de $95 \%$ dos casos, preferencialmente na faixa etária entre 14 e 17 anos, podendo repercutir precocemente aos 10 ou 11 anos e também tardiamente após os 23 anos. Refere-se a uma patologia grave, apresentando sérios riscos e a taxa de mortalidade apresenta números de $5 \%$ quando relacionada com diagnóstico e tratamento tardios. (Freitas, 2004)

\section{A ANOREXIA DURANTE A ESTRUTURAÇÃO PSÍQUICA}

Os bebês, ao nascerem, necessitam totalmente de sua mãe, estabelecendo-se uma relação de dependência absoluta com a mesma para sua sobrevivência. Winnicott ressalta que as bases de saúde mental do sujeito são constituídas na primeira infância através do meio fornecido pela mãe. Contudo, a função da mãe vai além dos cuidados fisiológicos que o bebê necessita para sobreviver, sendo essenciais os cuidados emocionais que estão diretamente relacionados à construção de sua personalidade, à maneira como se relacionará com outras pessoas quando adulto e como conduzirá sua vida (WINNICOTT, 1945, 1956).

De acordo com Santos (2017) a fase de dependência absoluta do bebê é um estado em que ele depende totalmente da mãe para ser, sendo integralmente afetado pelo tipo de cuidado que recebe. Durante a relação mãebebê, é preciso que haja uma ilusão vivenciada pelo bebê e aceita pela mãe de que a mãe é rente a ele, levando-o a se reconhecer como ser único exclusivo e plenamente dependente dela. 
Santos (2017) ressalta a importância de lembrar que não existe bebê sem uma mãe, mas isso não deve ser considerada uma indiferenciação, principalmente pela mãe. Um pequeno deslocamento entre ambos deve ser enxergado dentro da relação mãe-bebê.

Arcangioli (1995) baseado nas ideias de Winnicott retrata que a fase de dependência absoluta, ocorre durante os seis primeiros meses de vida do bebê e consiste da dependência total do bebê em relação ao meio, ou seja, o ambiente é apresentado a ele através da mãe ou de alguém que exerça esse papel, tal fator é considerado importante, pois contribui para a interpretação que o bebê realiza deste período, já que para o bebê, o meio e ele são a mesma coisa.

Para Winnicott, (1975) apud HUMBERG (2004), o desenvolvimento considerado saudável é o qual a mãe através da função holding (abrange desde $O$ ato de segurar fisicamente 0 bebe até 0 de the oferecer condições para que viva bem no ambiente) e de sua compreensão, desempenha a capacidade de separar seu próprio eu e o self do bebê.

De acordo com Vasconcelos (2009), o bebê não possui os meios necessários à sua subjetivação, a qual se constitui a partir da relação mãebebê, ou seja, da importância simbólica que o filho tem para ela. Para que 0 psiquismo do bebê se constitua é necessário que haja além de um organismo dotado de um aparelho biológico, pessoas que assegurem o cumprimento da função materna e da função paterna no simbólico, ou seja, alguém que introduza a criança na linguagem, por meio de seu desejo.

Segundo Rosemberg (1994), logo nos primeiros meses de vida, o bebê se identifica com a mãe e nela se une formando uma unidade mãe-bebê, condição fundamental para 0 desenvolvimento da criança. $O$ bebê depende totalmente dos cuidados e amor da mãe e, de acordo com a autora, essa primeira relação é responsável por colocar o desejo do bebê em movimento, supondo na criança um sujeito que está se constituindo. Daí se destaca a relevância destes momentos iniciais na trajetória de constituição do sujeito.

De acordo com Santos (2017) entender os Transtornos Alimentares é entrar em contato com uma mãe incapacitada de olhar para seu filho como ser individual, levando-a a não aceitar a separação inicial. São mães imaturas que dependem de seu bebê para sobreviverem, cuja experiência da maternidade é vivenciada de forma psicótica emocionalmente, ou seja, houve recusa da castração e cria-se uma nova realidade, pensando o filho como parte faltante e não um indivíduo com vida própria. Essas "falsas mães" dificultam e até impedem a entrada do pai na vida do bebê, consequentemente o filho é prejudicado e não adquire um mundo simbólico e não se torna SER. 


\section{DISCUSSÃO}

O filme analisado foi o "O Mínimo Para Viver" que conta a história da jovem Ellen, de vinte anos, que sofre de anorexia, um transtorno alimentar comum entre mulheres e adolescentes. A personagem é obcecada em ser sede de um corpo extremamente magro, mesmo que para isso, coloque sua vida em questão, não tendo noção do risco de morte que corre. Sem vontade de se livrar da doença e ter uma vida saudável, a jovem passa os dias sem perspectivas de melhora e esperança. Porém, no decorrer da trama, ela encontra um médico não convencional que a desafia a enfrentar sua precária situação e abraçar a vida, tudo pode mudar.

$\mathrm{Na}$ primeira semana de tratamento o médico segue o protocolo propondo uma conversa familiar, todas comparecem menos o pai. Nesta reunião ficou evidente que a garota já não era mais vista em sua totalidade sendo considerada um problema, o que a entristeceu e ao retornar para a clínica não conseguiu ingerir nenhum alimento e voltou a estaca zero, controlando seu peso através da medição de seus braços.

Miranda (2007) cita que o emagrecer presente na anorexia é uma forma de dramatização executada no corpo, a fim de demonstrar o desejo de fazer a mãe e seus conteúdos sumirem internamente dela. A maneira com é estabelecida e manejada a relação mãe-bebê, ou seja, a capacidade de cuidado e a organização mental influenciam fortemente na formação da estrutura da personalidade da criança.

Ramalho (2004), de acordo com a psicanálise, relata que os sintomas da anorexia surgem a partir de dificuldades nas relações primordiais, já que estas influenciam diretamente a imagem (formada através do olhar do Outro) que as mulheres têm de si mesmas. O autor ainda contribui ao citar a interpretação da anorexia ligada à recusa da feminilidade como defesa e maneira para manter o corpo infantil. Sendo assim, a interpretação psicanalítica da anorexia está intimamente conectada com a feminilidade que nasce a partir da edificação edipiana.

No desenvolvimento da anorexia, a função materna exerce influências e pode tornar-se uma consequência, pois as portadoras desse transtorno alimentar anseiam por um limite na relação mãe-bebê e realizam tal desejo negando a comida, recusando a se alimentar. Para Fonseca (2013), o comportamento invasivo da mãe tem como consequência tal recusa, é como se a anoréxica, através disso, obtivesse o controle dessa relação.

Os pais da jovem são separados há alguns anos e a sua mãe se mudou de cidade para morar com a atual namorada. Durante a trama, a jovem demonstra as consequências negativas de ter se sentido "abandonada" pela mãe. Para Guimarães (2013), a primeira e fundamental questão feminina é a separação da mãe, apenas assim, ela conseguirá ter um futuro individualizado. 
No entanto, se essa separação apresentar complicações, vai de acordo com que Freud chamou atenção dizendo que "é daí que vêm à maioria dos problemas neuróticos das mulheres". Nitidamente, no começo do filme, a madrasta assume a função materna e vive-se uma ausência física e da função paterna.

Segundo Vighietti (2001) a pessoa diagnosticada com anorexia não é preparada para a experiência de separação de sua mãe que é uma particularidade da fase da adolescência, pois com a falta de liberdade inviabiliza um desenvolvimento autônomo da jovem. Acarretando em consequências graves ao desejarem tentativas de se separarem das mães.

Para Busse (2004), não resta às pacientes outra saída, a não ser tentar obter o controle do próprio corpo, na tentativa de ter o domínio de si, ou seja, ocorre uma transferência para o peso e para o comer todas as ansiedades e problemas psicológicos. Ainda para Busse (2004), o sintoma anoréxico consiste em uma tentativa frustrada da menina de estabelecer uma demarcação entre ela e a mãe. Considera-se caracteristicamente superficial a relação afetiva entre a anoréxica e seu pai. A figura paterna é apagada e não é valorizada na diferenciação no seio do casal. (Jeammet, 1993, p. 242).

Em conversa com sua irmã, Ellen relata se considerar no "controle" da situação e com o médico que posteriormente a ajudaria em seu tratamento, ela diz que não se sente doente, mesmo com os exames precários. Fava e Peres (2011) julgam a doença como consequência de uma escolha pela recusa do corpo, ou seja, o desejo pelo outro, recusando a própria feminilidade. Com a conversa de Ellen e Luke no jardim da clínica, fica claro a repulsa citada a cima pelo desejo do outro por ela quando relata que nunca fui abusada sexualmente, mas chegou a se sentir atacada e extremamente incomodada com os desejos dos homens para com ela quando seus seios começaram a crescer na adolescência. A condição de mulher, para as anoréxicas, pode ser relacionada à passividade e a submissão, experimentadas como situações duras e difíceis de serem processadas. As dietas restritivas podem ser incorporadas na tentativa de controlar seu próprio organismo, como a própria jovem acreditava estar, negando-se a enxergar que o risco de morte que corria era alto e pertinente.

Oliveira et all (2013) consideram a construção da imagem corporal de suma importância para a compreensão dos transtornos alimentares. Os autores alegam que a partir dos lutos vividos na adolescência (fase de maior incidência da anorexia), fase que a jovem Ellen vive no filme, surgem às dificuldades de visualizar a si mesmo. Ellen relata para sua irmã a ausência de sua menstruação há tempos, este sintoma é tido como um dos principais sintomas físicos da anorexia, considerado por alguns autores como Souza e Santos (2006), como a negação da maturidade sexual e da feminilidade em um corpo em constante mudança rumo à vida adulta. Em vista 
disso, a menina acredita não se tornar mulher e deseja conservar seu corpo infantil.

O médico que desafia e instiga a anoréxica, trabalha em tratamentos de transtornos alimentares de maneira nada ortodoxa, propondo a internação na "Limiar", um ambiente caseiro e confortável, com no máximo sete pessoas residentes por vez. Nesta casa, os pacientes são reforçados com pontos a cada atitude positiva, fazem as refeições juntos, terapias em grupo e também acompanhamento psicológico individual.

Na primeira semana do novo tratamento de Ellen, o médico segue o protocolo e a convoca para uma terapia familiar. Todas se fizeram presentes, a mãe e sua namorada, a irmã e a madrasta, menos seu pai, que permanece ausente telefonando para dizer que não poderia comparecer.

A partir da chegada do pai na relação é quando se instaura a rivalidade edípica o Complexo de Édipo de Freud simboliza a privação da mãe para a criança, fazendo com que a figura paterna exerça a função de iniciar uma situação triangular e, assim, constituindo uma distancia entre a criança e a mãe (Coriat, 1997, citada por Thiesen, 2014). O pai de Ellen não aparece em nenhum momento do filme, a mãe relata que ele não aceita a filha do jeito que ela é já a madrasta o defende mesmo também notando a ausência dele consigo mesma e com a segunda filha.

Se por aspectos narcísicos, a mãe não permitir a entrada no pai na situação triangular, o bebê fica como único objeto capaz de satisfazer 0 desejo da mãe e aprisionado à relação fusional com ela. (Dor, 1991, citado por Borges, 2005). Descrever a carência paterna no Édipo não significa a carência em uma dimensão realista, mas de um terceiro elemento que esteja presente nos desejos da criança e da mãe.

Nodin e Leal (2005) questionam se em indivíduos diagnosticados com anorexia o pai não exerce o papel de elemento diferenciador durante a triangulação edipiana. $\mathrm{O}$ abundante envolvimento da mãe com estas garotas pode ter impossibilitado a identificação com a figura paterna e, por conseguinte, a esperada elaboração do período edipiano, justificando os tipos de relação superficial com essa mesma figura.

No decorrer do filme, a mãe de Ellen não aparece muito e volta à vida da filha após a convocação do Doutor para a reunião, indo embora logo em seguida. Posteriormente, quando a jovem desiste da clínica, viaja para ir morar novamente com sua mãe e a namorada dela. Nessas cenas em que mostra a relação das três, fica explícito que a namorada da mãe de Ellen exerce a função paterna, tanto com a jovem, quanto com a mãe, impondo limites e separações entre ambas. Essa função ficou nítida quando a anoréxica chega a casa delas em estado debilitado e a madrasta diz que ela dormiria fora 
de casa em uma barraca e na manhã seguinte iria ajudar com os afazeres da fazenda.

Ramalho (2004) esclarece a frágil imagem que as anoréxicas têm de si citando o fato delas se sentirem saciadas apenas nas suas necessidades biológicas e não encontrarem amparo para as demandas psíquicas, ou seja, não Ihes é oferecido um olhar através do qual seria possível um reconhecimento enquanto sujeito. $O$ olhar pode ter acontecido, mas não foi $O$ bastante para saciar Ellen. A ideia de Ramalho pôde ser esclarecida nas situações em que a mãe e a esposa do pai de Ellen tentam "cuidar" dela.

A relação mãe-bebê vivenciada no filme foi constituída com vários vazios, desde os primeiros meses da filha, a mãe relata que elas "não tinham uma ligação", não era conectadas e isso repercutiu como abandono no mundo interno da garota. Ao decorrer da infância e da adolescência, fase retratada no filme, ela passa por outras experiências de abandono que reforçam os sentimentos da relação primária.

A anoréxica vivencia uma "batalha interna" entre o desejo de independência e a real e considerável dependência materna. É valido acrescentar que, muitas vezes, como apresentado no filme, não se pode contar com a ajuda de um terceiro membro - função paterna - adentrando na relação.

A relação mãe-bebê é trazida a tona nas cenas finais do filme, onde a mãe de Ellen inicia uma conversa sincera com a filha, se demonstrando arrependida, e sentindo-se culpada pela doença. A mãe desabafa nunca ter sentido uma conexão com a menina ainda bebê, principalmente enquanto a alimentava. Para CELERI (2005) a ocorrência de uma possível falha na relação entre mãe e bebê - no processo de individualização e de construção do mundo externo - contribui para o desfecho da anorexia.

A cena mais tocante do filme se dá quando a mãe propõe de alimentar a filha com a mamadeira, ela resiste, mas logo demonstra desejo em ser alimentada. Para Fonseca (2013) o comer é tido como ato simbólico, presente na relação entre o bebê e o mundo externo. Após o nascimento, um dos primeiros contatos psíquico e físico é com o seio materno, através dele, a criança ingere muito mais do que o leite.

Ellen deita no colo materno feito um bebê totalmente dependente daquela mãe para se alimentar, conhecer o mundo e tornar-se uma pessoa separada dela. É nessa cena da mamada que as duas são capazes de reeditar uma experiência perturbada para ambas e assim, vivenciarem o primeiro laço humano afetivo. É por meio da alimentação que se dá o primeiro vinculo entre a mãe e 0 filho, situação necessária para o desenvolvimento da criança. $O$ alimentar é essencial na vida de todos nós, principalmente do bebê, por sustentar seu bem estar físico e psíquico refletindo na relação com o meio. (Fonseca, 2013). 


\section{CONSIDERAÇÕES FINAIS}

Conclui-se que a relação materna vivenciada no filme foi perturbada, devido à dificuldade da mãe em se "conectar" com Ellen. É especificamente nessa falta de conexão que surgem os transtornos alimentares. Se a mãe é psiquicamente incapaz de conectar-se, ela interpretará os sinais dele segundo suas necessidades. Com isso, o bebê se desenvolve em uma relação simbiótica, ou seja, dependente do objeto primário (FERNANDES, 2006).

A relação materna mostrada no filme também é simbiótica, ou seja, não houve a cisão psíquica, retardando a conquista da alteridade. O pai de Ellen não aparece em nenhum momento do filme e seria através desse terceiro que o limite na relação entre mãe e filha atuaria. Para a autora Fonseca (2013), com a entrada do pai, a mãe perde a condição de alusão fálica e da abordagem objetal de seu bebê. É essencial que esse lugar ao pai seja dado, para que o bebê seja capaz de desejar o Outro terceiro, deixando a relação primária. Essa transição psíquica permitiria a jovem o fim da condição de prolongamento do corpo materno, a partir disso, se tornaria um sujeito desejante. Nitidamente, a ausência do terceiro responsável pela função paterna prejudicou o desenvolvimento psíquico saudável da jovem.

No desenvolvimento da anorexia, a função materna exerce influências e pode tornar-se uma consequência, pois as portadoras desse transtorno alimentar anseiam por um limite na relação mãe-bebê e realizam tal desejo negando a comida, recusando a se alimentar. Para Fonseca (2013), o comportamento invasivo da mãe tem como consequência tal recusa, é como se a anoréxica, através disso, obtivesse o controle dessa relação.

A recusa das anoréxicas é entendida por Fernandes (2006) como uma ocultação do desejo. A sensação de fome aparente ser erotizada em si mesma, ao privar-se de se alimentar, Ellen desafia suas necessidades vitais. É tida como recusa de si mesma, mas igualmente em relação à figura materna ou paterna.

\section{REFERÊNCIAS}

ARCANGIOLI, A.M. Introdução à obra de WINNICOTT. In: Introdução às obras de Freud, Ferenczi, Groddeck, Klein, Winnicott, Dolto, Lacan. Transmissão da Psicanálise - 41. Rio de Janeiro: Jorge Zahar; 1995.

Aumont, J. \& Marie, M. (2004). A análise do filme. Rio de Janeiro: Texto e Grafia.

BOMFIM, Irma Helena Ferreira Benate. Narrativas Maternas: um estudo transcultural com mães brasileiras e francesas. 2014, 338 f. Tese em 
Psicologia. Faculdade de Filosofia, Ciências e Letras da USP, Ribeirão Preto, 2014.

BELL, R. M.. Holly anorexia. Chicago: University of Chicago, 1985

BUSSE, S. R. Anorexia, bulimia e obesidade. Barueri: Manole, 2004.

BYNUM, C.W. Holy feast and holy fast. Londres: University of California Press, 1987.

BIDAUD, E. Anorexia mental, ascese, mística: uma abordagem psicanalítica. Rio de Janeiro: Companhia de Freud, 1998.

BIDAUD, E. Anorexia. Rio de Janeiro: Companhia de Freud, 1998.

CORDÁS, T.A. (2004). Transtornos alimentares: classificação e diagnóstico. Revista de Psiquiatria Clínica, 31 (4), p. 154-157, 2004.

CORDÁS, T.A.; CLAUDINO, A.M. Transtornos alimentares: fundamentos históricos. Rev. Bras. Psiquiatr., São Paulo, n. 24 (Supl III), p. 3-6, 2002. Acesso: 15 de setembro de 2019. Disponível em: http://www.scielo.br/pdf/rbp/v24s3/13963.pdf.

FAVA MV; PERES RS. Do vazio mental ao vazio corporal: um olhar psicanalítico sobre as comunidades virtuais pró-anorexia. Paidéia set.-dez. 2011, 21(50):353-61. [acesso 9 jun. 2020]. Disponível em: http://www.scielo.br/pdf/paideia/v21n50/08.pdf

FREITAS, S. Transtornos Alimentares: Introdução, diagnostico, epidemiologia e etiologia. In: BRASIL, M.A.A; BOTEGA, N.J. (Org.). Programa de Educação Continuada ABP Brasil. Rio de Janeiro: Guanabara Koogan, 2004.

FONSECA, G. S. Anorexia. Recusa do corpo? - UNIJUÍ - Rio Grande do Sul. 2013.

FONSECA,S. L.; RENA, L. C. C. B. Transtornos alimentares na Adolescência: Em busca do corpo ideal. Mosaico: estudos em Psicologia v. I $\mathrm{n}^{\circ} .1,2008$.

GIARD. L. Artes de nutrir. In M. Certeau (Org.), A inv enção do cotidiano 2: morar, cozinhar (pp. 211-233). Rio de Janeiro: Vozes, 1998.

GIL, A. C. Como elaborar projetos de pesquisa. São Paulo: Atlas, 2008.

GUIMARÃES IMC. A relação mãe e filha e os impasses no caminho da feminilidade. Dissertação de Mestrado - PUC - Rio. Rio de Janeiro, 2013. [acesso 10 jun. 2020]. Disponível em: http://www.maxwell.vrac.pucrio.br/22243/22243.PDF

RAMALHO RM. A escuta da palavra silenciada na anorexia e na bulimia. 2004. [acesso 22 maio. 2020]. Disponível em:

http://www.convergenciafreudlacan.org/inove4/php/download.php?id_rel=77 
HABERMAS, T. Friderada: a Case of Miraculous Fasting. Int J Eat Disord 5: 555-62, 1986.

HUMBERG, L. V. Dependência do vínculo: uma releitura do conceito de codependência. 2004. Dissertação (mestrado em Fisiopatologia)-Faculdade de Medicina, Universidade de São Paulo, São Paulo, 2004.

IJ Sena, MLSO Farias. Função paterna e adolescência em suas relações com a violência escolar. Rev mal est subj. 2010;10(1):117-136.

MANNONI, M. Instituição Psiquiátrica e Psicanálise II - Um caso de anorexia mental. In: O psiquiatra, seu louco e a psicanálise. Rio de Janeiro: Zahar, 1971.

Manual diagnóstico e estatístico de transtornos mentais: DSM-5. Tradução de: Maria Inês Corrêa Nascimento et al. Revisão técnica: Aristides Volpato Cordioli et al. Ed. 5. Porto Alegre: Artmed, 2014.

MATHEUS TC. Adolescência: clínica psicanalítica. São Paulo: Casa Psi Livraria; 2007.

Miranda, M. R. A complexidade da relação mãe-filha nos transtornos alimentares: um olhar da psicanálise. In CEPPAN - Revista de Transtornos Alimentares, no 04, p. 7-9, 2009.

MIRANDA, M. R. Em busca das palavras perdidas - Corpo-carcereiro da mente nos distúrbios alimentares. In Revista IDE, Linguagem II, $\mathrm{n}^{\circ} 45$, vol. 30, p. 28-34, 2007.

OLIVEIRA DM; FULGENCIO LP. Contribuições para o estudo da adolescência sob a ótica de Winnicott para a educação. Psic em rev. 2010;16(1):64-80.

OLIVEIRA, Jonas Gomes; CARVALHO, Barbara Raquel; ROSA, Helena Carolina; SANTOS, Lourisnédia E.; MOURA, Thais Alves; MOREIRA, Nayanny Sampaio. A anorexia nervosa na adolescência e suas consequências na imagem corporal: um olhar psicanalítico. Cadernos Brasileiros de Saúde Mental, ISSN 1984-2147, Florianópolis, v.5, n.12, p. 40-59, 2013. Disponível em: http://stat.elogo.incubadora.ufsc.br/index.php/cbsm/article/view/1632/3186 Acesso em 15 de abril de 2019.

Organização Mundial da Saúde. CID-10 Classificação Estatística Internacional de Doenças e Problemas Relacionados à Saúde. 10a rev. São Paulo: Universidade de São Paulo; 1997. vol.2.

SANTOS, M.A.B. Transtornos Alimentares: da compulsão à recusa, a vivência da dor emocional no corpo. Ribeirão Preto: Sociedade Brasileira de Psicanalise de Ribeirão Preto - SBPRP, 2017.

RAIMBAULT, G.; ELIACHEF, C. Las indomables. Figuras de la anorexía. 
Buenos Aires: Nueva Visión, 1991.

ROSENBERG, A. M. S. A constituição do sujeito e o lugar dos pais na análise com crianças. In: $O$ lugar dos pais na psicanálise de crianças. São Paulo: Escuta, p. 21-60, 1994.

VASCONCELOS, R. M. de A. R. L. Autismo Infantil: a importância do tratamento precoce. $2009 . \quad$ Disponível em: http://www.abrapso.org.br/siteprincipal/images/Anais_XVENABRAPSO/76.\%20 autismo\%20infantil\%20-

\%20a\%20import\%C2ncia\%20do\%20tratamento\%20precoce.pdf

VIGLIETTI, G. V. Os pais na anorexia nervosa. Uma abordagem psicanalítica. Revista Brasileira de Psicanálise, p.25-42, 2001.

VANDEREYCHEN. W, Ron Van Deth. From fasting saints to anorexic girls: the history of self-starvation. New York: University Press; 1994.

WEINBERG, C. Do altar às passarelas - da anorexia santa à anorexia nervosa. São Paulo: Annablume, 2004.

WEINBERG, C.; CORDÁS, T. A;. MUNOZ, P. A. Santa Rosa de Lima: uma santa anoréxica na América Latina? Revista. Psiquiátrica. RS, p.51-56, 2005. Acesso: $\quad 15 \quad$ abr 2019.2 Disponível em: http://www.scielo.br/pdf/rprs/v27n1/v27n1a06.pdf

WINNICOTT, D. W. A criança e seu mundo (6a ed.). Rio de Janeiro: Guanabara, 1982.

WINNICOTT, D. W. (1945). Desenvolvimento emocional primitivo. In: Da pediatria à psicanálise: obras escolhidas. Rio de Janeiro: Imago, 2000, cap. 12, p. 218-232.

WINNICOTT, D. W. (1956). A preocupação materna primária. In: Da pediatria à psicanálise: obras escolhidas. Rio de Janeiro: Imago, 2000, cap. 24, p. 399-405. 


\title{
REVISÃO DOS IMPACTOS DO ABANDONO AFETIVO ENTRE PAIS E FILHOS PELO USO DA TECNOLOGIA
}

\author{
Clara Cunha Procopio \\ Isabela Duzzi Cintra \\ Stefania Gonçalves Stefani Silva \\ Sofia Muniz Alves Gracioli
}

\section{INTRODUÇÃO}

A sociedade contemporânea é caracterizada sobre o avanço da tecnologia, e a crescente proliferação dessa era digital. Assim, identifica-se que a introdução da tecnologia foi significativa na sociedade moderna e teve muitas contribuições com todo seu avanço. O uso da tecnologia está cada vez mais freqüente nas atividades humanas, sendo um assunto de maior prevalência em todos os tipos de contexto, principalmente no âmbito familiar.

A partir disso, é possível perceber que no ambiente familiar um bebê já nasce inserido em meio a tantos celulares, televisões e todos os outros tipos de tecnologia, o que cada vez mais afeta a sua vida pessoal e o desenvolvimento da criança, visto que, os pais depositam todo o seu tempo nos aparelhos e esquecem a importância de proporcionar afetividade aos seus filhos, gerando conseqüências de abandono afetivo.

O tema tem como importância de analisar os impactos que o abandono afetivo pode causar em uma criança, em conseqüência do uso da tecnologia por parte dos pais, gerado pelo interesse de passar mais tempo fazendo o uso de algum tipo de tecnologia, ao invés de utilizar esse tempo junto do seu filho. E a forma que os pais utilizam a tecnologia para suprir as necessidades da criança, como o brincar, fazendo com que desenvolvam impactos cognitivos e emocionais no desenvolvimento da criança.

Atualmente, levando em consideração a correria do dia-a-dia na vida dos pais, o abandono afetivo é um aspecto pouco comentado, visto que, acaba sendo uma coisa natural e despercebida. Porém, deve-se lembrar em todos os momentos de exaustão em que os pais preferem que os filhos permanecem em celular, computador, videogame e televisão do que fiquem juntos realizando alguma outra tarefa, essa ausência dos pais pode acabar influenciando para que os filhos supram essa falta com outras coisas futuramente.

Dessa forma, o objetivo do perante artigo é revisar o impacto da tecnologia nas relações pais e filhos na infância. A metodologia do trabalho 
será uma revisão bibliográfica crítica, fazendo uso de artigos científicos e livros da área.

\section{TECNOLOGIA NOS DIAS ATUAIS}

A tecnologia nos dias atuais adotou um caráter diferente dos quais se tinha no início, ela inicialmente era mais voltada para pesquisas ou compartilhamento de informações, e dirigida somente para um grupo muito restrito de pessoas. Pode-se observar que a tecnologia na atualidade, atingiu um maior alcance de pessoas, na qual o seu acesso se tornou muito fácil para a sociedade contemporânea, tendo como objetivo ainda de ajudar a compartilhar informações e na realização de pesquisas, porém, ela também se tornou uma forma de lazer e diversão. No entanto, as pessoas estão cada vez mais gastando seu tempo em sua utilização, e esquecendo suas relações pessoais e presenciais.

A relação do homem com tecnologia surge a partir das necessidades humanas, pois, passa a ser considerada uma ciência aplicada para a resolução dos problemas. Dessa forma, fez se necessária em todos os setores das atividades humanas. Lévy (1999), afirma que a tecnologia é considerada importante devido à significação que damos a elas.

Com o tempo a tecnologia passou por uma reestruturação, ocupando uma posição de grande importância na sociedade atual, passando a interferir em todos os contextos e relações sociais. Segundo Avena e Rabinovich (2016), a família encontra-se em um tempo histórico que devido às transformações e todo o avanço não poderia deixar de ser afetada.

Thomazini e Goulart (2018), com essa idéia, constatam que as relações humanas são diretamente afetadas pela tecnologia, ocasionando principalmente no distanciando da essência das interações pessoais. Em conseqüência disso, as crianças já nascem inseridas em meio toda essa tecnologia, devido às influências do seu contexto familiar. Paiva e Costa (2015) apontam que as crianças que nasceram no século XXI, nasceram em uma época onde a tecnologia tem grande importância na manutenção das relações sociais, o que torna impossível viver sem ela.

O uso da tecnologia por meio da telecomunicação, como celulares, computadores e todos os outros tipos, no início tinha por finalidade de manter relações, ou seja, comunicações à distância, algo realmente necessário entre as empresas. Contudo, a tecnologia ganhou espaço em diversas áreas da humanidade, no qual passaram a utilizar como forma de lazer e entretenimento, porém, no decorrer do tempo e com todos os avanços o uso tornou se parte do cotidiano das pessoas, atingindo uma capacidade inadequada e excessiva devido a sua utilização, sendo capaz de substituir pessoas e interações sociais. Paiva e Costa (2015) ressaltam 
que a tecnologia substitui de maneira silenciosa hábitos comuns de interação física com pessoas e com o meio ambiente.

No entanto, a realidade encontra se distorcida do que era proposto inicialmente pelo uso da tecnologia, devido à superficialidade das relações que são estabelecidas através do mundo virtual.

De acordo com Piaget:

O homem é um ser essencialmente social, impossível, portanto, de ser pensado fora do contexto da sociedade em que nasce e vive. Em outra palavra, o homem não social, o homem considerado como molécula isolada do resto dos seus semelhantes, o homem visto como independente das influências dos diversos grupos que frequenta, o homem visto como imune aos legados da história e da tradição esse homem simplesmente não existe (PIAGET apud LA TAILLE et al, 1992, p.11).

Dessa forma, é possível perceber que o ser humano necessita do convívio social, porém com todo esse cenário fica impossível distanciar da grande massa tecnológica, e parte dessa população afetada enfrenta 0 distanciamento afetivo, principalmente o âmbito familiar.

De acordo com uma pesquisa realizada pela revista crescer, eles obtiveram o seguinte resultado.

\begin{abstract}
Uma pesquisa realizada com 1.521 crianças de 6 a 12 anos pela Highlights, uma revista infantil norte-americana, mostrou que $62 \%$ das crianças reclamam que os pais estão distraídos demais para ouvi-las. E - surpresa! - os celulares são os principais responsáveis por isso. Em $28 \%$ dos casos, pais e mães estavam tão entretidos com 0 aparelho que mal prestavam atenção aos filhos. E não é só: juntos, celulares, TV's, smartphones e tablets foram a causa desse distanciamento entre filhos e pais em $51 \%$ dos casos. (SALEH, 2014, $\mathrm{s} / \mathrm{p})$.
\end{abstract}

Frente a isso, a influência dos dispositivos móveis na dinâmica da família contemporânea vem ocupando espaço na interação, alterando as estruturas e funcionamento nas relações entre pais e filhos, dificultando uma relação saudável e afetiva entre ambos.

Ao percorrer por toda a literatura, nota se que os pais vêm passando mais tempo fazendo o uso das tecnologias do que tendo momentos com seus filhos, dessa maneira pode ser ressaltado o abandono afetivo, que é uma conseqüência desse uso e que usualmente traz grandes conseqüências na vida da criança.

\title{
3. RELAÇÃO E CONSEQUÊNCIAS DA TECNOLOGIA ENTRE PAIS E FILHOS
}

A concepção de família é adquirida logo no início da descoberta de uma gravidez, com isso, os futuros pais já começam a pensar sobre suas responsabilidades como provedores. São de saber comum que os pais são os 
principais na formação da educação, do respeito, da higiene e de toda a base essencial para seus filhos.

Com o surgimento e o avanço da tecnologia, é possível perceber os impactos que ela produziu no contexto familiar. É muito destacado na literatura o vício das crianças e adolescentes sobre o uso de aparelhos digitais, mas pouco se fala sobre o constante uso que os pais também fazem e a conseqüência do abandono afetivo que pode ser causado.

Atualmente, é possível perceber o condicionamento das famílias em virtude dessa era digital, que corresponde esse descuido dos pais em relação ao convívio com os filhos. Dessa maneira, as famílias estão sofrendo grandes impactos e mudanças, com relação a todos esses fatores que o uso da tecnologia provoca na relação entre pais e filhos. Segundo Bonfim e Pedroso (2017) a negligência afetiva se faz cada vez mais presente, devido os pais passarem mais tempo num mundo totalmente virtual.

A falta de responsabilidade e de cuidado dos pais principalmente na fase de desenvolvimento dos filhos pode acarretar conseqüências totalmente prejudiciais na formação da identidade, e durante todo o processo de crescimento na vida social dessa criança.

De acordo com Chalita:

A família tem a responsabilidade de formar o caráter, de educar para os desafios da vida, de perpetuar valores éticos e morais. Os filhos se espelhando nos pais e os pais desenvolvendo a cumplicidade com os filhos. [...] A preparação para a vida, a formação da pessoa, a construção do ser são responsabilidades da família. É essa a célulamãe da sociedade, em que os conflitos necessários não destroem o ambiente saudável. (CHALITA, 2001, p. 20).

O abandono afetivo consiste na omissão dos genitores (pai ou mãe) em não realizar o dever de cuidado à criança, ou seja, trata-se da falta de comprometimento dos pais sobre a educação e criação do mesmo. A partir dessa constatação, pode-se notar os prejuízos na relação entre pais e filhos, no qual a responsabilidade dos pais em construir uma boa estrutura familiar e garantir melhor qualidade de vida psíquica e moral aos filhos encontra-se na atualidade depreciativa em relação ao convívio familiar.

A família é o primeiro contato da criança com o mundo que a cerca, é ela que faz a mediação e a apresentação da criança com o mundo externo, no entanto os pais estão negligenciando essa relação, causando conseqüências na vida social, no desenvolvimento escolar, na falta de empatia, mudanças no comportamento e problemas emocionais.

Como é ressaltado por Alves, em seu artigo:

As consequências desse abandono são as mais variadas, e incluem estigma de rejeição, de ser ignorado, destrói princípios, desvia o caráter, desestrutura personalidades, destrói a autoestima e a autoconfiança da criança ou do jovem, o que poderá acarretar, no 
futuro, a construção de um adulto desestimulado, que apresenta dificuldades em expressar seus sentimentos, bem como com problemas psíquicos, como por exemplo, depressão, ansiedade, traumas, o que será refletido nas pessoas que convivem com ele. (ALVES, 2013, p.3)

De acordo com Falcão (2019, p.8), seu artigo, diz o seguinte, "embora não haja uma previsão expressa na Carta Magna, a afetividade surge com o enlace do Princípio da Proteção Integral à Criança e o da Dignidade da Pessoa Humana, reconhece-se que o afeto é primordial para o crescimento daquela criança enquanto cidadão e sujeito de direitos". Então, analisando o que é dito pela autora, se nota como a ausência de afeto, principalmente de uma figura parental, pode trazer complicações quanto a formação social desta criança.

Esta mesma autora, ressalta o seguinte,

São jovens que não possuem a devida atenção, orientação e ternura que deveria ser advinda dos pais, passam a procurar diálogos com terceiros, sentem a necessidade de suprir essa carência, seja em um ambiente também virtual ou no uso de remédios, e assim acaba que se forma um ciclo vicioso em que a ausência de afeto pode gerar sujeitos vazios de princípios e inseguros quanto a sentimentos e relações subjetivas. (FALCÃO, 2019. p. 9)

O que é dito sobre a autora, mostra que esse abandono mesmo que ocorra na infância, tem o poder de causar impactos neste indivíduo até sua vida adulta, o que pode acarretar problemas de auto-estima, de personalidade e sociais.

Por meio de todas as conseqüências apontadas, é possível perceber a falta de diálogo entre pais e filhos em virtude da tecnologia que se faz cada vez mais presente no âmbito familiar. De acordo com o Estatuto da

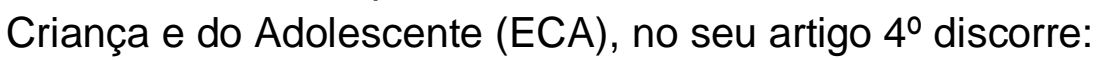

É dever da família, da comunidade, da sociedade em geral e do Poder Público assegurar com absoluta prioridade, a efetivação dos direitos referentes à saúde, à alimentação, à educação, ao esporte, ao lazer, à profissionalização, à cultura, à liberdade e a convivência familiar e comunitária. (BRASIL, 1990)

Diante isso, é fundamental a participação dos pais na vida da criança, a fim de evitar conseqüências irreparáveis. Desta forma, os pais têm por responsabilidade de estabelecer a criança aspecto financeiro e principalmente afetivo, a partir de trocas de experiências, como valores éticos e morais, se tratando sempre com prioridade a educação dos filhos.

\section{CONSIDERAÇÕES FINAIS}

O artigo teve como objetivo de revisar os impactos do abandono afetivo por parte dos pais pelo uso excessivo da tecnologia, e as conseqüências na relação entre pais e filhos. A partir do tema, constata-se que 
na atualidade a tecnologia tornou-se responsável pelo distanciamento entre pais e filhos, devido os pais terem preferência em aproveitar o tempo livre para a utilização do mundo virtual, ao invés de estabelecer relações afetivas aos filhos.

Dessa forma, as conseqüências encontradas na literatura estão inteiramente relacionadas à vida da criança pela falta de responsabilidade dos pais em construir uma relação boa e garantir melhor qualidade de vida psíquica, moral e ética aos filhos.

Além disso, o abandono afetivo no início do desenvolvimento da criança pode acarretar grandes conseqüências futuras, como dificuldades em manter relações sociais, dificuldades na aprendizagem escolar e na vida, pois 0 afeto é de extrema importância para o surgimento de novas relações que a criança estabelece na socialização secundária. A participação afetiva dos pais na vida da criança é fundamental para o bom desempenho escolar e social.

Na perspectiva da psicologia é importante investir em campanhas para a conscientização do impacto da tecnologia nas relações familiares, e a conseqüência dela pelo uso demasiado por parte dos pais, na necessidade de analisar as transformações subjetivas que surgir em virtude dessa nova era tecnológica. Enfatizando as complicações que surgem na vida criança por meio do abandono afetivo.

As dificuldades encontradas para a realização da pesquisa foi na busca de referências bibliográficas sobre o impacto do abandono afetivo sob a utilização da tecnologia por parte dos pais, devido existir de diversas pesquisas referente o uso descontrolado da tecnologia por parte das crianças.

Diante dessa pesquisa, consideramos que seja necessária mais divulgação sobre a importância dos pais aproveitarem o tempo necessário com seus filhos, através de campanhas e palestras. A fim de promover discussões sobre o quanto o uso excessivo da tecnologia influencia e afeta diretamente na relação entre pais e filhos, e destacar principalmente sobre a participação afetiva na vida dos filhos e sobre quantos os filhos sentem essa ausência dos pais e acabam procurando essa falta e atenção em várias outras coisas da vida.

A partir desse artigo pode se desenvolver novas pesquisas com temas relacionados ao abandono afetivo causado especialmente pelo uso constante da tecnologia por parte dos pais, e as conseqüências geradas na vida criança. Ao qual contribuirá na orientação de pais sobre as conseqüências do uso exagerado da tecnologia, e a falta de comprometimento e participação no desenvolvimento da criança. 


\section{REFERÊNCIAS}

ALVES, Taíses Araujo da Silva. Tecnologias de informação e comunicação (tic) nas escolas: da idealização à realidade. Universidade Lusófona de Humanidades e Tecnologias Instituto de Ciências da Educação. Lisboa, 2009. Disponível em:

http://recil.grupolusofona.pt/bitstream/handle/10437/1156/Taises\%20Araujo\%20 -\%20versao\%20final\%20da\%20dissertacao.pdf?sequence=1 Acessado em:

BRASIL. Lei no 8.069, de 13 de julho de 1990. Dispõe sobre o Estatuto da Criança e do Adolescente e dá outras providências. Diário Oficial [da] República Federativa do Brasil, Brasília, DF, 16 jul. 1990. Disponível em: http://www.planalto.gov.br/ccivil_03/leis//8069.htm. Acesso em: 06 de outubro de 2020.

FALCÃO, Leticia Prazeres. O fenômeno da parentalidade distraída e abandono afetivo: quanto custa o cuidado na sociedade tecnológica. 2019. Disponivel em: https://d1 wqtxts1 xzle7.cloudfront.net/61756550/559116413-1-PB_120200112-22976-1ipej75.pdf?1578832272=\&response-contentdisposition=inline\%3B+filename\%3DO_FENOMENO_DA_PARENTALIDADE DISTRAIDA_E.pdf\&Expires $=1599246866 \&$ Signature=UDIP7vDvalFmJSizJK2ul hXpfN0b5vneSzDvyCdBJybq60wft MUrrTAv8pUiJjm--

6nZDazImj4UqFjAng70GgYt1f5EnqaprIQ0r3LEq0vD0yht174J2vJnAR 1j6MOs nj9DskglB6nfV-jPMq5CtjQyNzUBfEWyTczw85rc vi1gjiSJjBnE-5wul9t4Kx8Ps51 mMUyTdPJitnpEx3749BxSKiLHO Q8TJX08XnW6lgO rU 82s4WaerD FUYOhdhEdT4jg XPfQt2IFiyy1oTWgle2DibalPZBBzjnbeYmAKH9udkNJpJmily Z2 1YUP3b8kEbkm3hj5jZqnA_\&Key-Pair-Id=APKAJLOHF5GGSLRBV4ZA. Acesso em: 05 de setembro de 2020.

LA TAILLE, Yves de et al. Piaget, Vygotsky, Wallon: teorias psicogenéticas em discussão. São Paulo: Summus Editorial, 2019. 176 p. Acessado em: 27 de março de 2020.

PAIVA, Natalia Moraes Nolêto de; COSTA,Johnatan da Silva. A influência da tecnologia na infância: desenvolvimento ou ameaça?. 2015. Disponível em:https://www.psicologia.pt/artigos/textos/A0839.pdf. acesso em: 28 de março de 2020.

PEDROSO, Cláudia Maria dos Santos. BONFIM, Evandro Luiz Soares. 0 impacto da tecnologia no ambiente familiar e suas consequências nas escolas. Unifesp, 2017. Disponível em:

http://uniesp.edu.br/sites/_biblioteca/revistas/20171030115836.pdf. Acessado em: 27 de março de 2020.

SALEH, Naíma. A tecnologia está afetando as relações familiares dentro da sua casa? Publicado em 12 dez. 2014. Disponível em: https://revistacrescer.globo.com/Familia/Rotina/noticia/2014/12/tecnologia-estaafetando-relacoes-familiares-dentro-da-sua-casa.html. Acessado em: 27 de março de 2020. 
SILVA, Thayse de Oliveira. SILVA, Lebiam Tamar Gomes. Os impactos sociais, cognitivos e afetivos sobre a geração de adolescentes conectados às tecnologias digitais. Revista psicopedagógica vol.34 no.103. Universidade Federal da Paraíba. João Pessoa, 2017. Disponível em: http://pepsic.bvsalud.org/scielo.php?script=sci_arttext\&pid=S010384862017000100009 . Acessado em: 06 de abril de 2020.

THOMAZINI, Magnus Guerreiro; GOULART, Elias Estevão. Relações familiares: a influência do virtual. 2018. Disponivel em:https://www.researchgate.net/profile/Elias_Goulart/publication/332158948 RELACOES_FAMILIARES_A_INFLUENCIA_DO_VIRTUAL/links/5ca3d90d928 51c8e64aebdb3/RELACOES-FAMILIARES-A-INFLUENCIA-DO-VIRTUAL.pdf. Acesso em: 28 de março de 2020. 


\title{
TRANSTORNO DISSOCIATIVO DE IDENTIDADE ASSOCIADO A EVENTOS TRAUMÁTICOS: um recorte sobre o longa metragem O Segredo de Marrowbone
}

\author{
Bernardo Pereira Cangemi \\ bernardo.p.c.2@gmail.com \\ Julia Lopes Rodrigues \\ jlopesrod17@gmail.com \\ Sofia Muniz Alves Gracioli \\ sofiagracioli@yahoo.com.br
}

\section{INTRODUÇÃO}

A estrutura psicológica é constituída por meios sociais, ambientais e contextuais, além de um meio interno de significativa importância, que se molda na subjetividade e na individualidade humana, contando com fatores conscientes e inconscientes. Dessa maneira, a forma como nos comportamos, pensamos, sentimos e entendemos 0 mundo se desenvolve a partir, principalmente, das condições personalizantes íntimas. Cada ser, em estado de funcionamento mental equilibrado, possui uma exclusiva identidade, que 0 denomina e o diferencia de outros povos, fundamentando o processo de ser único. Em situações diversas, esse funcionamento pode se desequilibrar, rompendo os mecanismos que sustentam o fenômeno mental e ocasionando em transtornos que são contemplados em abordagens como a neuropsicologia, a psiquiatria e a psicopatologia.

$\mathrm{Na}$ atualidade, a psicopatologia se faz presente na psicologia como uma totalidade, inserida em diversos métodos e estudos sobre a mente humana. Os diferentes transtornos psicológicos estão sendo retratados em filmes e séries variados, como Precisamos Falar Sobre Kevin (2011), As Vantagens de ser Invisível (2012), Bates Motel (2013), Atypical (2017), O Mínimo para Viver (2017), Fragmentado (2017), Clinical (2017), Fratura (2019), Coringa (2019) e Por Lugares Incríveis (2020), ganhando espaço cinematográfico mundialmente. Dessa forma, com o filme Marrowbone lançado a apenas três anos desse estudo (2017), e sua associação com Freud, Jung e outros pensadores da Psicopatologia Geral, torna-se o presente artigo científico parte do meio atual de pesquisa e cultura, adentrando na sociedade moderna como forma de integração entre a população e o conhecimento sobre as doenças mentais.

O objetivo do presente trabalho é revisar sobre as definições de Transtorno Dissociativo de Identidade e Transtornos Relacionados a Eventos Traumáticos, vinculados aos mecanismos de defesa psíquica e o EGO, derivados da teoria psicanalítica, além dos conceitos de Jung sobre os 
complexos que levam à regressão da libido, correlacionando tais temas aos devaneios psíquicos do personagem Jack.

A necessidade de investigação do tema se deve à ascensão das patologias psicológicas na sociedade, que passaram a ganhar foco nos assuntos culturais atuais, assim como estão presentes nos indivíduos que se veem retratados nos obras cinematográficas e nos livros. Além disso, se deve ao interesse explícito dos autores do artigo no filme e assunto retratados, sendo avaliado na matéria de Fundamentos e Pesquisa em Psicologia III, pela Professora Doutora Sofia Muniz Alves Gracioli, no $5^{\circ}$ semestre do curso de Psicologia, ministrado no Centro Universitário Municipal de Franca, UniFACEF, em Franca - SP, no primeiro semestre de 2020.

Para investigar e esclarecer o enunciado, utilizou-se uma revisão bibliográfica crítica sobre o Transtorno Dissociativo de Identidade e Transtornos Relacionados a Eventos Traumáticos, relacionando os estudos com a Psicanálise Freudiana, com a teoria Junguiana, além de um recorte do filme $O$ Segredo de Marrowbone e uma análise pessoal entre a correlação dos transtornos e o psiquismo do personagem referido, Jack Marrowbone.

\section{A FORMAÇÃO DA PERSONALIDADE E A HISTÓRIA DE MARROWBONE}

A personalidade é constituída ao longo do desenvolvimento humano, sendo uma constante interação entre fatores biológicos e ambientais que constituem o sujeito, sua maneira de olhar o mundo, sua individualidade e identificações de maneira subjetiva. É integrante do funcionamento psicológico equilibrado dos seres humanos. Para Jung (1875), "a expressão "equilíbrio mental" não é apenas uma figura de linguagem, pois se trata realmente de uma perturbação do equilíbrio entre o conteúdo consciente e inconsciente" (JUNG, 2011).

Considerando as teses de Freud (1856), a personalidade é constituída por três núcleos: o ID, o EGO e o SUPEREGO que interagem completamente entre si, tornando-se praticamente singulares, ainda que possuam seus mecanismos e princípios próprios. Esses sistemas, agindo conjuntamente, concebem o comportamento e a identidade do indivíduo, das quais partes tornam-se conscientes e outras permanecem nos confins da mente, armazenadas no inconsciente.

Simplificando a teoria exposta, o ID é o princípio original da psique e muitas vezes inconsciente, responsável pelo instinto, vontades, desejos, a reserva de energia, buscando sempre a descarga de libido, escape da tensão e o aumento do prazer, o que origina os outros dois itens. Para o criador da obra, "o ID é "a verdadeira realidade psíquica" porque ele representa 
o mundo interno da experiência subjetiva e não tem nenhum conhecimento da realidade objetiva". (CAMPBELL; LINDZEY; HALL, 2000).

Partindo desse aparelho surge o EGO, que "passa a existir porque as necessidades dos organismos requerem transações apropriadas com o mundo objetivo da realidade" (CAMPBELL; LINDZEY; HALL, 2000), seu objetivo é planejar meios para satisfazer as tensões do sujeito no mundo externo, atendendo eventualmente às urgências de prazer de forma realista. De acordo com Jung (1875), "o ego forma o centro crítico da consciência e, de fato, determina com grande medida que conteúdos permanecem no domínio da consciência e quais se retiram, pouco a pouco, para o inconsciente". O Ego, por si, tem instâncias necessárias para assegurar a identidade do indivíduo. Por ter sua energia derivada do ID, o EGO deve mediar suas exigências com o ambiente - quando este estiver apto para corresponder às vontades internas estando em constante inspeção por parte do SUPEREGO.

Essa última unidade é responsável pelos valores morais do ser, influenciado pela cultura, por ideais extrínsecos e intrínsecos, é o mediador da conduta e dos sentimentos, levando a consciência para um estado de recompensas e punições, auto controlando a identidade do indivíduo. De acordo com Campbell:

[...] A personalidade normalmente funciona como um todo, e não como três segmentos separados. De maneira muito geral, o id pode ser pensado como o componente biológico da personalidade, o ego como o componente psicológico e o superego como o componente social. (CAMPBELL; LINDZEY; HALL, 2000, n.p).

Sendo esse o princípio que rege o funcionamento psicológico dos sujeitos, é preciso distinguir a personalidade consciente e inconsciente. A consciência é vital para os humanos e estaria repleta de sentimentos, sentidos, emoções e pensamentos, acessando e participando de tudo o que se passa no meio externo e interno, para Stein (1943), "a consciência é como um quarto cujas quatro paredes cercam o conteúdo psíquico que temporariamente o ocupa. E a consciência precede o ego, o qual se converte, em última instância, no seu centro". Em outra instância, na teoria descrita por Freud, o inconsciente é visto como um depósito de tudo aquilo que não se torna consciente, estruturando os complexos psíquicos que não podem ser propriamente acessados. Na opinião de Zimerman (1930), esse sistema topográfico:

[...] Designa a parte mais arcaica do aparelho psíquico, onde, por meio de uma herança genética, existem pulsões (quando essas nunca emergem nos sistemas consciente e pré-consciente, elas são consideradas como "repressões primárias"), acrescidas das respectivas energias e com "protofantasias". Além disso, o inconsciente também consiste num depósito de repressões secundárias, as quais chegaram a emergir sob forma disfarçada no consciente (como nos sonhos ou sintomas) e voltam a ser reprimidas para o Inconsciente. (ZIMERMAN, 2007, p. 83). 
Entendendo-se, em partes, como a personalidade é formada no viés da psicanálise e partindo do pressuposto de que cada pessoa possui uma identidade única e singular, cita-se Pasquali (1999):

\begin{abstract}
A estrutura e a dinâmica da personalidade se formam, desenvolvem e atuam dentro de dois contextos, a saber, o habitat físico e o habitat cultural. Estes contextos definem a especificidade de ser e de se comportar de cada indivíduo e, portanto, de cada tipo. Embora a estrutura básica do ser humano seja fundamentalmente universal e única, a forma típica de cada sujeito ser e se comportar depende da forma como cada um vivencia estes habitats durante a história do seu desenvolvimento como ser humano. [...] Os contextos não fazem parte da estrutura originária, das potencialidades do ser humano, mas eles são elementos essenciais e estruturantes da personalidade deste mesmo ser. (PASQUALI, 1999, p. 31).
\end{abstract}

O longa metragem $O$ Segredo de Marrowbone (El Secreto de Marrowbone) foi dirigido por Sergio G. Sánchez e teve sua estreia mundial em outubro de 2017, com o país de origem a Espanha, possui 110 minutos e se encaixa nos gêneros drama, suspense e terror. Apresenta, em todo o enredo, duas grandes questões: por que todos os espelhos da casa são cobertos e evitados? Qual o segredo perturbador existente no sótão?

O filme retrata a história de uma família que se acomoda em um casarão na zona rural americana, fugindo do pai e buscando um recomeço. Após a morte da mãe, os quatro irmãos (Jack, Billy, Jane e Sam) se escondem para que não sejam levados pelo serviço social, buscando permanecer juntos até que o filho mais velho, Jack (George Mackay), atinja a maioridade, assuma a guarda dos familiares e o controle da moradia. Fica evidente a fuga constante da figura parental masculina, que está em constante conflito com os filhos, perseguindo-os.

Com o desenvolver do filme, os quatro conhecem a vizinha Allie (Anya Taylor-Joy), que se torna uma grande amiga, o romance de Jack e 0 principal contato dos irmãos com o público.

Certo dia, quando o pai aparece no casarão e atira na janela de um dos quartos, Jack vai ao seu encontro, enfrentando-o e tentando devolver uma caixa com dinheiro que o perseguidor tanto procurava. Após um violento conflito, Jack acaba caindo de um penhasco e batendo a cabeça, ficando desacordado. Ao acordar e retornar para a moradia, ele descobre que seu progenitor matou os irmãos e deixou seus cadáveres no sótão. O sobrevivente, então, encarcera o assassino no cômodo, trancando portas, janelas e a saída da chaminé, mantendo-o preso no local.

Após o evento traumático, Jack desenvolve em si as personalidades dos irmãos, assumindo suas identidades, em total estado de negação diante do acontecido, continuando sua rotina normalmente enquanto age inconscientemente como si próprio, Billy, Jane (Mia Goth) e Sam (Matthew Stagg), permitindo que cada uma das identidades assuma a consciência 
quando necessário. Para que não existam brechas em sua defesa psíquica, ele cobre os espelhos, evitando ver sua forma física e torna o sótão estritamente proibido.

O drama é descoberto quando um advogado da cidade mais próxima e empecilho no romance de Jack e Allie, Tom Porter (Kyle Soller), vai até a casa reivindicar algumas papeladas sobre a venda da moradia. Obcecado por seu ciúme, ele investiga a família Marrowbone, descobrindo o passado dos mesmos. Determinado a acabar com a ligação entre os dois personagens citados, Tom decide usar das informações obtidas para chantagear o irmão mais velho. Em certo momento, Porter se dirige até a moradia e começa a quebrar as barreiras que trancavam o sótão, libertando os segredos que lá estavam trancados.

Para que Jack, nesse momento em estado de pânico, consiga deter o pai de cometer mais atrocidades e se libertar do sótão, suas outras personalidades entram em contato com Allie, contando a ela toda a história através de um livro. Allie faz com que o protagonista consiga encarar 0 acontecido e colocar um ponto final na situação.

Após o desfecho do drama, a morte do pai e o enfrentamento do ocorrido com os irmãos, o personagem dá início a um tratamento para conseguir se desvencilhar das outras identidades, contando com o apoio da vizinha, passando a viver apenas como Jack Marrowbone e suas lembranças dos eventos que marcaram sua estrutura psíquica.

\section{TRANSTORNO DISSOCIATIVO DE IDENTIDADE E TRANSTORNOS RELACIONADOS A EVENTOS TRAUMÁTICOS}

A junção dos sistemas descritos por Freud arquiteta a personalidade desde a infância e ao longo do desenvolvimento, atuando em conjunto de fatores sociais e culturais. Além das influências externas, existem aspectos conscientes - como partes que são conhecidas pelo indivíduo e que demonstram noções sobre o próprio "eu", traços familiares e exteriorizados de maneira perceptível -, aspectos inconscientes - tais aqueles que fundamentam a subjetividade do sujeito, sua individualidade de sentimentos, pensamentos, valores, emoções, e as diversas maneiras de se relacionar com o mundo que não são facilmente percebidas, necessitando de uma investigação aprofundada para que sejam captadas - bem como fatores fisiológicos que podem também interferir na organização psíquica.

$\mathrm{Na}$ progressão da personalidade, são esses os princípios que permeiam a constituição psicológica e que atuam no equilíbrio mental dos seres. Em algumas circunstâncias, esse equilíbrio pode sofrer rupturas que ocasionam em transtornos e patologias, prejudicando o funcionamento dos complexos representados pelo psiquismo. Essas circunstâncias podem ser, 
muitas vezes, descritas como traumáticas e tendem a desorganizar a vida mental do sujeito.

O trauma se dá quando a pessoa é submetida a um evento angustiante que gera um nível de estresse que o indivíduo não consegue lidar, sentindo-se emocionalmente sobrecarregado. Esta experiência pode ser intensa a ponto de afetar os comportamentos, pensamentos e sentimentos da vítima. Geralmente, os traumas são associados a situações de violência, como assaltos, estupros, guerras, mortes inesperadas na família ou outras situações que causam um desgaste emocional e culpa em demasia.

As perturbações dissociativas estão associadas diretamente aos eventos traumáticos e que não há TDI sem a presença de traumas reais, reincidentes e graves. Esses traumas resultam em processos dissociativos e permitem a emersão de estados alterados de consciência. (ANDRADE; FILHO; MARTINS, 2017, p. 120, apud Putnam, Ross e Steinberg, 1989, p. 44)

O conceito de trauma psíquico é compreendido como consequência de um acontecimento que abalou de tal forma o indivíduo, que provoca modificações consideráveis no seu modo de funcionamento psíquico. Consequentemente, o indivíduo traumatizado tentará evitar ao máximo, consciente ou inconscientemente, relembrar um fato ligado ao que the foi traumatizante.

Em decorrência dessa perturbação, o sujeito pode vir a apresentar um quadro de Transtorno de Estresse Pós-traumático, onde as principais características são o desenvolvimento de sintomas após a exposição a um evento traumático. Segundo o DSM V (2014), esses sintomas podem variar entre: revivência do medo, estados de humor anedônicos ou disfóricos e cognições negativas, excitação e sintomas reativos externalizantes, hipervigilância e, por fim, sintomas dissociativos. Algumas pessoas exibem combinações desses sintomas.

A experiência traumática pode ser revivida de diversas maneiras através de memórias intrusivas e involuntárias do evento, sonhos angustiantes e até estados dissociativos, que podem durar desde alguns segundo até dias. Durante esses estados, o indivíduo se comporta como se de fato estivesse revivendo o momento e pode ter desde intrusões visuais ou sensoriais breves de parte do evento traumático até uma perda total de realidade e do ambiente ao seu redor.

Consequentemente ao trauma, a dissociação muitas vezes é interpretada como um mecanismo de defesa, sendo este um conceito teórico que diz respeito ao controle de informações capazes de provocar ansiedade ou sofrimento. Seguindo um viés psicanalítico, concluímos que esse mecanismo ocorre, ainda que inconscientemente, de forma proposital para que o Ego seja 
poupado de um possível desprazer psíquico ocasionado por algum medo, culpa, evento traumático ou qualquer outra manifestação perigosa ao Ego.

Em conformidade com o DSM-IV (2014), os transtornos dissociativos são qualificados como "perturbação e/ou descontinuidade da integração normal de consciência, memória, identidade, emoção, percepção, representação corporal, controle motor e comportamento". O Transtorno de Dissociação de Identidade é caracterizado pela presença de dois ou mais estados de personalidade distintos ou uma experiência de possessão, que varia quanto à função psicológica e aos períodos de aparecimento.

Segundo Andrade, Filho e Martins (2017, p. 120, apud Mari e Kieling, 2013, n.p), a maior parte dos portadores desse transtorno são mulheres, apresentam um histórico de abuso sexual ou físico na infância e possuem comorbidade com outros transtornos mentais e abuso de substâncias.

Conforme o exposto, compreende-se que a psique, confrontada por eventos traumáticos, concebe formas internas de defender sua vida mental, de maneira a permear a preservação da personalidade. Essa proteção consiste em mecanismos diversos que são evocados pelo Ego, e podem ser compostos por repressões, dissociações, adesão de identidades ou comportamentos histéricos e desequilibrados. Assim, a partir do estudo das psicopatologias e das teses prescritas por Freud, realiza-se a ponderação sobre os vínculos entre os transtornos pós-traumáticos adquiridos por Jack Marrowbone.

\section{JACK MARROWBONE E A DISSOCIAÇÃO DA IDENTIDADE}

No longa metragem El Secreto de Marrowbone (2017), o personagem principal Jack Marrowbone é quem sofre com as perturbações psíquicas derivadas de situações desconcertantes em momentos de sua vida. É válido ressaltar que as alterações e os traumas mentais serão analisados a partir de uma visão psicológica, excludente a fisiológica, uma vez que não se voltaram as variações biológicas derivadas dos acontecidos.

No início do filme é possível perceber, através de uma análise conjunta, como a personalidade do protagonista é estável, sua identidade é singularizada, única e diferenciada. Essa instância é prorrogada durante diversas cenas.

Com a morte de sua mãe, o objetivo marcante de sua individualidade passa a ser proteger Sam, Jane e Billy até que alcance a maioridade e possa assumir a guarda destes, evitando a separação familiar. $O$ funcionamento mental de Jack começa a sofrer mutações após o encontro traumático e violento com o pai. Tomado pela irracionalidade ao se deparar com seus irmãos assassinados e jogados no sótão, a consciência de Jack é 
retirada da realidade, e ele cria defesas internas e externas para se proteger do trauma vivenciado.

As defesas externas dão origem às barreiras construídas nas saídas que dão acesso ao local, encarcerando e reprimindo o acontecido ao sótão. Internamente, seu Ego aciona mecanismos de defesa psíquica para lidar com o evento traumático, sendo estes designados à repressão e a dissociação, buscando preservar a sanidade de Jack. Esses mecanismos são caracterizados como:

[...] processos subconscientes desenvolvidos pela personalidade, os quais possibilitam a mente desenvolver uma solução para conflitos, ansiedades, hostilidades, impulsos agressivos, ressentimentos e frustrações não solucionados ao nível da consciência. [...] Sua afinidade é tentar defender-se, estabelecer compromissos entre impulsos conflitantes e aliviar tensões internas. (SILVA, 2011, p. 0102).

É a partir da defesa do Ego que seu psiquismo origina as dissociações, que são para a teoria psicanalítica, um "mecanismo considerado proposital, ainda que inconsciente, podendo ser desencadeado por eventos específicos ou se apresentar como traço de personalidade" (JUNIOR, PALLADINO-NEGRO, LOUZÃ. 1999).

No caso de Jack, a defesa é transformada em um ciclo selado com excelência, na qual a dissociação vem unida com a repressão, sendo notável a atuação dessa defesa, buscando cindir os acontecidos na realidade com a percepção do protagonista, que reprimindo o sofrimento desencadeado, consegue seguir sua rotina normalmente. A repressão é um mecanismo comum de defesa, que objetiva em afastar determinadas fantasias, sentimentos, pensamentos, acontecimentos da consciência, mantendo-os no inconsciente, inacessíveis.

Para que sua dissociação e repressão não apresentem falhas, as personalidades de seus irmãos são inseridas em sua vida mental, e o personagem principal assume suas identidades, deixando-o presentes em vivência interna. As identidades apoderam-se sucessivamente da consciência como forma de mecanismo de defesa contra os eventos traumáticos (a morte da mãe e dos irmãos e o confronto com o pai) e, por conseguinte, atuam como se ainda estivessem vivos na realidade do filme, mesmo que apenas através do corpo e mente de Jack.

É notável a cisão das personalidades quando, na cena clímax da história, Jack está dialogando com Jane e Billy, escondido em sua cabana de cobertores (feita por Sam, o mais novo, como um abrigo) e, para interpretar cada persona, muda constantemente de lugar, além de assumir comportamentos e falas características de cada um. Para ele, interpreta-se como cada irmão presente no local, conversando entre si. Para quem assiste, é 
apenas o único personagem vivo se deslocando sobre o cômodo enquanto interpreta os outros.

Em outra cena, há uma discussão entre os personagens mais velhos, enquanto o caçula assiste o conflito se desencadeando. Ao entrarem em total discordância, J. Marrowbone sente uma intensa dor de cabeça, especificamente na área envolta por uma cicatriz (que foi ganha durante 0 enfrentamento com o pai e a queda de Jack), desmaiando em seguida. Ao que se apreende dessa representação, seria como se o psiquismo do intérprete cedesse à turbulenta pressão acarretada pela confusão de suas personalidades.

Para Carl Gustav Jung (1875), pensador e criador da Teoria Analítica Junguiana, a energia psíquica corresponde ao impulso permanente da vida, que se manifesta no sistema mental fechado, e tem seu potencial energético transformado enquanto o ser está em constante desenvolvimento. A energia, ou libido, é a força que rege e movimenta o âmago da psique, "[...] é um conceito abstrato de relações de movimento, algo inapreensível, um $X$, comparável (mas não idêntica) à energia física" (SILVEIRA, 1981). O movimento da libido pode se prender a nós, que não se desfazem e permeiam a personalidade, chamados de complexos.

\begin{abstract}
Os complexos são agrupamentos de conteúdos psíquicos carregados de afetividade. Compõem-se primariamente de um núcleo possuidor de intensa carga afetiva. Secundariamente estabelecem-se associações com outros elementos afins, cuja coesão em torno do núcleo é mantida pelo afeto comum a seus elementos. Formam-se assim verdadeiras unidades vivas, capazes de existência autônoma. Segundo a força de sua carga energética, o complexo torna-se um ímã para todo fenômeno psíquico que ocorra ao alcance de seu campo de atração. (SILVEIRA, 1981, p. 30).
\end{abstract}

Complexos são formados por marcas de acontecimentos, frutos de conflitos da primeira infância ou do presente: choques e traumas. Entretanto, é necessário esclarecer que os complexos não são ao todo negativos ou doentios, podendo desempenhar funções positivas. Somente quando sugam qualidades excessivas de energia psíquica é que se tornam patológicos. (SILVEIRA, 2011). Há, também, a concepção de "regressão da libido", em que o Ego não é capaz de lidar com as situações vivenciadas e, por isso, a energia fica estagnada, recuando para o interior e acionando conteúdos inconscientes.

Esse movimento de regredir e analisar o complexo desencadeante dessa condição é natural, uma noção de "retornar e trabalhar no que se torna impossível de lidar sem recuo". Entretanto, converte-se ao mórbido quando implica prejuízo na dinâmica do indivíduo, enrijece e não progride, continuando no lugar de complexo inabordável.

Constata-se, a partir do exposto, que a energia psíquica de Jack é entrelaçada em um complexo, formulado a partir da impossibilidade de 
confrontar e resolver a situação traumática, que origina os mecanismos de defesa mental. É interiorizando as identidades de seus irmãos que o protagonista consegue continuar vivo cognitivamente, sem afundar-se ao caos psíquico da perda de seus entes, prosseguindo com a estabilidade gerada por suas instâncias patológicas, como a repressão e a dissociação.

\section{CONSIDERAÇÕES FINAIS}

Concluímos que o transtorno dissociativo vivenciado pelo protagonista do filme abordado no presente artigo nos serve para exemplificar e legitimar a teoria de que, na maioria dos casos, as patologias se desenvolvem após o indivíduo experienciar um trauma impossível de ser assimilado por seu aparelho psíquico, uma vez que esses só vêm à tona após Jack ter seus irmãos brutalmente assassinados pelo pai. Vale lembrar que nem toda pessoa que passa por um evento traumático vai, necessariamente, desenvolver os transtornos.

Ressaltamos igualmente que, neste trabalho, foi levada em consideração somente a parte psicológica, desconsiderando quaisquer danos biológicos que podem ter ocorrido durante a queda de Jack após sua briga com o pai.

Sobre o tratamento psicoterápico, deve-se sempre tratar as personalidades de maneira respeitosa e tentar entender o que cada uma representa. O principal objetivo é uni-las, fazendo com que se tornem somente uma (SPIEGEL, 2017).

Também se faz relevante a abordagem do assunto uma vez que 0 público, de forma geral, fica confuso ao ver o filme, visto que não sabem se estão diante de mais uma obra de ficção científica ou de um transtorno real e, através desta revisão bibliográfica, gostaríamos de empoderá-los com um pouco mais de conhecimento científico.

O TDI é um transtorno complexo, com um diagnóstico difícil e uma sintomatologia muito diversificada, havendo poucos estudos a seu respeito e nenhum material científico a respeito do filme. Essa escassez acabou por dificultar um pouco a produção de nosso artigo.

Por fim, destacamos a possibilidade de aprofundamento no tema em um próximo trabalho, em que poderia ser estabelecida uma relação entre os irmãos de Jack e as estruturas mentais postuladas por Freud, na qual Billy faria referência ao ID, Sam ao Ego e Jane ao Superego, podendo aprofundar mais sobre a análise a respeito da correlação de Jack, seu psiquismo e as concepções de grandes pensadores da psicologia. 


\section{REFERÊNCIAS}

ANDRADE, Suellen do Socorro Gomes; FILHO, Nazir Rachid; MARTINS, Suellen de Sousa. TRANSTORNO DISSOCIATIVO DE IDENTIDADE NO FILME FRAGMENTADO: uma análise psicopatológica do personagem Kevin Wendell Crumb. Revista Multidisciplinar Pey Këyo Científico. v. 3, n. 1. p. 113-131. Amapá: Faculdade Estácio de Macapá, 2017. Disponível em: < http://revistaadmmade.estacio.br/index.php/pkcroraima/article/view/4618/2122> . Acesso em 03 de maio de 2020.

AMERICAN PSYCHIATRIC ASSOCIATION. DSM-IV: Manual diagnóstico e estatístico de transtornos mentais. Trad. Maria Inês Corrêa Nascimento; 5 .ed. Porto Alegre: Artmed, 2014.

CAMPBELL, John B.; LINDZEY, Gardner; HALL, Calvin S. Teorias da Personalidade. 4. ed. Porto Alegre: Artmed Editora, 2000. Disponível em: <https://books.google.com.br/books?hl=pt-BR\&lr=\&id=iHYYyG0a8IC\&oi=fnd\&pg=PA7\&dq=teorias + da + personalidade+artigos\&ots=TVEWIqnXg \&sig=DhKxNLVKAQ4queO8RCDyjT0u47E\#v=onepage\&q\&f=false $>$. Acesso em: 14 de fevereiro de 2020.

DALGALARRONDO, Paulo. Psicopatologia e semiologia dos transtornos mentais. 2. ed. Porto Alegre: Artmed, 2008.

JUNIOR, Paulo Jacomo Negro; PALLADINO-NEGRO, Paula; LOUZÃ, Mario Rodrigues. Dissociação e transtornos dissociativos: modelos teóricos. Rev. Bras. Psiquiatr. v. 21, n. 4, p. 239-248. São Paulo: 1999. Disponível em: <http://www.scielo.br/scielo.php?script=sci_arttext\&pid=S151644461999000400014\&Ing=en\&nrm=iso >. Acesso em: 20 de abril de 2020.

JUNG, Carl Gustav. Psicogênese das Doenças Mentais. 4. ed. Petrópolis: Vozes, 2011. (Coleção Obra Completa, vol. 3).

O Segredo de Marrowbone. Direção de Sergio G. Sánchez. Espanha: Lionsgate, 2017. (110 min.).

PASQUALI, Luiz. Os Tipos Humanos: A Teoria da Personalidade. Brasília: UnB, 1999.

SILVA, Elizabete Bianca Tinoco. Mecanismos de Defesa do Ego. Minas Gerais: FUNEDI, 2011.

SILVEIRA, Nise da. JUNG. In: Tipos psicológicos. 7. ed. Rio de Janeiro: Paz e Terra, 1981. (Coleção Vida e Obra, 21). 
SPIEGEL, DAVID. Transtornos dissociativos de identidade. MD, Stanford University School of Medicine, 2017. Disponível em:

$<$ https://www.msdmanuals.com/pt-pt/profissional/transtornos-

psiqui\%C3\%A1tricos/transtornos-dissociativos/transtorno-dissociativo-deidentidade >. Acesso em: 03 de maio de 2020.

STEIN, Murray. Jung: o mapa da alma - uma introdução. 5. ed. São Paulo: Cultrix, 2006.

ZIMERMAN, David E. Fundamentos Psicanalíticos: teoria, técnica e clínica. Porto Alegre: Artmed, 2007. 


\title{
“TRATAMENTO” DE CONVERSÃO DA HOMOSSEXUALIDADE E A PERPETUAÇÃO DA CULTURA HOMOFÓBICA
}

\author{
Caio César de Paula \\ caiocesardepaula1409@gmail.com \\ Sofia Muniz Alves Gracioli \\ sofiagracioli@yahoo.com.br
}

\section{INTRODUÇÃO}

A imposição que a cultura traz para a sociedade é vasta, e os moldes sociais presentes nela permeiam nas relações humanas, o que agrava nos preconceitos e tabus. A necessidade de seguir e estar em um padrão de acordo com o que é pregado como correto, faz com que a sociedade assuma papéis contra todos que não estão de acordo com o aceitável socialmente.

Levando em conta aspectos sociais, morais, jurídicos, antropológicos e subjetivos, a homofobia pode ser entendida como todo um conjunto de práticas e discursos negativos a respeito da homossexualidade (Butler, 2003).

Na contemporaneidade, a homossexualidade ainda é vista como doença, pecado, aberração, ou consequência da criação feita pelos pais, agravando nos constantes ataques homofóbicos que resultam em violência física e verbal, e principalmente assassinatos, e há também presente na sociedade tentativas de converter a pessoa homossexual em uma pessoa heterossexual, tanto de maneira compulsória, quanto pela própria pessoa que não aceita sua sexualidade.

\begin{abstract}
Muito mais que um medo ou uma fobia da dissidência da heteronormatividade, a homofobia é movida por um sistema de prazer baseado em crenças e valores advindos da pretensa superioridade da heterossexualidade e suas regulações de gênero diante de outras formas de expressão do erotismo ou da identidade de gênero. Tratase, portanto, de um dispositivo regulatório da sexualidade acionado por discursos e ações que vão desde a sutil invisibilização e segregação a formas violentas de opressão e dominação. (TOLEDO, Lívia Gonsalves; TEIXEIRA FILHO, Fernando Silva, 2013, p. 01).
\end{abstract}

A necessidade de investigação das consequências destes tratamentos de conversão da homossexualidade se deve ao fato de ser algo extremamente comum na sociedade, ainda mais após o debate na Câmara Federal brasileira sobre a permissibilidade de psicólogos oferecerem tratamento de conversão à heterossexualidade para homossexuais, além das consequências para a formação da identidade pessoal e da aceitação da sexualidade que estes indivíduos sofrem, juntamente com abalos psicológicos que potencialmente podem levar à depressão, ansiedade e mais do que comum nestes casos, o suicídio. 
O objetivo do presente trabalho foi pesquisar e enfatizar os impactos sobre pessoas que passaram por qualquer tipo de tratamento para se converterem à heterossexualidade, abordando as consequências tanto para o autoconhecimento, quanto para questões ligadas à saúde mental destes indivíduos.

Para investigar e esclarecer o tema exposto, realizou-se uma revisão bibliográfica crítica com uso de artigos científicos e livros com a finalidade de procurar sobre como os métodos de conversão da homossexualidade são aplicados e como é o processo de autoaceitação do homossexual e o impacto para a perpetuação da homofobia na cultura.

\section{A HOMOSSEXUALIDADE AO LONGO DA HISTÓRIA}

Ao decorrer da história da humanidade, as relações homossexuais ocorreram e possuíram diversos significados e preceitos, por exemplo nas cidades-estados de Atenas, era comum a prática homossexual como forma de conexão afetiva e intelectual, entre os tutores e seus aprendizes, com a permissão dos pais. Segundo Eskridge (1993), também pode-se citar a Roma antiga, em que relações homossexuais eram comuns, desde que quem estivesse na posição ativa fosse mais velho durante a relação sexual.

A homossexualidade foi se caracterizando para outros rumos, a partir da cultura judaica e com a popularização do cristianismo que iniciou a ligação entre homossexual e pecado, o que se perpetua até nos dias atuais, é extremamente comum determinadas entidades cristãs determinarem que 0 homossexual é algo pecaminoso, proibido e sem a graça de Deus. Segundo Eskridge (1993, p. 1450, apud FARO, Julio Pinheiro. 2015, p. 3). Na Idade Média cristã, a Igreja "era espiritualmente contra a relação entre pessoas do mesmo sexo porque dela não poderia resultar a procriação", admitindo, porém, paradoxalmente, "em alguns casos, uniões entre pessoas do mesmo sexo, especialmente entre clérigos". Contos, poemas e cartas eróticos já eram comuns nessa época.

Durante o nazismo, diversas classificações eram dadas aos prisioneiros, e uma destas era a de homossexual, identificada com um triângulo rosa na vestimenta do sujeito, e também uma estrela de Davi amarela e rosa, indicando que o indivíduo é homossexual e judeu, estima-se que $60 \%$ dos homossexuais do holocausto morreram, passavam por diversas experiências, na tentativa de se curarem da homossexualidade. Até mesmo o oficial Ernst Röhm (assumidamente homossexual, amigo de Hitler e primeiro comandante da SA, grupo parlamentar nazista), foi morto durante o holocausto.

No século XIX, a eclosão das teorias biológicas e a razão como resposta para tudo, fizeram com que muitos estudos fossem realizados na 
tentativa de se explicar a homossexualidade, no século XX, inclusive, foram realizados diversos experimentos, como a lobotomia cerebral, a fim de curar a homossexualidade, e claro que houveram diversos protestos para lutar contra essa discriminação e caracterização da homossexualidade como doença.

Em 1973, a Associação Psiquiátrica Americana reconheceu formalmente que a homossexualidade, por si, não é uma doença (Murphy, 1987, p. 195), retirando-a do DSM-II (Manual Diagnóstico e Estatístico de Transtornos Mentais, segunda versão, na sigla em inglês) e substituindo-a por uma nova classificação, perturbação de orientação sexual, criada para aqueles homossexuais angustiados, frustrados com sua orientação sexual, logo, para aqueles que buscavam mudanças ou ajustamentos; na terceira versão do DSM, a classificação possuía o rótulo de homossexualidade egodistônica (Bayer \& Spitzer, 1982, p. 32).

Segundo Guimarães (2011, p. 30, nota 4), em 1975, a Associação Americana de Psicologia também deixou de considerar como doença, distúrbio ou perversão a homossexualidade e, em 1985, o Conselho Federal de Medicina brasileiro tomou a mesma decisão.

Portanto, nota-se que a homossexualidade passou por altos e baixos, houveram épocas em que não haviam qualquer repressão contra a relação sexual entre indivíduos do mesmo sexo, mas também durante grande parte da história da humanidade até nos dias atuais, o homossexual é visto como algo aversivo, chegando ao ponto de o próprio homossexual passar pelo processo de se assumir para a família, o que não ocorre com indivíduos heterossexuais, e as práticas de "cura da homossexualidade" continuam a permear na atualidade.

\section{CONTEXTO EMOCIONAL DO HOMOSSEXUAL}

Ser homossexual, ou demonstrar homossexualidade, é crime em 70 países, lembrando que há 193 países no mundo, há inclusive pena de morte em determinados países. Outro dado contribuinte para a preocupação com o contexto emocional do homossexual é que apenas 27 países do mundo todo permitem a união estável entre casais do mesmo sexo, e em relação à homicídio, no Brasil estima-se ocorra uma morte por homofobia a cada 23 horas, portanto, não é de se espantar que o contexto emocional do homossexual é atingido negativamente devido à cultura brasileira.

A cultura influência no pensamento e ação do homem, pois somos moldados de acordo com o contexto em que nos socializamos, e em relação a cultura brasileira:

Atualmente, o padrão normal em sexualidade, na nossa sociedade, se traduz por diversas regras sociais: ser heterossexual, casar-se na maturidade, encontrar um par que seja igualmente compatível com seu nível educacional e econômico, respeitar a moral, não praticar 
crimes sexuais, usar da pornografia para fins pessoais e privados sem a exploração de outras pessoas etc. (MAIA, 2009, p.268).

Alguns fatores são primordiais em relação a homofobia, em especial a homofobia no Brasil, que são: Família, Escola e Religião, para melhor compreensão destes tópicos, podemos iniciar em relação à família.

\title{
3.1. Homofobia Na Família
}

É comum o preconceito com pessoas que não estão de acordo com o padrão estabelecido, as famílias brasileiras em geral perpetuam a discriminação e os filhos a passam a diante.

\begin{abstract}
Meninos e meninas aprendem, também desde muito cedo, piadas e gozações, apelidos e gestos para dirigirem àqueles e àquelas que não se ajustam aos padrões de gênero e de sexualidade admitidos na cultura em que vivem (LOURO, 2003, p. 19).
\end{abstract}

A partir dos preceitos dos pais, os filhos absorvem e formam as suas opiniões, e claro que grande parte será de acordo com a dos pais, pois crescemos em detrimento dos desejos paternos e maternos, logo, o homossexual muitas vezes não se aceita, pois não quer "envergonhar" os pais, ou então, tem medo de ser expulso de casa, ou até mesmo cresceu em uma família que considera a homossexualidade algo demoníaca e acaba por se reprimir.

\begin{abstract}
A homofobia familiar é um fenômeno que faz parte da vida da comunidade LGBT e que se configura como uma crise cultural ampla, visto que se trata de uma violência inequívoca, mas, ao mesmo tempo, negada e invisibilizada no mundo privado. A família cria punições sobre seus membros homossexuais que vão desde "pequenos desrespeitos a graus variados de exclusão, chegando a ataques brutais que deformam a vida da pessoa gay, ou até a crueldades diretas e indiretas" (Schulman, 2010, p. 70).
\end{abstract}

Portanto, a família se faz presente no processo de autoaceitação do homossexual, tanto como influenciadora para que o sujeito procure tratamentos de conversão homossexual, seja forçado, ou por vontade própria.

\subsection{Homofobia na Escola}

O ambiente escolar deveria ser agradável para todos os estudantes, contudo, é extremamente comum ser um ambiente desfavorável para aqueles que não se sentem incluídos nas normas e regras de convívio, mesmo que muitos não se encaixassem nos padrões devido aos pensamentos que Ihes são ensinados desde casa. Junqueira (2009) reforça que a escola é um lugar de opressão, discriminação e preconceito, onde muitos jovens acabam por evitar corredores, intervalos ou até mesmo de frequentar as aulas devido ao alto índice de rejeição que sofrem. 
O bullying é frequente e na escola é muito comum uma criança que não se adequa aos demais colegas, sofrer intimidação e diversas piadas apenas por não querer partilhar dos mesmos interesses, e muitas vezes como forma de defesa, o sujeito homossexual passa a ter preconceito contra homossexuais, pois assim estará de acordo com a sociedade e não será julgado pelos demais.

Segundo Louro (2000), é comum uma criança estudar desde o ensino fundamental até o médio numa mesma escola, fazendo com que crie laços de amizades desde cedo. Contudo, muitas crianças são excluídas e afastadas pelas demais já nessa fase, por apresentar comportamentos distintos e considerados fora do "normal" para um menino ou menina. Consentida e ensinada na escola, a homofobia expressa-se pelo desprezo, pelo afastamento, pela exposição do ridículo. Como se a homossexualidade fosse "contagiosa", cria-se uma grande resistência em demonstrar simpatia para com sujeitos homossexuais; a aproximação pode ser considerada como uma adesão a tal prática ou identidade.

A escola se faz presente em grande parte do desenvolvimento da personalidade do indivíduo, e sendo na maioria das vezes um ambiente homofóbico, acaba se tornando mais um fator que atrasa a autoaceitação da sua orientação sexual.

\subsection{Homofobia na Religião}

A condenação da homossexualidade como pecado, é um tema propagado atualmente, muitas instituições religiosas pregam que 0 homossexual é algo que "não é de Deus", vale o destaque das religiões cristãs, por serem a maioria no Brasil, são os exemplos mais claros de homofobia no contexto brasileiro.

Vários vídeos de pastores, padres, propagadores da fé, condenando os homossexuais circulam nas redes sociais, ou seja, não se manifesta somente no plano de percepções e juízos morais pessoais, mas envolve formas de atuação em rede em oposição à visibilidade e ao reconhecimento de minorias sexuais, articulando múltiplos atores e grupos e cortando as esferas pública e privada. (NATIVIDADE, Marcelo; DE OLIVEIRA, Leandro, 2009, p. 18).

A religião reforça um estereótipo preconceituoso, grande parte dos homicídios contra a pessoa homossexual possuí como justificativa a religião, não somente homicídios, mas também suicídios, é comum o homossexual doutrinado pela religião com estigmas preconceituoso se matar como forma de se livrar de todo o sofrimento e culpa que este sente por ser homossexual. 
Conforme uma variante psicologizante destes discursos homofóbicos, as pessoas "nascem heterossexuais" e, em decorrência de fatores externos, como traumas familiares, tornam-se infelizes, deprimidas e instáveis, desenvolvendo desejos homossexuais por efeito dessas experiências passadas. A homossexualidade não é vista como uma identidade, mas como o sintoma de uma trajetória pessoal percorrida em ambientes que não correspondem ao modelo ideal da família cristã. (TOLEDO, Lívia Gonsalves; TEIXEIRA FILHO, Fernando Silva, 2013, p. 15).

Conclui-se então que o indivíduo homossexual, provavelmente passará por discriminação em todas as socializações, seja pela escola, família, igreja, e isso impacta no processo de autoaceitação deste sujeito, pois se todos ao seu redor condenam quem é gay/lésbica (homo), como ir contra a vontade do outro e assumir a sua própria numa cultura homofóbica? Consequentemente, este indivíduo pode procurar um tratamento de conversão do homossexual, de maneira consentida ou forçada, seja pelos pais ou responsáveis.

\section{TRATAMENTO DE CONVERSÃO DO hOMOSSEXUAL E SUAS CONSEQUÊNCIAS}

A homofobia que a sociedade possuí como marca presente, traz consequências na autoaceitação de indivíduos que se percebem homossexuais, muitas vezes estes sujeitos se reconhecem como pecadores, sem a graça de Deus, escória para a sociedade, vergonha para a família, aberração, possessão demoníaca, entre outros, o que resulta na procura de uma conversão para a heterossexualidade.

O "preconceito" e a "discriminação" contra homossexuais manifestam-se de formas muito plurais: silêncios, posicionamentos contrários, recusa de direitos, julgamentos morais, reprodução de estereótipos, exclusões mais diretas e outras mais veladas. (TOLEDO, Lívia Gonsalves; TEIXEIRA FILHO, Fernando Silva, 2013, p. 15).

Muitos homossexuais se casam com pessoas do sexo oposto, na tentativa de se fazer presente no que é determinado "normal" pela sociedade, contudo, não é raro que estas pessoas procurem amantes do mesmo sexo, e acabam sendo flagrados ou descobertos, e essa frustação causa constantes suicídios, pois o sujeito se vê no fim da linha das possibilidades.

Há também a conversão por métodos religiosos, geralmente utilizam os termos, santificação, purificação, libertação, na maioria das vezes são realizados por evangélicos ou católicos. O exorcismo é frequentemente utilizado, além das excessivas orações e repetições de frases para "curar" este indivíduo, durante o exorcismo, é preciso que o sujeito liste os nomes das pessoas do mesmo sexo que tiveram relação sexual para o pastor. E o pastor irá expurgar todos os demônios, como se a pessoa estivesse em possessão. 
Outra forma de conversão é a castidade, em que o sujeito não terá relações sexuais com ninguém e também não pode se masturbar até se "curar", grande parte do público que já experienciou este método, afirma que as poluções noturnas são frequentes. É pedido também que não frequente nenhum ambiente que possua alguém homossexual, e que se possível até mude de residência, de emprego etc.

Existem muitos homossexuais não assumidos, é comum um homossexual assumido conhecer diversas pessoas casadas que traem seus parceiros com pessoas do mesmo sexo, a não aceitação de si próprio no Brasil é imensa, o que agrega em casamentos falsos, desenvolvimento de uma homofobia internalizada, e a perpetuação do preconceito e do medo de se assumir.

\section{COMPREENDENDO A SEXUALIDADE}

Ser homossexual está interligado à orientação sexual, assim como o heterossexual, bissexual, pansexual, assexual, entre outros. Contudo, ainda há uma dúvida em relação ao termo e principalmente na população é comum ouvir-se "opção sexual". Entende-se orientação sexual, pois é a direção ou a inclinação do desejo afetivo e sexual do sujeito, enquanto o termo opção dá a entender que o indivíduo escolher ser daquela sexualidade.

Ninguém escolhe ser homossexual, bissexual, heterossexual, pansexual, assexual, ainda mais em uma sociedade que mata pessoas por não serem heterossexuais, é cabível entender que definitivamente não é uma opção.

Atualmente se compreende que a sexualidade do sujeito irá se desenvolvendo ao longo da vida, ou seja, ao longo dos estágios do desenvolvimento a pessoa irá perceber o que a atraí afetivamente e sexualmente, e há pesquisas, inclusive que indicam que a sexualidade tem uma tendência fluída, ou seja, a sexualidade seria um espectro, enquanto outras pesquisas determinam que a sexualidade seja algo fixo para sempre. Independentemente das teorias é necessário compreender que o ser humano pode ou não tem uma sexualidade, e quando não é uma orientação sexual heterossexual estará sujeito a uma carga enorme de estigmas sociais.

Além de orientação sexual, o sujeito (se quiser) também possuí, a identidade de gênero, expressão de gênero e sexo biológico, pode parecer difícil compreender todos, mas é válido lembrar que o ser humano é complexo e vasto e disposto a tantas possibilidades, e é bem provável que futuramente as "classificações" sobre a sexualidade mudem, assim como ocorre atualmente. 


\subsection{Identidade de Gênero}

A identidade de gênero está relacionada em como o sujeito se considera, como o sujeito se compreende, por exemplo: homem, mulher, genderqueer ou até mesmo uma não classificação (KILLERMANN, 2017). Os termos Cis e Trans são opcionais, mas frequentemente utilizados como luta política e autoafirmação, principalmente ao se falar de sujeitos Transexuais e Travestis.

A divisão entre os sexos parece estar na ordem das coisas(...) ela está presente, ao mesmo tempo, em estado objetivado (...) em todo o mundo social, e em estado incorporado, nos corpos e nos habitus dos agentes, funcionando como sistemas de esquemas de percepção, de pensamento e de ação (Bourdieu, 1999, p. 17).

Importante ressaltar que, identidade de gênero independe de expressão de gênero, por isso, se declarar como homem, mulher, não tem relação alguma com vestimentas, genitálias, ou quaisquer outra forma que 0 senso comum atribuiu como "gênero".

\subsection{Travesti e Transexual}

Cisgênero é o indivíduo que se identifica com o sexo biológico, enquanto o Transgênero é o sujeito que não se identifica com o sexo biológico dado no nascimento. Ser Transexual ou Travesti independe de ter que realizar procedimentos estéticos, cirurgias ou se vestir de determinada maneira, a partir do momento em que o sujeito se afirma como Trans é a fala que importa, e não - aspecto visual, embora grande parte da comunidade Trans faça readaptações corporais em relação à expressão de gênero.

Travesti é uma identidade de gênero feminina, o que afirmará se determinado indivíduo é Transexual ou Travesti é o próprio sujeito e não o seu entorno. Importante ressaltar também que Drag Queen/King não é uma identidade de gênero, mas sim uma expressão artística.

\subsection{Expressão de Gênero}

A expressão de gênero está relacionada a forma como o sujeito se expressa de acordo com o que a sociedade compreende como "masculino" e "feminino", por exemplo: andrógino, masculino, feminino. Lembrando que o que define masculino e feminino são valores tradicionais, e a tendência é compreender que essa distinção talvez não seja adequada, contudo, é necessário entender também que diversas pessoas sentem a necessidade de declarar sua expressão de gênero. (KILLERMANN, 2017). 


\subsection{Sexo Biológico}

O sexo biológico está mais relacionado ao contexto de saúde, em que se classifica o sujeito com base nos cromossomos $X X$ (mulheres) e $X Y$ (homens) e Intersex, combinação de ambos. Atualmente existe uma militância interligada ao sujeito Intersex, pois culturalmente é errado ser Intersex, e a luta vem justamente para mostrar que não há nada de errado o indivíduo Intersex possuir gônadas masculinas e femininas. (KILLERMANN, 2017).

\subsection{Orientação Sexual}

A orientação sexual está interligada a o que nos atraí sexualmente, afetivamente, espiritualmente, ou qualquer outra relação que desperte desejo. $O$ homossexual possuí atração com o mesmo sexo. $O$ heterossexual com o sexo oposto, o bissexual com ambos os sexos, e o pansexual independe de uma classificação para gênero, como nas outras sexualidades, se atraindo por pessoas. Há também pessoas assexuais, ou seja, não se atraem sexualmente. Isso não significa que são pessoas sozinhas, ou que "não conseguiram ninguém", mas sim indivíduos sem a necessidade sexual. (KILLERMANN, 2017).

\subsection{Bissexual X Pansexual}

Uma grande dúvida, principalmente na comunidade LGBTQIA+é em relação a diferença entre bissexual e pansexual, algumas sexualidades têm a necessidade de se atrair por um gênero, por exemplo, o bissexual se atraí por homens e mulheres, entre outros. Enquanto o sujeito pansexual se atraí por pessoas, ou seja, independe, não há necessidade, de se atrair por determinado gênero, mas sim por uma pessoa.

Imaginemos que há um bissexual e um pansexual em uma festa, o sujeito bissexual pode achar um homem bonito, ou seja, o gênero é algo que vem a cabeça. Enquanto na mente do sujeito pansexual o que atraí é a pessoa, não vem a mente que aquela pessoa é de determinado gênero, apenas ocorre uma atração pela pessoa.

Independentemente de concordância ou não com a diferenciação de pansexual e bissexual, é necessário permitir que as pessoas se afirmem como queiram afirmar, e não tentar enquadrar sobre o que está certo ou errado. O respeito deve vir acima de tudo e limitar ou invisibilizar uma sexualidade é também um preconceito. 


\section{CONSIDERAÇÕES FINAIS}

A partir deste artigo concluo que o tratamento de conversão da homossexualidade faz com que a perpetuação da homofobia permaneça, resultando em diversos métodos para "curar" o homossexual, e agravando no medo deste sujeito que faz relações homossexuais, ocasionando em uma não aceitação do próprio eu, o medo de ser expulso de casa, julgado pelo sociedade, perder o emprego, ou a crença de que irá para o inferno, atrasa 0 progresso que os movimentos LGBT+ conquistaram aos longos dos anos.

Somente quando a cultura brasileira evoluir e perceber que orientação sexual, é somente mais um aspecto presente em cada pessoa e que isso não influência na capacidade de ser cidadão e humano comum como qualquer outro, estes tratamentos irão ser extinguidos, porém é um processo lento e retrógrado nos dias atuais, pois ainda membros da área da saúde, e entidades religiosas defendendo a legalização das práticas de conversão.

O Brasil é um país homofóbico, mas claro que diversos direitos foram conquistados aos LGBT+, porém de nada adianta um decreto afirmar que homofobia é crime, se a cultura brasileira é homofóbica. Morrer por ser homossexual é comum, se matar por ser homossexual é comum, o que nos mostra o quão moldáveis o ser humano é, pois grande parte destes homicídios tem como justificativa a religião, e em um país predominantemente cristão, não é à toa que a homofobia existe, claro que há diversas entidades cristãs que acolhem não somente homossexuais, mas qualquer sexualidade, são passos curtos, mas que fazem toda a diferença para a construção de uma cidadania harmônica.

Realizar este artigo foi árduo, pois ler os relatos de quem passa por tratamentos de homossexualidade em pleno século 21, é de tamanho atraso na minha opinião, futuramente pretendo realizar uma pesquisa de campo sobre indivíduos que passaram por estes processos de tratamento de conversão para compreender a saúde mental e a autoaceitação, pois conheço um público que se diz "curado" e também os que conseguiram ir contra e hoje se aceitam homossexuais, não encontrei artigos científicos que relatam 0 processo de conversão à heterossexualidade, ou que mostrem os abalos psicológicos, por isso o interesse na pesquisa futura.

\section{REFERÊNCIAS}

BAYER, R., \& SPITZER, R. L. Edited correspondence on the status of homosexuality in DSM-III. Journal of the History of the Behavioral Sciences, 18(1), 32-52, 1982.

BOURDIEU, Pierre. A dominação masculina. Bertrand Brasil: Rio de Janeiro, 1999. 
BUTLER, J. Bodies that matter: on the discursive limits of 'sex'. London: Routledge, 1993.

ESKRIDGE, W. N., Jr. A history of same-sex marriage. Virginia Law Review, 79(7), 1419-1513, 1993.

FARO, Julio Pinheiro. Uma nota sobre a homossexualidade na história. Rev. Subj., Fortaleza, v. 15, n. 1, p. 124-129, abr. 2015. Disponível em <http://pepsic.bvsalud.org/scielo.php?script=sci_arttext\&pid=S2359$07692015000100014 \&$ Ing=pt\&nrm=iso >. Acesso em 02 abr. 2020.

GAMA, Maria Clara Brito da. Cura Gay? Debates parlamentares sobre uma (des) patologização da homossexualidade. Sex., Salud Soc. (Rio J.), Rio de Janeiro, n. 31, p. 4-27, abr. 2019. Disponível em <http://www.scielo.br/scielo.php?script=sci_arttext\&pid=S198464872019000100004\&Ing=en\&nrm=iso >. acesso em 02 abr. 2020.

GUIMARÃES, A. Sexualidade heterodiscordante no mundo antigo. In M. B. Dias, (Coord.). Diversidade sexual e direito homoafetivo. São Paulo, Revista dos Tribunais, 2011.

JUNQUEIRA, Rogério Diniz (Org.). Diversidade Sexual na

Educação: problematizações sobre a homofobia nas escolas. Brasília, DF, 2009.

KILLERMANN, Sam. The Genderbread Person. It's Pronounced Metrosexual, 2017. Disponível em: <https://www.itspronouncedmetrosexual.com/\#menu>. Acesso em: 20 set. 2020.

LOURO, Guacira Lopes. O corpo educado: Pedagogias da Sexualidade. Belo Horizonte, Autêntica, 2000.

Gênero, Sexualidade e Educação: Uma perspectiva pós-

estruturalista. Petrópolis, RJ, Editora Vozes, 2003.

MURPHY, T. F. Homosexuality and nature: Happiness and the law at stake. Journal of Applied Philosophy, 4(2), 195-204, 1987.

NATIVIDADE, Marcelo. Homossexualidade, gênero e cura em perspectivas pastorais evangélicas. Rev. bras. Ci. Soc., São Paulo, v. 21, n. 61, p. 115-132, junho, 2006. Disponível em

$<$ http://www.scielo.br/scielo.php?script=sci_arttext\&pid=S0102-

69092006000200006\&lng=en\&nrm=iso>. Acesso em 02 abr. 2020.

SCHULMAN, S. Homofobia familiar: uma experiência em busca de reconhecimento. Revista Bagoas, 5, 67-78, 2010.

TOLEDO, Lívia Gonsalves; TEIXEIRA FILHO, Fernando Silva. Homofobia familiar: abrindo o armário 'entre quatro paredes'. Arq. bras. psicol., Rio de Janeiro, v. 65, n. 3, p.376-391, 2013. Disponível em <http://pepsic.bvsalud.org/scielo.php?script=sci_arttext\&pid=S180952672013000300005\&lng=pt\&nrm=iso >. Acesso em 02 abr. 2020. 
VIOLÊNCIA E ABUSO SEXUAL: sua repercussão na vida da mulher

\author{
Camila Campos Fernandes \\ camilacampos24@icloud.com \\ Irma Helena Ferreira Benate Bomfim \\ irma@benate.com.br
}

\title{
1. INTRODUÇÃO
}

A violência é um dos fatores mais discutidos em sociedade, pelo fato de causar dor e sofrimento ao homem, podendo ser este aquele que agride ou aquele que é agredido. Por meio de uma análise feita sobre a violência sexual contra meninas e mulheres pelo Atlas da Violência pelos autores Cerqueira et. al. (2018), foi retratado que em cinco anos, o número de registros de estupro no sistema de saúde no Brasil dobrou.

Uma pesquisa feita pela ONU Mulheres e Portal Papo de homem de Venturi (2016), concluiu que $6 \%$ dos homens participantes da pesquisa afirmaram já terem dado sacudidas, apertões ou empurrões na parceira, enquanto $13,6 \%$ das mulheres participantes da pesquisa afirmaram já terem sofrido o mesmo ato de violência.

De acordo com a Organização Mundial da Saúde (2003) a violência é definida como o uso intencional da força física ou poder, contra si mesmo ou outra pessoa, a qual resulte ou tenha a possibilidade de resultar em ferimento, morte, dano psicológico, mau desenvolvimento ou privação.

Nesse sentido, fundamentalmente, o abuso sexual consiste no envolvimento da vítima em atividades de manipulação de seus órgãos genitais ou do agressor, abusos verbais, masturbação, ato sexual genital ou anal, estupro, exibicionismo, voyeurismo, exposição a filmes, imagens ou situações de pornografia (Amazarray \& Koller, 1998; Pfeiffer \& Salvagni, 2005).

As tradicionais concepções sobre maus-tratos são categorizadas como abuso físico, negligência, abuso sexual e abuso emocional. Essa questão dos maus-tratos, dentre eles o abuso sexual, em função da frequência de casos e das consequências negativas tanto para o sujeito vitimado quanto para a sua família, é considerada como um grave problema de saúde pública (OMS, 1999).

Esses tipos de maus-tratos possuem consequências sérias que são resultantes das experiências traumáticas de tal evento e afetam diversos aspectos do desenvolvimento cognitivo e emocional de vítimas de tal violência. Esse fenômeno é universal, e atinge todas as idades e classes sociais (PFEIFFER \& SALVAGNI, 2005).

O presente artigo visa apresentar uma revisão bibliográfica referente à conceituação de violência e de abuso sexual, bem como os tipos de violências contra a mulher, assim como às consequências psicossociais do abuso sexual. 


\section{A VIOLÊNCIA}

O conceito de violência é de difícil compreensão devido a sua complexidade e, ao ser associado ao sexual, se sobrepõem a esse de forma que obscurece as questões da sexualidade. Inicialmente obtém-se a definição de violência como sendo qualquer ato violento, constrangimento físico ou moral (FERREIRA, A. B. H., 2000, p. 783).

Por meio da definição de violência dada pelo dicionário de língua portuguesa pode-se perceber que a cultura esta instaurada no termo. Por estar atualmente no discurso social de forma intensiva, a violência pode ser considerada de fácil entendimento, porém existem diferenças em relação a sua compreensão por autores que pesquisam sobre esta temática, indo além do significado da palavra. "Qualquer reflexão teórico-metodológica sobre a violência pressupões $o$ reconhecimento da complexidade, polissemia e controvérsia do objeto. Por isso mesmo, geram muitas teorias, todas parciais" (MINAYO e SOUZA, 1998, p.513).

A violência é definida pela Organização Mundial da Saúde (2003) como:

Uso intencional de força física ou poder, ameaçados ou reais, contra si mesmo, contra outra pessoa, contra um grupo ou comunidade, que resultem ou tenham grande probabilidade de resultar em ferimento, morte, dano psicológico, mau desenvolvimento ou privação.

Alguns consideram a violência um fenômeno proveniente de causalidade social, possuindo raiz na dissolução da ordem pela vingança dos oprimidos ou por falta de condições do Estado para lidar com a questão. "Explicam o fenômeno como resultante dos efeitos disruptivos dos acelerados processos de mudança social, provocados, sobretudo, pela industrialização e urbanização" (MINAYO e SOUZA, 1998, p. 516). Outros explicam a violência como resultado de necessidades biológicas, psicológicas ou sociais, estando esta subordinada a determinações da natureza. Buscam "substituir o processo social e histórico pelo conceito de "agressão" que provém da biologia, etologia, genética e medicina" (MINAYO e SOUZA, 1998, p. 514).

De acordo com Marques (2006) há um grupo de teorias que, baseado nas contradições do capitalismo, entendem a violência como uma estratégia de sobrevivência das camadas populares. Eles consideram somente o aspecto exterior a violência, ou seja, "deixam de lado outros aspectos da violência social e cultural que têm raízes estruturais profundas e internalizadas nos sujeitos, e que atingem a todos nós, independentemente de classe, cor, raça, sexo ou idade" (MINAYO e SOUZA, 1998, p. 517).

Para Minayo e Souza (1998) as explicações de natureza econômica não bastam para explicar as questões sociais que determinam o fenômeno, porém elas concordam que são "elemento fundamental de uma violência maior que é o próprio modo organizativo-cultural de determinado 
povo. Ao escolher os que "são" e os que "não são" a partir das leis de propriedade, a sociedade revela sua violência fundamental, como na dialética hegeliana do escravo e do senhor" (MINAYO e SOUZA, 1998, p. 518).

Um outro grupo atribui a falta de autoridade do Estado e da incompetência de seus poderes repressivos, jurídicos e policiais. Essa concepção omite a discussão sobre o domínio econômico e político das classes dominantes e perpetua a crença de um Estado neutro. "As ideias desses intelectuais combinam com o senso comum, que advoga a força repressiva como condição de "ordem e progresso" (MINAYO e SOUZA, 1998, p. 518).

De acordo com as Nações Unidas (1993), a violência contra a mulher consiste em quaisquer atos violentos que se baseiem no gênero, que provoque ou tenha probabilidade de provocar danos físicos, sexuais e/ou psicológicos, incluindo a ameaça para a prática dos referidos atos, a coerção ou privação arbitrária da liberdade em ambiente privado ou público.

Esse fenômeno alcança mulheres de diferentes classes sociais, origens, religiões, estados civis, escolaridades, raças, orientações sexuais e idades (BRASIL, 2011). No Brasil, de acordo com os autores Silva, Falbo e Cabral (2009) e Moura et. al. (2013), a violência contra a mulher se apresenta com elevada prevalência, instituindo-se esta problemática como um dos problemas prioritários a ser enfrentado pela saúde pública e pelos direitos humanos (MOURA et. al., 2011).

De acordo com o Waiselfisz (2015) no Mapa da Violência, o Brasil apresenta taxa de 4,8 homicídios para cada 100 mil mulheres, ocupando a $5^{\underline{a}}$ posição num grupo de 83 países. Apenas El Salvador, Colômbia, Guatemala e a Federação Russa evidenciam taxas superiores ás taxas do Brasil.

Além de destruir milhares de vidas, a violência contra as mulheres provoca danos físicos, depressão e comportamentos suicidas (BALONE, ORTONALI, 2003). Segundo Pedrosa (2009) os danos da violência sobre a saúde da mulher podem assumir caráter de cronicidade, exigindo apoio adequado, tanto de profissionais da saúde, quanto de familiares e amigos da vítima.

Dados obtidos pela Organização Mundial da Saúde no ano de 2005 revelam que em 10 países os danos à saúde mental foram os mais enfatizados. Segundo Adeodato et. al. (2005) as mulheres vítimas de violência apresentam sentimentos de solidão, desamparo, irritação, tristeza crônica, ansiedade, insônia e distúrbios sociais.

Marques (2005) afirma que diante de uma ameaça, normalmente a reação de um indivíduo deveria ser a evitação, porém no contexto conjugal observa-se a repetição cíclica de ocorrências de violência contra a mulher. Segundo Hirigoyen (2006), ocasionalmente, diferentes situações impedem que 
as mulheres encontrem alternativas para sair de seus relacionamentos violentos. A violência inicia-se com pequenas violências, podendo estas serem morais e verbais, e em seguida evoluem para agressões físicas, de forma que a violência tende a ser naturalizada (HIRIGOYEN, 2006).

De acordo com Edwards (2011) entre $31 \%$ e $85 \%$ das relações abusivas continuam por algum tempo após o incidente inicial de abuso. Sem ajuda externa, a mulher possui grande dificuldade de romper os vínculos com 0 companheiro violentador (SAFFIOTI, 2004). Segundo Soares (1999) o rompimento do ciclo de violência é um processo demorado e, naturalmente difícil.

Os estudos de Lima e Werlang (2011) e de Miranda, Paula e Bordin (2010) demonstram que, apesar do registro de mais de uma queixa, as mulheres permanecem com os agressores por, pelo menos, três anos. Portanto, como enfatiza Gomes et. al. (2013), quando inseridas nesse contexto, as mulheres tendem ao isolamento, cada vez mais acentuado, e gradativamente a perda de sua rede de apoio, tornando-as mais vulneráveis.

\section{O ABUSO SEXUAL}

De acordo com o dicionário de língua portuguesa, a palavra abuso significa: "Mau uso, ou uso errado, excessivo ou injusto; excesso; exorbitância de atribuição ou poderes; aquilo eu contraria as boas normas, os bons costumes; ultrajem de pudor, violação" (FERREIRA, A. B. H., 2000).

A violência sexual revela o complexo contexto de poder que marca as relações sociais entre os sexos. Por violência sexual se compreende o estupro, tentativa de estupro, atentado violento ao pudor, sedução, atos obscenos e assédio, que podem ocorrer de forma conjugada, inclusive, com outros tipos de violência física como lesão corporal, tentativa de homicídio maus tratos e ameaças (PIMENTEL et. al., 1998).

$\mathrm{Na}$ maioria das vezes, as mulheres vítimas de violência apresentam problemas que não se reduzem às consequências imediatas dos atos violentos vivenciados, mas apresentam interfaces que precisam da contribuição interdisciplinar, como as cicatrizes deixadas na vida sexual, afetiva, social, profissional.

O advento da Lei 12.015/2009, de 2009, o estupro passou a ser definido como: "Constranger alguém, mediante violência ou grave ameaça, a ter conjunção carnal ou a praticar ou permitir que com ele se pratique outro ato libidinoso".

No período compreendido entre o final do século XIX até a primeira metade do século $X X$, vários autores passaram à enxerga a sexualidade sob uma nova ótica, conceito este que só foi possível, devido a 
valoração da individualidade na idade moderna, a qual serviu de base para a organização da sociedade capitalista.

A partir da segunda metade do século XX, podem-se destacar dois eventos importantes que marcaram 0 estudo da sexualidade: 0 desenvolvimento de métodos contraceptivos, que rompe com associação, que ate então existia, entre a atividade sexual e a reprodução; e o surgimento de novas reflexões sobre o tema.

Nessa época, as mulheres encontravam-se totalmente desamparadas, não existindo nenhum tipo de lei que resguardasse os seus direitos, consideradas seres inferiores, eram vítimas de constantes assédios e estupros, ficando totalmente vulnerável a todos os tipos de violência, já que os seus agressores não sofriam nenhuma punição.

É neste contexto histórico, que surgem os movimentos feministas, com objetivo de combater as descriminações ocasionadas pelas desigualdades derivadas dos padrões estabelecidos pela moralidade sexual, lutando pelos direitos legais da mulher, dentre os quais pode destacar: direito a integridade física, a autonomia, direitos trabalhistas, reprodutivos, proteção contra a violência doméstica, assédio sexual e estupro.

Esses movimentos foram os principais responsáveis pelo crescimento sobre o estudo de gênero, dando novas perspectivas sobre as questões teóricas e de investigação sobre a sexualidade, as quais passaram a ser vistas sob uma nova ótica, ocasionando várias consequências como: a alteração do estereótipo masculinidade, feminilidade e seus respectivos papéis; novas atitudes liberais em relação ao corpo e as emoções; maior tolerância ao sexo antes do casamento; maior tolerância as diferenças sociais e a educação sexual.

Nos últimos anos o atendimento às mulheres vítimas de violência sexual tem merecido atenção de diversos setores sociais, particularmente, das organizações de mulheres e de associações médicas. Essas mobilizações em torno do tema resultaram na criação de serviços que atendem mulheres vítimas de violência sexual e doméstica, bem como de instrumentos jurídicos e legais, permitindo melhor atendimento.

\section{CARACTERIZAÇÃO DOS TIPOS DE VIOLÊNCIA CONTRA A MULHER}

Desde 1970, a violência vem se tornando um problema de saúde pública. Segundo Minayo e Deslandes (2009) a violência contra a mulher representa uma parcela significativa nos números de morbidade e mortalidade na população brasileira. Com a construção de um processo histórico de supervalorização do ser masculino em detrimento do feminino, ocorreu certa naturalização da violência contra a mulher, pois, a própria mulher e a 
sociedade, aceita, até os dias atuais, esse papel de submissão em relação ao homem (RIBEIRO et al, 2012).

Casique e Furegato (2006) comentam que dentre as diferentes formas de violência de gênero estão inseridas a violência intrafamiliar ou violência doméstica e a violência no trabalho, as quais se manifestam por meio de agressões físicas, psicológicas e sociais.

As autoras definem a violência intrafamiliar como sendo uma forma de violência em que muitas mulheres estão submetidas, que possui origem entre os membros da família, independentemente se o agressor esteja ou não compartilhando o mesmo domicílio. Dentre as agressões inclui-se violação, maltrato físico, psicológico, sexual e econômico, podendo, algumas vezes, culminar em morte.

Rojas (2001) apud Casique Furegato (2006) afirmam que o abuso psicológico, sexual ou físico ocorre entre pessoas relacionadas afetivamente, como marido e mulher, ou adultos contra menores ou idosos de uma família. $O$ abuso pode caracterizar-se pelo conjunto de condutas que causam dano físico, dor ou ferimento intencional à vítima.

O artigo $7^{0}$ da Lei Maria da Penha $n^{\circ}$ 11.340/2006 define cinco principais tipos de violência: violência física, violência psicológica, violência sexual, violência patrimonial e violência moral.

A violência psicológica é um dos tipos de violência doméstica que ocorre com bastante frequência. Segundo Day et al (2003), esse tipo de violência é a forma mais subjetiva, embora seja muito frequente a associação da violência sexual com agressões corporais. Essa violência deixa marcas profundas no desenvolvimento, podendo comprometer toda a vida mental e emocional da vítima. Os autores ainda comentam sobre os danos de a violência psicológica serem imediatos, e poderem estar representados em pesadelos repetitivos, ansiedade, raiva, culpa, vergonha e medo.

O artigo 7ํㅡ, V, da Lei oํ 11.340/2006 diz que a violência moral é entendida como qualquer conduta que configure calúnia, difamação ou injúria. A autora Felício (2016) afirma que a calúnia ocorre quando o agente imputa à vítima a prática de determinado fato criminoso, sendo este um fato falso. "A difamação ocorre quando é atribuída à vítima a prática de determinado fato desonroso à sua figura, e a injúria ocorre quando se atribui à vítima qualidades negativas como preconceitos raciais, ou de gênero" (FELíCIO, 2016, p.n.p).

A violência patrimonial ocorre quando algo de valor é subtraído da vítima, levando esta a perder o patrimônio e a ter despesas financeiras. "Muitas vezes, esse tipo de violência ocorre sob coação, quando o abusador obriga a vítima a ceder recursos financeiros contra a sua vontade" (FELíCIO, 2016, p.n.p). 
Já a violência física é uma forma de agressão, e aparece em pesquisas como sendo a forma de violência mais frequente, seguida da violência sexual. O Conselho Nacional de Justiça (2018) define a violência física como sendo uma ação ou omissão que coloque em risco ou cause danos à integridade física de uma pessoa. A violência física é a mais frequente, pois "como a vítima é indefesa e esta em desenvolvimento, o caráter disciplinador da conduta exercida pelo progenitor ou por quem o substitua é um aspecto bastante relevante, variando de uma "palmada", a espancamentos e homicídios" (DAY et al, 2003).

Embora a violência doméstica ocorra mais frequentemente entre casais que já convivem, a violência sexual ainda é um dos principais tipos de violência que a mulher sofre de seu parceiro ou companheiro.

De um modo geral, a violência sexual é o ato que o homem utiliza para provocar na mulher constrangimento com o propósito de limitar a autodeterminação sexual, tanto pode ocorrer mediante violência física como através de grave ameaça, ou seja, com o uso da violência psicológica (FELÍCIO, 2016).

Mulheres em situação de violência sexual experimentam sequelas físicas e psicológicas, tornando-se mais vulneráveis a diversos problemas de saúde (BRASIL, 2012). De acordo com o Conselho Nacional de Justiça (2018), a violência sexual é definida como a ação que obriga uma pessoa a manter contato sexual, físico ou verbal, ou a participar de outras relações sexuais com uso da força, intimidação, coerção, chantagem, suborno, manipulação, ameaça ou qualquer outro mecanismo que anule ou limite a vontade pessoal. Considera-se também como violência sexual o fato de o agressor obrigar a vítima a realizar estes atos com terceiros.

Felício (2016) ressalta ainda que no Código Penal Brasileiro, a violência sexual pode ser caracterizada de forma física, psicológica ou com ameaça, compreendendo estupro, atentado violento ao pudor e o ato obsceno.

\section{CONSEQUÊNCIAS PSICOSSOCIAIS DO ABUSO SEXUAL}

Reconhecida internacionalmente pelas entidades dos direitos humanos e organismos internacionais como a Organização Mundial da Saúde (OMS) e Organização Pan-Americana da Saúde (OPAS), a problemática da violência contra a mulher é vista como um problema de saúde pública.

A Organização Mundial da Saúde (2003) considera como violência todo ato sexual indesejado que cause danos físicos, emocionais, sexuais e psicológicos, através de ameaças, coerção ou privação da liberdade, independentemente do ambiente e do relacionamento das pessoas. Como afirma Souza, Drezett, Meirelles e Ramos (2012), a violência sexual 
caracteriza-se por qualquer contato sexual não consentido, ou qualquer ato contra a sexualidade da pessoa.

Dias (2010, p.243-244) afirma que "o abuso sexual constitui uma forma de violência na qual o abusador se aproveita de sua superioridade (física ou psicológica), ato o qual gera como consequência um atraso ou prejuízo no desenvolvimento ou estruturação da personalidade".

Inclui-se como violência sexual situações de estupro, assédio sexual, sexo forçado no casamento, jogos sexuais e práticas eróticas não consentidas ou impostas, voyeurismo, e manuseio ou penetração oral/anal/genital com pênis ou objetos de maneira forçada. É considerada também a exposição forçada a atos libidinosos, exibicionismo, masturbação, linguagem erótica, interações sexuais e material pornográfico. (BRASIL, 2009).

Assim, o abuso sexual passa a ser um crime contra a dignidade e liberdade sexual, pode ser cometido em qualquer cenário e contra homens ou mulheres. No entanto, Cerqueira e Coelho (2014) apresentam as mulheres como sendo as principais vítimas desta violência.

Os estudos dos autores Grossin et al (2003), Faravelli et al (2004) e Campbell et al (2007) apresentam dados em comum sobre dois tipos de agressores existentes e a faixa etária agredida por eles. O maior número de atos praticados é composto por vítimas mulheres mais jovens, as quais possuem como agressor um conhecido, frequentemente intrafamiliar, em que há uma pequena taxa de procura por auxílio. Já outros atos são praticados por agressores desconhecidos, muitas vezes por mulheres mais velhas, com idade média de 22 anos, havendo uma maior taxa de agressão física, de denuncia e de procura por auxílio.

De acordo com Krug, Dahlberg, Mercy, Zwi e Lozano (2002), calcula-se que a prevalência global de estupro é de 2 a $5 \%$ e a incidência de vítimas por ano é de 12 milhões. Mason e Lodrick (2013) comentam que a prevalência de estupro em mulheres, ao longo da vida, corresponde a aproximadamente $20 \%$, evidenciando dados nacionais que indicam uma média diária de 21,9 mulheres que procuram atendimentos em serviços de saúde por violência sexual, e 14,2 de mulheres por dia sendo notificadas como vítimas de estupro.

Mesmo as vítimas de violência sendo usuárias assíduas dos serviços de saúde, Pereira et al (2012) argumentam que normalmente as vítimas não relatam a agressão sofrida, mesmo com sinais e sintomas aparentes.

O abuso sexual é um fenômeno complexo e difícil de enfrentar por parte de todos os envolvidos, especialmente para as vítimas. A violência sexual pode acarretar diversos problemas de saúde para a mulher, tanto imediatamente após o evento, quanto a médio e longo prazo, além de consequências físicas e psicológicas. 
Em seu estudo, Sugar, Fine e Eckert (2004), relatam que metade das pessoas que denunciaram a agressão sexual possuíam lesões, sendo as lesões não genitais mais comuns do que as genitais. De acordo com White e McLean (2006) a ausência de lesão genital não implica o consentimento e não exclui a penetração, mesmo em mulheres que negam uma atividade sexual prévia. Mesmo as lesões pequenas devem ser documentadas e podem precisar de tratamento assim como as lesões maiores.

Geralmente, as mulheres vítimas de violência sexual não apresentam apenas problemas imediatamente após os atos violentos vivenciados, mas podem apresentar também demandas que necessitam de um apoio interdisciplinar por, conta das cicatrizes deixadas na vida sexual, afetiva, social e profissional (OLIVEIRA, et al , 2005).

Ao ter suas barreiras violentadas, a vítimas busca construir novos limites entre si e o mundo, porém essas barreiras são construídas a partir da dinâmica do trauma, adquirindo manifestações físicas como ganha de peso, desleixo pessoal e falta de cuidado consigo mesma, podendo também desenvolver problemas dermatológicos, problemas de aprendizagem e/ou comportamentais.

Oliveira et al (2005), pontuam que a obrigatoriedade do atendimento para interrupção de gravidez nos casos de estupro e risco de vida da mãe prevista no Código Penal Brasileiro desde 1940, é cumprida apenas por alguns dos mais de 6.000 municípios do Brasil oferecem o serviço de atendimento sobre a prática da Lei do "aborto legal" às mulheres vítimas de estupro.

Faundes, Rosas, Bedone e Orozco (2006), comentam que a maioria das gravidezes resultantes de estupros são rejeitadas pelas mulheres, terminando frequentemente em aborto. Isso pode possuir poucas consequências para a saúde da mulher em países onde o aborto é legal e os serviços de qualidade são de fácil acesso, porém pode acarretar graves consequências nos países com leis restritivas em que o aborto seguro não é acessível, mesmo ainda nos casos previstos em lei, como ocorre no Brasil.

A preservação das evidências é essencial para auxiliar os processos judiciais necessários para processar o agressor. "As mulheres que foram estupradas devem ser questionadas se gostariam de denunciar $o$ ataque à polícia e passar por um exame forense" (WELCH e MASON, 2007, p. n.p).

Há a possibilidade de a vítima contrair infecções sexualmente transmissíveis do agressor e/ou infecções do trato reprodutivo, dependendo da prevalência do local e da natureza da agressão. Welch e Mason (2007) comentam que a clamídia, hepatite B, DST, sífilis e a gonorreia são comuns, podendo alguns levar à doença inflamatória pélvica e à infertilidade em mulheres que não forem tratadas.

O risco de adquirir o HIV é existente, principalmente em casos de estupro anal, trauma e sangramento, necessitando o agressor ser um portador de HIV ou usuário de drogas injetáveis. 
Além de doenças sexualmente transmissíveis e a gravidez indesejada, as vítimas de estupro podem apresentar lesões físicas que podem levar a fraturas graves ou traumas.

Dada a gravidade do problema no que tange à violação dos direitos humanos e ao impacto físico, psíquico e social, Krug et al (2002) esclarece que a violência sexual foi reconhecida como um problema de saúde pública global em 1993, pela Organização Pan- Americana da Saúde (OPAS) e pela OMS.

As consequências psicológicas são variáveis, já que o significado que a vítima atribui para a experiência do abuso sexual é único. Como afirmam Mason e Lodrick (2013) a vítima pode adquirir transtornos psicológicos como depressão, dificuldade para restabelecer relacionamentos íntimos após o estupro, fobias, dificuldade com ajustamento social e funcionamento sexual, ansiedade, uso de drogas ilícitas, tentativas de suicídio, estresse póstraumático, transtornos do sono, pesadelos, transtornos de apetite, entre outros. Após o estupro a sintomatologia pode se tornar mais aparente e mais grave, incluindo nos sintomas: a ansiedade, depressão ou TEPT e também queixas psicossomáticas.

Kilpatrick, Veronen e Best (1985) relatam em seu estudo que das 507 vítimas de estupro pesquisadas, 30\% tiveram pelo menos um episódio de depressão maior, e $21 \%$ estavam deprimidas no momento da pesquisa. Em contrapartida, apenas $10 \%$ das mulheres que nunca foram estupradas sofreram depressão grave e apenas $6 \%$ estavam deprimidas no momento da pesquisa.

Os autores afirmam que os sentimentos de vergonha e humilhação são frequentemente descritos, muitas vezes persistindo e contribuindo para a perda da autoestima das vítimas. O nível de tentativas e ideação suicida é notável entre as vítimas de estupro, o qual 33\% das vítimas em comparação com $8 \%$ das "não vítimas" já haviam cogitado o suicídio, enquanto $13 \%$ das vítimas fizeram pelo menos uma tentativa de suicídio.

\section{CONSIDERAÇÕES FINAIS}

Considerando o breve estudo bibliográfico feito referente à conceituação de violência e de abuso sexual, bem como os tipos de violências contra a mulher, assim como às consequências psicossociais do abuso sexual pode-se constatar a importância da discussão sobre o assunto, visto que a quantidade de relatos sobre abuso sexual vem crescendo cada vez mais na sociedade.

Evidenciam-se no âmbito jurídico a criação de uma legislação de proteção à mulher, e psicossociais como 0 aumento de instituições socioeducativas e de saúde, como ações de desenvolvimento científico, valorização, proteção, distinção de suas necessidades, de seus desejos e, por 
conseguinte de descoberta da sua grande importância, enquanto pessoa e cidadã.

Desta forma, os abusos e negligencias contra a mulher, que em muitas décadas foram ignorados, ganharam visibilidade e passaram a ser questionados e denunciados na tentativa de preservação da vida e dos direitos das mulheres nos vários contextos em que vive. A Lei Maria da Penha representa esse avanço, pois criminaliza e penaliza o agressor.

Dentre as principais consequências abordadas pelos autores pesquisados, visualizam-se também as consequências físicas, psicológicas e sociais, as quais ganharam maior consistência teórica devido ao aumento de pesquisas que comprovam sua existência e merecem ser consideradas pelos profissionais envolvidos.

O estudo acerca deste tema é de grande relevância no cenário atual, já que é notório o crescente aumento deste fenômeno entre a população mundial, evidenciando-se um problema social e de saúde pública, que afeta a integridade física e psíquica da mulher, além de constituir uma flagrante violação aos direitos humanos. Logo, a psicologia não pode se furtar de buscar compreender esta problemática, em face da magnitude de sua repercussão, tanto no âmbito social quanto no âmbito subjetivo das mulheres vitimadas.

\section{REFERÊNCIAS}

AMAZARRAY, M. R., \& KOLLER, S. H. Alguns aspectos observados no desenvolvimento de crianças vítimas de abuso sexual. Psicologia Reflexão e Crítica, p. 559-578, 1998.

ADEODATO, V. G., CARVALHO, R. R., SIQUEIRA, V. R., SOUZA, F. G. M. Qualidade de vida e depressão em mulheres vitimas de seus parceiros. Revista Saúde Pública, 2005.

BALLONE, G. J., ORTOLANI, I. V. Violencia Domestica. 2003. Disponivel em: http://www.psiqweb.med.br. Acesso em: 30 de setembro de 2019.

\section{BRASIL. Politica Nacional de Enfrentamento a Violencia contra as}

Mulheres. Brasilia: Secretaria Especial de Politicas para as Mulheres, 2011. Disponivel em: http://www.spm.gov.br/central-deconteudos/publicacoes/publicacoes/2015/balanco180-10meses-1.pdf. Acesso em: 30 de setembro de 2019.

BRASIL. Ministério da Saúde. Secretaria de Atenção à Saúde. Área Técnica de Saúde da Mulher. Prevenção e tratamento dos agravos resultantes da violência sexual contra mulheres e adolescentes. 3 ed. Brasília: Ministério da Saúde: Norma Técnica, 2012. Disponível em: http://bvsms.saude.gov.br/bvs/publicacoes/prevencao_agravo_violencia_sexual mulheres_3ed.pdf. Acesso em: 02 de outubro de 2019. 
BRASIL. Ministério do desenvolvimento social e combate à fome: Tipificação Nacional de Serviços Socioassistenciais. Brasília: MDS, 2009.

CAMPBELL, L.; KEEGAN, A.; CYBULSKA, B.; FORSTER, G. Prevalence of mental health problems and deliberate self-harm in complainants of sexual violence. Journal of Forensic and Legal Medicine. London, 2 Ed., v.14, p.75-78, 2007. Disponível em: https://www.sciencedirect.com/science/article/pii/S1353113106000733. Acesso em: 29 de março de 2019.

CASIQUE, L. C.; FUREGATO, A. R. F. Violência contra mulheres: reflexões teóricas. Rev. Latino-am Enfermagem. Ribeirão Preto, 2006. Disponível em: http://www.scielo.br/pdf/rlae/v14n6/pt_v14n6a18.pdf. Acesso em: 02 de outubro de 2019.

CERQUEIRA, D.; COELHO, D.; LIMA, R.; BUENO, S.; NEME, C.; FERREIRA, H.; ALVES, P.; PINHEIRO, M.; ASTOLFI, R.; MARQUES, D.; REIS, M.; MERIAN, F. Atlas da violência 2018. Rio de Janeiro, 2018. Disponível em: http://www.agenciapatriciagalvao.org.br/dossies/fontes-e-pesquisas/wpcontent/uploads/sites/3/2018/06/IPEA_FBSP_AtlasdaViolencia2018Relatorio.pd f. Acesso em: 05 de maio de 2019.

CONSELHO NACIONAL DE JUSTICA. Formas de violência contra a mulher. Brasília: CNJ, 2018. Disponível em: http://www.cnj.jus.br/programas-eacoes/lei-maria-da-penha/formas-de-violencia. Acesso em: 02 de outubro de 2019.

DAY, V.; TELLES, L. et al. Violência doméstica e suas diferentes manifestações. R. Psiquiatr. Rio Grande do Sul, p. 9-21, 2003. Disponível em: http://www.scielo.br/pdf/rprs/v25s1/a03v25s1. Acesso em: 02 de outubro de 2019.

DIAS, Maria Berenice. Incesto e alienação parental. 2. ed. São Paulo: RT, 2010. p. 243-244.

EDWARDS, K. Leaving an Abusive Dating Relationship: an analysis of the investment model and theory of planned behavior. (Electronic Thesis or Dissertation), 2011.

FAUNDES, A.; ROSAS, C.; BEDONE, A.; OROZCO, L. Violência sexual: procedimentos indicados e seus resultados no atendimento de urgência de mulheres vítimas de estupro. Rev. Bras. Ginecol. Obstet. Campinas, 2006. FAVARELLI C.; GIUGNI A.; SALVATORI S.; RICCA V. Psychopathology after rape. Am J Psychiatry. Washington, 2004. Disponível em: https://ajp.psychiatryonline.org/doi/pdf/10.1176/appi.ajp.161.8.1483. Acesso em: 29 de março de 2019. 
FELÍCIO, C. P. Tipos de violência contra a mulher. Jus. Piauí, 2016.

Disponível em: https://jus.com.br/artigos/49523/tipos-de-violencia-contra-amulher. Acesso em: 02 de outubro de 2019.

FERREIRA, Aurélio Buarque de Holanda. Dicionário da língua portuguesa. Rio de Janeiro: Nova Fronteira, 2000.

GOMES, N. P., CARVALHO, M. R. S., COUTO, T. M., DINIZ, N. M. F. Violência conjugal $\mathrm{e} O$ atendimento da mulher na delegacia e no serviço de saúde. Revista Baiana de Enfermagem. Salvador, v. 27, n. 2, p. 146-53, 2013.

GROSSIN C.; SIBILLE I.; GRANDMAISON G.L.; BRANASR A.; BRION F.; DURIGON M. Analysis of 418 cases of sexual assault. Forensic Sciense International. France, 2-3 Ed., v. 131, p.125-130, 2003. Disponível em: https://www.sciencedirect.com/science/article/pii/S0379073802004279. Acesso em: 29 de março de 2019.

HIRIGOYEN, M. A Violência no Casal: da coação psicológica a agressão física. Trad. Maria Helena Kuhner. Rio de Janeiro: Bertrand Brasil, 2006.

KILPATRICK, D.; VERONEN, L.; BEST, C. Factors Predicting Psychological Distress Among Rape Victims. Trauma and its Wake. Ed. CE Figley, New York, 1985.

KRUG E. G.; DAHLBERG L. L.; MERCY J. A.; ZIW A. B.; LOZANO R. World report on violence and health. World Health Organization, Geneva, 2002. Disponível em:

http://apps.who.int/iris/bitstream/handle/10665/42495/9241545615_eng.pdf?seq uence=1. Acesso em: 23 de outubro de 2018.

LIMA, G. Q., \& WERLANG, B. S. G. Mulheres que sofrem violência doméstica: contribuições da psicanálise. Psicologia em Estudo, 2011.

MARQUES, T. M. Violência Conjugal: estudo sobre a permanência de mulheres em relacionamentos abusivos. 291f. Dissertação (Mestrado em Psicologia) - Universidade Federal de Uberlândia, Instituto de Psicologia, 2005. Disponível em: http://repositorio.ufu.br/handle/123456789/1516. Acesso em: 30 de setembro de 2019.

MARQUES, Margarete dos Santos. A escuta ao abuso sexual: o psicólogo e o sistema de garantia de direitos da criança e do adolescente sob visão da psicanálise. São Paulo, 2006.

MASON, F.; LODRICK, Z. Psychological consequences of sexual assault. Best Practice \& Research Clinical Obstetrics \& Gynaecology. United Kingdom, v. 27, 2013.

MINAYO, M. C. de S.; DESLANDES, S. F. Análise da implantação da rede de atenção às vítimas de acidentes e violências segundo diretrizes da 
Política Nacional de Redução da Morbimortalidade sobre Violência e

Saúde. Revista Ciência \& saúde coletiva. V.14, n.5. Rio de Janeiro, 2009. Disponível em: http://www.scielo.br/scielo.php?script=sci_arttext\&pid=S141381232009000500002. Acesso em: 20 de outubro de $201 \overline{9}$.

MINAYO, Maria Cecília; SOUZA, Edinillsa R. Violência e saúde como um capo interdisciplinar e de ação coletiva. In: História, Ciência, Saúde. Manguinhos, p.513-531, 1998.

MIRANDA, M P. M., PAULA, C.S., BORDIN, I. A. Violência conjugal física contra a mulher na vida: prevalência e impacto imediato na saúde, trabalho e família. Revista Panamericana de Salud Publica, 2010.

MOURA, L. B. A., REIS, P. E. D., FAUSTINO, A. M., GUILHEM, D., BAMPI, L. N. S., MARTINS, G. Vivencias de violência experimentadas por mulheres do distrito federal: estudo descritivo. Online Brazilian Journal of Nursing, 2011. Disponivel em:

http://www.objnursing.uff.br/index.php/nursing/article/viewFile/3534/1106.

Acesso em: 30 de setembro de 2019.

Organización mundial de la salud. Informe mundial sobre la violência y la salud. 2003. Disponível em:

http://apps.who.int/iris/bitstream/handle/10665/112670/9275315884_spa.pdf?se quence=1. Acesso em: 07 de maio de 2019.

ORGANIZAÇÃO MUNDIAL DA SAÚDE. WHO recognizes Child Abuse as a major public health problem, 1999. Disponível em: https://www.who.int/en/. Acesso em: 13 de maio de 2019.

OLIVEIRA, E.; BARBOSA, R.; MOURA, A.; KOSSEL, K.; MORELLI, K.; BOTELHO, L.; STOIANOV, M. Atendimento às mulheres vítimas de violência sexual: um estudo qualitativo. Rev. Saúde Pública. São Paulo, v. 39, n. 3, 2005.

PEDROSA, C. M. A construção de uma ferramenta social para promoção da saúde e dos direitos das mulheres. Ribeirão Preto, v. 19, n. 42, p. 123130, 2009.

PEREIRA A.; SESPEDE, C; CORTELETE, C; BARRETO, C; BIAZON, E; VERRENGIA, L; LIBERATTI, M; ROSA, M; LOPES, M; STORTI, M; GÓES, M; MORENO, N; FILHO, R. P.; PLEPIS, R; SILVA, S; MUNIZ, S; ABRÃO, S, CROCE, $T$; JÚIOR, W. P. Protocolo de proteção à mulher, criança $\mathbf{e}$ adolescente vítimas de violência sexual, doméstica e intrafamiliar. Maringá, 2012.

PIMENTEL, S.; SCHRITZMEYER AL.; PANDJIARJIAN V. Estupro: crime ou "cortesia"? Abordagem sociojurídica de gênero. Porto Alegre: Sergio Antionio Fabris, 1998.

PFEIFFER, L., \& SALVAGNI, E. Visão atual do abuso sexual na infância e adolescência. Jornal de Pediatria Rio de Janeiro, p. 197-204, 2005. 
RIBEIRO, P. R.; MARQUES, D.; MAGALHÃES, L.; NUNES, R.; MAIA, S.; MARTINS, W. Violência contra a mulher. Fortaleza, 2012. Disponível em: http://www.intercom.org.br/papers/regionais/nordeste2012/expocom/EX320741-1.pdf. Acesso em: 20 de outubro de 2019.

SAFFIOTI, H. I. B. Gênero, patriarcado, violência. São Paulo: Editora Fundação Perseu Abramo, 2004.

SILVA, M. A., FALBO, N. G. H., CABRAL, F. J. E. Maus-tratos na infancia de mulheres vítimas de violência. Psicologia em Estudo: p. 121-127, 2009.

SOARES, B. M. Mulheres invisíveis: violência conjugal e as novas politicas de segurança. Rio de Janeiro: Civilização Brasileira, 1999.

SOUZA, F. B. C.; DREZETT, J.; MEIRELLES, A. de C.; RAMOS, D. G. Aspectos psicológicos de mulheres que sofrem violência sexual. 2012. Disponível em:

https://www.sciencedirect.com/science/article/pii/S141320871300006X\#bib0005 Acesso em: 16 de outubro de 2018.

SUGAR, N. F.; FINE, D. N.; ECKERT, L. O. Physical injury after sexual assault: Findings of a large case series. American Journal of Obstetrics and Gynecology. London, v. 90, 2004. Disponível em:

https://www.sciencedirect.com/science/article/pii/S0002937803009128 . Acesso em: 29 de outubro de 2018.

VENTURI, Gustavo. Precisamos falar com os homens?. USP, 2016.

Disponível em:

http://www.agenciapatriciagalvao.org.br/dossies/violencia/pesquisa/precisamosfalar-com-os-homens-onu-mulheres-papo-de-homem-2016/ . Acesso em: 08 de maio de 2019.

WAISELFISZ, J. J. Mapa da Violencia 2015: homicidios de mulheres no Brasil. Brasília, 2015. Disponivel em:

http://www.mapadaviolencia.org.br/pdf2015/MapaViolencia_2015_mulheres.pdf . Acesso em: 30 de setembro de 2019.

WELCH, J; MASON, F. Rape and sexual assault. BMJ Publishing Group Ltd, London, v. 334, 2007. Disponível em:

https://www.bmj.com/content/bmj/334/7604/1154.full.pdf . Acesso em: 29 de outubro de 2018.

WHITE, C; MCLEAN, I. Adolescent complainants of sexual assault; injury patterns in birgin and non-virgin groups. Journal of Clinical Forensic Medicine. London, v.13, ed. 4, p. 172-180, 2006. Disponível em: https://www.sciencedirect.com/science/article/pii/S135311310600040X . Acesso em: 30 de outubro de 2018. 


\section{ÍNDICE}

\section{A}

Alany Alves Borges, 270

Aline de Paula Rodrigues, 322

Ana Laura Pacheco, 191

Anna Claudia Reis Carvalho, 238

Anna Laura de Abreu Sampaio, 199

Antônio Ancelmo Neto Barros, 72

\section{B}

Bernardo Pereira Cangemi, 343

\section{C}

Caio César de Paula, 39, 178, 258, 355

Camila Campos Fernandes, 366

Camila de Figueiredo Ramos, 209

Clara Cunha Procopio, 335

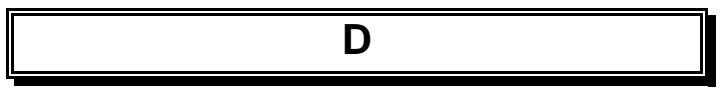

Daniela de Figueiredo Ribeiro, 10, 57, 292, 305

\section{G}

Gabriela dos Reis Nascimento Delfino, 238

Gabriela Maia de Almeida, 10, 199

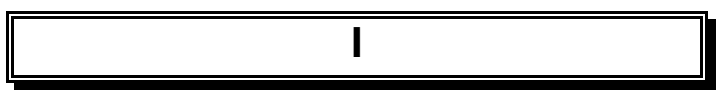

lago Gonzales de Q. Silva, 115 Irma Helena Ferreira Benate

Bomfim, 322, 366

Isabela Duzzi Cintra, 335

Isabella dos Santos Machado, 199

Isabella Riqueti Garcia, 248

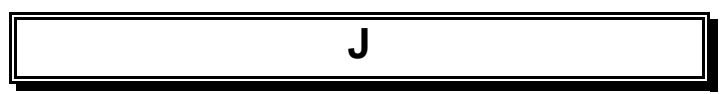

João Marcus Roque Cardoso, 50

Julia Lopes Rodrigues, 178, 343

Júlia Moraes, 191

Juliana Presotto Pereira Netto, 163

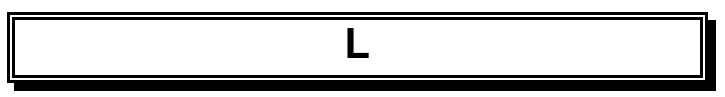

Lara Junqueira Gomes, 142, 157, 158

Letícia Sousa Victor, 39

Livia Aquino Alves, 292

Lucas Moreira de Oliveira, 163

\section{M}

Manoela Pacheco Chagas, 226

Maria Cherubina de Lima Alves, 93, 199, 209, 258

Maria Luísa Casillo Jardim Maran, 270

Mariana Felix Malta, 26

Marina Neves Alves, 57

Marina Vanini Pinheiro, 238

Mateus Lemos de Azevedo, 50

Mauricio Crivelenti Abrão, 50

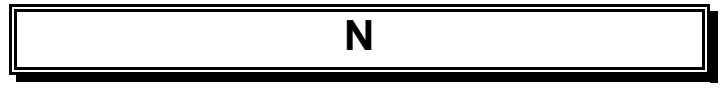

Nathália Bosco Mendes da Silva, 199

$\mathbf{P}$

Paulo de Tarso Oliveira, 80

\section{$\mathbf{R}$}

Rafaella Orlando de Souza, 80, 199

Rayssa Lima, 191

Rebeca Silva Moreti, 305 


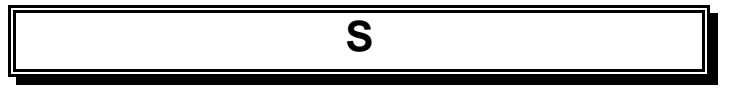

Sofia Muniz Alves Gracioli, 26, 39, $50,72,115,142,157,158,163$, $178,226,238,248,335,343,344$, 355

Sofia Muniz Aves Gracioli, 191

Sofia Rodrigues de França Roland, 93
Stefania Gonçalves Stefani Silva, 335

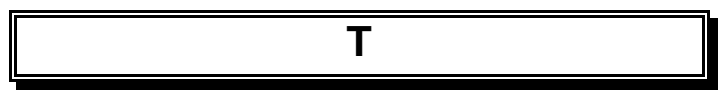

Tayná Gonçalves Morais, 199

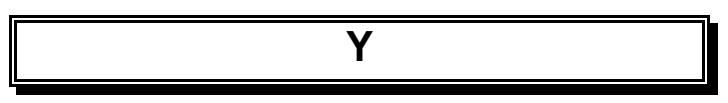

Yanca Araújo Polastrine, 39 
ISBN VOLUME

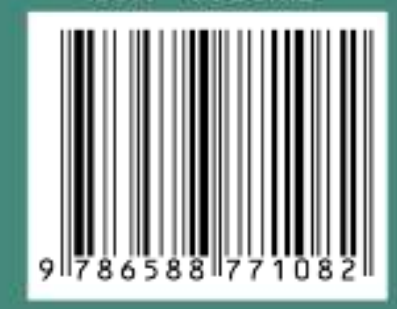

ISBN COLECÃO

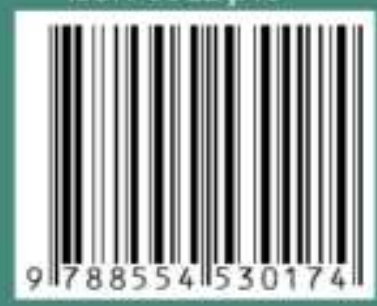

08009404688

1637134688

unifacef.com.br

f 